Л. Ф. Борисова

\title{
ОБЕСПЕЧЕНИЕ БЕЗОПАСНОСТИ СУДОХОДСТВА В РЫБОПРОМЫСЛОВЫХ РАЙОНАХ
}

Допущено Управлением науки и образования Федерального агентства по рыболовству в качестве учебного пособия для студентов высших и средних образовательных организаций, обучаюшихся по направлениям подготовки бакалавриата 35.03.09 «Промышленное рыболовство», магистратуры 35.04.08 «Промышленное рыболовство» и специальности (СПО) 35.02.11 «Промыиленное рыболовство»

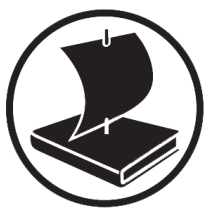

Москва

МОРКНИГА

2016 
УДК:656.061.52: 629.5.052 (075.8)

ББК 39.471-5Я 73

Б 82

Издание осуществлено бюджетного при организационной и финансовой поддержке Федерального государственного образовательного учреждения «Центральный учебно-методический кабинет по рыбохозяйственному образованию» (ФГБОУ «ЦУМК») Федерального агентства по рыболовству.

\section{Р е ц е н 3 е н т ы :}

Стариченков А. Л., доктор технических наук, доцент, заведующий лабораторией безопасности транспортных систем ФГБУН «Институт проблем транспорта им. Н.С. Соломенко РАН (ИПТ РАН)»;

Карпушин И. С., кандидат технических наук, доцент, заведующий кафедрой «Управление судном» ФГБОУ ВПО «Дальрыбвтуз»;

Сухинин А. И., заместитель директора, начальник службы безопасности мореплавания ФГБНУ «Полярный научно-исследовательский институт морского рыбного хозяйства и океанографии им. Н.М. Книповича (ПИНРО)».

\section{Б 82 Борисова, Л. Ф.}

Обеспечение безопасности судоходства в рыбопромысловых районах : учебное пособие / Л. Ф. Борисова. - М.: МОРКНИГА, 2016. - 415 с.

Рекомендовано Научно-методическим советом по рыб̈ому хозяйству Федерального учебно-методического объединения в системе ВО по укрупненной группе специальностей и направлений подготовки 35.00 .00 «Сельское, лесное и рыбное хозяйство» (НМС РХ ФУМО ВО).

Изложены принципы построения и функционирования систем безопасности мореплавания в районах с интенсивным судоходством - систем установления путей, систем управления движением судов, систем судовых сообщений; рассмотрены современные подходы к организации лоцманской проводки судов с использованием новейшего оборудования, а также принципы оценки безопасности в морских транспортных системах.

Предназначено для межвузовского использования при подготовке студентов (курсантов) рыбохозяйственных вузов РФ, а так же будет полезна судоводительскому составу рыбопромысловых судов.

The principles of construction and functioning of the navigation safety systems in intensive navigation areas (routeing systems, vessel traffic service, ship reporting systems) have been presented. Modern approaches to the organization of the vessels pilotage using the latest equipment and principles of safety valuation in marine transport systems have been considered.

It is intended for inter-institute use in preparation of students (cadets) of the direction of preparation of bachelors 35.03.09 "Industrial Fishing" and of magisters 35.04.08 "Industrial Fishing”.

ISBN 978-5-903680-16-0

$$
\text { удк:656.061.52: } 629.5 .052 \text { (075.8) }
$$

ББК 39.471-5Я 73 


\section{ОГЛАВЛЕНИЕ}

СОДЕРЖАНИЕ ……………………………….... 3

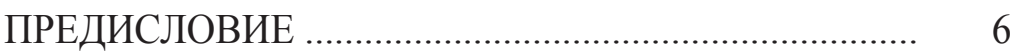

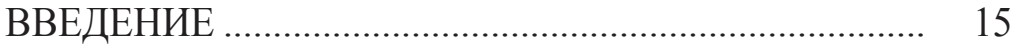

ОСНОВНЫЕ СОКРАЩЕНИЯ ....................................... 24

1. ПРИНЦИПЫ ОБЕСПЕЧЕНИЯ БЕЗОПАСНОСТИ В МОРСКИХ ТРАНСПОРТНЫХ СИСТЕМАХ ........ 29

1.1. Цели и задачи обеспечения безопасности мореплавания ........................................................... 29

1.2. Системы обеспечения безопасности мореплавания 33

1.3. Структура безопасности морских систем ............ 38

1.4. Основные показатели безопасности морских транспортных систем .................................................. 41

1.5. Современное состояние безопасности ................. 44

1.6. Показатели безопасности водного транспорта ..... 49

1.7. Нормирование показателей безопасности ........... 54

1.8. Стандартизация показателей безопасности судо-

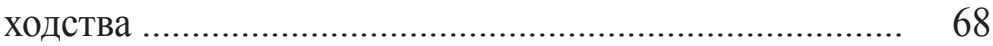

Контрольные вопросы ................................................... $\quad 70$

2. МОДЕЛИ БЕЗОПАСНОСТИ СУДОХОДСТВА ........ 71

2.1. Причины аварийных ситуаций на водном транспорте ...................................................................... 71

2.2. Методология обеспечения безопасности судов .... 85

2.3. Методология формализованной оценки безопасности судоходства ……….............................................. 93

2.4. Методология вероятностного анализа безопасности объектов судоходства ............................................ 109

2.5. Сценарное моделирование с использованием деревьев событий и отказов для анализа рисков в судоходстве

2.6 Методика анализа риска объектов инфраструктуры мореплавания 
2.7. Моделирование аварий при перевозках опасных грузов

2.8. Информационное обеспечение управления безопасностью

2.9. Организация программного обеспечения и банка данных систем управления безопасностью судоходства

Контрольные вопросы

3. СИСТЕМЫ ОБЕСПЕЧЕНИЯ БЕЗОПАСНОСТИ МОРЕПЛАВАНИЯ

3.1. Международное нормативно-правовое регулирование безопасности мореплавания .............................. 152

3.2. Радиосвязь в системах безопасности мореплавания 168

3.3. Глобальная морская система связи при бедствии и для обеспечения безопасности .................................... 180

3.4. Назначение и развитие систем установления путей 194

3.5. Обобщенная структура системы установления путей ................................................................... 203

3.6. Схемы разделения в системах установления путей 206

3.7. Общие принципы использования систем разделения путей …………................................................ 213

3.8. Условия введения систем установления путей ..... 225

3.9. Определение геометрических размеров системы разделения путей ....................................................... 230

Контрольные вопросы ................................................... 236

\section{4. СИСТЕМЫ УПРАВЛЕНИЯ БЕЗОПАСНОСТЬЮ} МОРЕПЛАВАНИЯ

4.1. Обеспечение безопасности мореплавания при лоцманских проводках

4.2. Назначение и этапы развития систем управления движением судов

4.3. Состав и принципы функционирования систем управления движением судов 
4.4. Состав и принципы функционирования автоматических идентификационных систем

4.5. Принципы и системы отображения электронных навигационных карт

4.6. Принципы организации взаимодействия модулей программного комплекса системы управления судоходством 306

4.7. Системы судовых сообщений

4.8. Перспективы развития систем безопасности судоходства

Контрольные вопросы

5. ОБЕСПЕЧЕНИЕ БЕЗОПАСНОСТИ СУДОХОДСТВА В РАЙОНАХ РЫБНОГО ПРОМЫСЛА

5.1. Особенности плавания в районах рыбного промысла

5.2. Государственный надзор за безопасностью плавания судов рыбопромыслового флота в районах промысла

5.3. Безопасность групповых переходов судов к району рыбного лова

5.4. Безопасность совместного плавания и промысла судов

5.5. Обеспечение безопасности рыболовных судов .... 368

5.6. Обеспечение безопасности при проведении промысловых операций

Контрольные вопросы 395 ЛИТЕРАТУРА 396 


\section{ПРЕДИСЛОВИЕ}

Интенсивность судоходства растет из года в год. Мировой океан бороздят научно-исследовательские и рыбопромысловые суда, подводные аппараты, гидросамолеты и экранопланы, суда на воздушной подушке и подводных крыльях, буксиры и доки, плавучие краны и понтоны, корабли военно-морских сил, пограничной и таможенной служб и другие суда. В таких условиях все большее значение приобретает проблема обеспечения безопасности судоходства. Статистика свидетельствует об устойчивой тенденции роста числа аварий, причем на первом месте среди всех типов аварийных ситуаций (АС) находятся столкновения судов (20,5 \%). Столкновения судов в наибольшей степени свидетельствуют о проблемах, существующих в организации движения, в первую очередь в прибрежных и береговых зонах, прилегающих к морским портам, которые отличаются повышенной оживленностью судоходства. Наращивание экспорта энергоносителей и сырья, ожидаемое в ближайшие десятилетия, создает условия роста потенциальной угрозы экологическому благополучию морских регионов, опасности загрязнения традиционных районов промысла морских биологических ресурсов. Экологическая опасность усугубляется отсутствием в территориальных водах России специальных морских коридоров для танкеров. Значит, любое судно в акватории может столкнуться с танкером.

Рыболовный промысел является специфичным видом деятельности на море. Плавание судов в районе рыбного промысла отличается повышенной степенью опасности из-за большого скопления рыбопромысловых судов на ограниченной акватории, границы которой не определены. При переходе из порта к месту лова и возвращении обратно в порт промысловое судно подчиняется общим правилам и нормам регулирования мореплавания и обеспечения безопасности, обязательным для всех кораблей, а в районе промысла безопасность совместного плавания судов, занятых ловом, регулируется специальными нормами, соглашениями и правилами ведения промысла и обеспечения безопасности. В условиях роста 
общей интенсивности судоходства производственная деятельность рыбопромыслового флота сопряжена с дополнительными рисками. Ситуация усугубляется наблюдаемым в настоящее время физическим износом большей части рыбопромысловых судов, что увеличивает и без того высокие риски аварий. Планируемое кардинальное обновление рыбопромыслового флота и ожидаемое пополнение флота современными судами не снимают проблем обеспечения безопасности судоходства.

Учащающиеся аварийные случаи на морском транспорте, ведущие к катастрофическим последствиям, гибели людей, экологическим катастрофам, а также возросшая угроза террористических актов выдвигают проблему обеспечения безопасности на морском транспорте в ранг общенациональной безопасности. Отдельные вопросы безопасности на морском транспорте нашли свое отражение в ряде законодательных актов, таких как: Морская доктрина Российской Федерации, Кодекс торгового мореплавания РФ, Кодекс внутреннего водного транспорта РФ, определяющих государственную политику Российской Федерации в области морской деятельности.

Обеспечение безопасности судоходства в современных условиях является комплексной многоаспектной проблемой, решаемой с использованием разнообразных способов и методов, которые с позиций теории управления и принятия решений можно подразделить на два уровня: микроскопический и макроскопический.

Микроскопический уровень обеспечения безопасности мореплавания подразумевает принятие решений на каждом конкретном судне в отдельности. При этом судоводитель решает ряд важных производственных задач (добыча морских биоресурсов, или переход судна из порта отхода в порт назначения в кратчайшие сроки, или выполнение работ по разведке энергоресурсов на морском шельфе и других работ) при условии соблюдения безопасности людей (экипажа и пассажиров), судна и груза. Выполнение этих задач основано на использовании, главным образом, традиционных методов управления судном, навигации, лоции и мореходной астрономии. Эти методы рассматривают проблему безопасности 
с позиции отдельного судна, они хорошо изучены и отражены в учебной литературе. Однако этого недостаточно в сложных условиях мореплавания на акватории с большим скоплением судов, к которым, в частности, относятся районы рыбного промысла.

Бурный рост мирового судоходства и связанный с ним рост рисков столкновений и аварий сформировал в последние десятилетия макроскопический подход к решению проблемы обеспечения безопасности мореплавания. В этом случае проблема безопасности судоходства рассматривается с точки зрения системного подхода, и методы реализации этого подхода трактуются как средства дополнительной помощи в судовождении. Реализация ряда организационно-нормативных, технологических и технических мер на международном уровне позволила создать системы, помогающие судоводителю в решении его главной задачи, которые получили название «систем безопасности мореплавания» (maritime safety system) [44].

Иногда этот термин трактуется расширительно, включая организационные структуры (например, Международная морская организация - ИМО), нормативные документы (резолюции ИМО), технологические решения (конструкция корпуса судна с двойным дном), однако, имея в виду сущностное содержание этого термина, к системам безопасности мореплавания относятся следующие:

- система установления путей движения судов (СУП);

- система управления движением судов (СУДС);

- Глобальная морская система связи при бедствии и для обеспечения безопасности (ГМССБ);

- система судовых сообщений (ССС).

Эти системы предназначены для решения различных задач, таких как организация движения судов путем разделения встречных потоков судов в прибрежных водах, радиолокационный контроль и оперативное управление движением судов на подходах к портам, минимизация последствий навигационной аварийности путем содействия проведению спасательных операций, защита наиболее экологически уязвимых морских районов и другие. Макроскопический характер таких систем обусловливается тем, что 
для реализации поставленных перед ними задач задействуются специально созданная береговая инфраструктура, нормативно-организационное и информационно-технологическое обеспечение, особое структурирование морских районов.

Статистика происшествий с судами показывает, что в 40 \% случаев аварийности причиной является неадекватность поступающих судоводителю данных о реальной навигационной обстановке на маршруте. В большинстве из них нарушались принципы объективности, адекватности и интегративности потоков в навигационных и других сообщениях СУДС. Наиболее отчетливо это проявлялось в стесненных условиях плавания, когда неверные сведения об обстановке на водном пути приводили к ошибочной оценке ситуаций, созданию предпосылок аварий и происшествий. Исследованиям информационного обеспечения СУДС морская наука стала уделять достаточное внимание лишь в последнее десятилетие. В опубликованных работах по СУДС отсутствуют методология и теоретические положения с принципами формирования и методиками оценки безопасности информационного ресурса. Отмеченные недостатки понижают возможности систем безопасности судоходства, затрудняют управление судном и свидетельствуют о растущем запросе на решение информационно-аналитических проблем в функционировании СУДС, на дальнейшую интеллектуализацию этих систем.

Государственные образовательные стандарты подготовки специалистов судоводительского и морского радиотехнического профилей предусматривают изучение систем установления (разделения) путей движения судов (УПДС), и особенно глобальной морской системы связи при бедствии (ГМССБ). Также в стандартах определено изучение отдельных составляющих, входящих в состав систем безопасности мореплавания, например, систем радиолокации (РЛС), автоматических идентификационных (информационных) систем (АИС), средств автоматизированной радиолокационной прокладки (САРП). Имеющаяся учебная литература представляет их достаточно полно. Однако получившие широкое распространение и активно развивающиеся в последние годы системы управ- 
ления движением судов (СУДС) и системы судовых сообщений не получили должного отражения в учебниках.

Вместе с тем в настоящее время нет ни одного района Мирового океана, где не действовала бы какая-либо система безопасности мореплавания. Участие судов в системах безопасности мореплавания может быть обязательным или добровольным. Причем системы могут быть обязательными для всех судов без исключения или для судов определенного класса в зависимости, например, от длины, валовой вместимости, типа судна и его национальной принадлежности. Участие судна в любой из этих систем как налагает на судоводителя определенные обязательства, так и предоставляет ему конкретные возможности, связанные с обеспечением безопасности мореплавания. Поэтому еще на этапе планирования рейса судоводитель обязан предусмотреть все возможные ситуации, в которых может оказаться судно в связи с участием в системах безопасности мореплавания.

При изложении материала большое внимание уделено принципам оценки безопасности морских транспортных систем по показателям безопасности и рисков потерь, а также системам установления (разделения) путей движения и системам управления движением судов, включая аспекты их перспективного развития, которые в наименьшей степени отражены в имеющейся учебной литературе.

Содержание данного учебного пособия соответствует профессиональным циклам Федеральных государственных образовательных стандартов высшего профессионального образования по направлению подготовки бакалавров 35.03.09 - «Промышленное рыболовство» и магистров 35.04 .08 - «Промышленное рыболовство» и специальности (СПО) 35.02.11 «Промышленное рыболовство». Учитывая определенную общность изучаемых проблем, учебное пособие также может быть полезно студентам (курсантам), обучающимся по специальностям 25.05.03 «Техническая эксплуатация транспортного радиооборудования» и 26.05.05 «Судовождение», а также по смежным специальностям вузов и практикующим морским специалистам.

Структура учебного пособия имеет следующие особенности. Содержимое учебного пособия разделено на пять тематических 
разделов. Первые два раздела посвящены теоретическим принципам обеспечения безопасности судоходства. Вопросы, которые рассматриваются в этих разделах, имеют общесистемный характер и опираются на методологию формализованной оценки безопасности (ФОБ) и расчетно-графические методы вероятностного анализа безопасности (ВАБ), принятые ИМО к внедрению в качестве превентивных мер обеспечения безопасности на море, направленные на «опережение» нежелательных событий.

Количественная оценка рисков возникновения нежелательных и аварийных ситуаций, базирующаяся на методах ФОБ и ВАБ, широко используется во многих видах промышленности, связанных с эксплуатацией опасных объектов, таких как атомная промышленность, химическая промышленность и исследование космоса, но является относительно новой для морской индустрии. Вместе с тем совершенствование Руководства по ФОБ, анализ предлагаемых проектов по ФОБ и координация всех работ по этой методологии находятся в сфере особого внимания Международной морской организации. Вопросы формализованной оценки безопасности постоянно включаются в повестку дня заседаний Комитета по безопасности на море и Комитета по защите морской среды ИМО. К сожалению, методы и модели ФОБ не нашли должного отражения в современной учебной литературе, предназначенной для профессиональной подготовки дипломированных морских специалистов. Данное учебное пособие имеет целью восполнить этот пробел и дать представление о чрезвычайно важном направлении анализа безопасности судоходства.

В первом разделе, базируясь на понятии системы безопасности судоходства, рассмотрены ключевые теоретические положения и общие принципы обеспечения безопасности морских транспортных систем, формулируются задачи обеспечения безопасности мореплавания, определяются показатели безопасности и оценки рисков потерь. Этот раздел формирует представление об общесистемных подходах и принципах безопасности, необходимых для изучения последующих тем.

Во втором разделе показаны принципы моделирования систем безопасности судоходства. Этот раздел включает анализ сценариев 
развития аварийных ситуаций, причинно-следственные модели возникновения аварий и мероприятия по обеспечению безопасности водного транспорта, а также принципы имитационного моделирования безопасности судоходства. Материалы первого и второго разделов будут полезны при выполнении расчетных, курсовых и выпускных квалификационных работ, а также будут интересны магистрантам и аспирантам при выполнении исследовательских работ.

В следующих двух разделах, третьем и четвертом, рассмотрены принципы построения и условия эксплуатации современных систем обеспечения безопасности мореплавания, которые обеспечивают безопасный переход рыбопромысловых судов из порта к месту лова и возвращение обратно в порт. В зависимости от характера управления условно разделены, соответственно, на системы с пассивным и активным управлением.

К системам безопасности судоходства пассивного типа отнесены системы, которые сами не вырабатывают управляющие решения при возникновении опасной ситуации, но обеспечивают условия для их выработки: слежение, сбор необходимой информации о судоходной обстановке, оповещение, телекоммуникационное взаимодействие, инструкции, правила и регламенты движения судов. Другими словами, пассивная система не имеет обратной связи по управлению. Решения вырабатываются вне такой системы.

Системы активного типа, наоборот, в зависимости от обстановки на акватории способны автоматизированно вырабатывать и доставлять на судно управляющие решения, то есть это системы управления безопасностью мореплавания с обратной связью по управлению. Активный характер таких систем обусловлен широким использованием вычислительной техники, информационных технологий и программных методов выработки управляющих решений, а также применением автоматических систем слежения и идентификации судов, средств электронно-цифровой картографии. Дальнейшая интеллектуализация таких систем определяет перспективный вектор развития экспертных систем управления безопасностью судоходства.

Третий раздел посвящен системам обеспечения безопасности мореплавания пассивного типа. Рассмотрен комплекс документиро- 
ванных международных соглашений (Конвенций) по нормативноправовому регулированию безопасности мореплавания, принципы организации радиосвязи в системах безопасности мореплавания, структура и компоненты ГМССБ, схемы пространственного разделения судопотоков в системах установления путей, принципы использования и условия введения систем установления путей, включая организацию движения судов, занятых ловом рыбы. Показаны примеры организации и применения систем в России и за рубежом.

Четвертый раздел включает изучение современных систем лоцманской проводки судов, СУДС и систем судовых сообщений. Рассмотрены принципы организации и использования АИС, систем отображения электронных навигационных карт, а также организация взаимодействия модулей программного комплекса СУДС. В заключение рассмотрены перспективные направления развития систем безопасности судоходства, включая разработки, предназначенные для применения в районах рыбного промысла.

Содержание третьего и четвертого разделов имеет практическую направленность и является необходимым составляющим элементом современной подготовки будущих морских специалистов, а также будет интересно широкому кругу читателей различного уровня специализированной подготовки, включая практикующих специалистов и заинтересованных специалистов смежных профессий.

В пятом разделе изложены нормы, регулирующие безопасность судоходства в районах рыбного промысла. Материал данного раздела охватывает обширный круг вопросов, представляющих специальный интерес для профессионального работника рыбопромысловой отрасли. Рассмотрены национальные нормативные правовые акты и международные договоры, заключенные и ратифицированные Российской Федерацией в последние годы, которые регламентируют взаимодействие рыбопромысловых судов при групповых переходах в район промысла, совместном плавании и ведении промысла, а также обеспечивают безопасность самого судна.

В конце каждого раздела имеются контрольные вопросы, которые могут быть использованы как для самоконтроля обучающегося, так и при итоговом тестировании знаний. 
Структура учебного пособия учитывает порядок изложения материала от общесистемных подходов к структурным компонентам и их взаимодействию в системе безопасности и далее к конкретным техническим реализациям систем безопасности судоходства по нарастанию уровня интеллектуализации, позволяющего снизить долю участия человека в принятии решения. Такой подход дает возможность читателю не придерживаться порядка чтения, предложенного автором, и включать отдельные разделы в смежные курсы.

Список литературных источников свидетельствует о большом интересе к проблемам обеспечения безопасности судоходства с помощью использования высокотехнологичных систем в нашей стране и за рубежом и об отсутствии соответствующей отечественной учебной литературы в данной предметной области.

Целью настоящего учебного пособия является восполнение недостатка современного обучения будущих специалистов рыбопромысловой отрасли в области эксплуатации, обслуживания и технической поддержки морских транспортных средств и систем в части изучения возможностей, методов и средств реализации систем обеспечения безопасности мореплавания в районах интенсивного судоходства, к числу которых относятся рыбопромысловые районы.

Автор выражает глубокую благодарность рецензентам: кандидату технических наук, доценту И. С. Карпушину, заведующему кафедрой управления судном ФГБОУ ВПО «Дальрыбвтуз» (г. Владивосток), доктору технических наук, доценту А. Л. Стариченкову, заведующему лабораторией безопасности транспортных систем ФГБУН «Институт проблем транспорта им. Н. С. Соломенко Российской академии наук (ИПТ РАН)» (г. Санкт-Петербург), А. И. Сухинину, заместителю директора, начальнику службы безопасности мореплавания ФГБНУ «Полярный научно-исследовательский институт морского рыбного хозяйства и океанографии им. Н. М. Книповича (ПИНРО)» (г. Мурманск) за полезные советы и замечания, способствовавшие улучшению содержания книги. 


\section{ВВЕДЕНИЕ}

Рыбопромысловый флот составляет основу рыбной промышленности России. На его долю приходится более 70 \% общей стоимости основных производственных фондов всего рыбопромышленного комплекса. Рыбный промысел занимает ведущие позиции в решении центральной народнохозяйственной задачи обеспечения населения качественными и доступными морепродуктами питания.

Морское судоходство издавна связано с определенным риском. И в наше время случаются не только повреждения, но и гибель судов из-за неудовлетворительных прочности, остойчивости, надежности оборудования и оснащения судна, неправильного размещения груза, ошибок в судовождении, а также вследствие пожаров, столкновений и посадок на мели. Поэтому повышение безопасности плавания судов всегда было важнейшей задачей судоходства.

С ростом интенсивности судоходства увеличилось количество морских катастроф, в результате которых гибнут люди и большие материальные ценности. Учащающиеся аварии на морском транспорте выдвинули вопросы безопасности в ранг межгосударственных. Международным морским сообществом давно признано, что ввиду международного характера судоходства деятельность, направленная на повышение его безопасности, станет более эффективной, если будет осуществляться на международном уровне, а не отдельными странами, действующими в одностороннем порядке и без координации с другими странами. Эти предпосылки привели к тому, что в феврале 1948 года Конференция ООН по морскому праву приняла Конвенцию о Международной морской консультативной организации, которая была преобразована в 1982 году в Международную морскую организацию (ИМО International Maritime Organization, IMO), специализирующуюся в области безопасности на море и охраны морской среды.

В настоящее время членами ИМО являются 166 государств. В работе ИМО принимают участие в качестве наблюдателей 36 межправительственных и 63 неправительственные международные организации, включая региональные соглашения о государственном 
портовом контроле. По своему статусу и функциям ИМО является технической организацией, и ее основная задача - разработка международных стандартов (правил и процедур) для обеспечения безопасности мореплавания, морской безопасности и защиты окружающей среды от загрязнения с судов, а также механизмов внедрения и исполнения этих международных стандартов. Разработанные стандарты оформляются в виде международных конвенций и кодексов, носящих обязательный или рекомендательный характер.

Под эгидой ИМО принято 47 международных конвенций и протоколов к ним, 15 кодексов, носящих обязательный характер, свыше 20 кодексов и наставлений рекомендательного характера, более двух тысяч рекомендаций в виде резолюций и циркулярных писем.

Высшим органом ИМО является Ассамблея, которая проводит свои сессии один раз в два года. В январе 1959 года состоялась 1-я сессия Ассамблеи ИМО, и с этого момента СССР (а затем - Россия) участвует в работе ИМО. В период между сессиями Ассамблеи работой организации руководит Совет, состоящий из 40 государств-членов и избираемый на срок 2 года. Россия традиционно избирается в Совет ИМО в приоритетном списке.

Непосредственное ежедневное функционирование Организации обеспечивает постоянный Секретариат, возглавляемый Генеральным секретарем. Штаб-квартира Секретариата находится в Лондоне. Секретариат не принимает решений в отношении международных требований и является исполнительным органом ИМО.

Для обсуждения технических вопросов и принятия решений по техническим поправкам к конвенциям и кодексам, а также для выработки рекомендаций по применению уже принятых правил и процедур в Организации созданы и действуют 5 комитетов и 9 подкомитетов по отраслям деятельности Организации:

- Комитет по безопасности на море (КБМ) является основным и старейшим органом, ведающим вопросами в области охраны человеческой жизни на море;

- Комитет по защите морской среды (КЗМС) занимается вопросами предотвращения загрязнения морской среды от судоходной деятельности; 
- Юридический комитет (Юрком) работает в области морского права;

- Комитет по облегчению формальностей судоходства (ФАЛ) разрабатывает меры по унификации документов в области мореплавания и процедур обработки этих документов различными ведомствами;

- Комитет по техническому сотрудничеству (КТС) обеспечивает реализацию потребностей Организации в области оказания помощи государствам-членам в развитии инфраструктуры судоходства, и прежде всего в обеспечении безопасности и защиты морской среды.

Законотворческая работа ИМО является частью нормативноправового регулирования функционирования морского транспорта в мире, и в России в частности, и поэтому чрезвычайно важна для России. Ключевые вопросы международного судоходства охвачены положениями международного права, имеющими обязательный характер. В большинство документов ИМО заложен специфичный для международного права принцип обязательности международного соглашения для всех государств, имеющих флот. Практически все решения и рекомендации, оформленные в виде резолюций и циркулярных писем, получают на практике статус требований, обязательных для всех судов. Стандарты ИМО обращены к правительствам, но непосредственными исполнителями большинства требований являются судовладельцы или операторы судов и моряки.

К концу 80-х годов в ИМО возросла озабоченность низким уровнем управления безопасностью и предотвращением загрязнения в судоходстве. В ответ на это принят Международный кодекс по управлению безопасностью (МКУБ), которому в 1998 году придан статус обязательного. Кодекс требует создания и соблюдения системы организационных мер управления безопасностью на судне и в судоходной компании.

Требования международных норм по обеспечению безопасности на море, защиты окружающей среды от загрязнения с судов и охраны судов, принятых в рамках ИМО, контролируются государствами 
порта, объединенными в региональные соглашения о портовом контроле. В мире под эгидой ИМО создано 9 региональных соглашений о государственном портовом контроле. Россия является участником трех из них: Парижского, Токийского и Черноморского меморандумов.

Россия, будучи преемником Советского Союза, является стороной большинства международных морских конвенций и кодексов, принятых под эгидой ИМО, и эти конвенции и кодексы являются обязательными для исполнения российскими судами, их экипажами и судоходными компаниями. Требования международных инструментов обязательного характера (конвенций, кодексов), относящиеся к техническим аспектам обеспечения безопасности и предотвращения загрязнения, вносятся в Правила Российского морского регистра судоходства. Российские суда, заходящие в российские порты, инспектируются службами капитанов портов на предмет выполнения международных требований.

В России внедрены и выполняются основные международные конвенции в области торгового мореплавания, такие как Международная конвенция об охране человеческой жизни на море (COЛАС), Международная конвенция по предотвращению загрязнения с судов (МАРПОЛ), Международная конвенция о грузовой марке (КГМ), Международная конвенция о подготовке и дипломировании моряков и несении вахты (ПДНВ), Международные правила предупреждения столкновения судов (МППСС), Конвенция по обмеру судов и другие.

Рыбный промысел в акватории Мирового океана регулируется как нормами Международного морского права, так и нормативными актами отдельных государств или договоренностями между ними, обеспечивающими как целостность государственных границ, так и предотвращение бесконтрольного отлова рыбы и других биологических ресурсов Мирового океана. Хотя все суда обязаны выполнять конвенции ИМО, рыболовство настолько отличается от других видов деятельности на море, что применение конвенционных соглашений к рыболовным судам имеет специфику. По сути, ни одна из конвенций ИМО не может непосредственно применяться 
к рыболовным судам. Предполагалось, что Торремолиносская международная конвенция по безопасности рыболовных судов 1977 года решит некоторые из этих проблем, однако из-за технических трудностей Конвенция так и не вступила в силу. Она была изменена протоколом, принятым в 1993 году. Протокол устанавливает единые принципы и правила относительно постройки и оборудования рыболовных судов, направленных на обеспечение безопасности мореплавания и экипажей в соответствии с МК СОЛАС 74/78, КГМ 66, ПДНВ, по обмеру, МАРПОЛ.

ИМО всегда придавала исключительное значение подготовке судового персонала. В 1978 году Организация созвала конференцию, которая приняла Международную конвенцию о подготовке и дипломирования моряков и несении вахты. Конвенция вступила в силу в апреле 1984 года. Она впервые установила приемлемые на международном уровне минимальные стандарты для экипажей. В 1995 году Конвенция была пересмотрена с целью предоставления ИМО полномочия проверять осуществление сторонами Конвенции административных процедур, процедур подготовки кадров и дипломирования. Поправки вступили в силу в 1997 году (ПДНВ-78 с поправками).

В России организована подготовка кадров морских специальностей в полном соответствии с международными требованиями, что подтверждено экспертами ИМО, посетившими морские учебные заведения России. Российские морские дипломы признаются всеми странами мира. Россия включена в белый список, формируемый ИМО в отношении подготовки и дипломирования моряков.

Роль Международной морской организации в современной судоходной индустрии трудно переоценить. Являясь фактически законотворческой организацией, ИМО к тому же имеет действенные инструменты воздействия как на отдельные суда, судоходные компании, так и на целые государства.

В 1993 году ИМО на 62-й сессии КБМ впервые начала рассматривать вопросы, связанные с внедрением методов превентивного нормирования. При этом учитывался положительный опыт применения таких методов в атомной индустрии 60 -х годов и химической 
промышленности 70-х. В 1996 году совместная рабочая группа Комитета по безопасности на море и Комитета по защите окружающей среды подготовила проект Временного руководства ИМО по формализованной оценке безопасности (ФОБ).

Методологическим особенностям построения и функционирования современных систем поддержки принятия решений по безопасному движению судов посвящены научные исследования известных отечественных ученых А. В. Алексишина, Л. Л. Вагущенко, И. И. Гладких, Г. В. Егорова, В. М. Кошевого, А. И. Кравченко, А. С. Мальцева, Н.Н. Цымбала.

Современная научная методология информационного и математического обеспечения автоматизированных СУДС показана в работе [3]. Предложенные технологии управления: «Информационный портрет состояния судна», «Нечеткое управление судном», «Цикл выработки решения по управлению судном», на основании имеющейся неполной информации, расширяют представление о выработке командного решения, способствуют предупреждению столкновения судов и устанавливают судоводительские процедуры по предупреждению аварийности. Недостаток информации не способствует должному взаимообмену между судами и приводит к невозможности получения (учета) вероятностных и качественных данных.

Целесообразность использования в оценке транспортной безопасности метода вероятностного анализа безопасности (ВАБ) обоснована в работе [107]. В основе метода лежат деревья событий и деревья отказов устройств систем, ответственных за управление движением. Считается, что анализ безопасности следует проводить по структурно-логическим моделям. Использование таких моделей позволяет получать только качественную оценочную составляющую риска аварий и связанных с ней угроз, и не позволяет характеризовать достаточность принятых мер по локализации и ликвидации последствий аварии.

Метод анализа моделей противодействия угрозам нарушения информационной безопасности, базирующийся на выборе рационального варианта реагирования, освещен в работе [122]. Новизна 
предложенного исследования заключается в принятии решения на множестве альтернатив средств и методов информационной безопасности в зависимости от определения уровня его эффективности. В работе [98] разработана модель, позволяющая априори представлять и определять вероятные величины потенциальных потерь и затрат на создание систем информационной безопасности (СИБ). Восстановление в случае реализации угроз, а также анализ дрейфа спроектированной СИБ выполняется системой оценок привлекательности угроз и определением их опасности. На основе разработанной системы оценок предложена модель оценки конкретной угрозы на пути движения.

Описанные общеметодологические и специальные подходы к познанию сложных информационных процессов, происходящих в судоходстве, дают основания утверждать, что получение высоких результатов, гарантирующих безопасность управления судном, должно обеспечиваться качественно новой методологией и техническими и информационными системами, ее реализующими.

Вся история создания и применения Международных правил предупреждения столкновений судов в море 1972 года свидетельствует о невозможности полностью решить проблему безопасного расхождения только по Правилам. Со времени принятия МППСС-72 существенно изменились условия судоходства. Повысилась плотность судоходства, введены новые типы судов: суда больших размеров, как следствие, имеющие худшую маневренность, суда с необычными маневренными характеристиками, быстроходные суда.

Частичная или полная замена человека техническими средствами в области оценки ситуации сближения судов и в выработке принятия решений по расхождению является выходом для решения проблемы предупреждения столкновений. Применяемые сегодня средства для предупреждения столкновений (САРП, АИС, ЭКНИС и др.) служат лишь для определения количественных значений параметров сближения судов. Задача оценки опасности сближения (с целью определить - нужен или не нужен маневр) 
и выбора маневра (когда начать маневр, вид маневра) решается только человеком. Понятно, что решить задачу однозначной оценки ситуации расхождения при значительной неопределенности большого количества параметров сближения человеку невозможно.

Новые реалии требуют новых подходов. Появились новые информационные технологии, требующие перестройки МППСС под возможность их формализации, наполнения количественными оценками, создания приемлемых для программирования алгоритмов, разработки машинных программ. Разрабатываются и реализуются высокотехнологичные автоматизированные экспертные системы на базе датчиков, систем слежения, современных средств радиосвязи и вычислительной техники, способные самостоятельно (без участия человека) решать задачи оценки опасности ситуации сближения судов и выбора маневра расхождения. Практика введения систем установления путей движения судов (СУП), управления движением судов (СУДС), судовых сообщений (ССС), Глобальной морской системы связи при бедствии и для обеспечения безопасности (ГМССБ) показала, что даже частичная согласованность параметров движения способна сильно уменьшить неопределенность в выборе курсов судов и снизить количество опасных встреч.

Сегодня уровень развития средств автоматизации производственных процессов, в том числе и судовых процессов, на базе электроники, нанотехнологий, средств накопления и беспроводной передачи больших объемов информации, спутниковых систем, средств видеонаблюдения и других систем позволяет создать автоматическую автономную систему, значительно минимизирующую функции человека при принятии решений при расхождении судов. Создание таких автономных систем является длительным во времени процессом. Наиболее приемлемый прямой путь - это включение ее в создаваемую под эгидой ИМО систему е-Навигации. Е-Навигация - это концепция, в основе которой лежит координация систем морской навигации и береговых служб в соответствии с потребностями пользова- 
телей, сбор, интеграция, передача, воспроизведение и анализ информации о ситуации на море, на борту судов и на берегу с помощью электронных средств.

Реализация на практике всех этих систем и современных подходов к оценке рисков способна существенно продвинуться на пути к решению центральной проблемы в области судоходства обеспечению безопасности. 


\section{ОСНОВНЫЕ СОКРАЩЕНИЯ}

A1, A2, A3, A4 - Морские районы ГМССБ

АИС (англ. AIS, Automatic Identification System) - Автоматическая информационная (идентификационная) система

АЗС - Автоматического захвата и сопровождения подсистема АКС - Автоматизированный комплекс судовождения

АМЛР - Ассоциация морских лоцманов России

АППУ - Антенно-приемопередающее устройство

АРБ (англ. EPIRB, Emergency Position Indicating Radio-Beacon)

- Аварийный радиобуй

АРМ - Автоматизированное рабочее место

АРТП - Автоматический радиотехнический пост

АС - Аварийная ситуация

БД - База данных

БДД - База данных документов

БД3 - База данных знаний

БДОИ - База данных оперативной информации

БС - Береговая станция

БНС - Береговая земная станция

БРЛС - Береговая радиолокационная станция

ВАБ - Вероятностный анализ безопасности

ВРНС - Всемирная радионавигационная система

ВЧ (англ. НF) - Высокие частоты, короткие волны

ГМССБ (англ. GMDSS, Global Maritime Distress and Safety

System) - Глобальная морская система связи при бедствии

ГНСС - Глобальная навигационная спутниковая система

ДКС - Дистанция кратчайшего сближения

ИКАО - Международная организация гражданской авиации

ИМКО (от англ. IМСО, Intergovernmental Maritime Consultative

Organisation) - Межправительственная морская консультативная организация

ИМО (от англ IMO, International Maritime Organization) - Me-

ждународная морская организация

ИНК - Информационно-навигационный комплекс 
ИС - Информационная система

КБМ - Комитет по безопасности на море ИМО

КВ (англ. НF) - Короткие волны, высокие частоты

КЗМС - Комитет по защите морской среды ИМО

КЗОС - Комитет по защите окружающей среды ИМО

КТМ РФ - Кодекс торгового мореплавания Российской Федерации

ЛВЖ - Легковоспламеняющаяся жидкость

МАКО (англ. IACS, International Association Classification Societies) - Международная ассоциация классификационных обществ

MAMC (англ. IALA, International Association of Lighthouse Authorities) - Международная ассоциация маячных служб

МАП - Морская администрация порта

МГО (англ. IHO, International Hydrographic Organization) - Meждународная гидрографическая организация

МККР - Международный консультативный комитет по радиосвязи

МКУБ (англ. ISM CODE, International Safety Management Code) - Международный кодекс по управлению безопасной эксплуатацией судов и предотвращением загрязнения

МОМП - Международная организация по морскому праву

МОТ - Международная организация труда

MПС (англ. MMS, Maritime Mobile Service) - Морская подвижная служба

МПСС (англ. MMSS, Maritime Mobile-Satellite Services) - Mopская подвижная спутниковая служба

МППСС (англ. COLREGS, International Rules of Preventing Collision at Sea) - Международные правила предупреждения столкновений судов в море

МРП - Морской рыбный порт

МСКЦ - Морской спасательный координационный центр

МСС - Международный свод сигналов

МСЭ (англ. ITU, International Telecommunication Union) - Международный союз электросвязи 
МЭК (англ. IEC, International Electrotechnical Commission) Международная электротехническая комиссия

НАВTЕКС (от англ. NAVTEX, NAVigational TEleX) - Международная автоматизированная система оповещения

НИКС - Навигационно-информационная компьютерная система

ОВЧ (англ. VНF) - Очень высокие частоты (УКВ)

ОДМ - Операторский дисплейный модуль

ООП - Объектно-ориентированное программирование

ОТИ - Объект транспортной инфраструктуры

ПВ (англ. МF) - Промежуточные волны

ПК - Программный комплекс (сетевых служб взаимодействия в МСУДС)

ПКП - Псевдограф кодовых пересечений

ПОБ - Программа обеспечения безопасности

ППИ - Пункт приема информации на суше

ПСО - Поисково-спасательная операция

ПСПП - Правила совместного плавания и промысла

РИСС - Региональная информационная система наблюдения за судоходством

РЛС - Радиолокационная станция

РЛМО - Радиолокационный маяк-ответчик

РМРС - Российский морской регистр судоходства

РСБМ - Региональная система безопасности мореплавания

РТП - Радиотехнический пост

РТС - Региональная транспортная система

САРП - Система автоматической радиолокационной прокладки

CB (англ. MF) - Средние волны

СКЦ - Спасательный координационный центр

СНC - Спутниковые навигационные средства (системы)

СНО - Средства навигационного оборудования

СОЛАС (от англ. SOLAS, Safety of Life at Sea) - Международная

Конвенция по охране человеческой жизни на море

СПОИ - Станция приема и обработки информации

СРЛС - Судовая радиолокационная станция

ССПД - Система связи и передачи данных 
CCC (англ. SRS, Ship Reporting System) - Система судовых сообщений

СУБ - Система управления безопасностью судоходства

СУБД - Система управления базой данных

СУБ СК - Система управления безопасностью судоходной компании

СУДС (англ. VTS, Vessel Traffic Service) - Система управления движением судов (Служба движения судов)

СУП - Система установления путей движения судов

ТС - Транспортная система (средство)

ТФОП - Телефонная сеть общего пользования

ТЭТ - Технико-эксплуатационные требования

УБПЧ (англ. NBDP, Narrow Band Direct Printing) - Узкополосная буквопечатающая частотная радиотелеграфия, радиотелекс УДС - Управление движением судов

УКВ (англ. VHF) - Ультракороткие волны, метровые волны ФАО - Продовольственная сельскохозяйственная организация ФГУП - Федеральное государственное унитарное предприятие

ФОБ (англ. FSA, Formal Safety Assessment) - Формализованная оценка безопасности

ФЦП - Федеральная целевая программа

ЦИВ (англ. DSC, Digital Selective Calling) - Цифровой избирательный вызов

ЦУДС - Центр управления движением судов

ЦУС - Центр управления системой

ЭКС - Электронно-картографическая система

ALAPA (от англ. As Low As PracticabLe AchievabLe, «настолько низко, насколько это достижимо практически») - Принцип абсолютной безопасности

ALARA (от англ. As Low As ReasonabLe AchievabLe, «настолько низко, насколько это достижимо в пределах разумного) - Принцип приемлемого риска

ECDIS (Electronic Chart Display and Information System) - Навигационно-информационная компьютерная система 
ISO (International Organization for Standardization) - Международная организация по стандартам

MMSI (Mobile Maritime Service Identificator) - Опознаватель Морской подвижной службы

PSC (Port State Control) - Контроль государством порта

ROT (Rate-Of-Turn) - Угловая скорость поворота

SART (Search And Rescue Transponder) - Поисково-спасательный радарный транспондер

VTMIS (Vessel Traffic Management and Information Service) Система информационных служб управления судоходством 


\section{1. ОБЕСПЕЧЕНИЕ БЕЗОПАСНОСТИ В МОРСКИХ ТРАНСПОРТНЫХ СИСТЕМАХ}

\section{1. Цели и задачи обеспечения безопасности мореплавания}

В международном морском праве спектр значений термина «безопасность мореплавания» может варьироваться весьма широко. Он включает в себя предотвращение столкновений судов, аварий на море, борьбу с терроризмом, пиратством, предотвращение актов насилия против лиц на борту судна, если таковые могут угрожать безопасному плаванию судна, и другие составляющие, которые могут предотвратить или минимизировать нарушение безопасности мореплавания.

Целью обеспечения безопасности судоходства является устойчивое и безопасное функционирование морского транспортного комплекса; защита интересов личности, общества и государства, а также объектов и субъектов морской транспортной инфраструктуры и потребителей транспортных услуг.

К объектам инфраструктуры морского порта (инфраструктуры мореплавания) относятся объекты и субъекты, имеющие морские порты конечным пунктом назначения, а именно: торговые суда, суда рыбопромыслового флота, маломерные плавучие средства, их персонал, грузы и багаж, морские вокзалы, якорные стоянки, морские торговые, рыбные, специализированные порты, портовые средства, гидротехнические сооружения, каналы, объекты систем связи, навигации и управления движением морских транспортных средств, а также иные обеспечивающие функционирование транспортного комплекса морского порта здания, строения, сооружения, устройства и оборудование.

Основными задачами обеспечения безопасности мореплавания являются [8]:

- определение угроз безопасности судоходства;

- оценка уязвимости объектов инфраструктуры мореплавания; 
- нормативно-правовое регулирование безопасности мореплавания;

- категорирование объектов инфраструктуры морского порта;

- подготовка специалистов по безопасности мореплавания;

- осуществление контроля и надзора безопасности мореплавания;

- разработка и реализация требований безопасности мореплавания;

- информационное, материально-техническое и научно-техническое обеспечение безопасности мореплавания.

При анализе безопасности мореплавания необходимо учитывать следующие принциипь [13]:

1. Требования по обеспечению безопасности в области морского транспорта разрабатываются и устанавливаются федеральным органом исполнительной власти, уполномоченным в области морского транспорта, по согласованию с федеральным органом исполнительной власти в области обеспечения безопасности, и федеральным органом исполнительной власти, уполномоченным в области внутренних дел, и являются обязательными для исполнения субъектами транспортной инфраструктуры.

2. Требования по обеспечению безопасности морского транспорта должны учитывать нормы в области защиты персонала, пассажиров и грузов от актов незаконного вмешательства, а также соответствовать требованиям государственных стандартов.

3. На отношения в области обеспечения транспортной безопасности не распространяются положения законодательства о техническом регулировании.

Bсе объекты транспортной инфраструктуры морского порта должны соответствовать следующим основным требованиям:

1. Объекты транспортной инфраструктуры (ОТИ), являющиеся объектами повышенной опасности и уязвимости, подлежат обязательной охране в порядке, установленном Правительством Российской Федерации.

2. Объекты транспортной инфраструктуры и транспортные услуги, оказываемые транспортной инфраструктурой морского 
порта, подлежат обязательной сертификации на соответствие требованиям транспортной безопасности.

3. Лицензирование деятельности инфраструктуры морского порта осуществляется при условии обязательной сертификации эксплуатируемых ими объектов инфраструктуры и предоставляемых услуг на соответствие требованиям по обеспечению безопасности мореплавания.

4. Организация обязательной сертификации объектов инфраструктуры морского порта, а также оказываемых услуг по обеспечению безопасности мореплавания осуществляется федеральным органом исполнительной власти, уполномоченным в области морского транспорта в соответствии с федеральными законами и иными нормативными правовыми актами Российской Федерации. Обязательная сертификация осуществляется компетентной организацией в области обеспечения безопасности мореплавания.

5. Государственный контроль (надзор) за соблюдением требований по обеспечению безопасности мореплавания осуществляется федеральным органом исполнительной власти по надзору в области морского транспорта и федеральным органом исполнительной власти в области обеспечения безопасности.

Для каждого объекта инфраструктуры морского порта должна выполняться оценка рисков функционирования. При этом организация проведения оценки рисков возлагается на субъект инфраструктуры морского порта и осуществляется компетентной организацией в области безопасности мореплавания с привлечением специализированных организаций.

Методика оценки уязвимости (рисков) объектов инфраструктуры морского порта предусматривает следующие процедуры:

- разработку ее содержания компетентной организацией в области обеспечения безопасности мореплавания;

- утверждение федеральным органом исполнительной власти, уполномоченным в области морского транспорта (по согласованию с федеральным органом исполнительной власти в области обеспечения безопасности), и федеральным органом исполнительной власти, уполномоченным в области внутренних дел. 
В соответствии с Федеральным законом «О транспортной безопасности» под оценкой уязвимости следует понимать определенные действия инспекторско-ревизорского характера или технического аудита объектов транспортной инфраструктуры и транспортных средств по оценке соответствия степени защищенности объектов тем категориям и требованиям, которые должны быть предварительно присвоены каждому объекту транспортного комплекса. Схема мероприятий, проводимых при оценке уязвимости объекта инфраструктуры морского транспортного комплекса, представлена на рисунке 1.1.1.

ОЦЕНКА УЯЗВИМОСТИ ОБЪЕКТА МОРСКОЙ ТРАНСПОРТНОЙ СИСТЕМЫ

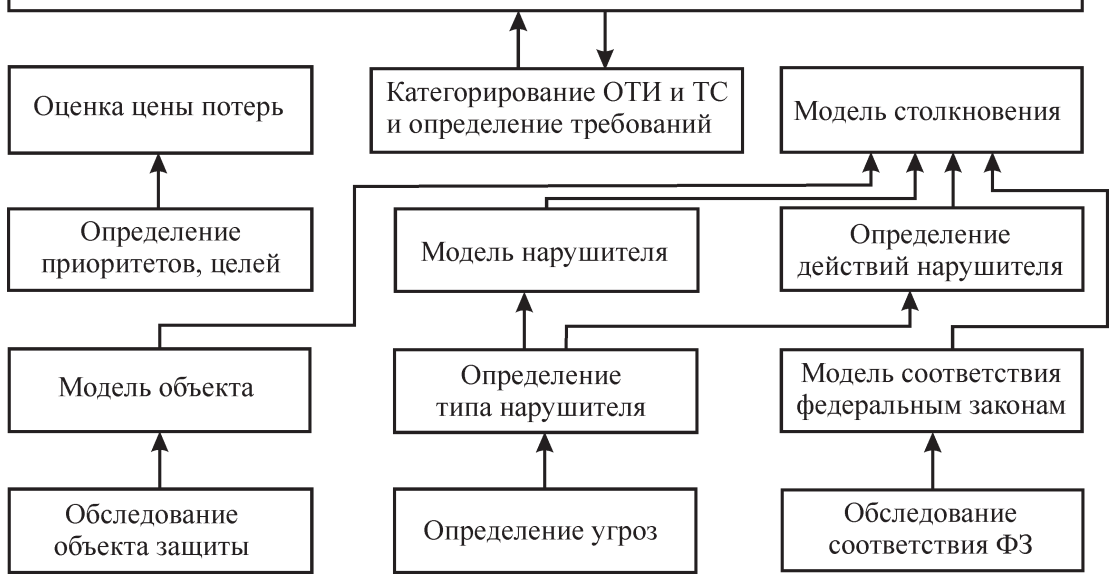

Рис. 1.1.1. Мероприятия по оценке уязвимости объекта инфраструктуры морского транспортного комплекса

По итогам проверки, в случае если объект не соответствует присвоенной категории, должны быть определены рекомендации по приведению объекта в соответствие установленным требованиям, разработан план мероприятий по реализации рекомендаций и приняты практические шаги по их осуществлению с обязательной последующей проверкой исполнения. 


\section{2. Системы обеспечения безопасности мореплавания}

Комплексная система обеспечения безопасности мореплавания должна содержать не менее трех составляющих [33]. К ним относятся:

- навигационная безопасность мореплавания;

- технологическая безопасность;

- система охранных мероприятий в свете требований Кодекса ОСПС.

Для обеспечения навигационной безопасности мореплавания в общем случае выполняются мероприятия по созданию следующих подсистем:

- установленных путей движения судов (УПДС);

- управления движением судов (СУДС);

- мониторинга и автоматического сопровождения судов;

- автоматической информационной системы (АИС);

- средств навигационного оборудования (CHO);

- морской радиосвязи, судовых сообщений и обеспечения информацией;

- правил плавания и других нормативно-правовых актов, регулирующих мореплавание.

Более расширенно эти мероприятия включают следующие действия:

- создание и модификацию систем управления движением судов (СУДС), обеспечивающих плавание судов на подходах к портам и в узкостях, на основе радиолокационного контроля местоположения судов на фарватерах (каналах), АИС, и предоставление судам необходимой навигационной информации в случаях возникновения затруднений и при нарушениях режима движения;

- обеспечение работы морских районов Глобальной морской системы связи при бедствиях (ГМССБ);

- установление правил плавания на акваториях портов;

- организацию лоцманского, буксирного и ледокольного обеспечения движения судов; 
- создание, развитие и поддержание в рабочем состоянии системы средств навигационного оборудования - плавучих, береговых, светящих, радиотехнических и пр., для обеспечения возможности высокоточного определения координат судов и ограждения навигационных опасностей;

- рациональное распределение потоков судов путем создания системы установленных путей движения судов (УПДС), включающей схемы разделения движения, зоны прибрежного плавания, глубоководные пути, специально предназначенные для судов с опасными грузами, места якорных стоянок и др.;

- обеспечение необходимых габаритов элементов, составляющих акваторию порта: разворотных мест, операционных акваторий причалов, ковшей и бассейнов; возможность непрерывного высокоточного определения места судов, гарантирующую их нахождение в отведенных полосах движения при любых условиях видимости;

- информационное обеспечение судов навигационной и гидрометеорологической информацией по региону;

- контроль положения судов и соблюдение ими режима плавания, оказание помощи при затруднениях в определении места, а также в аварийных ситуациях;

- высокую эффективность операций при поиске и спасании, а также при ликвидации последствий аварий;

- надежную радиосвязь между всеми участниками движения и береговыми лоцманами-операторами, контролирующими движение в обслуживаемой зоне, а также с морским спасательно-координационным центром (СКЦ);

- введение нормативных актов (Правил плавания), определяющих обязанности участников движения с учетом маневренных возможностей судов, характера перевозимого груза и систем управления этим движением.

Систему обеспечения безопасности в области морского транспорта образуют также органы законодательной, исполнительной и судебной ветвей власти, компетентная организация и специализированные организации в области безопасности морского транспорта, государственные центры по подготовке специалистов 
в области транспортной безопасности, субъекты инфраструктуры морского порта.

Правительство Российской Федерации организует координацию деятельности федеральных органов исполнительной власти, органов исполнительной власти субъектов Российской Федерации, органов местного самоуправления и субъектов инфраструктуры в области безопасности морского транспорта. Федеральные органы исполнительной власти разрабатывают в пределах своей компетенции предложения по координации деятельности органов исполнительной власти в процессе реализации принятых решений в области обеспечения безопасности морского транспорта и оценивают их эффективность. Для решения оперативных и текущих вопросов, связанных с обеспечением безопасности мореплавания, государственные органы могут создавать межведомственные рабочие группы и комиссии по выработке мер предупреждения и защиты, а также по расследованию причин и обстоятельств, происшедших на объектах морской транспортной инфраструктуры.

Обеспечение безопасности мореплавания достигается проведением на государственном уровне системы мер организационного, экономического, технического и иного характера на плановой основе, адекватных угрозам жизненно важных интересов личности, общества и государства.

Для оценки безопасности могут быть использованы специализированные организации, обладающие компетенцией в области безопасности морского транспорта и выполняющие следующие основные функции [13]:

- проведение оценки уязвимости (рисков) объекта инфраструктуры морского порта;

- разработку планов обеспечения безопасности объектов инфраструктуры морского порта;

- сертификацию объектов инфраструктуры морского порта и транспортных услуг на соответствие требованиям безопасности мореплавания;

- категорирование объектов инфраструктуры морского порта с привлечением специализированных организаций в области безопасности мореплавания; 
- ведение реестра категорированных объектов инфраструктуры морского порта;

- одобрение программ по подготовке специалистов в области безопасности мореплавания;

- внесение в федеральный орган исполнительной власти, уполномоченный в сфере морского транспорта, предложений по аккредитации специализированных организаций в области безопасности мореплавания;

- организацию научно-технического и материально-технического обеспечения безопасности мореплавания.

Безопасность элемента морской транспортной системьл (ТС) можно определить как свойство функционировать без последствий в указанном смысле, а при их возникновении - восстанавливать параметры или нормальное функционирование [13]. В этом случае характеристика уровня безопасности оценивается вероятностью отсутствия таких происшествий или восстановления параметров и функционирования после возникновения происшествий. Очевидно, что вероятность отсутствия происшествий является функцией вероятностей проявления отдельных неблагоприятных факторов, а вероятность восстановления параметров или функционирования зависит от состояния мер технического, организационного, социального и правового характера, а также от тяжести последствий происшествия.

Наше государство, на котором лежит полная ответственность за обеспечение транспортной безопасности, создает эффективную систему защиты транспортной инфраструктуры, ориентируясь на современный зарубежный опыт и учитывая экономические возможности страны. Очевидно, что объекты транспортной инфраструктуры полностью защитить невозможно. Для этого потребовались бы средства, сопоставимые со стоимостью самого транспортного комплекса страны, что не может себе позволить даже самое развитое в экономическом смысле государство. Реально возможно создание такой системы защиты, которая минимизирует ущерб от потенциальных угроз.

По мнению ученых и практиков, наиболее рациональным путем обеспечения транспортной безопасности является категорирование 
(классификация) объектов транспортной инфраструктуры по степени их потенциальной опасности, то есть по величине потенциального ущерба, возникающего в случае наиболее опасного сценария террористической атаки. Затем следует определить необходимую степень защиты для каждой категории объектов на основе оценки рисков нарушения их безопасности. Данный вариант обеспечения транспортной безопасности уже опробован в ряде стран. Такой подход позволяет наиболее эффективно распределить выделяемые для обеспечения транспортной безопасности финансовые, материальные и людские ресурсы.

Подход к построению системы обеспечения безопасности на основе категорирования опасных и критически важных объектов принят у нас в стране и закреплен в Федеральном законе от 9 февраля 2007 года № 16-Ф3 «О транспортной безопасности». Практическая реализация данного закона связана с необходимостью решения целого комплекса технических, технологических, организационноэкономических, методологических и финансовых проблем.

Для оценки степени потенциальной угрозы безопасности мореплавания на объектах инфраструктуры морского порта также может быть использовано категорирование опасности. Под категорией опасности понимается комплексная характеристика, которая отражает степень потенциальной угрозы безопасности мореплавания в случае возникновения аварийных или опасных ситуаций на объектах инфраструктуры морского порта [89].

Критерии категорирования объектов инфраструктуры морского транспорта устанавливаются федеральным органом исполнительной власти, уполномоченным в области морского транспорта, по согласованию с федеральным органом исполнительной власти, уполномоченным в области обеспечения безопасности, и федеральным органом исполнительной власти, уполномоченным в области внутренних дел.

Категорирование объектов инфраструктуры морского транспорта осуществляется компетентной организацией в области безопасности морского транспорта с участием специализированных организаций в области безопасности морского транспорта. 
Категорированные объекты включаются в реестр объектов транспортной безопасности, порядок ведения которого устанавливается федеральным органом исполнительной власти, уполномоченным в области транспорта. Ведение реестра осуществляется компетентной организацией в области транспортной безопасности.

Для различных объектов транспортной инфраструктуры следует использовать различные показатели безопасности.

\section{3. Структура безопасности морских систем}

Функциональная структура любой системы определяет требования к обеспечению ее безопасности. Применительно к морской системе можно выделить следующие основные составляющие [15]:

- безопасность морских транспортных процессов;

- безопасность системы управления плавательными средствами;

- экономическая безопасность;

- экологическая безопасность;

- информационная безопасность;

- антитеррористическая безопасность.

Под транспортным процессом в общем случае понимается перемещение транспортных средств, грузов и пассажиров с целью реализации основных функций ТС.

Безопасность транспортных процессов определяется их свойством обеспечивать приемлемый уровень безопасности для участников этих процессов, функциональных элементов ТС, окружающей среды и населения. Безопасность морских транспортных процессов обеспечивается безопасностью плавательных средств и безопасностью инфраструктуры морского порта.

Безопасность плавательных средств определяет их свойство функционировать безопасно или с нанесением допустимого ущерба для окружающей среды, населения и других элементов TC. Различают собственную безопасность плавательных средств и безопасность перемещения ими грузов и пассажиров.

Безопасность инфраструктуры морского порта характеризуется свойством быть безопасной или обладать приемлемым уровнем 
опасности для транспортных процессов, окружающей среды и населения. Она включает в себя безопасность хранения грузов и плавательных средств, в выполнении погрузочно-разгрузочных работ, утилизации грузов (транспортных средств, объектов инфраструктуры), строительства и эксплуатации объектов.

Безопасность системы управления плавательныли средствами определяется способностью исключать или своевременно парировать возникновение инцидентов, аварийных или чрезвычайных ситуаций для отдельных плавательных средств и объектов инфраструктуры морского порта.

Безопасность системы управления обеспечивается за счет мониторинга, контроля и прогнозирования процессов, протекающих в морской ТС, и складывается из следующих компонентов:

- информационной безопасности ТС и ее компонентов;

- надежности, готовности средств дистанционного контроля и управления;

- надежности системы управления работой плавательных средств;

- безопасности транспортных процессов;

- экономической безопасности.

Экономическая безопасность - свойство ТС обеспечивать экономическую, инвестиционную и иную коммерческую деятельность субъектов ТС при возникновении различного рода рисков, опасных и чрезвычайных ситуаций. Экономическая безопасность включает информационную безопасность ТС и ее компонентов, безопасность системы управления плавательными средствами, безопасность транспортных процессов, антитеррористическую безопасность.

Экологическая безопасность - это безопасность ТС для окружающей среды и населения. Она предполагает анализ трех видов взаимосвязей:

- «человек-техника» внутри транспортной системы, характеризующая экологические и биологические аспекты влияния работы технических средств судовождения и сферы их обслуживания на людей, занятых в сфере судоходства;

- «техника-природа», характеризующая различные аспекты воздействия ТС на природную среду; 
- «техника-население», характеризующая прямое воздействие ТС на население, проживающее на определенной территории.

Экологическая безопасность характеризуется следующими основными показателями:

- уровнем загрязнений (по видам веществ и физическим полям), который определяет объем вредных веществ (излучений), попадающих в природную среду в процессе нормального (штатного) функционирования ТС и ее элементов;

- экологическим ущербом, наносимым загрязнением территории, определяется суммарными затратами, необходимыми на проведение мероприятий по устранению последствий загрязнений;

- экологическим риском, который определяется вероятностью возникновения аварийных ситуаций, оказывающих влияние на состояние окружающей среды или мерой опасности, характеризующей возможность возникновения аварии при транспортировке опасных грузов и тяжесть ее последствий.

Информационная безопасность - показатель, характеризующий безопасность информационных процессов в ТС, ее системе управления и автоматизированных системах, используемых для решения задач управления транспортными процессами [9].

Антитеррористическая безопасность определяет способность ТС и ее составляющих противостоять террористическим проявлениям и целенаправленному воздействию, препятствующему нормальной работе ТС, а также обеспечивать в случае их возникновения безопасность транспортных процессов и населения.

С учетом введенной структуры безопасности морской системы, задача обеспечения безопасного функционирования морской ТС заключается в обеспечении безопасности всех ее составляющих и может быть сформулирована следующим образом [15]:

Пусть $H_{i}$ - количественное значение комплексного показателя для отдельной составляющей безопасности системы.

Необходимо обеспечить условия функционирования системы, при которых $H_{i}$ является максимальной или лежит в диапазоне допустимых значений:

$$
\forall i\left\{H_{i} \rightarrow \max \mid H_{i} \in H_{\text {доп }}\right\} \Leftrightarrow H_{\mathrm{PTC}} \in H_{\text {РТС }}^{\text {доп }}
$$


Для решения данной задачи требуется обеспечить безопасность отдельных функциональных элементов системы, а также протекающих в ней транспортных, информационных и финансовых процессов.

Решение поставленной задачи требует внедрения специализированных систем управления безопасностью мореплавания. Под системой управления безопасностью мореплавания (СУБМ) понимается комплексная организационно-техническая система, выполняющая функции анализа состояния, контроля и обеспечения безопасности отдельных функциональных элементов и процессов системы морского порта и системы в целом.

В интересах обеспечения безопасности мореплавания, безаварийной работы судов, охраны окружающей среды, предупреждения аварийности и охраны человеческой жизни на море СУБМ должна руководствоваться требованиями международных конвенций (СОЛАС-74, МАРПОЛ 73/78, ПДНВ-78 и других), международных кодексов (МКУБ, ОСПС, ЛСА и других), резолюциями Международной морской организации (ИМО), федеральными законами Российской Федерации (Кодексом торгового мореплавания РФ, «О морских портах», «Общими правилами плавания и стоянки судов в морских портах РФ и на подходах к ним», «О внутренних морских водах, территориальном море и прилежащей зоне РФ» и другими), нормативными документами Минтранса России и Федерального агентства морского и речного транспорта.

\section{4. Основные показатели безопасности морских транспортных систем}

Качество работы судоходных компаний и государственных контролирующих органов обеспечения безопасности мореплавания оценивается показателями аварийности на флоте. Всесторонняя оценка риска аварийных ситуаций основывается на анализе причин их возникновения (отказов технических устройств, ошибок персонала, внешних воздействий) и условий развития аварий, поражения производственного персонала, населения, причинения ущерба имуществу эксплуатирующей организации или третьим 
лицам, вреда окружающей природной среде. Опыт показывает, что в качестве основных критериев безопасности морских ТС следует рассматривать следующие показатели [15]:

- значения концентраций опасных веществ (экологическая безопасность);

- уровень аварийности и травматизма на морском транспорте (функциональная безопасность);

- уровень ущерба от аварий и инцидентов на морском транспорте (функциональная безопасность);

- уровень риска как интегральной характеристики безопасности.

При анализе опасностей, связанных с отказами технических устройств, выделяют технический риск, показатели которого определяются соответствующими методами теории надежности.

Одной из наиболее часто употребляющихся характеристик опасности является индивидуальный риск - частота поражения отдельного индивидуума (человека) в результате воздействия исследуемых факторов опасности. Индивидуальный риск выражается отношением числа пострадавших людей к общему числу рискующих за определенный период времени.

При расчете распределения риска по территории вокруг объекта и отображении полей риска показатель «индивидуальный риск» определяется потенциальным территориальным риском и вероятностью нахождения человека в районе возможного действия опасных факторов.

Другим комплексным показателем риска, характеризующим пространственное распределение опасности по объекту и близлежащей территории, является потенцииальный территориальный риск - частота реализации поражающих факторов в рассматриваемой точке территории. Потенциальный риск, в соответствии с названием, выражает собой потенциал максимально возможной опасности для конкретных объектов воздействия, находящихся в данной точке пространства. Как правило, потенциальный риск оказывается промежуточной мерой опасности, используемой для оценки социального и индивидуального риска при крупных авариях. 
Распределения потенциального риска и распределение людей в исследуемом районе позволяют получить количественную оценку социального риска. Для этого нужно определить число пострадавших при каждом сценарии от каждого источника опасности и затем определить зависимость частоты событий $(F)$, в которых пострадало на том или ином уровне число людей, больше определенного $(N)$, от этого определенного числа людей (социальный риск).

Другой количественной интегральной мерой опасности объекта является коллективный риск, определяющий ожидаемое количество пострадавших в результате аварий за определенный период времени.

Для целей экономического регулирования безопасности и страхования важным является такой показатель риска, как статистически ожидаемый ущерб в стоимостных или натуральных показателях (математическое ожидание ущерба или сумма произведений вероятностей причинения ущерба за определенный период на соответствующие размеры этих ущербов).

Для оценки безопасности морского судна целесообразно использовать следующие показатели [15]:

1. Вероятность появления происшествий (реализации класса риска) за время функционирования морского судна $Q(\tau)$.

2. Ожидаемые средние затраты на предупреждение происшествий и снижение возможного ущерба $M_{\tau}[S]$.

3. Ожидаемый средний ущерб от происшествий в случае их появления в период функционирования морского судна $M_{\tau}[Y]$.

В общем случае при анализе риска аварии часто приходится иметь дело с неточными и неполными исходными данными, а в рассмотрение принимается только основная часть спектра сценариев возможных аварий на морском транспорте.

В самом простом случае для решения подобных задач (в дополнение к методам теории вероятностей) могут использоваться методы математической статистики, как для определения законов распределения случайных величин потерь при аварии на морском транспорте, так и для нахождения неизвестных параметров этих распределений. 
При количественной оценке риска аварии задачей-максимум является определение полного ряда распределения рассматриваемых случайных величин $X, D$ и $N$, построение $(F / Y)$-кривых или функций плотности вероятности потерь $G$ от аварии. Задача-минимум - это оценка основных числовых характеристик случайных величин материальных $G$ и людских $N$ потерь: математического ожидания, моды и дисперсии [14].

\section{5. Современное состояние безопасности}

Статистические данные свидетельствуют о том, что за последние 10 лет уровень аварийности судов под российским флагом увеличился в 4 раза. Причем тенденция роста числа и сохранения соотношения различных аварийных ситуаций в целом сохраняется на протяжении достаточно длительного времени [7]. По классификации Российского морского регистра судоходства (РМРC), основными причинами аварийных случаев являются нарушения Международных правил предупреждения столкновений судов (МППСС) в море и Правил технической эксплуатации, ухудшение качества ремонта судов, значительный их возраст и соответственно выработанный ресурс судовых механизмов и оборудования. Кроме того, к ним следует отнести невыполнение судоводителями требований нормативных документов, недостаточное знание маневренных характеристик и правил плавания в сложных навигационных и гидрометеорологических условиях.

Пожары на судах занимают 4-8 \% в учете аварийных случаев, однако это свидетельствует об ослаблении требований со стороны судовладельцев к вопросам пожарной безопасности.

Доминирующей причиной, влияющей на аварийность флота, является человеческий фактор. Работа, проводимая на федеральном уровне, по навигационной безопасности судоходства основана на выполнении международных конвенций, требований национального законодательства и направлена на повышение уровня безопасности мореплавания и предупреждение аварийности судов, совершенствование государственного надзора за торговым мореплаванием. 
Однако ограниченные ресурсные возможности, а также доминирующие коммерческие интересы усугубляют риск аварий и происшествий.

В некоторых судоходных компаниях наметились тенденции к снижению роли служб безопасности мореплавания, сокращению капитанов-наставников, механиков, что оказывает отрицательное влияние на работу по профилактике аварийности, на проведение политики обеспечения безопасности мореплавания.

Статистические данные свидетельствуют об устойчивой тенденции роста числа аварий. Значительно увеличились аварийные ситуации (AC) с судами смешанного (река-море) плавания, с речными судами, выходящими в море (70 \% общего числа АC).

Несмотря на технический прогресс, совершенствование подготовки и повышения квалификации, по-прежнему отмечается слабый уровень подготовки судовых специалистов. Наиболее часто АC происходят по навигационным причинам (посадка судов на мель и столкновения). Имеются основания полагать, что эта тенденция сохранится и в ближайшем будущем. Технические виды АС в настоящее время снижены, пожары и взрывы практически стабильны.

В целом тенденции в структуре аварийности российского флота аналогичны таковым мирового торгового флота [7]. Из материалов расследования АС следует, что штурманская работа на судах не организована должным образом. Контроль безопасного плавания путем непрерывного ведения исполнительной прокладки не осуществляется. При плавании в районах со стесненными условиями наблюдение не усиливается, не используются судовые радиолокационные станции, место нахождения судна не контролируется, выполняется лишь эпизодическое снятие координат с GPS. Причиной столкновений судов часто является нарушение МППСС-72 и отсутствие хорошей морской практики.

Контроль мореплавания и обеспечение безопасности судоходства на акватории порта и на подходах к нему не всегда выполняются с должной ответственностью. Имеются случаи передоверия управления судном лоцману. 
Причины возникновения технических АС в той или иной степени связаны с недостатками в организации работы судовых экипажей, их недостаточной профессиональной подготовкой, в действиях береговых служб управления, технического обслуживания и судоремонта. Причины роста аварийности на морском флоте следует искать в экономических, технических, информационных аспектах деятельности флота, а также в человеческом факторе.

Возраст судов является одной из причин повышения аварийности. Судоходные компании не уделяют должного внимания профилактической работе по снижению аварийности, работая в условиях жесткой конкуренции на рынке морских транспортных услуг (отсутствие стабильной грузовой базы, относительно низкие фрахтовые ставки, значительное налоговое бремя, сложные таможенные процедуры). Предпосылки для АС создает минимизация затрат судоходных компаний на техническое перевооружение и поддержание судна, его машин, механизмов, приборов и систем в требуемом техническом состоянии.

В судоходных компаниях отмечается «информационная недостаточность» по аварийным случаям. Анализ по всем АС зачастую ведется поверхностный, и до экипажей судов доводятся причины лишь некоторых аварий. Такая практика противоречит Международному кодексу проведения расследований аварий и инцидентов на море (Резолюция ИМО А849(20) от 27.11.97 г.), в соответствии с которым целью расследования аварий является предотвращение их в будущем.

Более чем в 85 \% случаев причинами аварий являются ошибки людей. В последние годы наблюдаются снижение базового уровня подготовки и недостаточные практические навыки у моряков, особенно пришедших на морской флот из смежных ведомств. Межведомственная миграция моряков приводит на мостик и в машинное отделение специалистов, не прошедших всех ступеней подготовки либо прошедших их в ускоренном темпе. В системе дополнительной профессиональной подготовки законодательно не закреплена цикличность повышения квалификации моряков. Важнейшие элементы тренажерной 
подготовки по отработке навыков управления судном, несению ходовой навигационной вахты не являются обязательными.

Современные высокоавтоматизированные комплексы морской техники, управляемые автоматами по жестким алгоритмам, освободили человека от большинства рутинных интеллектуальных операций, оставив за ним функции эргатического резерва. Усилилась зависимость безопасности сложных технологических процессов от эффективности управляющих воздействий лиц, принимающих решения в экстремальных условиях и аварийных ситуациях [16, 17]. Учет и описание всего комбинаторного множества нештатных ситуаций в условиях ограниченного времени становится невыполнимой задачей. Для сложных многофункциональных человекомашинных систем невозможно не только вычислить оптимизируемый функционал, но даже представить его в явном виде.

Традиционная технология принятия управленческих решений базируется на использовании многочисленных наставлений, директивных, нормативных, правовых и технических документов на бумажных носителях, плохо приспособленных для поиска, восприятия и переработки необходимой информации. Общие соображения и рекомендации таких документов, безусловно, полезны, но в экстремальных ситуациях они не позволяют быстро находить конкретные управленческие решения. Громоздкая документация и правила ее применения не обеспечивают оперативного проведения сложных расчетов и численных оценок процессов, которые должны быть выполнены с упреждением по отношению к управляемым быстропротекающим событиям.

В резолюции ИМО № А796(19) от 23 ноября 1995 года отмечается, что в настоящее время на современных технически оснащенных судах для принятия решений в аварийных случаях необходимо обращаться к большому числу наставлений и руководств, а находящиеся на мостике дисплеи цифровых неунифицированных приборов не позволяют легко и быстро обнаружить критические тенденции. Процесс поиска информации требует времени, а нерациональное размещение приборных дисплеев на мостике иногда приводит к еще большему замешательству. Для усовершенство- 
вания базы быстрого принятия решений в аварийных ситуациях на судах ИМО рекомендовала создание интегрированной системы контроля и принятия решений в аварийных ситуациях.

Статистика аварийных происшествий показывает, что, хотя прямые причины аварий часто можно отнести на счет действий отдельных лиц, доминирующими чаще всего являются ошибки группы лиц, то есть организационные. Анализ специалистов-психологов показывает наличие все возрастающего разрыва между сложностью современной техники и психологическими возможностями человека как элемента сложной системы «человек-машина». Обслуживающий технику персонал средней квалификации не может оперировать углубленными знаниями в области специальных разделов математики, теории управления и физики сложных процессов, без которых невозможно прогнозировать развитие аварийных процессов и принимать необходимые управленческие решения. Руководящая и операторская деятельность человека на борту судна информационно перегружена и плохо обеспечена технологией принятия управленческих решений, учитывающей психологическое состояние человека, особенно в экстремальных ситуациях. По данным страховых обществ, ошибки людей в области морского транспорта соотносятся с другими причинами аварий не менее как 5:1.

Практически в судоходных компаниях не существует систем экономического стимулирования безаварийной работы экипажей. Некоторые аварии свидетельствуют о недостаточной психологической подготовке моряков адекватно действовать в экстремальных ситуациях.

Важнейшими факторами снижения аварийности является реализация программ обновления флота и его технического перевооружения, а также обеспечение стабильной финансово-экономической работы флота. В значительной степени этому будет способствовать создание Российского международного реестра судов и обеспечение согласованных действий Российского морского регистра судоходства и судоходных компаний по доведению до каждого члена экипажа политики российского классификационного общества в области качества технического надзора. 


\section{6. Показатели безопасности водного транспорта}

Центральное место среди показателей безопасности работы водного транспорта занимают факторы, оказывающие влияние на безопасность самого судна. Их можно условно разбить на пять групп (рис.1.6.1) [15]:

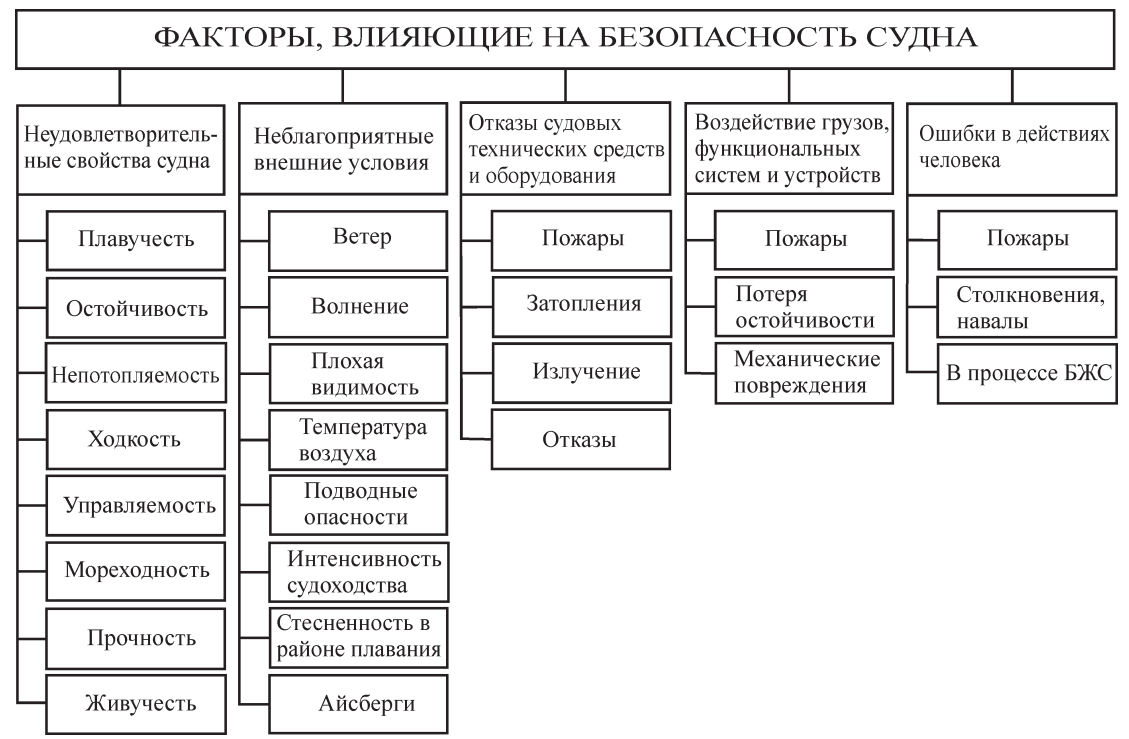

Рис. 1.6.1. Факторы, оказывающие влияние на безопасность судна

- свойства судна (неудовлетворительные плавучесть, остойчивость, непотопляемость, ходкость, управляемость, мореходность, прочность, живучесть);

- неблагоприятные внешние условия: ветер, волнение, течение, плохая видимость (туман, темное время суток), температура воздуха, айсберги, подводные препятствия (рифы, скалы, отмели), интенсивность судоходства, стесненность в районе плавания и т. д.;

- отказы судовых технических средств и оборудования;

- воздействия грузов, функциональных систем и устройств целевого назначения (промысловое оборудование, системы поиска и добычи полезных ископаемых со дна моря и др.); 
- ошибки в действиях экипажа, пассажиров, персонала либо бездействие лиц, обеспечивающих безопасность судна.

Среди факторов, влияющих на безопасность человека, можно также отметить ряд групп (рис. 1.6.2):

- факторы, зависящие от состояния безопасности и надежности судна как транспортного средства в нормальных и аварийных режимах, а также от состава и состояния судовых спасательных средств индивидуального и коллективного пользования;

- факторы, определяющие уровень организации и оснащенности поисково-спасательной службы в стране и взаимодействие ее с поисково-спасательными службами других стран;

- внешние воздействия, метеоусловия;

- психофизиологическое состояние и профессиональная подготовка, дисциплинированность экипажа.

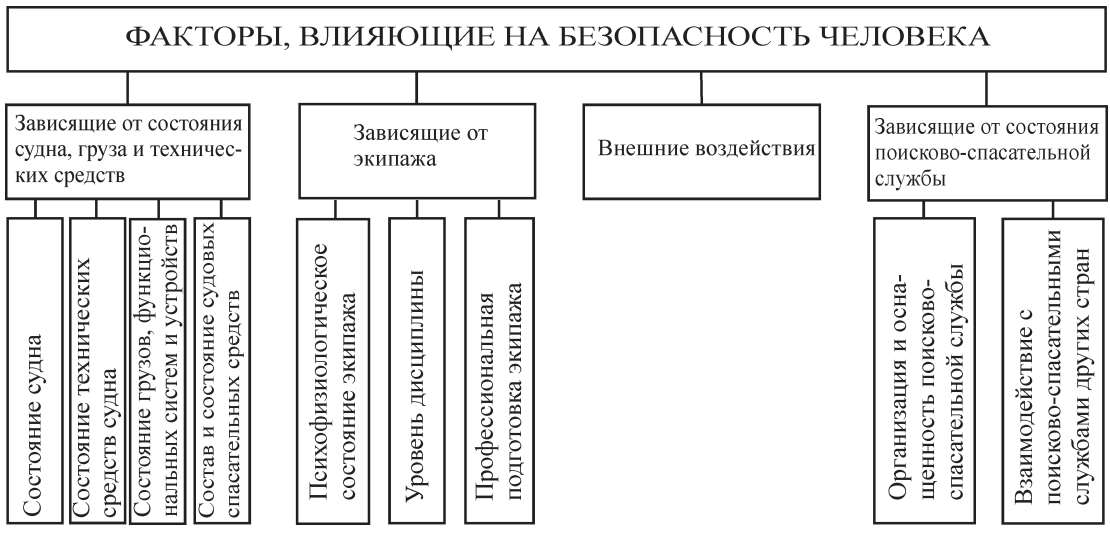

Рис. 1.6.2. Факторы, влияющие на безопасность человека

Опасные воздействия на окружающую среду могут проявляться вследствие следующих причин (рис. 1.6.3):

- аварийные повреждения судна или его технических средств, вызывающих разливы топлива и нефтепродуктов, радиоактивное заражение при авариях судов с ядерными энергетическими установками и т. д.;

- несоблюдения правил хранения и перевозки опасных грузов или несовершенства этих правил; 


\begin{tabular}{|c|c|c|c|c|}
\hline \multicolumn{5}{|c|}{$\begin{array}{c}\text { ФАКТОРЫ, ВЛИЯЮЩИЕ НА БЕЗОПАСНОСТЬ } \\
\text { ОКРУЖАЮЩЕЙ СРЕДЫ }\end{array}$} \\
\hline $\begin{array}{l}\text { Аварийные } \\
\text { повреждения } \\
\text { судна и его } \\
\text { технических } \\
\text { средств }\end{array}$ & $\begin{array}{l}\text { Несоблюдение } \\
\text { правил хранения } \\
\text { и перевозки } \\
\text { опасных грузов }\end{array}$ & $\begin{array}{l}\text { Ошибочные } \\
\text { действия экипа- } \\
\text { жа при заправке, } \\
\text { погрузке- } \\
\text { выгрузке, БЖС }\end{array}$ & $\begin{array}{l}\text { Пожары и } \\
\text { взрывы на } \\
\text { судне }\end{array}$ & $\begin{array}{l}\text { Сильное волно- } \\
\text { образование } \\
\text { при использо- } \\
\text { вании некоторых } \\
\text { типов судов }\end{array}$ \\
\hline
\end{tabular}

Рис. 1.6.3. Факторы, влияющие на безопасность окружающей среды

- ошибочные действия экипажа при заправке топливом, погрузке-выгрузке опасных грузов, осуществлении мер по борьбе за живучесть судна и др.;

- пожары и взрывы на судне, особенно находящемся вблизи других пожаро- и взрывоопасных судов и береговых объектов;

- использование типов судов, особенно быстроходных, создающих мощную волновую систему, приводящую к повреждениям и разрушениям берегов и береговых сооружений.

На безопасность груза влияют следующие факторы (рис. 1.6.4):

- физико-химические и другие свойства грузов;

- условия размещения груза на судне;

\begin{tabular}{|c|c|c|c|}
\hline \multicolumn{4}{|c|}{ ФАКТОРЫ, ВЛИЯЮЩИЕ НА БЕЗОПАСНОСТЬ ГРУЗА } \\
\hline Свойства грузов & $\begin{array}{l}\text { Условия размещения } \\
\text { груза на судне }\end{array}$ & $\begin{array}{l}\text { Внешние } \\
\text { воздействия }\end{array}$ & $\begin{array}{l}\text { Аварийные } \\
\text { повреждения, пожары, } \\
\text { взрывы }\end{array}$ \\
\hline
\end{tabular}

Рис. 1.6.4. Факторы, влияющие на безопасность груза

- внешние условия и воздействия: качка, крен, заливаемость, обледенение;

- аварийные повреждения судна и судовых технических средств, пожары и взрывы.

Можно сформулировать факторы, оказывающие влияние на безопасность остальных элементов системы водного транспорта. Приведенные факторы могут уточняться, дополняться по мере углубления исследований. Чем подробнее учитывается влияние 
факторов, тем точнее могут быть получены количественные показатели безопасности.

С формальной точки зрения безопасность водного транспорта является сложной функцией разнообразных, как правило, случайных факторов и может быть определена в виде

$$
\left\{\begin{array}{l}
P_{c}=F_{1}\left(\Phi_{\mathrm{c} 1}, \ldots, \Phi_{\mathrm{ci}}\right) \\
P_{\ni}=F_{2}\left(\Phi_{э 1}, \ldots, \Phi_{э i}\right) \\
P_{\text {oc }}=F_{3}\left(\Phi_{\text {ос } 1}, \ldots, \Phi_{\text {ос }}\right) \\
P_{\text {гp }}=F_{4}\left(\Phi_{\text {гр } 1}, \ldots, \Phi_{\text {гр } i}\right),
\end{array}\right.
$$

где $P_{c}, P_{э}, P_{o c}, P_{z p}-$ вероятности, относящиеся соответственно к судну, экипажу, окружающей среде, грузу; $\Phi_{\text {сi }}, \Phi_{\text {эj }}, \Phi_{\text {осq }}, \Phi_{\text {грl }}-$ факторы, влияющие на безопасность судна, экипажа, окружающей среды, груза соответственно [15].

В настоящее время для характеристики безопасности водного транспорта нашли применение статистические и вероятностные показатели, которые различают как общие и частные, абсолютные и относительные.

Общие показатели характеризуют безопасность мореплавания независимо от причин аварийности, а частные показатели - безопасность мореплавания по конкретным причинам аварийности или по группе причин.

К общзим абсолютным статистическим показателям безопасности относятся: число аварий, число и валовая вместимость погибших судов, число человеческих жертв, количество и стоимость погибшего груза за определенный промежуток времени, например, за год. К частным абсолютнылм статистическим показателям относятся те же показатели, но вызванные определенной причиной. Эти сведения регулярно публикуются. Журнал «Морской флот» ежемесячно приводит общие абсолютные потери мирового флота (число судов и общая валовая вместимость), а также частные потери по аварийным причинам: столкновения, посадки на грунт, опрокидывание, пожары и взрывы, а также прочие причины. 
Относительные показатели безопасности являются более универсальными. Они характеризуют число аварий и потерь, приведенных к определенному объему выполненных работ (число перевезенных пассажиров, грузов, число рейсов и их продолжительность или протяженность и т. д.). Относительные статистические показатели позволяют оценить достигнутый уровень безопасности, уровень совершенства судов, судовых технических средств, организации и обеспечения аварийно-спасательных работ, степень подготовки и дисциплины экипажа. Главным достоинством статистических показателей, получаемых в результате статистической обработки данных, является их объективность. Вместе с тем эти показатели имеют ряд существенных недостатков. Они отражают уже свершившиеся события, не могут быть использованы для решения перспективных задач управления уровнем безопасности, для поиска путей предотвращения аварий и т. д.

Количественно показатели уровня безопасности удобно выражать в виде вероятностей. Например, вероятность безопасного плавания без аварийных происшествий можно представить показателем

$$
P_{\sigma}=\prod_{i=1}^{n}\left(1-P_{\mathrm{ac} i}\right),
$$

где $P_{\text {асі }}-$ вероятность появления аварийной ситуации от $i$-го источника (фактора).

Выражения вероятностей при оценке различных состояний и процессов различаются. Разработка системы вероятностных показателей безопасности имеет самостоятельное значение и должна основываться на моделях безопасности, которые для каждого конкретного случая и процесса различны. Например, вероятность спасения экипажа $\left(P_{c n}\right)$ при оставлении судна можно определить показателем

$$
P_{\text {спэ }}=P_{\text {спб }}=P_{\text {спАСС }} \cdot\left(1-P_{\text {спб }}\right),
$$

где $P_{\text {спб }}-$ вероятность спасения экипажа с использованием судовых спасательных средств индивидуального и коллективного пользо- 
вания; $P_{\text {спАсс }}-$ вероятность спасения экипажа с помощью средств и сил аварийно-спасательных служб.

При необходимости учета дополнительных факторов (возможность использования экипажем бортовых спасательных средств, использование средств поисково-спасательных служб других государств и т. д.) выражение (1.6.3) усложнится и примет, например, вид:

$$
\begin{aligned}
& P_{\text {спэ }}=P_{\text {спб }}+\left(1-P_{\text {спб }}\right) \cdot P_{\text {спАСС }}+ \\
& +\left(1-P_{\text {спб }}\right) \cdot\left(1-P_{\text {спАСС }}\right) \cdot P_{\text {спИАСС }}
\end{aligned}
$$

где $P_{\text {спилсс }}$ - вероятность спасения экипажа с помощью средств иностранных спасательных служб.

В более общем виде выражение вероятности, характеризующей безопасность человека на море, имеет вид:

$$
P_{\text {бч }}=\left(1-P_{\text {ас }}\right)+P_{\text {ас }} \cdot P_{\text {лас }}+P_{\text {ас }} \cdot\left(1-P_{\text {лас }}\right) \cdot P_{\text {спэ }}
$$

где $P_{\text {ас }}-$ вероятность появления аварийной ситуации; $P_{\text {лас }}-$ вероятность ликвидации или локализации аварийной ситуации; $P_{\text {спэ }}-$ вероятность спасения экипажа.

Изложенное позволяет сделать вывод о том, что для определения количественных показателей безопасности водной системы необходимо решение следующих проблем:

- разработка моделей безопасности для различных элементов системы и с учетом разнообразных ситуаций;

- определение вероятностных характеристик частных событий, входящих в модели безопасности.

Под частными событиями здесь понимается проявление факторов, оказывающих влияние на безопасность. При этом для оценки вероятностных характеристик должны учитываться законы распределения, установленные по результатам предшествующего опыта.

\section{7. Нормирование показателей безопасности}

Под нормированием показателей безопасности в общем случае понимается процесс установления их нормативных значений (нормативов) - предельно допустимых значений. Например, нормативами 
являются минимально допустимое значение показателя безопасности движения $P\left(S_{0}\right)$, максимально допустимое значение показателя риска потери $Q\left(M_{i}\right)$ и показателя экономического ущерба $Q\left(N_{i}\right)$.

Для этого возможно использование двух принципов, основанных на экономическом и этическом подходах к решению задачи. В соответствии с первым принципом нормативы безопасности устанавливаются из условий их экономической целесообразности, а со вторым - по оценкам общества о необходимом уровне безопасности.

Повышение безопасности движения, как правило, связано с инвестициями, поэтому экономическая целесообразность различных проектов определяется по методикам оценки их эффективности. Эффективность любого инвестиционного проекта характеризуется системой следующих основных показателей [12]:

- коммерческой эффективности, учитывающей финансовые последствия реализации проекта для его непосредственных участников;

- бюджетной эффективности, отражающей финансовые последствия осуществления проекта для федерального, регионального или отраслевого бюджетов;

- экономической эффективности, учитывающей затраты и результаты, которые связаны с реализацией проекта и выходят за пределы прямых финансовых интересов участников инвестиционного проекта.

Оценка предстоящих затрат и результатов при определении эффективности инвестиционного проекта осуществляется в пределах расчетного периода, продолжительность которого называется горизонтом расчета. Горизонт расчета измеряется количеством шагов расчета, каждый из которых может быть равным месяцу, кварталу или году.

Сравнение различных вариантов повышения безопасности движения рекомендуется проводить, используя такие показатели, как чистый дисконтированный доход (интегральный эффект), индекс доходности (индекс прибыльности), внутренняя норма доходности (внутренняя норма прибыли), срок окупаемости и др. 
Для решения задачи оптимизации показателей безопасности в экономическом смысле удобно воспользоваться выражением чистого дисконтированного дохода $\left(Э_{\text {инт }}\right)$ при реализации перевозочного процесса:

$$
\ni_{\text {инт }}=\sum_{t=0}^{T}\left(R_{t}-3_{t}\right) \cdot \frac{1}{(1+E)^{t}},
$$

где $T$ - горизонт расчета, равный номеру шага расчета, на котором производится ликвидация технического средства; $t$ - шаг расчета; $R_{t}$ - результаты, достигнутые на $t$-м шаге расчета; $3_{t}$ - затраты, осуществляемые на том же шаге; $E$ - норма дисконта, равная приемлемой для инвестора норме дохода на капитал.

Под дисконтированием понимается приведение разновременных затрат, результатов, эффектов к их ценностям в какой-либо один момент времени, например, начальный $(t=0)$.

В соответствии с выражением (1.7.1) для повышения значения $Э_{\text {инт }}$ необходимо, в частности, уменьшать затраты 3. . В общем случае затраты определяются капитальными вложениями К и текущими затратами $C$, то есть

$$
3=\mathrm{K}+C
$$

сумма дисконтированных капиталовложений определяется с помощью выражения

$$
\mathrm{K}=\sum_{t=0}^{T} \mathrm{~K}_{t} \cdot \frac{1}{(1+E)^{t}},
$$

где $\mathrm{K}_{t}$ - капиталовложения на $t$-м шаге; сумма дисконтированных текущих затрат определяется с помощью выражения

$$
C=\sum_{t=0}^{T} C_{t} \cdot \frac{1}{(1+E)^{t}},
$$

где $C_{t}$ - текущие затраты на $t$-м шаге.

При решении задачи нормирования показателей безопасности целесообразно рассматривать лишь те затраты $3_{\text {, }}$, необходимость 
которых обусловлена обеспечением заданного уровня безопасности:

где

$$
\begin{gathered}
3_{\mathrm{b}}=\mathrm{K}_{\mathrm{b}}+\mathrm{C}_{\mathrm{b}} ; \\
\mathrm{K}_{\mathrm{b}}=\sum_{t=0}^{T} \mathrm{~K}_{\mathrm{b} t} \cdot \frac{1}{(1+E)^{t}}, \\
C_{\mathrm{b}}=\sum_{t=0}^{T} C_{\mathrm{b} t} \cdot \frac{1}{(1+E)^{t}} .
\end{gathered}
$$

Текущие затраты $C_{\text {Б }}$ подразделяются на две части: $C_{\text {Б1 }}$ - затраты, необходимые для поддержания заданного уровня безопасности, и $C_{\text {Б2 }}-$ ущерб от переходов движения в опасные состояния:

$$
C_{\mathrm{b}}=C_{\mathrm{b} 1}+C_{\mathrm{b} 2}
$$

Увеличение безопасности движения, как правило, возможно только в результате увеличения $\mathrm{K}_{\mathrm{5}}$ и $C_{\mathrm{5}}$. Однако с увеличением безопасности движения уменьшается экономический ущерб $C_{\text {Б2 }}$. Кривые идеализированных зависимостей затрат $\mathrm{K}_{\mathrm{b}}+C_{\mathrm{Б} 1}$ и ущерба $C_{\text {Б2 }}$ от уровня безопасности движения приведены на рисунке 1.7.1. Из графика суммарных затрат следует, что существует некоторое оптимальное значение показателя безопасности движения $P_{\text {opt }}\left(S_{o}\right)$, при котором их объем имеет минимальное значение, а чистый дис-

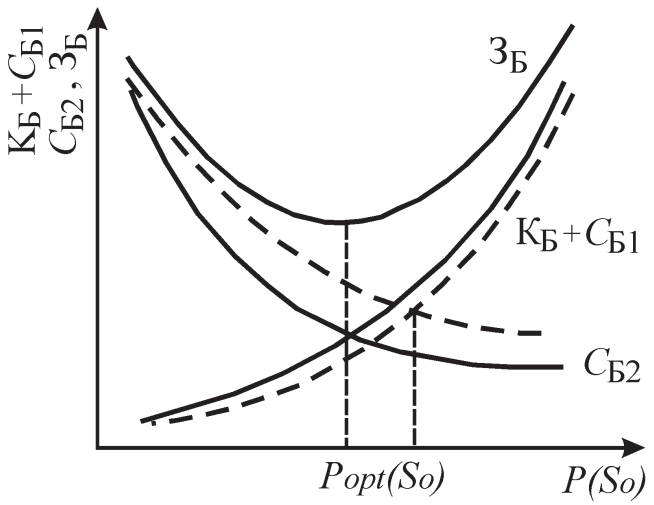

Рис. 1.7.1. Характер изменений объемов $\mathrm{K}_{\mathrm{5}}+C_{\mathrm{5}}, C_{\mathrm{5} 2}, 3_{\mathrm{5}}$ в функции $P\left(S_{o}\right)$ 
контированный доход Э достигает наибольшего значения. В этом заключается принцип установления экономически целесообразного показателя безопасности движения.

Под этически обоснованными нормативами безопасности движения понимаются нормативы, достаточные только относительно норм морали и нравственности конкретного общества. При таком подходе следует принимать во внимание, что абсолютной безопасности движения принципиально достичь невозможно. Кроме того, уровень безопасности движения зависит не только от объема ресурсов, выделяемых на его обеспечение, но и от степени развития науки, техники и технологической базы общества. Отсюда следует, что требования общественности к безопасности движения реально достижимы лишь в рамках ограничений, определяемых объемом научных знаний, освоенных технологий и экономическим состоянием государства.

Результаты нормирования показателей безопасности движения, полученные в соответствии с рассмотренными двумя подходами, не всегда совпадают. Тогда в качестве норматива принимается тот показатель, значение которого больше.

При решении практических задач экономической оптимизациии нормативов безопасности судоходства не удается получить непрерывных зависимостей объемов $\left(\mathrm{K}_{\mathrm{5}}+C_{\text {Б1 }}\right)$ и $C_{\text {Б2 }}$ от величины показателя безопасности $P\left(S_{o}\right)$, как это показано на рисунке 1.7.1. Реально эти графики строятся по точкам. Точки относятся к отдельным вариантам работы ТС, которые обеспечивают различные значения показателей безопасности движения и характеризуются определенными объемами капитальных и текущих затрат, необходимых для обеспечения этих показателей. Различные варианты работы ТС характеризуются различными способами повышения безопасности движения. Эти способы бывают альтернативными, когда применяется только один из них, или неальтернативными, когда возможно их одновременное применение.

Транспортные потери характеризуются потерями различного вида. Это потери грузов, технических средств, объектов хозяйствования, 
потери экологического и социального характера, потери здоровья и жизни пассажиров, технического персонала, населения. Стоимостное выражение потери вида $M_{i}$ рассматривается как экономический ущерб $N_{i}$ от этого вида потери. Каждый из способов обеспечения одного и того же значения показателей безопасности характеризуется своим объемом экономического ущерба:

$$
C_{\mathrm{5} 2}=\sum_{i} N_{i} Q\left(N_{i}\right)
$$

При изменении показателей безопасности технических средств возможно изменение и параметров, влияющих на экономическую эффективность перевозочного процесса. Например, повышение запаса прочности элементов технических средств приводит одновременно к повышению их безопасности и надежности. Известны методы повышения безопасности, когда надежность технических средств уменьшается и, как следствие, возрастает экономический ущерб от неопасных отказов.

Решение задачи оптимизации нормативов безопасности возможно при определенных ограничениях на виды потерь. Например, в случае нормирования безопасности мореплавания в качестве возможных потерь учитываются здоровье и жизнь людей. В таких случаях говорят об оптимизации показателей безопасности в том или ином узком смысле.

Зависимости, приведенные на рисунке 1.7.2, построены с использованием диаграмм Парето. Диаграмма Парето - инструмент, позволяющий выявить и отобразить проблемы, установить основные факторы, с которых нужно начинать действовать, и распределить усилия с целью эффективного разрешения этих проблем.

Горизонтальные оси обеих диаграмм разделены на отрезки, которые соответствуют $N_{\text {в }}$ альтернативным вариантам увеличения значений исследуемых показателей. При построении диаграммы Парето важно, чтобы среди $N_{\text {в }}$ альтернативных вариантов был вариант с оптимальным значением исследуемого показателя. По вертикальной оси каждой диаграммы отложены значения исследуемого показателя. По вертикальной оси диаграммы на рисунке 


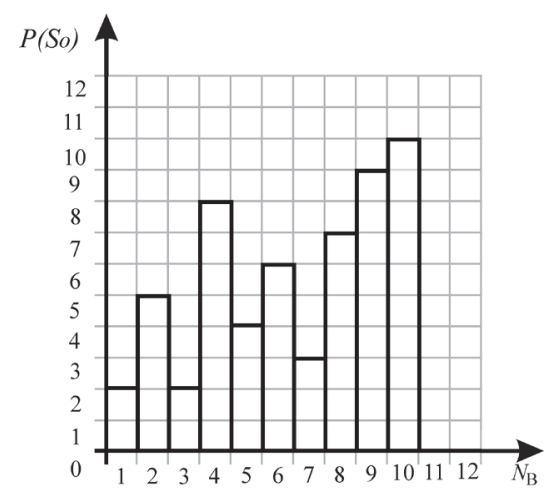

Рис. 1.7.2. Диаграмма

безопасности движения

при альтернативных вариантах ее повышения

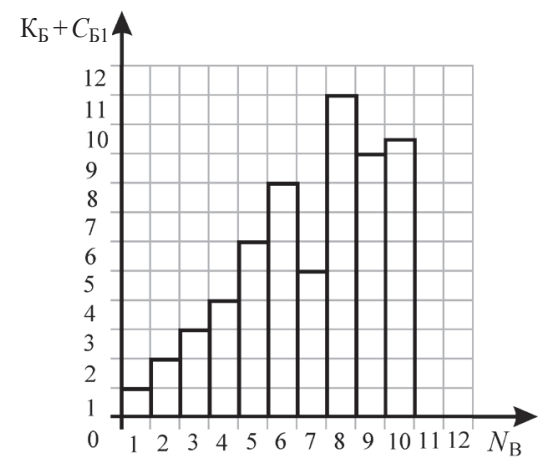

Рис. 1.7.3. Диаграмма затрат на безопасность движения при альтернативных вариантах ее повышения

1.7.3 отложены значения показателя безопасности движения $P\left(S_{o}\right)$, а по вертикальной оси диаграммы на рисунке 1.7 .3 - значения $\left(\mathrm{K}_{\mathrm{5}}+C_{\mathrm{b1}}\right)$ для различных альтернативных вариантов повышения безопасности движения.

На рисунке 1.7.4 в системе координат $\left(\left(\mathrm{K}_{\mathrm{5}}+C_{\mathrm{6} 1}\right) ; P\left(S_{o}\right)\right)$ отмечены точки, соответствующие тем же вариантам повышения безопасности, что и на рисунках 1.7.3 и 1.7.4. Эти точки используют для построения графика зависимости $\left(\mathrm{K}_{\mathrm{5}}+C_{\mathrm{Б} 1}\right)$ от $P\left(S_{o}\right)$. Кривая зави-

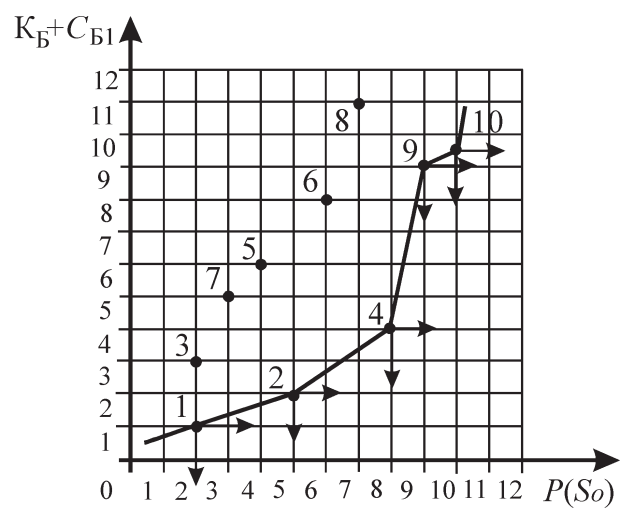

Рис. 1.7.4. Зависимость $\left(\left(K_{\mathrm{5}}+C_{\text {Б1 }}\right) ; P\left(S_{o}\right)\right)$ при альтернативных вариантах повышения безопасности 
симости проходит через точки, соответствующие минимальным значениям $\left(\mathrm{K}_{\mathrm{b}}+C_{\text {Б1 }}\right)$ относительно значения показателя безопасности $P\left(S_{o}\right)$. Варианты, не удовлетворяющие указанному условию, рассматриваются как экономически невыгодные и вследствие этого не используются при построении графика.

Графически ординаты искомой зависимости находятся следующим образом. Для каждой из точек с помощью дополнительных осей координат ограничивают пространство правого нижнего квадранта. Точка считается принадлежащей искомому графику, если в пределах построенного квадранта и на его осях не окажется точек, относящихся к другим вариантам. График зависимости $\left(\left(\mathrm{K}_{\mathrm{5}}+C_{\mathrm{51}}\right)\right.$; $\left.P\left(S_{o}\right)\right)$ проходит через последовательность таких точек, называемых доминирующими.

В тех случаях, когда варианты повышения безопасности движения неальтернативны, построение доминирующей последовательности сводится к выбору такой последовательности вариантов, при которой меньшим значениям $P\left(S_{0}\right)$ соответствуют и меньшие объемы затрат. Для этого строится сначала диаграмма Парето эффективности затрат (рис. 1.7.5) при различных вариантах повышения безопасности $\left(\mathrm{K}_{\mathrm{5}}+C_{\mathrm{b1}}\right)$. В качестве показателя затрат на повышение безопасности применяется отношение приращения показателя безопасности $\Delta P\left(S_{0}\right)$ к приращению затрат на обеспечение безопасности $\Delta\left(\mathrm{K}_{\mathrm{b}}+C_{\mathrm{Б} 1}\right)$ :

$$
\ni_{\mathrm{B}}=\frac{\Delta P\left(S_{o}\right)}{\Delta\left(\mathrm{K}_{\mathrm{b}}+C_{\mathrm{b} 1}\right)}
$$

Здесь под приращениями $\Delta P\left(S_{0}\right)$ и $\Delta\left(\mathrm{K}_{\mathrm{b}}+C_{\mathrm{Б} 1}\right)$ понимается увеличение соответственно показателя безопасности движения и связанных с ним затрат по сравнению с некоторым базовым вариантом. Это может быть вариант с минимальным уровнем безопасности или вариант, применяемый в эксплуатируемой ТС. Диаграмма дает наглядное представление об относительной эффективности сравниваемых вариантов. Используя диаграмму, можно достаточно 
просто определить последовательность применения различных вариантов с целью увеличения показателя безопасности движения.

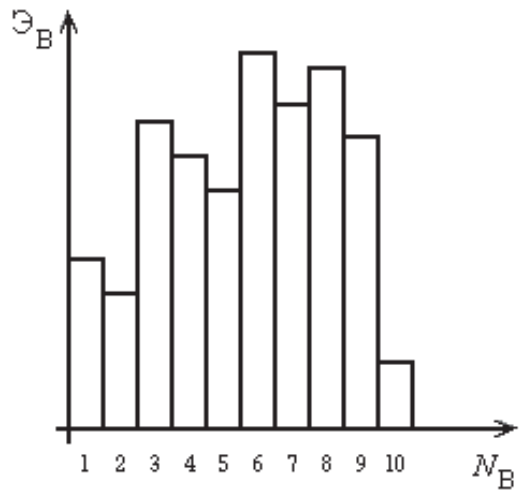

Рис. 1.7.5. Диаграмма изменения эффективности затрат при неальтернативных вариантах повышения безопасности

По диаграмме (рис. 1.7.5) определяем, что первым следует применять вариант 6, затем варианты 6 и 8 и остальные:

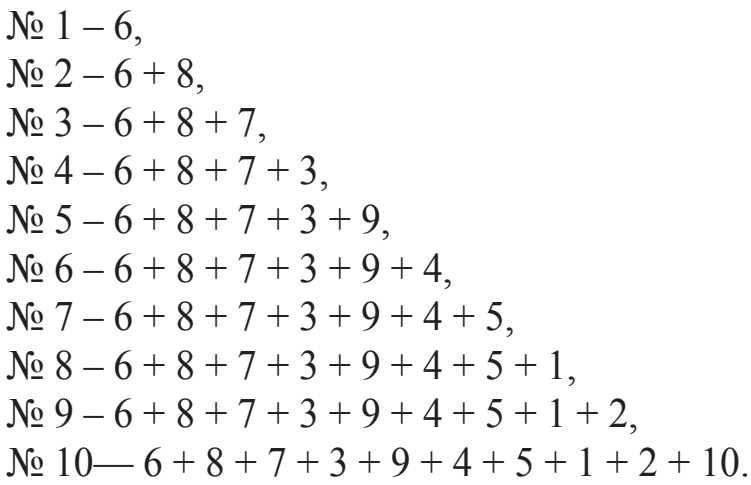

Далее, используя последовательность вариантов 6, 8, 7, 3, 9, $4,5,1,2,10$, строим график зависимости $\left(\left(\mathrm{K}_{\mathrm{b}}+C_{\text {Б1 }}\right) ; P\left(S_{o}\right)\right)$ в виде интегральной накопительной зависимости (рис. 1.7.6). Результаты повышения значения показателя безопасности при одновременном применении нескольких вариантов складываются, т. к. они обладают свойством аддитивности. 
Возможна ситуация, когда существуют как альтернативные, так и неальтернативные варианты. Тогда для построения графика $\left(\left(\mathrm{K}_{\mathrm{5}}+C_{\mathrm{Б} 1}\right) ; P\left(S_{o}\right)\right)$ все варианты разбиваются на альтернативные группы, каждая из которых объединяет неальтернативные варианты. Например, предположим, что альтернативными являются следующие группы:

№ $1-2,4,9$;

№ $2-1,3,7$;

№ $3-5,6,8,10$.

Для каждой группы определяем последовательность вариантов в соответствии с правилом, применяемым для построения графика $\left(\left(\mathrm{K}_{\mathrm{5}}+C_{\mathrm{Б} 1}\right) ; P\left(S_{\mathrm{o}}\right)\right)$ неальтернативных вариантов:

№ $1-9,(9+4),(9+4+2)$;

№ $2-7,(7+3),(7+3+1)$;

№ $3-6,(6+8),(6+8+5),(6+8+5+10)$.

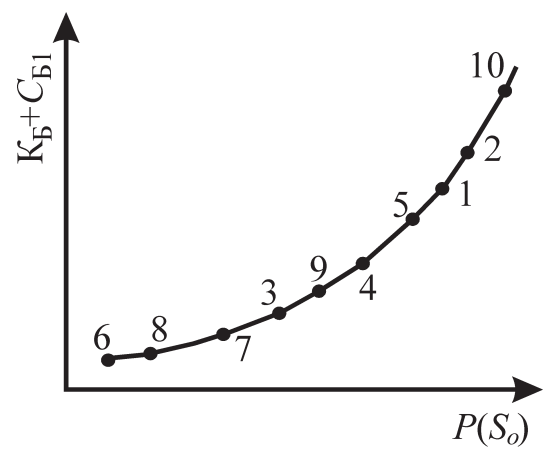

Рис. 1.7.6. Зависимость $\left(\left(\mathrm{K}_{\mathrm{5}}+C_{\mathrm{Б} 1}\right) ; P\left(S_{o}\right)\right)$ при неальтернативных вариантах повышения безопасности

Далее каждый вариант последовательно, в соответствии с его эффективностью, изображаем в системе координат $\left(\left(\mathrm{K}_{\mathrm{b}}+C_{\mathrm{Б} 1}\right)\right.$; $\left.P\left(S_{o}\right)\right)$ в виде точки.

Для получения доминирующей последовательности из множества точек отбираем часть в соответствии с правилом, изложенным при рассмотрении альтернативных вариантов. Для определения экономически оптимального значения норматива безопасности движения строим график зависимости $\left(C_{\mathrm{Б1}} ; P\left(S_{o}\right)\right)$. 
Для каждого из вариантов повышения безопасности движения, рассмотренных выше при определении зависимости $\left(\left(\mathrm{K}_{\mathrm{5}}+C_{\mathrm{61}}\right)\right.$; $\left.P\left(S_{o}\right)\right)$, рассчитываем объем экономического ущерба $C_{\text {Б2 }}$. Под экономическим ущербом понимается результат воздействия на плавательное средство и среду движения поражающих факторов $H_{j}$, которые возникают в результате перехода движения плавательного средства в опасные состояния $S_{o k}$. Для снижения потерь, и соответственно экономического ущерба, необходимо снижать вероятность возникновения опасных состояний движения $Q\left(S_{o k}\right)$ и условные вероятности возникновения поражающих факторов $H_{j}$ в этих опасных состояниях $Q\left(H_{j} / S_{o k}\right)$.

Величина вероятности $Q\left(H_{j} / S_{o k}\right)$ при одном и том же значении $Q\left(S_{o k}\right)$ может быть различной. Например, для снижения вероятности разлива опасных жидкостей, перевозимых танкерами, они оборудуются специальными защитными устройствами. В результате снижается условная вероятность возникновения поражающего фактора в виде разлива опасной жидкости, например, нефти. Объем ущерба зависит также от эффективности защитных мероприятий, которые разрабатываются на случай возникновения аварий. К таким мероприятиям, например, относится создание запаса материалов получателем груза для исключения остановки производства из-за недопоставки в результате аварии.

При определении зависимости $\left(3_{5} ; P\left(S_{o}\right)\right)$ в общем случае необходимо оценивать экономическую целесообразность всех мероприятий по снижению объема потерь, осуществляемых всеми заинтересованными сторонами. Для этого можно использовать совмещенную диаграмму Парето (рис. 1.7.7). На горизонтальную ось диаграммы наносим номера вариантов $N_{B}$ снижения ущерба. На положительной вертикальной оси откладываем дополнительные затраты $\Delta\left(K_{\mathrm{5}}+C_{\mathrm{Б} 1}\right)$ на снижение объема ущерба. На отрицательной вертикальной оси наносим значения снижения ущерба $C_{\text {Б2 }}$. Экономически целесообразными являются те мероприятия, для которых выполняется условие $\Delta C_{\text {Б2 }}>\Delta\left(\mathrm{K}_{\mathrm{5}}+C_{\text {Б1 }}\right)$.

Из диаграммы (рис. 1.7.7) следует, что экономически целесообразными являются варианты 1, 2, 4, 6, 7, 8, 9. Если эти варианты 
неальтернативны, то очередность их применения определяется последовательностью 7, 2, 8, 4, 6, 1, 9. Эффективность применения вариантов 1, 9, и 4, 6 одинакова, поэтому очередность их применения не имеет значения.

Предположим, что изображенные на рисунке 1.7.1 сплошными линиями зависимости относятся к случаю, когда использованы наиболее рациональные варианты повышения $P\left(S_{o}\right)$ и все экономически целесообразные варианты снижения ущерба. Тогда, если одно или несколько экономически целесообразных мероприятий не будет использовано, линия зависимости $\left(\left(\mathrm{K}_{\mathrm{5}}+C_{\mathrm{61}}\right) ; P\left(S_{\circ}\right)\right)$ пройдет

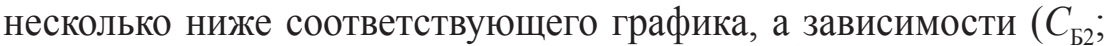
$\left.P\left(S_{o}\right)\right)$ выше. Это приведет к увеличению $P_{\text {opt }}\left(S_{o}\right)$ и увеличению минимального значения 3 .

Оптимальное в экономическом смысле значение показателя безопасности движения определяем с помощью графика зависимости $\left(3_{\mathrm{5}} ; P\left(S_{o}\right)\right)$. Седловая точка этого графика соответствует минимуму $3_{\text {Б }}$ и определяется из условия:

$\mathrm{K}_{\mathrm{b}}+C_{\mathrm{b} 1}=C_{\mathrm{b} 2}$.

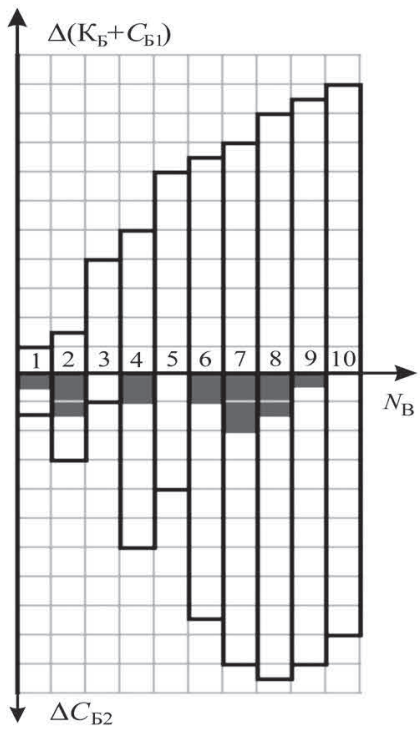

Рис. 1.7.7. Совмещенная диаграмма Парето изменения дополнительных затрат по снижению ущерба 
Минимальная величина затрат $3_{\text {Б }}$ может быть найдена непосредственно из условия (1.7.12) без графических построений. Графические построения позволяют более наглядно продемонстрировать метод оптимизации показателя безопасности движения. Седловая точка зависимости $\left(3_{5} ; P\left(S_{\text {o }}\right)\right)$ может не соответствовать ни одному из реальных вариантов. В этом случае в качестве оптимального принимается вариант, который в наибольшей степени соответствует условию (1.7.12).

После определения оптимального значения показателя безопасности движения $P_{\text {opt }}\left(S_{o}\right)$, с учетом мероприятий по его обеспечению, можно определить нормативы показателей безопасности всех структурных составляющих подсистем региональных транспортных систем. В качестве норматива принимается значение показателя безопасности структурной составляющей подсистемы PTC, которое обеспечивает экономически оптимальное значение показателя безопасности движения.

Этический норматив безопасности движения устанавливается относительно потери жизни и здоровья человека. Непосредственно должно нормироваться значение показателя риска потери жизни человека в результате перехода движения плавательного средства в опасное состояние. Использовать строгие научные методы (или, по крайней мере, методы, находящиеся на уровне методов, применяемых при установлении экономически оптимальных нормативов безопасности движения) при этом не представляется возможным.

Установление этического норматива гибели человека в результате аварий в значительной степени зависит от духовного состояния общества, от состояния социальной, политической и экономической системы государства. Чем больше развита и сориентирована на решение социальных проблем экономика общества, тем выше ценится в нем личность и ее безопасность. Вместе с тем жесткость требований общественности к безопасности движения, как и к безопасности других ответственных технологических процессов, зависит от особенностей психики отдельного человека. Так, результаты исследований показывают, что при вероятности гибели человека $10^{-6}$ в год в результате техногенных чрезвычайных ситуаций 
общественность обычно не выражает чрезмерной озабоченности. Основываясь на этом, многие специалисты принимают величину $10^{-6}$ как нормативное значение показателя техногенного риска гибели человека. Эту величину можно принять за психологически обоснованный норматив показателя риска гибели человека.

Отношение людей к этической величине риска зависит от того, насколько они свободны в принятии решений подвергать себя этому риску или нет. Например, решение об участии в регате или в соревновании с целью установления спортивного рекорда принимает сам спортсмен (судоводитель). Другое дело, когда человек в силу независящих от него обстоятельств вынужден пользоваться услугами морского транспорта. В этих случаях различие в оценке приемлемой величины показателя риска потерь достигает трех порядков, причем во втором случае требования к безопасности более жесткие.

Другой особенностью человеческой психики является то, что человек считает одиночные, но с тяжелыми последствиями чрезвычайные ситуации менее приемлемыми, чем большое количество происшествий с менее тяжелыми последствиями. Например, общественность более резко реагирует на относительно редкие крупные морские аварии с большими человеческими жертвами, чем на ежедневную гибель людей в автомобильных катастрофах. При этом гибель морского судна рассматривается как событие действительно неординарное, а автомобильные происшествия - явление повседневное, как неизбежный атрибут современной жизни большого города. В то же время известно, что безопасность движения автомобиля существенно ниже, чем морского судна.

Таким образом, установление этического норматива показателя риска гибели человека при его морском перемещении должно осуществляться с учетом реального состояния общества, общей безопасности личности в обществе, а также с учетом текущего состояния безопасности мореплавания. Если этический норматив риска гибели человека окажется более жестким, чем экономически целесообразный, то на его основе должны устанавливаться и нормативы безопасности отдельных структурных составляющих морских подсистем. 
В этом случае с помощью методов, рассмотренных выше, определяется наиболее рациональный в экономическом смысле вариант реализации подсистемы, обеспечивающий норматив риска гибели человека. Значения показателей безопасности структурных составляющих такой системы и принимаются в качестве нормативных.

\section{8. Стандартизация показателей безопасности судоходства}

Нормирование показателей безопасности мореплавания и рисков потерь является частью более общего процесса, называемого стандартизацией. Согласно Закону Российской Федерации «О стандартизации», стандартизаиия - это деятельность по установлению норм, правил и характеристик в целях обеспечения безопасности продукции и услуг для окружающей среды, жизни, здоровья и имущества, безопасности хозяйственных объектов с учетом риска возникновения природных и техногенных катастроф и других чрезвычайных ситуаций, а также в других целях.

Государственное управление стандартизацией в России осуществляет Федеральное агентство по техническому регулированию и метрологии (Госстандарт России). К нормативным документам относятся государственные стандарты Российской Федерации; применяемые в установленном порядке международные стандарты, правила, нормы и рекомендации по стандартизации; стандарты отраслей; стандарты предприятий; стандарты научно-технических, инженерных и других общественных объединений.

Нормативные документы по стандартизации на продукцию и услуги, в том числе судоходные, подлежащие обязательной сертификации, должны содержать требования, по которым осуществляется обязательная сертификация, методы контроля на соответствие этим требованиям, правила маркировки продукции и услуг, требования к информации о сертификации, включаемой в сопроводительную документацию.

Государственные стандарты разрабатываются на продукцию и услуги, имеющие межотраслевое значение, и не должны 
противоречить законодательству Российской Федерации. Государственные стандарты должны содержать, в частности, требования к продукции, работам и услугам по их безопасности для окружающей среды, жизни, здоровья и имущества. Эти требования являются обязательными для соблюдения государственными органами управления и субъектами хозяйственной деятельности.

Нормативные документы по стандартизации должны применяться государственными органами управления и объектами хозяйственной деятельности на стадиях разработки, подготовки продукции к производству, ее изготовления, реализации, использования (эксплуатации), хранения, транспортирования, при выполнении работ и оказании услуг, разработке технической документации (конструкторской, технологической, проектной), в том числе технических условий. Это положение в полной мере относится и к такой продукции, как технические средства судовождения.

Органами, осуществляющими государственный контроль и надзор за соблюдением обязательных требований государственных стандартов, являются Госстандарт России и другие, специально уполномоченные органы управления в пределах их компетенции. Юридические и физические лица, а также органы государственного управления, виновные в нарушении положений Закона РФ «О стандартизации», несут (в соответствии с действующим законодательством) уголовную, административную либо гражданскоправовую ответственность. 


\section{Контрольные вопросы}

1. Что является целью обеспечения безопасности судоходства?

2. Назовите основные задачи обеспечения безопасности мореплавания.

3. Назовите системы обеспечения навигационной безопасности мореплавания.

4. Что понимается под безопасностью элемента морской транспортной системы?

5. Что характеризует категория опасности объекта инфраструктуры морского порта?

6. Назовите основные составляющие безопасности морской системы.

7. Назовите основные показатели безопасности морской транспортной системы.

8. Какие факторы влияют на безопасность судна?

9. Назовите факторы, влияющие на безопасность человека и окружающей среды.

10. Что понимается под нормированием показателей безопасности? 


\section{2. МОДЕЛИ БЕЗОПАСНОСТИ СУДОХОДСТВА}

\section{1. Причины аварийных ситуаций на водном транспорте}

Обеспечение безопасности человека на море было и остается важнейшей проблемой судоходства, судостроения и смежных областей производства. Обеспечение сохранности человеческой жизни и имущества на море определяет понятие безопасности мореплавания.

Под навигаиионной опасностью судна понимается внешний по отношению к судну объект, непредвиденное или непредотвратимое столкновение (соударение, соприкосновение) с которым может привести к потере судном мореходного состояния.

Опасными внешними объектами являются естественные подводные, надводные или осыхающие объекты рельефа морского дна и побережья, подводные объекты искусственного происхождения (подводные препятствия), плавающие неуправляемые предметы (бревна, деревья, утерянные рыболовные снасти, сорванные с якорей буи, бочки, мины и т. д.), технические сооружения на море и на побережье (буровые вышки, платформы, мосты и т. п.).

Навигационные опасности по характеру воздействия можно подразделить на опосредствованно и непосредственно воздействующие. К опосредствованно воздействующим относятся такие опасности, которые сами по себе не могут лишить судно мореходного состояния, но создают условия, способствующие этому. К таким опасностям относятся туманы, сильные ветры (за исключением случаев, когда динамическое воздействие ветра может привести к потере остойчивости), низкая температура воздуха, снежные заряды и т. п. Эти гидрометеорологические явления считают особо опасными и чрезвычайными [19].

Непосредственно воздействуюшие опасности можно классифицировать по характеру их воздействия на судах [22]:

- ударного механического,

- вытесняющего из воды, 
- электрического и электрохимического,

- горения,

- потери плавучести,

- смещения центра масс и т. д.

Опасности можно также классифицировать по виду вреда, причиняемого их воздействием:

- повреждение или разрушение корпуса судна или судовых конструкций;

- посадка судна на грунт;

- опрокидывание судна;

- затопление судна;

- потеря или ограничение движения судна;

- гибель и телесные повреждения людей;

- утрата груза, его повреждение или потеря им потребительских свойств;

- повреждение технических сооружений в море или на берегу;

- неконтролируемое нарушение экологического равновесия окружающей среды и т. д.

Одна и та же по физической природе опасность может относиться к различным группам по виду причиняемого вреда. Так, штормовое волнение моря может проявляться как опасность, причиняющая повреждения корпусу судна, или вызывающая опрокидывание судна, или как опасность, воздействующая опосредствованно и способная привести к посадке судна на мель или на рифы.

Количественная оценка опасности как вероятности утраты судном мореходного состояния в данной конкретной обстановке на интервале времени $d t$ определяется в зависимости от вероятностей утраты мореходного состояния при воздействии опасных факторов [22]:

$$
\begin{aligned}
& P_{n}=1-\left[1-p_{1}(d t)\right] \times\left[1-p_{2}(d t)\right] \times \ldots \times\left[1-p_{n}(d t)\right]= \\
& =1-\prod_{i=1}\left[1-p_{i}(d t)\right],
\end{aligned}
$$

где $p_{i}(d t)$ - вероятность утраты мореходного состояния под воздействием $i$-го фактора. 
Пример 1. Пусть при плавании в открытом море при удовлетворительном состоянии погоды вероятности потери судном мореходного состояния в течение суток равны следующим величинам:

- от столкновения с незамеченным плавающим предметом $1 \times 10^{-7}$,

- от столкновения с другим судном - $1 \times 10^{-6}$,

- от пожара $1 \times 10^{-8}$,

- от отказа механизмов и конструкций $-1 \times 10^{-7}$.

Тогда в соответствии с формулой (2.1.1) вероятность потери мореходного состояния судном при плавании в открытом море в течение суток равна

$$
\begin{aligned}
& P=\left[1-1 \times 10^{-7}\right] \times\left[1-1 \times 10^{-6}\right] \times\left[1-1 \times 10^{-8}\right] \times \\
& \times\left[1-1 \times 10^{-7}\right]=1,21 \times 10^{-6}
\end{aligned}
$$

Пример 2. Пусть при плавании судна по фарватеру вероятность потери мореходного состояния от отказа механизмов и конструкций не изменилась, а другие вероятности потери мореходного состояния равны:

- от столкновения с незамеченным плавающим предметом $1 \times 10^{-6}$,

- от столкновения с другим судном - $1 \times 10^{-5}$,

- от посадки на мель $-1 \times 10^{-5}$,

- от столкновения с гидротехническими сооружениями и знаками навигационного ограждения $-1 \times 10^{-5}$.

Тогда вероятность потери мореходного состояния судном при плавании по фарватеру в течение суток равна

$$
\begin{aligned}
& P=1-\left[1-1 \times 10^{-6}\right] \times\left[1-1 \times 10^{-5}\right] \times\left[1-1 \times 10^{-5}\right] \times\left[1-1 \times 10^{-5}\right] \times \\
& \times\left[1-1 \times 10^{-5}\right] \times\left[1-1 \times 10^{-7}\right]=3,111 \times 10^{-4},
\end{aligned}
$$

таким образом, опасность возросла в 25,7 раза.

Разумеется, для определения значений $p_{i}(d t)$ необходимы накопление и анализ статистического материала, но даже приближенная 
их оценка может оказаться полезной для определения хотя бы относительной степени опасности.

Важное место в исследовании проблем безопасности принадлежит формализации и моделированию различных аспектов систем водного транспорта. При этом под формализащией в последующем подразумевается упорядоченное и специальным образом организованное представление исследуемых объектов, процессов в них, их целей и свойств, а под моделированием понимается использование полученных в результате формализации искусственных образований, имеющих идентичные оригиналу характеристики, в целях получения новых данных или знаний об исследуемых категориях.

Формализация развития процесса перехода нормального функционирования или нормальных параметров системы в такое аварийное состояние, при котором возникает или реализуется реальная угроза гибели судна, жизни человека, потери груза, нарушению окружающей среды и т. д., занимает центральное место в формировании модели управления безопасностью судоходства.

Развитие аварийной ситуации на водном транспорте проиллюстрировано на рисунке 2.1.1. Аварийный процесс может происходить по одной или нескольким ветвям схемы модели аварийной ситуации (АС) [13].

Несмотря на наглядность и простоту рассмотренной модели, очевиден ее основной недостаток - она не дает представления о численном значении и «весовом» показателе отдельных параметров и факторов, оказывающих влияние на безопасность.

Меры по снижению рисков при мореплавании должны разрабатываться с учетом степени влияния тех или иных факторов на развитие АС, приводящее к трагическим последствиям в конкретных условиях. В этих целях целесообразно применение причинноследственной модели возникновения аварий водного транспорта [13]. Вариант такой модели изображен на рисунке 2.1.2. Здесь выделены различные категории причин: объективные, главные, сопутствующие и непосредственные.

Объективные причины не связаны с конкретными условиями плавания конкретного судна. Они определяются сложившейся 


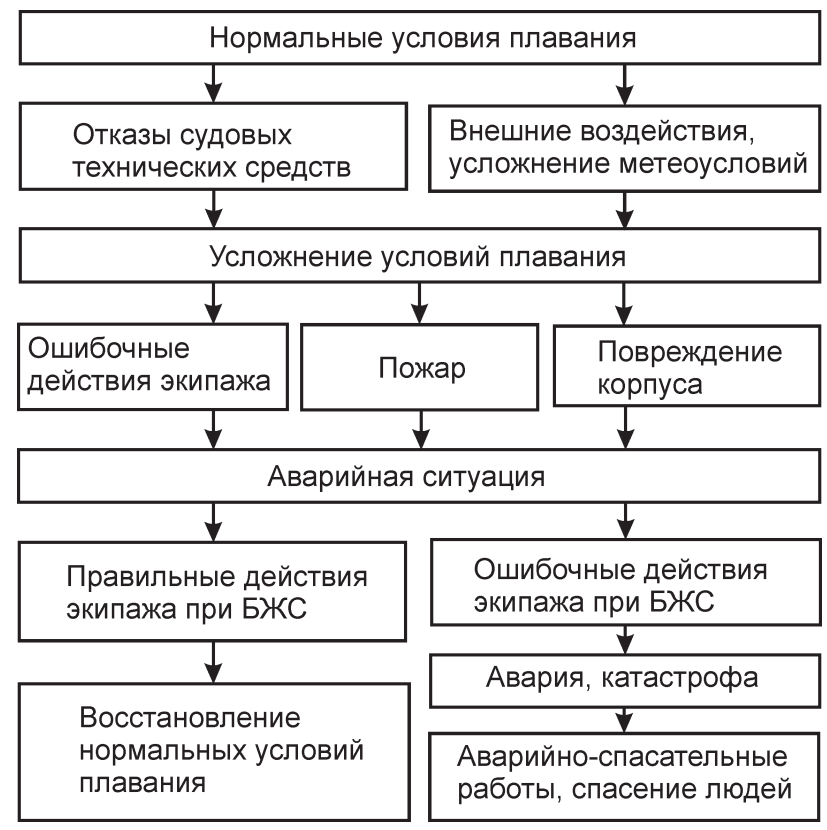

Рис. 2.1.1. Схема развития аварийных ситуаций

в стране системой обеспечения безопасности на море и могут служить основанием для проявления причин других категорий. Важность выявления объективных причин состоит в том, что их устранение может способствовать радикальному снижению риска, хотя и потребует, возможно, принятия мер на государственном уровне.

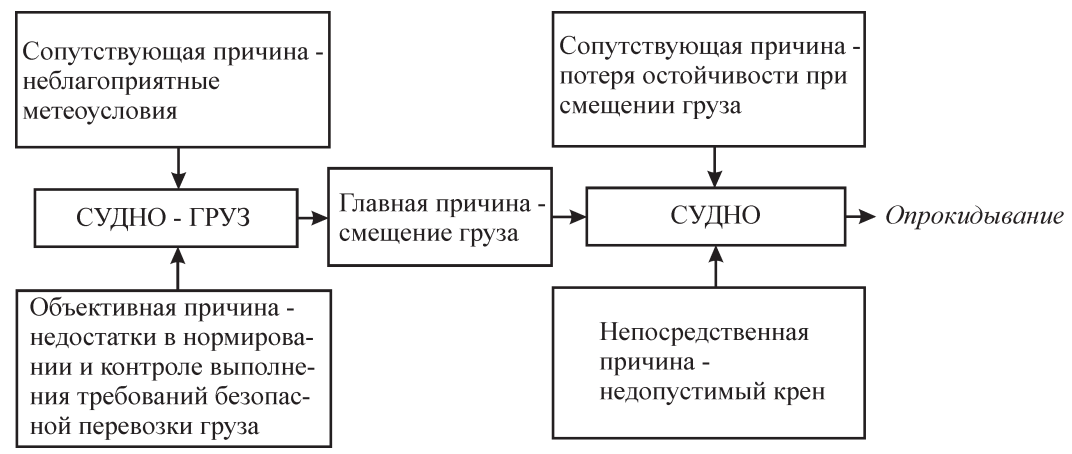

Рис. 2.1.2. Причинно-следственная модель возникновения аварий 
Главная причина создает потенциальную возможность возникновения аварийной ситуации, она связана с конкретным судном, его составной частью, экипажем данного судна, свойствами перевозимого груза и конкретными условиями эксплуатации.

Непосредственные и сопутствующие причины создают реальные условия для превращения потенциальной возможности в действительность.

При расследовании аварийных случаев могут возникнуть различные точки зрения по отнесению тех или иных причин к соответствующей категории, а также по определению самих причин. В этом случае целесообразно применение метода экспертных оценок (с привлечением независимых экспертов).

Аварийный случай возникает обычно в результате совместного действия нескольких неблагоприятных факторов из-за причин разных категорий, причем один и тот же фактор в зависимости от обстоятельств может выступать в качестве различных по категории причин.

Вид и детализация разрабатываемой модели безопасности зависит от конкретной задачи, стоящей перед исследователем. Разнообразные факторы могут классифицироваться в зависимости от источника возникновения [13]:

- технические факторы;

- личностные факторы;

- факторы воздействия внешней среды.

При анализе технических факторов необходимо учитывать (помимо показателей надежности) также состав, степень автоматизации, соответствие мировому уровню развития технических средств и оборудования, средств контроля, методов и средств борьбы за живучесть судна, спасательных средств. Этот учет, в частности, позволит более обоснованно установить вероятностные характеристики появления, ликвидации (локализации) аварийной ситуации, спасения экипажа.

На каждом этапе жизненного цикла судна стоят вполне определенные задачи по обеспечению безопасности. Формулировки этих задач не содержат в полной мере качественных и количественных 
требований, которые должны обеспечиваться и подтверждаться в процессе проектирования, изготовления, испытаний и эксплуатации судов. При создании и эксплуатации судна должны быть реализованы организационные и технические мероприятия, которые обеспечивают безопасность и направлены на достижение, поддержание и контроль заданного уровня безопасности для всех элементов системы. С этой целью в составе обязательных документов при проектировании судна необходимо предусматривать разработку «Программы обеспечения безопасности» (ПОБ), которая должна определять перечень работ и мероприятий, проводимых на всех стадиях жизненного цикла. При разработке ПОБ может быть учтен опыт работы при создании других видов транспортных средств (рис. 2.1.3).

\begin{tabular}{|c|c|c|c|}
\hline \multicolumn{4}{|c|}{ ОБЕСПЕЧЕНИЕ БЕЗОПАСНОСТИ ВОДНОГО ТРАНСПОРТА } \\
\hline $\begin{array}{l}\text { Разработка и реализация } \\
\text { требований } \\
\text { "Программы обеспечения } \\
\text { безопасности" на всех } \\
\text { этапах жизненного } \\
\text { цикла }\end{array}$ & $\begin{array}{l}\text { Совершенствование } \\
\text { и расширение } \\
\text { функциональных } \\
\text { возможностей систем } \\
\text { управления } \\
\text { движением судов }\end{array}$ & $\begin{array}{l}\text { Создание единой } \\
\text { государственной } \\
\text { морской поисково- } \\
\text { спасательной } \\
\text { службы (ЕГМПСС) }\end{array}$ & $\begin{array}{l}\text { Профессиональная } \\
\text { подготовка, } \\
\text { медицинское, } \\
\text { правовое, социальное } \\
\text { обеспечение } \\
\text { экипажей судов }\end{array}$ \\
\hline
\end{tabular}

Рис. 2.1.3. Мероприятия по обеспечению безопасности водного транспорта

Наряду с этим необходимо осуществление разносторонних мероприятий в следующих областях:

- профессиональной подготовки, медицинского, правового и социального обеспечения экипажей судов;

- совершенствования и расширения функциональных возможностей систем управления движением судов (СУДС);

- создания единой государственной морской поисково-спасательной службы (ЕГМПСС), в задачи которой должно входить оперативное осуществление аварийно-спасательных и поисковых работ.

Помимо вышеперечисленных мероприятий, необходимо уделять особое внимание разработке и совершенствованию системы управления безопасностью судоходных компаний (СУБ СК). 
Количественная оценка степени опасности эксплуатируемого оборудования является одним из важнейших этапов анализа безопасности. Получение априорной количественной оценки опасности создаваемого оборудования путем проведения специальных натурных испытаний, включающих возможность возникновения происшествий и связанного с ними ущерба, является неприемлемой по этическим и экономическим соображениям. Наиболее подходящим способом определения вероятности их возникновения является метод имитационного моделирования с использованием логико-лингвистической модели процесса возникновения происшествий.

Функционирование имитационной модели может быть основано на том, что возникновение происшествий является следствием развития причинной цепи предпосылок, в которой инициаторами и составными частями являются ошибочные действия или бездействие работников, неполадки и отказы технологического оборудования, а также нерасчетные воздействия на них внешних факторов. В рамках человекомашинной системы наиболее существенные причины аварий могут быть разделены на четыре группы по компонентам системы: факторы влияния условий рабочей среды, безопасности оборудования, уровня используемой технологии и факторы человека-оператора (персонала, обслуживающего установку). Численные значения доли различных факторов опасности в общих причинах аварийности и травматизма могут быть определены на основе анализа статистических данных причин аварий и происшествий, хранящихся в Ростехнадзоре, актов технического расследования причин аварий и происшествий, оперативных сообщений об авариях и форм их учета. Пример состава и характеристики причин факторов опасности в системе водного транспорта приведен в таблице 2.1.1 [13]. 
Таблица 2.1.1

Состав и характеристики факторов опасности

в системе водного транспорта

\begin{tabular}{|c|c|c|c|}
\hline Компонента & Код & Фактор опасности & $\begin{array}{l}\text { Доля в общих } \\
\text { причинах АС }\end{array}$ \\
\hline 1 & 2 & 3 & 4 \\
\hline $\begin{array}{l}\text { рабочая } \\
\text { среда }\end{array}$ & $\begin{array}{l}\mathrm{C} 01 \\
\mathrm{C} 02 \\
\mathrm{C} 03 \\
\mathrm{C} 04\end{array}$ & $\begin{array}{l}\text { комфортность рабочей сре- } \\
\text { ды по физико-химическим } \\
\text { параметрам } \\
\text { качество информационной } \\
\text { модели состояния среды } \\
\text { возможность внешних опас- } \\
\text { ных воздействий } \\
\text { возможность внешних не- } \\
\text { благоприятных воздействий }\end{array}$ & $\begin{array}{l}0,028 \\
0,048 \\
0,045 \\
0,025\end{array}$ \\
\hline персонал & $\begin{array}{l}\text { H01 } \\
\text { H02 } \\
\text { H03 } \\
\text { H04 } \\
\text { H05 } \\
\text { H06 } \\
\text { H07 } \\
\text { H08 } \\
\text { H09 } \\
\text { H12 } \\
\text { H13 }\end{array}$ & $\begin{array}{l}\text { пригодность по физиологи- } \\
\text { ческим показателям } \\
\text { технологическая дисципли- } \\
\text { нированность } \\
\text { качество приема и декодиро- } \\
\text { вания информации } \\
\text { навыки выполнения работ } \\
\text { качество мотивационной } \\
\text { установки } \\
\text { знание технологии работ } \\
\text { знание физической сущно- } \\
\text { сти процессов в системе } \\
\text { способность правильно оце- } \\
\text { нивать информацию } \\
\text { качество принятия решения } \\
\text { самообладание в экстре- } \\
\text { мальных ситуациях } \\
\text { обучаемость действиям в } \\
\text { нештатных ситуациях }\end{array}$ & $\begin{array}{c}0,02 \\
0,04 \\
0,062 \\
0,04 \\
0,04 \\
0,033 \\
0,04 \\
0,043 \\
0,06 \\
0,056 \\
0,047\end{array}$ \\
\hline
\end{tabular}


Продолжение табл. 2.1.1

\begin{tabular}{|c|c|c|c|}
\hline Компонента & Код & Фактор опасности & $\begin{array}{l}\text { Доля в общих } \\
\text { причинах АC }\end{array}$ \\
\hline \multirow[t]{2}{*}{1} & 2 & 3 & 4 \\
\hline & H14 & $\begin{array}{l}\text { точность корректирующих } \\
\text { действий }\end{array}$ & 0,06 \\
\hline $\begin{array}{l}\text { оборудова- } \\
\text { ние }\end{array}$ & $\begin{array}{l}\text { M01 } \\
\text { M02 } \\
\text { M03 } \\
\text { M04 } \\
\text { M05 } \\
\text { M06 } \\
\text { M07 } \\
\text { M08 }\end{array}$ & $\begin{array}{l}\text { качество конструкции рабо- } \\
\text { чего места обслуживающего } \\
\text { персонала (операторов, су- } \\
\text { доводителя) установки } \\
\text { степень учета особенностей } \\
\text { работоспособности чело- } \\
\text { века } \\
\text { оснащенность источниками } \\
\text { опасных и вредных факто- } \\
\text { ров } \\
\text { надежность вспомогатель- } \\
\text { ных узлов и элементов } \\
\text { безотказность основных уз- } \\
\text { лов и элементов } \\
\text { длительность действия опас- } \\
\text { ных и вредных факторов } \\
\text { уровень потенциала опас- } \\
\text { ных и вредных факторов } \\
\text { безотказность приборов и } \\
\text { устройств безопасности }\end{array}$ & $\begin{array}{r}0,02 \\
0,03 \\
0,055 \\
0,007 \\
0,007 \\
0,026\end{array}$ \\
\hline технология & $\begin{array}{l}\text { T01 } \\
\text { T02 } \\
\text { T03 }\end{array}$ & $\begin{array}{l}\text { удобство подготовки и вы- } \\
\text { полнения работ } \\
\text { удобство технического об- } \\
\text { служивания и ремонта } \\
\text { сложность алгоритмов опе- } \\
\text { ратора }\end{array}$ & $\begin{array}{c}0,02 \\
0,038 \\
0,012\end{array}$ \\
\hline
\end{tabular}


Окончание табл. 2.1.1

\begin{tabular}{|c|c|c|c|}
\hline Компонента & Код & \multicolumn{1}{|c|}{ Фактор опасности } & $\begin{array}{c}\text { Доля в общих } \\
\text { причинах АС }\end{array}$ \\
\hline 1 & 2 & \multicolumn{1}{|c|}{3} & 4 \\
\hline Т05 & Т04 & $\begin{array}{l}\text { возможность появления че- } \\
\text { ловека в опасной зоне } \\
\text { возможность появления } \\
\text { других незащищенных эле- } \\
\text { Тентов в опасной зоне } \\
\text { надежность технологиче- } \\
\text { ских средств обеспечения } \\
\text { безопасности }\end{array}$ & 0,008 \\
\hline
\end{tabular}

При определении характеристик факторов опасности каждый из факторов оценивается с учетом ряда составляющих. Так, например, значение фактора «Н05 - качество мотивационной установки» определяется такими составляющими, как ответственность оператора, его морально-волевые качества, влияние коллектива, боязнь потерять работу, размер заработной платы. Аналогично оцениваются и все другие факторы.

В общем виде решение рассматриваемой задачи с использованием имитационной модели сводится к нахождению функциональной зависимости между оценками факторов опасности и вероятностью возникновения происшествия в человекомашинной системе в виде

$$
y=f\left(x_{1}, x_{2}, \ldots, x_{30}\right),
$$

где $x_{1}, x_{2}, \ldots, x_{30}-$ формализованные оценки факторов опасности.

Явный вид зависимости (2.1.2) в имитационной модели может быть определен с применением методов планирования эксперимента.

С целью формализации исходных данных может быть использована балльная система оценок факторов, опирающаяся на универсальную лингвистическую шкалу оценок, выраженную в числовом виде. Это позволяет унифицировать качественные и количественные исходные данные. Балльная система оценок факторов 
причин аварийности для рассматриваемого примера приведена в таблице 2.1.2.

Таблица 2.1.2

Балльная система оценок факторов причин аварийности

\begin{tabular}{|l|c|}
\hline $\begin{array}{c}\text { Лингвистическая } \\
\text { шкала оценок }\end{array}$ & Числовое значение \\
\hline низкое & $-1,0$ \\
\hline ниже среднего & $-0,667$ \\
\hline среднее & $-0,333$ \\
\hline выше среднего & 0 \\
\hline хорошее & 0,333 \\
\hline очень хорошее & 0,667 \\
\hline высокое & 1,0 \\
\hline
\end{tabular}

Значимости некоторых из факторов опасности для рассматриваемого примера, полученные с использованием имитационного моделирования [89], приведены в таблице 2.1.3.

Таблица 2.1.3

Характеристика и значимость факторов

безопасности оборудования

\begin{tabular}{|c|l|c|}
\hline $\begin{array}{c}\text { Фактор } \\
\text { опасности (код) }\end{array}$ & \multicolumn{1}{|c|}{ Составляющая фактора } & $\begin{array}{c}\text { Значимость } \\
\text { для данного } \\
\text { фактора }\end{array}$ \\
\hline 1 & \multicolumn{1}{|c|}{2} & 3 \\
\hline $\begin{array}{c}\text { Качество кон- } \\
\text { струкции рабо- } \\
\text { чего места (М01) }\end{array}$ & Фазическая динамика, нагрузка & 0,15 \\
& Перемещаемого груза & 0,15 \\
& Рабочая поза & 0,15 \\
& Наклоны корпуса & 0,15 \\
& Перемещение в пространстве & 0,15 \\
& (технологические переходы) & 0,15 \\
& Стереотипные движения & 0,1 \\
\hline
\end{tabular}


Продолжение табл. 2.1.3

\begin{tabular}{|c|c|c|}
\hline $\begin{array}{c}\text { Фактор } \\
\text { опасности (код) }\end{array}$ & Составляющая фактора & $\begin{array}{c}\text { Значимость } \\
\text { для данного } \\
\text { фактора }\end{array}$ \\
\hline 1 & 2 & 3 \\
\hline $\begin{array}{l}\text { Степень учета } \\
\text { особенностей } \\
\text { работоспособ- } \\
\text { ности человека } \\
\text { (М02) }\end{array}$ & $\begin{array}{l}\text { Учет возможных психофизио- } \\
\text { логических состояний человека } \\
\text { Вырабатываемость оборудования } \\
\text { Защита от возможных неадекват- } \\
\text { ных действий человека }\end{array}$ & $\begin{array}{l}0,35 \\
0,35\end{array}$ \\
\hline $\begin{array}{l}\text { Оснащенность } \\
\text { источниками } \\
\text { опасных и вред- } \\
\text { ных факторов } \\
\text { (М03) }\end{array}$ & $\begin{array}{l}\text { Общее количество источников } \\
\text { опасности (электроэнергия, меха- } \\
\text { ническая энергия, сжатый воздух } \\
\text { и др.) } \\
\text { Летальность энергоисточников } \\
\text { Разрушающий потенциал энер- } \\
\text { гоисточников }\end{array}$ & $\begin{array}{l}0,4 \\
0,3 \\
0,3\end{array}$ \\
\hline $\begin{array}{l}\text { Надежность } \\
\text { вспомогатель- } \\
\text { ных узлов и эле- } \\
\text { ментов (М04) }\end{array}$ & $\begin{array}{l}\text { Надежность вспомогательных } \\
\text { неответственных элементов уста- } \\
\text { новки, отказ которых не может } \\
\text { явиться непосредственной при- } \\
\text { чиной происшествия }\end{array}$ & 1,0 \\
\hline $\begin{array}{l}\text { Безотказность } \\
\text { основных } \\
\text { узлов и элемен- } \\
\text { тов (М05) }\end{array}$ & $\begin{array}{l}\text { Надежность основных элементов } \\
\text { конструкции установки, отказ } \\
\text { которых может в определенных } \\
\text { условиях привести к происшест- } \\
\text { вию (в том числе КИП, средства } \\
\text { сигнализации и защиты) }\end{array}$ & 1,0 \\
\hline $\begin{array}{l}\text { Длительность } \\
\text { действия опас- } \\
\text { ных и вредных } \\
\text { факторов (М06) }\end{array}$ & $\begin{array}{l}\text { Скорость срабатывания средств } \\
\text { противопожарной защиты } \\
\text { Скорость и надежность локали- } \\
\text { зации возгораний } \\
\text { Надежность средств индивиду- } \\
\text { альной защиты }\end{array}$ & $\begin{array}{l}0,3 \\
0,4 \\
0,3\end{array}$ \\
\hline
\end{tabular}


Окончание табл. 2.1.3

\begin{tabular}{|c|c|c|}
\hline $\begin{array}{c}\text { Фактор } \\
\text { опасности (код) }\end{array}$ & Составляющая фактора & $\begin{array}{c}\text { Значимость } \\
\text { для данного } \\
\text { фактора }\end{array}$ \\
\hline 1 & 2 & 3 \\
\hline $\begin{array}{l}\text { Уровень потен- } \\
\text { циала опасных } \\
\text { и вредных фак- } \\
\text { торов (М07) }\end{array}$ & $\begin{array}{l}\text { Объем запасов топлива } \\
\text { Класс опасности горючих мате- } \\
\text { риалов } \\
\text { Рабочее напряжение электро- } \\
\text { установок } \\
\text { Рабочее давление сжатых газов } \\
\text { Механическая энергия установок }\end{array}$ & $\begin{array}{l}0,3 \\
0,1 \\
0,1 \\
0,1\end{array}$ \\
\hline $\begin{array}{l}\text { Безотказность } \\
\text { приборов и } \\
\text { устройств без- } \\
\text { опасности (М08) }\end{array}$ & $\begin{array}{l}\text { Надежность приборов и устройств } \\
\text { безопасности установки, отказ ко- } \\
\text { торых является непосредственной } \\
\text { причиной возникновения про- } \\
\text { исшествий (предохранительные } \\
\text { клапаны, автоматические выклю- } \\
\text { чатели и др.) }\end{array}$ & 1,0 \\
\hline
\end{tabular}

На основании полученных результатов составляется уравнение регрессии для решаемой задачи:

$$
\begin{aligned}
& \tilde{y}=1,73 \cdot 10^{-4}-4,37 \cdot 10^{-5} x_{1}-1,60 \cdot 10^{-5} x_{2}-6,95 \cdot 10^{-5} x_{3}- \\
& -4,26 \cdot 10^{-5} x_{4}-4,26 \cdot 10^{-5} x_{5}-1,59 \cdot 10^{-5} x_{6}-3,38 \cdot 10^{-5} x_{7}- \\
& -4,03 \cdot 10^{-5} x_{8}+6,2 \cdot 10^{-6} x_{1} x_{2}+1,63 \cdot 10^{-5} x_{1} x_{3}+1,02 \cdot 10^{-5} x_{1} x_{4}+ \\
& +7,3 \cdot 10^{-6} x_{1} x_{5}+4,8 \cdot 10^{-6} x_{2} x_{3}+1,68 \cdot 10^{-5} x_{3} x_{4}+1,65 \cdot 10^{-5} x_{3} x_{5}+ \\
& +7,9 \cdot 10^{-6} x_{4} x_{5}-3,8 \cdot 10^{-6} x_{1} x_{2} x_{3}-6,2 \cdot 10^{-6} x_{1} x_{2} x_{4}-3,5 \cdot 10^{-6} x_{1} x_{2} x_{5}+ \\
& +3,6 \cdot 10^{-6} x_{1} x_{4} x_{5}+7,1 \cdot 10^{-6} x_{2} x_{3} x_{4}+7,8 \cdot 10^{-6} x_{2} x_{3} x_{5}+ \\
& +1,32 \cdot 10^{-5} x_{2} x_{4} x_{5}+1,05 \cdot 10^{-5} x_{1} x_{2} x_{3} x_{4}+8,6 \cdot 10^{-6} x_{1} x_{2} x_{3} x_{5}+ \\
& +1,58 \cdot 10^{-5} x_{1} x_{2} x_{4} x_{5},
\end{aligned}
$$

где факторы приняты согласно таблице 2.1.1: $x_{1}$ - фактор М03; $x_{2}$ - фактор M06; $x_{3}$ - фактор M01; $x_{4}$ - фактор M02; $x_{5}$ - фактор M05; $x_{6}$ - фактор M07; $x_{7}$ - фактор M08; $x_{8}$ - фактор M04. 
Полученное уравнение (2.1.3) может быть использовано для оценки вероятности происшествия.

Пример 1. Пусть значения всех факторов безопасности спроектированной судовой энергетической установки первоначально были оценены экспертами в данной области «выше среднего», то есть числовые значения всех факторов (М01-М08) были равны 0. Тогда из выражения (2.1.3) получаем, что вероятность происшествия для данной установки за время несения одной вахты (4 часов) равна $1,73 \cdot 10^{-4}$.

Пример 2. Пусть после выполненной доработки приборов и устройств безопасности значение фактора M08 $\left(x_{7}\right)$ было оценено экспертами как «высокое», что соответствует числовому значению фактора 1,0 . После подстановки значения $x_{7}=1,0$ (значения остальных факторов остались равными 0) в (2.1.3) получаем вероятность возникновения происшествия равной $1,33 \cdot 10^{-4}$, то есть она существенно (на $30 \%$ ) снизилась.

Таким образом, выражение (2.1.3) уже на стадии проектирования судового оборудования можно использовать для количественной оценки вероятности возникновения происшествий в процессе его эксплуатации.

\section{2. Методология обеспечения безопасности судов}

К настоящему времени благодаря накопленному опыту в решении практических судостроительных задач сформирована методология обеспечения безопасности судов при навигационных авариях в результате применения конструктивных мероприятий. Она включает следующие основные направления (рис. 2.2.1): разработку сценариев аварийной ситуации, обоснование критериев безопасности (защищенности), построение расчетных моделей разрушения корпусных (в том числе специальных защитных) конструкций [13].

Разработка сиенариев аварийной ситуачии необходима для конкретизации основных закономерностей возникновения и протекания аварии с полнотой, достаточной для построения математической модели. Поскольку статистических данных для 
этого обычно недостаточно, восполнение указанного информационного дефицита целесообразно осуществлять за счет построения расчетных сценариев, дополняющих недостающую информацию системой непротиворечивых допущений и экспертных оценок.

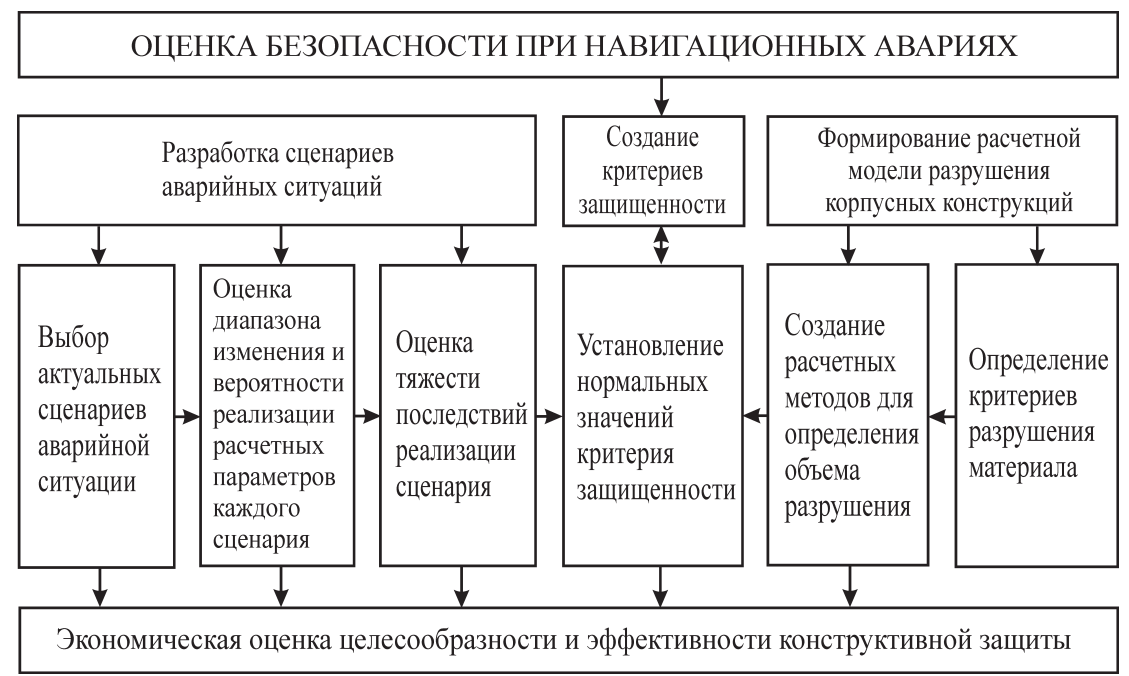

Рис. 2.2.1. Укрупненная схема оценки безопасности судна при навигационных авариях

Обоснование критериев безопасности (защищенности) имеет целью создание надежной критериальной базы, позволяющей давать оценку (по крайней мере сопоставительную) той или иной схеме конструктивной защиты. При наличии достаточного объема информации о статистических и физических закономерностях протекания аварий критерий может иметь экономическую природу, в противном случае возможно создание критерия, отражающего накопленный опыт, на основе условных измерителей.

Построение расчетных моделей разрушения корпусных (в том числе специальных защитных) конструкичий служит для оценки объема повреждений в зависимости от разрушающего воздействия и размеров корпусных конструкций. Расчетные модели позволяют оценить влияние толщин обшивки и настилов, системы набора и размеров балок, количество и расположение 
основных и дополнительных перекрытий судового корпуса на защищенность судна в аварийной ситуации.

Разработка расчетных сценариев аварийных ситуаций - это, с одной стороны, один из наиболее важных, а с другой - один из наименее алгоритмизируемых аспектов решения проблемы безопасности судов при навигационных авариях. Так, используемое в морской практике понятие «посадка на мель» включает в себя целый спектр расчетных сценариев: посадка на песчано-илистый грунт в условиях мелководья, удар о подводный камень, посадка на рифы, «обсыхание» при отливе и другие случаи. Из числа расчетных сценариев следует исключить случаи, не представляющие опасности (например, касание песчано-илистого грунта), а также те, при которых гибель судна предрешена (например, выбрасывание судна на камни в условиях интенсивного волнения моря).

С учетом изложенного можно выделить три основных расчетных сценария аварийной ситуации типа «посадка на мель»: «обсыхание» на мели; столкновение с жесткой неподвижной преградой; удар днищем о камень в условиях качки на волнении (рис. 2.2.2) [13].
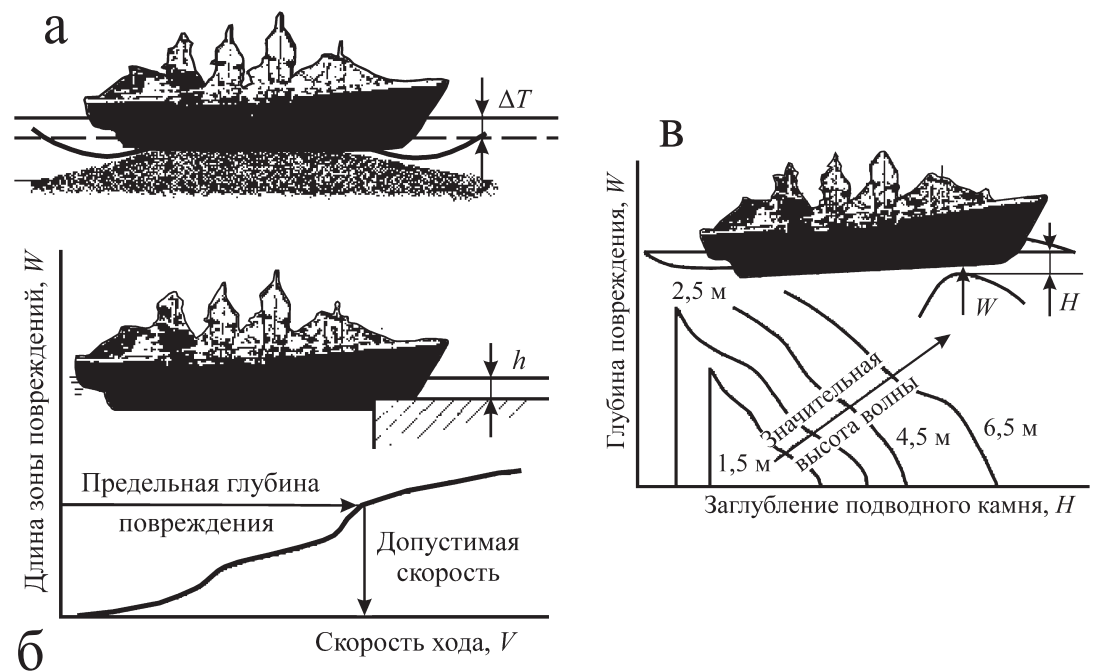

Рис. 2.2.2. Расчетные сценарии аварийной ситуации «посадка на мель»: a - «обсыхание» на мели; б - столкновение с подводным препятствием; в - контакт с подводным камнем на волнении 
Существуют три группы критериев защищенности: простейшие, полуэмпирические и экономические. К простейшим можно отнести широко распространенное в мировой практике нормирование минимального отстояния грузового помещения от наружной обшивки нефтяных танкеров - химовозов.

Полуэмпирический сопоставительный критерий рекомендуется использовать в тех случаях, когда построение экономического критерия затруднительно.

Обобщение существующего опыта обеспечения защищенности судов возможно на основе комплексного критерия, ориентированного на выполнение сравнительных оценок безопасности в рамках метода условных измерителей. В данном критерии в качестве меры, характеризующей экологическую защищенность судна при столкновениях, используется величина $K$ [13]:

$$
K=\frac{1}{4,446^{\alpha}} \cdot \frac{a_{1} a_{2} a_{3}}{k_{1} k_{2} k_{3} k_{c}} \cdot \frac{V_{0}}{V_{1}} \sqrt{\frac{E}{E_{0}}},
$$

где $\alpha$ - показатель токсичности груза; $a_{1}, a_{2}, a_{3}$, - показатели маневренных качеств судна, его навигационного оборудования и подготовки экипажа; $k_{1}, k_{2}, k_{3}$ - коэффициенты, учитывающие район плавания с точки зрения частоты заходов в порты, сложности навигационной обстановки, экологических последствий аварии; $k_{c}$ - коэффициент снижения объема разлива опасного жидкого груза за счет применения специальных мероприятий (например, использования снижающей давление воздушно-газовой смеси над свободной поверхностью жидкого груза); $V_{0}, V_{1}$ - нормативный и прогнозируемый объемы разлива груза; $E$ - энергоемкость противотаранной защиты рассматриваемого судна; $E_{0}$ - нормативный уровень энергоемкости судов, удовлетворяющих действующим требованиям, но не имеющим дополнительной специальной защиты.

Использование критерия полуэмпирического или экономического типа возможно при наличии надежного метода определения входящей в его структуру в том или ином виде энергоемкости деформирования корпусных конструкций, разрушаемых в процессе 
аварии. Первый расчетный метод оценки объема повреждений в аварийной ситуации был предложен Минорским (США) для случая столкновения судов в связи с проектированием атомного судна «Саванна». Этот метод устанавливает достаточно простую связь между энергоемкостью деформирования и размерами корпусных конструкций сталкивающихся судов, однако может существенно завышать энергоемкость.

Оценка объема разрушения на основе модельных экспериментов осложнена несовместимостью критериев подобия, а также трудностью корректного моделирования в мелком масштабе сварных соединений. Это приводит к тому, что достоверными можно считать только результаты натурных и полунатурных экспериментов, объем которых ограничен высокой стоимостью. В отечественной практике используются подходы, основанные на инженерных расчетных моделях, обоснованность которых подтверждена экспериментами на натурных и полунатурных конструкциях. В основе лежит, как правило, определенное представление о последовательности и характере разрушения (срез, трещина, разрыв от растяжения и др.) - так называемый «сценарий разрушения» конструкции, который обычно определяется на основании экспериментальных данных. При этом расчетные формулы могут быть построены на базе достаточно простых физических моделей с возможностью их последующей корректировки по результатам экспериментов (путем введения поправочных коэффициентов).

Развитие в последние годы вычислительной техники и появление хорошо апробированных в международной практике программных комплексов, позволяющих рассчитывать деформирование конструкций в области глубокой пластики, дает возможность применять их и к оценке объема повреждений в аварийных ситуациях. При этом возникают определенные вычислительные трудности в случаях нелинейной потери устойчивости и изменения топологии конструкции. Кроме того, для изучения влияния отдельных параметров конструкции на ее энергоемкость требуется проведение большого числа трудоемких расчетов, что также затрудняет использование этого подхода в практике. 
Серьезные аварии танкеров, сопровождающиеся крупными разливами нефти, до настоящего времени являются печальной реальностью. Особенно чувствительна окружающая среда к разливам в районах Севера, где одна из самых уязвимых в мире экосистем. В Арктике нефтяные разливы более вероятны, а последствия разлива труднее ликвидировать, чем в других регионах. Это связано с недостатком естественного освещения, низкими температурами, динамикой ледяного покрова, сильными ветрами и плохой видимостью. Природно-климатические условия арктических морей не позволяют эффективно ликвидировать последствия разливов нефти и загрязнений другими опасными грузами. Ледовая обстановка затрудняет судоходство и замедляет восстановление загрязненных экосистем, низкая скорость растворения нефти в холодных водах связана с более длительным негативным воздействием на окружающую среду. Нефтяной разлив является самым серьезным потенциальным источником крупномасштабного загрязнения при транспортировке нефти. Предупреждение разливов нефти и создание механизмов, регулирующих безопасное движение грузовых судов в Арктике, является актуальной задачей, направленной на обеспечение безопасности морских перевозок [131].

Это, с одной стороны, делает актуальной проблему оценки безопасности танкеров и позволяет ставить вопрос об усилении их корпусных конструкций, а с другой - позволяет выполнить более точную вероятностно-экономическую оценку целесообразности и эффективности конструктивной защиты, базирующуюся на сопоставлении затрат на создание защиты с уменьшением вероятных убытков от аварий благодаря наличию такой защиты.

Для типичного современного танкера с двойным дном и двойными бортами в качестве основных переменных можно рассматривать коэффициенты увеличения толщины обшивки борта $k_{b}$ и настила палубы $k_{d}$, а в качестве минимизируемой функции цели можно принять сумму годового уменьшения прибыли от потери грузоподъемности из-за дополнительной защиты и возможного убытка от столкновения, равного произведению годовой вероятности аварии на стоимость ликвидации ее последствий, а именно: 


$$
\frac{C_{s}}{T_{0} D W}\left[G_{d}\left(k_{d}-1\right)+G_{b}\left(k_{b}-1\right)\right]+\int_{0}^{V_{\Sigma}} C(V) p(V) d V+C_{s} P_{p}=\min ,(2.2 .2)
$$

где $C_{s}-$ строительная стоимость танкера; $T_{0}-$ нормативный срок окупаемости; $D W$ - дедвейт; $G_{d}, G_{b}$ - соответственно масса конструкций палубы и двойного борта танкера без противотаранных усилений; $C(V)$ - стоимость ликвидации последствий разлива нефти объемом $V ; p(V)$ - плотность вероятности объема разлива; $V_{\Sigma}$ - максимально возможный объем перевозимой на танкере нефти; $P_{p}-$ среднегодовая вероятность потери судна в результате аварийного столкновения.

Специальные исследования позволили разработать методологию определения и построения конкретных аппроксимаций для главных параметров рассматриваемой модели, включая убытки от разлива в зависимости от объема, убытки от потери дедвейта за счет усиления защиты, функцию распределения скорости столкновения, плотность вероятности объема разлива [13]. Результаты экономического анализа целесообразности усиления противотаранной защиты нефтяных танкеров представлены в виде кривых на рисунке 2.2.3. Кривые (рис. 2.2.3а) определяют оптимальные значения коэффициентов усиления двойного борта и палубы в зависимости от средней годовой частоты столкновений для танкеров различной длины, а кривая (рис. 2.2.3б) характеризует зависимость критической вероятности столкновений $\left(p_{c m}^{o в}\right)_{\text {кр }}$, при превышении которой целесообразно усиление бортовых конструкций танкера, от длины танкера $L$.

На основе сформированной таким образом расчетной модели были определены значения $k_{b}^{\text {opt }}$ и $k_{d}^{o p t}$, соответствующие минимуму функции цели (рис. 2.2.3), при этом варьировалась средняя вероятность столкновения $p_{c m}^{o в}$. Результаты значительно зависят от принятой оценки ущерба от разлива нефти.

Таким образом, целесообразность усиления корпусных конструкций танкеров для предотвращения разлива нефти при столкновении зависит от вероятности столкновения. В том случае, если среднегодовая частота всех столкновений составляет 
$10^{-3}(\text { судно •год) })^{-1}$ и менее, усиление корпусных конструкций нецелесообразно. Следует отметить, что танкеры различного водоизмещения не являются одинаково безопасными с точки зрения возможности разлива нефти в результате столкновения. Более крупные танкеры, даже отвечающие всем существующим международным требованиям, имеют больший риск стать причиной серьезного загрязнения.

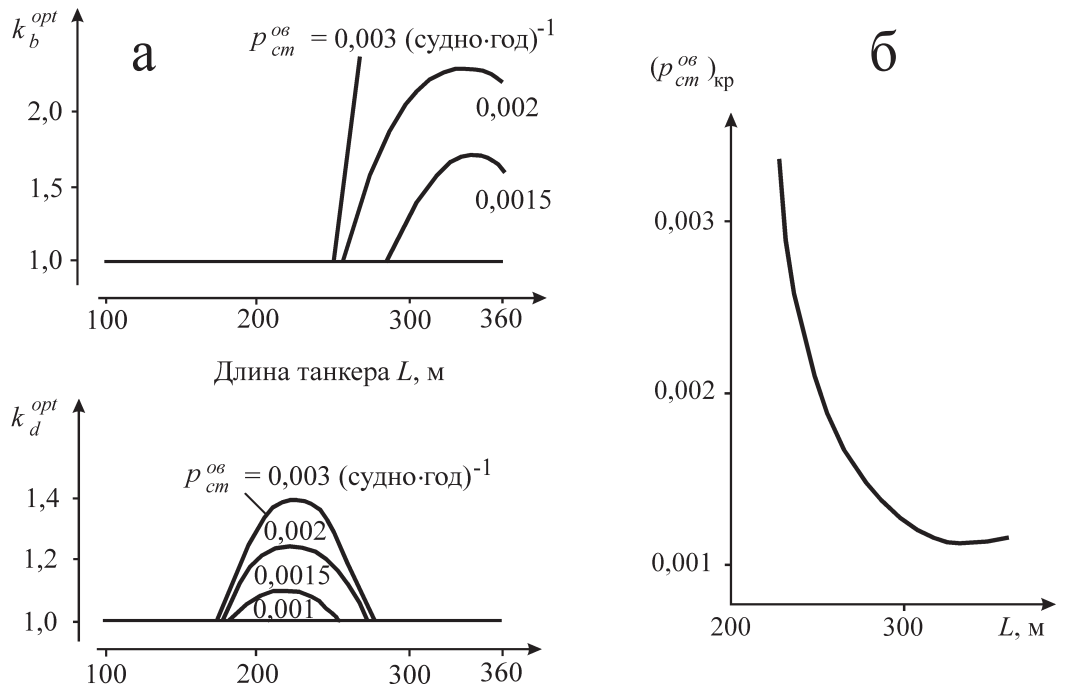

Рис. 2.2.3. Результаты экономического анализа целесообразности усиления противотаранной защиты нефтяных танкеров:

a - оптимальные значения коэффициентов усиления конструкций в зависимости от средней годовой частоты столкновений; б - зависимость критической вероятности столкновений от длины танкера $L$

Применительно к наиболее распространенной навигационной аварии - столкновению судов - регламентация общего сценария затруднений не вызывает. Однако конкретизация расчетных значений параметров этого сценария (скорости судов, водоизмещения, формы и конструкции корпуса таранящего судна и угла между диаметральными плоскостями судов в момент столкновения - угол столкновения и т. д.) осуществляется на основании специальных проработок. 


\section{3. Методология формализованной оценки безопасности судоходства}

Международная морская организация (ИМО) в 1993 году приняла «Международный кодекс по управлению безопасной эксплуатацией судов и предотвращения загрязнения» (МКУБ), требующий внедрения судовладельцами систем управления безопасностью, базирующихся на анализе и защите от выявленных рисков. Современным подходом к управлению безопасностью судоходства на основе анализа рисков является методология формализованной оценки безопасности.

На безопасность мореплавания оказывает влияние множество факторов. Одним из них является деятельность Российского морского регистра судоходства (РМРС) как органа классификации и технического надзора за флотом. Уровень безопасности мореплавания оценивается по различным показателям. Одним из таких показателей является задержание судов портовыми властями (PSC - Port State Control, контроль государством порта). Процедура контроля судов государством порта является не привилегией властей порта захода судна, а юридической обязанностью государств членов соответствующих международных инструментов (конвенций, договоров). Эта обязанность оговаривается в конвенциях. При этом ведется учет причин задержаний по основаниям, относимым к ответственности классификационного общества. На практике ни одно государство не может выполнить требование о контроле абсолютно всех заходящих в его порты судов, это является причиной заключения региональных межгосударственных соглашений (меморандумов) по контролю. Меморандумы устанавливают наибольший практически достижимый показатель в процентах количества проверяемых судов от общего числа судов, заходящих в порты региона (государства) за определенный срок.

Однако в публикуемых отчетах о задержании судов (Парижского и Токийского меморандумов о контроле судов) фигурируют лишь абсолютные показатели (например, общее число задержаний или выявленных несоответствий), на основании которых делаются 
качественные выводы о «плохих» и «хороших» флагах и классификационных обществах.

Более объективно оценить риск влияния различных факторов, например, технического надзора РМРС на задержание судов позволяет применение современного математического аппарата функционального анализа. С этой целью ИМО рекомендовала методологию формализованной оценки безопасности (ФОБ - FSA, Formal Safety Assessment) [138].

Относительно новый для морской индустрии метод ФОБ давно известен во многих видах промышленности, таких как атомная промышленность, химическая промышленность и исследование космоса. ФОБ выражает собой существенное изменение в подходе к вопросам безопасности - вместо «реагирования» на опасность с помощью формализованной оценки безопасности вырабатываются превентивные решения, направленные на «опережение» нежелательных событий.

Впервые ИМО начала рассматривать вопросы, связанные с внедрением методов превентивного нормирования, на 62-й сессии Комитета по безопасности на море в 1993 году. При этом учитывался положительный опыт применения таких методов в атомной индустрии 60-х годов и химической промышленности 70-х.

В связи со значительным числом катастроф с судами, перевозящими навалочные грузы, Агентство по морской безопасности Великобритании в 1995 году предоставило в ИМО основы методики формализованной оценки безопасности. В 1996 году совместная рабочая группа Комитета по безопасности на море (КБМ) и Комитета по защите окружающей среды (КЗОС) подготовила проект Временного руководства ИМО по формализованной оценке безопасности.

В 1997 году Временное руководство было одобрено КБМ на 68-й сессии и опубликовано в виде циркулярного письма КБМ (циркуляр 829) и циркулярного письма Комитета по защите морской среды (циркуляр КЗМС 335). В этом же году была создана специализированная рабочая группа Международной ассоциации классификационных обществ (МАКО) по ФОБ. 
В 1999-2001 годах совместная рабочая группа КБМ и КЗМС ИМО при активном содействии МАКО переработала Временное руководство по ФОБ, и в 2002 году переработанное руководство было выпущено в виде циркулярного письма КБМ № 1023 и циркулярного письма КЗМС № 392.

Вопросы по формализованной оценке безопасности постоянно включаются в повестку дня заседаний Комитета по безопасности на море и Комитета по защите морской среды. Наиболее крупными проектами являются вопросы формализованной оценки безопасности навалочных судов, рассмотренные в международном проекте под руководством Великобритании (MSC 75/5/1, 2002), проектов МАКО (MSC 74/5/4, 2001) и Японии (MSC 75/5/2, 2002). В Международной морской организации создана корреспондентская группа по ФОБ, в задачи которой входит совершенствование Руководства по ФОБ, анализ предлагаемых проектов по ФОБ и координация всех работ по этой методологии.

Формализованная оценка безопасности - это структурированная и систематическая методика, направленная на повышение безопасности в море, включающая в себя защиту жизни, здоровья моряков, окружающей среды и имущества посредством анализа риска и сравнительного анализа затрат и результатов.

На каждое судно влияет множество факторов природного, экономического и социального характера. Судоходной морской индустрии присущи многочисленные риски нежелательных событий.

Под риском понимается сочетание вероятности и последствий наступления неблагоприятных событий. Знание вероятности неблагоприятного события (потерь) $p$. позволяет определить вероятность благоприятных событий $p_{+}$по формуле

$$
p_{+}=1-p \text {. }
$$

Также риском часто называют непосредственно предполагаемое событие, способное принести кому-либо ущерб или убыток, причем под терминами «ущерб» или «убыток» понимаются в самом широком смысле различные негативные последствия от матери- 
альных издержек, недополученной прибыли, ущерба имиджу до финансовых потерь, потери здоровья или настроения.

В общем случае последствия неблагоприятных событий можно разделить на три группы ущерба:

- причинение ущерба жизни и здоровью людей (членов экипажа судна и пассажиров);

- экономические ущербы из-за повреждения и разрушения технических объектов, включая объекты морской инфраструктуры, и косвенные убытки из-за выхода технических объектов из эксплуатации;

- ущерб и неблагоприятные последствия для окружающей среды.

При рассмотрении социальных, экономических и экологических сторон неблагоприятных событий целесообразно оперировать понятиями прямого, косвенного и полного ущерба.

Совокупность действий, направленных на снижение уровня технологического риска, уменьшение потенциальных потерь и других негативных последствий нежелательных событий, принято называть управлением риском. Управление риском направлено на предотвращение возникновения происшествий в ходе производственной деятельности и выработку мер по локализации негативных последствий в тех случаях, когда нежелательные события произошли.

Формализация процедуры управления риском связана с получением его количественной оценки. При этом используются методы статистической теории принятия решений, где функция риска $R(\theta)$ для параметра $\theta$ оценки $\delta(x)$, вычисленная при некоторых наблюдаемых значениях $x$, определяется как математическое ожидание функции потерь $L$

$$
R(\theta)=\int L(\theta, \delta(x)) f(x \mid \theta) d x
$$

Целью ФОБ является снижение величины риска и оценивание расходов и выгоды от решений, направленных на снижение рисков. Это достигается путем представления ясных обоснований предлагаемых управляющих мер и возможности сравнить разные 
варианты таких мер. Методы ФОБ позволяют создать прозрачный механизм принятия решений.

Ключевым моментом всей методики ФОБ является возможность рассматривать потенциальные опасности до того, как произойдут серьезные аварии. Применительно к деятельности РМРС постановка задачи в методологии ФОБ сводится к тому, чтобы оценить вероятность (риск) допускаемых ошибок (несоответствий) в деятельности РМРС, связанной с классификационным и конвенционным надзорами за судами.

Вся методология ФОБ разбита на пять основных этапов и нулевой подготовительный этап (рис. 2.3.1):

0 . Выбор сценария развития АС.

1. Идентификация опасности.

2. Анализ риска.

3. Способы управления риском.

4. Оценка стоимости и экономии при принятии способов управления риском.

5. Рекомендации по принятию решений.

Любой проект, который рассматривается с точки зрения формализованной оценки безопасности, должен быть выполнен по всем пяти шагам.

Суть формализованной оценки безопасности состоит в нахождении вероятности развития опасных ситуаций по конкретным сценариям, а также в оценке тяжести их последствий с целью вычисления уровня риска. Для вычисления риска используется простая формула:

$$
R=F C,
$$

где $R$ - риск,

$F$ - частота (или вероятность) нежелательного события,

$C$ - степень тяжести последствий нежелательного события (стоимость потерянного имущества, объем денежных средств, затраченных на преодоление последствий, которые возникли в результате нежелательного события; количество жертв, понесенных в результате одного нежелательного события, и т. д.). 


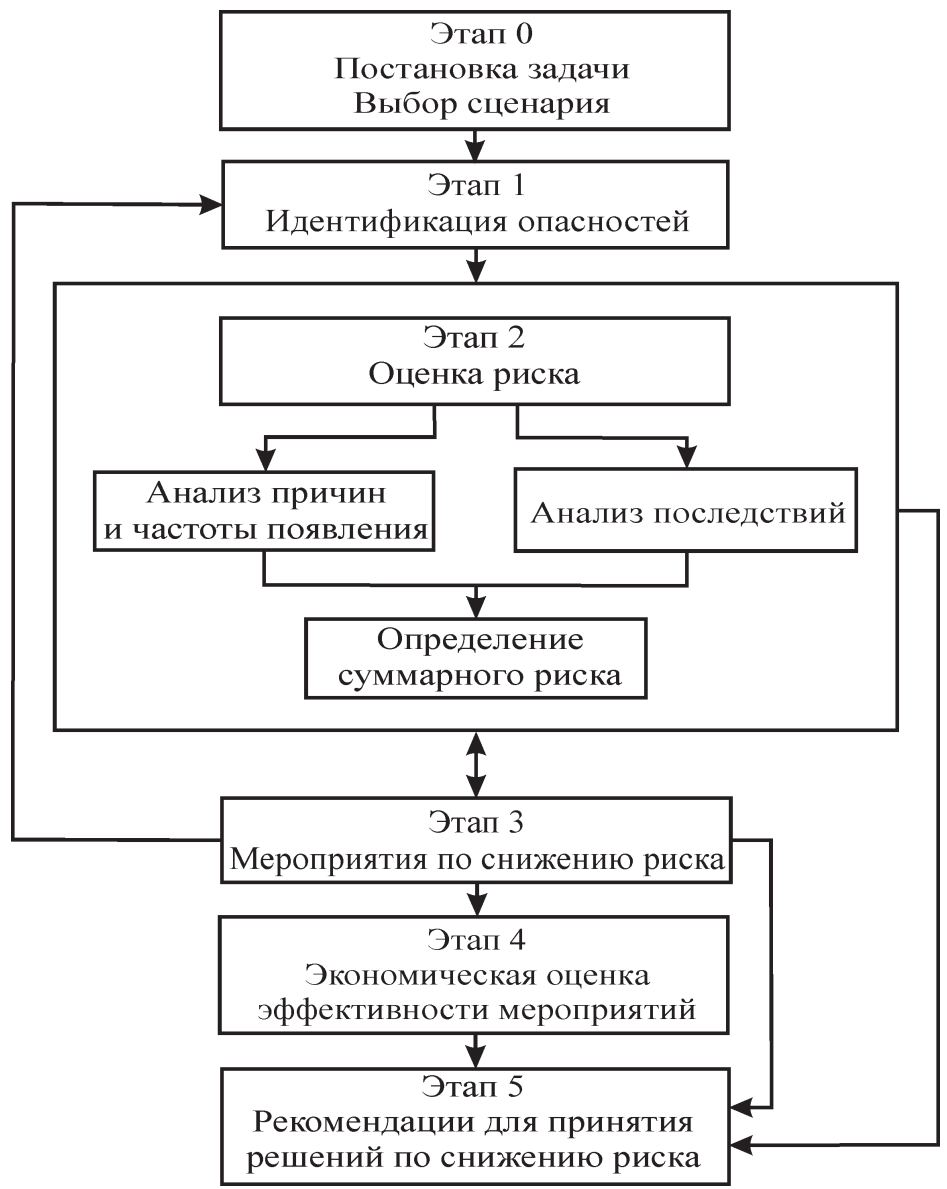

Рис. 2.3.1. Структурная схема методологии формализованной оценки безопасности

Тщательно выполненный систематический анализ доступных различных вариантов управления риском, а также оценка как затрат, так и выгод для этих вариантов в том случае, если они применяются, позволяет выработать окончательное решение о требованиях безопасности.

Поскольку риски должны быть оценены с точки зрения их приемлемости, необходимо указать критерии приемлемости риска. Решение о приемлемости риска принимается при условии, что 
полученный при анализе риск меньше некоторого заранее определенного допустимого его уровня:

$$
R \leq R_{\text {доп }}
$$

где $R_{\text {доп }}$ - допустимый (приемлемый) риск нежелательного события. Схема анализа риска с использованием критерия приемлемости показана на рисунке 2.3.2 [44].

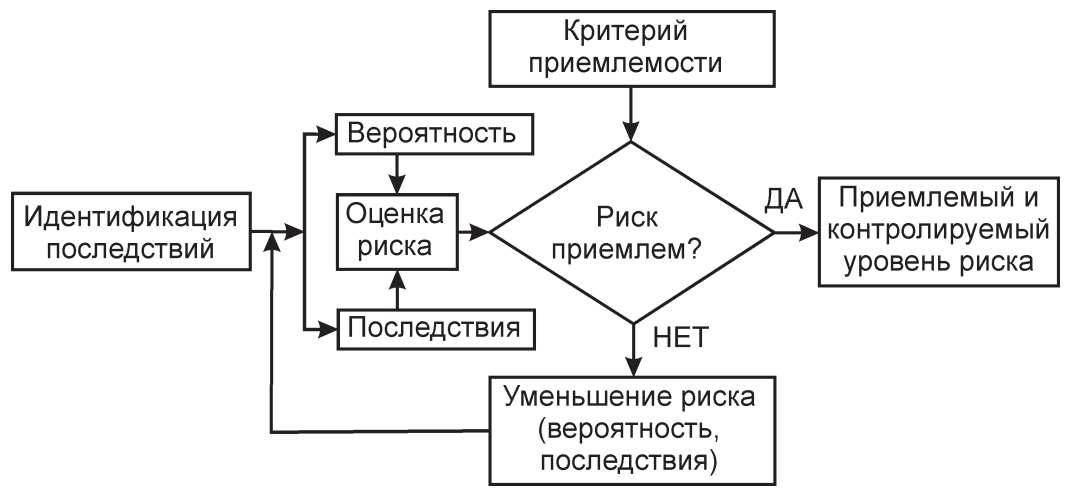

Рис. 2.3.2. Схема анализа риска

Анализ зависимости (2.3.3) показывает, что при фиксированной величине $R_{\text {доп }}$ условие (2.3.4) может быть соблюдено при различных соотношениях между $F$ и $C$. Поэтому если при анализе различных вариантов проектов одного судна или судовой энергетической установки (СЭУ) степень тяжести последствий нежелательного события задать постоянной, то можно перейти к нормированию риска по величине $F_{\text {доп, }}$ определяемой из выражения

$$
F_{\text {доп }}=R_{\text {доп }} / K,
$$

где $K=\mathrm{const}$ - постоянная безразмерная величина, коэффициент пропорциональности.

В этом случае принятие решения о приемлемости риска возможно при выполнении условия

$$
\mathrm{F} \leq F_{\text {доп }} .
$$


Однозначных критериев приемлемости риска в Руководстве ИМО по ФОБ в настоящее время нет.

Традиционный подход к обеспечению безопасности при эксплуатации технических систем и технологий базируется на принципе «абсолютной безопасности» - ALAPA (аббревиатура от англ. As Low As PracticabLe AchievabLe, «настолько низко, насколько это достижимо практически»). Принцип ALAPA означает внедрение всех мер защиты, которые практически осуществимы. Однако это невозможно реализовать.

С технической точки зрения, в соответствии с законами существования техносферы, достижение абсолютной безопасности требует от системы полного отсутствия (равенства нулю) запасенной энергии, что на практике нереализуемо. С гуманистической точки зрения требование абсолютной безопасности, привлекательное на первый взгляд, может обернуться трагедией для людей. Абсолютная безопасность означает для человека нулевой риск. Обеспечить нулевой риск в реальной системе, в которой процессы имеют вероятностный характер, невозможно. Человек, стремясь получить абсолютную безопасность, будет вынужден затрачивать неприемлемо большие усилия и время на это, постоянно подвергаясь риску попасть внезапно и неожиданно в опасную ситуацию. Очевидно, целесообразно ориентироваться на определенный (приемлемый) риск и быть готовым к возможности возникновения опасной ситуации.

Такой подход связан с концепцией «приемлемого риска», известного как принцип ALARA (аббревиатура от англ. As Low As ReasonabLe AchievabLe, «настолько низко, насколько это достижимо в пределах разумного», учитывая социальные и экономические факторы). Он означает, что, если абсолютная безопасность недостижима, следует стремиться хотя бы к такому уровню риска, с которым общество в данный период времени готово согласиться.

В настоящее время большинство стран мирового сообщества придерживается принципа ALARA, который трактуется как «предвидеть и предупредить». Согласно этой концепции управление риском соответствует следующим четырем принципам: 
1 - оправданность деятельности по управлению риском, означающая, что практическая деятельность не может быть оправдана, если выгода от этой деятельности в целом не превышает вызываемого ею ущерба;

2 - оптимизация защиты по критерию среднестатистической ожидаемой продолжительности предстоящей жизни в обществе, подразумевающая, что оптимальным считается вариант сбалансированных затрат на продление жизни за счет снижения уровня риска и за счет выгоды, получаемой от хозяйственной деятельности;

3 - учет всего спектра существуюших опасностей, обеспечивающий доступность широким слоям населения всей информации о принимаемых решениях по управлению риском;

4 - учет требований о непревышении предельно допустимых экологических нагрузок на экосистемы, состоящий в том, что обеспечение безопасности человека, живущего сегодня, следует достигать путем реализации таких решений, которые не снижают способность природы обеспечить безопасность и потребности человека будущего поколения.

Например, в соответствии с концепцией «приемлемого риска», риск смертельного случая для индивида может быть представлен как годовой уровень смертельных случаев или как значение FAR (отношение количества смертельных случаев к $10^{8}$ рабочих часов). Такие уровни могут быть установлены посредством сравнения с другими отраслями, с естественными опасностями, с хорошо изученными решениями, по которым накоплена обширная статистическая информация, и т. д.

Степень приемлемости, соответствующая $10^{-3}$ на судно в год для членов экипажа, используется многими регулятивными органами как предел приемлемости. Для пассажиров в морской индустрии обычно используется более строгий критерий, поскольку пассажиры менее информированы о рисках, не получают «компенсации за риск», выраженной в заработной плате, а наоборот, тратят собственные средства и в меньшей степени контролируют ситуацию. В этом случае обычно считается допустимым уровень, соответствующий $10^{-5}-10^{-6}[98]$. 
Кроме гибели, риском для человека также является риск снижения числа лет жизни в добром здравии и риск получения телесных повреждений. В некоторых опытных приложениях телесные повреждения оцениваются по шкале их тяжести и переводятся в эквивалент смертельных случаев. Например, по установленной градации [98] 10 легких повреждений эквивалентны одному повреждению средней тяжести, 10 повреждений средней тяжести приравниваются к одному тяжелому повреждению, а 10 тяжелых повреждений считаются эквивалентом смертельного случая. В связи с этим параметром принятия решения является не смертность, а «эКвивалент смертельного случая», учитывающий риск телесных повреждений индивида.

Исходными данными для каждого этапа ФОБ является статистический информационный материал. На подготовительном этапе происходит сбор информации об исследуемой системе или объекте, статистических данных и выбор сценариев развития аварийной ситуации.

Например, в качестве базы для оценок используется статистика по задержаниям судов, поднадзорных РМРС, в портах странучастниц меморандумов о контроле судов государством порта по основаниям, относимым к ответственности классификационного общества.

Для оценки риска на первом этапе (идентификация опасностей) используются качественные понятия, позволяющие указать частоту нежелательных событий и тяжесть их последствий. Конкретные сочетания частоты и тяжести представляют собой нетерпимый, приемлемый и терпимый уровни риска. Эти уровни должны быть определены в рамках задачи определения критериев приемлемости риска. Там, где эти риски низки (обычно до 10-100 раз), они полагаются «широко приемлемыми». Более высокий уровень риска должен быть оправдан против затрат на его уменьшение и возможных выгод, которые делают его терпимым, - эти риски рассматриваются как «терпимые». Риски вне этого уровня классифицируются как «нетерпимые» или «непереносимые». Уровней рисков в общем случае может быть больше названных трех. 
Общий вид типичной матрицы рисков для оценки события, потенциально влекущего за собой опасность, составленной в соответствии с процедурой ФОБ, представлен в таблице 2.3.1. В матрице могут быть подставлены коэффициенты, рассчитанные на основе статистических данных или на основе суждений экспертной группы.

Таблица 2.3.1

Общий вид матрицы риска

\begin{tabular}{|l|c|l|l|l|}
\hline $\begin{array}{c}\text { Частота } \\
\text { опасности }\end{array}$ & $\begin{array}{l}\text { Вид или группа } \\
\text { несоответствий }\end{array}$ & \multicolumn{3}{l|}{ Уровень возможных последствий } \\
\hline $\begin{array}{l}\text { Крайне } \\
\text { редко }\end{array}$ & $\mathrm{X}$ & Уровень 6 & Уровень 5 & Уровень 4 \\
\hline Редко & $\mathrm{X}$ & Уровень 5 & Уровень 4 & Уровень 3 \\
\hline Умеренно & $\mathrm{X}$ & Уровень 4 & Уровень 3 & Уровень 2 \\
\hline Часто & $\mathrm{X}$ & Уровень 3 & Уровень 2 & Уровень 1 \\
\hline
\end{tabular}

При формировании матрицы риска в первую очередь выделяется и определяется степень и частота проявления опасности. В качестве первого приближения могут рассматриваться следующие категории показателей [13]:

a) степень опасности:

- низкая - несоответствия, не приводящие к задержанию судна, не содержащие потенциальную угрозу возникновения аварийной ситуации;

- средняя - несоответствия, дающие основания для задержания судна, содержащие потенциальную угрозу возникновения аварийной ситуации, но при этом слабо влияющие на мореходные и эксплуатационные характеристики судна;

- высокая - несоответствия, влекущие за собой необходимость задержания судна, поскольку существенно снижают его мореходные и эксплуатационные характеристики, несут угрозу возникновения аварийных ситуаций или загрязнения моря, содержат высокий риск для человеческой жизни при возникновении аварийной ситуации; 
- чрезвычайная - несоответствия, требующие немедленного задержания судна, так как их последствия приводят к аварийной ситуации;

б) частота опасности (отношение количества несоответствий данного вида к общему числу несоответствий):

- крайне редко - менее $1 \%$;

- редко - $1-5 \%$;

- умеренно - 5-10\%;

- часто - более $10 \%$.

Опасности с низкой степенью частоты в дальнейшем можно не рассматривать, так как они не несут негативных последствий для судоходства. Для объективной оценки риска ошибок классификационного общества могут служить фактические данные о несоответствиях судов по основаниям, относимым к ответственности классификационного общества, выявленные по результатам их проверки государствами-участниками меморандумов о контроле судов государством порта.

Систематизация причин задержаний по основаниям, относимым к ответственности классификационного общества, в системе Парижского меморандума началась в 1998 году. В настоящее время она находится в стадии развития и совершенствования. Установлена единая автоматизированная система оценки видов несоответствий с соответствующей числовой кодировкой по группам.

На втором этапе ФОБ выполняется анализ риска и происходит суммирование рисков. При наличии достоверных статистических данных риск можно подсчитать количественно. Если данных недостаточно, производится пошаговый экспертный анализ развития сценариев событий, и каждому событию назначаются вероятности (частоты нежелательных событий) и степень тяжести последствий. При этом риск также подсчитывается количественно.

Суммарный риск рассчитывается с применением методов функционального анализа, позволяющего моделировать систему в целом и выявлять ее слабые звенья. Суммирование рисков обычно выполняется на основе деревьев событий. Вершинами дерева событий являются функциональные блоки, отображающие 
различные события, которые могут последовать после инициирующего события, а ветви показывают различные вероятности, которые могут возникнуть на каждом этапе анализа.

Полученная информация используется для разработки практических рекомендаций по совершенствованию процессов технического надзора в РМРС.

Расчет показателей риска может быть выполнен по формуле

$$
\begin{gathered}
R=\sum_{i=1}^{N} \alpha_{i} P_{i}, \\
\sum_{i=1}^{N} \alpha_{i}=1,
\end{gathered}
$$

где $\alpha$-степень значимости, назначаемая в зависимости от уровня; $P_{i}$ - вероятность ошибки (относительная частота несоответствия), которая может быть определена как отношение зафиксированных несоответствий к общему числу оказанных услуг РМРС за отчетный период $N$.

Выражение (2.3.7) является общей оценкой и может быть применено к любым видам деятельности РМРС.

Относительная частота несоответствия может быть определена по совокупной выборке по формуле

$$
P_{i}=N_{D E F i} / N_{D E F}
$$

где $N_{D E F i}$ - число несоответствий данной группы; $N_{D E F}-$ общее число отмеченных несоответствий в совокупной выборке за расчетный период.

Схема оценки базируется на процедуре идентификащии опасности. В ходе процедуры идентификации экспертным образом выделяются характерные виды (группы) ошибок (несоответствий) и оценивается степень их опасности по уровню возможных последствий.

Пример матрицы процедуры идентификации рисков представлен в таблице 2.3.2. Группировка несоответствий проведена по 
видам средств обеспечения защиты (например, судовые свидетельства, спасательные средства, противопожарная защита и т. д.) и по принципу равной степени опасности.

Таблица 2.3.2

Матрица процедуры идентификации рисков

\begin{tabular}{|c|c|c|c|}
\hline $\begin{array}{c}\text { Группа видов } \\
\text { несоответствий }\end{array}$ & $\begin{array}{c}\text { Степень } \\
\text { опасности }\end{array}$ & Частота & Уровень \\
\hline судовые свидетельства & чрезвычайная & редко & 3 \\
\hline & высокая & крайне редко & 5 \\
\hline & средняя & крайне редко & 6 \\
\hline спасательные средства & чрезвычайная & умеренно & 2 \\
\hline & высокая & редко & 4 \\
\hline & средняя & редко & 5 \\
\hline
\end{tabular}

Используя соответствующий статистический материал в процедуре ФОБ, можно оценить риски различных видов:

- вероятностный риск

$$
R 1=\sum_{i=1}^{6} \alpha_{i}\left(\sum_{j=1}^{M} N_{D E F i j} / N_{D E F}\right) ;
$$

- условный риск

$$
R 2=R 1 / \lambda, \text { где } \lambda=N_{D E F} / N_{D E T} ;
$$

- приведенный вероятностный риск

$$
R 3=R 1 / N_{S} ;
$$

- приведенный условный риск

$$
R 4=R 2 / N_{S},
$$

где $M$ - число групп видов несоответствий; $N_{D E T}-$ общее число задержаний за расчетный период; $N_{D E F i j}$ - число несоответствий $i$-го уровня в $j$-й группе; $N_{S}$ - число судов, состоящих под надзором РМРС в расчетный период. 
Третий этап ФОБ состоит в выработке вариантов управления риском. На этом этапе рассматриваются возможности управления частотой или смягчением последствий. Результатом является матрица вариантов управления риском, которая представляет входные данные для четвертого шага - оценки затрат и выгод. Пятый шаг ФОБ - выработка рекомендаций для принятия решений.

В практике анализа риск для общества (то есть риск, которому подвергаются все люди за определенное время) обычно оценивают с использованием характеристики случайной величины потерь, называемой диаграммой $F N$. Такие же диаграммы $F N$ принято использовать и при выполнении ФОБ $[35,98]$.

Диаграмма $F N$ отображает на логарифмической шкале зависимость числа смертельных исходов на судно в год (частота нежелательных событий) от количества смертельных исходов (степень тяжести последствий). Большое число смертельных исходов (100-1000) относится к катастрофическим последствиям. Наклонные линии ограничивают изнутри зону так называемого приемлемого риска. Если риск является неприемлемым, то есть находится выше зоны приемлемого, то его степень можно уменьшить различными способами: техническими, организационными или административными.

При этом наклоны большинства из используемых кривых $F N$ составляют

$$
(-1) /(\log f)=-\log (N)+\text { const . }
$$

На рисунке 2.3.3 показан пример диаграммы $F N$.

Наклон, равный (-1), наиболее распространен среди используемых показателей неприятия риска. Однако некоторые регулятивные органы (например, в Швейцарии и Нидерландах) используют наклон, равный $(-2)$, акцентируя внимание на крайнем неприятии риска больших аварий.

На всех шагах проекта ФОБ работает команда экспертов: 6-7 специалистов разного профиля. Один из экспертов (координатор проекта) должен иметь навыки по методологии ФОБ и по анализу риска. Очень важна степень согласия экспертов на каждом этапе 


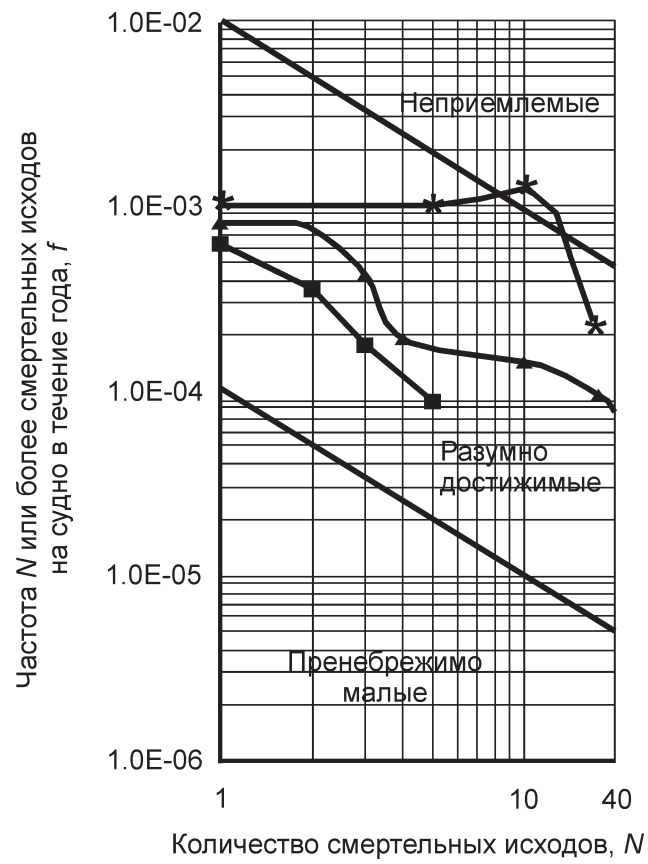

Рис. 2.3.3. Диаграмма формализованной оценки безопасности (диаграмма $F N$ ) проекта, поэтому Российским морским регистром судоходства предложен специальный коэффициент конкордации для оценки степени согласия экспертов [2].

Методология ФОБ является универсальным инструментом, пригодным для оценки рисков и принятия решений в любой отрасли с высокими рисками для людей, собственности и окружающей среды, включая рыбопромысловую отрасль. Технический надзор и оценки рисков различных видов способствуют улучшению качества оказываемых РМРС классификационных и конвенционных услуг, снижению задержания судов портовыми властями государств (PSC) и повышению общей безопасности мореплавания.

Одной из слабых сторон ФОБ является привязка к конкретному (настоящему) моменту при оценке безопасности. Вместе с тем все технологические объекты эксплуатируются определенный промежуток времени с неизбежным протеканием процессов старения и различных видов износа, что не может не сказаться отрицательно на 
надежности и, как следствие, безопасности судового оборудования и судна в целом. Для мониторинга безопасности объектов необходимо периодически оценивать ФОБ, что, безусловно, невозможно в процессе эксплуатации.

\section{4. Методология вероятностного анализа безопасности объектов судоходства}

Исторически были развиты два подхода к оценке безопасности и риска: детерминированный и вероятностный.

Детерминированныій подход подразумевает, что каждая система безопасности должна выполнять заданные функции при любом исходном событии аварии. При таком подходе, очевидно, неполно учитываются все возможные ситуации и невозможно получить адекватную количественную оценку безопасности.

Основой вероятностного подхода является системный количественный анализ различных сценариев аварий, а также последовательное исследование каждого случая, включая пути развития процессов и ситуаций, с учетом наложенных отказов элементов системы, масштаба последствий, влияния неопределенностей и человеческого фактора.

Всестороннюю оценку риска аварий и связанных с нею угроз, а также анализ достаточности принятых мер по предупреждению аварии, локализации и ликвидации последствий аварии позволяет выполнить аппарат, наиболее известный под обобщенным названием «вероятностный анализ безопасности» (ВАБ). Количественная оценка происшествия событий, влекущих за собой нежелательные события, на основе ВАБ относится к решению задач второго этапа процесса ФОБ - анализу риска.

В соответствии с руководящими документами (РД 01.120.00КТН-228-06) вероятностный анализ безопасности - это метод расчетной оценки уровня безопасности промышленных объектов, основанный на выявлении, описании и моделировании сценариев развития возможных инцидентов и аварий, позволяющий оценить вероятность их возникновения и вызванные ими последствия. 
Методология ВАБ основана на системном анализе безопасности. Она обеспечивает установление основных источников аварий, разработку необходимых средств и мероприятий для достижения приемлемого уровня безопасности на стадии проектирования, а также для поддержания этого уровня безопасности в процессе эксплуатации объекта. ВАБ позволяет оценить уровень принципов обеспечения безопасности, определить условия их эффективного применения и дать направление по дальнейшему совершенствованию действующих нормативных документов.

Применительно к системам судовождения в зависимости от содержания, целей и предназначения результатов можно выделить четыре уровня ВАБ.

Уровень ВАБ-0 подразумевает качественный и количественный анализы надежности систем и оборудования судна, важных для его безопасности. Он предусматривает анализ и оценку надежности персонала, отказов по общей причине, перечни исходных событий аварии и другие.

Уровень $B A Б$-1 предполагает разработку вероятностных моделей для определения аварийных ситуаций (АС). По этим моделям производится количественная оценка последствий $\mathrm{AC}$, определяются причины таких событий, рассчитываются вероятности или частоты проявления аварий.

Уровень ВАБ-2 предусматривает анализ состояний с повреждением корпуса судна и выделением и (или) разливом опасных грузов в окружающую среду, моделирование системы локализации, определение состава и количества выбрасываемых в окружающую среду вредных веществ, оценку вероятностей или частот таких событий.

Уровень ВАБ-3 подразумевает анализ распространения опасных веществ при аварии, оценку опасности для местности (акватории и береговой зоны), расчет комплексных показателей безопасности, включая оценку риска судоходства.

Основная задача выполнения ВАБ - выделение наиболее опасных сценариев, которые вносят наибольший вклад в оценку риска. Вероятностный анализ безопасности производится на стадии 
раннего проектирования группой специалистов, среди которых, как правило, присутствуют проектировщики, технологи и специалисты по ВАБ. В качестве исходной информации используется, как правило, проектная и эксплуатационная документация.

Основой ВАБ является широко применяемая в мировой практике и рекомендуемая в документах ИМО к применению в морской отрасли методология деревьев событий и деревьев отказов (или неисправностей). Логико-графические методы анализа деревьев отказов и событий предназначены для выявления причинноследственных связей между комбинацией случайных локальных событий, возникающих с различной частотой на разных стадиях аварии (отказы оборудования, человеческие ошибки, внешние воздействия, наличие встречных судов и плохо различимых объектов, столкновения, посадка на мель, разрушение, выброс, пролив вещества, воспламенение, взрыв, интоксикация и т. д.). Порядок проведения ВАБ представлен на рисунке 2.4.1.

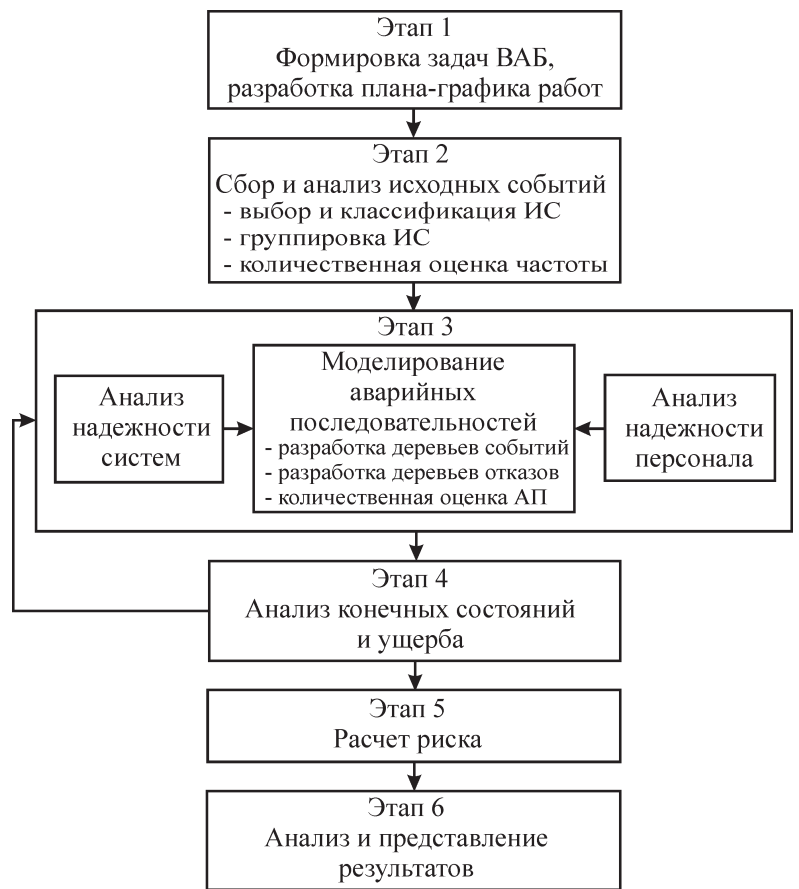

Рис. 2.4.1. Этапы проведения вероятностного анализа безопасности 
Во многих случаях проведение ВАБ в полном объеме может быть затруднено. Тогда выполняются только качественный и количественный анализы надежности объекта.

Анализ исходных событий (этап 2) предполагает составление полного перечня потенциально опасных событий и выделение из этого перечня группы исходных событий для дальнейшего моделирования. Выполнение этого шага необходимо для сокращения перебора возможных аварийных сценариев. Исходными данными для выполнения этого этапа служат анализы аналогичных аварийных ситуаций. Важным достоинством ВАБ является учет человеческого фактора при анализе риска.

Исходные события, частота (интенсивность) которых очень низкая и последствия незначительны, исключаются из начального перечня. Эта процедура называется скрининг. Скрининг позволяет сократить перечень исходных событий до разумного предела, что в дальнейшем позволит осуществить количественный расчет риска.

Безопасность объектов морских транспортных систем определяется рядом событий, включая ошибки персонала, внешние события, природные явления и т. п., которые нельзя трактовать как отказы системы. Анализ аварий показывает, что, как правило, они происходят в результате наложения цепочки событий, последовательность которых удобно отобразить в виде деревьев событий и деревьев отказов (или неисправностей). Используя деревья отказов и событий, на этапе 3 моделируются аварийные ситуации и высчитываются вероятности отказа отдельных элементов системы и событий, которые приводят к аварии. Методология моделирования с использованием деревьев событий и отказов рассмотрена в разделе 2.5 .

Анализ конечных состояний (этап 4) заключается в описании конечных состояний и анализе всех возможных видов ущерба, обусловленного протеканием событий. В результате проведенного последовательного анализа исходов на дереве событий каждому конечному состоянию ставится в соответствие величина эквивалентного ущерба.

Классификация и группировка заключаются в сравнении величины эквивалентного ущерба (для каждого исхода) с величинами 
приемлемого и допустимого ущербов, что позволяет разделить конечные состояния на несколько групп:

- аварийные (AC) - эквивалентный ущерб превышает допустимый;

- неработоспособные опасные (НОС) - эквивалентный ущерб превышает приемлемый, но не превосходит допустимый;

- неработоспособные (НС) - эквивалентный ущерб не превосходит приемлемый (только экономический ущерб);

- работоспособные (РС) - эквивалентным ущербом можно пренебречь (незначительный экономический ущерб).

Значения приемлемого и допустимого ущербов являются производными от экономического состояния страны или региона. Чем выше уровни развития страны и жизни населения, тем ниже значения приемлемого и допустимого ущербов.

Расчет риска (этап 5) выполняется с использованием дерева событий, по которому определяются аварийные последовательности развития аварий.

Если для некоторого исходного события $I_{0}$ можно выделить $n$ вариантов развития аварии $E_{1}, \ldots, E_{n}$ (аварийных последовательностей в дереве событий), то авария может наступить при реализации любой из $n$ несовместных аварийных последовательностей. Таким образом, авария - это событие (в вероятностном смысле), которое является суммой несовместных событий $E_{1}, \ldots, E_{n}$.

Вероятность (условная) аварии в общем виде описывается формулой

$$
Q\left(I_{0}\right)=\sum_{i=1}^{n} Q\left(E_{i} \mid I_{0}\right), i=1,2, \ldots, n,
$$

где $Q\left(E_{i} \mid I_{0}\right)$ - вероятность реализации $i$-той аварийной последовательности для данного исходного события.

Тогда по формуле полной вероятности (безусловной) наступления аварии можно рассчитать безусловную вероятность наступления аварии, то есть риск аварии при наступлении исходного события $I_{0}$ :

$$
R\left(I_{0}\right)=P\left(I_{0}\right) \sum_{i=1}^{n} Q\left(Q\left(E_{i} \mid I_{0}\right)\right)=\sum_{i=1}^{n} P\left(I_{0}\right) Q\left(Q\left(E_{i} \mid I_{0}\right)\right),
$$


где $P\left(I_{0}\right)$ - вероятность наступления исходного события $I_{0}$ за некоторый период времени $T$, например, один год. Эту вероятность определяют, пользуясь результатами анализа исходного события на этапе 2.

На практике, учитывая, что исходные события аварий достаточно редки, распределение вероятности их наступления за время $T$ принято считать пуассоновским:

$$
P(v=m)=\lambda^{m} e^{-\lambda} / \mathrm{m} !=0,1,2, \ldots \lambda>0,
$$

где $P(v=m)$ - вероятность наступления ровно $m$ исходных событий за единицу времени, а $\lambda$ - интенсивность наступления исходных событий, измеряемая их числом в единицу времени.

Для высоконадежных потенциально опасных объектов справедливо $m=1, \lambda T \approx 0, P(v=1)=P\left(I_{0}\right) \approx \lambda$, и для расчета риска целесообразно использовать формулу, учитывающую не вероятность, а интенсивность (частоту) наступления исходного события:

$$
R\left(I_{0}\right)=\lambda \sum_{i=1}^{n} Q\left(E_{i} \mid I_{0} .\right.
$$

Большинство количественных анализов безопасности содержит оценку риска именно в этой формуле, например [108].

Анализ и представление результатов расчета риска (этап 6) является заключительным этапом ВАБ. Его содержание во многом зависит от общих целей ВАБ. Результаты расчета риска позволяют решить задачи сравнения нескольких вариантов безопасности объекта и выявления принципиальной достижимости требуемой безопасности. Анализ результатов расчета риска позволяет выделить наиболее важную (в аспекте безопасности) аварийную последовательность, которая вносит наибольший вклад в величину риска, и выработать (скорректировать) мероприятия по снижению риска опасности возникновения и развития нежелательного события.

Результаты анализа риска аварии обосновываются и оформляются таким образом, чтобы выполненные расчеты и выводы 
могли быть проверены и повторены специалистами, которые не участвовали при первоначальном анализе.

Таким образом, вероятностный анализ безопасности представляет собой сложную комплексную задачу системного анализа, выполнение которой невозможно без разработки и использования соответствующего методического и программного обеспечения.

\section{5. Сценарное моделирование с использованием деревьев событий и отказов для анализа рисков в судоходстве}

Сценарное моделирование с использованием так называемых объединенных деревьев отказов и деревьев событий в документах ИМО получило название RCT (Risk Contribution Trees) - деревья для анализа рисковых последствий. Основным смыслом использования RCT является представление отдельных событий дерева событий, начиная с инициирующего события, в виде деревьев отказов (неисправностей). Графические возможности деревьев отказов позволяют в удобной и наглядной форме представить взаимосвязь и влияние отдельных факторов на вероятность реализации событий на всех стадиях развития опасного состояния, что существенно повышает эффективность системного инструмента анализа риска в целом.

Дерево отказов лежит в основе логико-вероятностной модели потенциально опасного события (аварии, происшествия, последствия, нежелательного события, несчастного случая и пр.).

Дерево отказов (Fault Tree, FT) - это графологическая, иерархическая схема (напоминающая перевернутое дерево), в которой вершины, отображающие события отказов элементов объекта, связаны с помощью ребер и логических операторов «И» и «ИЛИ» с рассматриваемым головным событием - отказом всего объекта в соответствии с причинно-следственными взаимосвязями. Вершиной этого дерева является конечное событие - отказ объекта.

Дерево отказов строится с использованием условных логических символов, обозначение и смысловое содержание которых 
поясняют таблицы обозначения событий (табл. 2.5.1) и логических операций (табл. 2.5.2). Логический символ может иметь один или несколько входов, но только один выход, или выходное событие.

Таблица 2.5.1

Символические обозначения событий в дереве отказов

\begin{tabular}{|l|l|}
\hline Элементарный символ & \multicolumn{1}{|c|}{ Содержание символа } \\
\hline & $\begin{array}{l}\text { головное или промежуточное событие } \\
\text { анализируемое в дереве отказов }\end{array}$ \\
\hline & $\begin{array}{l}\text { исходное событие, обеспеченное доста- } \\
\text { точными данными }\end{array}$ \\
\hline $\begin{array}{l}\text { ное событие, оно не анализируется из-за } \\
\text { отсутствия данных или из-за нецелесо- } \\
\text { образности }\end{array}$ \\
\hline $\begin{array}{l}\text { условное событие, используется с логи- } \\
\text { ческим знаком «ЗАПРЕТ» }\end{array}$ \\
\hline $\begin{array}{l}\text { ожидаемое событие, которое может } \\
\text { произойти или не произойти }\end{array}$ \\
\hline
\end{tabular}

Таблица 2.5.2

Символические обозначения логических операций в дереве отказов

\begin{tabular}{|l|l|}
\hline Элементарный символ & \multicolumn{1}{|c|}{ Содержание символа } \\
\hline & $\begin{array}{l}\text { логический элемент «И»: выходное } \\
\text { событие происходит, если все входные } \\
\text { события случаются одновременно }\end{array}$ \\
\hline
\end{tabular}


Окончание табл. 2.5.2

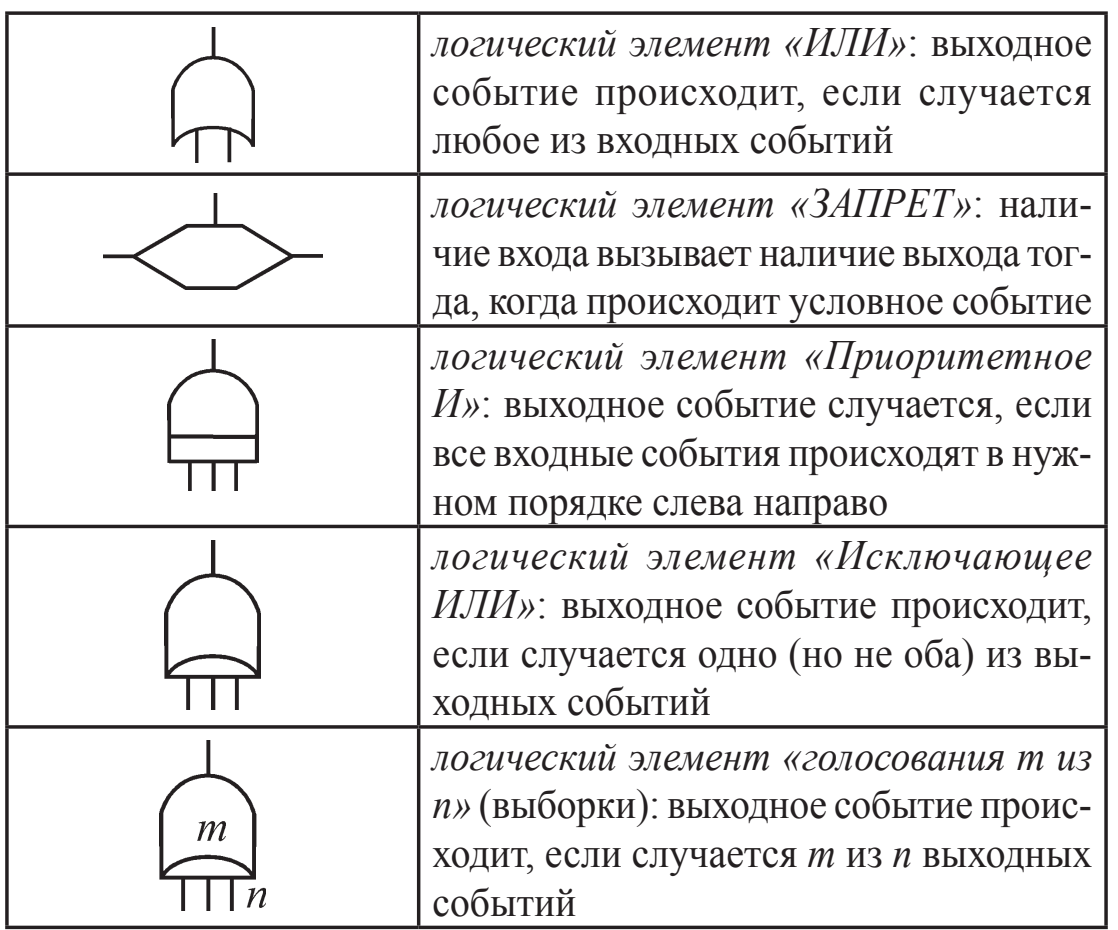

Правила использования логических элементов:

1. Для любого события, подлежащего анализу, вначале рассматриваются все события, являющиеся входами операций «ИЛИ», а затем события, являющиеся входами операций «И».

2. События, входные для операции «ИЛИ», должны формулироваться так, чтобы каждое из них способно было вызвать появление выходного события, а вместе они исчерпывали бы все возможные пути появления выходного события.

3. События, входные для операции «И», должны формулироваться так, чтобы появление выходного события было возможно лишь при совместной их реализации.

4. Если в системе возможны головные события, различающиеся по характеру и тяжести последствий, то для каждого из таких событий строят отдельное дерево отказов. Эти деревья могут объединяться в общее дерево отказов системы. 
Порядок построения дерева отказов:

1. Выбирается уровень детализации рассматриваемой эргатической системы. Рассматриваются все возможные нежелательные события в системе.

2. События разделяются на самостоятельные группы.

3. В каждой группе выделяется головное событие, к которому в различных комбинациях приводят все события данной группы и которое должно быть предотвращено.

4. Рассматриваются все первичные и вторичные события, которые могли вызвать головное событие.

5. Устанавливаются причинно-следственные связи между событиями через соответствующие логические операции (логическое «И», логическое «ИЛИ»).

6. Рассмотрение событий продолжается (по п.п. 1-5) для всех групп событий до тех пор, пока все рассматриваемые события не станут основными, или анализ события прекращается по причине его незначительности, нецелесообразности или отсутствия данных.

7. События представляются графически в виде дерева отказов.

8. Выполняется количественный анализ (вычисление вероятностей событий).

Пример простого дерева отказов приведен на рисунке 2.5.1. Следует отметить, что дерево отказов для данной ситуации не является единственно возможным. В принципе построение дерева может быть продолжено и от события C.

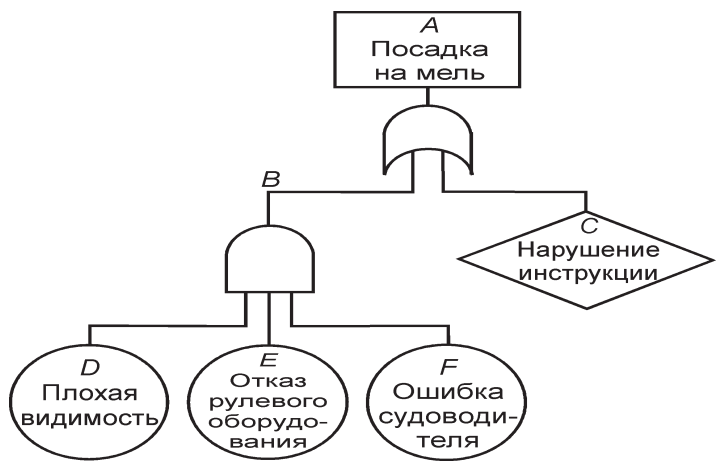

Рис. 2.5.1. Пример дерева отказов с использованием логических элементов И и ИЛИ 
Дерево отказов может использоваться для качественного и количественного анализа исходной системы. Качественный анализ состоит в нахождении всех возможных комбинаций базисных или элементарных событий, которые могут обусловить наступление исследуемого конечного события. Количественный анализ дерева заключается в определении вероятности наступления конечного события (аварии) на основе данных о вероятностях наступления базисных событий.

При качественном анализе деревьев отказов (Fault Tree Analysis FTA) выявляются комбинации отказов (неполадок) оборудования, ошибок персонала и внешних (техногенных, природных) воздействий, приводящих к основному событию (аварийной ситуации). Метод используется для анализа возможных причин возникновения аварийной ситуации и расчета ее частоты на основе знания частот исходных событий. Анализ дерева отказов позволяет выделить ветви прохождения цепочки событий к головному событию и используется, главным образом, для выявления «слабых» мест и определения наиболее эффективных мер предупреждения аварии.

В процессе такого анализа последовательно выявляются все минимальные различающиеся комбинации элементов - критические группы элементов (КГЭ) или минимальные сечения.

Под минимальным сечением понимается совокупность первичных событий в системе, обладающая двумя свойствами:

- совместная их реализация приводит к отказу системы;

- наступление любой комбинации меньшего числа событий не приводит к отказу системы.

Анализ начинается с поиска таких комбинаций, состоящих из одного элемента, затем из двух, трех и т. д. элементов.

Количественный анализ достаточно прост, если известны КГЭ, проанализированы все виды отказов (построено дерево отказов) и известны вероятности отказов (неблагоприятных событий).

В соответствии с законами алгебры логики (булевой алгебры), используя дерево отказов, можно описать логические связи событий, имея в виду, что логический элемент «И» обозначает логическую операцию конъюнкции событий (логическое умножение), 
логический элемент «ИЛИ» обозначает логическую операцию дизъюнкции событий (логическое сложение).

Используя буквенные обозначения событий, представленные на рисунке 2.5.1, логические связи событий в дереве отказов записываются в виде

$$
A=B \vee C, \quad B=D \wedge E \wedge F
$$

или

$$
A=B+C, \quad B=D \cdot E \cdot F,
$$

обе формы записи в (2.5.1) тождественны.

Если известны вероятности отказов или неблагоприятных событий, то вероятность конечного события или вероятность отказа системы можно количественно оценить, используя методы теории надежности. Анализ надежности элементов системы заключается в вычислении показателей надежности элементов, включенных в аварийную последовательность. В теории надежности операция конъюнкции событий эквивалентна параллельному соединению событий (объектов, элементов, компонентов системы), а операция дизъюнкции - их последовательному соединению.

Последовательное соединение элементов системы (в смысле надежности) рассматривается тогда, когда отказ любого ее элемента приводит к отказу системы. Примерами такой системы могут служить трубопроводы и маслопроводы в пределах турбины, последовательное включение измерительных приборов в цепь и т. п. Отказ любого элемента маслопровода (например, штуцера) приводит к отказу всего маслопровода.

Параллельное соединение элементов системы (в смысле надежности) рассматривается тогда, когда ее отказ возникает только в случае отказа всех содержащихся в ней элементов. Примером такой системы служит работа нескольких генераторов, мощность каждого из которых достаточна для обеспечения заданной потребности. Система энергоснабжения откажет тогда, когда откажут все генераторы.

Для безотказной работы системы в течение времени $t$ необходимо, чтобы все элементы, входящие в КГЭ, работали безотказно в 
течение этого времени $t$. Обозначим $P(t)$ - вероятность безотказной работы системы, $p_{i}(t)$ - вероятность безотказной работы элемента, $Q(t)$ - вероятность отказа системы, $q_{i}(t)=1-p_{i}(t)-$ вероятность отказа элемента. Используя известные теоремы теории вероятности для последовательно и параллельно соединенных элементов, можно определить риски наступления нежелательных конечных событий (в смысле надежности):

- при последовательном соединении элементов система работает безотказно (то есть событие произойдет), если безотказно работают все элементы этой системы, тогда вероятность безотказной работы системы можно вычислить как произведение вероятностей безотказной работы всех ее элементов:

$$
P(t)=\prod p_{i}(t)
$$

- при параллельном соединении элементов вероятность отказа системы (то есть событие не наступит) происходит только в случае отказа всех входящих в нее элементов, тогда вероятность отказа системы вычисляется как произведение вероятностей отказов всех ее элементов:

$$
Q(t)=\prod q_{i}(t)
$$

а вероятность безотказной работы равна

$$
P(t)=1-\prod\left(1-p_{i}(t)\right)
$$

Пример. Пусть вероятности наступления событий в дереве отказов на рисунке 2.5.1 равны соответственно: $p_{C}=0,1, p_{D}=0,6, p_{E}=0,2$, $p_{F}=0,1$. Определим вероятность наступления события $A-$ посадки судна на мель.

Вероятность наступления события $B$ равна $p_{B}=1-[(1-0,6)$ $(1-0,2) \times(1-0,1)]=0,712$. Вероятность наступления события $A$ равна $p_{A}=0,712 \cdot 0,1=0,071$.

Главное преимущество метода дерева отказов заключается в том, что анализ ограничивается выявлением только тех элементов 
системы и событий, которые приводят к данному конкретному отказу системы или аварии.

Дерево событий (Event Tree, ET) - графологическая схема (диаграмма), представляющая возможные сочетания событий, в результате которых могут сложиться определенные обстоятельства или произойти события (нежелательные последствия).

Дерево событий используется для анализа факторов, влияющих на аварию, поломку или нежелательное событие. Дерево событий отображает вероятность или частоту аварии, а также меры предосторожности, которые необходимо предпринять после случившегося для того, чтобы минимизировать или предотвратить увеличение масштабов происшествия. При анализе рисков с использованием дерева событий, как и в методе построения дерева отказов, в качестве отправной точки используется вершина, отображающая нежелательное событие, которое выбирается в результате анализа видов, последствий и критичности отказов. Однако в отличие от методики анализа дерева отказов, используемой при анализе надежности объекта, целью моделирования методом построения дерева событий является установление последствий наступления нежелательного события.

Построение дерева событий - это логическое представление различных событий, которые могут последовать после инициирующего события. Деревья событий упорядочивают и отображают события протекания аварии согласно требованиям по ослаблению исходных событий. Они показывают, как среагируют системы на рассматриваемое исходное событие, будут ли выполнены при этом функции безопасности, условия безопасной эксплуатации и что произойдет в итоге. Ветви дерева показывают различные вероятности, которые могут возникнуть на каждом этапе.

Каждое дерево событий включает логическую диаграмму состояний (граф) и таблицу, поставленные в однозначное соответствие друг к другу (рис. 2.5.2).

Логическая диаграмма состояний представляет собой разомкнутый граф (дерево), состоящий из горизонтальных и вертикальных линий, направленных слева направо вдоль ячеек таблицы. Логи- 


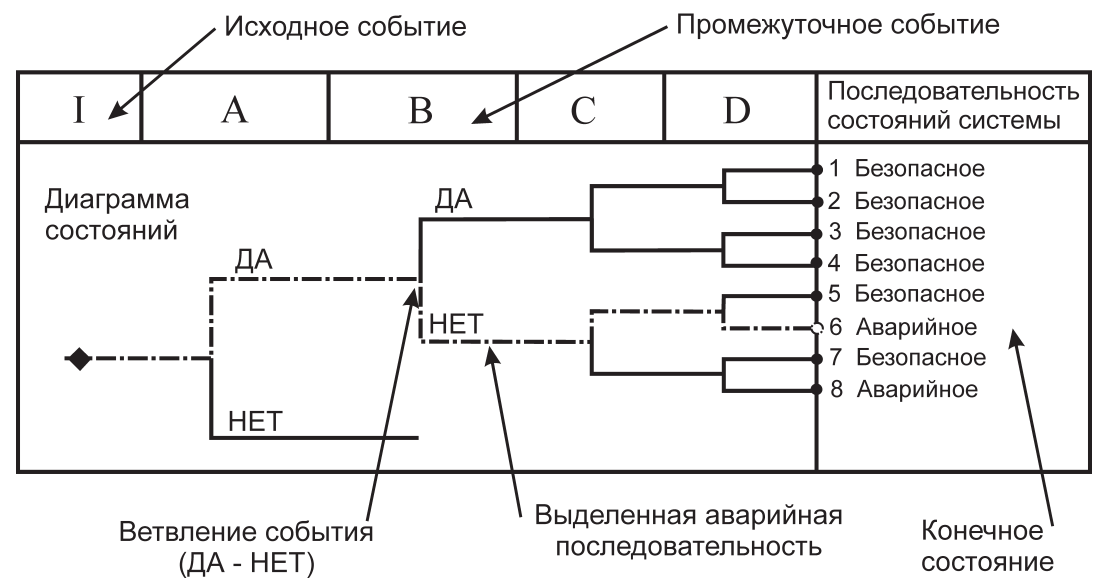

Рис. 2.5.2. Структура дерева состояний

ческая диаграмма устанавливает множество конечных состояний системы и условия их реализации при аварии.

Таблища содержит последовательно составленные ячейки. В левой крайней ячейке таблицы указывается исходное событие или его условное обозначение, в последующих ячейках размещаются промежуточные события или их условные обозначения. Событиями могут быть состояния функций безопасности, состояния систем, базисные события, действия оператора по восстановлению систем.

Разветвление горизонтальной линии в пределах какой-либо ячейки таблицы означает либо осуществление (верхняя ветвь «ДА»), либо неосуществление (нижняя ветвь «НЕТ») события, указанного в ячейке, в зависимости от критерия успеха. В правой части диаграммы у соответствующих ветвей указываются возможные конечные состояния. Траектории от исходного события до конечного состояния дерева отображают пути развития аварии - аварийные последовательности.

При анализе деревьев событий (Event Tree Analysis - ETA) строятся последовательности событий, исходящих из основного события (аварийной ситуации). Осуществляется логический перебор различных путей развития аварии (ветвей дерева событий) и ее последствий. Результатом оценки риска является перечень исходов 
для каждого рассматриваемого случая; при этом рассчитываются частота и последствия, то есть величины ожидаемых последствий.

Дерево событий используется для определения и анализа различных вариантов последовательности развития аварии, включающей сложные взаимодействия между техническими системами обеспечения безопасности. Вероятность каждого сценария развития аварийной ситуации рассчитывается путем умножения вероятности основного события на вероятность конечного события (рис. 2.5.3). При его построении используется прямая логика. Все значения вероятностей очень малы. Дерево не дает численных решений.

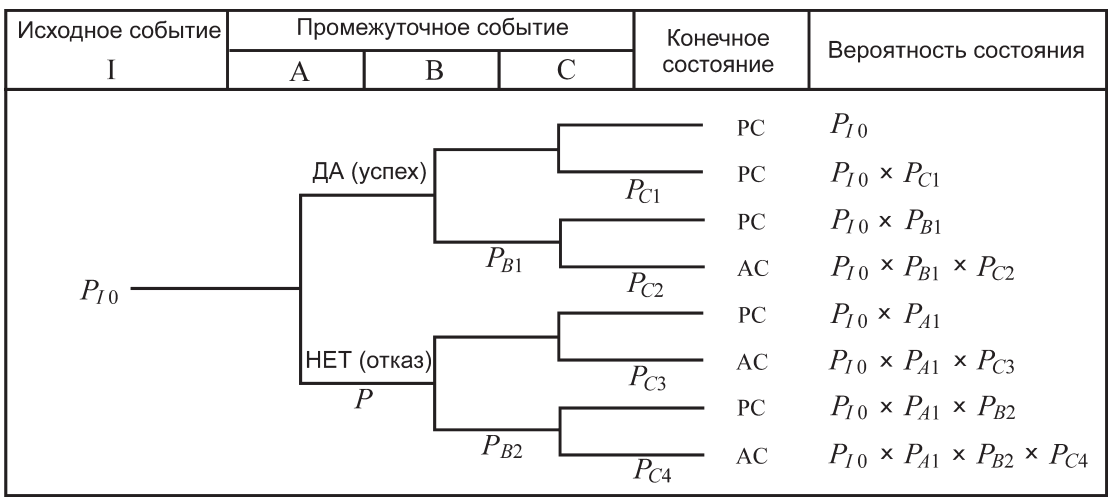

Рис. 2.5.3. Схема расчета вероятностей аварийных последовательностей в дереве событий: РС - работоспособная ситуация;

$\mathrm{AC}$ - аварийная ситуация

Деревья событий могут быть функциональными или системными - в зависимости от стадии (глубины) моделирования.

Функииональные деревья событий отображают успешное или неуспешное выполнение функций безопасности, требуемых для обеспечения проектного протекания аварий или снижения аварийных последствий. В заголовках таблицы промежуточных состояний записываются названия и условные обозначения функций безопасности.

В системных деревьях событий промежуточными событиями являются успешное функционирование либо отказы систем, их 
отдельных каналов, структурных частей, компонентов и (или) ошибочные действия персонала, которые могут повлиять на выполнение рассматриваемых функций безопасности. В качестве промежуточных событий в таблице системного ДС записываются названия или обозначения систем, их отдельных каналов, структурных частей, компонентов или действий персонала.

Как правило, при анализе систем, состоящих из большого числа элементов, методы деревьев событий и отказов применяются совместно, и построение структурно-логической модели проводится в два этапа. На первом этапе строятся системные деревья событий или отказов, элементами которых являются функциональные блоки (каналы) системы. На втором этапе выполняется построение деревьев отказов для каждого функционального блока (канала). Поэтапное построение моделей надежности с использованием промежуточных моделей в форме структурно-функциональных диаграмм и (или) системных деревьев событий дает более глубокое понимание поведения системы и позволяет учесть все особенности ее использования, которые могут повлиять на количественные показатели надежности.

Для каждого конечного состояния на функциональном дереве событий разрабатывается вероятностная модель в виде структурно-функциональной схемы и (или) дерева отказов.

Схема функииональной цуелостности (СФЦ) - это логически универсальное графическое средство структурного представления исследуемых свойств системных объектов. По построению аппарат СФЦ реализует все возможности алгебры логики в функциональном базисе «И», «ИЛИ» и «НЕ».

Основные графические символы СФЦ включают в себя (табл. 2.5.3):

- два вида вершин (функциональная и фиктивная);

- два вида направленных ребер (конъюнктивная дуга и дизъюнктивная дуга);

- два вида выходов дуг из вершин (прямой и инверсный).

Дуга (ребро) $y_{i}$, исходящая из вершины $i$ в СФЦ, называется выходной или интегративной функцией и представляет логические условия реализации (или нереализации) элементом $i$ своего функ- 
ционального назначения в системе. Структурный анализ системы означает графическое представление логических условий реализации собственных функций элементами и подсистемами. Таким образом, СФЦ аналитически эквивалентна системе логических уравнений, составленной по прямым $y_{i}$ и инверсным $\bar{y}_{i}$ выходам всех функциональных, фиктивных и размноженных вершин. Типовые фрагменты СФЦ представлены в таблице 2.5.4.

Таблица 2.5.3

Функциональные символы схемы функциональной целостности

\begin{tabular}{|c|c|}
\hline Элемент СФЦ & Содержание \\
\hline \multicolumn{2}{|r|}{ Вершина } \\
\hline & $\begin{array}{l}\text { функциональная вершина обозначает: } \\
\text { - в логических моделях исходы бинарных со- } \\
\text { бытий }\left\{x_{i}, \bar{x}_{i}\right\} \\
\text { - в вероятностных моделях - вероятности } p_{i} \text {, } \\
q_{i}=1-p_{i}\end{array}$ \\
\hline & $\begin{array}{l}\text { фиктивная вершина является вспомогатель- } \\
\text { ной, используется для удобства графического } \\
\text { представления сложных логических связей и } \\
\text { отношений между элементами системы }\end{array}$ \\
\hline \multicolumn{2}{|r|}{ Ребро } \\
\hline & $\begin{array}{l}\text { дизъюнктивное ребро - стрелка представляет: } \\
\text { - направленность функционального подчинения } \\
\text { между связанными вершинами; } \\
\text { - логический оператор «ИЛИ» между множест- } \\
\text { вом входящих в одну вершину дизъюнктивных } \\
\text { ребер }\end{array}$ \\
\hline & $\begin{array}{l}\text { конъюнктивное ребро - точка представляет: } \\
\text { - направленность функционального подчинения } \\
\text { между связанными вершинами; } \\
\text { - логический оператор «И» между множеством } \\
\text { входящих в одну вершину конъюнктивных ребер }\end{array}$ \\
\hline
\end{tabular}


Окончание табл. 2.5.3

\begin{tabular}{|c|l|}
\hline Элемент СФЦ & \multicolumn{1}{|c|}{ Содержание } \\
\hline$i$ & $\begin{array}{l}\text { прямой выход ребра из вершины представляет } \\
\text { собой условие реализации } y_{i} \text { выходной (интегра- } \\
\text { тивной) функции соответствующим элементом }\end{array}$ \\
\hline$i \rho-$ & $\begin{array}{l}\text { инверсный выход ребра из вершины представ- } \\
\text { ляет собой условие нереализации } \bar{y}_{i} \text { выходной } \\
\text { (интегративной) функции соответствующим } \\
\text { элементом (логический оператор «НЕ») }\end{array}$ \\
\hline
\end{tabular}

Таблица 2.5.4

\section{Типовые фрагменты схемы функциональной целостности}

\begin{tabular}{|c|c|}
\hline $\begin{array}{c}\text { Логический } \\
\text { фрагмент }\end{array}$ & Содержание \\
\hline & $\begin{array}{l}\text { головная вершина, в которую не заходит ни } \\
\text { одного ребра; элементы систем считаются } \\
\text { достоверно обеспеченными }\end{array}$ \\
\hline$y_{i}$ & $\begin{array}{l}\text { последовательное соединение (конъюнктив- } \\
\text { ное или дизъюнктивное ребро) - логическое } \\
\text { произведение (конъюнкция, операция «И») } \\
\text { элементарного события } x_{i} \text { и функциональ- } \\
\text { ного события } y_{i}: y_{i}=x_{i} \wedge y_{j} \text {, одновременное } \\
\text { свершение всех входящих в данное соеди- } \\
\text { нение простых и функциональных событий }\end{array}$ \\
\hline$y_{i}=x_{i} \wedge\left(y_{j} \vee y_{k}\right)$ & $\begin{array}{l}\text { параллельное соединение (дизьюнктивные } \\
\text { ребра) - дизъюнктивная логика обеспечения } \\
\text { реализации выходной функции } y_{i} \text { элемента } i \\
\text { системы } y_{i}=x_{i} \wedge\left(y_{j} \wedge y_{k}\right) \text { определяет безотказ- } \\
\text { ные условия работы данной трехэлементной } \\
\text { схемы в целом }\end{array}$ \\
\hline
\end{tabular}


Окончание табл. 2.5.4

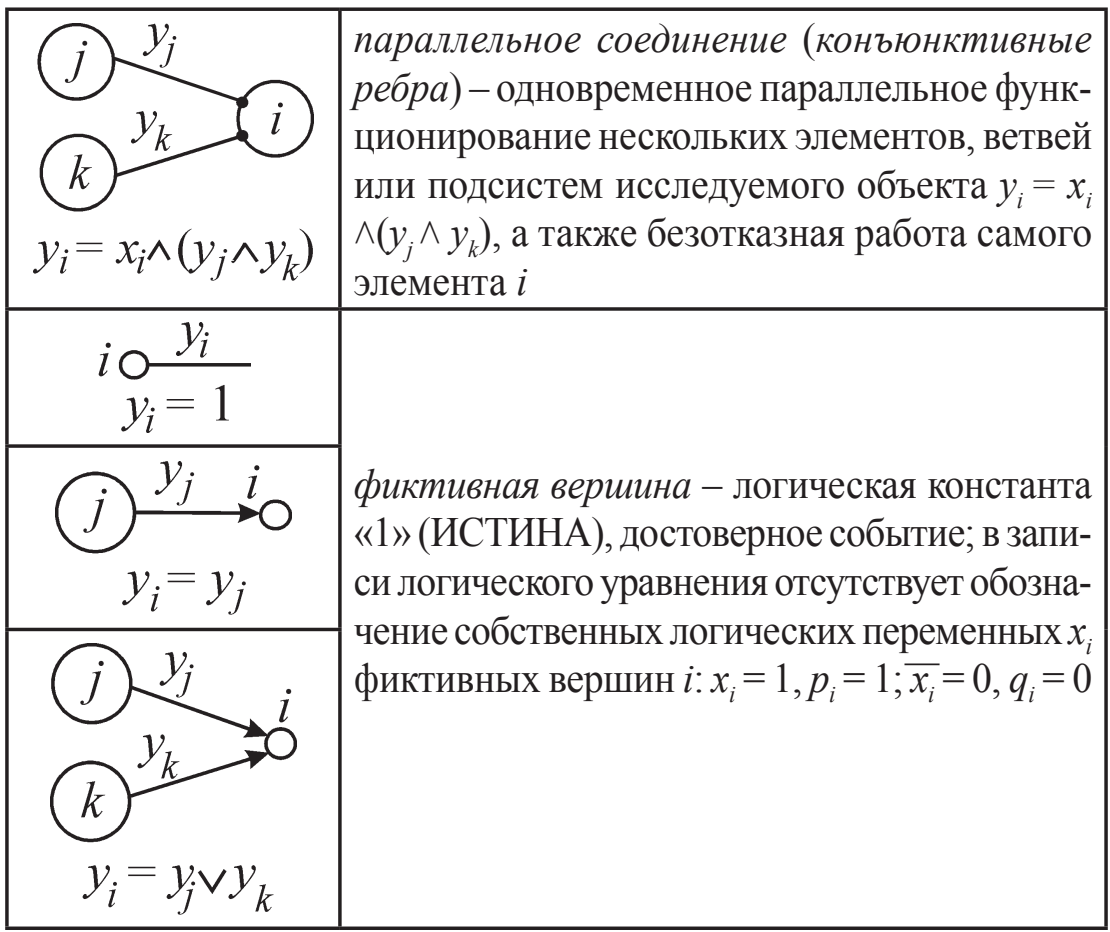

Пример обобщенного логического фрагмента схемы функциональной целостности приведен на рисунке 2.5.4.

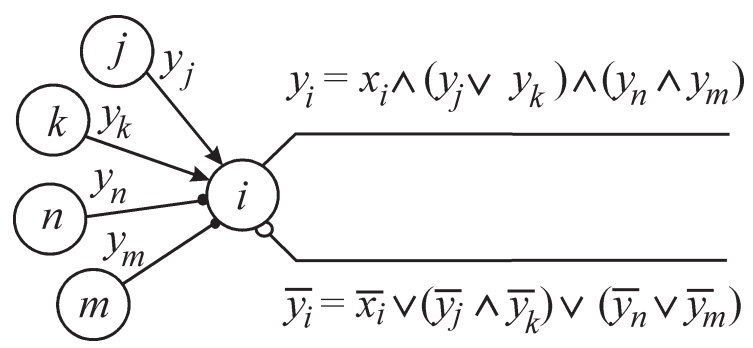

Рис. 2.5.4. Обобщенный фрагмент схемы функциональной целостности

Решение системы логических уравнений по заданному логическому критерию функционирования, полученных с использованием схемы функциональной целостности, позволяет найти логическую функцию работоспособности исследуемой системы. 
Обобщенно методику анализа риска аварии по методу дерева событий можно изложить в следующих основных положениях:

1. Выбирается исходное событие, инициирующее возможную аварию.

2. Разрабатывается сценарий аварии.

3. Определяется вероятность исходного события, по методу дерева отказов определяются вероятности событий работоспособности и вероятности событий отказов, систем, определенных сценарием аварии.

4. Строится дерево событий. Входному ребру дерева событий приписывается вероятность исходного события. Каждому ребру пути, определяющего аварийную последовательность развития аварии, приписывается вероятность события работоспособности или отказа соответствующей системы.

5. Рассчитывается вероятность каждого пути в виде аварийной последовательности ребер, как произведение вероятностей, приписанных этим ребрам.

6. На основе экспертного анализа дерево, состоящее из $m$ исходных вариантов аварии, делится на две части, события которых соответственно $H_{1}$ и $H_{2}$. Сумма этих событий равна достоверному событию $H_{1}+H_{2}=1$.

Событие $H_{1}$ включает в себя $t$ вариантов аварийных последовательностей (путей), $t<m$, которые, по мнению эксперта, имеют практическую возможность привести к аварии. Остальные $(m-t)$ вариантов относятся к событию $H_{2}$ и исключаются.

7. Вычисляется вероятность события риска аварии, равного сумме вероятностей несовместных событий путей (аварийных последовательностей).

Методы деревьев отказов и событий являются трудоемкими и применяются, как правило, для анализа проектов или модернизации сложных технических систем и производств.

Для выполнения расчетного анализа нужна подробная математическая модель объекта, позволяющая моделировать поведение объекта в целом и отдельных его систем. На основе такой модели могут быть разработаны тренажеры для обучения персонала и 
для поддержания его квалификации на требуемом для безопасной эксплуатации объекта уровне.

Решение задач оценки риска и выработки рекомендаций по управлению риском позволяет говорить о необходимости использования следующих классов моделей [13]:

1. Модели надежности - предназначены для анализа показателей надежности функциональных узлов; строятся на основе структурных и функциональных схем технологических узлов с учетом специфики технологического процесса.

2. Модели безопасности - предназначены для анализа надежности систем противоаварийной защиты и безопасности технологических блоков и систем; строятся на основе структурных и функциональных схем систем противоаварийной защиты.

3. Модели аварий - предназначены для оценки вероятности возникновения аварии, оценки возможных масштабов выбросов опасных веществ, выявления возможных последствий аварии; строятся на основе структурных и функциональных схем технологического оборудования, описаний технологического процесса и систем защиты, а также на основе сценариев аварий.

4. Модели оценки последствий аварий - предназначены для пространственного моделирования зон действия опасных и поражающих факторов, оценки ущерба (разрушений, потерь), вызываемых этими факторами; строятся на основе моделей развития опасных факторов (взрыв, пожар, заражение местности).

5. Модели поиска решений по управлению риском - предназначены для выработки заключений об уровне опасности анализируемого объекта и его компонентов и предложений по снижению рисков аварий и повышению безопасности анализируемого объекта.

Взаимосвязь указанных классов моделей иллюстрирует рисунок 2.5.5, на котором изображена схема анализа риска аварий при эксплуатации объектов судовождения.

На рисунке видно, что для получения оценки риска, на основании которой вырабатываются мероприятия по предупреждению, локализации и ликвидации последствий аварий, необходим совместный учет ущерба от аварии и вероятности самой аварии. 


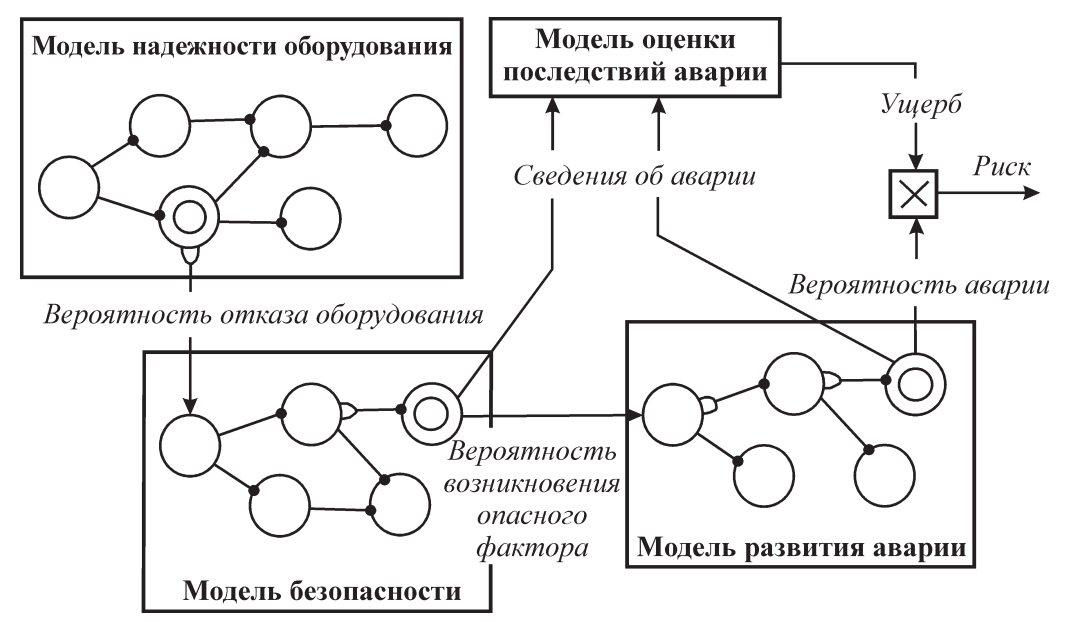

Рис. 2.5.5. Схема анализа риска аварий при эксплуатации объектов судовождения

\section{6. Методика анализа риска объектов инфраструктуры мореплавания}

Методика анализа риска объектов инфраструктуры мореплавания базируется на использовании комплекса моделей безопасности. Процедура анализа включает в себя следующие шесть этапов [13]:

1) анализ надежности основного технологического оборудования водной транспортной системы (ТC);

2) анализ надежности системы противоаварийной защиты ТС;

3) анализ сценариев развития аварии;

4) оценка последствий аварии;

5) расчет значений показателей риска;

6) выработка рекомендаций по управлению риском.

Анализ риска, в общем случае, является многоитерационной процедурой, в которой на каждом этапе учитываются результаты, полученные на каждом из предыдущих этапов. Реализация (планирование) мероприятий по управлению риском приводит к изменению структуры и характеристик основного оборудования и систем защиты. В результате любое принятое решение приводит 
к изменению полученных ранее показателей риска. Рассмотрим содержание этапов анализа риска.

Анализ надежности оборудования ТС включает обследование объекта и создание системы моделей, описывающих функционирование технологического оборудования в штатных режимах использования. Источником данных для разработки моделей являются:

- описание технологического процесса блока или установки;

- структурные, функциональные и технологические схемы блока;

- сведения о режимах работы, характеристиках надежности и иных характеристиках основного и вспомогательного технологического оборудования.

Анализ надежности оборудования ТС направлен на выявление «слабых» мест на основе оценки вероятности возникновения опасных ситуаций вследствие отказов оборудования. Технологическое оборудование включает основное и вспомогательное оборудование, а также кабельные линии связи.

С учетом анализа надежности оборудования разрабатывается стратифицированный комплекс моделей, включающий несколько уровней стратификации (слоев детализации). Число выделяемых уровней и глубина детализации схем определяется поставленными задачами моделирования.

На верхних уровнях иерархии предметом анализа является структура объекта исследования и функциональные связи между различными элементами структуры. На нижних уровнях иерархии предметом анализа является функциональная структура и особенности технологического процесса. При анализе работы оборудования учитывается его собственная надежность, надежность систем снабжения электроэнергией, водой, топливом и другими необходимыми ресурсами.

Оборудование в схемах нижнего уровня можно условно разделить на три группы:

- основное технологическое оборудование, обеспечивающее выполнение технологического процесса; для описания технологического процесса используется модель надежности; 
- защчитное оборудование, обеспечивающее защиту стабилизатора при возникновении потенциально опасных ситуаций; для описания функционирования защитного оборудования используется модель безопасности;

- вспомогательное оборудование (например, приводы насосов И Т. П.).

Для выполнения анализа надежности установки сформируется банк данных, содержащий сведения по надежности, защищенности и другим характеристикам оборудования, а также разрабатываются модели, описывающие штатное функционирование установки и ее элементов в ходе технологического процесса. Входной информацией являются показатели надежности и технического состояния оборудования. Выходной информацией являются вероятности безотказной работы или вероятности отказа оборудования, узлов, блоков и установок в целом.

Функции управления риском, относящиеся к данному этапу, заключаются в организации технического обслуживания и ремонта, позволяющего исключить отказы оборудования в период между регламентными работами и повысить надежность оборудования.

Анализ надежности системы противоаварийной защзиты включает обследование объекта и создание комплекса моделей, описывающих функционирование технологического оборудования и систем противоаварийной защиты при опасных отклонениях параметров технологического процесса.

Модели в процедуре анализа надежности системы противоаварийной защиты разрабатываются на основе данных, полученных из различных источников:

- описание технологического процесса блока (установки);

- структурные, функциональные и технологические схемы блока;

- описание и схемы системы противоаварийной защиты;

- сведения о режимах работы, характеристики надежности и иные характеристики оборудования систем защиты.

Целью данного этапа является выявление «слабых» мест и оценка вероятности возникновения потенциально опасных ситуаций вследствие отказов технологического оборудования и систем противоаварийной защиты. 
Общая методология анализа надежности систем противоаварийной защиты в целом аналогична методологии анализа основного оборудования. Существенной особенностью является то, что основой для анализа надежности систем защиты являются результаты анализа потенциально опасных ситуаций.

Для анализа надежности систем защиты установки формируется банк данных, содержащий сведения по надежности, защищенности и другим характеристикам оборудования и устройств защиты, а также разрабатываются модели, описывающие функционирование устройств защиты при возникновении опасных факторов.

Входной информацией являются показатели надежности и технического состояния оборудования и устройств защиты. Выходной информацией являются вероятности безотказной работы или вероятности отказа устройств защиты, а также вероятность возникновения опасной ситуации как следствие неспособности системы защиты исключить развитие опасных факторов.

Функиии управления риском, относящиеся к данному этапу, заключаются в организации системы технического обслуживания и ремонта средств противоаварийной защиты, задачей которой является исключение отказов оборудования и повышение надежности систем противоаварийной защиты.

Анализ сценариев развития аварии включает исследование всех возможных вариантов аварии, определение факторов, способствующих или препятствующих развитию аварии, а также создание комплекса моделей, описывающих выделенные сценарии развития аварий.

Целью данного этапа является определение места и объемов выброса опасных веществ, типов веществ и возможных вариантов развития аварии. Схема типового сценария развития аварии изображена на рисунке 2.6.1 [13].

Анализ сценариев развития аварии выполняется в следующем порядке:

1. Выделяются все потенциально опасные факторы, способные привести к опасным ситуациям и в дальнейшем к авариям.

Под опасным фактором понимается выход параметров технологического процесса за допустимые пределы, приводящие к возможности возникновения опасных ситуаций. 


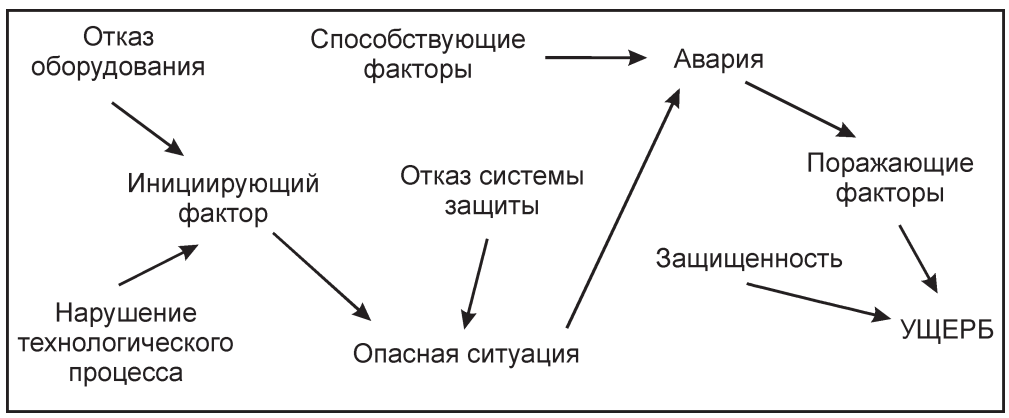

Рис. 2.6.1. Типовой сценарий развития аварии

2. Определяются возможные опасные ситуации для каждого опасного фактора.

Под опасной ситуацией понимается состояние оборудования, узла, блока или установки, при котором имеется потенциальная возможность возникновения аварии, - разрушение оборудования, утечки или выброс веществ и т. п.

3. Определяется для каждой опасной ситуации перечень факторов, которые способствуют или препятствуют возникновению аварии.

4. Определяются поражающие факторы, возникающие при аварии и определенных способствующих факторах.

Для анализа сценариев развития аварий формируется банк данных, который содержит сведения по надежности, защищенности и другим характеристикам оборудования и устройств защиты, а также разрабатываются модели, описывающие развитие опасных факторов и влияние способствующих факторов.

Входной информацией являются вероятности безотказной работы оборудования и устройств защиты. Выходной информацией являются вероятности возникновения различных аварийных ситуаций.

Управление риском на данном этапе заключается в организации инженерно-технических мероприятий, которые направлены на исключение факторов, способствующих развитию аварии.

Оиенка последствий аварии состоит в исследовании всех возможных вариантов развития аварии и определении ее последствий.

Мерой оценки последствий в зависимости от решаемой задачи анализа риска является ущзерб. Целью данного этапа является 
определение величины возможного ущерба от аварии и оценка возможных потерь.

Мерой ущерба при оценке социального риска являются жертвы среди обслуживающего персонала и гражданского населения, при оценке технического риска - возможные разрушения оборудования и т. п.

Оиенка последствий аварии выполняется с использованием аналитических моделей, которые описывают потенциально возможные для рассматриваемого объекта (установки) виды аварий.

Обобщенная классификация аварий приведена в таблице 2.6.1 [13].

Таблица 2.6.1

Классификация последствий аварий

\begin{tabular}{|c|c|c|c|}
\hline $\begin{array}{l}\text { Опасная } \\
\text { ситуация }\end{array}$ & $\begin{array}{c}\text { Сценарий } \\
\text { аварии }\end{array}$ & Последствия & $\begin{array}{c}\text { Вероят- } \\
\text { ность воз- } \\
\text { никновения }\end{array}$ \\
\hline $\begin{array}{l}\text { разгерметизация } \\
\text { оборудования, } \\
\text { мелкая течь }\end{array}$ & $\begin{array}{l}\rightarrow \text { образование } \\
\text { пролива } \\
\rightarrow \text { образование } \\
\text { газового облака }\end{array}$ & $\begin{array}{l}\rightarrow \text { пожар } \\
\rightarrow \text { взрыв об- } \\
\text { лака }\end{array}$ & $\begin{array}{l}\rightarrow \text { низкая } \\
\rightarrow \text { низкая }\end{array}$ \\
\hline $\begin{array}{l}\text { повреждение и } \\
\text { разгерметизация } \\
\text { оборудования, } \\
\text { крупная течь }\end{array}$ & $\begin{array}{l}\rightarrow \text { образование } \\
\text { пролива } \\
\rightarrow \text { образование } \\
\text { газового облака } \\
\\
\rightarrow \text { образование } \\
\text { токсичного газо- } \\
\text { вого облака }\end{array}$ & $\begin{array}{l}\rightarrow \text { пожар } \\
\rightarrow \text { взрыв об- } \\
\text { лака, факель- } \\
\text { ное горение, } \\
\text { огненный шар } \\
\rightarrow \text { взрыв, хи- } \\
\text { мическое за- } \\
\text { ражение }\end{array}$ & $\begin{array}{l}\rightarrow \text { высокая } \\
\rightarrow \text { высокая } \\
\text { средняя } \\
\text { низкая } \\
\\
\rightarrow \text { высокая }\end{array}$ \\
\hline $\begin{array}{l}\text { разрушение обо- } \\
\text { рудования, вы- } \\
\text { брос больших } \\
\text { объемов веще- } \\
\text { ства }\end{array}$ & $\begin{array}{l}\rightarrow \text { образование } \\
\text { пролива } \\
\rightarrow \text { образование } \\
\text { газового облака } \\
\\
\rightarrow \text { образование } \\
\text { токсичного газо- } \\
\text { вого облака }\end{array}$ & $\begin{array}{l}\rightarrow \text { пожар, } \\
\text { взрыв } \\
\rightarrow \text { факель - } \\
\text { ное горение, } \\
\text { взрыв облака, } \\
\text { огненный шар } \\
\rightarrow \text { взрыв, хи- } \\
\text { мическое за- } \\
\text { ражение }\end{array}$ & $\begin{array}{l}\rightarrow \text { высокая } \\
\rightarrow \text { высокая } \\
\text { высокая } \\
\text { низкая } \\
\\
\rightarrow \text { высокая }\end{array}$ \\
\hline
\end{tabular}


Анализ последствий аварий выполняется с учетом факторов, способствующих реализации их различных сценариев.

Модель аварии учитывает особенности технологического процесса и функционирования систем защиты и включает три этапа.

На первом этапе определяются потенциально опасные ситуации и их возможные последствия:

- выброс больших объемов сырья под давлением в результате разрушения оборудования;

- крупная течь в результате появления нарушения герметичности или появления дефектов оборудования (например, трещин);

- мелкая течь в результате нарушения герметичности.

На втором этапе определяются факторы, способствующие возникновению и развитию аварии в зависимости от класса выбрасываемого вещества и вида опасной ситуации. Например, если рабочим телом в стабилизаторе давления является летучая легковоспламеняющаяся жидкость, то способствующими факторами является наличие источников открытого огня, источников искрения и нагретых поверхностей.

На третьем этапе определяются сценарии и формируется модель развития аварии.

Функциями управления риском на данном этапе являются оповещение персонала, введение в действие планов эвакуации и ликвидации чрезвычайных ситуаций.

Расчет значений показателей риска. Риск аварии $\mathrm{R}$ определяется как математическое ожидание вероятности возникновения потенциально опасных факторов и возможного ущерба от аварии

$$
R=p_{\text {ОФ }} C,
$$

здесь $p_{\text {оФ }}-$ вероятность проявления потенциально опасных факторов, следствием которых может быть авария; $C$ - ожидаемый ущерб от действия рассматриваемых опасных факторов в случае возникновения аварии.

Вероятность $p_{\text {оФ }}$ является функцией надежности различных групп оборудования, эффективности функционирования персо- 
нала, условий, способствующих развитию аварий, и вычисляется с использованием моделей надежности и безопасности в виде:

$$
p_{\mathrm{O} \Phi}=f\left(H_{\mathrm{OO}}, H_{\mathrm{A} 3}, H_{\mathrm{BO}}, H_{\Pi}, \mathrm{O} \Phi\right),
$$

где $H_{\mathrm{OO}}, H_{\mathrm{A} 3}, H_{\mathrm{BO}}$ - надежность основного оборудования, аварийной защиты и вспомогательного оборудования; $H_{\Pi}-$ надежность обслуживающего персонала (операторов) установки; ОФ - наличие условий (способствующих факторов) для развития аварии при наличии опасных факторов (вероятность или интенсивность возникновения способствующих факторов).

Ожидаемый ущерб $C$ определяется с использованием моделей оценки последствий аварий. На основании сведений о месте аварии, действующих опасных факторах, объеме и составе участвующих в аварии опасных веществ рассчитываются зоны поражения (действия опасных факторов - ударной волны, термического воздействия, химического заражения и др.) и с использованием картографического блока системы управления безопасностью судоходства (СУБ) определяются объекты, попавшие в зоны поражения. В зависимости от выбранного для оценки риска критерия (социальный риск, территориальный риск и т. д.) определяется ожидаемый ущерб $C$ либо как материальный ущерб от аварии (прямой и косвенный), либо как число возможных жертв аварии.

\section{7. Моделирование аварий при перевозках опасных грузов}

В большинстве случаев развитие первичной аварии (например, нарушение герметичности танка) непосредственно не ведет к проявлению опасных факторов - заражению территорий (при химической аварии), разрушению оборудования (при взрывах и пожарах), поражению экипажа. Проявление поражающих факторов в большинстве случаев возникает при наличии сопутствующих условий, в частности [13]:

- для химической аварии - это температура окружающей среды, сила и направление ветра, состояние атмосферы; 
- для взрывов и пожаров - это наличие взрывопожароопасных концентраций вещества, источников огня или нагрева, избыточного давления в емкостях.

Модель развития аварии судна, перевозящего опасные грузы (химически опасные, пожароопасные или взрывоопасные), приведена на рисунке 2.7.1.

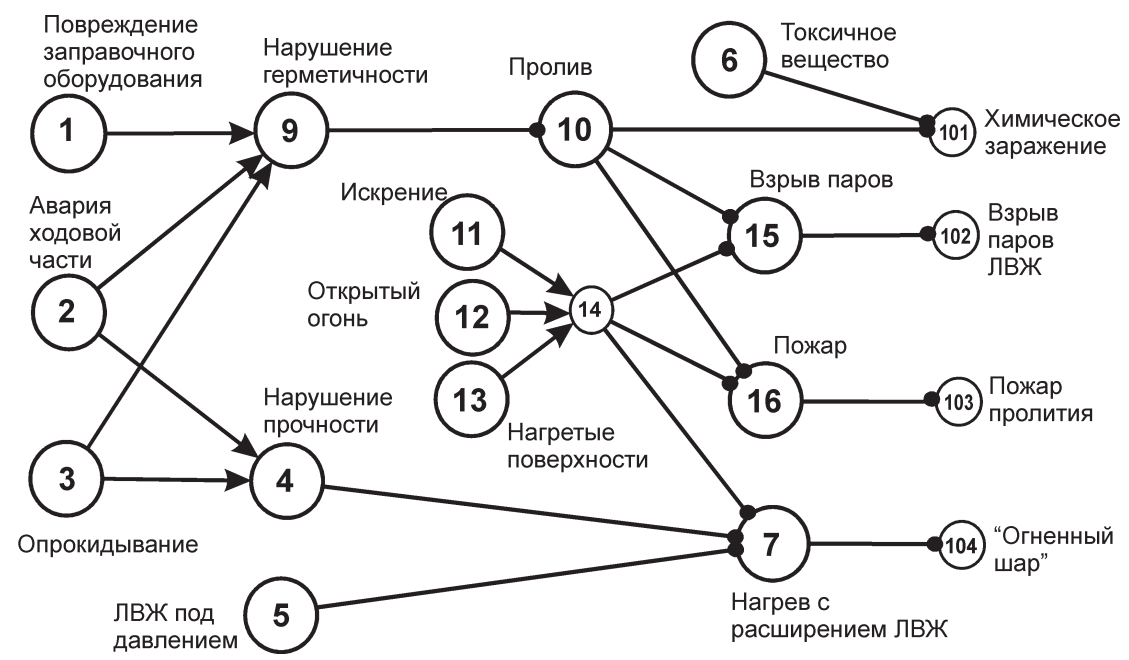

Рис. 2.7.1. Модель формирования опасных факторов при авариях судов, перевозящих опасные грузы

Анализ большого числа аварий на судах, перевозящих опасные грузы, позволяет утверждать, что в качестве первичных поражающих факторов выступают в соответствии с рисунком 2.7.1 следующие:

- повреждение заправочного оборудования (вершина 1), вызванное неисправностями запорных устройств или трубопроводов для приема груза (легковоспламеняющейся жидкости - ЛВЖ);

- авария ходовой части (вершина 2), вызванная неисправностями или столкновением с другим судном или посторонним объектом;

- опрокидывание судна (вершина 3) в результате неправильных маневров или при столкновении с другим судном или посторонним объектом. 
В рассматриваемом примере критериями опасности являются вероятности возникновения химического заражения (вершина 101), взрыва паров легковоспламеняющейся жидкости (вершина 102), пожар разлива опасного вещества (вершина 103), возникновение «огненного шара» (вершина 104) и комбинированный сценарий, включающий все перечисленные критерии.

Для описания сценария развития аварии использован аппарат схем функииональной цуелостности, который основан на общем логико-вероятностном методе и, в основном, удовлетворяет требованиям к моделям, используемым для решения задач анализа риска. Описание элементов модели и принятые при моделировании значения вероятностей событий приведены в таблице 2.7.1.

Таблица 2.7.1

Исходные данные для моделирования

\begin{tabular}{|c|c|c|}
\hline $\begin{array}{c}\text { Номер } \\
\text { элемента }\end{array}$ & \multicolumn{1}{|c|}{ Параметр (описание вершины) } & $\begin{array}{c}\text { Значение } \\
\text { вероятности }\end{array}$ \\
\hline 1 & \multicolumn{1}{|c|}{2} & 3 \\
\hline \multicolumn{3}{|c|}{ Вероятности возникновения аварийных факторов } \\
(в течение 1 года)
\end{tabular}


Окончание табл. 2.7.1

\begin{tabular}{|c|c|c|}
\hline \multicolumn{3}{|c|}{$\begin{array}{c}\text { Вероятности присутствия опасных факторов } \\
\text { (относительно общего объема перевозок опасных грузов) }\end{array}$} \\
\hline 5 & $\begin{array}{l}\text { Опасное вещество находится под дав- } \\
\text { лением }\end{array}$ & 0,15 \\
\hline 6 & Вещество является токсичным & 0,10 \\
\hline \multicolumn{3}{|c|}{$\begin{array}{l}\text { Вероятности появления факторов, } \\
\text { вызывающих горение при аварии }\end{array}$} \\
\hline 11 & Искрение & 0,10 \\
\hline 12 & Открытый огонь & 0,05 \\
\hline 13 & $\begin{array}{l}\text { Наличие поверхностей, нагретых до } \\
\text { температуры самовоспламенения опас- } \\
\text { ного вещества }\end{array}$ & 0,25 \\
\hline \multicolumn{3}{|c|}{ Вероятности проявления сценария аварии } \\
\hline 7 & $\begin{array}{l}\text { Нагрев хранилища (танка) с ЛВЖ под } \\
\text { давлением }\end{array}$ & 0,60 \\
\hline 10 & Пролив опасного вещества & 0,90 \\
\hline 15 & Взрыв паров опасного вещества & 0,80 \\
\hline 16 & Пожар пролития & 0,80 \\
\hline
\end{tabular}

Модель формирования опасных факторов (рис. 2.7.1) является упрощенной, а выбранные по таблице 2.7.1 значения вероятностей - усредненными.

Результаты моделирования приведены в таблице 2.7.2. Эти результаты следует рассматривать как качественную оценку опасности возникновения аварий. В столбцах 2 и 3 таблицы указаны значения вероятностей и интенсивностей возникновения различных видов аварий в течение одного года для одного хранилища (танка).

В столбце 4 таблицы 2.7.2 в порядке убывания значимости указаны номера элементов исследуемой модели, соответствующие рисунку 2.7.1 и таблице 2.7.1. В скобках указаны элементы, имею- 
щие одинаковую значимость. Подчеркиванием выделены факторы, способствующие развитию аварии. Жирным выделены факторы, которые определяют саму возможность возникновения аварии.

Таблица 2.7.2

Результаты расчета вероятности аварий

\begin{tabular}{|c|c|c|c|}
\hline Вид аварии & $\begin{array}{c}\text { Вероятность } \\
\text { аварии }\end{array}$ & $\begin{array}{c}\text { Интенсив- } \\
\text { ность, } \\
\text { 1/год }\end{array}$ & $\begin{array}{c}\text { Значимость } \\
\text { параметров (по } \\
\text { убыванию) }\end{array}$ \\
\hline 1 & 2 & 3 & 4 \\
\hline $\begin{array}{l}\text { химическое } \\
\text { заражение }\end{array}$ & $3,634 \cdot 10^{-3}$ & $6,413 \cdot 10^{-4}$ & $6,(1-3), \underline{9}$ \\
\hline взрыв паров ЛВЖ & $1,043 \cdot 10^{-2}$ & $5,209 \cdot 10^{-4}$ & $\begin{array}{l}(1-3), \underline{\mathbf{9}},(\underline{\mathbf{1 1 - 1 3}}), \\
15,10\end{array}$ \\
\hline $\begin{array}{l}\text { пожар пролива } \\
\text { ЛВЖ }\end{array}$ & $1,043 \cdot 10^{-2}$ & $5,209 \cdot 10^{-4}$ & $\begin{array}{l}(1-3), \underline{\mathbf{9}},(\underline{\mathbf{1 1}-\mathbf{1 3}}), \\
16,10\end{array}$ \\
\hline «огненный шар» & $6,839 \cdot 10^{-4}$ & $8,319 \cdot 10^{-4}$ & $\begin{array}{l}(2,3), 5,(\underline{\mathbf{1 1}-\mathbf{1 3}}), \\
7\end{array}$ \\
\hline комбинированная & $1,543 \cdot 10^{-2}$ & $4,762 \cdot 10^{-4}$ & $\begin{array}{l}(2,3), 1, \underline{9}, 6, \\
(\underline{\mathbf{1 1}-\mathbf{1 3}})\end{array}$ \\
\hline
\end{tabular}

\section{8. Информационное обеспечение управления безопасностью}

Информационное обеспечение систем управления безопасностью (СУБ) представляет собой совокупность единой системы классификации и кодирования информации, а также унифицированных систем документации. Информационное обеспечение определяет процедуры сбора, обработки и передачи информации; процедуры подготовки и принятия решений в области управления риском.

Информационное обеспечение реализуется на основе информационных технологий. В соответствии с определением ГОСТ 
34.003-90 под термином «информационные технологии» понимается совокупность методов, способов, приемов, средств обработки информации и регламентированного порядка их применения, направленных на удовлетворение информационных потребностей.

Решение функциональных задач анализа и управления безопасностью ТС опирается на использование следующих информационных технологий:

- технология распределенных баз данных, обеспечивающая совместное и автономное решение задач различными автоматизированными подсистемами СУБ. Технология распределенных баз данных основана на технологиях автоматизированных банков данных и документов;

- технология распределенного преобразования информации, обеспечивающая решение каждым уровнем иерархии СУБ своих функциональных задач и позволяющая реализовать параллельное решение задач на всех уровнях иерархии управления $\mathrm{TC}$;

- CALS-технологии, обеспечивающие поддержку жизненного цикла элементов ТС (транспортных узлов, коммуникаций, транспортных средств и т. п.) в части эксплуатации, ремонта, обслуживания и утилизации.

В таблице 2.8.1 [13] приведено краткое описание особенностей используемых информационных технологий.

Технология распределенного преобразования информации предполагает использование единого информационного пространства и оснащение каждого уровня управления безопасностью ТС комплексом программных средств, позволяющих решать функциональные задачи данного уровня, а также решать задачи нижестоящих уровней иерархии.

Анализ информационных процессов в ТС показывает, что для обеспечения функционирования различных уровней управления безопасностью ТС необходимо создать единую систему кодификации информации и стандартный набор шаблонов документов.

Информационное обеспечение ТС включает:

- систему моделей, описывающих процедуры сбора, обработки и передачи информации; 
- систему моделей, описывающих процедуры подготовки и принятия решений в области оперативного управления работой ТС и ее долгосрочного развития;

- систему нормативных документов и законодательных актов, регламентирующих вопросы функционирования ТС.

Таблица 2.8.1

Информационные технологии управления безопасностью морских транспортных систем

\begin{tabular}{|c|c|c|}
\hline $\begin{array}{c}\text { Наименование } \\
\text { технологии }\end{array}$ & $\begin{array}{l}\text { Назначение } \\
\text { технологии }\end{array}$ & $\begin{array}{c}\text { Применение } \\
\text { технологии }\end{array}$ \\
\hline $\begin{array}{l}\text { банки докумен- } \\
\text { тов }\end{array}$ & $\begin{array}{l}\text { автоматизация до- } \\
\text { кументооборота на } \\
\text { всех уровнях иерар- } \\
\text { хии СУБ }\end{array}$ & $\begin{array}{l}\text { на всех уровнях иерар- } \\
\text { хии СУБ для решения } \\
\text { функциональных задач } \\
\text { управления ТС и для } \\
\text { взаимодействия с дру- } \\
\text { гими системами управ- } \\
\text { ления государственных } \\
\text { органов }\end{array}$ \\
\hline банки данных & $\begin{array}{l}\text { создание единого } \\
\text { информационного } \\
\text { пространства на ос- } \\
\text { нове общей струк- } \\
\text { туры баз данных и } \\
\text { единой системы ко- } \\
\text { дификации инфор- } \\
\text { мации }\end{array}$ & $《-\rangle$ \\
\hline $\begin{array}{l}\text { распределен- } \\
\text { ные базы дан- } \\
\text { ных }\end{array}$ & $\begin{array}{l}\text { обеспечение коор- } \\
\text { динированной дея- } \\
\text { тельности различ- } \\
\text { ных подсистем СУБ }\end{array}$ & $\langle-»$ \\
\hline
\end{tabular}


Окончание табл. 2.8.1

\begin{tabular}{|c|c|c|}
\hline $\begin{array}{c}\text { Наименование } \\
\text { технологии }\end{array}$ & $\begin{array}{l}\text { Назначение } \\
\text { технологии }\end{array}$ & $\begin{array}{c}\text { Применение } \\
\text { технологии } \\
\end{array}$ \\
\hline $\begin{array}{l}\text { распределенное } \\
\text { преобразование } \\
\text { информации }\end{array}$ & $\begin{array}{l}\text { совместная деятель- } \\
\text { ность различных } \\
\text { уровней иерархии } \\
\text { управления ТС }\end{array}$ & $\begin{array}{l}\text { решение функциональ- } \\
\text { ных задач различных } \\
\text { уровней иерархии с воз- } \\
\text { можностью параллельно- } \\
\text { последовательного реше- } \\
\text { ния задач на всех уровнях } \\
\text { иерархии управления ТС }\end{array}$ \\
\hline $\begin{array}{l}\text { CALS (Computer } \\
\text { A c qu i s i t i o n } \\
\text { and Life-cycle } \\
\text { Support - не- } \\
\text { прерывная ин- } \\
\text { формационная } \\
\text { поддержка жиз- } \\
\text { ненного цикла } \\
\text { продукции) }\end{array}$ & $\begin{array}{l}\text { сопровождение эле- } \\
\text { ментов ТС на всех } \\
\text { стадиях жизненного } \\
\text { цикла изделий }\end{array}$ & $\begin{array}{l}\text { использование при при- } \\
\text { менении (эксплуатации), } \\
\text { обслуживании, ремонте, } \\
\text { хранении и утилизации } \\
\text { элементов ТС }\end{array}$ \\
\hline
\end{tabular}

Для эффективного решения задач прогнозирования развития и координированного управления работой ТС в состав информационного обеспечения должен входить развитый комплекс модельного обеспечения. Пример структуры модельного обеспечения морской ТС представлен на рисунке 2.8.1.

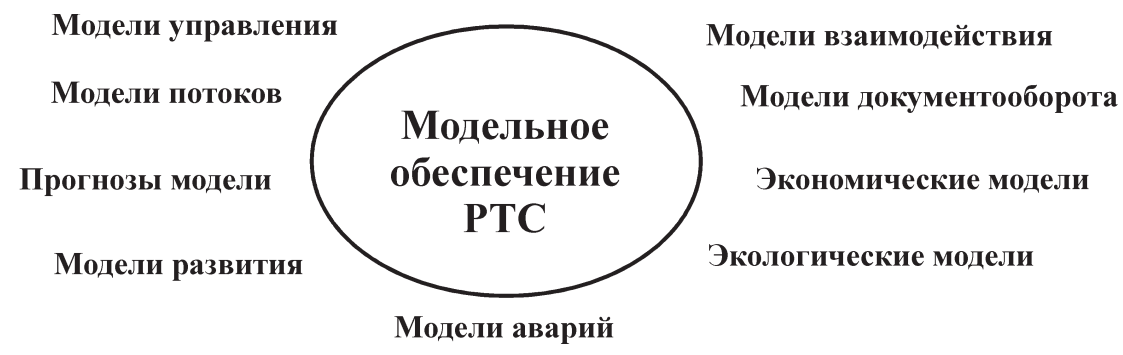

Рис. 2.8.1. Структура модельного обеспечения морской транспортной системы 
Модельное обеспечение представляет собой совокупность моделей, описывающих различные аспекты существования ТС, и включает:

- прогнозные модели, обеспечивающие решение задач прогнозирования развития экономики региона, ТС и ее отдельных элементов;

- модели развития, обеспечивающие поиск и выработку оценки эффективности различных вариантов развития ТС с учетом многокритериальной системы ограничений;

- модели взаимодействия, определяющие взаимодействие различных экономических субъектов, элементов ТС. Описывают внутреннюю структуру ТС, экономическую и хозяйственную структуру региона;

- модели управления, описывающие процессы управления функционированием и развитием ТС;

- модели потоков, описывающие транспортные, информационные и энергетические потоки в ТС;

- экономические модели описывают экономику региона, а также отношения между бюджетами различных уровней;

- экологические модели описывают систему моделей оценки и прогнозирования изменения состояния окружающей среды;

- модели аварий позволяют выполнять моделирование и прогнозирование возможного развития ситуаций при авариях на объектах транспорта, транспортных узлах, объектах народного хозяйства и др.;

- модели документооборота, описывающие процедуры обмена информацией между различными элементами ТС и систему нормативных документов, которые регламентируют работу транспортных систем.

Комплекс моделей, используемых для описания ТС, должен удовлетворять ряду требований:

- иметь единый используемый формальный аппарат;

- обеспечивать построение стратифицированного комплекса моделей, в котором каждая вершина модели описывается собственной моделью; 
- обеспечивать возможность решения задач анализа и синтеза с различным числом уровней стратификации, которое определяется необходимой глубиной анализа;

- обеспечивать возможность сопряжения моделей по схеме выход-вход, когда результат, полученный на выходе одной модели, является входным значением для другой модели;

- обеспечивать возможность выполнения расчетов от входа к выходу и от выхода к входу с вычислением параметров на основе комплексных критериев (аддитивные, мультипликативные и т. п.).

Информационная СУБ является распределенной вычислительной системой, каждый узел которой решает различные задачи принятия решений, сбора, обработки и хранения оперативной информации. Это означает, что все узлы СУБ должны иметь доступ к специализированным структурам данных, обеспечивающим решение поставленных перед ним задач. Оптимальная организация программного обеспечения и банка данных СУБ обеспечивает эффективное информационное обеспечение управления безопасностью в системах управления судоходством.

\section{9. Организация программного обеспечения и банка данных систем управления безопасностью судоходства}

Рассмотрим для примера ряд требований к банкам данных и знаний СУБ, выполнение которых позволит построить надежную, с точки зрения обеспечения целостности и сохранности информации, и эффективную, с точки зрения простоты и удобства доступа к информации, структуру баз данных и знаний.

Структуры баз данных и знаний СУБ, а также системы управления базами данных и знаний должны обеспечивать следующие показатели эффективности информационной системы:

1) надежность и живучесть системы управления готовности;

2) оперативность обработки запросов и предоставления информации; 
3) актуальность информации - соответствие имеющейся в СУБ информации реальному состоянию;

4) эффективность и удобство обработки информации, достигаемые за счет использования эффективных и надежных алгоритмов обработки информации;

5) эффективность и удобство доступа к данным (знаниям), достигаемые за счет построения оптимальной структуры баз данных и знаний;

6) релевантность (смысловое соответствие) и пертинентность (степень соответствия информации информационной потребности) информации, а также исключение ошибок первого и второго рода;

7) экономическую эффективность СУБ, выражающуюся в том, что затраты на обработку, передачу и хранение основной и резервной информации, а также обслуживание баз данных и знаний не должны превышать значений, снижающих экономический эффект от внедрения системы;

8) исключение различного рода аномалий, включая аномалии добавления, изменения, удаления, хранения и преобразования информации.

Эффективные структуры баз данных оперативной информации (БДОИ), документов (БДД) и знаний (БДЗ) являются залогом построения эффективных алгоритмов управления данными и знаниями. Они в значительной мере определяют эффективность функционирования систем управления базой данных и базой знаний. В свою очередь, эффективность доступа к данным и знаниям определяет такие существенные характеристики СУБ, как производительность, готовность и живучесть.

В наибольшей мере перечисленным требованиям удовлетворяет технология баз данных (знаний) объектной структуры или распределенных баз данных. Данная технология предполагает, что каждый элемент СУБ имеет свою базу данных оперативной информации и базу знаний, структура и содержание которой соответствует задачам, решаемым этим элементом. Построение распределенных баз данных и знаний СУБ позволяет:

1) повысить надежность и живучесть СУБ за счет обеспечения информационной избыточности; 
2) повысить оперативность обработки запросов за счет сокращения времени, требуемого на доступ к данным;

3) разработать эффективные структуры баз данных (знаний) и алгоритмы обработки информации для каждого элемента СУБ;

4) обеспечить своевременную актуализацию информации, позволяющую каждому из элементов СУБ принимать эффективные и адекватные решения по управлению готовностью;

5) сократить время принятия решений (управляющих воздействий) и повысить их достоверность за счет повышения надежности и эффективности доступа к информации (данным и знаниям), актуальности информации и т. д.

При использовании распределенных баз данных и знаний можно сократить обмен информацией между различными уровнями СУБ и повысить компетентность элементов СУБ. Каждый узел СУБ передает другим узлам только ту информацию, которая необходима им для выработки управляющих или координирующих решений. Однако при этом возникает проблема координации деятельности узлов СУБ и остро встает вопрос обеспечения надежности и живучести СУБ, т. к. отказ отдельных узлов СУБ в этом случае может привести к необратимой потере части информации, а также к потере СУБ способности управлять объектом принятия решений. Повысить надежность и живучесть распределенной СУБ можно за счет следующих мероприятий:

1) дублирования вычислительных устройств элементов принятия решений, БДОИ и БДЗ, обеспечивающего аппаратурную и информационную избыточность;

2) построения сетей с открытой конфигурацией, обеспечивающей алгоритмическую и информационную избыточность;

3) смешанный вариант, обеспечивающий аппаратурную, алгоритмическую и информационную избыточность.

В процессе разработки СУБ, как распределенной вычислительной системы, необходимо разработать такие структуры БДОИ, БДЗ и программных средств управления БДОИ, БДД и БДЗ (СУБД и СУБЗ), чтобы обеспечить компромисс между надежностью системы и ее экономической эффективностью. 
Резюмируя вышеизложенное, моделирование как метод, позволяющий понять принципы, закономерности и свойства исследуемых процессов и явлений, можно считать эффективным способом оценки количественных показателей безопасности в морских транспортных системах.

Модель, воспроизводящая в той или иной форме наиболее существенные свойства процесса-оригинала, является достаточно адекватным его эквивалентом. Исследование процессов с помощью использования моделей обеспечения безопасности позволяет получать необходимую информацию, имитируя нормальные и рискованные режимы без ущерба реальным системам обеспечения безопасности. 


\section{Контрольные вопросы}

1. Назовите основные этапы развития аварийной ситуации.

2. Какие особенности имеет причинно-следственная модель возникновения аварии?

3. Как можно классифицировать факторы развития аварийной ситуации в зависимости от источника возникновения?

4. Назовите основные мероприятия по обеспечению безопасности на водном транспорте.

5. В чем состоит сущность логико-лингвистической модели процесса возникновения происшествий на основе развития причинной цепи предпосылок?

6. Назовите мероприятия по обеспечению безопасности судов при навигационных авариях.

7. Сформулируйте в общем виде сценарий развития навигационной аварии столкновения судов.

8. Используя структурную схему методологии формализованной оценки безопасности, поясните процедуру выработки управляющих решений по снижению риска развития аварийной ситуации.

9. Поясните сущность метода вероятностного анализа безопасности.

10. Назовите этапы процедуры анализа риска объектов инфраструктуры и их содержание. 


\section{3. СИСТЕМЫ ОБЕСПЕЧЕНИЯ БЕЗОПАСНОСТИ МОРЕПЛАВАНИЯ}

\section{1. Международное нормативно-правовое регулирование безопасности мореплавания}

Системы безопасности мореплавания по типу используемого управления условно можно разделить на системы с пассивным и активным управлением. Системы безопасности пассивного типа сами не вырабатывают управляющие решения при возникновении опасной ситуации, но обеспечивают условия для их выработки: нормативно-правовое регулирование, слежение, сбор необходимой информации о судоходной обстановке, оповещение, телекоммуникационное взаимодействие, инструкции, правила и регламенты движения судов. Другими словами, пассивная система не имеет обратной связи по управлению. Решения вырабатываются вне такой системы.

К системам первого типа относятся:

- комплекс документированных соглашений по нормативноправовому регулированию мероприятий, связанных с достижением необходимого уровня надежности и живучести судна и обеспечения его безопасной деятельности в Мировом океане (нормы Международного морского права, нормативные акты отдельных государств и правовые договоренности между ними, а также требования к технологическим решениям и конструкциям судна);

- Глобальная морская система связи при бедствии и для обеспечения безопасности (ГМССБ), ориентированная, главным образом, на радиосвязь с использованием оповещений и сигналов бедствия, срочности и безопасности (аварийную);

- системы установления путей движения судов, обеспечивающие пространственное разделение судопотоков с целью уменьшения числа или полного устранения ситуаций сближения судов на встречных курсах. 
Системы безопасности мореплавания активного типа, наоборот, в зависимости от обстановки на акватории способны автоматизированно вырабатывать и доставлять на судно управляющие решения, то есть это системы управления с обратной связью по управлению. Активный характер таких систем обусловлен широким использованием вычислительной техники, информационных технологий и программных методов выработки управляющих решений, а также применением автоматических систем слежения и идентификации судов, средств электронно-цифровой картографии.

К системам второго типа относятся:

- системы лоцманской проводки, обеспечивающие безопасность и помощь опытного лоцмана при проводке судов в тех местах, где требуются точные знания местности и условий плавания;

- системы управления движением судов (СУДС), включающие различные службы помощи в судовождении в районах с интенсивным судоходством;

- системы судовых сообщений (CCC), обеспечивающие формализованные обмены сообщениями между судами и береговыми службами, в случае аварии на море такая система позволяет значительно сократить время, затрачиваемое на поиск судна и оказание услуг по спасанию.

Требования к обеспечению безопасности мореплавания можно разделить на следующие группы:

- требования к конструкции, оборудованию и снабжению судов;

- требования по обеспечению безопасности при эксплуатации судна (безопасная загрузка, перевозка, швартовка, обеспечение безопасности навигации и т. д.);

- требования к организации поиска и спасания;

- требования к укомплектованию экипажа судна;

- обеспечение безопасности морского судоходства;

- контроль в портах, организация расследования аварий.

По мере развития техники, увеличения размеров морских судов, резкого повышения интенсивности судоходства во многих районах Мирового океана все более настоятельно ставились вопросы о необходимости международно-правового регулирования безопас- 
ности мореплавания. Наиболее важным из всех международных соглашений по безопасности судов является Международная конвенция по охране человеческой жизни на море 1974 года (CОЛАC, Safety of Life at Sea - SOLAS) [106]. Главной целью данного нормативного документа является установление минимальных стандартов, отвечающих требованиям по безопасности при постройке, оборудовании и эксплуатации судов.

Толчком к принятию первой конвенции 1914 года по охране человеческой жизни на море явилась катастрофа с пассажирским судном «Титаник» в 1912 году. Вскоре после трагической гибели «Титаника» была созвана первая международная конференция по охране человеческой жизни на море (1914 год). Конвенция, проект которой обсуждался на конференции, не была принята в связи с начавшейся Первой мировой войной. Однако острота проблемы привела к тому, что уже в 1929 году была созвана вторая конференция, завершившаяся принятием Конвенции по охране человеческой жизни на море. Конвенция СОЛАС-29 вступила в силу в 1933 году.

В 1948 году многие вопросы по обеспечению безопасности человеческой жизни на море были детализированы, и Конвенция была полностью пересмотрена. Однако главная проблема - отсутствие международного координирующего органа, который мог бы осуществлять практическую работу по детальной разработке требований конвенции, так и осталась нерешенной. Ситуация усугублялась различием национальных требований к обеспечению безопасности на море и правил транспортировки тех или иных грузов, что вызывало полную неразбериху в бурно растущем объёме перевозок морем. Требования к маркировке и упаковке опасных грузов были в разных странах различные и порой взаимоисключающие друг друга.

Образование ООН и его специализированных комитетов и агентств создало благодатную почву для возникновения в начале января 1959 года Межправительственной морской консультативной организации (ИМКО, Inter-Governmental Maritime Consultative Organization - IMCO), которая в 1982 году была переименована в ИМО (International Maritime Organization - IMO). Первым шагом 
ИМКО стал пересмотр требований Конвенции СОЛАС-48, в результате чего в 1965 году вступила в силу Международная конвенция СОЛАС-1960. Одновременно было одобрено первое издание Международного кодекса морской перевозки опасных грузов (МК МПОГ, MMOГ, International Maritime Dangerous Goods Code - IMDG Code) [57]. В настоящее время МК МПОГ является общепризнанным международным документом, регламентирующим морскую перевозку опасных грузов в качестве дополнения к Международной конвенции по охране человеческой жизни на море.

Международная конвенция СОЛАС-1974 была одобрена IMO и вступила в силу в 1980 году. В настоящее время действует Конвенция СОЛАС-74, в которую внесены многочисленные изменения, в том числе Протоколом 1978 года и Протоколом 1988 года. Участниками этой Конвенции являются около 150 государств, флот которых составляет приблизительно 98 \% мирового валового тоннажа.

Конвенция применяется ко всем торговым судам, совершающим международные рейсы, а именно к пассажирским судам всех размеров, перевозящим более 12 пассажиров, и грузовым судам валовой вместимостью 500 регистровых тонн и более.

Правила Конвенции, если специально не предусмотрено иное, не применяются к следуюшим судам:

a) военным кораблям и военным транспортам;

б) грузовым судам валовой вместимостью менее 500 регистровых тонн;

в) судам, не имеющим механических средств движения;

г) деревянным судам примитивной конструкции;

д) прогулочным яхтам, не занимающимся коммерческими перевозками;

е) рыболовным судам.

Конвенция включает 13 статей и Приложение, которое составляет его неотъемлемую часть. Приложение состоит из 12 глав: глава 1 посвящена общим положениям; глава 2 - конструкции судов; глава 3 - спасательным средствам; глава 4 - радиосвязи; глава 5 - безопасности мореплавания; глава 6 - перевозке грузов; глава 7 -перевозке опасных грузов; глава 8 - ядерным судам; глава 9 - управлению 
безопасной эксплуатацией судна; глава 10 - мерам безопасности для высокоскоростных судов; глава 11 - специальным мерам по повышению безопасности на море; глава 12 - дополнительным мерам безопасности для судов, перевозящих навалочные грузы.

Конвенция определяет порядок освидетельствования судов, приборов, систем и оборудования, выдачи соответствующих свидетельств о безопасности. Раскрываются требования к контролю над освидетельствованием и расследованием аварий. Излагаются требования к конструкции судна: делению на отсеки, остойчивости, его машинам и электрическим установкам. Определяются меры пожаробезопасности на пассажирских и грузовых судах и на танкерах. Раздельно для пассажирских и грузовых судов излагаются требования к спасательным шлюпкам, плотам и иным спасательным средствам (кругам, устройствам для метания линя и прочим), расписаниям по тревогам. Регламентируются требования к радиотелефонным и радиотелеграфным устройствам, радиовахте, радиожурналам.

Требования по безопасности мореплавания касаются информации об опасностях, метеорологической информации, данных ледовой разведки, аварийных и спасательных сигналов. Особо выделены требования к ядерным судам, судам, перевозящим зерно и опасные грузы.

В связи с конференцией 1988 г. по Глобальной морской системе связи при бедствии и для обеспечения безопасности (ГМССБ, Global Maritime Distress and Safety System - GMDSS) в Конвенции СОЛАС 74/78 была полностью заменена глава 4 «Радиосвязь», в которой установлена новая система связи, основывающаяся на современных достижениях с использованием спутников. Согласно этой системе оборудование, которое необходимо иметь на борту судна, зависит не от его размера (тоннажа), а от морских районов, в которых оно плавает, причем Мировой океан разделен на четыре района (A1 - в пределах зоны действия в режиме радиотелефона; А2 - в пределах зоны действия, по крайней мере, одной средневолновой станции; A3 - в пределах зоны действия системы геостационарных спутников ИНМАРСАТ и А4 - за пределами районов А1, А2, А3). 
Кроме того, в Конвенции приводятся проформы различных свидетельств, подтверждающих, что судно и его оборудование поддерживаются в состоянии, которое отвечает требованиям Конвенции и гарантирует пригодность для выхода в море без опасности для судна или людей, находящихся на борту.

Для осуществления этих предписаний участвующие в Конвенции государства должны проводить первоначальное (до начала эксплуатации) и периодические последующие освидетельствования и подтверждать соответствие судна требованиям Конвенции выдачей ему ряда свидетельств: Свидетельства о безопасности пассажирского судна, Свидетельства о безопасности грузового судна по конструкции, Свидетельства о безопасности грузового судна по оборудованию и снабжению, Свидетельства о безопасности грузового судна по связи и других. Свидетельства выдаются правительством государства флага или от его имени уполномоченной им организацией.

В России эта функция возложена на Российский морской регистр судоходства (РМРС). Согласно Конвенции СОЛАС-74 и Протоколу 1978 года к ней, а также Международной конвенции о грузовой марке 1966 года эта организация наделена исключительной обязанностью осуществлять проверку и освидетельствование своих судов, а также продление, изъятие старого или выдачу нового Свидетельства о безопасности.

Государства флага должны обеспечить, чтобы суда, плавающие под их флагом, исполняли требования СОЛАС. Конвенцией предписано множество сертификатов для доказательства того, что ее требования выполнены. Подобные документы обычно называются «конвенционными» и выдаются либо самой Администрацией флага, либо от её имени («по уполномочию Администрации») при наличии соответствующего поручения.

Условия контроля также позволяют Договаривающимся правительствам инспектировать суда, ходящие под флагами других государств. Эта процедура получила название «контроль государства порта» (Port State Control, PSC).

При наличии какого-либо несоответствия должностное лицо, осуществляющее контроль, принимает меры, препятствующие 
отходу судна до тех пор, пока его выход в море не будет безопасен для пассажиров и экипажа.

Международный кодекс по управлению безопасной эксплуатацчией судов и предотвращением загрязнения (МКУБ, International Safety Management Code - ISM CODE) был принят Ассамблеей ИМО в 1993 году [58]. Для придания Кодексу обязательной силы в Приложение к Конвенции СОЛАС-74 была включена глава IX «Управление безопасной эксплуатацией судов», в которой содержится отсылка к указанному Кодексу. Цели Кодекса состоят в обеспечении безопасности на море, предотвращении несчастных случаев или гибели людей и избежании причинения ущерба окружающей среде, в частности морской среде, и имуществу.

В соответствии с МКУБ каждая компания должна разработать, задействовать и поддерживать систему управления безопасностью (СУБ), которая включает следующие функциональные требования:

- политику в области безопасности и защиты окружающей среды;

- инструкции и процедуры для обеспечения безопасной эксплуатации судов и защиты окружающей среды согласно соответствующему международному праву и законодательству государства флага;

- установленный объем полномочий и линии связи между персоналом на берегу и на судне, а также внутренней связи;

- порядок передачи сообщений об авариях и случаях несоблюдения положений Кодекса;

- порядок подготовки к аварийным ситуациям и действий по их устранению;

- порядок проведения внутренних проверок и обзора управления.

Компания должна определить ответственность, полномочия и взаимоотношения всего персонала, осуществляющего управление, выполнение и проверку работы, касающейся безопасности и предотвращения загрязнения и оказывающей на них влияние, и оформить это в виде документов.

В целях обеспечения безопасной эксплуатации каждого судна и осуществления связи между компанией и находящимися на судах 
лицами, каждая компания должна назначить лицо (или лиц) на берегу, имеющее прямой доступ к руководству на самом высоком уровне управления. Ответственность и полномочия назначенного лица должны включать контроль над соблюдением норм безопасности и предотвращения загрязнения, связанных с эксплуатацией каждого судна, а также обеспечение предоставления достаточных ресурсов и оказания соответствующей помощи на берегу по мере необходимости.

Компания должна обеспечить, чтобы капитан имел надлежащую квалификацию для управления судном, был полностью осведомлен о СУБ компании и получал необходимую поддержку для безопасного выполнения своих обязанностей.

Наряду с конструкцией, оборудованием и снабжением судна, безопасность навигации судна обеспечивается выполнением ряда специальных правил, поддерживаемых системой навигационных и метеорологических предупреждений, службой ледовой разведки, гидрографическими службами, системами управления движением судов, установления путей движения судов и схем разделения движения, организацией лоцманской проводки.

Особое место среди этих норм занимают Международные правила предупреждения столкновения судов в море (МППСС, International Rules of Preventing Collision at Sea - COLREGS) [66]. МППСС были приняты в Лондоне в 1972 году, в настоящее время их участниками являются около 140 государств, флот которых составляет приблизительно 97 \% мирового тоннажа.

МППСС-72 объединяют 38 правил и 4 приложения. Правила разделены на пять частей, в них определен порядок пользования сигналами (флажными, звуковыми или световыми), применения радиолокаторов, расхождения и скорости судов при их сближении и другие.

Часть «А» содержит общие положения (правила 1-3), в которых регламентированы вопросы применения Правил, вопросы ответственности за их невыполнение и вопросы определения и использования в правилах терминов.

Часть «В» содержит правила плавания и маневрирования (правила 4-19) при любых условиях видимости, плавание судов, находящихся на виду друг у друга, плавание судов при ограниченной видимости. 
Часть «С» посвящена огням и знакам (правила 20-31).

Часть «Д» определяет звуковые и световые сигналы (правила 32-37).

Часть «Е» содержит изъятия из правил для судов, заложенных к постройке до вступления МППСС-72 в силу.

В приложениях к МППСС-72 регламентированы следующие вопросы:

- расположение и технические характеристики огней и знаков (Приложение I);

- дополнительные сигналы для судов, занятых ловом рыбы вблизи других судов (Приложение II);

- технические характеристики звукосигнальных устройств (Приложение III);

- сигналы бедствия (Приложение IV).

Важным документом в области правового обеспечения необходимого уровня технического состояния судна является Международная конвенция о грузовой марке (КГМ-66/88, International Convention on Load Lines - LL-66/88) [53], которая устанавливает единые принципы и правила, касающиеся предельной загрузки судов, совершающих международные рейсы. В 1988 году специальным Протоколом в нее были внесены изменения, позднее, в 2003 году, дополненные Комитетом по безопасности на море ИМО. Измененная Конвенция вступила в силу в 2005 году.

Судну, к которому применяется Конвенция, запрещается выход в море, если оно не было соответствующим образом освидетельствовано, ему не была нанесена грузовая марка и не выдано Международное свидетельство о грузовой марке или, при необходимости, Международное свидетельство об изъятии для грузовой марки.

Освидетельствование и нанесение грузовых марок производят должностные лица администрации, которая может поручить это либо назначенным инспекторам, либо должным образом уполномоченным организациям (в России эти функции осуществляет Российский морской регистр судоходства). Судно подлежит первоначальному освидетельствованию, освидетельствованию для возобновления свидетельств и ежегодному освидетельствованию. 
Согласно Правилам определения грузовых марок (Приложение I к Конвенции), применяются следующие грузовые марки: летняя, зимняя, зимняя для Северной Атлантики, тропическая, тропическая для пресной воды и грузовая для пресной воды. Применяются также шесть лесных грузовых марок. В Приложении II даются определения зон, районов и сезонных периодов.

Организации поиска и спасания судов посвящена Международная конвенция по поиску и спасанию на море (CAP-79, International Convention on Maritime Search and Rescue - SAR-79) [56], принятая на Международной конференции в Гамбурге (Федеративная Республика Германия) в 1979 году. Конвенция создает Международный план поиска и спасания людей, терпящих бедствие на море, с целью поощрения сотрудничества между поисково-спасательными организациями всего мира и между участниками поисково-спасательных организаций на море, чтобы независимо от района Мирового океана, в котором происходит авария, действия по поиску и спасанию терпящих бедствие людей координировались между расположенными в этом районе службами САР.

Конвенция предлагает договаривающимся сторонам обеспечить наличие в их странах соответствующих средств для поиска и спасания, заключать между собой соглашения по поиску и спасанию, в частности, предусматривающие облегченный доступ спасательных средств одного государства в территориальное море другого государства, а также предлагает устанавливать общие процедуры для эффективного и быстрого поиска и спасания. Конвенция также предусматривает создание государствами спасательно-координационных центров и подцентров, включая назначение координатора на месте проведения операции.

После принятия Конвенции по решению Комитета по безопасности на море ИМО Мировой океан был разделен на тринадцать поисково-спасательных зон. В каждой из зон соответствующие государства должны установить границы районов, в которых они несут ответственность за проведение поисково-спасательных операций.

Стороны Конвенции устанавливают системы судовых сообщений, в пределах которых суда должны сообщать о своем ме- 
стоположении. В случае аварии на море такая система позволяет значительно сократить время, затрачиваемое на поиск судна и оказание услуг по спасанию. Эта система также помогает оказывать, при необходимости, срочную медицинскую помощь морякам на судах. Технические требования Конвенции САР содержатся в Приложении, состоящем из пяти глав.

В 1995 году было принято решение внести в Конвенцию несколько важных поправок, в частности, привести Конвенцию в соответствие с положениями по поиску и спасанию, выработанными Международной организацией гражданской авиации (ИКАО). Пересмотр технических требований, содержащихся в Приложении, был поручен Подкомитету ИМО по радиосвязи и поиску и спасанию (Подкомитет COMSAR). Поправки были приняты Комитетом по безопасности на море ИМО на его 69-й сессии в мае 1998 года и вступили в силу в 2000 году.

В 2004 году был принят комплект поправок, касающийся лиц, терпящих бедствие на море, в частности, были добавлены:

- определение лиц, терпящих бедствие на море;

- положения по оказанию помощи капитану при доставке спасенных в море людей в безопасное место;

- положения, обязующие спасательно-координационные центры или спасательные подцентры устанавливать наиболее подходящие места для высадки лиц, обнаруженных терпящими бедствие на море.

Одновременно с пересмотром Конвенции САР в ИМО проводилась работа по усовершенствованию практических руководств по поиску и спасанию. В 1971 году было выпущено Руководство ИМО по поиску и спасанию для торговых судов (MEPCAP, Merchant Ship Search and Rescue Manual - MERSAR-95), а в 1978 году - Международное авиационное и морское наставление по поиску и спасанию (Наставление ИАМСАР, Manual - International Aeronautical and Maritime Search and Rescue Manual - LA.MSAR). Оба документа ИМО предлагали заинтересованным национальным организациям практические рекомендации по вопросам оказания помощи терпящим бедствие людям и судам в море. Дальнейшее развитие средств связи и технических возможностей авиационного и морского поиска 
и спасания, а также необходимость более тесного сотрудничества обеих отраслей в этой области привели к тому, что ИМО и ИКАО совместно приняли Руководство по межсдународному авиационному и морскому поиску и спасанию (Руководство МАМПС), которым в настоящее время пользуются все воздушные и морские суда [97].

В предисловии к Руководству МАМПС определена основная цель Руководства, которая «заключается в оказании содействия государствам в удовлетворении ими своих собственных потребностей в области поиска и спасания (SAR) и выполнении принятых ими на себя обязательств по Конвенции о международной гражданской авиации, Международной конвенции по поиску и спасанию на море и Международной конвенции по охране человеческой жизни на море (SOLAS)».

Руководство МАМПС состоит из трех томов. Каждый том IAMSAR подготовлен с учетом конкретных функций системы SAR и может использоваться как самостоятельный документ или, в сочетании с другими двумя томами, для получения полного представления о системе SAR: том I «Руководство по организации и управлению», том II «Координация операций», том III «Подвижные средства». В указанных томах содержатся рекомендации, позволяющие выработать единый подход к организации и обеспечению авиационных и морских служб SAR. Государствам предлагается развивать и совершенствовать свои службы SAR, сотрудничать с соседними государствами и рассматривать свои службы SAR как часть глобальной системы.

Район бедствия подразделяется на две категории:

- прибрежный, в котором помощь судну, терпящему бедствие, может быть оказана с судов, самолетов, вертолетов и спасательных судов;

- океанский, в котором помощь может быть оказана с самолетов и судов. Причем в наиболее отдаленных районах помощь может быть оказана только с судов, находящихся поблизости.

Третий том предназначен для судоводителей. Он должен находиться на борту каждого морского судна и использоваться в качестве пособия по вопросам, связанным с осуществлением функций поиска, спасания или координатора на месте проведения операции, 
а также при решении связанных с SAR задач в случае собственных аварийных ситуаций.

Для координации деятельности, обеспечивающей безопасность на море и в воздушном пространстве над ним, была принята $\mathrm{Me-}$ ждународная конвенция о спасании 1989 года (SALVAGE) [54], установившая новый международно-правовой режим спасания. Конвенция вступила в силу в 1996 году, Россия ратифицировала ее в 1998 году. Конвенция определяет понятие «спасательная операция» как любое действие или любую деятельность, предпринимаемые для оказания помощи любому судну или другому имуществу, находящимся в опасности в любых судоходных или иных водах.

В общей проблеме правового обеспечения безопасности мореплавания, наряду с вопросами охраны человеческой жизни на море, большое значение имеет подготовка квалифицированных кадров для комплектования экипажей судов и их грамотная (профессиональная) эксплуатация. Анализ аварийности мирового судоходства свидетельствует о том, что более трети всех аварийных происшествий на море происходит в результате ошибок, допущенных экипажами судов. В большинстве случаев эти ошибки носят навигационный характер, но случаются также технические и эксплуатационные ошибки. Морская практика свидетельствует, что квалифицированные действия экипажей судов во многих случаях предотвращали или спасали положение в, казалось бы, безвыходных ситуациях. Поэтому в международном и национальном законодательстве регламентации подготовки экипажей судов уделяется значительное внимание.

Согласно Конвенции ООН 1982 года каждое государство в отношении судов, плавающих под его флагом, принимает меры по комплектованию и обучению экипажей судов. Судно должно возглавляться капитаном и офицерами соответствующей квалификации, в частности, в области судовождения, связи, судовых машин и оборудования, а экипаж по квалификации и численности - соответствовать типу, размерам и оборудованию судна.

В 1978 году в Лондоне была принята Международная конвенция о подготовке и дипломировании моряков и несении вахты (ПДНВ, International Convention on Standards of Training, Certification and 
Watchkeeping - International STCW Convention, STCW) [55], вступившая в силу в 1984 году. В 1995 году структура и содержание Конвенции ПДНВ были существенно изменены. Последующие изменения внесены в 1997 году, и вскоре было рекомендовано именовать Конвенцию ПДНВ с поправками (STCW as amended).

Согласно ст. VI Конвенции дипломы капитанов, лиц командного или рядового состава выдаются кандидатам, которые отвечают требованиям работы, возраста, состояния здоровья, квалификации и экзаменов, установленным в Приложении к Конвенции. В нем содержатся только обязательные минимальные требования о дипломировании специалистов. Все технические детали были установлены в Кодексе по подготовке и дипломированию моряков и несению вахты 1995 года (Кодекс ПДНВ).

В 2010 году в Маниле (Филиппины) состоялась Международная конференция стран-участниц Международной конвенции о подготовке и дипломировании моряков и несении вахты 1978 года, на которой были приняты поправки к Конвенции и новая редакция Кодекса ПДНВ [75].

Конвенция ПДНВ в новой редакции предлагает новые международные стандарты, необходимые для морских институтов и преподавателей, чтобы давать современному моряку столь востребованные навыки и знания.

В последние годы остро встала проблема безопасности, связанная с угрозами терроризма и пиратства. В отличие от безопасности мореплавания, которая обеспечивается выполнением ряда специальных требований, проблема терроризма на море в большей степени касается безопасности морского судоходства и может быть разделена на две части:

- акты насилия против лиц на борту судна и незаконные акты против самого судна при его нахождении, как правило, вне территориального моря какого-либо государства;

- акты вооруженных нападений и ограблений судов, находящихся в основном во внутренних морских водах или территориальном море государства.

Терроризм на море представляет серьезную угрозу безопасности мореплавания. Как и пиратство, он является преступлением меж- 
дународного характера. По методам и способам осуществления они очень похожи. Разница только в целях, которые преследуют исполнители: для пиратов главное - корыстные цели (обогащение, нажива), а для террористов главным является запугивание населения и властей с целью выполнения своих, как правило, политических и иных противоправных требований.

Захват в 1985 году группой террористов итальянского лайнера Achillo Lauro вызвал широкую реакцию в мире. Генеральная Ассамблея ООН приняла Резолюцию «О мерах по предотвращению международного терроризма и изучению причин, лежащих в основе терроризма» (1985 г.), в которой среди прочего предложила ИМО изучить проблему актов терроризма на борту или против морских судов с целью вынесения рекомендаций в отношении принятия соответствующих мер.

В 1988 году в Риме были приняты Конвенция о борьбе с незаконныли актами, направленными против безопасности морского судоходства [39], вступившая в силу в 1992 году, и Протокол о борьбе с незаконнылми актами, направленными против безопасности стационарных платформ, расположенных на континентальном шельфе [86]. В настоящее время участниками этих документов являются свыше 50 государств, включая Российскую Федерацию. Указанные соглашения предусматривают меры борьбы с терроризмом на море.

Каждое государство-участник предусматривает соответствующие наказания за преступления террористического характера, указанные в статье 3 Конвенции, с учетом тяжкого характера этих преступлений. Конвенция устанавливает, какие действия выполняет государство-участник, на территории которого находится преступник или предполагаемый преступник, в случаях возникновения угрозы или совершения преступления.

Конвенция предусматривает сотрудничество государств-участников в предотвращении преступлений. Она применяется, если судно совершает плавание или его маршрут включает плавание в воды, через воды или из вод, расположенных за внешней границей территориального моря какого-либо одного государства или за боковыми границами его территориального моря с сопредельными 
государствами. Конвенция не затрагивает иммунитета военных кораблей и других государственных судов, эксплуатируемых в некоммерческих целях.

Аналогичные действия в отношении лиц, совершающих преступления на борту или против стационарных платформ, расположенных на континентальном шельфе, предусмотрены в Протоколе о борьбе с незаконными актами, направленными против безопасности стационарных платформ, расположенных на континентальном шельфе.

К терроризму на море обычно прибегают организованные антиконституционные и антиправительственные группировки, пользующиеся поддержкой организованных преступных групп, которые заинтересованы в достижении террористами преследуемых ими целей. По данным ИМО, число пиратских нападений в различных районах Мирового океана имеет устойчивую тенденцию к росту. Так, в 2006 году было зарегистрировано 239 случаев пиратских нападений на суда, в 2007-м - 263, в 2008-м - 293, в 2009-м - 406 [32].

Возрастающая угроза терроризма привела к тому, что в 2001 году ИМО были разработаны новые международные стандарты в области морской безопасности и изложены в Международном кодексе по охране судов и nортовых средств (МК ОСПС) [59]. В Кодексе впервые было сформулировано понятие «портового средства», что явилось следствием выработки единых подходов мирового сообщества к обеспечению безопасности на морском транспорте.

Целью Кодекса является предупреждение совершения возможных терактов. Так, в соответствии с положениями Кодекса договаривающиеся правительства должны устанавливать уровни охраны объектов (пассажирских судов, включая высокоскоростные пассажирские суда; грузовых судов, включая высокоскоростные суда, вместимостью 500 тонн и более; морских передвижных буровых установок; портовых средств, обслуживающих суда, совершающие международные рейсы) и предоставлять руководство по защите от происшествий, связанных с охраной. Более высокие уровни охраны предполагают наличие большей вероятности происшествия.

Для установления соответствующего уровня охраны принимаются к рассмотрению следующие факторы: 
- степень доверия к информации об угрозе;

- степень обоснованности информации об угрозе;

- степень конкретности информации об угрозе или степень неизбежности угрозы;

- потенциальные последствия такого происшествия.

Положения Кодекса вступили в действие в 2004 году. В соответствии с ними на всех судах водоизмещением более 500 тонн должны быть установлены новейшие системы связи и навигации - автоматические идентификационные системы, системы охранного оповещения и связи при бедствии и обеспечении безопасности. Все корабли должны иметь план безопасности судна, специального офицера по безопасности. Экипаж судна должен пройти специальную подготовку и знать, что делать при угрозе захвата судна пиратами или террористами. Порты также должны иметь планы охраны, обзавестись вооруженной охраной, системами видеонаблюдения, связи, мониторинга грузов и проходящих судов.

На практике уже имеются примеры, когда морские суда, не соответствующие новым международным требованиям в области морской безопасности, не допускаются в порты, несмотря на важность груза и срочность его доставки. Такие факты влекут за собой большие потери для судовладельцев, а иногда даже приводят к банкротству. Причем такие риски страховыми компаниями не страхуются.

В России создана и действует оптимальная система проведения экспертных оценок уязвимости и разработки планов охраны участвующих в международных морских перевозках судов и портовых средств. Налажен процесс их одобрения морскими властями. Освидетельствование судов и портовых средств на предмет соответствия требованиям Кодекса ОСПС проводится по отработанной схеме.

\section{2. Радиосвязь \\ в системах безопасности мореплавания}

Радиосвязь является ключевым элементом систем обеспечения безопасности мореплавания. Это единственное средство связи 
судов, так как их местоположение не всегда известно. Благодаря радиосвязи возможно оперативное и экономичное взаимодействие с судами, зачастую удаленными от береговых баз на сотни и тысячи миль. Используя в качестве носителей информации электрические сигналы, распространяющиеся в пространстве при помощи электромагнитных волн, радиосвязь поддерживает передачу любых сообщений (буквенно-цифровой текст, звуковые сигналы, изображения) на любые расстояния, одновременный прием сообщений в нужном числе пунктов, а в случае необходимости обеспечивает конфиденциальность. Благодаря всему этому радиосвязь является в настоящее время основным средством связи на море.

Системы обеспечения безопасности мореплавания условно можно разделить на системы с пассивным и активным управлением. При этом к системам первого типа относятся Глобальная морская система связи при бедствии и для обеспечения безопасности (ГМССБ), ориентированная, главным образом, на радиосвязь с использованием оповещений и сигналов бедствия, срочности и безопасности (аварийную), и системы установления путей движения судов, обеспечивающие пространственное разделение судопотоков с целью уменьшения числа или полного устранения ситуаций сближения судов на встречных курсах.

В системах пассивного типа (оповещение, разделение) отсутствует выработка реактивных управлений. При возникновении опасной ситуации ответные управляющие решения инициируются и вырабатываются в других, внешних, системах (операторы, диспетчеры береговой службы, поисково-спасательные организации, капитаны судов, терпящих бедствие и оказывающих помощь).

К системам второго типа относятся системы лоцманской проводки, системы управления движением судов (СУДС) и системы судовых сообщений. Активный характер таких систем обуславливается наличием в них обратной связи по управлению, широким использованием вычислительной техники, информационных технологий и программных методов выработки управляющих решений, а также применением автоматических систем слежения и идентификации судов, средств электронно-цифровой картографии и телекоммуникаций.

Радиосвязь является ключевым элементом систем обеспечения 
безопасности мореплавания. Это единственное средство связи судов, так как их местоположение не всегда известно. Благодаря радиосвязи возможно оперативное и экономичное взаимодействие с судами, зачастую удаленными от береговых баз на сотни и тысячи миль. Используя в качестве носителей информации электрические сигналы, распространяющиеся в пространстве при помощи электромагнитных волн, радиосвязь поддерживает передачу любых сообщений (буквенно-цифровой текст, звуковые сигналы, изображения) на любые расстояния, одновременный прием сообщений в нужном числе пунктов, а в случае необходимости обеспечивает конфиденциальность. Благодаря всему этому радиосвязь является в настоящее время основным средством связи на море.

Организация связи, порядок работы судовых и береговых радиостанций, действия персонала при эксплуатации средств радиосвязи и порядок обработки корреспонденции осуществляются в соответствии с Регламентом радиосвязи Международного союза электросвязи [90] и Правилами радиосвязи морской подвижной службы Российской Федерации [95]. Регламент радиосвязи определяет, что работа судовой или судовой земной станции осуществляется под руководством капитана или лица, ответственного за судно.

Основное назначение радиосвязи морской подвижной службы (MПC, Maritime Mobile Service MMS) состоит в обеспечении следующего:

- безопасности мореплавания и охраны человеческой жизни на море;

- оперативно-диспетчерского руководства работой флота, портов, предприятий и организаций морского транспорта;

- обмена информацией с взаимодействующими организациями и ведомствами;

- обмена информацией с организациями и представителями за границей и иностранными организациями, а также в случаях обмена по сигналам бедствия и вопросам охраны человеческой жизни на море;

- обработки частной корреспонденции пассажиров и членов экипажей судов.

В области морской радиосвязи используют следующие основные понятия и принципы [90, 93, 95]. 
Радиосвязь - это вид электросвязи, осуществляемой посредством радиоволн.

Радиоволны по определению Международной конвенции электросвязи - это электромагнитные колебания, частоты которых произвольно ограничены частотами ниже 300 ГГц, распространяющиеся в пространстве без искусственного волновода.

Paдиочастоты - частоты или полосы частот в диапазоне от 3 кГц до 300 ГГц. Этот диапазон соответствует частоте переменного тока электрических сигналов для вырабатывания и обнаружения радиоволн. Так как большая часть диапазона лежит за границами волн, которые могут быть получены при механической вибрации, радиочастоты обычно относятся к электромагнитным колебаниям.

Величины рабочих волн радиостанций принято выражать в метрах, сантиметрах и миллиметрах. Частота выражается в герцах (Гц), килогерцах (кГц), мегагерцах (МГц) или гигагерцах (ГГц). Длина и частота радиоволны обратно пропорциональны друг другу в соответствии с формулой:

$$
F=C / L,
$$

где $F$ - радиочастота, Гц,

$C$ - скорость света, равная 300000 км/час,

$L$ - длина волны, м.

Закон Российской Федерации «О связи» устанавливает следующие понятия, относящиеся к радиочастотам:

- радиочастотный спектр - совокупность радиочастот в установленных Международным союзом электросвязи пределах, которые могут быть использованы для функционирования радиоэлектронных средств или высокочастотных устройств;

- радиочастота - частота электромагнитных колебаний, устанавливаемая для обозначения единичной составляющей радиочастотного спектра;

- распределение полос радиочастот - определение предназначения полос радиочастот посредством записей в Таблице распределения полос радиочастот между радиослужбами Российской 
Федерации, на основании которых выдается разрешение на использование конкретной полосы радиочастот, а также устанавливаются условия такого использования.

Для предотвращения взаимных помех при одновременной работе большого количества станций страны - члены Международного союза электросвязи (МСЭ) договорились о разбивке используемого спектра частот на отдельные частотные полосы и о закреплении последних за различными радиослужбами: фиксированной, подвижной, МПС, радиовещательной, любительской и т. д.

Разбивка радиочастот на диапазоны соответствует решению Международного консультативного комитета по радиосвязи (МККР). Спектр частот, используемых для радиосвязи, разбит на 9 диапазонов, которые обозначаются целыми числами в возрастающем порядке. Разбивка радиочастот на диапазоны, принятая Регистром Российской Федерации, приведена в таблице 3.2.1.

Таблица 3.2.1

Разбивка радиочастот на диапазоны

\begin{tabular}{|c|c|c|}
\hline Название диапазона & Обозначение & Частота \\
\hline длинные волны & НЧ (LF) & менее 300 кГц \\
\hline средние волны & СЧ (MF) & от 300 до 1500 кГц \\
\hline промежуточные волны & ПВ (MF) & от 1,5 до 3 МГц \\
\hline короткие волны & ВЧ (HF) & от 3 до 30 МГц \\
\hline $\begin{array}{l}\text { ультракороткие волны, } \\
\text { в том числе: }\end{array}$ & УКВ (VHF) & $\begin{array}{l}30 \text { МГц и выше, в том } \\
\text { числе: }\end{array}$ \\
\hline метровые & OBЧ (VHF) & от 30 до 300 МГц \\
\hline дециметровые & УВЧ (UHF) & от 300 МГц до 3 ГГц \\
\hline сантиметровые & CBЧ (SHF) & от 3 до 30 ГГц \\
\hline миллиметровые & КВЧ (EHF) & от 30 до 300 ГГц \\
\hline децимиллиметровые & ГВЧ (ТHF) & от 300 до 3000 ГГц \\
\hline
\end{tabular}


В каждом диапазоне для использования в МПС выделены полосы частот, за которыми в неофициальной терминологии закрепились следующие названия:

- средние волнь (СВ): 405-526,5 кГц;

- промежуточные волны (ПВ): 1605-4000 кГц;

- короткие волны (КВ): 4-27,5 МГц (в этом диапазоне используются выделенные для МПС частоты в поддиапазонах 4, 6, 8, 12, 16, 18/19, 22 и 25/26 МГц, например, в поддиапазоне 4 МГц используются частоты в полосах 4063-4221 кГц и 4351-4438 кГц);

- ультракороткие волны (УКВ) 156-174 МГц.

Расстояние, на котором возможна радиосвязь, зависит от выбранной частоты, мощности передатчика, типа и размещения антенной системы, чувствительности приемника, условий распространения радиоволн. Для конкретного судового оборудования выбранная частота (длина волны) является основным фактором, определяющим дальность связи.

Различные радиослужбы используют частотные диапазоны в соответствии с Регламентом радиосвязи Российской Федерации и международными соглашениями. Часть полос (главным образом КВ) используется на основе международных соглашений, а другая часть - на основе региональных. Причем для уменьшения помех судовым станциям со стороны более мощных береговых станций полосы частот, выделенные в исключительное пользование морской радиослужбе, разбиты на более мелкие полосы и закреплены за различными видами морской радиосвязи. Так, МПС выделена полоса частот 4063-4438 кГц. Эта полоса разделена на более мелкие полосы для разных видов связи: полоса 4207,5-4209 кГц - для цифрового избирательного вызова (ЦИВ), полоса 4352,4-4436,4кГц - для дуплексной телефонии и т. д. Использовать частоты не по назначению либо вне выделенных частотных полос запрещено.

Частоты особой важности используются в МПС и морской подвижной спутниковой службе (МПСС) для вызова и обмена аварийной информацией по бедствию, срочности и безопасности. Частоты особой важности в ГМССБ приведены в таблице 3.2.2 
[124], здесь УБПЧ - узкополосная буквопечатающая частотная радиотелеграфия (NBDP Narrow Band Direct Printing).

Распространение радиоволн сильно зависит от свойств атмосферы, которая подразделяется на части, расположенные в следующем порядке:

- тропосфера - нижняя, плотная часть атмосферы до высоты 10-12 км;

- стратосфера - средняя часть, верхняя граница лежит на высоте 60-80 км;

- ионосфера - верхняя часть, характеризуется малой плотностью газа, молекулы которого под действием солнечной радиации ионизируются.

Ионизированный газ обладает электропроводностью и отражает радиоволны. Ионосфера ионизирована неоднородно, имеются три основных слоя D, Е и F. Степень ионизации атмосферы зависит от интенсивности солнечной радиации и изменяется в течение суток и года. Днем и в летнее время проводимость и толщина ионизированных слоев увеличивается, а ночью и в зимнее время - уменьшается. Более низкие частоты отражаются нижними слоями ионосферы, а более высокие частоты проходят сквозь нижние слои и отражаются более высокими слоями. Частоты выше 30 МГц проходят через все слои ионосферы.

Радиоволны распространяются двумя путями: непосредственно вдоль земной поверхности (поверхностные волны) и под углом к поверхности земли (пространственные волны).

Особенности распространения радиоволн различных диапазонов используются в морской радиосвязи:

- длинные волны (низкие частоты - HЧ, LF) используются для приема радиовещательных передач и передач станций специальных служб (точного времени, метеосводок и т. д.). Дальность действия составляет 2000-3000 км за счет хорошего огибания поверхностными волнами земной поверхности (дифракции). Пространственные волны не используются из-за сильного поглощения и плохого отражения в ионосфере. Связь стабильна и не зависит от времени года и времени суток; 
- средние волны (средние частоты - СЧ, MF) в основном используются для связи при бедствии и безопасности, а также для передач системы НАВТЕКС.

Таблица 3.2.2

Частоты особой важности в ГМССБ

\begin{tabular}{|c|c|c|}
\hline Радиотелефония & ЦИВ & УБПЧ \\
\hline \multicolumn{3}{|c|}{ Средние волны (MF, CB-диапазон) } \\
\hline & & $\begin{array}{l}\text { NAVTEX } 490 \text { кГц } \\
\text { NAVTEX } 518 \text { кГц }\end{array}$ \\
\hline \multicolumn{3}{|c|}{ Промежуточные волны (MF)(ПВ-диапазон) } \\
\hline SOS 2182 кГц & SOS 2187,5 кГц & SOS 2174,5 кГц \\
\hline \multicolumn{3}{|c|}{ Короткие волны (HF, КВ-диапазон) } \\
\hline $\begin{array}{l}\text { SOS } 4125 \text { кГц } \\
\text { SOS } 6215 \text { кГц } \\
\text { SOS } 8291 \text { кГц } \\
\text { SOS } 12290 \text { кГц } \\
\text { SOS } 16420 \text { кГц }\end{array}$ & $\begin{array}{l}\text { SOS 4207,5 кГц } \\
\text { SOS 6312 кГц } \\
\text { SOS 8414,5 кГц } \\
\text { SOS 12577 кГц } \\
\text { SOS 16804,5 кГц }\end{array}$ & \begin{tabular}{|l} 
SOS 4177,5 кГц \\
SOS 6268 кГц \\
SOS 8376,5 кГц \\
SOS 12520 кГц \\
SOS 16695,0 кГц \\
NAVTEX 4209,5 кГц \\
MSI 4210; 16806,5 кГц \\
MSI 6314; 19680,5 кГц \\
MSI 8416; 22376 кГц \\
MSI 12579; 26100,5 кГц
\end{tabular} \\
\hline \multicolumn{3}{|c|}{ Ультракороткие волны (VHF, УКВ диапазон) } \\
\hline $\begin{array}{l}\text { aeroS\&R 121,5; 123,1 } \\
\text { МГц } \\
\text { S\&R 156,3 МГц(Ch06) } \\
\text { Safety 156,65 МГц } \\
\text { (Ch13) } \\
\text { SOS 156,8 МГц (Ch16) }\end{array}$ & $\begin{array}{l}\text { S O S } 156,5 \\
\text { МГц(Ch70) }\end{array}$ & \\
\hline \multicolumn{3}{|c|}{$\begin{array}{l}\text { полоса 406 } \div 406,1 \text { МГц используется спутниковыми радиомаяка- } \\
\text { ми - указателями места бедствия в направлении Земля-космос } \\
\text { (КОСПАС/САРСАТ) }\end{array}$} \\
\hline
\end{tabular}


Окончание табл. 3.2.2

\begin{tabular}{|c|c|c|}
\hline Радиотелефония & ЦИВ & УБПЧ \\
\hline \multicolumn{3}{|c|}{$\begin{array}{l}\text { использование полос } 1544 \div 1545 \text { и } 1645,5 \div 1646,5 \text { МГц ограничено } \\
\text { операциями в случае бедствия и для обеспечения безопасности } \\
\text { (ИНМАРСАТ) }\end{array}$} \\
\hline \multicolumn{3}{|c|}{$\begin{array}{l}\text { полосы } 1530 \div 1544 \text { и 1626,5 } \div 1645,5 \text { МГц используются для целей, } \\
\text { не связанных с бедствием, в случае бедствия и для обеспечения } \\
\text { безопасности (ИНМАРСАТ) }\end{array}$} \\
\hline олоса 9,2 $\div 9,5$ ГГц & 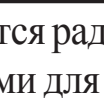 & \\
\hline
\end{tabular}

Средние волны сильно поглощаются землей и ионосферой (слоем D), особенно днем. Вечером после захода солнца слой D исчезает, пространственный луч отражается от слоя $\mathrm{F}$ и возвращается на землю. Ночью и зимой связь дальше, чем летом и днем, из-за уменьшения поглощения радиоволн в ионосфере (ночью) и уменьшения влияния атмосферных помех (зимой). Дальность устойчивой надежной связи 100-150 миль;

- короткие волны (высокие частоты - ВЧ, НF) широко используются в МПС для связи в случаях бедствия, приема информации по безопасности мореплавания и коммерческой радиосвязи. Короткие волны сильно поглощаются землей при распространении вдоль земной поверхности, однако хорошо отражаются от земли и ионосферы. Дальнее распространение коротких волн происходит путем последовательных отражений от земли и ионосферы. Днем более низкие частоты КВ-диапазона сильно поглощаются слоями D и Е. Ночью ионизация слабее, более высокие частоты слабо отражаются от слоя F, проходя сквозь него. Поэтому днем лучше использовать более короткие волны (8-25 МГц), а ночью более длинные (4-8 МГц). Дальность доходит до нескольких тысяч километров;

- метровые волны (очень высокие частоты ОВЧ, VHF) используются для телефонной связи между судами, судами и портовыми службами. Связь при бедствии осуществляется с помощью ЦИВ (70-й канал) и телефонии (16-й канал). Поверхностные волны не 
огибают земную поверхность, а пространственные не отражаются от ионосферы, проходят сквозь нее и уходят в космос. Дальность связи составляет 20-30 миль;

- дециметровые волны (ультравысокие частоты УВЧ, UHF) используются для спутниковой связи;

- сантиметровые волны (сверхвысокие частоты СВЧ, SHF) используются в радиолокации, для излучения сигналов SART. Дальность - прямая видимость.

Все используемые в МПС частоты (кроме аварийных) подразделяются на частоты вызова и рабочие частоты:

- частоты вызова предназначены для передачи начальных вызовов и информации по установлению связи между станциями;

- рабочие частоты используются для обмена сообщениями и назначаются ведущей станцией.

Рабочие частоты могут быть парные и непарные:

- nарные частоты обычно присваиваются береговым станциям, при этом каждой частоте передачи строго соответствует определенная частота приема;

- в случае непарных частот станции могут по взаимному согласию использовать произвольные комбинации передающих и приемных частот.

Частотный канал - участок частотного спектра, на котором обеспечиваются передача и прием информации.

Для обмена информацией между двумя радиостанциями используются различные способы связи:

- симплексная связь, при которой передача возможна только в одном направлении канала связи; при организации двусторонней радиосвязи передача и прием на каждой радиостанции осуществляется поочередно;

- дуплексная связь, при которой возможны одновременно передача и прием на каждой радиостанции;

- полудуплексная связь - это двусторонняя симплексная связь, при которой переход с передачи на прием и обратно производится автоматически, причем принимающая станция может перебить работу передающей станции и начать передачу. 
Дуплексная и полудуплексная связи требуют применения двух частот при сеансе радиосвязи, а симплексная связь может осуществляться с использованием одной или двух частот.

Система морской радиосвязи является совокупностью систем связи, технических средств связи и среды распространения. В морской практике используют следующие виды систем радиосвязи:

1. Спутниковая система действует в направлениях судно-судно, судно-берег и берег-судно, дальность действия неограниченна (за исключением полярных шапок) при наличии высокой надежности.

2. Дальняя связь использует КВ средства связи в направлении судно-берег и судно-судно (как альтернативу системе ИНМАРСАТ в районе $\mathrm{A} 3$ и единственное средство в районе A4). В случаях бедствия и безопасности основным средством оповещения является система ЦИВ. После получения и подтверждения вызова по бедствию связь с судном, терпящим бедствие, осуществляется в основном режиме радиотелефонии или в резервном режиме радиотелекса на соответствующих частотах бедствия.

3. Связь на средние расстояния использует диапазон $\mathrm{CB}$; для передачи по поводу бедствия и безопасности с использованием радиотелефонии, ЦИВ и УБПЧ выделены специальные частоты в диапазоне 2 МГц, а для передачи навигационных и других предупреждений, а также срочной информации по системе НАВТЕКС - частоты 490 и 518 кГц.

4. Ближняя связь использует УКВ-диапазон; для передачи вызовов ЦИВ выделен 70-й канал, а для обмена при бедствии, срочности и безопасности - 16-й канал.

5. Радиотелексная связь (УБПЧ) используется для передачи текстовой информации в ПВ- и КВ-диапазонах. В международной практике используется следующая аббревиатура телекса: английская - TELEX, TELEPRINT, NBDP (Narrow Band Direct Printing), TOR (Telex Over Radio), TLX, RTLX; русская - УБПЧ (узкополосное буквопечатание). При передаче информации каждый знак кодируется международным телеграфным кодом - МТК5.

Эксплуатационные требования к узкополосному буквопечатающему телеграфному оборудованию для приема навигационных 
и метеорологических предупреждений и срочной информации для судов соответствуют Резолюции ИМО А.525(13). Оборудование работает в трех рекомендованных МККР режимах: режим A-ARQ; режим В - FEC и режим C - SELFEC (класс излучения F1B или $\mathrm{J} 2 \mathrm{~B})$. Причем режим FEC подразделяется на два режима - FEC collective и FEC selective [124].

Режим ARQ (Automatic Repetition reQuest - автоматическое повторение по запросу) является двухсторонним режимом с обратной связью. В этом режиме связь осуществляется с использованием двух каналов: прямого, по которому передается информация от ведущей радиостанции к ведомой, и обратного, по которому передается сигнал «повтор» в случае обнаружения ошибки в принятой информации, либо «запрос» на передачу следующего блока информации. Работа судовой радиостанции в режиме ARQ в порту запрещена Регламентом радиосвязи.

Режим FEC (Forward Error Correction - прямое исправление ошибок) является режимом без обратной связи (передача в одном направлении). Передающая станция передает сообщение знак за знаком с повторением каждого знака через четыре позиции. Таким образом, в режиме FEC обеспечивается только обнаружение ошибок. В этом режиме приемная станция не нуждается в передатчике. B режиме FEC возможна передача как всем судам (COLlective FEC - यиркулярный вызов), так и одной конкретной станции (SELective FEC - избирательный вызов). Режим FEC является идеальным режимом для передачи информации судам, которые стоят в портах и не имеют возможности работать на передачу.

6. Цифровой избирательный (селективный) вызов (ЦИВ, Digital Selective Calling - DSC) - вид связи, использующий цифровые коды и обеспечивающий автоматический вызов одной станции или группы станций, а также всемирно принятая система связи общего назначения для избирательного вызова и передачи телекоманд в целях автоматического сбора информации с судов. Система ЦИВ используется в УКВ/ПВ/КВ-диапазонах на специально выделенных частотах. Она позволяет войти в международную телефонную сеть в автоматическом режиме через береговую станцию. 
Система ЦИВ используется в основном для передачи следующих типов сообщений:

- оповещений о бедствии в направлении судно-берег, берегсудно и судно-суда в районе бедствия;

- подтверждения и ретрансляции принятых вызовов бедствия береговыми и судовыми радиостанциями;

- оповещений о предстоящей передаче информации, касающейся срочности и безопасности;

- вызовов, связанных с установлением связи для обмена общественной корреспонденцией (служебной и частной).

Приемник, оснащенный системой ЦИВ, реагирует только на свой уникальный идентификатор (MMSI\#-Maritime Mobile Service Identity number), подобный телефонному номеру, и на общий вызов для всех судов в зоне связи. После того, как произошел контакт между радиостанциями на канале вызова, дальнейший голосовой радиообмен производится в другом частотном канале. Вызов ЦИВ на приемном конце отображается информацией на дисплее контроллера и сопровождается звуковой сигнализацией.

Тактико-технические характеристики системы ЦИВ, требования к оборудованию, а также эксплуатационные характеристики системы изложены в Руководстве Международного союза электросвязи [61] и Рекомендации МСЭ-R M.493-11 (05/04) [94].

\section{3. Глобальная морская система связи при бедствии и для обеспечения безопасности}

Глобальная морская система связи при бедствии и для обеспечения безопасности (ГМССБ, Global Maritime Distress and Safety System GMDSS), разработанная членами ИМО, является эффективной глобальной системой связи для обеспечения безопасности мореплавания в Мировом океане. ГМССБ - это международная система, использующая современные наземные, спутниковые и судовые системы радиосвязи и обеспечивающая радиосвязь общего назначения и передачу оповещений при бедствии. ГМССБ представляет собой созданный в соответствии с требованиями 
Конвенции СОЛАС-74 комплекс обязательных технических мер, инфраструктуры и правил для оказания помощи в аварийных ситуациях в Мировом океане и обеспечения безопасности судоходства. Все суда, подпадающие под действие Международной конвенции о безопасности жизни на море (СОЛАС) должны соответствовать требованиям ГМССБ.

Развитие и внедрение методов ГМССБ проходило поэтапно [26].

Первая Международная конвенция по охране человеческой жизни на море СОЛАС-14 была принята в канун Первой мировой войны. Она предусматривала, в частности, обязательную радиовахту на частоте 500 кГц. Однако эти планы не осуществились из-за событий начала XX века.

Только СОЛАС-29 обязал ввести радиовахту в диапазоне СВ на частоте 500 кГц с использованием азбуки Морзе на пассажирских судах и грузовых судах с валовым регистровым водоизмещением 1600 тонн и более.

Конвенция СОЛАС-48 ввела требование по несению радиовахты на частоте 2182 кГц в режиме радиотелефонии для судов валовой вместимостью 300-1600 тонн.

Конвенция СОЛАС-74 обязала определенные классы судов при нахождении в море круглосуточно нести радиовахту на международных частотах вызова и бедствия, выделенных для этих целей МСЭ и включенных в Регламент радиосвязи. При этом суда должны быть оснащены соответствующим радиооборудованием. Капитан любого судна, находящегося в море, при приеме сигнала и сообщения бедствия от судна, воздушного судна или спасательного средства должен немедленно и на полном ходу проследовать к месту бедствия для оказания помощи потерпевшим и одновременно информировать их о предпринимаемых действиях.

Система связи при бедствии для судов в соответствии с правилами Конвенции СОЛАС-74 включала две основные неавтоматизированные подсистемы [25]:

- система радиотелеграфной связи на частоте $F=500$ кГц с использованием азбуки Морзе, что требовало наличия на борту судна квалифицированного радиооператора; 
- система радиотелефонной связи на частотах $F=2182$ кГц (ПВ) и $F=156,8$ МГц (УКВ), 16-й канал.

Свойства радиоволн указанных диапазонов не позволяют обеспечить глобальную радиосвязь. Ограниченность дальности действия средств связи, а также человеческий фактор снижали эффективность использования радиосвязи для охраны человеческой жизни на море.

В 1979 году Международная конференция по поиску и спасанию на море, созванная при содействии ИМО, приняла Конвенцию по поиску и спасанию на море (SAR-79), основная цель которой заключалась в подготовке глобального плана по поиску и спасанию на море на основе многосторонних соглашений, обеспечивающих взаимную поддержку при выполнении поисковых и спасательных операций в прибрежных и прилегающих к ним морских районах [72].

В 1988 г. ИМО провела Конференцию договаривающихся правительств Международной конвенции СОЛАС-74, на которой были приняты поправки к Конвенции, касающиеся радиосвязи и связанные с внедрением Глобальной морской системы связи при бедствии и для обеспечения безопасности мореплавания (ГМССБ). К этому времени широкое распространение получили системы спутниковой связи, внедрялась узкополосная буквопечатающая частотная радиотелеграфия (УБПЧ), которая вытесняла азбуку Морзе, была разработана система цифрового избирательного вызова (ЦИВ), позволявшая отказаться от несения слуховой радиовахты.

С 1992 года началось поэтапное внедрение ГМССБ:

- с 1 августа 1993 года все суда оборудованы приемниками НАВТЕКС, спутниковыми радиобуями;

- с 1 февраля 1995 года вновь строящиеся суда должны удовлетворять требованиям ГМССБ;

- с 1 февраля 1999 года все суда должны удовлетворять требованиям ГМССБ.

Наличие утвержденной техники и аппаратуры вне зависимости от водоизмещения судна позволяет всегда находиться на связи и в любой аварийный момент подать сигнал SOS. Система ГМССБ обеспечивает автоматическую передачу и прием аварийных сигналов 
на любом расстоянии, независимо от метеорологических условий и условий распространения радиоволн, и тем самым существенно повышает безопасность мореплавания.

Принципы организации ГМССБ определены Правилами Главы IV Международной конвенции СОЛАС-74 с поправками 1995 года, изменениями и дополнениями 2008 года и до 2012 года [42].

В соответствии с этими правилами в состав ГМССБ входят следующие системы [74]:

1 Система спутниковой связи ИНМАРСАТ;

2 Система спутниковой связи КОСПАС-САРСАТ;

3 Система наземной радиосвязи МПС в УКВ, СВ, ПВ, КВ диапазонах;

4 Система автоматической передачи навигационных, метеорологических и других извещений НАВТЕКС;

5 Оборудование радиолокационного обнаружения.

Обобщенную структуру ГМССБ и принцип взаимодействия ее компонентов иллюстрирует рисунок 3.3.1.

Международная система спутниковой связи ИНМАРСАТ (INMARSAT) предоставляет различные услуги, включая обычную телефонную связь, передачу данных, а также передачу сигналов бедствия (рис. 3.3.2) [127].

Система ИНМАРСАТ состоит из девяти спутников, находящихся на геостационарной орбите, и обеспечивает глобальное покрытие земной поверхности (около 98 \%), за исключением районов полюсов выше $70^{\circ}$ северной и южной широты. Система включает в себя береговые наземные станции спутниковой связи (БНС), позволяющие осуществлять выход в другие сети связи и ИНТЕРНЕТ путем коммутации судовых станций спутниковых связей и спутников.

Спутники ИНМАРСАТ обеспечивают двустороннюю связь между судном и берегом (рис. 3.3 .3 [102]), а также прием сообщений от аварийного радиобуя (АРБ). Через наземные узлы связи БНС информация поступает в координационный центр спасательной службы СКЦ. В направлении берег-судно спутники ведут трансляцию циркулярных сообщений, которые могут быть как аварийными, так и общего назначения. 


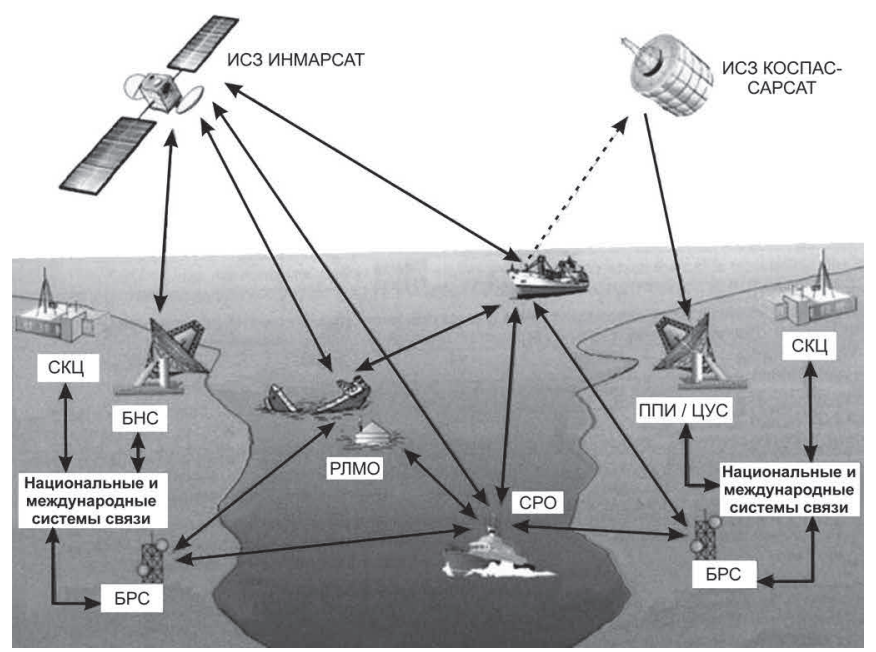

Рис. 3.3.1. Структура и принцип действия ГМССБ:

- искусственные спутники земли (ИСЗ) систем ИНМАРСАТ и КОСПАС-САРСАТ;

- спасательный координационный центр (Rescue Coordination Centre) СКЦ;

- пункт приема информации / центр управления системой (Local User Terminal /

Mission Control Center) ППИ / ЦУС;

- береговая наземная станция (Coast Earth Station) БНС;

- национальные и международные системы связи (National/International networks);

- радиолокационный маяк-ответчик (Search And Rescue Transponder, SART) - РЛМО;

- службы радиообнаружения (SAR Services) CPO;

- береговая радиостанция (Coast Radio Station HF, MF, VHF) - БРС.

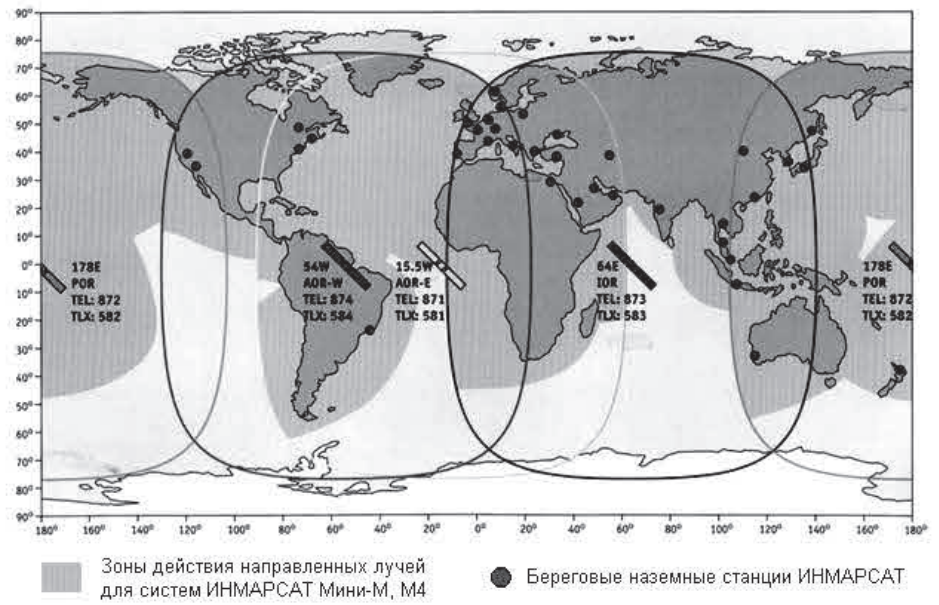

Рис. 3.3.2. Схема покрытия земной поверхности глобальными лучами в системе ИНМАРСАТ 
На 15-й сессии Подкомитета IMO по радиосвязи, поиску и спасанию (COMSAR 15, Лондон, 7-11 марта 2011 г.) отмечена избыточность требования главы IV «Радиосвязь» Международной конвенции по охране человеческой жизни на море 1974 года (МК СОЛАС) в отношении оснащения судов УКВ АРБ, работающем на канале 70, поскольку данное оборудование является устаревшим [99].

Международная космическая поисково-спасательная система KOCПAC-CAPCAT (COSPAS-SARSAT) предназначена для обнаружения и определения местоположения судов, самолетов и других объектов, терпящих бедствие (рис. 3.3.4) [127].

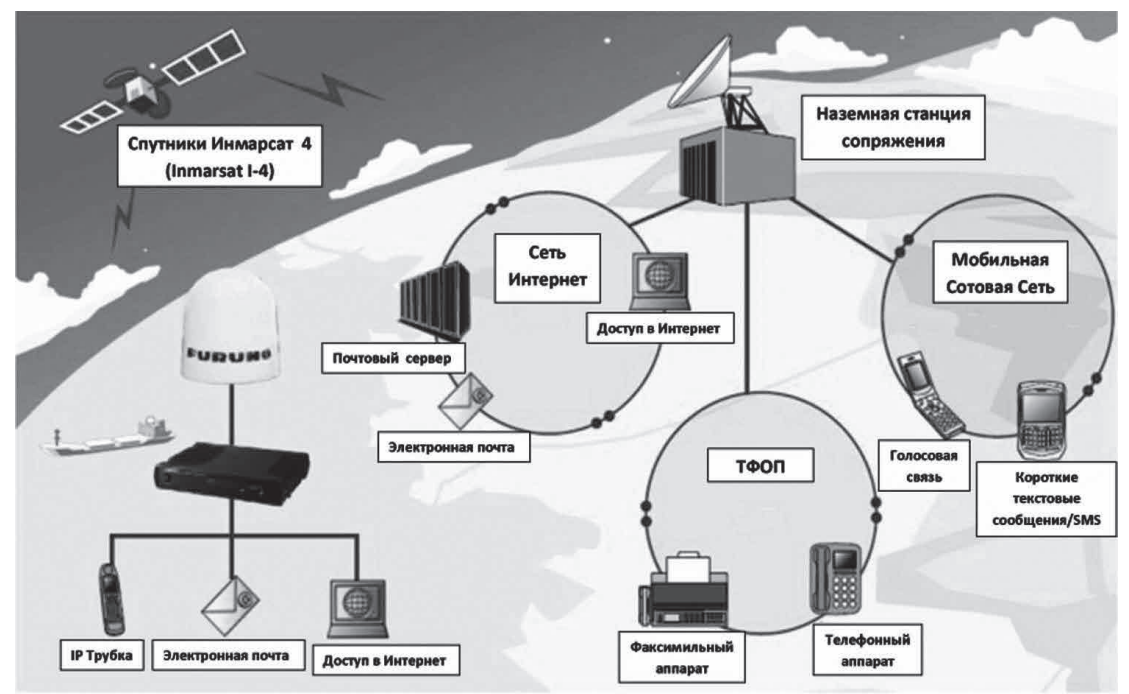

Рис. 3.3.3. Структура средств связи в системе ИНМАРСАТ

Система КОСПАС-САРСАТ одобрена Международной морской организацией (ИМО) и Международной организацией гражданской авиации (ИКАО). Система образована в 1977 году на основе международного сотрудничества СССР (КОСПАС) с одной стороны и США, Канады и Франции (SARSAT) с другой.

Система КОСПАС-САРСАТ состоит из пунктов приема информации на суше (ППИ), группировки спутников, находящихся на орбитах в 800-1000 км от поверхности Земли, и аварийных 


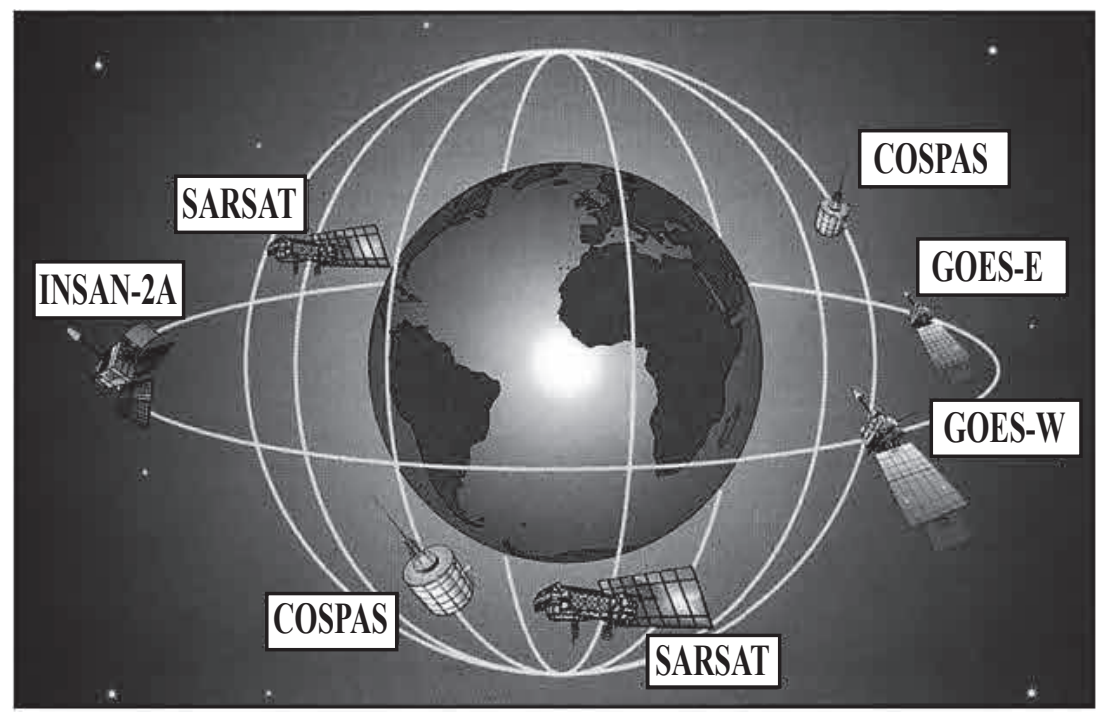

Рис. 3.3.4. Космическая группировка системы КОСПАС-САРСАТ

радиобуев (АРБ), расположенных на судне и срабатывающих при аварийных ситуациях.

Географическое положение излучающих АРБ определяется системой автоматически с использованием эффекта Доплера. Аварийный сигнал принимается спутником и передается на ППИ для последующей его ретрансляции в службу спасения. Принцип определения местоположения АРБ - доплеровский сдвиг является преимуществом системы КОСПАС-САРСАТ по сравнению с определением координат в системе ИНМАРСАТ, так как спутники ИНМАРСАТ неподвижны относительно Земли, и буй должен передать свое местоположение сам, с помощью встроенного приемника ГНСС. С другой стороны, передача сообщений в системе ИНМАРCAТ происходит быстрее, чем в системе КОСПАС-САРСАТ.

Система наземной радиосвязи морской подвижной службы (MПC, Maritime Mobile Service - MMS) предназначена для осуществления связи между радиостанциями различной ведомственной и государственной принадлежности. Резолюция ИМО А.801(19) 23.11.1995 г. с поправками определяет принципы обеспечения радиослужб для ГМССБ [37]. 
В соответствии с решаемыми задачами в системе радиосвязи МПС выделяют три подсистемы [73, 87]:

- подсистема обеспечения безопасности мореплавания и охраны человеческой жизни на море;

- подсистема обеспечения оперативно-диспетчерского руководства флотом;

- подсистема обеспечения нужд экипажей судов и пассажиров.

Подсистемы различаются требованиями к качественным показателям передачи информации, организацией взаимодействия структурных элементов системы связи, принципами использования технических средств, а в ряде случаев и самими техническими средствами.

В особую служебную подсистему выделен ведомственный радиоконтроль за выполнением требований по организации радиообмена и использованием технических средств связи.

Составными частями указанных подсистем являются службы, обладающие автономностью в решении задач в интересах различных подсистем:

- служба радионаблюдения обеспечивает наблюдение за вызовами береговых и судовых радиостанций для установления связи между станциями различной принадлежности;

- служба радиосвязи обеспечивает взаимный обмен сообщениями между береговыми и судовыми радиостанциями;

- служба радиоосведомления и радиоопределения обеспечивает сбор и передачу сведений, связанных с изменением навигационной и метеорологической обстановки, определением места судна с помощью средств связи, а также оповещением о точном времени;

- служба радиоконтроля обеспечивает контроль по радиоканалам МПС за соблюдением международных, государственных и ведомственных требований к организации связи и использованию технических средств с целью предотвращения взаимных непреднамеренных помех при одновременной работе большого числа радиостанций.

Специальные службы подсистемы радиосвязи МПС обеспечивают мореплавателей дополнительными сведениями, способствующими их безопасному плаванию, к ним относятся: 
- служба метеорологии, которая обеспечивает передачу гидрометеорологических сведений для всеобщего радиоприема;

- служба радиопеленгаторных станций, которая использует прием радиоволн для определения направлений на передающие радиостанции;

- служба радиомаячных станций, которая используется для целей навигации и дает возможность подвижной радиостанции определить свой пеленг или направление на радиомаячную станцию;

- служба сигналов точного времени, которая обеспечивает передачу сигналов времени высокой точности для всеобщего приема;

- служба радиостанизий, обеспечивающих передачу навигационных извещений мореплавателям;

- служба радиостанщ̧ий, предназначенных для передачи медицинских консультаций.

Основным средством оповещения в ГМССБ является система ЦИВ, работающая на специально выделенных частотах для аварийной и общественной радиосвязи. МПС выделены следующие полосы частот:

- в УКВ-диапазоне 156-174 МГц;

- в СВ-диапазоне 405-526,5 кГц;

- в ПВ-диапазоне 1605-4000 кГц;

- в КВ-диапазоне 4-27,5 МГц.

Международная система НАBTEKC (NAVTEX - NAVigational TeleX, НАВИГАЦИОННЫЙ ТЕЛЕКС) обеспечивает передачу и автоматический прием навигационной и метеорологической информации и других срочных извещений с помощью узкополосной буквопечатающей телеграфии (УБПЧ) с помехоустойчивым кодированием на частоте 518 кГц. Кроме того, могут использоваться национальные службы НАВТЕКС, осуществляющие передачи на частотах 490 кГц и 4209,5 кГц [92, 116].

Система НАВТЕКС состоит из береговых наземных станций и судовых приемников, наличие которых на судах обязательно с 1993 года. Передачи между станциями и приемниками ведутся на английском языке и осуществляются по расписанию. 
НАВТЕКС является частью Всемирной службы навигационных предупреждений. Вещание ведется в прибрежных районах в непосредственной близости от БНС. Дальность связи по радиоканалу зависит от чувствительности приемника, мощности передатчика на базовой станции, высоты расположения антенны, а также других дополнительных факторов и не превышает 400 миль. При нахождении судна на расстоянии, превышающем дальность действия системы, навигационная, метеорологическая и другая информация передается по каналам связи через ИНМАРСАТ или с помощью УБПЧ на отведенных для этого каналах на частотах в КВ-диапазоне.

Состав радиооборудования для судов, подпадающих под требования СОЛАС-74, определяется следующими основными требованиями:

- каждое судно должно иметь оборудование, способное выполнить каждую из функций ГМССБ в районе плавания судна;

- каждое судно должно иметь как минимум две независимые друг от друга системы радиосвязи, способные обеспечить передачу оповещения о бедствии;

- любое отдельное оборудование в ГМССБ должно выполнять более одной функции и может быть сопряжено с другим оборудованием;

- оборудование должно быть простым в эксплуатации и при необходимости работать без оператора;

- спасательные средства (шлюпки, плоты) должны быть снабжены оборудованием, способным вести связь при проведении ПСО в диапазоне УКВ;

- спасательные средства должны быть оборудованы радиолокационным маяком-ответчиком (PЛMO, SART).

Кроме этого, необходимо иметь комплект аварийных переносных радиостанций и РЛМО, а суда, работающие в районах, обслуживаемых системой НАВТЕКС, должны иметь приемник данной системы.

Радиолокаиионное обнаружение основывается на работе радиолокационных станций в районе бедствия и засветке объектов и сигналов, попадающих в действие луча станций. 
Сигнал бедствия, определяющий местоположение человека или судна, подается с помощью АРБ, который входит в обязательный комплект оборудования каждого судна и может использоваться как на суше, так и на воде. Радиобуй погружается в воду, освобождается от скобы и всплывает на поверхность, излучая в течение двух суток сигналы на разной частоте. Имея в конструкции светодиод, он также может использоваться как маяк.

Следующим по важности компонентом в составе ГМССБ является спутниковый терминал, который позволяет вести регулярный контроль водного маршрута, получая новые данные о погодных условиях и рядом расположенных судах, а также быть постоянно на связи с диспетчерами береговой линии.

УКВ-радиостанция, работающая на различных частотах, используется для подачи сигнала бедствия и для оказания помощи находящимся в том же квадрате судам.

Кроме АРБ, оборудования систем ИНМАРСАТ и КОСПАССАРСАТ и УКВ-радиостанции с ЦИВ, на 70-м канале в системе ГМССБ предусмотрена работа РЛМО, работающего в диапазоне 2,3 см и позволяющего получать данные о местонахождении человека или терпящего аварию судна. При облучении ответчик дает на мониторе РЛС засветку в виде последовательности точек или дуг в направлении обратного пеленга от направления на радар, тем самым обозначается местонахождение РЛМО.

Для быстрого реагирования и прибытия на место аварии Мировой океан в ГМССБ поделен на четыре морских района: А1, A2, А3 и А4, плавание в которых налагает на суда особые обязательства (рис. 3.3.5):

- морской район Al - район в пределах зоны действия по крайней мере одной береговой УКВ-радиостанции (156-174 МГц), обеспечивающей постоянную возможность передачи сообщений с использованием цифрового избирательного вызова (20-50 морских миль);

- морской район $A 2$ - район (за исключением морского района A1) в пределах зоны действия по крайней мере одной береговой радиостанции, работающей в диапазоне промежуточных волн 
(1605-4000 кГц) и обеспечивающей постоянную возможность передачи сообщений о бедствии с использованием цифрового избирательного вызова (до 150 морских миль);

- морской район $A 3$ - район (за исключением морских районов A1 и A2) в пределах зоны действия системы геостационарных спутников ИНМАРСАТ, обеспечивающей постоянную возможность оповещения о бедствии (примерно между $70^{\circ}$ северной и южной широты);

- морской район $A 4$ - район, находящийся за пределами морских районов A1, A2 и А3 и перекрывающий главным образом северную и южную приполярные области.

Границы морских районов A1 и A2 наносятся на навигационные карты.

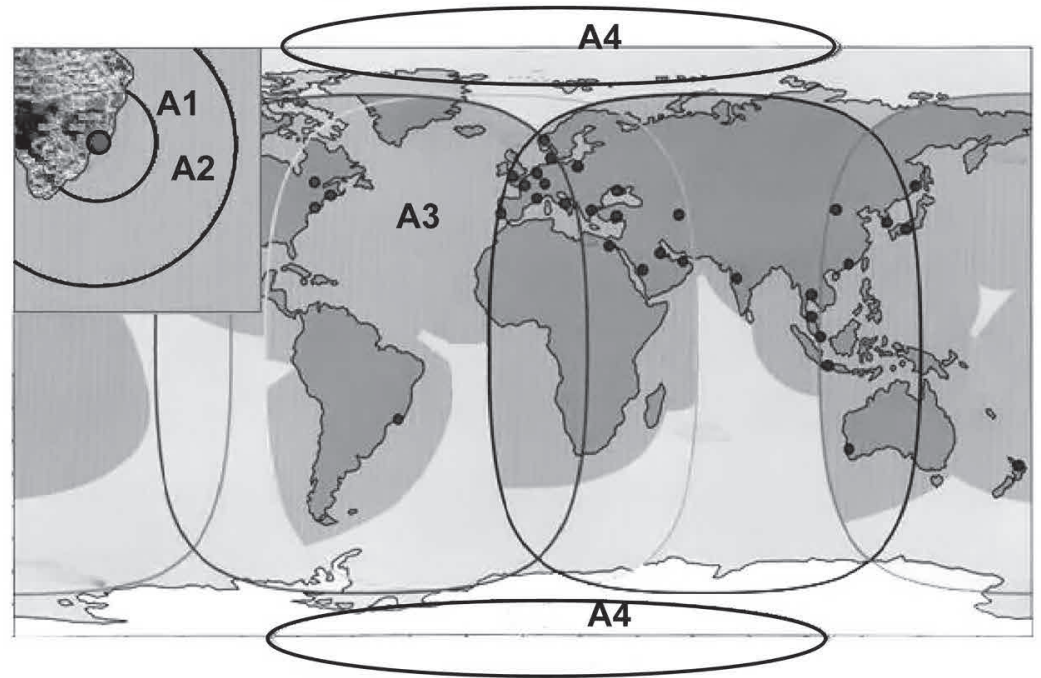

Рис. 3.3.5. Структурирование Мирового океана на морские районы ГМССБ

Состав обязательного судового радиооборудования определяется морским районом ГМССБ, а не водоизмещением или типом судна [69]. Обобщенные требования к составу радиооборудования БНС ГМССБ в зависимости от морского района плавания приведены в таблице 3.3 .1 [72]. 
Таблица 3.3.1

\section{Требования к составу радиооборудования береговой наземной станции ГМССБ}

\begin{tabular}{|c|l|l|}
\hline Морской район & Радиооборудование БНС & \multicolumn{1}{|c|}{ Зона действия } \\
\hline А1 & УКВ (ЦИВ) и АРБ & $20-30$ миль \\
\hline А2 & $\begin{array}{l}\text { УКВ (ЦИВ), СВ (ЦИВ) } \\
\text { и АРБ }\end{array}$ & 150 миль \\
\hline А3 & $\begin{array}{l}\text { УКВ (ЦИВ), СВ (ЦИВ) } \\
\text { или КВ (ЦИВ) и АРБ или } \\
\text { ИНМАРСАТ }\end{array}$ & $\begin{array}{l}\text { до } 70^{\circ} \text { северной и } \\
\text { южой широт }\end{array}$ \\
\hline А4 & $\begin{array}{l}\text { УКВ (ЦИВ), СВ /КВ } \\
\text { (ЦИВ) и АРБ }\end{array}$ & $\begin{array}{l}\text { северная и южная } \\
\text { приполярные об- } \\
\text { ласти }\end{array}$ \\
\hline
\end{tabular}

Технико-эксплуатационные требования к береговому оборудованию ГМССБ приведены в своде правил [5] Министерства транспорта Российской Федерации.

Основная конщепщия ГМССБ заключается в том, что береговые поисково-спасательные службы и суда в районе бедствия должны быть в кратчайшие сроки оповещены об аварии для организации и проведения скоординированной поисково-спасательной операции (ПСО). Ответственность за проведение спасательных работ и оказание помощи возлагается на береговые поисковые спасательные службы. ГМССБ должна обеспечивать связь, относящуюся к срочности и безопасности, а также передачу на суда информации, обеспечивающей безопасность мореплавания, включая навигационные и метеорологические предупреждения.

В соответствии с концепцией ГМССБ имеющееся на борту каждого судна оборудование должно удовлетворять следующим основным функииям:

- передача оповещений о бедствии, означающая быструю и надежную передачу информации об аварии другим судам, находящимся вблизи аварийного судна, или спасательным координационным центрам, которые могут оказать ему помощь; 
- передача сообщений для координациии поиска и спасания, включающая обмен информацией между СКЦ и руководителем проведения ПСО или надводного поиска в районе аварии;

- прием и передача сообщений на месте бедствия, выполняемые участниками ПСО и аварийным судном в оперативном режиме радиотелефонии или телеграфии;

- прием и передача сигналов для определения местоположения или самонаведения, выполняемые для облегчения поиска аварийного судна или определения местоположения потерпевших аварию с использованием РЛМО и АРБ;

- прием и передача информащзи по безопасности на море, включающие навигационные и метеорологические предупреждения и другую срочную и важную для обеспечения безопасности мореплавания информацию; в ГМССБ предусмотрен автоматический прием всех видов информации данного типа;

- прием и передача сообщений общего назначения через береговые системы или сети связи, включающая обмен информацией между судовыми и береговыми радиостанциями по вопросам управления и эксплуатации судна, которые могут оказать косвенное влияние на безопасность судна;

- прием и передача сообщений по схеме «мостик-мостик», используемые для обмена между судами информацией, которая касается обеспечения их безопасного движения.

Для повышения надежности передачи информации о бедствии в ГМССБ предусмотрено множественное резервирование каналов связи на случай сбоев и отказов при работе, дублирование радиооборудования, береговое техническое обслуживание и ремонт, а также квалифицированное техническое обслуживание и ремонт на борту судна в море.

Таким образом, система ГМССБ представляет собой существенное усовершенствование способов аварийной связи. Она упрощает поиск и спасение выживших людей, улучшает координацию спасательных служб и судов, расположенных поблизости от места бедствия, обеспечивает мореплавателей жизненно важной информацией о безопасности на море. Средства ГМССБ обеспечивают 
не только радиосвязь общего назначения, но и, что наиболее важно, позволяют оперативно передавать оповещение при бедствии, используя различные, независимые друг от друга средства и системы связи. Будучи обязательной для всех судов, подпадающих под действие Международной конвенции о безопасности жизни на море (СОЛАС), то есть для грузовых судов водоизмещением свыше 300 тонн и всех пассажирских судов международного плавания, система ГМССБ оказывает влияние на все радиофицированные суда вне зависимости от их класса.

\section{4. Назначение и развитие систем установления путей}

Эффективным средством пассивного управления судопотоками является система установления путей. Системой установления nутей называется любая система, состоящая из одного или более путей, или меры по установлению путей, направленные на уменьшение вероятности аварий [70]. Системы установленных путей вводятся в целях повышения безопасности плавания в районах, где сходятся потоки судов, и в районах с большой интенсивностью движения, или где свобода движения судов ограничена наличием препятствий, малыми глубинами либо неблагоприятными гидрометеорологическими условиями. Системы могут также использоваться в районах, особо чувствительных в экологическом отношении или вблизи них в целях предупреждения или уменьшения опасности загрязнения морской окружающей среды, вызванного столкновением судов или посадкой их на мель. Идея создания системы установления путей движения судов основана на пространственном разделении судопотоков с целью уменьшения числа или полного устранения ситуаций сближения судов на встречных курсах. Например, система установленных путей движения судов в районе порта Jomard Entrance, находящегося в Milne Bay Province Папуа - Новой Гвинеи (восточное побережье Австралии), представлена на навигационной карте (рис. 3.4.1) [24]. Система установленных путей в Jomard Entrance содержит четыре двусторонних маршрута 
и район повышенной осторожности плавания. Один путь лежит примерно в 20 морских милях к северу от Jomard Entrance, три других пути находятся примерно на расстоянии в 3,5 мили к югу от входа. Через порт Jomard Entrance ежедневно проходит до 27 больших торговых судов.

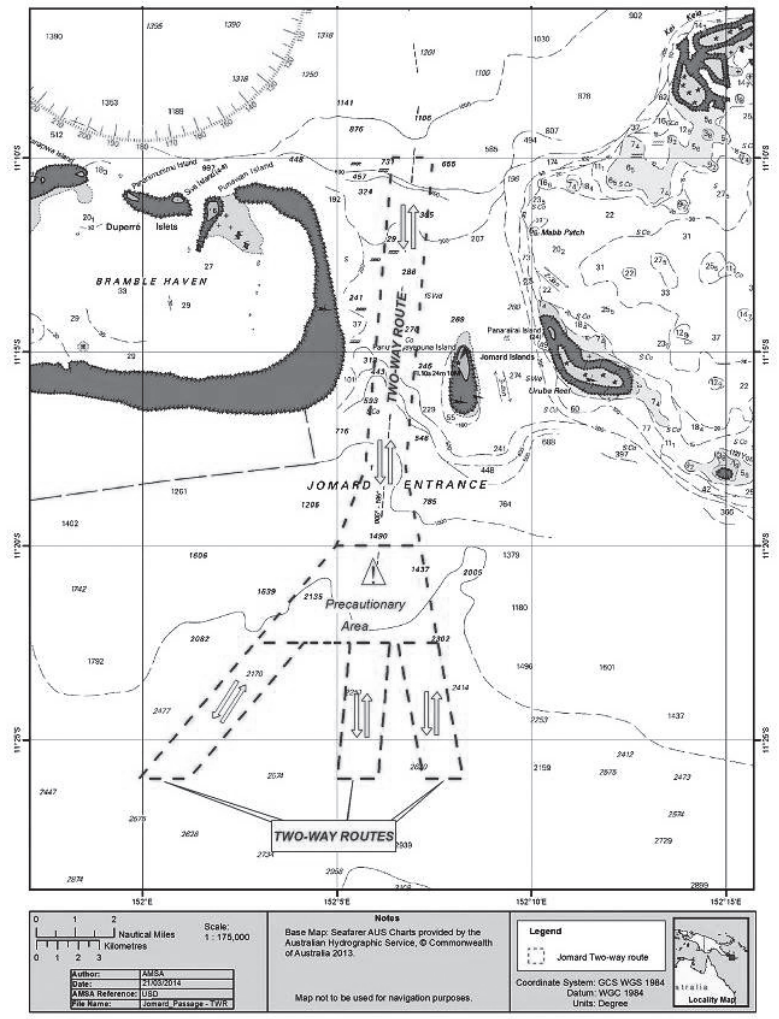

Рис. 3.4.1. Навигационная карта системы установленных путей движения судов в районе Папуа - Новой Гвинеи

Системы установления путей движения судов относятся к числу наиболее ранних систем обеспечения безопасности мореплавания. Рекомендованные пути традиционно использовались на протяжении многих веков.

Развитие концепции пространственного разделения судопотоков можно условно разделить на три периода [49]: 1) период 
зарождения в середине 1850-х годов и медленного последующего развития примерно до 1960 г.; 2) период бурного развития и организационно-нормативного обеспечения с 1960-го по 1985 г;; 3) период после 1985 г., когда утвержденные на международном уровне процедуры начали последовательно вводиться в районах оживленного судоходства.

На международном законодательном уровне практика плавания установленными путями впервые была введена в 1898 г. в целях обеспечения безопасности плавания пассажирских судов, совершавших рейсы через Северную Атлантику. Однако в законченном современном виде система установления путей сформировалась во второй половине XX века.

Законодательное оформление и признание на международном уровне эти системы получили в 1960 г. на Конференции по безопасности человеческой жизни на море. Была признана целесообразность организации регламентированного движения в местах схождения морских путей, а на судоходные компании была возложена задача определения границ таких районов и разработки рекомендованных путей. Этот процесс завершился в 1985 г. на 14-й Ассамблее ИМО, где была принята Резолюция А.572(14) «Общие положения об установлении путей движения судов». Эта резолюция фактически является четвертым изданием одноименной резолюции 1973 г., которая дважды перерабатывалась в 1977 г. и 1979 г. С тех пор Резолюция А.572(14) кардинально не изменялась и действует до настоящего времени.

В соответствии с Резолюцией А.572(14) «целью установления путей движения судов является повышение безопасности мореплавания в районах схождения путей и в районах, где интенсивность движения очень велика или где свобода движения судов затруднена стесненностью морского пространства, наличием навигационных опасностей, ограниченными глубинами или неблагоприятными метеорологическими условиями». В зависимости от конкретных опасных обстоятельств, влияние которых эта система позволит уменьшить, она может иметь все или некоторые из следующих целей [71]: 
- разделение встречных потоков судов таким образом, чтобы уменьшить вероятность столкновения судов;

- уменьшение опасности столкновения судов, следующих в установленных полосах движения, с судами, следующими курсами, пересекающими такие полосы;

- упрощение организации движения в районах схождения потоков судов;

- организация безопасного движения судов в районах интенсивных изысканий или разработок в открытом море;

- организация потока судов в районах или вокруг районов, где плавание всех судов или определенных классов судов опасно или нежелательно;

- уменьшение риска посадки судов на мель установлением специальной организации движения судов в районах, в которых глубины недостоверны или близки к осадке судна;

- организация движения судов на достаточном расстоянии от районов рыболовства или через районы рыболовства;

- направление потоков судов в обход экологически уязвимых районов.

Резолюция А.572(14) устанавливает различные методы практической реализации систем установления путей движения судов:

- разделение встречных потоков судов зонами разделения движения или линиями разделения в тех случаях, когда невозможно применить зоны;

- разделение встречных судопотоков естественными препятствиями и другими показанными на карте объектами;

- разделение транзитного и местного судоходства установлением зон прибрежного плавания;

- секторное разделение смежных систем разделения движением на подходах к узловым точкам;

- установление путей движения в районах узловых точек, в местах схождения путей, где соединяются системы разделения движения, введением районов кругового движения или районов повышенной осторожности плавания;

- установление районов, которых следует избегать; 
- установление двусторонних, глубоководных и/или рекомендованных путей, направлений потоков судов, маршрутов.

Идея разделения движения судов в нескольких вариантах была реализована задолго до становления и законодательного оформления системы установления путей движения [48]. Первая реализация этой идеи была связана с именем американского моряка и ученого М. Ф. Мори. В 1854 г. после того, как в результате столкновения почтового судна «Арктик» и парохода «Веста» в густом тумане на подходе к берегам Америки погибло более 300 пассажиров и членов экипажа, ряд судовладельцев обратились к М. Ф. Мори с просьбой разработать раздельные пути для пароходов, следующих через Атлантику в западном и восточном направлениях, с тем чтобы исключить или минимизировать их встречи в океане. К этому времени М. Ф. Мори уже приобрел международную известность разработкой научных основ выбора путей в океане с использованием гидрографической и метеорологической информации. Уже через месяц он разработал раздельные для обоих направлений пути движения между основными портами американского побережья и Западной Европы. Эти пути были опубликованы в руководствах для мореплавателей, они учитывали действие в этом районе преобладающих ветров и течений, что приводило к сокращению ходового времени.

Вторым по хронологии примером успешного применения принципа разделения движения служит внедрение рекомендованных («предписанных») курсов на Великих озерах Северной Америки в первой половине XX века. В частности, первые такие курсы были установлены в 1911 г. на озерах Верхнем и Гуроне, а последний курс - в 1949 г. на озере Онтарио. Противоположенные по направлению курсы были разделены полосой, ширина которой составляла 8-30 миль, что обеспечивало надежное предотвращение столкновений судов, следующих встречными или пересекающимися курсами в условиях пониженной видимости (рис. 3.4.2 [132]).

Влияние рекомендованных курсов на снижение навигационной аварийности характеризуется следующим образом: если за пер- 


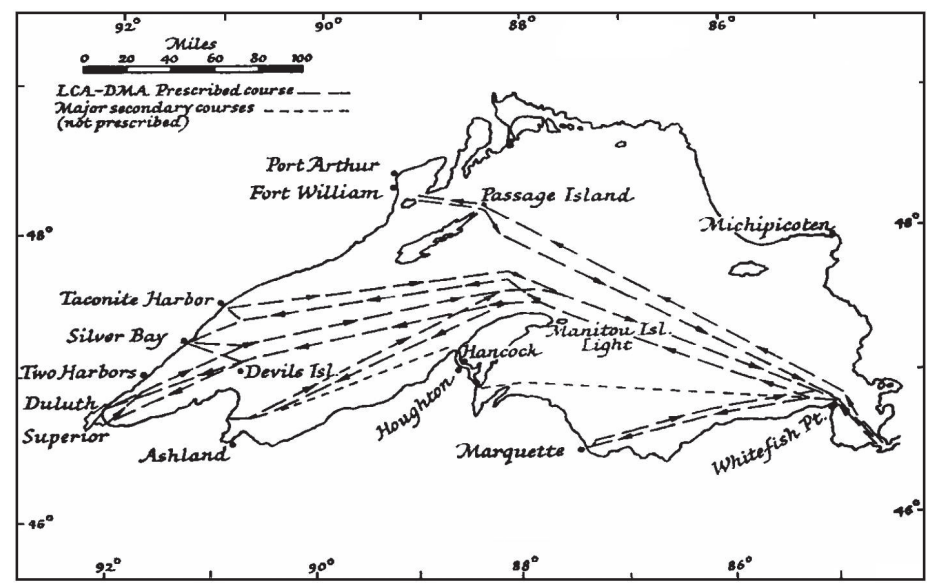

Рис. 3.4.2. Рекомендованные пути на озере Верхнем

вые десять лет XX века на этих озерах в результате столкновений затонуло 22 судна, то за такой же десятилетний период с 1954-го по 1963 г. при значительно возросшей интенсивности движения на всех пяти озерах в результате столкновений погибло всего 2 судна, причем оба этих случая были связаны с нарушением рекомендованных курсов.

Третьей формой реализации идеи разделения движения следует считать военные морские пути, безопасные от мин, которые начали разрабатываться Англией и Францией во время Первой мировой войны. В ходе Второй мировой войны в районах плавания, опасных от мин, появились протраленные фарватеры, которые функционировали на протяжении нескольких десятилетий после окончания военных действий. Такие фарватеры частично наносились на навигационные карты и объявлялись в извещениях мореплавателям и других пособиях и руководствах для плавания. Иногда они назывались «минными фарватерами». Некоторые из таких путей использовались до конца 1970-х годов, в частности пути NEMEDRI (Northern European and MEDitteranian Routing Instructions). По сути, пути NEMEDRI (рис. 3.4 .3 [50]) представляли собой протраленные фарватеры с двусторонним движением и осевой линией, обозначенной буями. Ширина одной полосы движения достигала двух 
миль. Фактически такие пути являются первым в международном мореплавании примером реализации идеи разделения движения судов с применением обозначенной буями осевой линии.

Идея разделения движения судов в том виде, в котором она реализуется в настоящее время, окончательно сформировалась с появлением на флоте радиолокационной техники, которая обеспечивала достаточно точное и надежное определение места судна в любую видимость на расстоянии до 50 морских миль от берега, а также выбор маневра для избежания столкновения.

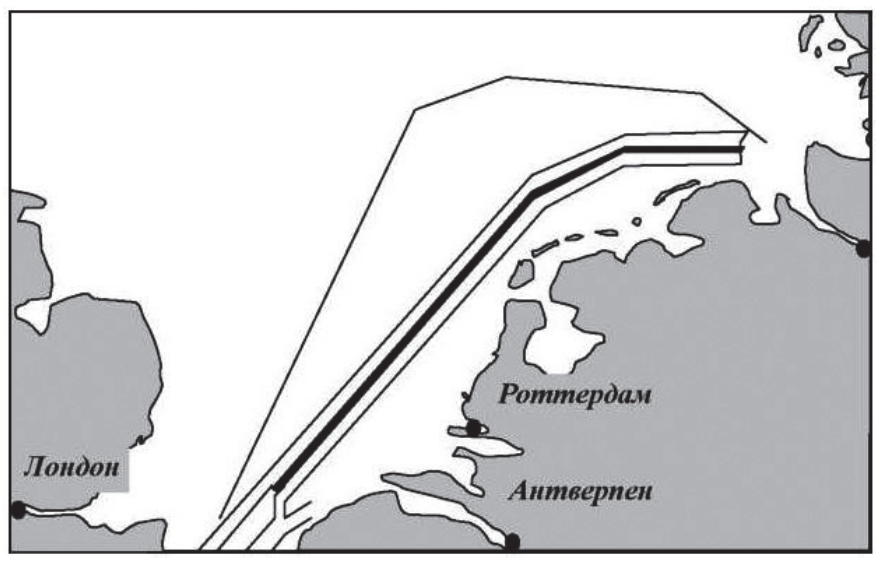

Pис. 3.4.3. Путь NEMEDRI от Дуврского пролива до Эльбы

Одним из первых в 1956 г. предложил систему разделения для пролива Гибралтар испанский военный моряк X. Гарсия-Фриас. Система разделения включала в себя такие понятия, как «полоса движения» и «зона разделения движения» (рис. 3.4 .4 [130]), ставшие сейчас классическими.

В основе его предложений лежала простая и неновая идея, которая встречалась еще в прежних правилах предупреждения столкновений: при плавании по узкому фарватеру в условиях интенсивного движения суда должны держаться правой стороны. При этом должна быть четко обозначена осевая линия или полоса. Однако в этот раз его предложение не нашло практической поддержки. 


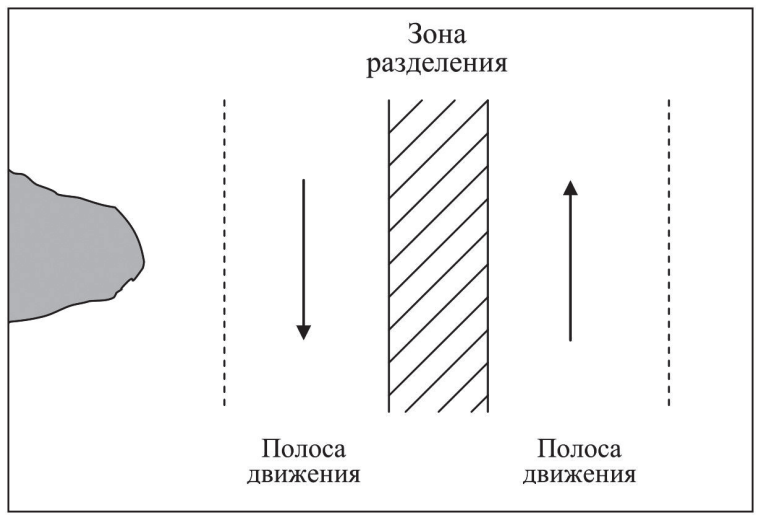

Рис. 3.4.4. Разделение движения по предложению Х. Гарсиа-Фриаса

На национальном уровне первые системы разделения движения появились примерно в одно и то же время во Внутреннем Японском море, на подходах к Нью-Йорку и в проливе Лаперуза (рис. 3.4 .5 [48]).

В Советском Союзе на национальном уровне процедуры установления путей впервые были предложены на морях Дальнего Востока в 1957 г. по инициативе Дальневосточного морского пароходства.

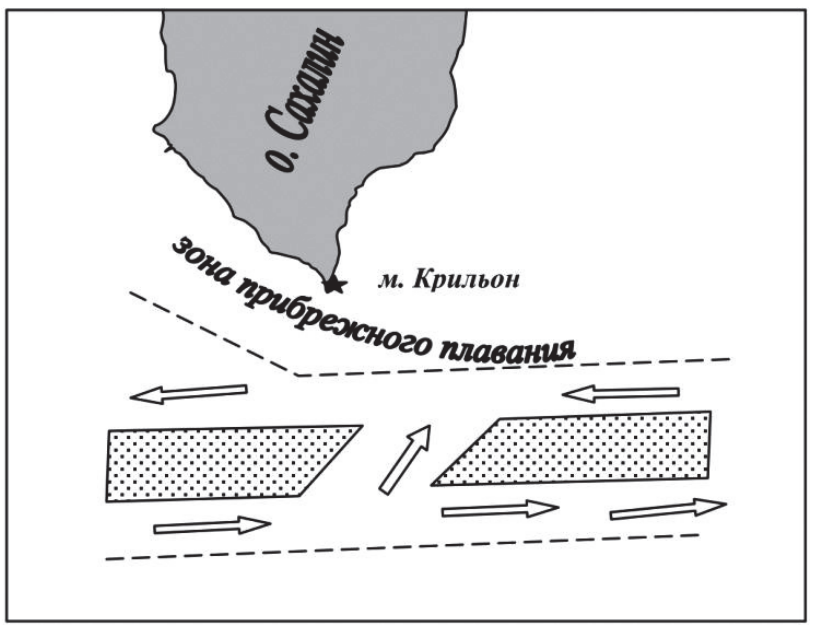

Рис. 3.4.5. Система разделения движения судов в проливе Лаперуза 
Первая международная система, одобренная ИМО, начала работать в 1967 г. в проливе Ла-Манш (рис. 3.4.6 [91]).

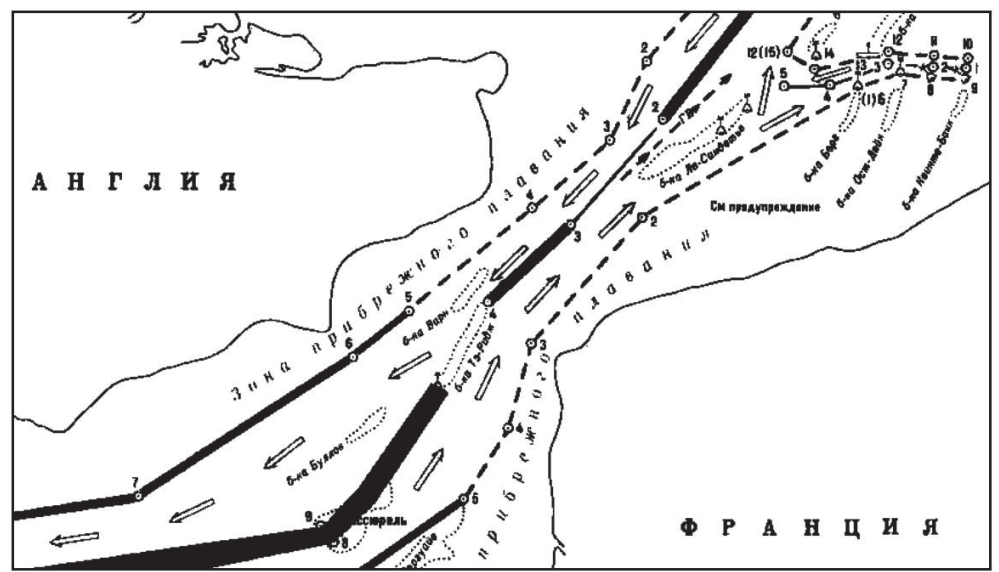

Рис. 3.4.6. Первая система разделения движения судов в проливе Ла-Манш, одобренная ИМО

За десятилетие, с 1967 г., когда появилась первая, одобренная ИМО система разделения в Дуврском проливе, до 1977 г., когда ИМО приняла Резолюцию А.374(X), в которой содержатся практически не измененные до настоящего времени положения о разделении движения, развитие систем разделения движения шло особенно быстрыми темпами, и к 1977 г. их количество достигло 107, из которых 67 были одобрены ИМО [130]. Вместе с развитием и расширением количества систем разделения движения происходили также случаи ликвидации некоторых систем, которые не оправдали себя. В настоящее время количество систем разделения движения, одобренных ИМО, превысило 90, а с учетом национальных систем - более 130 [48].

За эти годы ИМО приняла почти 40 резолюций по системам установления путей движения, в том числе системам разделения движения, важнейшей из которых является последнее четвертое издание «Общих положений об установлении путей движения судов», принятое в виде Резолюции А.572(14). Все одобренные ИМО системы разделения движения судов (их количество превысило 
100) и рекомендованные пути разрабатывались и принимались в соответствии с «Общими правилами об установлении путей движения судов».

Установленные пути и системы разделения движения объявляются в Извещениях мореплавателям и показываются на навигационных картах. Сведения о них приводятся в пособии «Рекомендации для плавания в районах разделения движения».

\section{5. Обобщенная структура системы установления путей}

Системы установленных путей в пределах территориальных вод вводятся властями прибрежных государств в соответствии с рекомендациями ИМО. На международном уровне ИМО является единственным органом, ответственным за введение и одобрение мер по установлению путей движения судов. Информация о системах установленных путей и связанных с ними мерах объявляется в Извещениях мореплавателям и отображается на морских картах.

Система установления путей движения судов включает системы разделения движения, двусторонние пути, рекомендованные фарватеры, районы, которых следует избегать, зоны прибрежного плавания, районы кругового движения, районы повышенной осторожности плавания и глубоководные пути [70].

Система (схема) разделения движения (Traffic separation scheme) устанавливается с целью разделения встречных потоков судов. Система включает в себя полосы движения (Traffic lane) и разделяющую их зону или линию разделения движения (Separation zone or line) (рис. 3.5.1).

В каждой полосе установлено одностороннее движение, то есть все суда в этой полосе движутся в одном направлении, которое указывается на карте стрелкой. Каждая полоса движения имеет свое название, отражающее направление и порт отхода или прихода.

Основным документом в ряду нормативных, определяющих надежность расхождения судов являются Международные правила предупреждения столкновения судов в море (МППСС-72, в 
дальнейшем Правила) [66]. Судно, следующее в системе разделения движения или вблизи нее, должно действовать в соответствии с Правилом 10, чтобы свести к минимуму возможность возникновения опасности столкновения с другим судном. В необходимых случаях подается сигнал YANKEE GOLF Международного свода сигналов, означающий «Ваши действия не соответствуют системе разделения движения». Границы полосы движения показаны пунктирной линией. На каждом конце зоны разделения полос движения устанавливается желтый буй с проблесковым огнем.

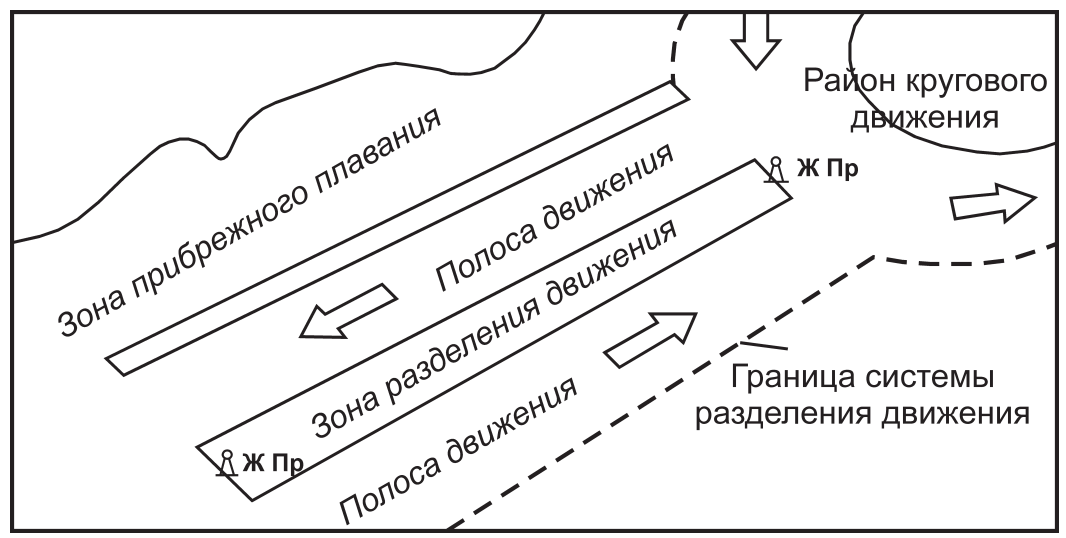

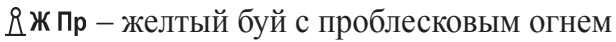

Рис. 3.5.1. Обобщенная схема системы разделения движения

Обобщенно структура системы установления путей изображена на рисунке 3.5.2. Все элементы системы разделены на три группы: системы разделения движения, установленные пути и специальные районы.

Разделение потоков судов, движущихся в противоположных или почти в противоположных направлениях, выполняется посредством установления зон (линий) разделения движения и полос движения. Чаще используют зоны определенной ширины, в узких проходах - линии, чтобы не сужать полосы движения. Там, где позволяет ширина, линии разделения могут переходить в зоны разделения. 


\begin{tabular}{|c|c|c|}
\hline \multicolumn{3}{|c|}{ Система установления путей движения судов } \\
\hline $\begin{array}{c}\text { Системы разде- } \\
\text { ления движения } \\
\text { судов }\end{array}$ & Уст & $\begin{array}{c}\text { Специальные } \\
\text { районы }\end{array}$ \\
\hline $\begin{array}{l}\text { полоса движе- } \\
\text { ния } \\
\text { разделе или линия } \\
\text { жения } \\
\text { секторное раз- } \\
\text { деление движе- } \\
\text { ния } \\
\text { точка пересече- } \\
\text { ния } \\
\text { пия схожде- } \\
\text { попока движения }\end{array}$ & $\begin{array}{l}\text { двусторонний путь } \\
\text { рекомендованный } \\
\text { путь } \\
\text { рекомендованный } \\
\text { рарватер } \\
\text { глубоководный путь } \\
\text { установленное на- } \\
\text { правление потока дви- } \\
\text { жения } \\
\text { рекомендованное на- } \\
\text { правление потока дви- } \\
\text { жения }\end{array}$ & $\begin{array}{l}\text { район кругового } \\
\text { движения } \\
\text { гона прибрежно- } \\
\text { плавания } \\
\text { район повышен- } \\
\text { посторожности } \\
\text { плавания } \\
\text { район, который } \\
\text { следует избегать }\end{array}$ \\
\hline & $\begin{array}{l}>\text { путь для судов с осо- } \\
\text { быми характеристи- } \\
\text { ками } \\
\text { > морской коридор для } \\
\text { мирного и (или) архи- } \\
\text { пелажного прохода }\end{array}$ & $\begin{array}{l}\gg \text { зона безопасно- } \\
\text { сти вокруг искус- } \\
\text { ственного соору- } \\
\text { жения }\end{array}$ \\
\hline $\begin{array}{l}\checkmark \text { другое направ- } \\
\text { ление потока дви- } \\
\text { жения }\end{array}$ & $\checkmark$ дру & $\begin{array}{l}\checkmark \text { режимный район } \\
\checkmark \text { другой район }\end{array}$ \\
\hline \multicolumn{3}{|c|}{$\begin{array}{l}\text { Элементы, попадающие под действие Резолюции А.572(14) } \\
\text { Элементы, определяемые другими международными доку- } \\
\text { ментами } \\
\checkmark \text { Элементы, определяемые национальными документами }\end{array}$} \\
\hline
\end{tabular}

Рис. 3.5.2. Обобщенная структура системы установления путей движения судов 
Внешними границами системы разделения движения являются внешние границы полос движения. За внешними границами системы разделения движения суда следуют в любом направлении.

\section{6. Схемы разделения в системах установления путей}

Система разделения линейного типа является наиболее простым и достаточно эффективным методом разделения встречных транзитных судопотоков в районах интенсивного судоходства (не менее 20 судов в сутки). Ширина и длина зон разделения и полос движения устанавливаются с учетом навигационных, географических, гидрометеорологических и гидрографических условий, а также интенсивности судоходства. Размеры зон разделения и полос движения должны быть ограничены, чтобы суда, не использующие систему разделения, могли бы свободно проходить в стороне от нее. В узких проходах и других стесненных водах вместо зоны разделения устанавливаются линии разделения. Часто зоны и особенно линии разделения движения обставляются дополнительными СНО, чтобы обеспечить возможность судам более надежно определять свое место относительно такой зоны или линии.

Там, где опасные для плавания районы лежат между системой разделения движения и берегом, они отделяют от прилегающих полос движения зоны прибрежного плавания (рис. 3.6.1).

Зона прибрежного плавания (Inshore traffic zопе) охватывает район, расположенный между прибрежной границей системы разделения движения и прилегающим берегом. Суда местного плавания, малые суда и яхты могут следовать в зоне прибрежного плавания в любом направлении. В соответствии с Правилом $10(d)$ МППСС-72, суда, которые могут безопасно использовать для транзитного прохода полосу движения в системе разделения, не должны, в общем случае, использовать зоны прибрежного плавания. Иногда между зоной прибрежного плавания и полосой движения также устанавливается разделительная зона. Суда обязаны следовать по своим полосам в соответствии со схемой разделения 
движения. В то же время малым судам и яхтам настоятельно не рекомендовано находиться в полосе трафика [66].

Секторное разделение движения используют там, где потоки судов, идущих с различных направлений, сходятся в одной точке или небольшом районе при подходе к портам, лоцманским станциям, подходным буям, плавучим маякам, началам фарватеров, каналов (рис. 3.6.1).

В качестве узловой точки могут рассматриваться подходы к портам, места приема лоцманов, места установки подходных буев или плавучих маяков, входы в фарватеры, каналы, эстуарии и т. п. Расположение подходных путей в секторных системах разделения, размеры полос движения и рекомендуемое направление движения в них определяются характером местных условий. Фактически секторная система разделения включает в себя несколько систем разделения линейного типа и обеспечивает их оптимальную адаптацию к местным условиям судоходства.

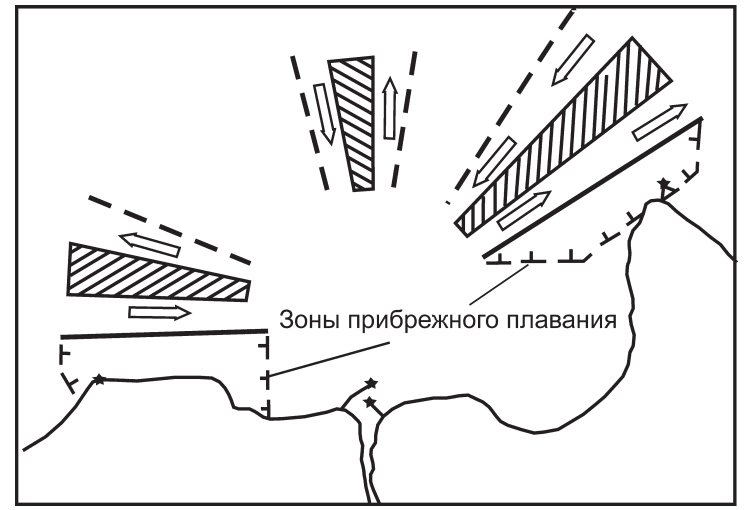

Рис. 3.6.1. Схема секторального разделения смежных систем разделения движения на подходах к узловым точкам

Установление путей движения в местах схождения и пересечения путей движения или систем разделения осуществляют введением района кругового движения, в котором суда движутся против часовой стрелки вокруг установленной круговой зоны или определенной точки, или района пересечения или соединения там, где пересекаются или соединяются два пути (рис. 3.6.2). 
Установленные пути могут быть рекомендованными и обязательными. В системах вводится установленное направление движения потоков судов (Established direction of traffic flow), которое на картах обозначается контурной стрелкой (сплошными линиями) или рекомендованное направление потока судов (Recommended direction of trafficflow), которое обозначается пунктирной стрелкой. Стрелки, нанесенные на карту в системе установленных путей, служат только для указания общего направления потока судов; не требуется, чтобы курс судна был проложен строго по стрелкам.

Рекомендованный путь (Recommended track) - это путь, который специально обследован, чтобы, насколько это возможно, гарантировать, что он свободен от опасностей, и которым рекомендуется следовать судам. Может быть как двусторонним, так и односторонним (рис. 3.6.3).

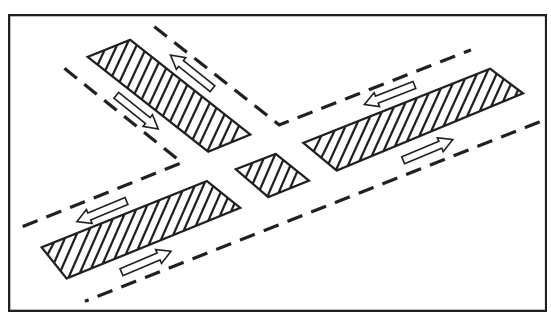

a

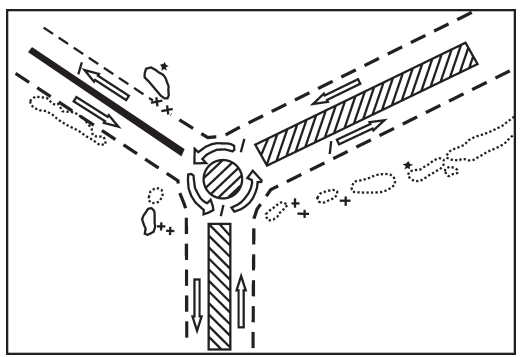

B

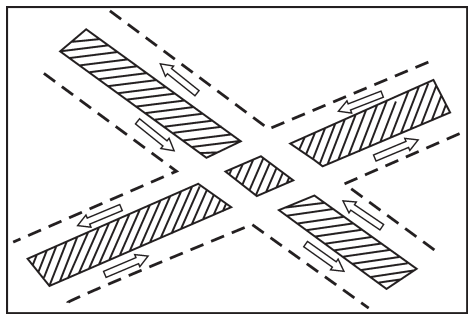

6

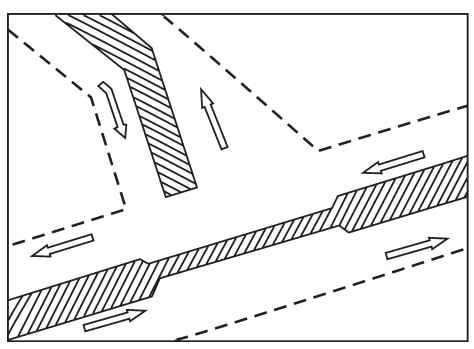

$\Gamma$

Рис. 3.6.2. Схемы установления путей движения в местах схождения и пересечения путей: a - разделение движения в районе схождения путей; б - разделение движения в районе пересечения путей; в - разделение движения в районе кругового движения; г-схождение путей в районе, где линия разделения движения заменяет зону разделения движения 
Разделение встречных потоков движения судов естественныли препятствиями и другими объектами осуществляется в местах, где имеются такие препятствия, как острова, банки, скалы, мели и отмели или затонувшие суда, которые ограничивают свободное плавание и обеспечивают естественное разделение встречных судопотоков. Характерным примером реализации такого метода является система разделения движения в проливе Ла-Манш.

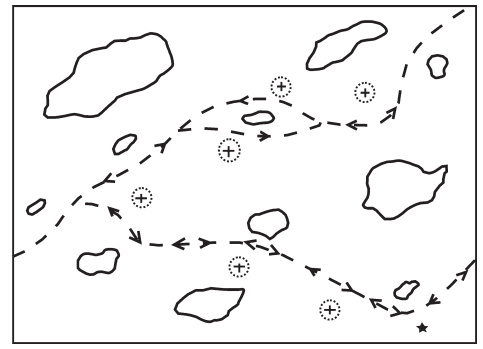

a

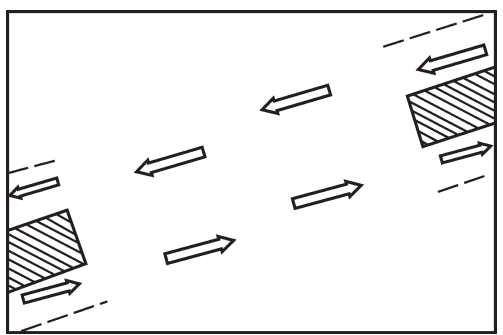

6

Рис. 3.6.3. Рекомендованные пути: а - рекомендованные пути с естественными препятствиями; б - рекомендованные направления потока судов между двумя системами разделения движения

Рекомендованный маршрут (Recommended route) устанавливается для удобства судов, следующих транзитом; он не имеет определенной ширины. Часто обозначается осевыми буями.

Двусторонний путь (Two-way route) является путем с определенными границами, по которому установлено двустороннее движение для обеспечения безопасности прохода судов через воды, плавание в которых затруднено или опасно (рис. 3.6.4). На двусторонних путях суда должны, насколько это возможно, держаться правой стороны.

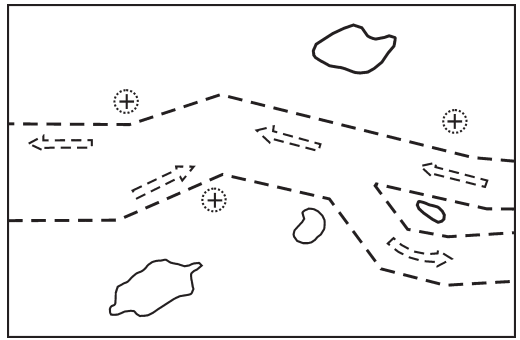

Рис. 3.6.4. Схема двустороннего пути (с односторонними участками) 
Глубоководный путь (Deep water route) представляет собой путь с определенными границами, в пределах которого тщательно обследовано морское дно на предмет отсутствия подводных препятствий (рис. 3.6.5). Глубоководный путь предназначается в первую очередь для судов, которые из-за своей осадки нуждаются в таком пути в данном районе. Прочие суда должны, насколько это возможно, избегать следования этим глубоководным путем.

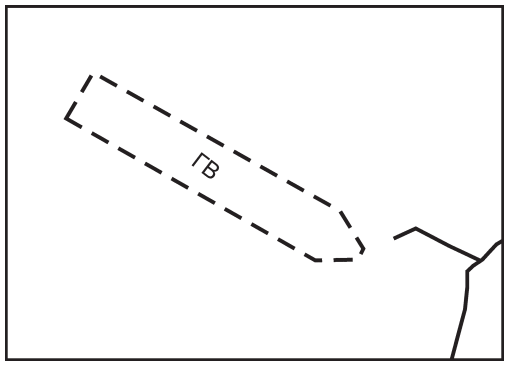

a

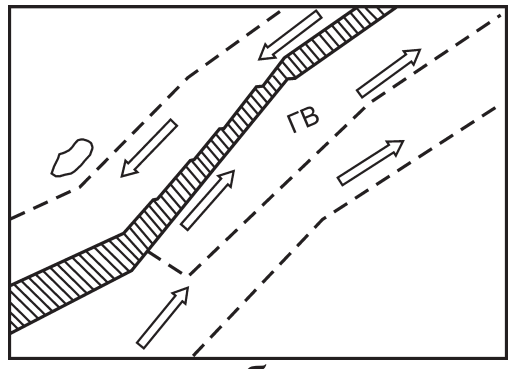

6

Рис. 3.6.5. Схемы глубоководных путей: а - двусторонний глубоководный путь; б - односторонний глубоководный путь (в пределах полосы движения)

На карте после сокращения $D W$ (на адмиралтейских картах, «ГВ» на российских картах) может быть помечено значение минимальной глубины, поддержание которой на глубоководном пути гарантировано (например, 19 м). К настоящему времени на Балтике установлены 3 признанных ИМО глубоководных пути, в Северном море -4 и по одному в Малаккском проливе и проливе Урага.

Направление потоков движения устанавливают в полосах прилегающих систем. Зона разделения может быть прервана или заменена линией разделения, чтобы подчеркнуть правильный метод перехода из одной системы разделения в другую. Такие районы устанавливаются в том случае, если в силу географических причин невозможно избежать ситуации схождения или пересечения двух судопотоков.

Если интенсивность судопотоков достаточно велика, то вместо района схождения или пересечения в зону разделения, прерывая ее, вводят район повыценной осторожности плавания, в котором 
применяют направление потоков движения вокруг установленной точки против часовой стрелки. Такой район создается у окончания какого-либо пути (рис. 3.6.6).

Район, которого следует избегать (Area to be avoided), представляет собой район с определенными границами, особенно опасный для плавания, или район, в котором особенно важно избегать аварийных происшествий (рис. 3.6.6). Все суда или суда определенных классов должны избегать захода в такой район. Однако этот район не должен считаться запретным районом, если это не оговорено особо.

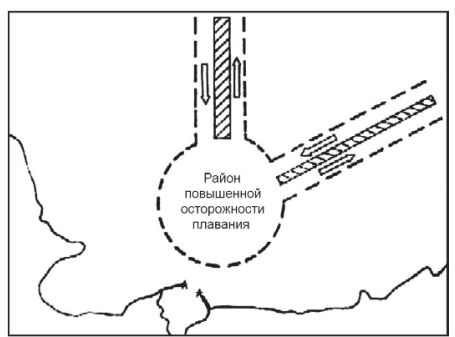

a

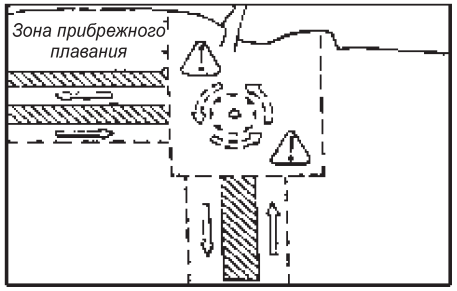

B
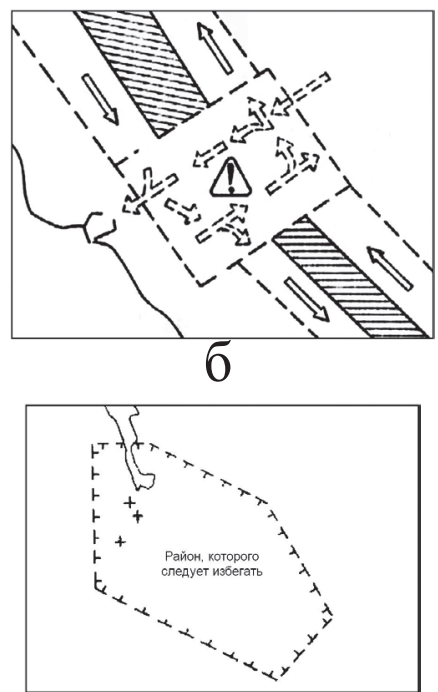

$\Gamma$

Рис. 3.6.6. Специальные районы плавания: a, б, в - районы повышенной осторожности плавания (a - установленный вокруг узловой точки; $\sigma$ - с рекомендованным направлением потока движения судов вокруг района, которого следует избегать; в - с рекомендованным направлением потока судов, установленный в месте схождения путей), г - район, которого следует избегать

Районы, которых следует избегать, устанавливаются в следующих местах:

- слабо изученных в гидрографическом отношении;

- где недостаточная обеспеченность средствами навигационного оборудования может привести к посадке на мель; 
- где знание местных условий существенно влияет на безопасность плавания;

- где существует возможность в результате аварии нанести непоправимый ущерб окружающей среде;

- где может возникнуть опасность повреждения важных средств навигационного оборудования.

Классы судов, которые должны избегать данного района, указываются в каждом отдельном случае.

Система установленных путей может включать в себя элементы, которые не отражены в Резолюции А.572(14), но предусматриваются другими международными или национальными документами. Например, морские коридоры для мирного или архипелажного прохода устанавливаются на основе положений Конвенции ООН по морскому праву 1982 г., а зоны безопасности вокруг искусственных сооружений на море впервые были введены Конвенцией ООН о континентальном шельфе 1956 г, затем несколько раз уточнялись различными документами ИМО, последним из которых является Резолюция А.671(16), принятая в 1989 г. в Лондоне.

Системы установленных путей могут также содержать или быть полностью сформированными из элементов, которые на рис. 3.5.2 обозначены как «другие пути», «режимные районы» и «другие районы», определяемые национальными законами или местными правилами плавания. К «другим путям» можно отнести, например, подходные фарватеры.

Еще более разнообразны такие элементы, как «режимные районы», к которым относятся следующие:

- запретные и временно запретные районы для плавания;

- запретные и/или опасные районы для постановки на якорь, лова рыбы (или лова рыбы специальными орудиями лова) подводных и дноуглубительных работ и других видов деятельности;

- районы с особым режимом плавания;

- временно опасные для плавания районы в навигационном отношении;

- районы бомбометания или учебных стрельб;

- девиационные и радиодевиационные полигоны; 
- районы якорных мест и районы приема лоцмана;

- морские заповедники и заказники и т. п.

Важная для мореплавателей информация о таких путях и районах приводится в различных навигационных пособиях и на картах (в том числе и в примечаниях), поэтому они в данном пособии не рассматриваются.

Все элементы системы установления путей, по сути, являются пространственными элементами, занимая определенную часть морской акватории. В общем случае их также можно представлять в качестве морских районов системы установления путей движения.

\section{7. Общие принципы использования систем разделения путей}

При плавании установленными путями и системами разделения движения, одобренными Межправительственной морской консультативной организацией (ИМКО) или национальными правительствами в своих территориальных водах, выполняются требования Международных правил предупреждения столкновения судов в море (МППСС-72), если это не оговорено особо. Установленные пути и системы разделения движения рекомендуются для плавания всех судов, если в их описаниях нет других указаний.

Проблема пересечения системы разделения движения сводится к пересечению полос движения или, еще более точно, к пересечению судопотока, движущегося на этой полосе. Помимо уменьшения количества сближений на встречных курсах, разделение движения с самого начала в неявном виде имело целью организацию оптимального пересечения судопотоков путем смещения в сторону моря или разнесения в пространстве районов их взаимодействия.

Правило 10 МППСС определяет следующие общие принципы использования систем разделения движения [66]. Суда, идущие по системе разделения движения, должны следовать по соответствующей полосе движения, в принятом для этой полосы направлении движения. Они должны держаться в стороне от зоны (линии) разделения движения. Вход (выход) на полосу 
движения осуществляется, как правило, на ее конечных участках. Войти (выйти) на полосу движения со стороны необходимо под возможно меньшим углом к направлению потока.

Суда, следующие в полосе движения, должны по возможности избегать входа (пересечения) в зону (линию) разделения, за исключением случаев, когда это связано с уклонением от непосредственной опасности или когда в зоне разделения производится лов рыбы.

Пересечение полосы движения производится по возможности под прямым углом. При этом необходимо избегать пересечения по носу курса судов, следующих в полосе движения.

Суда, занятые ловом рыбы, парусные суда и суда длиной менее 20 м уступают дорогу судам с механическим двигателем, следующим по полосе движения.

Суда, имеющие возможность транзитного прохода по полосе движения, должны избегать зон прибрежного плавания.

При плавании вблизи оконечностей систем разделения необходимо соблюдать особую осторожность. Постановка на якорь в пределах системы разделения движения или вблизи ее оконечностей не рекомендуется.

При плавании в системе разделения движения, установленной правительством страны и не утвержденной ИМО, не исключается встреча с судами, следующими в полосе движения против установленного потока движения.

При встречах и расхождениях судов в районах установленных систем разделения движения они должны строго соблюдать общие правила маневрирования. Использование систем разделения и следование по установленной полосе движения не дают судну никаких преимуществ перед другими встречными судами при расхождении.

Рассмотрим пример простого соединения путей с двусторонним движением, схема которого показана на рисунке 3.7.1 [139]. Маневр А, предпринимаемый привилегированным судном (по правилу 15 ему должны уступать дорогу) по правилу 10 (c), и маневр В, выполняемый в соответствии с правилом 10 (b) (iii), сопряжены с опасностью, которая может быть существенно снижена, если применить маневры C или D. По существу, эти маневры связаны с добровольным 
отказом от некоторой доли привилегированности, обусловленной правилом 15. С помощью маневров С или D привилегированное судно может упростить ситуацию как для себя, так и для других судов. Фактически эти два маневра в различной форме объединяют в себе пункты (c) и (b) (iii) правила 10. Маневр С возможен только в условиях хорошей видимости, так как может быть начат на расстоянии примерно 4 мили при сближении со стороны правого борта, чтобы иметь возможность наблюдать развитие ситуации справа по борту. Однако в условиях пониженной видимости единственным разумным вариантом остается маневрировать сначала по правилу 10 (b) (iii), а затем по правилу 10 (c), когда появится возможность быстрого пересечения полосы движения под прямым углом.

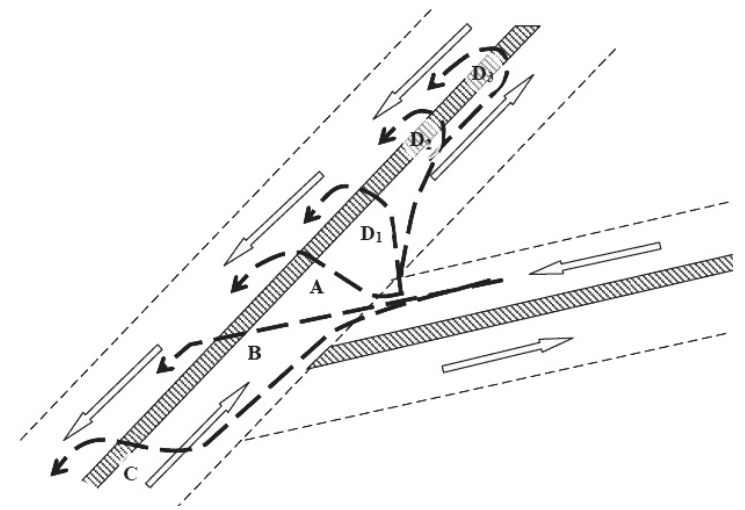

Рис. 3.7.1. Схема соединения путей с двусторонним движением

Такой маневр $(D)$ на рисунке 3.7.1 показан в виде нескольких вариантов. В любом случае такой образ действий имеет большое преимущество перед маневрами А, В и С, поскольку позволяет тщательно, шаг за шагом подойти к свободному «месту» в пересекаемом судопотоке и затем быстро пересечь полосу движения.

Характерным отличием организации судоходства на транспортных путях является широкое использование береговых сигнальных станций, которые обеспечивают регулирование движения судов с помощью разнообразных звуковых, световых и цветовых сигналов. Структурная схема средств сигнализации типичной сигнальной станции показана на рисунке 3.7 .2 [137]. 


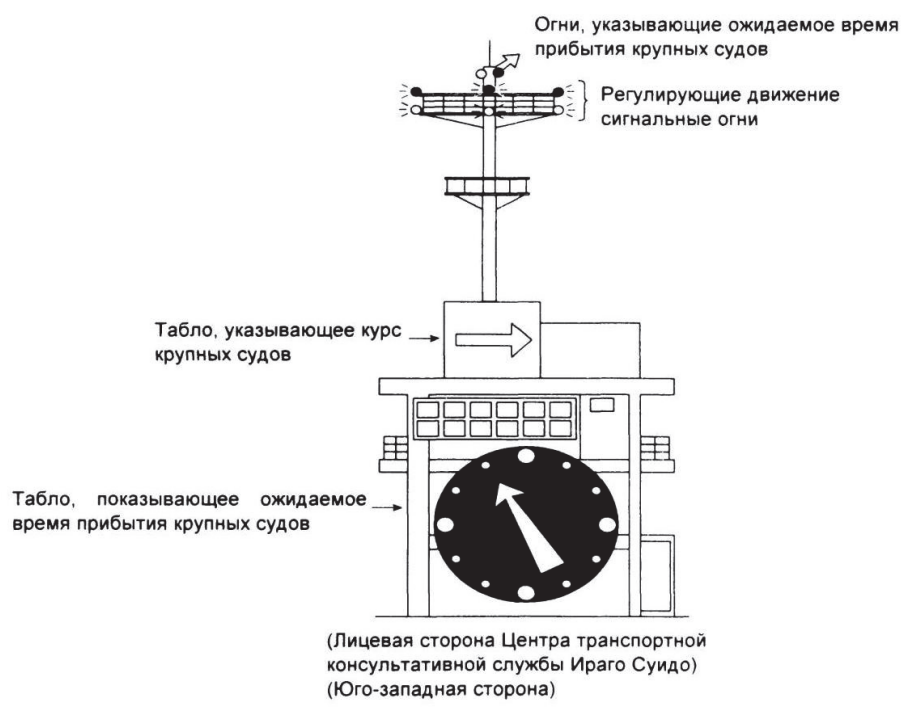

Рис. 3.7.2. Схема сигнализации типичной сигнальной станции на транспортном пути

В системе установления путей движения в отдельную группу выделены «другие пути». Примером может служить особая практика организации движения судов в территориальных водах Японии [48]. Специально для этих целей принят национальный закон «О безопасности морского судоходства». На основании этого закона во Внутреннем Японском море и в Токийском заливе введено 11 транспортных путей (traffic routes), которые имеют характеристики, присущие рекомендованным путям и двусторонним путям в системе установления путей движения, утвержденной ИМО. Основные правила движения на транспортных путях сводятся к следующему:

- суда, не занятые рыболовным или другим промыслом, входящие, сходящие или пересекающие транспортный путь, должны уступать дорогу другим судам, идущим по транспортному пути;

- суда, занятые рыболовным или другим промыслом, должны уступать дорогу крупным судам (к крупным судам относятся суда длиной 200 м и более);

- на пересечении или соединении транспортных путей всякое судно, за исключением крупных судов, чтобы исключить риск 
столкновения с крупным судном, проходящим по данному транспортному пути, должно уступать дорогу этому крупному судну;

- в районе, где установлен транспортный путь, все суда длиной более 50 м должны следовать по соответствующей полосе движения этого пути;

- на некоторых участках запрещено входить на транспортный путь, сходить с него или пересекать его;

- на большинстве транспортных путей скорость движения судов ограничена 12 узлами;

- при обгоне судов на транспортном пути, при намерении войти на путь или сойти с него, суда валовой вместимостью 100 и более тонн должны подавать соответствующие звуковые сигналы.

Видно, что некоторые требования этих правил противоречат МППСС-72.

К специальным районам системы установления путей, которые на рисунке 3.5.2 обозначены как «другие районы», можно отнести морские районы, в которых устанавливаются особые правила плавания с использованием отдельных элементов системы установления путей. Такие районы не всегда имеют определенные географические границы. В частности, это относится к морским районам разведки и добычи нефти и районам рыболовства. Рассмотрим более подробно особенности этих районов с точки зрения судовождения и организации движения.

Особенности плавания в морских районах разведки и добычи нефти и газа. Одно из направлений работы ИМО в части установления путей движения сформулировано как «организация безопасного движения судов в районах интенсивных изысканий или разработок в открытом море» [70]. Практически всегда это относится к исключительной экономической зоне и районам континентального шельфа, в которых проводятся работы по разведке и добыче природного газа или нефти и которые занимают около 7,5 \% площади океана.

На международном уровне правовая ситуация по освоению морских запасов закреплена в Конвенции о континентальном шельфе, принятой в Женеве в 1958 г. Термин «континентальный 
шельф» в соответствии со статьей 1 этой Конвенции применяется «к поверхности и недрам морского дна подводных районов, примыкающих к берегу, но находящихся вне зоны территориального моря, до глубины 200 м или за этим пределом до такого места, до которого глубина покрывающих вод позволяет разработку естественных богатств этих районов; к поверхности и недрам подобных подводных районов, примыкающим к берегам островов» [40].

Понятие «исключительной экономической зоны» определено в Конвенции Организации Объединенных Наций по морскому праву, подписанной в 1982 г. в Монтего-Бей, Ямайка [41]. Ширина исключительной экономической зоны не должна превышать 200 миль, отсчитывая от исходных линий, от которых отмеряется ширина территориальных вод. В статье 56 Конвенции прибрежному государству дается право на разведку и разработку природных ресурсов, создание и использование в этой зоне искусственных островов, установок и сооружений.

Зародившись в середине XX века, морская добыча нефти на континентальном шельфе и в исключительных экономических зонах неуклонно развивалась и в настоящее время составляет почти 30 \% всей мировой добычи. Сложившаяся ситуация обусловила возникновение новых проблем, связанных с обеспечением безопасности мореплавания в таких районах. Причем международное сообщество решает эти проблемы не только на уровне ИМО, но и на более высоком уровне.

Первым международным актом, где рассматриваются вопросы безопасности судоходства в районах морской нефтедобычи, была Конвенция о континентальном шельфе 1958 [40]. Эти же вопросы рассматриваются в Конвенции Организации Объединенных Наций по морскому праву (1982), которая включает в себя статью 60 «Искусственные острова, установки и сооружения в исключительной экономической зоне».

В Конвенции также содержится раздел 4 «Научно-исследовательские установки или оборудование в морской среде», в котором определяются зоны безопасности вокруг научно-исследовательских установок в пределах зоны, не превышающие 500 м (ста- 
тья 260), и правило непричинения помех на путях судоходства, согласно которому размещение и использование научно-исследовательских установок и оборудования любого типа не должно создавать препятствия на установившихся путях международного судоходства (статья 261) [41].

Обе Конвенции содержат, по существу, одни и те же требования, расширяющие их применение на разные районы Мирового океана (континентальный шельф и исключительная экономическая зона) и установки различного типа (разведочные, буровые и научно-исследовательские установки и сооружения).

В 1975 г. ИМО приняла Резолюцию А.341(1X) «Рекомендации о распространении информации, картографировании и комплектованию персонала буровых установок, нефтедобывающих платформ и других подобных сооружений», в которой говорится, что государство, выдающее лицензию на разработку нефтяных месторождений, несет ответственность за распространение информации, имеющей большое значение для обеспечения безопасности судоходства.

В Резолюции ИМО А.671(16) «Зоны безопасности и безопасность мореплавания вокруг прибрежных сооружений» (1989) содержатся рекомендации операторам морских установок о заблаговременном извещении мореплавателей о размещении таких установок, ширине зон безопасности и любых имеющихся фарватерах, а также необходимости сообщать о действиях судов-нарушителей. Судам же рекомендуется при плавании вблизи морских сооружений соблюдать зоны безопасности и использовать установленные пути и фарватеры.

В Руководстве «Общие положения об установлении путей движения судов» в разделе 5 говорится, что при планировании, введении, пересмотре или совершенствовании системы путей администрация, среди прочих факторов, должна учитывать и свои «права и практику в отношении разработки живых и минеральных ресурсов», а также «проводимые и возможные в будущем работы по исследованию морских районов и эксплуатации морского дна и его недр» [66]. 
В 1965 г. Международная ассоциация маячных служб (МАМС) разработала рекомендации об ограждении стационарных морских сооружений в целях безопасности мореплавания. Эти предложения вскоре были одобрены ИМО в качестве минимальных стандартов ограждения подобных сооружений, хотя в некоторых странах приняты более жесткие требования.

Ни в одном из указанных выше документов нет четких требований в отношении организации движения судов и выбора путей в районах морских разработок. Основные рекомендации сводятся к тому, что размещение средств нефтедобычи не должно мешать сложившимся судоходным потокам и установленным ИМО системам разделения движения.

Помимо международных требований, при решении проблемы обеспечения навигационной безопасности и организации движения в районах разведки и добычи нефти и газа на национальном уровне исторически сформировалось два внешне похожих, но по сути разных подхода: а) установление «судоходных безопасных проходов» (shipping safety fairways) и б) введение «судоходных свободных путей» (shipping clearways).

Принцип «судоходных безопасных проходов» определяет безопасные проходы, на которых установлено двухстороннее движение и которые связывают между собой основные порты побережья и районы нефтедобычи (рис. 3.7.3) [130]. Эти проходы наносятся на адмиралтейские навигационные карты, где они определены как «районы, где не допускается сооружение нефтяных установок». Ширина таких проходов составляет две мили, и они, как правило, не имеют средств навигационного ограждения, поэтому при плавании по ним большое значение имеет точность используемых средств определения места судна. Использование этих проходов судами необязательно, но настоятельно рекомендуется. В настоящее время такие безопасные проходы распространились от Южной Калифорнии до побережья Северной Атлантики.

Концепция «судоходных свободных путей», реализованная на континентальном шельфе Великобритании (рис. 3.7.4), является логическим развитием положений статьи 5 (параграф 6) Конвенции 


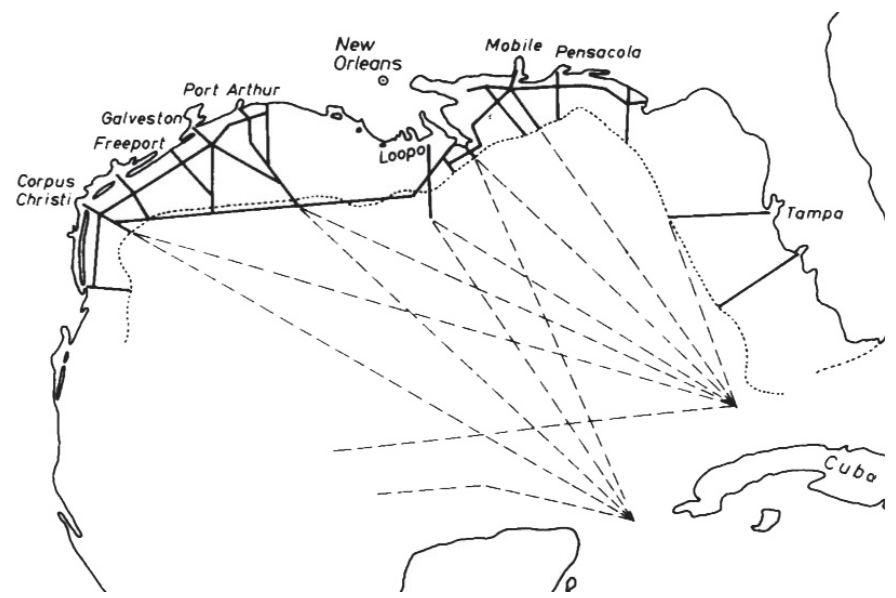

3.7.3. Судоходные безопасные фарватеры в Мексиканском заливе

о континентальном шельфе (1958), которая требует, чтобы нефтедобывающие установки находились в таких местах, где они не мешали бы традиционному морскому судоходству. Это же условие позднее было внесено в статьи 60 (параграф 7) и 261 Конвенции Организации Объединенных Наций по морскому праву (1982) [130].

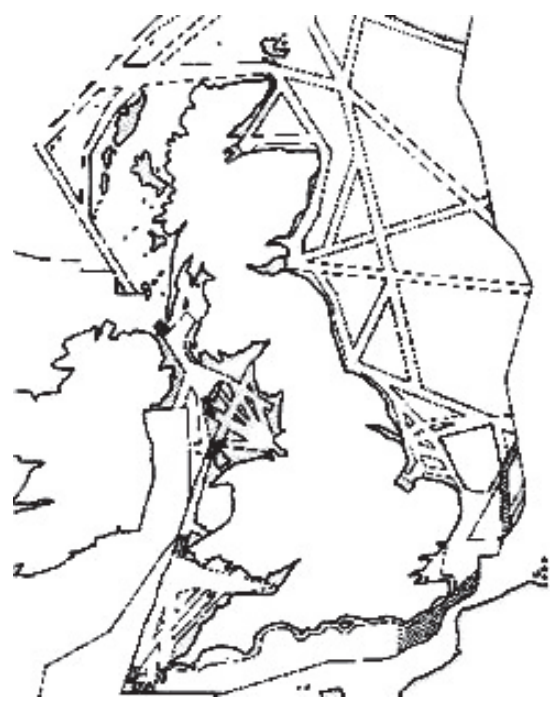

Рис. 3.7.4. Судоходные свободные пути на континентальном шельфе Великобритании 
Судоходные свободные пути не наносятся на морские навигационные карты, а лишь определяют границы районов с заданной плотностью судоходства и учитываются при решении вопроса о выдаче разрешений на производство разведочных и буровых работ на континентальном шельфе.

В отличие от безопасных проходов, свободные пути являются предупредительной мерой, они учитываются еще на этапе планирования изыскательских работ. В то же время судоходные свободные пути вместе с установленными системами разделения движения и рекомендованными маршрутами создают довольно сложную организационную схему судопотоков.

В Великобритании последнее время реализуется метод, основанный на введении «района разработок», который охватывает группу близко расположенных платформ. В таком районе официально объявляется особый режим плавания, закрытый для прохода судов, не связанных с производством или обслуживанием работ по разведке или добыче нефти и газа. Этот метод аналогичен используемому ИМО принципу «района, которого следует избегать, за исключением того, что «районы разработок» не утверждаются на международном уровне.

Для организации движения в зонах морских разработок применяются также обычные методы системы установления путей. Наконец, наиболее эффективно проблема организации движения в районах морских разработок решается с помощью систем управления движением судов, которые рассматриваются в разделе 4.

Районы рыбного промысла, с точки зрения обеспечения безопасности мореплавания, имеют важнейшее значение, поскольку противоречие между рыболовными и другими судами, использующими одни и те же воды, является наиболее острым. Многие интенсивные морские пути проходят вблизи традиционных районов рыбного промысла, что неизбежно ведет к появлению дополнительных рисков и снижению общего уровня безопасности мореплавания. Это характерно для Балтики, Северного моря, прибрежных вод Японии, Китая и других районов.

Рыболовные суда во время промысла создают участки повышенной концентрации судоходства в основном в районах континен- 
тального шельфа или в прибрежной зоне. Дополнительно проблема обостряется введением статуса территориальных вод (6, 12 миль и т. д.), когда в некоторых районах на границах территориальных вод образуются искусственные скопления рыбопромысловых судов, где в большинстве случаев и находятся системы разделения движения, как национальные, так и одобренные ИМО. Ярким примером является акватория к югу и юго-западу от Великобритании, где в районах традиционных морских промыслов располагаются несколько систем разделения движения.

Рыбопромысловые суда, с точки зрения обеспечения безопасности мореплавания, имеют особый статус, который определяется двумя международными документами: МППСС-72 и Международной конвенцией о безопасности рыбопромысловых судов, подписанной в 1977 г. в Торремолиносе.

Международные правила предупреждения столкновения судов в море (МППСС-72) приняты одноименной Конвенцией в 1972 г. Правила МППСС определяют особый статус рыбопромыслового судна, находящегося в ситуации «судна, занятого ловом рыбы». Это означает «любое судно, производящее лов рыбы сетями, ярусными крючковыми снастями, тралами или другими орудиями лова, которые ограничивают его маневренность, но не относятся к судну, производящему лов рыбы буксируемыми крючковыми снастями или другими орудиями лова, не ограничивающими маневренность судна» [66].

С точки зрения организации движения, судно, занятое ловом рыбы, в соответствии с МППСС-72:

- «не должно затруднять движение любого другого судна, следующего в пределах узкого прохода или фарватера» (правило 9 (с));

- «может использовать зону прибрежного плавания» (правило 10 (i)), в отличие от другого судна, если оно может безопасно использовать соответствующую полосу движения в прилегающей системе разделения;

- «судно ... не должно входить в зону разделения движения (правило 10 (е) (ii));

- «не должно затруднять движение любого другого судна, идущего в полосе движения» (правило 10 (i)); 
- «должно, насколько это возможно, уступать дорогу судну, лишенному возможности управляться, и судну, ограниченному в возможности маневрирования» (правило 18 (c)).

В соответствии с правилом 18 (a) и (b) судну, занятому ловом рыбы, должны уступать дорогу суда с механическим двигателем на ходу и парусные суда. Правило 26 и Приложение 2 МППСС-72 определяют огни и знаки, а также дополнительные сигналы, которые должны нести рыболовные суда.

Вторым документом, влияющим на условия безопасности плавания в районах рыбных промыслов, является Международная конвенция о безопасности рыбопромысловых судов. По сути, эта Конвенция для рыболовных судов играет такую же роль, как и Конвенция СОЛАС-74 для торговых судов. В частности, этой Конвенцией введено обязательное оборудование гирокомпасами и лагами судов длиной более 75 м, эхолотами - судов до 45 м и стандартными магнитными компасами - судов, длина которых превышает $20 \mathrm{M}$.

Проблема обеспечения безопасности плавания торговых судов в районах рыбного промысла традиционно решается на национальном и международном уровнях двумя способами: организацией движения в пределах рыбопромысловых районов и установлением морских путей в стороне от зон рыбного промысла.

Первый вариант уже много лет реализуется путем информирования судоводителей о местных и сезонных районах промысла через «Извещения мореплавателям» и другие навигационные пособия, описанием районов добычи рыбы в примечаниях на морских навигационных картах, введением местных правил плавания и рыболовства. Например, отечественным торговым судам на участке между Камчаткой и Японией с 1957 г. предписывается следовать рекомендованными двухсторонними путями, пролегающими через районы частых плотных туманов, богатые рыбой и часто посещаемые рыболовными судами. Следует отметить, что границы районов рыбного промысла на картах не указываются, а показываются точные географические границы районов, где рыбный промысел запрещен (рис. 3.7.5) [48]. 


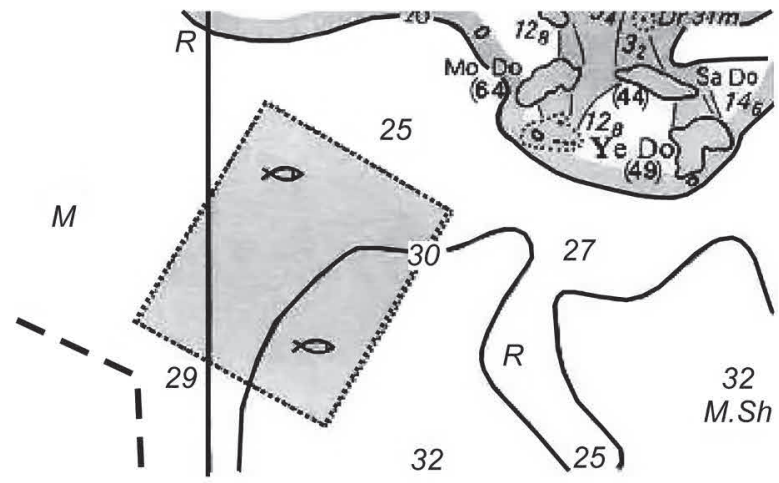

Рис. 3.7.5. Район, запретный для рыбной ловли (карта № 3391)

Второй вариант обеспечения безопасности плавания в районах рыбного промысла соответствует «организации движения судов на достаточном расстоянии от районов рыболовства или через районы рыболовства», которая определена в руководстве ИМО «Общие положения об установлении путей движения судов» [70]. В этом случае при планировании, введении или совершенствовании систем путей среди прочих факторов рекомендуется учитывать и «наличие районов рыболовства».

\section{8. Условия введения систем установления путей}

Непосредственно с практикой работы судоводителей в области теоретических проблем разделения движения судов связаны проблемы выбора критерия целесообразности разделения, ширины зоны разделения и полосы движения и оптимального варианта пересечения системы разделения движения.

В одобренном ИМО руководстве «Общие положения по установлению путей движения судов» (Резолюция А.572(14)) нет количественных критериев, однозначно определяющих ситуацию, при которой возникает необходимость или целесообразность разделения движения в зависимости от интенсивности движения и других факторов. Необоснованное введение таких путей может привести к неоправданному ограничению свободы действий 
судоводителей. В разделе 5 этого руководства при рассмотрении вопросов планирования говорится, что системы установленных путей, в частности системы разделения движения, должны вводиться только в том случае, если благодаря им может быть явно повышена безопасность плавания [70]. Вводимая система должна обеспечивать безопасный проход судов через район без излишнего ограничения законных прав и существующей практики и с учетом предполагаемых и существующих опасностей.

При планировании системы установленных путей правительство заинтересованной стороны должно учитывать следующие факторы:

- его права и практику в отношении разработки живых и минеральных ресурсов;

- ранее установленные системы путей в прилегающих водах, независимо от того, находятся они или нет под юрисдикцией правительства, предлагающего систему;

- существующие потоки судов в данном районе, включая прибрежное плавание, пересекающиеся потоки судов, районы военноморских учений и районы якорных мест;

- возможные изменения потоков судов в результате развития порта или рейдовых причалов;

- наличие районов рыболовства;

- проводимые и возможные в будущем работы по исследованию морских районов и эксплуатации морского дна и его недр;

- обеспеченность района существующими средствами навигационного обеспечения (CHO), изученность рельефа дна и наличие морских карт района;

- факторы окружающей среды, включая преобладающие в районе метеорологические условия, приливные и постоянные течения, а также возможность скопления льда;

- наличие районов охраны живых ресурсов и возможное их расширение и установление новых.

Как видно, при планировании систем установленных путей, в том числе систем разделения движения, не предполагается каких-либо количественных критериев. Некоторые количественные 
параметры указываются в разделе 6 руководства, посвященном критериям проектирования. Так, минимальная ширина полосы движения и зоны разделения должна устанавливаться, исходя из точности возможных способов определения места и с учетом действующих технических требований к судовому оборудованию, которые изложены в резолюциях и рекомендациях ИМО.

При плавании по системе установленных путей суда должны иметь возможность определять свое место в любой точке в пределах системы разделения и непосредственно на подходах к ней как днем, так и ночью, одним или несколькими из следующих способов:

- по визуальным пеленгам легко опознаваемых объектов;

- по радиолокационным пеленгам и дистанциям до легко опознаваемых объектов;

- по радиопеленгам.

В случае если есть сомнение в возможности судов однозначно определить свое место относительно положения линий разделения или зон разделения, то необходимо тщательно рассмотреть вопрос о соответствующем обозначении их буями. Как видно, из этих положений не ясно, при какой ситуации целесообразно вводить системы установленных путей и каким образом на это влияет интенсивность движения судов. Такие критерии были предложены в некоторых работах по теории судопотоков.

Впервые научно обоснованный критерий для определения необходимости разделения путей в зависимости от интенсивности движения предложен во второй половине 1960-х годов группой сотрудников Ленинградского высшего инженерного морского училища под руководством капитана дальнего плавания, кандидата технических наук В. В. Таратынова [112]. При разработке этого критерия была использована модель, при которой не регулируемое извне плавание судов рассматривается как функционирование двух пронизывающих друг друга встречных судопотоков 1 и 2, плотность которых убывает по мере удаления от середины (оси) потока. На основе анализа статистических данных о движении судов на Балтийском море установлено следующее: 
- расстояние кратчайшего сближения распределяется по нормальному закону;

- промежутки времени между моментами встреч судов распределяются по экспоненциальному закону;

- вероятность опасных встреч судов, требующих маневров для расхождения, зависит от расстояния между осями обоих судопотоков.

Ситуации опасного сближения на противоположенных курсах можно устранить, если разнести оси встречных судопотоков на расстояние

$$
3 \sigma_{1}+3 \sigma_{2}=6 \sigma
$$

где $\sigma_{1}$ и $\sigma_{2}-$ параметры нормального распределения отклонений судов от осей судопотоков (среднеквадратическое отклонение).

Однако такое разделение встречных судопотоков возможно лишь при достаточно большой ширине судоходного пространства. Кроме того, с экономической точки зрения такая мера целесообразна только в случае значительной протяженности морских путей.

Для решения этого вопроса предложен коэффициент экономической эффективности разделения путей, равный

$$
K_{\text {эф }}=1-\Delta S / S_{\text {опт }}
$$

где $\Delta S$ - удлинение путей в результате их разделения; $S_{\text {опт }}-$ длина оптимального пути, принятого до разделения.

Если по каким-то причинам расстояние между осями судопотоков становится меньше $6 \sigma$, то образуется полоса, в которой суда могут встретиться на опасных курсах. Величину такой опасности можно оценить с помощью вероятности опасных встреч: $P_{1}-$ для судопотока 1 и $P_{2}$ - для судопотока 2 .

Вероятность опасного сближения во встречных судопотоках зависит не только от плотности вероятности распределения Дкр по ширине и расстояния между их осями, но и от частоты встреч судов, то есть от интенсивности обоих судопотоков. Экспоненциальный 
характер распределения промежутков времени между двумя последовательными судами свидетельствует о том, что нерегулируемый судопоток имеет случайную природу. Поэтому для судна из состава судопотока 1 вероятность появления встречного судна увеличивается с течением времени после последнего расхождения и может быть выражена как

$$
P_{1}=1-e^{t / \text { Тж }}
$$

где $t$ - время от момента последней встречи судов; $T_{\text {ож }}-$ среднее время между встречами судов.

Общая вероятность опасного сближения двух судов из состава судопотоков 1 и 2 на участке пути равна

$$
P_{12}=P_{1} \cdot P_{2}
$$

Эта величина может служить количественной оценкой опасного сближения судов на встречных курсах на рассматриваемом участке. Вычисляя $P_{12}$ для отдельных участков пути, можно найти значение вероятности опасного сближения судов на встречных курсах на

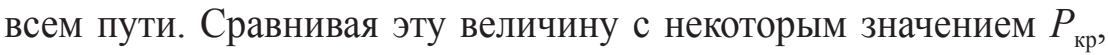
принятым в качестве критерия, можно принять решение о целесообразности разделения путей. В тех районах, где разнести оси встречных судопотоков невозможно, между ними следует ввести линию или зону разделения движения. Однако такие разделительные линии или зоны дают эффект только в том случае, если в районе плавания для судна имеется возможность в любое время знать свое место с достаточной точностью, что в настоящее время не составляет больших затруднений.

При анализе судоходства в узкостях и на подходах к портам, где пространство для маневрирования ограничено, можно использовать критерий, предложенный специалистами Дальневосточного высшего инженерного морского училища под руководством В. И. Удалова [48], который равен критической величине дистанции кратчайшего сближения (ДКС) судна: 


$$
D_{\text {кр }}=2 M_{\text {пр }}+d,
$$

где $M_{\text {пр }}$ - величина предельной погрешности определения места судна, равная утроенной средней квадратической погрешности; $d$-радиус зоны опасного сближения судна в условиях пониженной видимости.

Разделение движения считается целесообразным, если средний интервал $R$ между судами, движущимися в судопотоке, меньше критической ДКС:

$$
D_{\text {кр }}>R \text {. }
$$

Эти два критерия были учтены при введении порядка разработки и установления новых и изменения существующих систем разделения и других судоходных путей в отечественных водах [4].

Критерий максимальной дистанции кратчайшего сближения $D_{\text {кр }}^{s}$

$$
D_{\text {кр }}^{s}=\left.\max \right|_{\vee i} D_{\text {кр } i}^{c},
$$

где $D_{\text {кр } i}^{c}-$ среднее значение ДКС судов, входящих в $i$-тый путь, предлагается использовать при определении оптимальных схем расположения рекомендованных путей и скоростей движения судов по ним в системе управления движением судов, разработанной в Мурманском государственном техническом университете [10].

\section{9. Определение геометрических размеров системы разделения путей}

К геометрическим размерам системы разделения следует отнести протяженность этой системы, ширину полос движения и ширину зоны разделения.

В соответствии с руководством «Общие положения об установлении путей движения судов» протяженность любой системы разделения должна ограничиваться размерами, действительно 
необходимыми для обеспечения безопасного плавания [49]. Иными словами, такие размеры должны быть минимально необходимыми, и их фактические значения определяются, как правило, географическими особенностями района плавания. Протяженность существующих систем разделения движения составляет от нескольких десятков до нескольких сотен миль.

При выборе ширины полосы движения следует исходить из оптимальности использования судоходных глубин и районов безопасного плавания, имея в виду обеспечение максимальных глубин вдоль всего пути. Кроме того, при этом учитывается интенсивность судопотоков, общая частота использования данного района плавания судами и имеющееся водное пространство. Минимальная ширина полосы движения должна устанавливаться исходя из точности возможных способов определения места и с учетом действующих технических требований к судовому оборудованию, изложенных в резолюциях и рекомендациях ИМО. При этом суда, как требует указанное руководство ИМО, должны иметь возможность определять свое место в любом месте в пределах системы разделения движения и непосредственно на подходах к ней как днем, так и ночью одним из следующих способов:

- по визуальным пеленгам легко опознаваемых объектов;

- по радиолокационным пеленгам и дистанциям до легко опознаваемых объектов;

- путем радиопеленгования.

Наибольшим теоретическим исследованиям подвергся геометрический параметр ширина зоны разделения. В руководстве ИМО говорится, что для лучшего разделения встречных судопотоков и отделения зон прибрежного плавания от прилегающих полос движения при наличии достаточной акватории предпочтительнее устанавливать зоны разделения движения, а не линии разделения.

Значение ширины зоны разделения связывается с точностью определения места судна. В частности, в разделе, представляющем критерии проектирования систем разделения, отмечается, что «..там, где водное пространство позволяет использовать зоны разделения, ширина зон, если возможно, должна быть не менее утроенного 
значения поперечной составляющей средней квадратической погрешности, направленной поперек зоны разделения движения, наиболее подходящего способа определения места судна... Там, где это необходимо или желательно, и там, где это практически возможно, должно быть установлено дополнительное разделение, чтобы гарантировать достаточно заблаговременное обозначение для прохождения встречного потока судов по своей стороне» [70]. Как видно, этот критерий не однозначен. Следует заметить, что глобальное внедрение в практику судовождения спутниковых навигационных систем, особенно дифференциальных подсистем, по сути, сводит на нет значение критерия, основанного на «утроенном значении поперечной составляющей средней квадратической погрешности ... наиболее подходящего способа определения места судна».

Всестороннее исследование проблемы выбора ширины зоны разделения было выполнено во второй половине XX века группой японских ученых, которые опубликовали полученные ими результаты в 1979 г. [134].

На первом этапе было определено распределение траекторий судов в пределах полос движения. Для этого путем фотографирования экрана установленного на берегу радиолокатора с интервалом через одну минуту были получены обширные статистические данные о характере движения на 19 установленных путях в восьми проливах. Распределение траекторий судов на двустороннем пути с зоной разделения изображено на рисунке 3.9.1.

Установлено, что при коэффициенте множественной корреляции $R=0,992$ распределение траекторий судов по ширине полосы движения следует нормальному закону при стандартном отклонении

$$
\sigma=-9,485+0,106 W+3,329 \lambda,
$$

где $W$ - ширина пути, м; $\lambda$ - интенсивность судопотока, судов/час.

При этом среднее значение величины отклонения $X$ от центра двустороннего пути составляло около 10 \% от ширины пути, однако если осевая линия была обозначена буями, то это значение возрастало до 20 \% от ширины пути (рис. 3.9.1). 


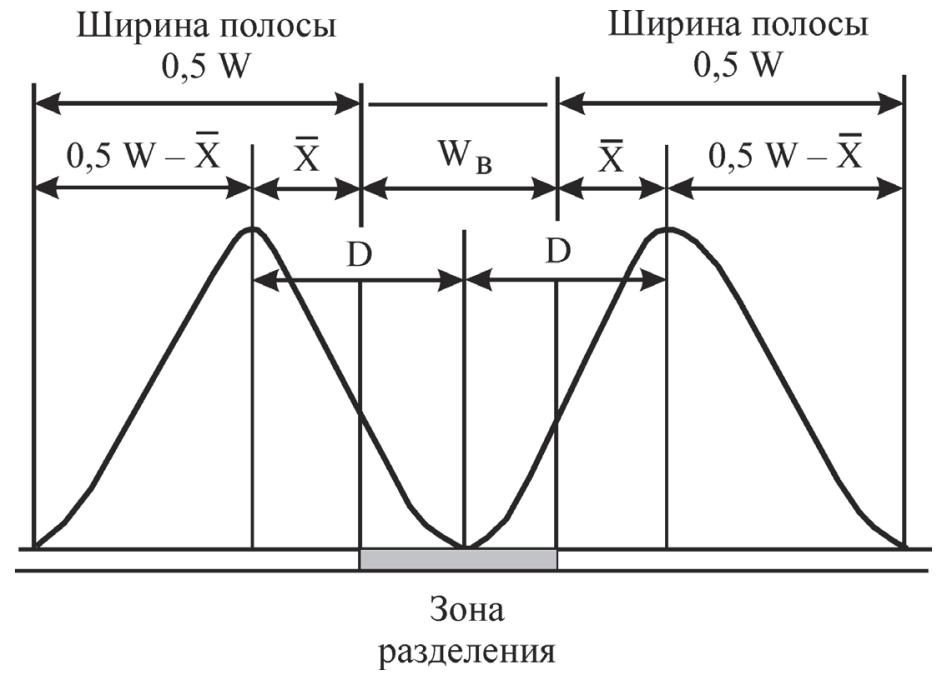

Рис. 3.9.1. Распределение траекторий судов на двустороннем пути с зоной разделения

С учетом отсутствия наложения друг на друга траекторий встречных судопотоков ширина зоны разделения определяется по формуле:

$$
W_{\mathrm{B}}=2(3 \sigma-k W),
$$

где коэффициент $k=0,1$, если осевая линия не ограждена буями, и $k=0,2$, если осевая линия ограждена.

Подставив в (3.9.2) выражение (3.9.1), можно получить формулу для расчета ширины зоны разделения в зависимости от ширины двустороннего пути и интенсивности движения. На рисунке 3.9.2 показаны графики этой зависимости для некоторых значений интенсивности движения [134].

Вторым критерием, который должен учитываться при определении ширины полосы разделения, должна быть вероятность выполнения пересекающим судном маневра на расхождение с судном, движущимся по полосе справа налево, что соответствует МППСС-72. Этот маневр предпочтительно выполнять в зоне разделения, и чем она шире, тем больше возможностей для расхождения 
у пересекающего судна. Для этого введено понятие «ограничивающей вероятности» $P_{d}$, с увеличением которой возможности безопасного расхождения уменьшаются.

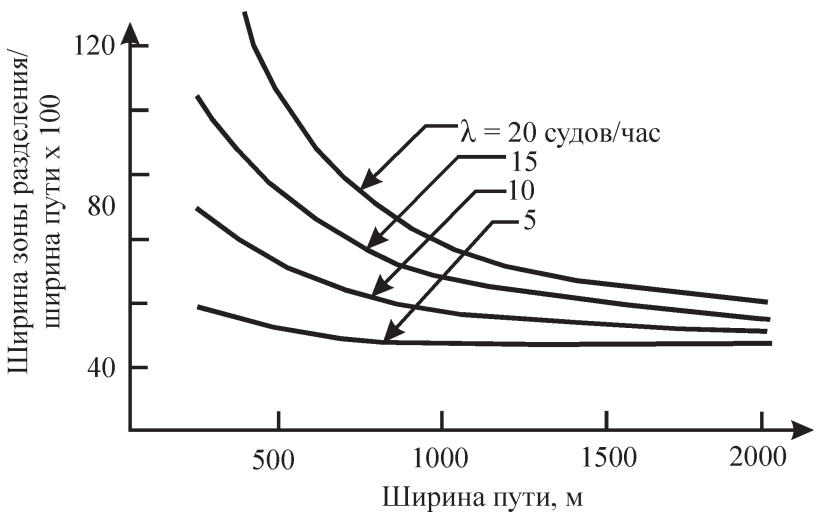

Рис. 3.9.2. Ширина полосы разделения, когда осевая линия ограждена буями

Для расчета ограничивающей вероятности получена формула [48]:

$$
P_{d}=\left(1-e^{-\lambda T}\right) /\left(\sqrt{2 \pi} \int_{t(0)}^{t\left(\tau_{\alpha}\right)} e^{-\frac{\xi}{2}} d \xi\right)
$$

где $t\left(\tau_{a}\right)=\left(\tau_{a}-2 D\right) \sqrt{ }(42 \sigma), t(0)=\sqrt{ }(2 D / \sigma), T=110, \mathrm{c}, \tau_{a}-$ время, необходимое для расхождения, оно связано с шириной зоны разделения и скоростью судна. На рисунке 3.9.3 приведены кривые зависимости ограничивающей вероятности от ширины зоны разделения при фиксированных значениях других параметров [134].

Помимо этих двух факторов - перекрытия зон распределения траекторий и ограничивающей вероятности маневра на расхождение - в предложенную модель можно вводить и другие факторы, например особенности района плавания или качественный состав судопотоков. 

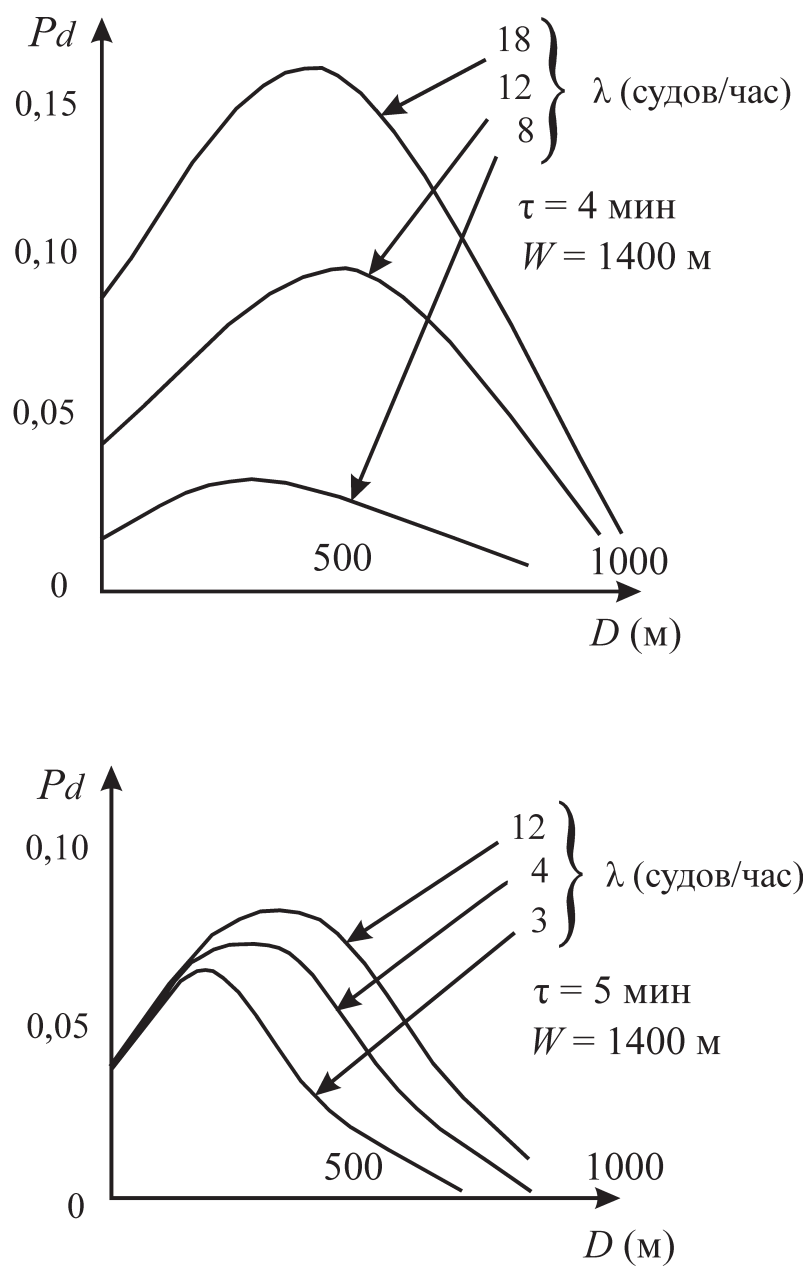

Рис. 3.9.3. Зависимость между шириной зоны разделения и ограничивающей вероятностью 


\section{Контрольные вопросы}

1. С какой целью используется Глобальная морская система связи при бедствии и для обеспечения безопасности (ГМССБ)?

2. Какова структура ГМССБ?

3. Какие особенности имеет цифровой избирательный вызов (ЦИВ)?

4. Какая система называется системой установления путей? В каких районах вводятся такие системы?

5. Какие структурные компоненты включает система установления путей?

6. Какие элементы системы разделения движения судов попадают под действие Резолюции А.572(14)?

7. Какие принципы использования систем разделения движения определяют правила МППСС-72?

8. Назовите особенности плавания судна, занятого ловом рыбы, в районе системы разделения движения. Как обеспечивается безопасность плавания в районе рыбного промысла?

9. Какие критерии используют для определения целесообразности введения систем установления путей?

10. Как можно определить геометрические размеры системы разделения движения судов? 


\section{4. СИСТЕМЫ УПРАВЛЕНИЯ \\ СУДОХОДСТВОМ}

\section{1. Обеспечение безопасности мореплавания при лоцманских проводках}

Системы активного управления судоходством и обеспечения безопасности мореплавания в районах с интенсивным движением базируются на использовании различных служб помощи в судовождении, к числу которых относятся лоцманские службы, системы управления движением судов и системы судовых сообщений. Тенденцией современного развития таких систем является широкое внедрение методов, средств и систем комплексной автоматизации и интеллектуализации в управлении, направленных на замену человека машиной и снижение негативного влияния «человеческого элемента» на управление отдельным судном и флота в целом. Все это способствует снижению уровня аварийности и обеспечивает рост провозной способности судопотоков.

Древнейшим и самым консервативным средством регулирования движения судов в портовых районах является лоцманская служба, которая обеспечивает безопасность при проводке судов в тех местах, где требуются точные знания местности и условий плавания, а также осуществляет надзирательство за соблюдением установленных в тех или иных районах правил судоходства (рис. 4.1.1 [51]).

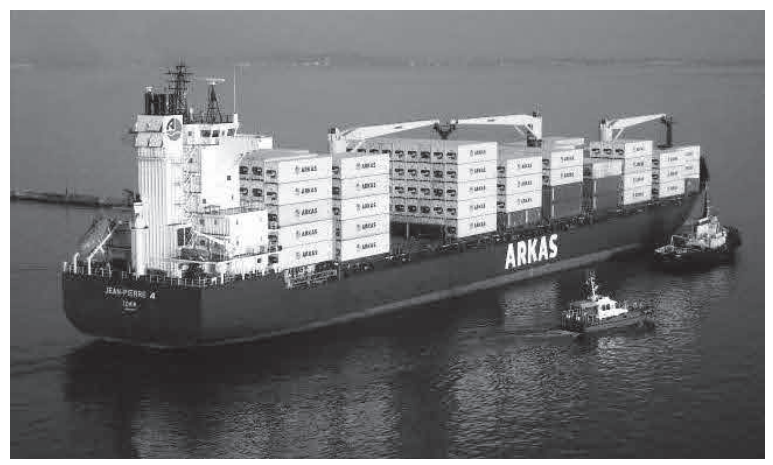

Рис. 4.1.1. Лоцманская проводка контейнеровоза JEAN PIERRE 
В соответствии со статьей 86 Кодекса торгового мореплавания Российской Федерации (КТМ РФ) лоцманская проводка судов осуществляется в целях обеспечения безопасности плавания судов и предотвращения происшествий с судами, а также защиты морской среды [133]. Лоцманская проводка судов осуществляется морскими лоцманами, имеющими выданные капитанами морских портов лоцманские удостоверения о праве лоцманской проводки судов в определенных районах.

Термин «лоцман» имеет голландское происхождение, он был официально введен Морским уставом в 1720 году. В Голландии lootsmann - это опытный рулевой, судоводитель, который хорошо знаком с конкретной акваторией и имеет лицензию, дающую право на обслуживание кораблей и судов. Любопытны также названия профессии в разных городах страны: в Мурманске - кормик, в Архангельске - корабельная вошь, в Санкт-Петербурге благодаря Петру I, который взял заграничное слово, - лоцман [1].

Лоцманская служба является старейшей службой обеспечения безопасности мореплавания. Уже около 500 года до н.э. был создан сборник для информирования мореплавателей, в котором описывались испанские берега. Заметки о лоцманстве имеются у римского автора Павзания (175 год н.э.), упоминание о лоцманах встречается в произведениях Цицерона, Овидия, Горация, Виргилия, Демосфена и других авторов древности [63].

Первые официальные сведения о деятельности русских лоцманов следует отнести к 1653 году, когда царем Алексеем Михайловичем (отцом Петра I) была дарована грамота архангельскому рыбаку Ивашке Котцову, согласно которой ему и его товарищам разрешалось проводить торговые суда по Белому морю и реке Северная Двина [63]. В 1693 году Петр I впервые встречает людей этой профессии в Архангельске. Начиная строить Петербург, царь создает Лоцманскую службу и в приказном порядке собирает всех людей, владеющих ремеслом, в одну команду. Официальный статус лоцманская команда получает при Петре I в 1705 году. Служба учреждается при Адмиралтействе, лоцманы поселяются вместе с женами и детьми. Корпус включал 24 человека, в том числе 11 
лоцманов. С ростом количества людей создается лоцманское поселение. В 1853 году в качестве места проживания лоцманских семей был выбран Подзорный остров в Финском заливе. На территории бывшего поселения ныне стоят корпуса Адмиралтейских верфей.

Формы объединения лоцманов и руководство ими в период становления лоцманского дела были различны не только на отдельных морях, но и в разных портах одного и того же моря. До 1917 года лоцманские службы были экономически самостоятельными. Свою деятельность они осуществляли на средства, поступающие в качестве лоцманского сбора. Государство со своей стороны лишь контролировало качество лоцманского обслуживания [129].

В советское время, вплоть до начала приватизации и акционирования портов, все лоцманские службы имели государственный статус. Лоцманский сбор вместе с другими портовыми сборами перечислялся в бюджет, а финансирование лоцманских подразделений осуществлялось по остаточному принципу. Следствием этого была низкая техническая оснащенность лоцманских организаций. Безопасность мореплавания поддерживалась на минимально возможном уровне. В соответствии с новым экономическим курсом страны в 1991 году лоцманским службам северного и западного бассейнов была предоставлена экономическая самостоятельность. Прибыль не делилась между учредителями - лоцманами, а направлялась на развитие и оснащение лоцманских служб. В дальнейшем, в ходе акционирования портов, эта практика была распространена и на другие порты.

В 1995 году лоцманы создали Ассоциацию морских лоцманов России (АМЛР), которая контролировала и управляла лоцманской деятельностью в стране, оставаясь в то же время лоцманским объединением, управляемым лоцманами. С учетом накопленного опыта, развития правовой базы Российской Федерации (Закон «О некоммерческих организациях» и др.) и рекомендаций лицензионной комиссии Минтранса России о внедрении опыта работы лоцманов в некоммерческих организациях, в 1996 году было принято решение о перерегистрации существующих лоцманских организаций в Автономные некоммерческие организации лоцманов 
(АНО), единственным учредителем которых является АМЛР. Была создана единая структура негосударственных некоммерческих лоцманских организаций, обеспечившая лоцманскими проводками более 80 \% всего грузооборота морских портов России и объединившая 75 \% лоцманов страны, то есть фактически была создана единая национальная лоцманская служба России.

В 1999 году был принят Кодекс торгового мореплавания, который разрешил деятельность коммерческих служб. Во многих портах, особенно крупных, начали создаваться «Общества морских лоцманов», куда стали вливаться наиболее опытные лоцманы. Негосударственные лоцманские службы обслуживали 85 \% морского российского грузопотока и получали 90-92 \% лоцманских сборов.

В 2001 году Постановлением Правительства Российской Федерации № 538 «О деятельности негосударственных организаций по лоцманской проводке судов» число морских портов, в которых допускается деятельность негосударственных организаций по лоцманской проводке судов, было ограничено (Архангельск, Владивосток, Выборг, Де-Кастри, Игарка, Находка, Николаевск-на-Амуре, Петропавловск-Камчатский, Туапсе, Холмск, Витино, Дудинка, Москальво, Мыс Лазарева и нефтеналивной порт Находка). Их доля в обслуживании судов сократилась приблизительно до 40 \% [129].

В настоящее время в России лоцманское обеспечение осуществляет ряд субъектов [129]:

- самостоятельные некоммерческие организации, учрежденные Ассоциацией морских лоцманов России (АМЛР) и работающие под контролем Департамента мореплавания Минтранса РФ;

- лоцманские службы в составе государственных морских администраций портов (МАЛ);

- лоцманские службы, входящие в состав государственных администраций морских рыбных портов (МРП) и находящиеся в подчинении Госкомрыболовства;

- линейные лоцманы на государственном гидрографическом предприятии, работающие на реках Енисей, Хатанга.

Морские лоцманы могут входить в лоцманские службы портов и гидротехнических баз, а также в самостоятельные лоцманские 
организации. Негосударственные организации по лоцманской проводке судов создаются с учетом особенностей, определяемых постановлением Правительства и иными правовыми актами Российской Федерации. Перечень портов, в которых допускается деятельность негосударственных организаций по лоцманской проводке судов, устанавливается Правительством Российской Федерации. Министерство транспорта РФ утверждает Положение о морских лоцманах России, устанавливает районы обязательной и необязательной лоцманской проводки и доводит об этом до всеобщего сведения в обязательных постановлениях морских портов, лоциях и «Извещениях мореплавателям».

Министерство транспорта РФ осуществляет контроль деятельности государственных лоцманских служб в морских портах, а также контроль в отношении негосударственных организаций лоцманов. В порядке осуществления такого контроля Министерство, в частности, вправе решать вопросы:

- будут ли и в каком объеме морские лоцманы таких организаций осуществлять обязательную проводку судов, если такая проводка установлена в соответствующем районе или в отношении определенных судов;

- удовлетворяют ли такие организации в отношении оснащенности, численности и обученности их работников целям лоцманского обслуживания.

Лоцманские службы в России независимо от их правового статуса являются неотъемлемой частью государственной системы обеспечения безопасности мореплавания. Лоцманские организации осуществляют свою деятельность на основании КТМ РФ, Положения о морских лоцманах России, Положения о лоцманской службе и лоцманской проводке судов по внутренним судоходным путям Российской Федерации [71], собственного Устава лоцманской организации, согласованного с органом государственного надзора и утвержденного в установленном порядке, других законодательных и подзаконных актов по безопасности мореплавания. По вопросам обеспечения безопасности мореплавания лоцманские службы непосредственно подчиняются капитану порта. Деятельность ледовых 
лоцманов на трассе Северного морского пути и лоцманов открытого моря регламентируется соответствующими положениями о них.

Во время лоцманской проводки судна лоцман обязан немедленно сообщать капитану морского порта о замеченных нарушениях:

- о любых переменах на фарватерах, которые могут создавать угрозу безопасности мореплавания;

- о любых происшествиях с судном, лоцманскую проводку которого он осуществляет, и с другими судами в обслуживаемом им районе;

- о невыполнении капитаном судна, лоцманскую проводку которого он осуществляет, правил плавания судов и правил предотвращения загрязнения с судов нефтью, вредными веществами, сточными водами или мусором.

Все лоцманские организации лицензируются, и их работа контролируется органами государственного надзора, капитанами портов. Любая лоцманская служба (организация) должна иметь сертификат на право осуществления своей деятельности, выданный органом, осуществляющим надзор за торговым мореплаванием. Лоцманские сертификаты выдаются лоцманам, сдавшим экзамен, капитаном морского порта. Выдача лоцманского сертификата не предполагает какой-либо ответственности органа, выдавшего сертификат, за ущерб, причиненный любым действием (бездействием) лоцмана. Ни морской порт, ни независимые организации лоцманов не несут ответственности за вред, причиненный в результате ненадлежащего исполнения лоцманской проводки перед третьей стороной. Ответственность за безопасность судна несет капитан.

В районах обязательной лоцманской проводки судно не имеет права осуществлять плавание без лоцмана, если только оно не относится к категории судов, освобождаемых от обязательной лоцманской проводки. Категории таких судов устанавливаются капитанами морских портов и доводятся до всеобщего сведения в обязательных постановлениях в морских портах.

При обязательной лоцманской проводке лоцман принимается на судно по воле капитана и в силу предписаний законов прибрежного государства (включая местные правила плавания) и некоторых 
международных норм (Конвенции ООН по морскому праву 1982 года, Конвенции о международном режиме портов 1923 года и других международных норм). Районы обязательной лоцманской проводки устанавливаются по следующим причинам:

- существуют сложные местные гидрометеорологические, гидрографические, навигационные и иные условия плавания, которыми не в состоянии быстро и комплексно овладеть капитан иностранного или национального судна, чтобы эффективно применить полученную информацию для проводки вверенного ему судна (например, сложные местные условия плавания, количество и интенсивность движения судов, особенности конструкции проводимого судна - большие размеры, осадка и т. д.);

- существуют опасные для мореплавания и окружающей среды эксплуатационные и иные характеристики судна, критерии которых определены в нормативных актах прибрежного государства, международных нормах или рекомендациях международных организаций (например, ядерная энергетическая установка; судно в аварийном состоянии; на борту судна имеются опасные грузы - нефть, газ, радиоактивные вещества и т. д.).

В районах, в которых лоцманская проводка судов является необязательной, капитан судна может взять на судно лоцмана, если в этом есть необходимость. Капитан приглашает морского лоцмана для получения недостающей информации, необходимой для безопасного управления судном. Он получает точную информацию от лоцмана до начала проводки и во время ее осуществления, поскольку возможно возникновение каких-либо новых навигационных и иных фактов, правильное истолкование которых способен лучше дать лоцман.

В районах необязательной лоцманской проводки капитан морского порта может устанавливать обязательную лоцманскую проводку судов, которые сами или перевозимые ими грузы могут создавать угрозу причинения ущерба морской среде, или судов, имеющих серьезные повреждения корпусов, механизмов или оборудования, что может влиять на безопасность мореплавания в порту. Категории таких судов доводятся до всеобщего сведения в 
обязательных постановлениях в морских портах, лоциях и «Извещениях мореплавателям».

Присутствие лоцмана на судне не снимает с капитана ответственности за управление судном. Лоцман является только советчиком капитана. Все приказания рулевому и в машину капитан отдает лично. Если в целях ускорения выполнения маневра капитан разрешает лоцману самому отдавать приказания, то в этом случае они будут считаться выполненными по приказанию капитана, который несет ответственность. В случае ухода капитана с мостика он обязан указать лоцману лицо, ответственное за управление судном в его отсутствие.

Если капитан, приняв на судно лоцмана, не будет следовать его рекомендациям, последний имеет право в присутствии третьего лица отказаться от продолжения проводки судна. Лоцман обязан потребовать, чтобы об этом было записано в судовом журнале и в лоцманской квитанции, а также сообщить о происшедшем в портнадзор. Однако и после отказа от проводки лоцман обязан оставаться на мостике и, если капитану потребуются сведения, необходимые для безопасного плавания, он обязан сообщать их. Если же капитан потребует, чтобы лоцман возобновил проводку, то он не вправе отказаться и обязан продолжить проводку. В случае сомнения в правильности рекомендаций лоцмана капитан вправе отказаться от его услуг.

При возникновении обстоятельств, отражающихся на безопасности лоцманской проводки (ухудшение видимости, туман, уменьшение глубин на фарватере и т. п.), капитан судна обязан по требованию лоцмана использовать средства судового электрорадионавигационного оборудования (эхолот, радиолокатор, радиопеленгатор и др.), а при наличии в районе лоцманской проводки СУДС воспользоваться ее услугами.

Капитан морского порта вправе запретить проводку судов, когда безопасной проводке препятствуют гидрометеорологические обстоятельства (плохая видимость, шторм, ледовые условия и т. д.), а также при наличии других обстоятельств.

В некоторых районах плавания (в Коринфском и Панамском каналах) установлена принудительная лоцманская проводка, при 
которой лоцман самостоятельно управляет судном и контролирует его движение. На данной территории действия лоцмана заменяют действия капитана [80].

На трассе Северного морского пути используется ледокольная проводка. Без ледокола идти через лед запрещается. Время и порядок следования судов через лед, а также число проводимых одновременно судов определяется в порту капитаном порта, а в море - капитаном ледокола. Капитаны судов, следующих во льдах за ледоколами, обязаны подчиняться приказаниям капитана ледокола, касающимся движения во льдах, и действовать, сообразуясь с ними. Ледокол и морская администрация порта не несут материальной ответственности за убытки проводимого судна, возникшие во время проводки через лед.

Лоцманские службы содержатся за счет лоцманских сборов, используемых на развитие и обеспечение их деятельности.

В целом положения российского законодательства, регламентирующие лоцманское дело, соответствуют нормам международного права.

Обеспечение безопасности при проводках морских и речных судов в порты является одной из самых сложных процедур в навигации. Всестороннее развитие российского транспорта и портовой инфраструктуры России сегодня невозможно без внедрения высоких технологий в транспортный процесс. К числу современных решений обеспечения безопасности мореплавания при лоцманских проводках относится электронная картография.

Ряд специализированных мобильных систем электронной картографии, которые используются в лоцманских службах, были созданы на базе стандартного программного обеспечения «Экнис Navi Sailor 3000» производства российской группы компаний Транзас (TRANsport SAfety Systems). Производство сертифицировано на соответствие международному стандарту качества ISO $9001[115,117]$.

В 2007-2008 годах в сотрудничестве с Лоцманской службой Морской администрации Швеции SMA была разработана система Transas Navi-Sailor 4000 Pilot специально для нужд лоцманских 
организаций по всему миру. Система с продуманным набором поддерживаемых функций предназначена для использования государственными и частными лоцманскими службами, занимающимися проводками судов в морских и речных портах, в их ежедневной работе по обеспечению эффективной работы до, во время и после проводки судна [125].

Система создавалась в тесном сотрудничестве с морскими лоцманами портов Петербурга, Выборга и Приморска. При разработке продуктов «Транзас» учитывались результаты тестирования и эксплуатации в лоцманских службах портов Петербург, Мурманск, Кандалакша, Выборг. Система Navi-Pilot получила сертификат одобрения от Департамента морского транспорта Российского морского регистра судоходства и сертификационных обществ BSH (Германия), DNV (Норвегия).

Электронно-картографическая система (ЭКС) для лоцманов Navi-Pilot - эффективное средство навигации, обеспечивающее безопасность лоцманской проводки путем оперативного представления достоверной информации по маневрам судна в режиме реального времени. Систему Navi-Pilot отличает возможность выполнения как функций стандартной ЭКС, так и ряда специфичных задач, связанных с особенностями выполнения лоцманской проводки. Navi-Pilot может устанавливаться на бизнес-ноутбук или защищенный промышленный портативный компьютер. Внешний вид системы Transas Navi-Sailor 4000 Pilot представлен на рисунке 4.1.2 [125].
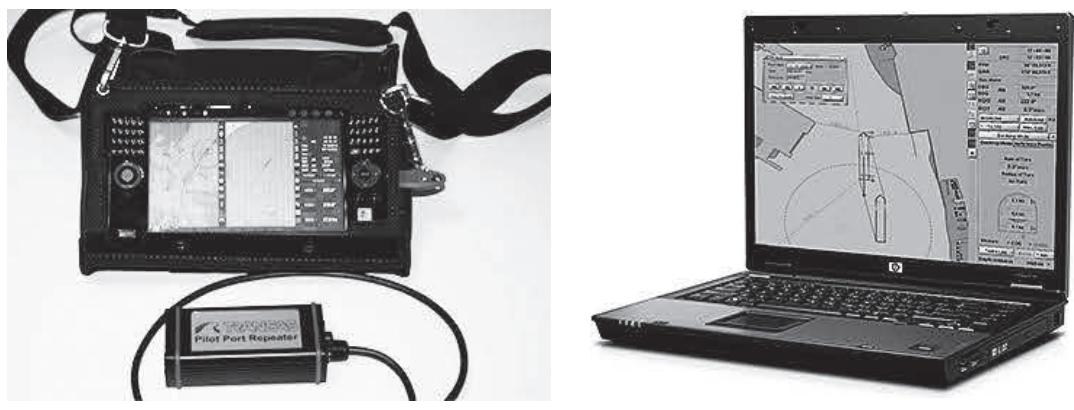

Рис. 4.1.2. Внешний вид системы Transas Navi-Sailor 4000 Pilot 
Основными функциями системы являются отображение текущего местоположения и вектора движения судна, информации об опасных районах на электронной карте, данных о приливах и течениях, ведение электронного судового журнала основных событий и действий оператора, планирование поисково-спасательных операций, сопряжение системы с АИС-транспондером посредством интерфейса Pilot Plug (возможна передача данных по Bluetooth с помощью устройства Bluetooth Power Box) и другие. Помимо стандартных функций электронно-картографической системы (ЭКС), система Navi-Pilot может выполнять ряд задач, связанных с особенностями лоцманской проводки. К специализированным возможностям ЭКС Navi-Pilot относятся: функция проигрывания маневра с возможностью расчета и отображения предполагаемого движения судна, отображение векторов скорости перемещения носа (кормы), а также рассчитываемого по угловой скорости поворота (Rate-Of-Turn - ROT) радиуса поворота судна при швартовке, отображение пеленга (дистанции) до указанного пользователем места постановки якоря и другие.

Современный лоцман может подниматься на борт судна с одним собственным планшетом. В этом ему поможет система Транзас Pilot PRO, разработанная Группой Транзас специально для планшетов на платформе Apple iPad и операционной системе Apple iOS. Bec и размер имеют для лоцманского комплекта существенное значение. Изделия, основанные на ноутбуках, весят, наряду с зарядным устройством, до 4-5 кг. А если учесть, что лоцман использует для переноса рюкзак или плечевую сумку, и при посадке на судно ему приходится подниматься по шторм-трапу и в ненастную погоду, то планшет iРad является выигрышным вариантом как по весу, так и по размеру.

Лоцману для работы необходимо использовать актуальные навигационные данные. Для этого лоцманы применяют «Переносной лоцманский комплект с электронной картографической системой, индивидуальными средствами позиционирования и идентификации судов (Pilot Personal Unit - PPU)». В PPU включены электронные карты и подходные маршруты (рис. 4.1.3) [120]. 
Система PPU позволяет также получать достоверные навигационные данные в режиме реального времени, такие как координаты собственного судна по спутниковым системам местоопределения (GPS / GLONASS), точные дифференцированные поправки к ним, данные по курсу судна (Heading) и его угловой скорости поворота (ROT) [23].

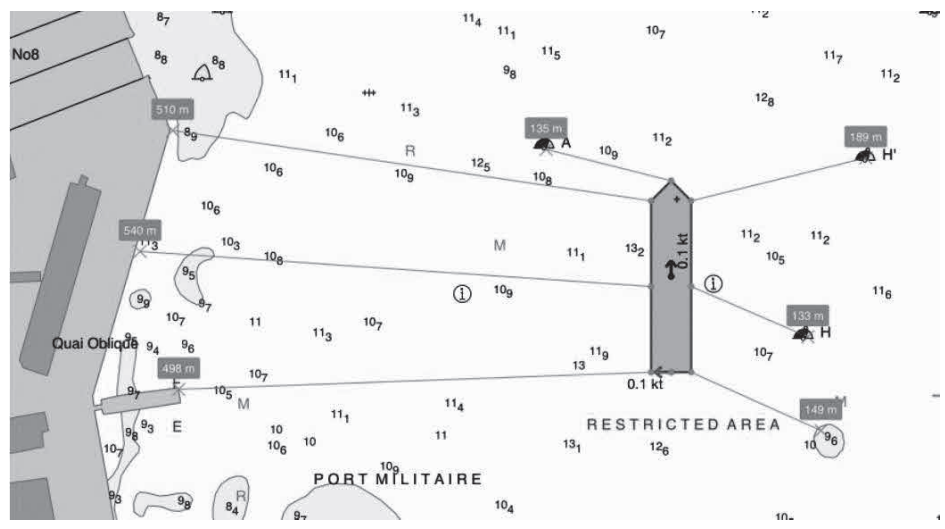

Рис. 4.1.3. Автоматическое отображение дистанций, заданных от судна для произвольных картографических объектов в системе Транзас Pilot PRO

Отдельного внимания заслуживает специализированная функциональность для лоцманов - наличие судового Predictor, который позволяет отобразить предвычисленную позицию собственного судна во времени «вперед», базируясь на моментальных навигационных данных от GPS, Heading и Rate-Of-Turn (рис. 4.1.4) [120].

Разработка следующих версий Транзас Pilot PRO продолжается. В них в том числе будут установлены база данных по приливам и течениям, система расчета безопасной глубины под килем судна на ходу и при «проседании» судна во время движения (Under Keel Clearance), а также специфицирована новая функциональность по интеграции Транзас Pilot PRO с Транзас СУДС (Береговой системой управления движением судов) в будущем.

В целом лоцманская служба имеет следующие недостатки:

- длительное время ожидания (простоя судна), при этом каждый час простоя судна в условиях ограниченной видимости или в 


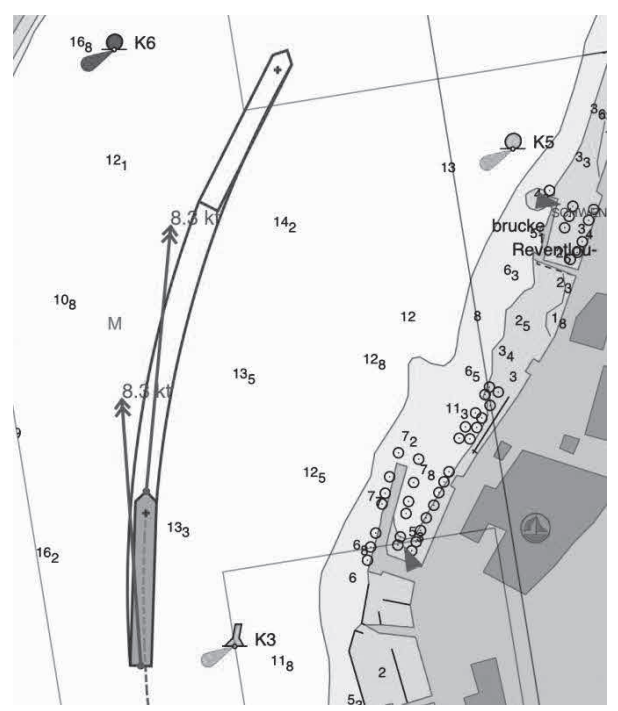

Рис. 4.1.4. Функциональность модуля Predictor в Транзас Pilot PRO

ожидании лоцмана из-за плохой или несвоевременной информации приносит значительные убытки как судовладельцу, так и целому ряду береговых организаций, вовлеченных в процесс обработки судна в порту;

- за лоцманское обслуживание взимается лоцманский сбор, который является единственным доходом лоцманов;

- необходимость в создании и поддержании на должном уровне инфраструктуры лоцманской службы;

- сильное влияние человеческого фактора, так как качество лоцманской проводки в большой степени зависит от личного опыта и от личностных качеств лоцмана;

- трудности внедрения современных средств информатизации и интеллектуализации процессов при лоцманской проводке.

В чистом виде в настоящее время лоцманская служба почти не применяется. Она интегрируется с другими службами помощи в судовождении.

Применение в СУДС автоматизированных идентификационных (информационных) систем (AИC-AIS) в комплексе с высокоточными средствами навигации позволяет пересмотреть 
взаимоотношения между участниками процесса организации движения судна в районе действия СУДС (капитан судна-лоцман-оператор СУДС). Ведущие морские страны (Великобритания, Германия, Нидерланды), традиционно уделяющие повышенное внимание развитию и использованию СУДС (VTS), используют Shore Based Pilotage - лоцманскую проводку с берега, осуществляемую посредством технических средств VTS специально подготовленными для этого операторами, имеющими дипломы лоцмана и соответствующий опыт работы в местных условиях.

Использование СУДС позволяет:

- сократить протяженность традиционной лоцманской проводки, принимать и высаживать лоцманов в защищенных акваториях;

- повысить эффективность работы лоцманских служб (при одновременном сокращении их числа и лоцманских судов);

- увеличить пропускную способность подходных путей;

- снизить величину лоцманского сбора и общие издержки судна по заходу в порт, повысить конкурентоспособность и эффективность работы порта.

В частности, такая практика используется в некоторых СУДС в норвежских шхерах в районах, в которых навигационные условия позволяют это делать [28]. При этом в качестве операторов СУДС используются специально подготовленные специалисты, имеющие достаточную лоцманскую практику, прошедшие тренажерную подготовку, хорошо знакомые с техническим оборудованием, его возможностями и недостатками.

Эту функцию СУДС, при условии существенного улучшения характеристик СУДС за счет внедрения новых технологий, можно назвать радиолокационной проводкой. Технологической основой радиолокационной проводки должны стать современные и перспективные технологии VTS (СУДС), такие как DGPS, ECDIS, AIS и средства прогнозирования траекторий движений отдельного судна и всех судов, взятых на обслуживание. Радиолокационную проводку можно рассматривать, как гибрид традиционной лоцманской проводки и оказание помощи в судовождении, при которой оказание помощи в судовождении выполняется из оперативного 
Центра СУДС опытным лоцманом-оператором ЭВМ на основании оперативной информации о движении всех судов на подконтрольной акватории в диалоговом режиме [13].

Понятие «радиолокационная проводка» отсутствует в Резолюциях IMO и не раскрывается в национальных документах. Исключение составляют ТЭТ и Типовое положение о СУДС 1996 года, которые содержат в перечне функций СУДС пункт о радиолокационной проводке: «Выдача данных о местоположении судна при радиолокационной проводке, которые носят информационный характер». Однако ни в Положении, ни в ТЭТ по СУДС 2002 года радиолокационная проводка уже не упоминается. Кроме этого, в «Общих правилах плавания и стоянки судов в морских портах РФ и на подходах к ним», введенных в действие с 1 июля 1993 года, кратко говорится, что «при радиолокационной проводке лоцманоператор СУДС постоянно информирует судно о его местоположении в принятой системе координат». При этом ничего не говорится ни о сообщениях с судна в Центр СУДС, ни о разграничении ответственности СУДС и капитана судна, ни о других важных аспектах.

Несмотря на отсутствие соответствующего понятия в международных документах и неопределенности национальных документов, радиолокационная проводка прочно закрепилась в практической деятельности отечественных СУДС, подменяя собой одну из важнейших служб СУДС - службу помощи в судовождении. Вероятно, что причиной появления в отечественных документах понятия «радиолокационная проводка» явился опыт эксплуатации первой в России СУДС порта Санкт-Петербург, обслуживающей морской подходной канал с большой протяженностью. С точки зрения документов IMO/IALA [136] участие СУДС в процессе судовождения по каналу является ничем иным, как оказанием помощи в судовождении в системе разделения движения. Наличие в этих условиях на борту судна лоцмана позволяет классифицировать данную ситуацию как лоцманскую проводку, осуществляемую при содействии СУДС, а не как радиолокационную проводку. Учитывая довольно специфические местные условия, сложившийся опыт работы СУДС, Санкт-Петербург не 
может переноситься однозначно на другие СУДС, действующие в значительно отличающихся условиях.

Для таких СУДС, как Владивосток и Находка, характерны довольно большие глубины акватории, хорошие радиолокационные ориентиры и практическое отсутствие навигационных опасностей вблизи фарватеров и на удалении от берегов. В этих условиях наличие на судне основных конвенционных судовых средств (гирокомпас, лаг и РЛС) обеспечивает автономное и безопасное судовождение. На таких акваториях оказание помощи в судовождении целесообразно только в особых обстоятельствах, например, выход из строя указанных приборов, ограниченная видимость. Наличие на современных судах приемников GPS/DGPS является дополнительным аргументом для такого вывода.

Важно отметить, что помощь в судовождении должна носить только информационный и рекомендательный характер и не должна ограничивать ответственность капитана за безопасность судна и перекладывать эту ответственность на СУДС.

\section{2. Назначение и этапы развития систем управления движением судов}

Под системой управления движением судов (СУДС) понимается специализированный технический комплекс, включающий в качестве основных подсистем радиолокационную аппаратуру, автоматизированные средства обработки, анализа и отображения информации, а также оборудование УКВ-радиосвязи. Радиолокационные данные от радиолокационной станции (РЛС) поступают в Центр управления СУДС, где обрабатываются совместно с данными от других радаров и сенсоров системы, отображаются на картографических операторских дисплейных модулях операторов и терминалах авторизованных сторонних пользователей (рис. 4.2.1) [119].

Системы СУДС появились в конце 1940-х годов и в разное время назывались по-разному: пост регулирования движения, береговая радиолокационная станция, береговая радиолокационная система, 
система регулирования судоходства, служба движения, служба безопасности движения и т. п. Определение «система управления движением судов (СУДС)» вошло в обращение с середины 1980-х годов и в настоящее время является общепринятым, в англоязычном варианте ему соответствует термин Vessel Traffic Service - VTS Служба движения судов.

В своем развитии системы управления движением судов (VTS) прошли несколько этапов. Первая СУДС была введена в эксплуатацию в начале 1948 года в порту Ливерпуль, когда на левом берегу в устье реки Мерсей была установлена судовая РЛС «Декка», дополненная аппаратурой УКВ-радиосвязи. Эта система предназначалась для обслуживания паромов и крупных судов в плохую видимость, помощи в проведении спасательных операций, а также для сбора навигационной, метеорологической и другой важной для навигации информации [50]. Такие системы, состоящие из судовых РЛС, аппаратуры УКВ-радиосвязи и вспомогательного оборудования, относятся к системам первого поколения. Успешный опыт эксплуатации систем первого поколения способствовал тому, что в последующие годы подобные СУДС появились во многих портах Западной Европы, Скандинавских стран, Соединенных Штатов Америки и других стран.

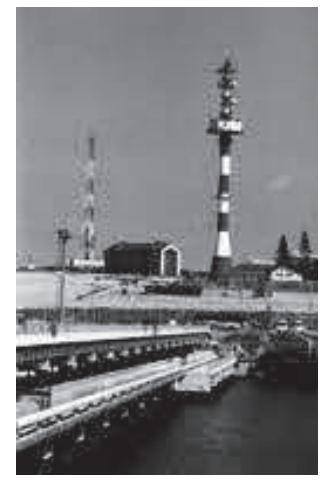

a

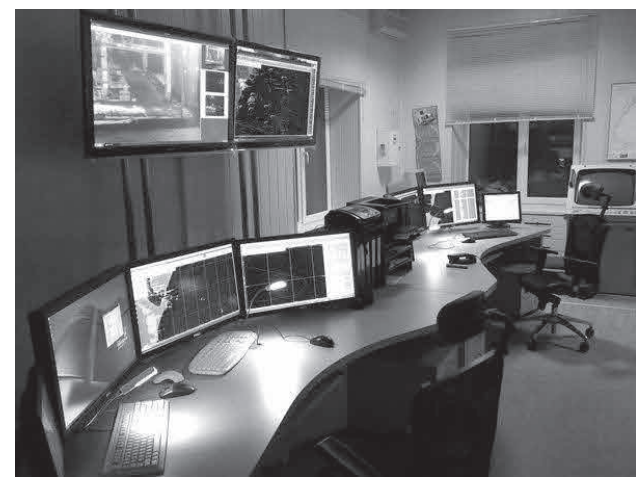

6

Рис. 4.2.1. Компоненты системы управления движением судов на базе программно-аппаратного комплекса Transas Navi-Harbour: a - радиолокационная станция; б - Центр управления СУДС Керченского пролива 
Второй этап развития СУДС связан с разработкой и внедрением специализированных береговых РЛС (БРЛС), которые по сравнению с судовыми РЛС имели ряд усовершенствований: повышенный уровень визуализации радиолокационной информации, выносные и секторные индикаторы, блок формирования электронных меток, с помощью которого на радиолокационном индикаторе индицировалась дополнительная информация. Усовершенствованная аппаратура позволила формировать особые системы управления движением - «радарные цепочки», представляющие собой несколько береговых РЛС, поддерживающих между собой радиосвязь и предназначенных для обслуживания протяженных водных путей с интенсивным движением. Первая такая СУДС была введена в эксплуатацию в 1956 году на Новом водном пути на подходах к Роттердаму (рис. 4.2.2) [50]. Обслуживание судов в режиме радиолокационной проводки выполнялось последовательно, радиолокационные посты передавали обслуживание судов друг другу по цепочке.

Дальнейшее развитие СУДС второго поколения получили с появлением телеуправляемых РЛС, работающих в необслуживаемом режиме, когда пуск в действие и остановка станций производятся дистанционно из оперативного центра. Такие станции обеспечи-

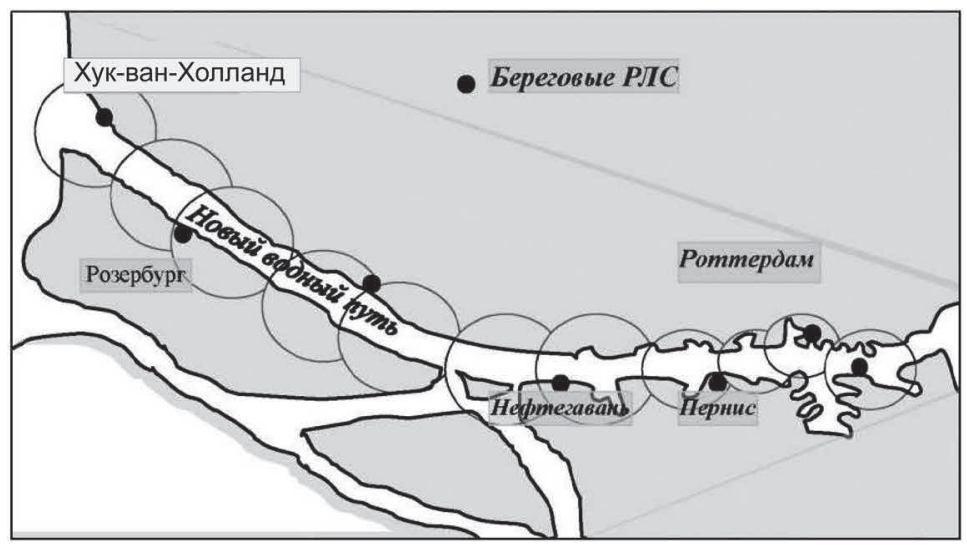

Рис. 4.2.2. Береговые РЛС в структуре СУДС на Новом водном пути (Роттердам) 
вают радиолокационный обзор всей необходимой акватории из одной точки. Первая СУДС с телеуправляемыми РЛС была введена в эксплуатацию в конце 1960 года на Нижней Эльбе в Германии. Вся структура СУДС включала в себя 14 телеуправляемых РЛС. Оперативный центр СУДС располагался в помещении лоцманской службы на территории порта Гамбург.

Успешная эксплуатация СУДС второго поколения выявила их широкие возможности. Возникла необходимость сформулировать общие принципы построения таких систем и уточнить задачи, возлагаемые на них. В 1973 году в Голландии была создана специальная рабочая группа, которая сформулировала эти задачи в общем виде следующим образом: «Система управления и регулирования судоходства прежде всего предназначена для повышения безопасности внутри и вокруг судоходной области. Кроме того, подобную систему следует использовать для более эффективного и экономичного использования инфраструктуры гавани и прилегающих к ней водных проходов» [30].

Бурное развитие мирового судоходства привело к появлению СУДС третьего поколения, автоматизированных СУДС, в которых применяется новейшее радиолокационное и электронное оборудование, быстродействующие ЭВМ, совершенные средства обработки и отображения информации. Автоматизированные СУДС сохраняют общие структурные принципы «радарных цепочек», но представляют собой качественно новый тип систем. Ряд трудоемких задач - автоматическое сопровождение судов по фарватерам с определением их координат, отклонений от установленных курсов, смещений с линии пути, выбор курсов при расхождении с другими судами, предупреждение опасных ситуаций - возлагается на ЭВМ.

Первая автоматизированная СУДС была введена в эксплуатацию в Сан-Франциско в августе 1972 года (рис 4.2.3) [50]. Эта система состояла из оперативного центра на острове Йерба-Буэна и телеуправляемой радиолокационной станции на мысе Бонита. Обработка данных по судам, плавучим средствам навигации и их анализ выполнялась подсистемой автоматического захвата и сопровождения (АЗС), которая могла одновременно обрабатывать 
до 253 целей. Подсистема АЗС освобождает оператора СУДС от «ручного» вычисления параметров движения целей и выбора маневра в случае необходимости предотвращения опасного сближения, а также от необходимости постоянного наблюдения за эхо-сигналами, что в условиях высокой интенсивности движения практически невозможно.

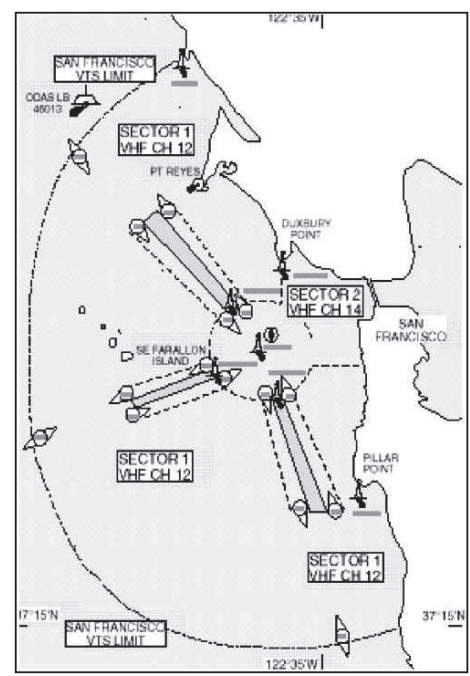

a

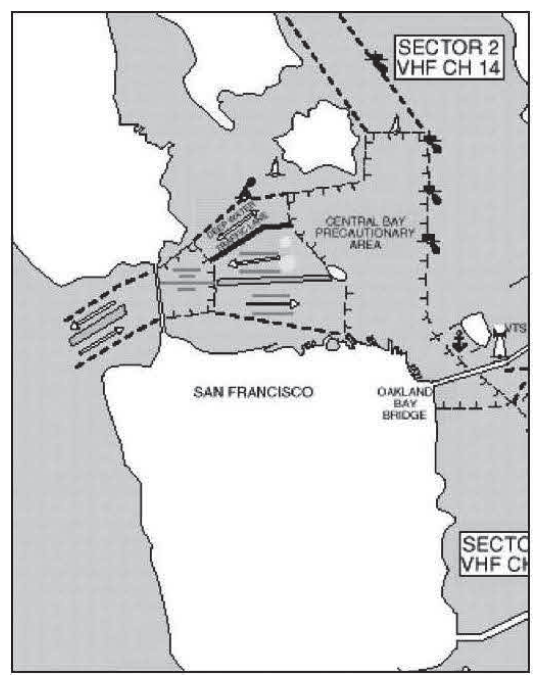

6

Рис. 4.2.3. Зона обслуживания автоматизированной СУДС в районе Сан-Франциско:

a - на подходах к Сан-Франциско; б - в бухте Сан-Франциско

Подсистема АЗС анализирует поступающие радиолокационные сигналы и непрерывно рассчитывает следующие данные: маршрутные координаты судов; их скорость, курс и примерные размеры, время и расстояние кратчайшего сближения между соседними целями. В качестве критерия опасности столкновения принята ситуация, когда суда следуют такими курсами и скоростями, которые приводят к их сближению на расстояние 300 м за время меньше 4 мин. В этом случае срабатывает предупреждающая сигнализация, оператор вмешивается в ситуацию и с помощью определенных процедур устраняет возможные опасные последствия. Подсистема 
АЗС также следит за судами, стоящими на якоре, за плавучими средствами навигационного оборудования (CHO) и при смещении их со штатного места вырабатывает сигнал предупреждения.

За пределами зоны радиолокационного контроля регулирование движения судов осуществлялось с помощью радиодонесений с судов о прохождении ими указанных в правилах плавания участков. Автоматизированный режим работы СУДС обеспечивается с помощью ряда специализированных подсистем.

В 2000 годы начали распространяться СУДС, использующие автоматические идентификационные (информационнье) системь (AИC-AIS). Такая система предполагает использование на судах специальных устройств - транспондеров, передающих на берег по запросу береговой СУДС GPS координаты судна, его название, регистрационные данные и служебную информацию, что значительно упрощает работу диспетчеров.

В последние годы ведутся активные работы по реализации СУДС четвертого поколения, использующие экспертную управляющую систему и систему управления базой данных в реальном масштабе времени. Системы четвертого поколения, кроме обработки визуальной информации, предоставляют оператору для выбора логические решения по оптимальному и безопасному управлению движением судов.

В нашей стране изучение возможностей и целесообразности внедрения СУДС началось в 50-е годы. Первые простейшие системы (первого поколения) были введены в эксплуатацию в УстьКамчатске и Одессе в 1956 году. Они состояли из судовой РЛС «Нептун», аппаратуры УКВ-связи и дополнительного оборудования [6].

Первая СУДС второго поколения была введена в эксплуатацию в 1961 году в порту Ленинград. Она была оснащена специализированной береговой РЛС «Раскат» отечественного производства (рис. 4.2.4, [20]). Связь между БРЛС, судами, портовыми службами и лоцманами поддерживалась по УКВ-радиотелефону на международных частотах. БРЛС «Раскат» работала по запросу, помогая судам проходить по узкой части морского канала в условиях плохой видимости. К 1966 году системы второго поколения, 
основанные на использовании БРЛС «Раскат», начали действовать в портах Жданов, Ильичевск и Мурманск, а в конце 70-х годов был налажен выпуск новых специализированных БРЛС «Океан-М-51». Впервые в мировой практике судовождения в этой станции создано автосопровождение цели и выдача линии относительного движения (ЛОД), применение вычислителя и системы сигнализации о появлении объекта в данном секторе обзора.

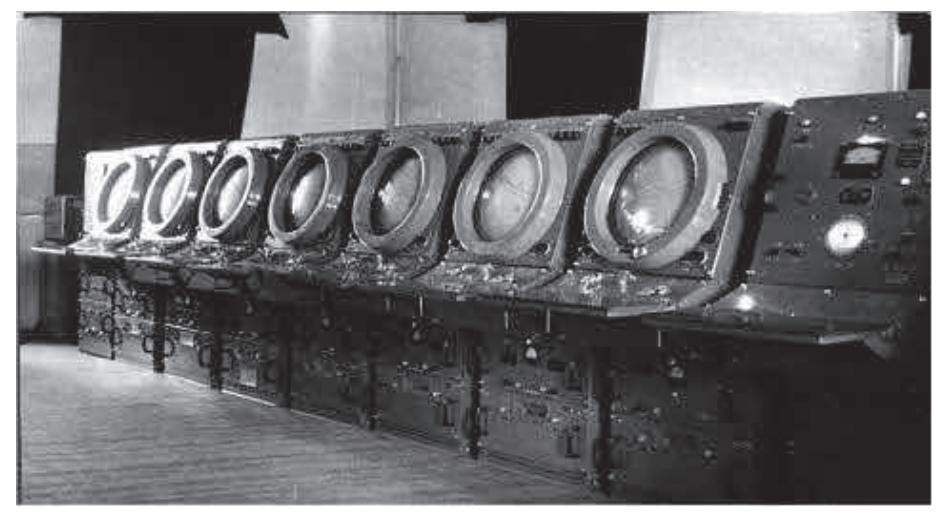

Рис. 4.2.4. Первая береговая радиолокационная станция «Раскат», Ленинградский порт, 1960 год

Система «Раскат» функционировала до своей реконструкции более 40 лет и дала огромный практический опыт для дальнейшей работы. Эффективность внедрения системы «Раскат» показала целесообразность расширения зоны применения СУДС и создания региональных систем, охватывающих подход к нескольким портам. С 1995 года начались работы по проектированию и реконструкции региональных систем безопасности мореплавания в восточной части Финского залива, Кольском заливе, заливе Петра Великого.

Первая отечественная автоматизированная СУДС (система третьего поколения) начала работать в 1980 году в заливе Находка на базе оборудования японской фирмы «OKI Electronics» (рис. 4.2.5) [48]. Год спустя была введена в эксплуатацию централизованная автоматизированная СУДС северо-западного района Черного моря. До конца 80-х годов системами третьего поколения было оборудовано большинство крупных портов нашей страны. 
В начале 1990-х годов АОЗТ «Морские компьютерные системы» приступило к организации и финансированию разработки РЛС, использующих радиоволны миллиметрового диапазона (MMB), гражданского применения «Балтика» (главный конструктор Н. Т. Ничипоренко) взамен устаревших систем «Раскат». Благодаря некоторым особенностям радиоволн этого диапазона возможно создание сверхширокополосных линий связи между наземными службами «земля-космос», «космос-космос». В области радиолокации приемлемые габаритные размеры антенных систем позволяют создать РЛС с высоким разрешением по углу, что дает возможность повысить информативность радиолокационного изображения, а также значительно улучшить точностные характеристики береговых и судовых РЛС. Физические особенности взаимодействия ММВ с атмосферой, гидрометеорами, со структурой неровностей морской и наземной поверхности, растительного покрова позволяют в этом диапазоне создать эффективные РЛС неконтактного измерения характеристик облучаемых объектов и мониторинга.

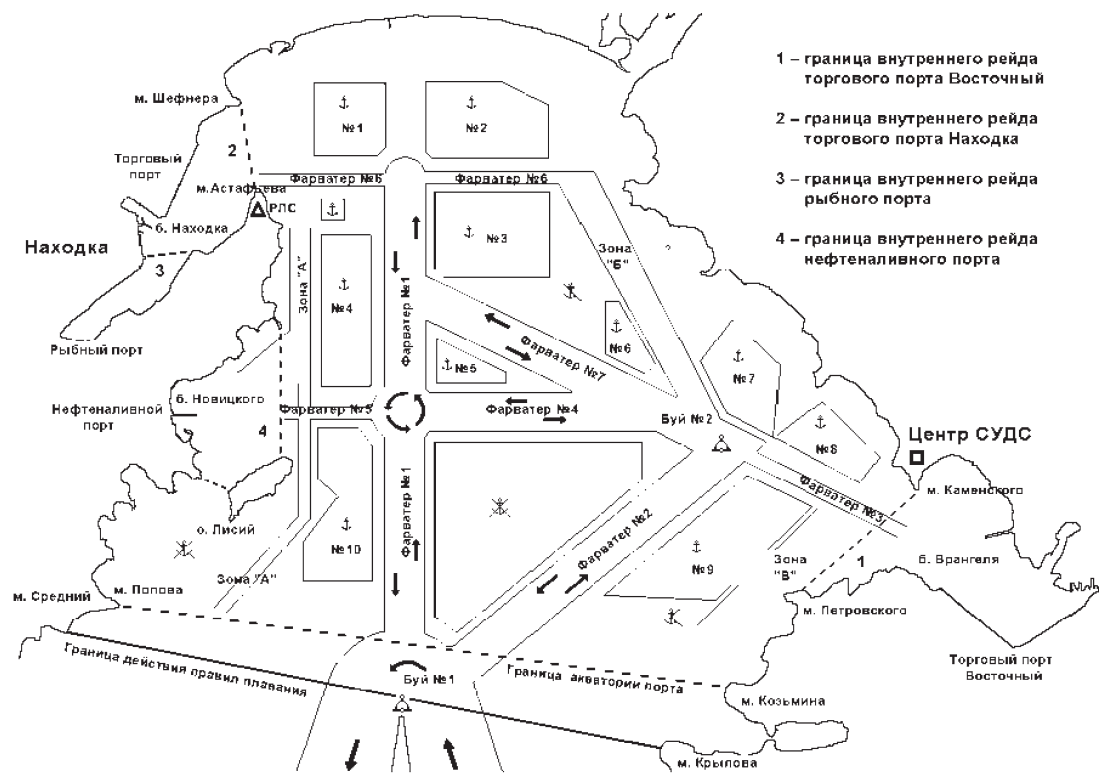

Рис. 4.2.5. Генеральная схема движения в заливе Находка 
Первые четыре образца антенно-приемопередающего устройства (АППУ) РЛС «Балтика-Б» (рис. 4.2.6) изготовлены на научнопроизводственном предприятии «НПП «Модуль», а компьютерный радиолокационный индикатор (КРИ) впервые в России разработан и изготовлен в $3 \mathrm{AO}$ «Морские комплексы и системы» (ЗАО «МКиС») [96].

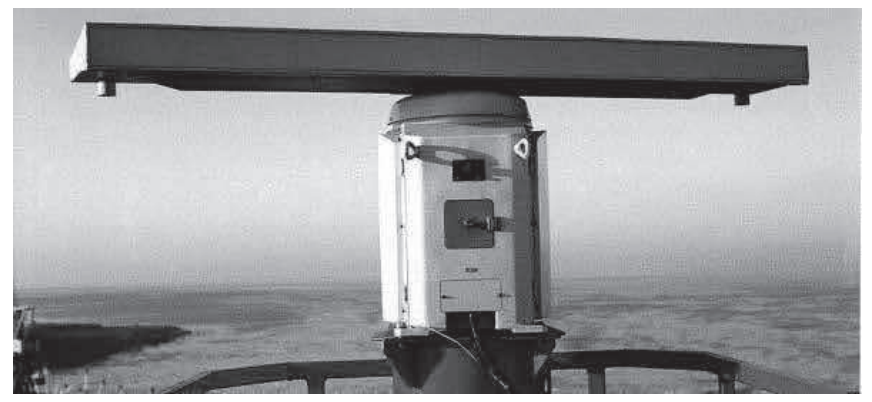

Рис. 4.2.6. Радиолокационная станция морского применения «Балтика-Б»

Первый образец РЛС «Балтика-Б» был установлен в СУДС порта Мурманск в 1996 году. Центр СУДС Кольского залива, на-

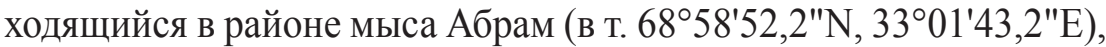
был оборудован БРЛС «Балтика-Б» и «Океан-М51», а также панорамной системой обработки и отображения информации «Балтика», компьютерной системой регистрации КСР-100 и станциями УКВ-связи. В настоящее время СУДС порта Мурманск присвоена высшая категория (рис. 4.2 .7 [67]).

В дальнейшем РЛС «Балтика-Б» были установлены в СУДС портов Санкт-Петербурга, Владивостока, Находки, Калининграда, Кавказа, Темрюка и мыса Тузла, Сочи, Мариуполя, Ейска [128].

В 1998-2000 годах по заказу Европейской комиссии был выполнен проект Vessel Traffic Management and Information ServiceNETwork (VTMIS-NET - Сеть систем управления движением и информационного обеспечения судов), базирующийся на национальных VTIMIS России, Финляндии и Эстонии. В разработке проекта приняли участие 27 фирм и организаций из 11 стран Европейского союза, а также ЗАО «ЦНИИМФ» от России [123]. Реализация проекта позволила ввести в международных водах 
Финского залива обязательную систему судовых сообщений и обеспечить непрерывный мониторинг судов.

В рамках реализации проекта VTMIS-NET в 2001 году Морская администрация порта (МАП) Санкт-Петербург представила госкомиссии первую радиобашню в Старом Петергофе - составную часть региональной системы безопасности мореплавания (РСБМ) в Финском заливе. В настоящее время РСБМ в восточной части Финского залива использует передовые технологии спутниковой

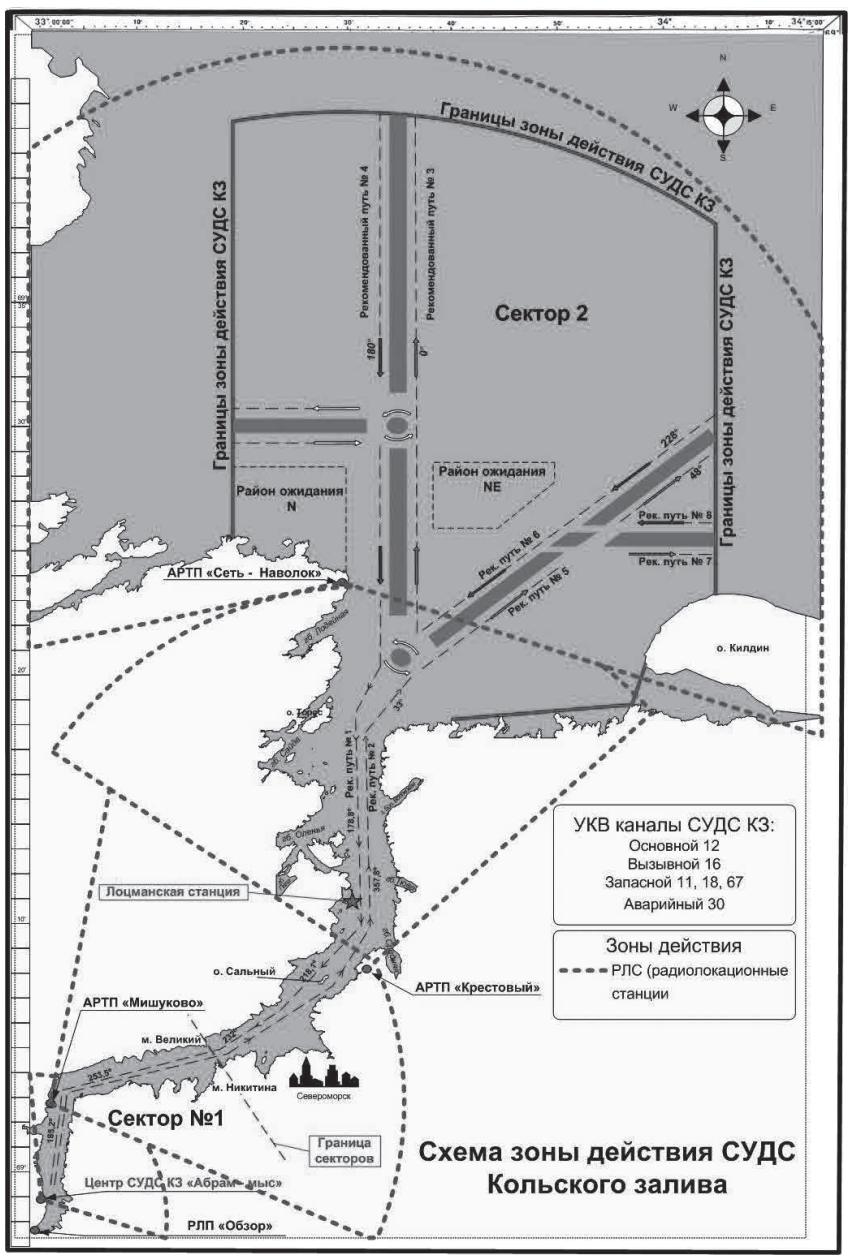

Рис. 4.2.7. Зона действия СУДС Кольского залива 
навигации, радиолокации и информатики. Система обеспечивает мониторинг судов в реальном масштабе времени и обмен любой информацией, необходимой для обеспечения безопасности мореплавания. Функциональные возможности РСБМ позволяют эффективно использовать ее в целях охраны окружающей среды, судов и портовых сооружений при выполнении комплекса антитеррористических мероприятий.

Все положения этой концепции реализованы также в РСБМ Кольского залива, в состав которой вошли объекты в Кольском заливе и на побережье Баренцева моря, в системах безопасности мореплавания в Азово-Черноморском и Каспийском регионах, в заливе Петра Великого, в Калининградском регионе Балтийского моря.

Важным концептуальным положением РСБМ является установление в регионе морских районов (А1 и А2) ГМССБ. Система ГМССБ предназначена для оповещения о бедствии Морского спасательно-координационного центра (МСКЦ) и организации поиско-спасательных операций в регионе с минимальными затратами времени. Характерным примером района А1 ГМССБ является Кольский залив (рис. 4.2.8 [33]).

Зона действия района А1 ГМССБ в Кольском заливе включает следующие элементы:

- базовые станции, установленные на Абрам-мысе;

- автоматизированный радиотехнический пост (АРТП) на мысе Крестовый;

- АРТП на мысе Сетьнаволок;

- Центр управления и МСКЦ.

Значительный успех в организации управления движением судов, несмотря на все трудности, переживаемые страной в 90-е и нулевые годы, был достигнут в портах залива Петра Великого. Региональная СУДС залива Петра Великого, образованная на основе информационной интеграции и координированной деятельности модернизированных и расширенных СУДС во Владивостоке и Находке, была введена в эксплуатацию в середине 2006 года. Район действия региональной СУДС распространяется на внутренние 


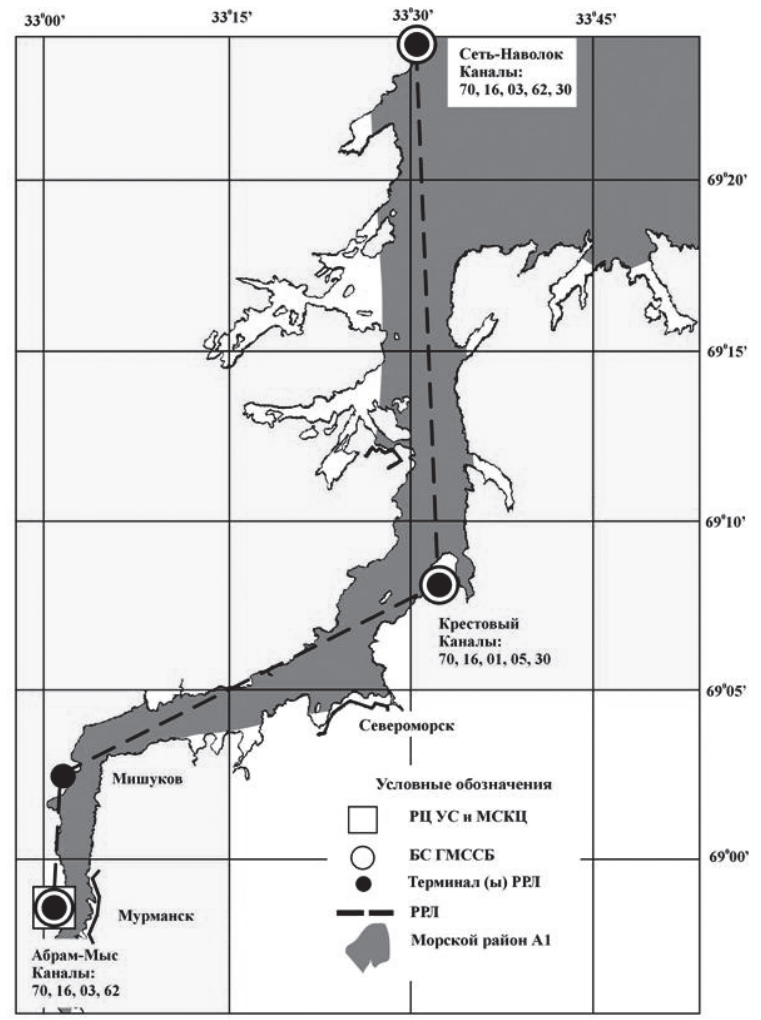

Рис. 4.2.8. Зона действия района А1 ГМССБ в Кольском заливе

морские воды залива Петра Великого и прилегающее территориальное море Российской Федерации и подразделяется на пять секторов (рис. 4.2.9) [68].

Региональная СУДС обеспечивает контроль, организацию и регулирование движения судов в портах Владивосток, Находка, Восточный, Посьет, Зарубино, Славянка и на подходах к ним. В середине 2006 года региональная СУДС залива Петра Великого была сертифицирована на высшую категорию и признана одной из лучших в России. Знания и опыт, накопленные управляющей Региональной СУДС компанией «Норфес», в дальнейшем были использованы при организации управления движением на современных принципах во всех портах нашей страны и послужили 


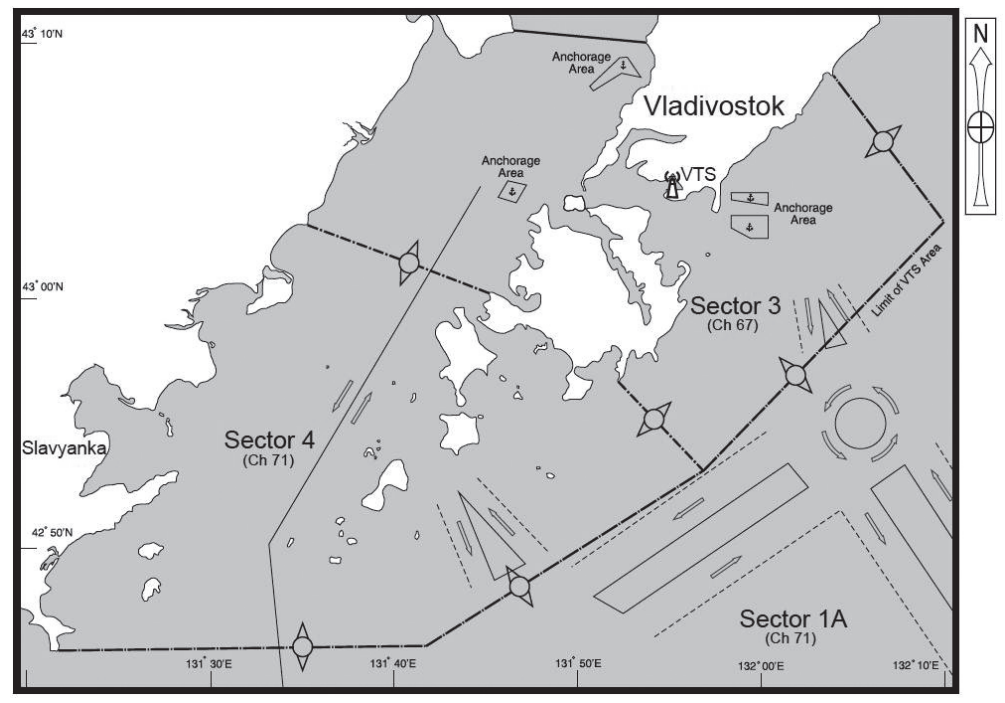

Рис. 4.2.9. Региональная СУДС залива Петра Великого

основой нового отраслевого стандарта. Этот опыт был воспринят и при создании Группой «Транзас» (Transas, TRANsport SAfety Systems - Системы безопасности на транспорте) новой отечественной СУДС Navi-Harbour («НАВИ-ХАРБОР») - системы мирового уровня, внедренной в настоящее время в крупнейших портах нашей страны и целого ряда зарубежных стран (рис. 4.2.10).

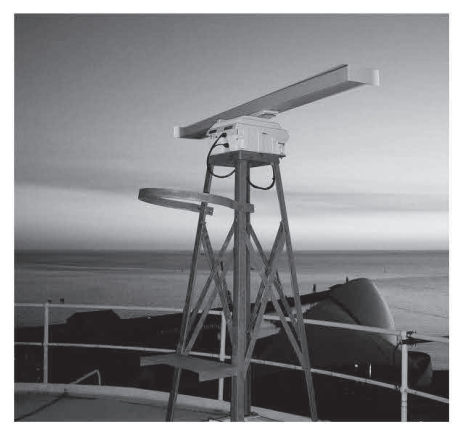

a

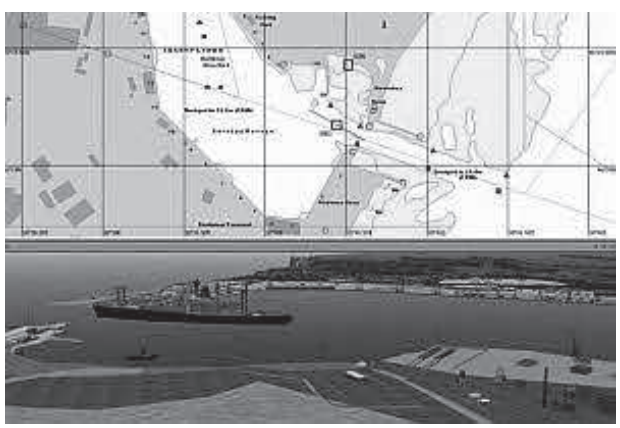

6

Рис. 4.2.10. Элементы системы СУДС Transas Navi-Harbour:

a - пост наблюдения [110]; б - визуализация акватории с помощью модуля визуализации 3D СУДС [118] 
B аппаратно-программном комплексе Navi-Harbour впервые использована опция 3D-видеоизображения движения судов. Этот инструмент, основанный на данных СУДС, поступающих в режиме реального времени, позволяет оператору следить за навигационной ситуацией с разных ракурсов. В результате качество информации, которая поступает непосредственно лоцману, было улучшено, что на практике позволило осуществить ряд лоцманских проводок в условиях нулевой видимости [110].

Обобщенная структура СУДС Transas Navi-Harbour изображена на рисунке 4.2.11 [110]. К операторскому дисплейному модулю (ОДМ, operator display unit) системы Navi-Harbour подключается радар (radar) и ряд дополнительных устройств (необязательных optional), например, телекамеры и датчики погодных условий. На каждом ОДМ отображается морская карта, собираются данные устройств, выводятся тревоги (предупреждения столкновений, сообщения об ошибках устройств и прочие) и другая информация, имеющая отношение к безопасности движения.

В 2008 году компания «Транзас» завершила создание Региональной информационной системы наблюдения за судоходством в Азово-Черноморском и Каспийском регионах на базе системы управления движением судов порта Туапсе (рис. 4.2.12) [68].

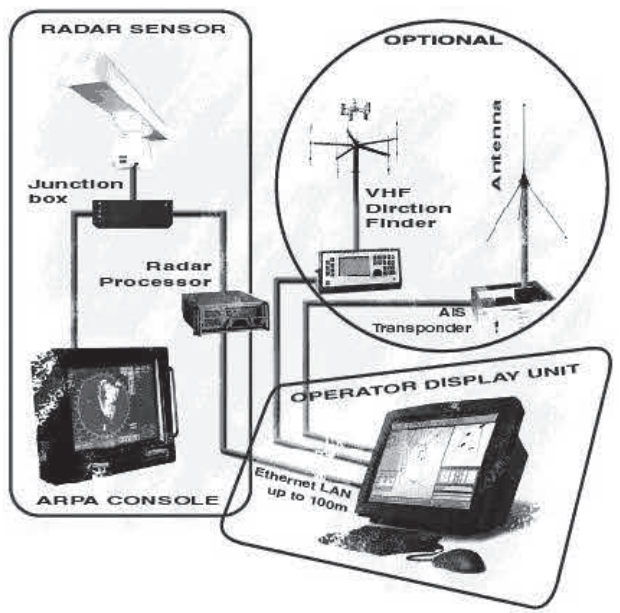

Рис. 4.2.11. Обобщенная структура СУДС Transas Navi-Harbour 
Региональная информационная система наблюдения за судоходством (РИСС) в Азово-Черноморском и Каспийском регионах включает в себя Центр сбора, обработки, хранения и анализа информации в порту Туапсе и 12 источников информации АИС в СУДС портов Новороссийск, Туапсе, Сочи, порт Кавказ, Таганрог, Ейск, Астрахань. Ядром системы наблюдения за судоходством является программное средство визуализации сети базовых станций АИС для мониторинга, опционального воспроизведения и анализа данных [45].

Другим направлением обеспечения безопасности судоходства на внутренних водных путях является развитие электронных систем. Это создание электронных навигационных карт (ЭНК), которые уже разработаны для Единой глубоководной системы, создание системы АИС в рамках Федеральной целевой программы (ФЦП) «Поддержание, развитие и использование системы ГЛОНАСС на 2012-2020 годы», которая предусматривает расширение внедрения и использования отечественных спутниковых навигационных технологий и услуг с использованием системы ГЛОНАСС в интересах специальных и гражданских (в том числе коммерческих и научных) потребителей, международного использования российских технологий спутниковой навигации за счет поддержания и развития системы ГЛОНАСС [85].

Следующим шагом повышения эффективности Региональной системы безопасности мореплавания в России стало поэтапное создание Единой системы контроля и управления судоходством (ЕСКУС). Создание ЕСКУС соответствует Федеральной целевой программе «Мировой океан», предусматривающей, в частности, создание единой общегосударственной системы информации об обстановке в Мировом океане, основанной на отраслевых и ведомственных системах информации, в том числе Министерства транспорта Российской Федерации. Технической основой ЕСКУС является информационная интеграция СУДС, систем АИС, систем радиосвязи и судовых сообщений в Морских районах A1/A2/A3 ГМССБ, а также Морской дифференциальной подсистемы ГНСС ГЛОНACC/GPS. Такая информационная интеграция, выполненная для одного отдельного порта (на локальном уровне), позволяет 


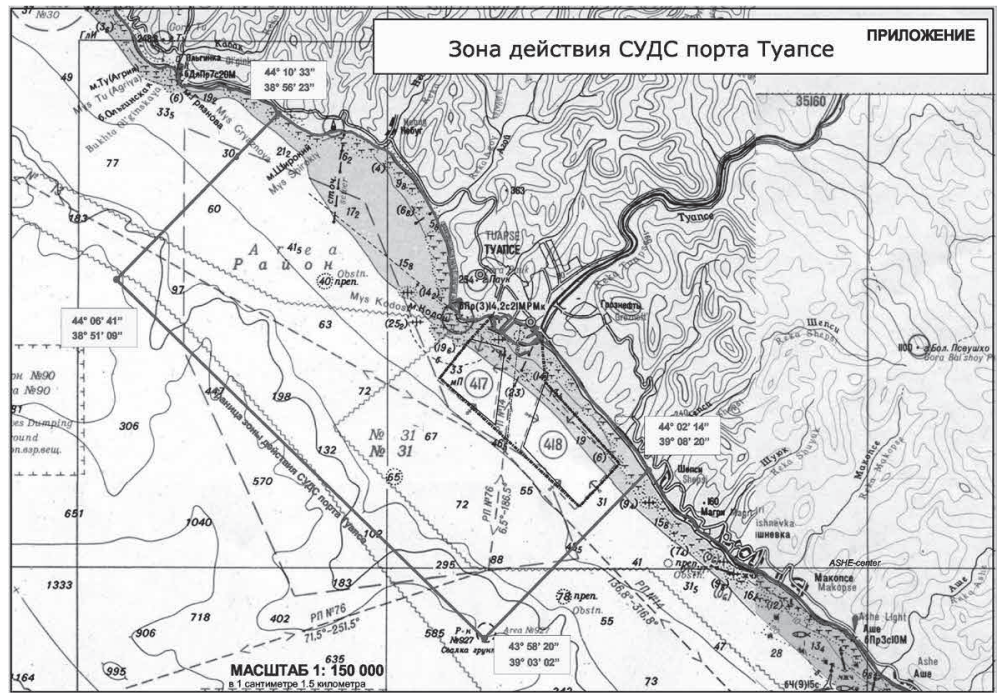

Рис. 4.2.12. Зона действия СУДС морского порта Туапсе

сформировать Локальную ЕСКУС [27]. Образование ЕСКУС более высоких уровней (регионального, бассейнового и национального) обеспечивается информационным обменом между элементами ЕСКУС различных уровней.

Важной составной частью ЕСКУС является система информационного обеспечения государственного контроля судоходства, основными функциями которой являются:

- предоставление информации государственным структурам, обеспечивающим контроль над судоходством на локальном, региональном, бассейновом и национальном уровнях;

- предоставление всем участникам транспортного процесса открытой информации по вопросам безопасности мореплавания и государственного контроля судоходства;

- участие морского транспорта РФ в обмене информацией в рамках международного сотрудничества.

Создание системы информационного обеспечения государственного контроля судоходства в составе ЕСКУС обусловливается рядом документов ИМО, которые обязывают Морские администрации государств - членов ИМО осуществлять эффективный 
контроль над техническим состоянием судов, квалификацией экипажей и охраной окружающей среды.

Уже созданы региональная система безопасности мореплавания Финского залива (РСБМ Финского залива), морского порта Калининград (региональная информационная система наблюдения за судоходством на Северо-Западе - РИСС Северо-Запада), морских портов Мурманск и Архангельск (РИСС Севера), морских портов Кавказ, Новороссийск, Сочи, Таганрог и Туапсе (РИСС Юга) и морского порта Владивосток (РИСС Востока), с привязкой судна к базам данных РСБМ Финского залива, к базам данных СУДС морских портов Архангельск и Мурманск и системам судовых сообщений, а также с привязкой к международным базам данных по судам ITU и INMARSAT. По базам данных РИСС Юг и РИСС Восток привязка судна осуществляется только к международным базам данных по судам ITU и INMARSAT.

Помимо объединенных в единую сеть РИСС Северо-Запад и РИСС Азово-Черноморского региона, в Российской Федерации действует значительное число базовых станций АИС, имеющих локальные пункты сбора, обработки, хранения и визуализации данных в рамках действующих СУДС и диспетчерских систем управления движением на внутренних водных путях. Объединение локальных АИС в сети и интеграция сетей АИС позволит организовать региональные центры сбора и обработки данных для создания единой Российской автоматизированной системы управления транспортными потоками.

Объединение локальных АИС Азово-Черноморского региона в единую сеть - первый этап международного проекта по созданию общего сервера сетей базовых станций АИС стран Черноморского побережья, реализация которого позволит получить интегрированную картину обстановки в Черноморском регионе. Для этого необходимо объединить данные, поступающие со всех базовых станций АИС, находящихся не только в России, но и в сопредельных странах: Грузии, Турции, Болгарии, Румынии, Украины [46].

В перспективе - создание единой международной информационной системы наблюдения за судоходством в портах мира. 
В частности, ведутся международные консультации на уровне министерств транспорта РФ и Турции об организации системы обмена данными АИС между национальными информационными системами безопасности мореплавания обеих сторон.

Сегодня РИСС Северо-Запад подключена к международной системе обмена информацией АИС с Балтийскими странами «АИСХелком», создана российско-финско-эстонская интегрированная информационная система контроля и управления судоходством Финского залива.

Данные от подключенных базовых станций АИС объединяются и отправляются по каналу VPN (Virtual Private Network защищенная виртуальная сеть) на центральный сервер Хелком (Швеция). Принимаемые от центрального сервера Хелком данные передаются на программу web-визуализации, которая позволяет клиентам получать оперативную информацию о расстановке и местоположении судов через Интернет с использованием обычного интернет-браузера. Информация через систему судовых сообщений направляется морским администрациям Эстонии и Финляндии на взаимной основе.

Дальнейшее развитие систем РИСС Северо-Запада и РИСС Юга включает подключение к сети обмена информацией по безопасности мореплавания стран Евросоюза SafeSeaNet.

Сеть SafeSeaNet - это информационная интеллектуальная система безопасности мореплавания Европейского союза, предназначенная для обмена данными и стандартизации основной информации, имеющейся на судах (под всеми флагами), и информации об их грузе, а также для обеспечения точной картины движения в прибрежных водах Европейского союза с усовершенствованным мониторингом прохождения судов (местоположение уточняется каждые 6 минут) [142]. Сеть SafeSeaNet представляет собой береговую сеть Европейского союза станций АИС, получающих с судов радиосообщения для автоматической идентификации (бортовые АИС), и систем обязательной передачи данных (рис. 4.2.13). Разработка сети ведется с 2004 года [140]. 


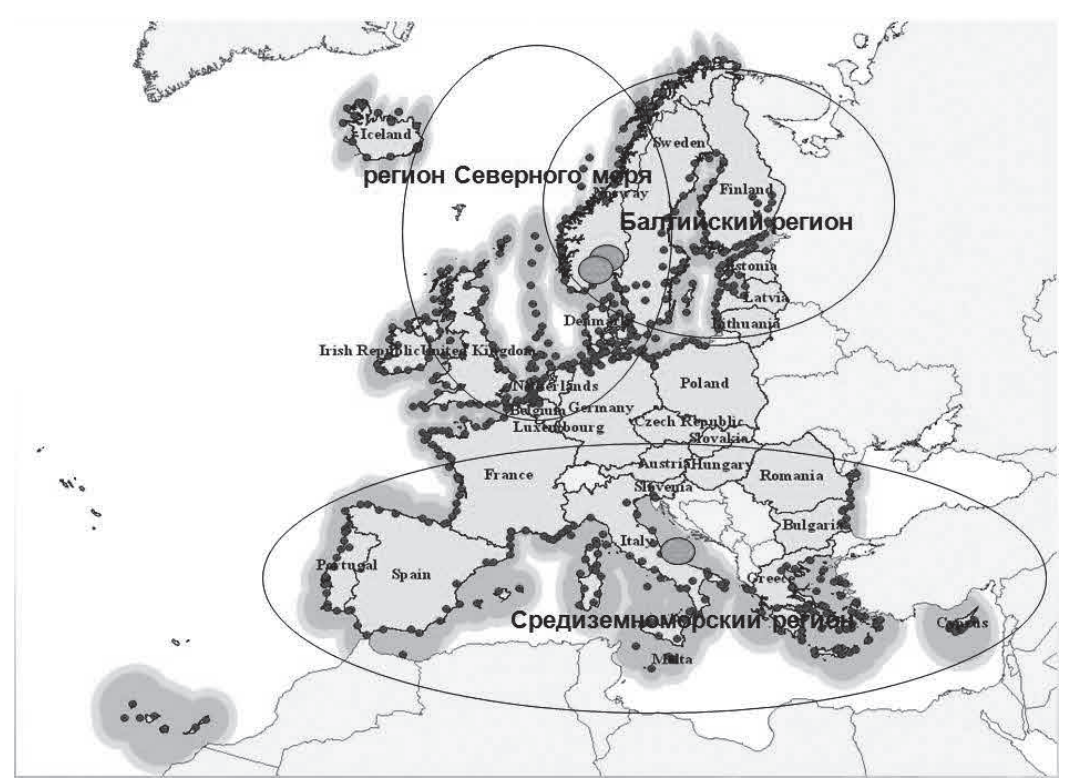

Рис. 4.2.13 - Береговые станции АИС сети SafeSeaNet Европейского союза

Сейчас наша страна располагает лишь разрозненными региональными СУДС. После создания интегрированной информационной сети, которая объединит морские спасательно-координационные центры страны, федеральная СУДС будет доступна всем ведомствам, заинтересованным в безопасности судоходства, а также в предотвращении экологических катастроф на море.

\section{3. Состав и принципы функционирования систем управления движением судов}

Системь управления движением судов (СУДС, англ. VTS Vessel Traffic Service) создаются и функционируют в соответствии с правовыми нормами, разрабатываемыми Международной морской организацией (ИМО). В соответствии с определением Резолюции ИМО А857 (20) и Международной конвенции по охране человеческой жизни на море (СОЛАС) СУДС создаются в целях охраны человеческой жизни на море, безопасности и эффективности судоходства, а также защиты окружающей среды. Правительства 
прибрежных государств обязуются создавать СУДС там, где, по их мнению, достаточно высоки интенсивность судоходства или степень риска аварий.

В России СУДС являются частью Государственной системы обеспечения безопасности мореплавания, создаются и действуют на акваториях морских портов и на подходах к ним, во внутренних морских водах, в территориальном море и прилежащей зоне. Панорамный вид СУДС в Новороссийске, имеющей высшую категорию, показан на рисунке 4.3.1 [109].

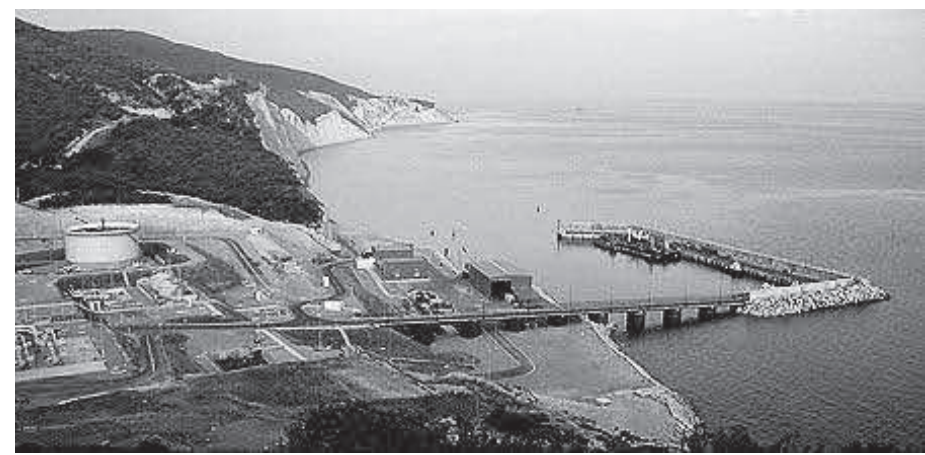

Рис. 4.3.1. Система управления движением судов в Новороссийске

Функционирование СУДС определяется следующими основными нормативно-правовыми документами:

- Конвенция СОЛАС-74 (правило 12 в новой редакции главы 5);

- Резолюция ИМО А. 857(20) «Руководство по СУДС» (1997);

- документ МАМС «Руководство МАМС по СУДС» (1998);

- документ МАМС «Рекомендации по стандартам подготовки и сертификации персонала СУДС» (Рекомендации МАMC V-103) (1998).

Наивысшим статусом среди этих документов обладает Конвенция СОЛАС-74, в правиле 12 которой говорится, что «СУДС способствует безопасности человеческой жизни на море, безопасности и эффективности судовождения и защите морской окружающей среды прилегающих береговых районов, мест проведения работ и морских сооружений от возможного неблагоприятного воздействия морского судоходства». 
К основным функииям СУДС относятся:

- «способность взаимодействовать с судоходством и осуществлять ответные действия на судоходные ситуации» - эта функция определена ИМО и МАМС как основная функция СУДС;

- организация и регулирование судоходства на акваториях портов и на подходах к ним, а также в стесненных водах, контроль за соблюдением правил и режимов плавания;

- обеспечение безопасности мореплавания в сложной навигационной, метеорологической и гидрологической обстановке;

- защита окружающей среды за счет снижения риска аварий и разливов нефтепродуктов;

- содействие в работе портовых служб (лоцманских, буксирных, диспетчерских и других), поисково-спасательных операций и операций по борьбе с разливами нефтепродуктов;

- контроль судоходства в прибрежных водах в интересах государства, информационное обеспечение пограничных и таможенных режимов.

СУДС предназначены для решения следующих основных задач:

- получение информации о навигационной обстановке от различных сенсоров;

- обобщение данных о целях и представление их в табличном виде и графически в сочетании с многослойными электронными картами;

- оперативный контроль за движением судов;

- планирование графика движения судов;

- анализ навигационной ситуации и выдача сигнала тревоги и предупреждения в соответствии с задаваемыми оператором критериями;

- предоставление вспомогательной навигационной и прочей информации;

- цифровая запись данных всей навигационной ситуации для последующего воспроизведения.

Типовая структура СУДС включает Центр управления движением судов (ЦУДС), с которым связаны удаленные информационные посты, где располагаются различные источники информации о судоходной обстановке и средства связи (рис. 4.3.2). 


\begin{tabular}{|c|c|c|c|c|}
\hline \multicolumn{5}{|c|}{ Источники информации о судоходной обстановке } \\
\hline РЛС & $\mathrm{CCC}$ & АИС & ТВH & ЭКС \\
\hline Радиоло- & УКВ-систе- & Автома- & Телевизи- & Электрон- \\
\hline кационные & мы судовых & тические & онные & ные карто- \\
\hline системы & сообщений & $\begin{array}{l}\text { идентифи- } \\
\text { кационные }\end{array}$ & системы & $\begin{array}{l}\text { графиче- } \\
\text { ские }\end{array}$ \\
\hline & & системы & & системы \\
\hline
\end{tabular}

Рис. 4.3.2. Источники информации СУДС

Поступающая информация обрабатывается и анализируется в ЦУДС, здесь принимаются управляющие решения и осуществляется взаимодействие с судами. Обработка информации в СУДС, как правило, полностью автоматизирована и выполняется компьютерами общего или специального назначения. В результате обработки информации формируется картина судоходной обстановки, которая отображается на ситуационных дисплеях.

Элементы структуры системы управления движением судов представлены на рисунке 4.3.3. Технологическую основу СУДС составляют:

- береговые радиолокационные станции (РЛС);

- системы автоматической обработки радиолокационной информации;

- телевизионные системы наблюдения;

- средства ОВЧ (УКВ)-радиосвязи с судами;

- радиопеленгаторы;

- радиорелейные линии связи;

- вычислительные сети и сети передачи данных;

- электронная картография;

- автоматические идентификационные (информационные) системы (АИС).

Радиопеленгаторы используются для определения местоположения судна и его идентификации.

Транспондеры АИС передают данные о судне и его грузе, пассажирском составе, маршруте плавания, времени прибытия и другую информацию в ЦУДС. 


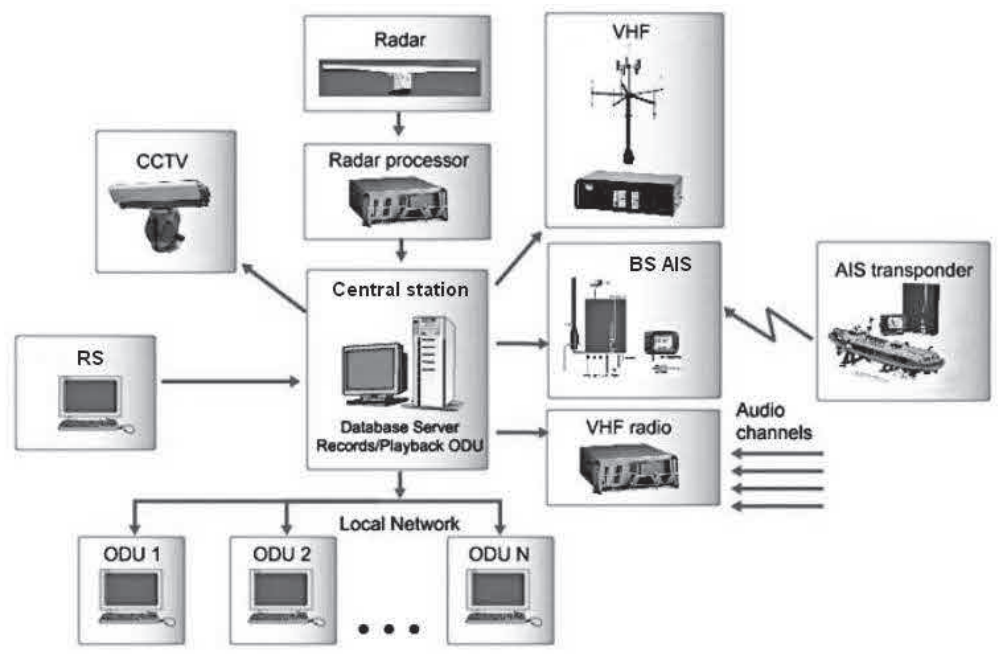

Рис. 4.3.3. Элементы типовой структуры СУДС (VTS):

AIS transponder - транспондер АИС;

Audio channels - звуковые каналы связи;

BS AIS - базовая станция АИС;

CCTV - управляемые телекамеры;

Control Centre - Центр управления движением судов;

Local Network - локальная сеть;

ODU - операторские дисплейные модули;

$\mathrm{RS}$ - удаленные информационные посты;

VHF - радиопеленгатор

УКВ-радиостанциии позволяют вести переговоры с судами.

Телекамеры предназначены для визуального наблюдения за судами в акватории порта.

Метеостанции позволяют получать данные о погоде (температуре, влажности, силе ветра).

Paдарные процессоры преобразуют сигналы от радара в цифровой вид, производят их обработку и выделение цели.

Система связи и передачи данных (ССПД) включает радиорелейные или волоконно-оптические линии связи, цифровые радиорелейные станции, модемы, радиомодемы и другое оборудование.

К операторскому дисплейному модулю (ОДМ) подключается радар и ряд дополнительных устройств, например, телекамеры 
и датчики погодных условий и других. На каждом ОДМ отображается морская карта, данные параметров устройств, выводятся тревоги (предупреждения столкновений, сообщения об ошибках устройств) и другая информация, имеющая отношение к безопасности движения судов.

Сервер базы данных в составе ЦУДС содержит базы данных по судам.

Управляющими звеньями СУДС являются операторы, которые анализируют судоходную обстановку, оценивают и прогнозируют ее развитие. Операторы СУДС посредством ОВЧ (УКВ)-радиосвязи передают на суда информацию, предупреждения, рекомендации и указания, обеспечивающие безопасное и эффективное судоходство в районе действия СУДС.

Комплект аппаратуры СУДС - это территориально распределенная система, включающая аппаратуру автономного радиотехнического поста (АРТП), которая размещается в специализированных контейнерах или капитальных сооружениях (автономная подсистема), и пульт рабочего места оператора (PMO), установленного в помещении ЦУДС. Пульт РМО и посты АРТП могут быть удалены друг от друга на расстояние до 30 километров и связаны системой связи и передачи данных (ССПД). Внешний вид оборудования СУДС представлен на рисунке 4.3.4.

Основными службами VTS (СУДС), в соответствии с Резолюцией A.857(20) и IALA VTS Manual, являются службы информации, организации движения, помощи в судовождении.

Служба информации обеспечивает своевременную передачу на суда важной информации, необходимой для принятия на борту судна решения в отношении дальнейшего плавания. Эта информация включает координаты, намерения и пункты назначения судов; поправки и изменения в опубликованной ранее информации, касающейся работы СУДС, такой как границы зоны обслуживания, радиоканалы, частоты, точки передачи сообщений; навигационные и гидрометеорологические условия плавания, состояние $\mathrm{CHO}$, интенсивность движения, данные об ограничениях и помехах для судовождения. 


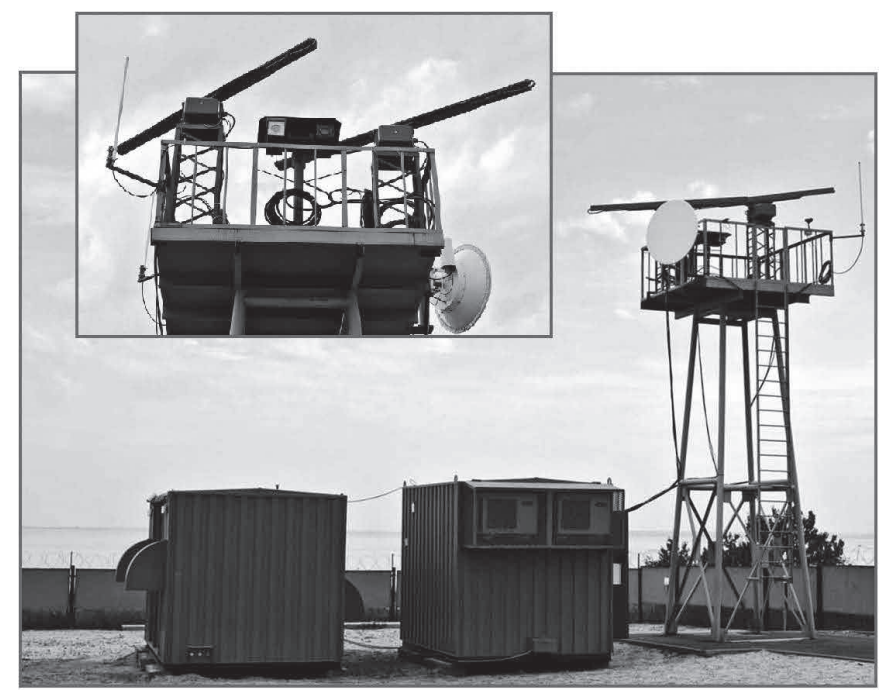

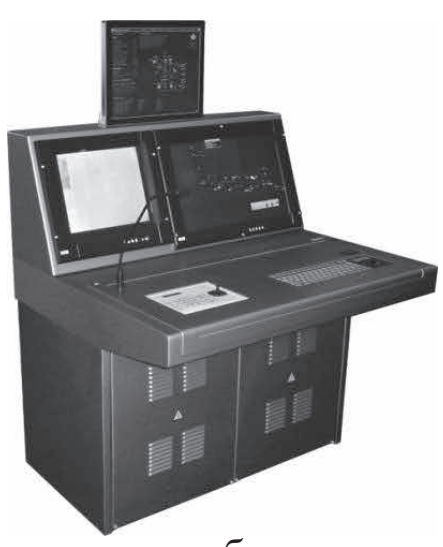

6 a

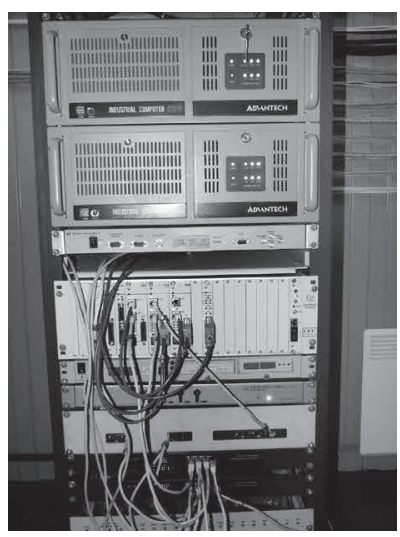

B

Рис. 4.3.4. Оборудование системы управления движением судов:

a - аппаратура автономного радиотехнического поста;

б - пульт рабочего места

оператора; в - аппаратура обработки данных, аппаратура связи и передачи данных

Служба организащии движения предназначена для предотвращения развития опасных ситуаций и обеспечения безопасного и эффективного судоходства в районе VTS (СУДС). Эта служба использует наблюдения за навигационной обстановкой и базируется 
на соблюдении правил плавания, планировании и регулировании движения судов.

Служба движения действует на основе следующих процедур:

- установление и эксплуатация СРД, системы сообщений с судов в особых случаях плавания и движения, установление порядка и (или) приоритетов движения судов;

- составление графика прохода судов через специальные районы;

- установление путей и скоростей движения;

- назначение мест якорных стоянок;

- организация движения путем выдачи рекомендаций или указаний.

Служба помощи в судовождении содействует принятию на судне решений по судовождению и контролю результатов этих решений. Помощь в судовождении оказывается или по запросу с судна, или, если VTS (СУДС) сочтет это необходимым (как правило, в сложных гидрометеорологических условиях), или при аварийном состоянии судна. Решение выносится на основании предоставления судну необходимой навигационной информации:

- путевой угол и путевая скорость судна;

- положение судна в маршрутных координатах;

- координаты и намерения окружающих судов.

Кроме передачи навигационной информации, может быть предусмотрена выдача рекомендаций по судовождению и предупреждений для отдельных судов.

По назначению и особенностям района действия СУДС подразделяются на следующие категории:

- nopmoвые, действующие на акваториях портов и на подходах к ним;

- речные, действующие на внутренних водных путях, на подходах к портам, расположенным на реках и в эстуариях;

- прибрежные, осуществляющие контроль за судоходством в территориальных водах прибрежных государств или в международных проливах.

Район действия портовой СУДС включает акваторию обслуживаемого порта и основные пути движения судов на подходе к 
порту. Район действия прибрежной СУДС включает акваторию, расположенную во внутренних водах, территориальном море и прилежащей зоне РФ с расположенными на ней транзитными путями движения судов, районами промысла морепродуктов и добычи полезных ископаемых на шельфе. Резолюция A857(20) требует четко различать портовые VTS и прибрежные VTS с точки зрения обеспечиваемых служб и выполняемых функций. Для nортовых VTS (СУДС) основной является служба организации движения. Для прибрежной VTS (СУДС) может оказаться достаточной только служба информации.

По размерам района действия и особенностям организации СУДС подразделяются на локальные, обслуживающие ограниченные акватории, небольшие участки побережья или внутренних водных путей, и региональные, обслуживающие акватории протяженностью в десятки и сотни миль.

Региональная СУДС образуется на основе информационной интеграции и координированной деятельности нескольких портовых или портовых и прибрежных СУДС. Район действия региональной СУДС является совокупностью районов действия портовых и прибрежных СУДС. В настоящее время в России функционируют десять СУДС, имеющих в своем составе береговые РЛС, АИС, радиорелейные линии, аппаратуру связи и другое оборудование. Например, крупнейшая на северо-западе РФ Региональная система безопасности мореплавания (РСБМ) восточной части Финского залива предназначена для комплексного решения задач эффективности и безопасности судоходства, обеспечения государственного контроля судоходства на акватории Финского залива (рис. 4.3 .5 [103]).

Система обеспечивает мониторинг судов в реальном масштабе времени и обмен информацией, которая необходима для обеспечения безопасности мореплавания. Функционирование системы базируется на следующих компонентах:

- навигационно-гидрографическое обеспечение (НГО) мореплавания через использование установленных путей движения судов (систем разделения движения, рекомендованных путей, фарвате- 
ров, специальных районов и др.), а также средств навигационного оборудования;

- Региональная система управления движением судов (РСУДС), обеспечивающая контроль соблюдения режима плавания и организацию движения судов с помощью береговых служб на всем протяжении судоходных путей в российской части Финского залива;

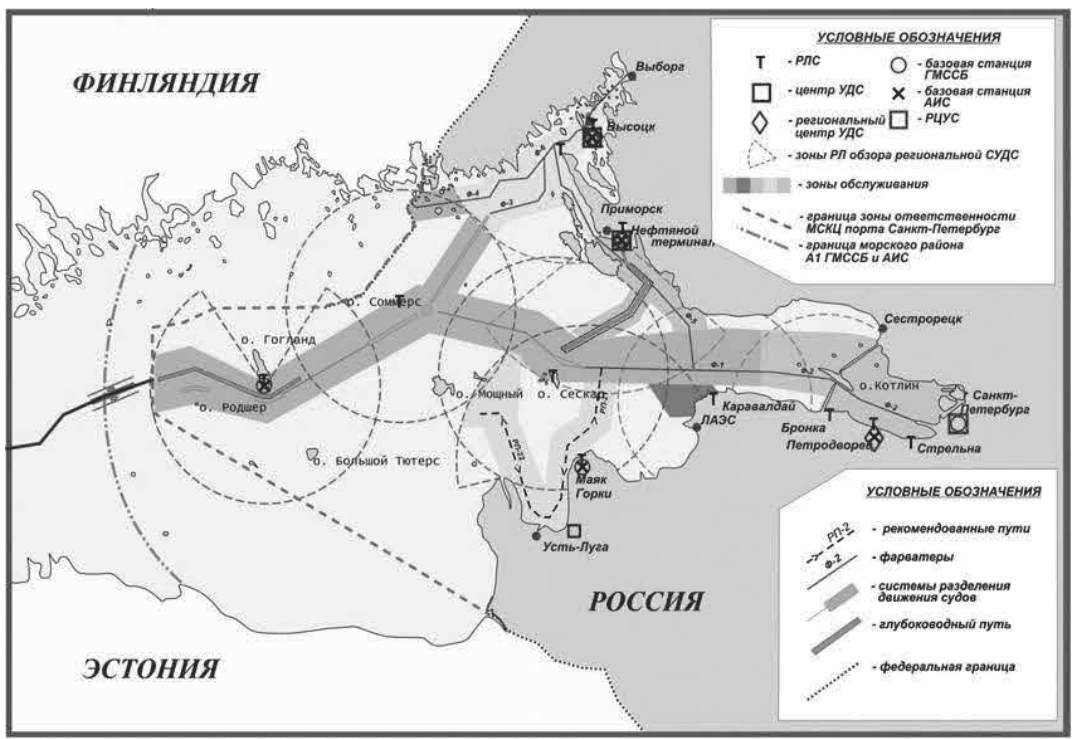

Рис. 4.3.5. Региональная система безопасности мореплавания в восточной части Финского залива

- контрольно-корректирующая станция морской дифференциальной подсистемы Глобальной навигационной спутниковой системы ГЛОНАCC/GPS, обеспечивающей высокоточное (до 10 м с вероятностью 95 \%) местоопределение судов;

- система ГМССБ, районы А1 и А2 которой покрывают всю восточную часть Финского залива;

- участие в международной Системе судовых сообщений Финского залива GOFREP.

РСБМ включает около 20 автоматизированных дистанционно управляемых автоматических радиотехнических постов (ДУ 
АРТП), связанных между собой радиорелейными линиями, 17 из которых расположены на радиобашнях, совмещенных с маяками. РСБМ включает в себя радиолокационные посты в Старом Петергофе, в здании филиала МАП в Приморске, на острове Котлин и полуострове Карвалдайский, СУДС в Усть-Луге и Высоцке, радиобашни на островах Сескар, Соммерс и Гогланд.

Оборудование, установленное на автоматизированных постах, управляется из Регионального центра управления связью (СанктПетербург) и из Регионального центра УДС в Петродворце. Большое значение имеет установление в регионе ГМССБ Морского спасательного координационного центра (МСКЦ) для обеспечения автоматического оповещения о бедствии и для обмена информацией при поисково-спасательных операциях или аварийных разливах нефти.

Техническая сложность РСБМ определяется установкой оборудования более чем на 20 объектах, включая:

- систему управления движением судов;

- сеть радиорелейных линий и мультиплексоров;

- устройства энергообеспечения и жизнеобеспечения объектов;

- систему мониторинга для дистанционного контроля состояния оборудования на объектах;

- оборудование распределенной базы данных для сбора, обмена и обработки информации по судовому потоку;

- оборудование метеостанций, мареографы, телевизионные камеры;

- береговые станции АИС.

Общая сумма бюджета всех технологических систем составила более 17 миллионов долларов (без учета строительства башен) [13]. На западе РСБМ будет соединяться с зонами АИС стран Балтийского моря. Интеграция РСБМ с аналогичными системами Финляндии и Эстонии позволит значительно снизить риск аварий судов в Балтийском море.

На современном этапе развития СУДС, при условии существенного улучшения характеристик СУДС за счет внедрения новых технологий, возникает возможность введения новой функции 
«радиолокационной проводки», выполняемой из оперативного Центра СУДС опытным лоцманом-оператором ЭВМ. Радиолокационная проводка обеспечивается сообщением капитану позиции судна относительно согласованного маршрута, оси судового хода и других параметров движения с рекомендациями или указаниями. Непосредственные команды на маневры дает капитан судна.

Радиолокационная проводка в зоне действия БРЛС обязательна при ухудшении видимости менее одного километра или в других сложных погодных условиях для всех аварийных судов. Также она обязательна для кораблей, имеющих неисправности технических средств судовождения, судовой энергетической установки, другого оборудования, которое может повлиять на безопасность плавания судна или других судов, создать угрозу загрязнения окружающей среды. Радиолокационная проводка может быть необходима и в иных случаях, по распоряжению капитана порта.

В общем случае, согласно действующему Положению о СУДС, помощь в судовождении оказывается по запросу судна или по решению Центра СУДС, преимущественно в сложных гидрометеорологических условиях, при выходе из строя или отсутствии на судне приборов, обеспечивающих безопасное движение его в данной навигационной обстановке. Основу помощи в судовождении составляет регулярная передача Центром СУДС на судно навигационной информации о позиции судна по отношению к навигационному ориентиру, фарватеру и путевым точкам, путевого угла и путевой скорости судна, положений и намерений других судов, а также рекомендаций по изменению курса и скорости. Важно отметить, что помощь в судовождении должна носить только информационный и рекомендательный характер и не должна ограничивать ответственность капитана за безопасность судна и перекладывать эту ответственность на СУДС.

В зависимости от степени радиолокационного перекрытия, районы действия VTS (СУДС) или секторы внутри района могут быть классифицированы следующим образом:

- районы без радиолокационного контроля (контроля посредством АИС или системы судовых сообщений); 
- районы с частичным радиолокационным контролем (с наличием зон, обеспечиваемых АИС или системой судовых сообщений);

- районы с полным радиолокационным контролем.

Безопасность и эффективность СУДС требует разграничения взаимной ответственности СУДС и капитана судна. Персонал СУДС, имея специальную подготовку и знания о местных особенностях водных путей, несет ответственность за управление движением судов в соответствующей зоне. Капитан, обладая знаниями маневренных характеристик управляемого им судна и профессиональным мастерством, несет ответственность за безопасность судна. Полагаясь на опыт и профессионализм персонала СУДС, капитан судна и выполняет указания оператора ЦУДС. Однако, учитывая добровольность участия судна в СУДС, капитан имеет право на собственное решение, даже противоречащее указаниям оператора СУДС, если он считает, что его собственное решение ведет к снижению риска опасного развития ситуации - управление судном есть исключительное право его капитана.

\section{4. Состав и принципы функционирования автоматических идентификационных систем}

Автоматическая идентификационная система (АИС, англ. AIS - Automatic Identification System) - в судоходстве система, состоящая из судовых транспондеров и служащая для идентификации судов, их габаритов, курса и других данных с помощью радиоволн УКВ-диапазона. В последние годы АИС также трактуют как Автоматическую информационную систему (AIS - Automatic Information System), что связано с расширением функциональности системы по сравнению с ординарной задачей идентификации судов.

Система АИС предназначена для повышения уровня безопасности мореплавания, эффективности судовождения и эксплуатации систем управления движением судов (СУДС), защиты окружающей среды, обеспечивая выполнение следующих функций:

- предупреждение столкновений в режиме «судно-судно»; 
- получение компетентными береговыми службами информации о судне и грузе;

- управление движением судов как инструмент СУДС в режиме «судно-берег»;

- обмен навигационными данными между судами при их расхождении в море;

- мониторинг и слежение за судами, операции по поиску и спасению (SAR).

Центральной функцией АИС является мониторинг и слежение за судами. Схема мониторинга судоходства в навигационно-информационной компьютерной системе приведена на рисунке 4.4.1.

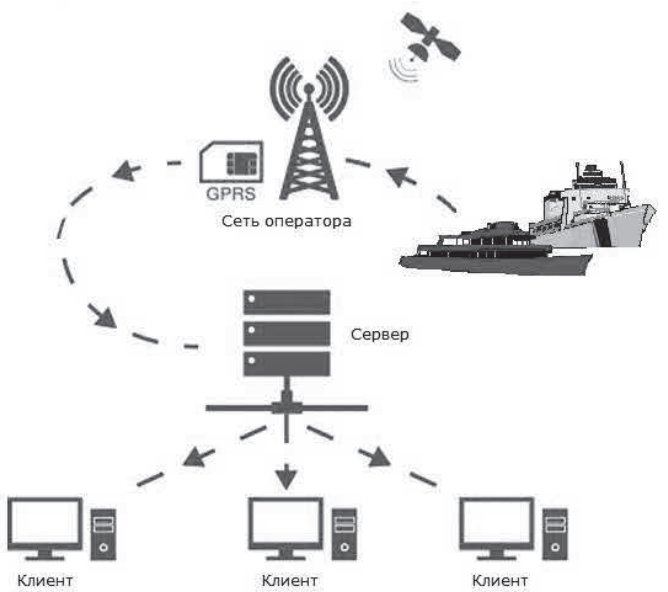

Рис. 4.4.1. Схема мониторинга судоходства

Обобщенно принцип функционирования системы мониторинга судов следующий. Выполняется сбор информации и показаний с приборов и датчиков, установленных на судах. Собранные данные обрабатываются и анализируются на серверах диспетчерской системы. Затем полученная информация представляется в диспетчерском центре в режиме реального времени. Пример отображения информации в системе видеомониторинга показан на рисунке 4.4.2 [111].

Исторически появление систем АИС связано с предложением в начале 1990-х годов Международной ассоциации маячных служб 
(MAMC) использовать судовые радиотранспондеры, работающие в диапазоне УКВ, для передачи сигналов опознавания. Сигналы транспондера, принятые Центром СУДС, позволяли опознавать контролируемое судно при подходе к зоне обслуживания и в процессе дальнейшего движения. В 1992 году по просьбе МАМС Международный союз электросвязи (МСЭ) выпустил рекомендацию М.825 по применению радиотранспондеров в системах УДС на канале 70 морской подвижной службы с использованием протокола ЦИВ ГМССБ. В сообщение от транспондера включались идентификационные данные и информация о местоположении судна. В дальнейшем было предложено включать в формат сообщения сведения о наличии опасного груза, чтобы автоматизировать сообщения, предусмотренные Резолюцией А.648(16) ИМО для Систем судовых сообщений.

На 63-й сессии Комитета по безопасности на море (КБМ) ИМО в мае 1994 года Германия внесла предложение о необходимости внедрения на судах транспондерных систем взаимного опознавания судов и передачи данных береговым службам (VTS CУДC), а также для повышения безопасности мореплавания (MSC 63/7/9).

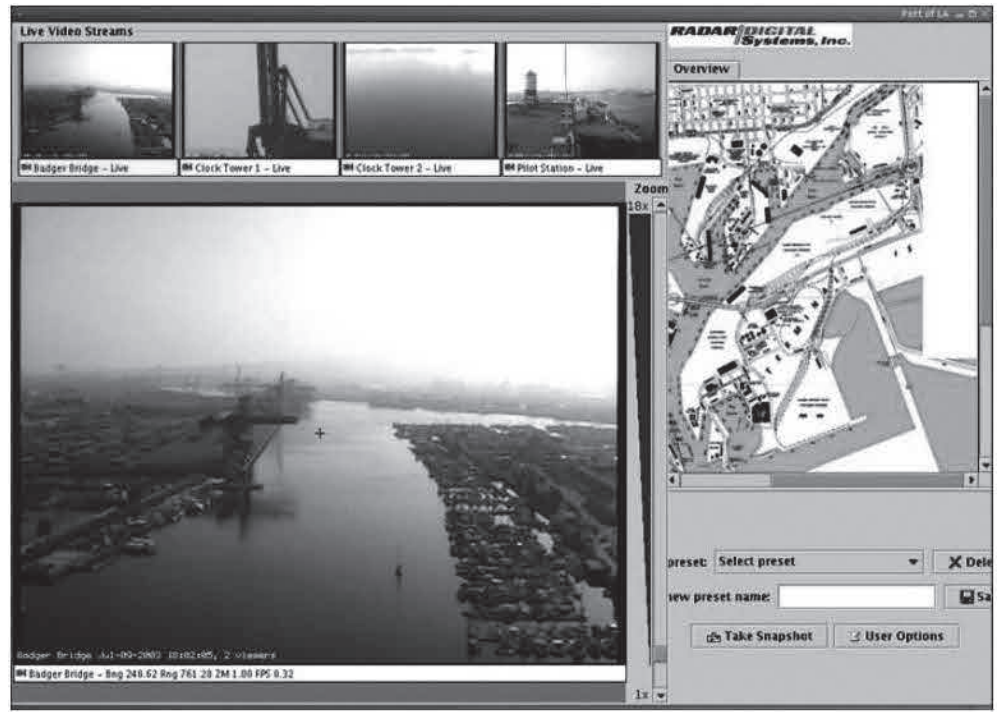

Рис. 4.4.2. Пример отображения информации в системе видеомониторинга 
На 40-й сессии ПКБМ (июль 1994 года) Швеция внесла предложение (NAV 40/7/15) о внедрении транспондеров с протоколом самоорганизующейся линии передачи данных с временным разделением и свободным доступом (SOTDMA - Self Organising Time Division Multiple Accsess). Этот протокол, заимствованный из авиации, использует один частотный канал для передачи информации с короткими временными интервалами. Протокол обеспечивает передачу с высокой степенью надежности (более 95 \%) информации о местоположении судна для взаимного предупреждения судов («судно-судно») и для точного контроля движения судов по узким подходным каналам и фарватерам в СУДС («судно-берег»). Предложение было поддержано Россией, Финляндией и рядом других государств. В декабре 1996 года КБМ принял решение в пользу единого универсального транспондера, базирующегося на применении протокола SOTDMA, а в мае 1998 года принял рекомендацию MSC.74(69) с эксплуатационными требованиями к судовым транспондерам.

В 1997 году Всемирная радиоконференция выделила для работы АИС на глобальной основе две частоты: 161,975 МГц (AIS-1) и 162,025 МГц (AIS-2). В октябре 1998 года Комитет по радиотехнике Международной электротехнической комиссии (МСЭ-Р) выпустил Рекомендацию М.1371, содержащую основные принципы построения АИС.

В настоящее время действие систем АИС регламентируется следующими основными нормативными документами:

- IEC 62320-1:2007 Оборудование и системы морской навигации и радиосвязи. Автоматические системы идентификации (AIS);

-IEC 61993-2(2001-12) Maritime navigation and radiocommunication equipment and systems - Automatic identification systems (AIS);

- Резолюция ИМО MSC.43(64) «Руководство и критерии к системам судовых сообщений»;

- Резолюция ИМО MSC.74(69) Приложение 3 «Рекомендации по эксплуатационным требованиям к универсальной судовой АИС»;

- Резолюция ИМО MSC.74(69) «Эксплуатационные требования к комбинированному судовому приемному оборудованию системы ГЛОНАCC/GPS»; 
- Стандарт МЭК 61993-2 Часть 2 «Судовое оборудование универсальной автоматической идентификационной системы (АИС) класса А. Технические и эксплуатационные требования, методы и требуемые результаты испытаний»;

- Стандарт МЭК 61993-1 «Судовые автоматические транспондеры, использующие режим ЦИВ в УКВ-диапазоне морской подвижной службы»;

- Рекомендации МСЭ-Р М.1371-1 «Технические характеристики универсальной судовой автоматической идентификационной системы (АИС), использующей множественный доступ с временным разделением в УКВ-полосе частот морской подвижной службы»;

- Резолюция ИМО А.917(22) «Руководство по использованию судовой АИС».

Оснащение системой АИС является обязательным для судов водоизмещением свыше 300 регистровых тонн, совершающих международные рейсы, судов водоизмещением более 500 регистровых тонн, не совершающих международные рейсы, и всех пассажирских судов. Суда и яхты с меньшим водоизмещением могут быть оборудованы прибором класса Б. Передача данных осуществляется на международных каналах связи AIS 1 и AIS 2 в протоколе SOTDMA. Применяется частотная модуляция с манипуляцией GMSK.

Типовая структура АИС для различных вариантов использования (судно, береговая станция, СУДС) показана на рисунке 4.4.3 [88].

Типовая структура АИС включает в себя следующие компоненты:

- УКВ-передатчик;

- один или два УКВ-приемника;

- приемник глобальной спутниковой навигации (например, GPS, ГЛОНАСС), в России наличие модуля ГЛОНАСС в приборе АИС является обязательным, основным источником координат, а модуль GPS - вспомогательным и может браться от приемника GPS по шине NMEA;

- модулятор/демодулятор (преобразователь аналоговых данных в цифровые и наоборот); 

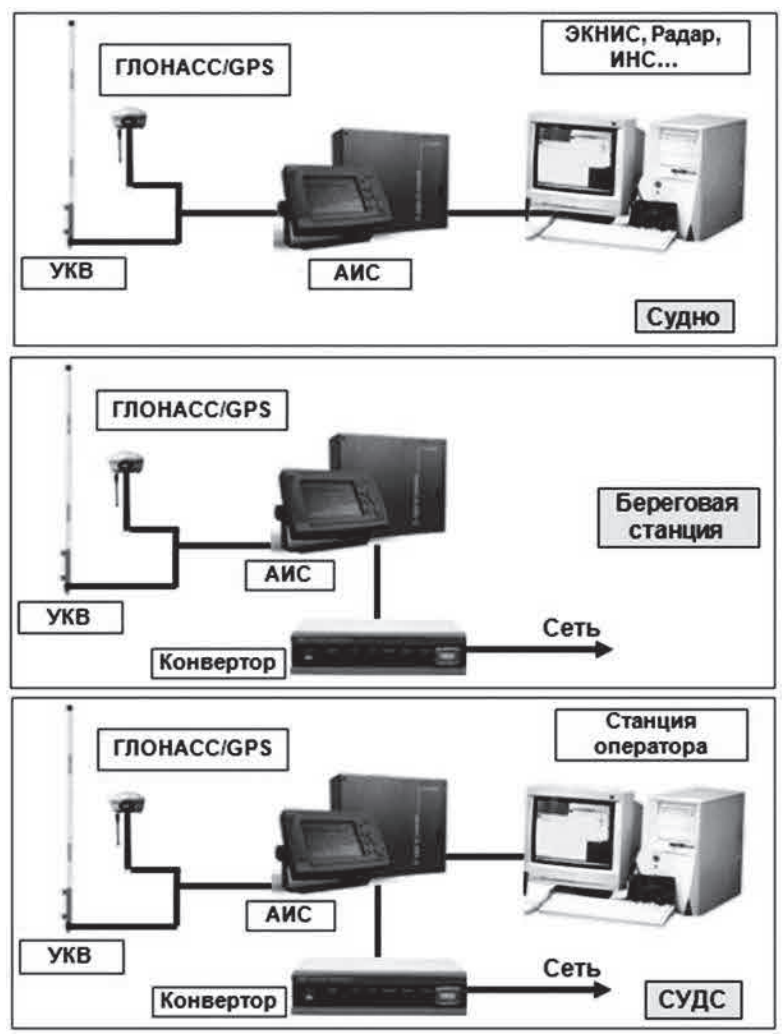

Рис. 4.4.3. Типовая структура автоматической идентификационной системы

- контроллер на основе микропроцессора;

- оборудование ввода-вывода информации на элементы управления.

С точки зрения функциональных возможностей, требования Резолюции IMO MSC.74 (69) к универсальной АИС состоят в следующем:

- система должна иметь возможность работать в режиме «судно-судно» с целью содействия предупреждения столкновений;

- служить для прибрежных государств средством получения информации о судне и его грузе;

- служить инструментом VTS (СУДС), обеспечивающим связь «судно-берег» (для управления движением судов). 
АИС в режиме «Автоматизированный зависимый контроль (САЗК)» обеспечивает управляемое береговыми службами СУДС автосопровождение судов и контроль их движения в обслуживаемой зоне. Обмен данными с судами в режиме САЗК и формирование потоков информации, исходящей от Центра СУДС и береговых служб (МСКЦ), обеспечивается базовой станцией АИС. Береговые базовые станции АИС, расположенные вдоль побережья, могут образовывать сети. Информация АИС отображается с помощью судовой системы отображения электронных карт (ECDIS), CAРП или персонального компьютера (в зависимости от наличия соответствующих интерфейсов). Береговыми системами отображения АИС являются консоль оператора СУДС, ECDIS либо персональные компьютеры. Пример визуализации информации АИС приведен на рисунке 4.4.4 [101].

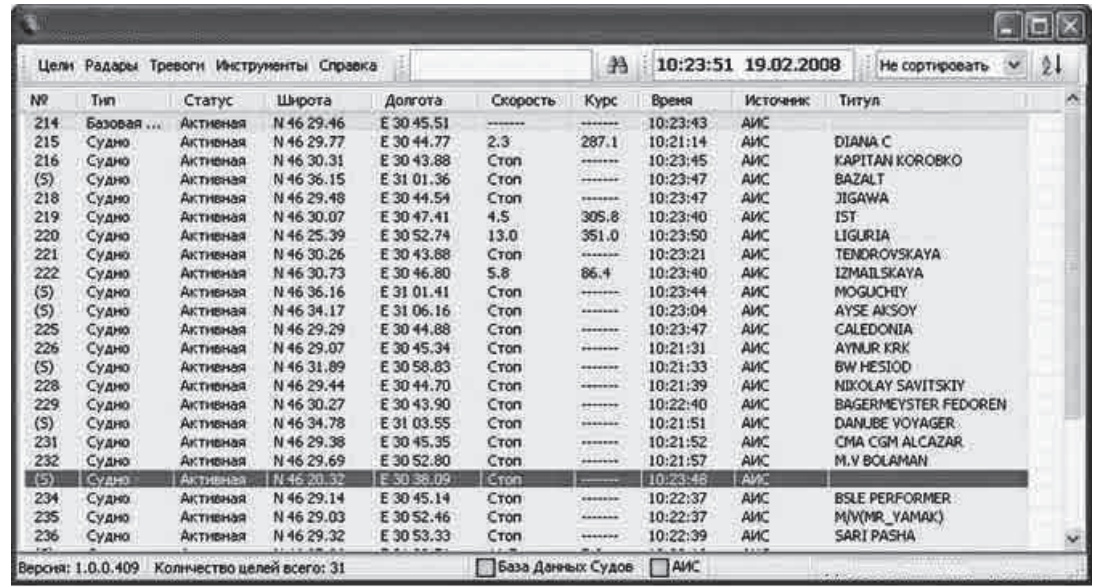

Рис. 4.4.4. Пример визуализации информации АИС

Действие АИС основано на приеме и передаче сообщений по УКВ-радиоканалам. Передатчик АИС работает на более длинных волнах, чем радары. Это позволяет обмениваться информацией не только при наличии прямой видимости, но и на местности, имеющей препятствия в виде не очень больших объектов, а также при плохих погодных условиях. 
Сообщения АИС могут содержать различную информацию:

- идентификационную информацию об объекте;

- информацию о состоянии объекта, получаемую автоматически с элементов управления объектом (в том числе с некоторых электрорадионавигационных приборов);

- информацию о географических и временной координатах, которые АИС получает от глобальной навигационной спутниковой системы;

- информацию, вводимую вручную обслуживающим персоналом объекта (связанную с безопасностью).

Предусмотрена передача дополнительной текстовой информации между терминалами АИС (пейджинг).

Работа каждой станции АИС (мобильной или базовой) жестко синхронизирована по времени UTC с погрешностью не более 10 мкс от встроенного приемника ГНСС (в РФ по сигналам комбинированного приемника ГНСС ГЛОНАCC/GPS). Для передачи информации используются непрерывно повторяющиеся кадры длительностью 1 минута, которые разбиваются на 2250 слотов (временных интервалов) длительностью по 26,67 мс.

Отображение информации об окружающей обстановке у современных АИС возможно в 2 режимах - в текстовом в виде таблицы с перечнем расположенных рядом судов и их данных и в виде упрощенной схематической карты с изображением взаимного расположения судов и расстояний до них, которые рассчитываются автоматически по переданным географическим координатам.

Использование систем АИС предоставляет ряд преимуществ по сравнению с другими системами и средствами обеспечения безопасности мореплавания. В области предупреждения столкновений судов к основным достоинствам АИС относятся следующие:

1. Повышается точность определения параметров и эффективность расхождения судов в море благодаря взаимному обмену координатами судов, определенными с высокой точностью (с помощью ДГНСС - 5-10 метров), а также информацией о текущем курсе.

2. Обеспечивается устойчивое и надежное автосопровождение судов, расходящихся на узких фарватерах или проходящих вбли- 
зи плавающих навигационных знаков благодаря использованию транспондеров, которые исключают свопинг («переброс») маркеров сопровождаемых судов-целей при их сближении, что имеет место при работе САРП.

3. Повышается надежность решения при расхождении судов благодаря взаимному обмену данными о гирокомпасном курсе практически в реальном времени; маневр судна-цели легко обнаруживается как по изменению значения гирокомпасного курса, так и по информации о значении скорости поворота, что позволяет устранить большие трудности, ранее возникавшие при использовании САРП.

4. Обеспечивается возможность наблюдения за малым судномцелью в условиях сильного волнения моря, т. к. на работу АИС не влияют осадки и волнение моря, как это имеет место при использовании РЛС.

5. Расширяется зона обслуживания СУДС за счет большей дальности действия АИС в сравнении с радиолокационным обзором.

6. Обеспечивается эффективный контроль за судами со стороны портовых властей, морских администраций и других береговых служб, а также со стороны служб ФПС и ВМФ (в территориальных водах) благодаря введению в базу данных СУДС информации о местоположениях, характеристиках и навигационных данных всех судов в обслуживаемом районе.

Вместе с тем имеются определенные трудности при использовании АИС:

1. Эффективное использование АИС возможно только при полномасштабном оснащении всех судов транспондерами.

2. Оснащение всех судов средствами АИС не означает полного отказа от РЛС, т. к. информация АИС относится только к объектам, на которых установлены транспондеры, в то время как радиолокатор позволяет наблюдать любые объекты, отражающие радиоволны (знаки навигационного ограждения, суда, береговую черту и другие).

3. В соответствии с решением ИМО эффективным инструментом для предупреждения столкновений и мониторинга судов может 
стать только глобально применяемая АИС. Это означает жесткую регламентацию требований к оборудованию АИС на международной основе, т. к. в этом будет обеспечена совместимость оборудования, установленного на разных судах, и высокая эффективность его использования.

Указанные проблемы определяют вектор развития систем АИС в мире. Так, США и Канада рассматривают вопрос об обязательном оснащении АИС всех судов длиной более 20 м, независимо от назначения и района плавания, в том числе и речных. Аналогичное соглашение уже принято в рамках ЕС об обязательном оснащении АИС всех рыболовных судов длиной более 15 м, а также речных судов внутреннего плавания. Китай завершает создание прибрежной сети станций АИС. Администрация Сингапура требует наличие транспондера АИС на всех коммерческих судах независимо от их водоизмещения.

Другим направлением развития является дополнение АИС космическим сегментом. Интегрирование существующей АИС и ее космического сегмента обеспечивает глобальный мониторинг морской деятельности. Схема интегрирования космического сегмента в автоматическую идентификационную систему показана на рисунке 4.4.5 [88].

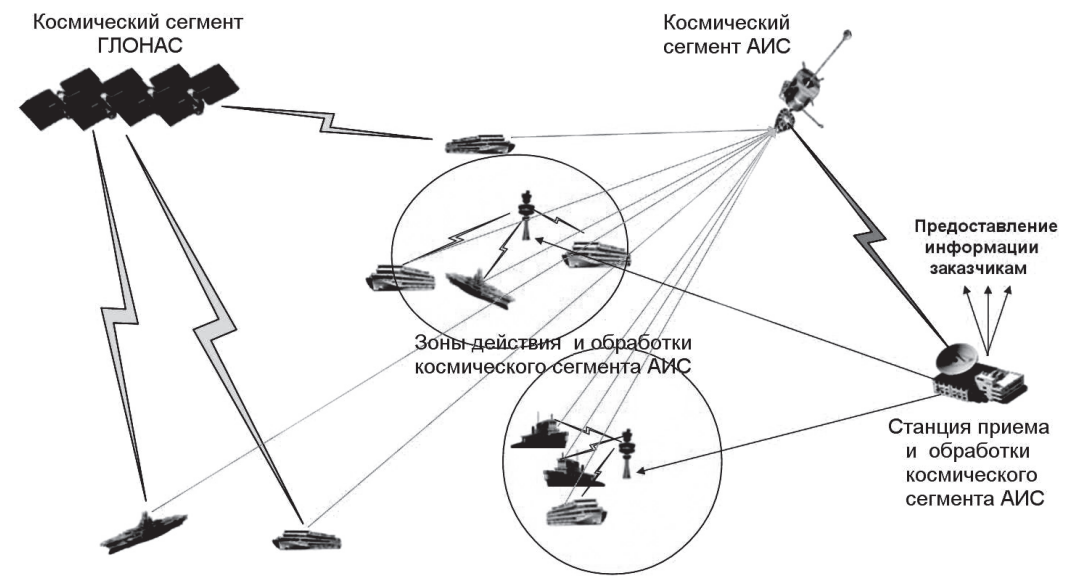

Рис. 4.4.5. Схема интегрирования космического сегмента в автоматическую идентификационную систему 
В России космический сегмент АИС разрабатывается в рамках проекта № 24 «Создание системы мониторинга и слежения подвижных объектов», поддержанного комиссией по модернизации и технологическому развитию при Президенте РФ. Полномасштабное развертывание и эксплуатация космического сегмента АИС определено в 2014 году [88]. Целью выполнения Проекта № 24 является повышение безопасности эксплуатации морского и речного транспорта, а также эффективности принятия управленческих решений на основе оперативности получения информации о местоположении подвижных объектов на глобальных морских акваториях и речных путях Российской Федерации. При этом решаются две основные задачи:

1. Создание космического сегмента автоматической идентификационной системы (АИС).

2. Создание наземного комплекса приема и обработки информации от космического сегмента АИС.

Текущее покрытие наземной сети АИС Российской Федерации включает Финский залив, порт Балтийск (Калининград) и подходы, Архангельск, Кольский залив и подходы, Азовское и Черное моря, залив Петра Великого (Владивосток, Находка), залив Анива, а также некоторые внутренние водные пути. Доработка станций приема и обработки информации (СПОИ) от космического сегмента АИС в Москве и Петропавловске-Камчатском, а также размещение дополнительных СПОИ в Южно-Сахалинске, Новосибирске, Норильске и Мурманске позволит полностью контролировать территориальные воды России. Зоны радиовидимости для низкоорбитальных космических аппаратов (угол более $10^{\circ}$ ) и расположение региональных центров приема данных космического сегмента АИС показаны на рисунке 4.4.6 [88].

Международное сотрудничество в области глобального мониторинга Земли реализуется в рамках проекта GLADIS [88]. Оно предусматривает создание международной спутниковой группировки, состоящей из 30 малоразмерных спутников нанокласса, находящихся на полярных орбитах. Спутники размещаются на пяти орбитах с 6-ю спутниками на каждой плоскости. Доступ- 


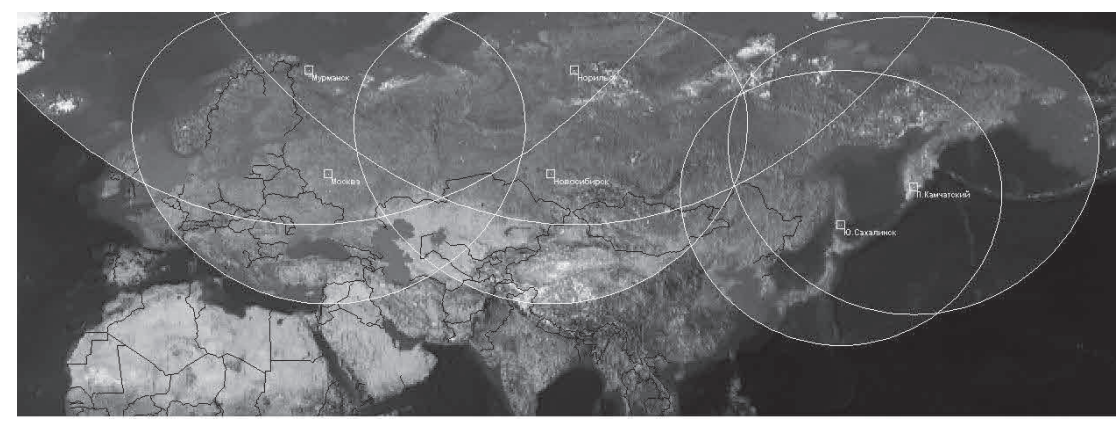

Рис. 4.4.6. Зоны радиовидимости и расположение региональных центров приема данных космического сегмента АИС

ность со спутника любой точки поверхности земного шара - не более 10 минут. Предполагается использование необслуживаемых фиксированных морских и наземных датчиков (подсистема Data exfiltration - Data-X), работающих на частотах АИС.

Схема функционирования АИС в космическом проекте GLADIS включает следующие возможности:

- спутник собирает данные (публичные) с АИС и данные (частные) с датчиков;

- при сбросе данных на наземную станцию обеспечивается защита данных;

- защищенный поток данных маршрутизируется на управляющий сервер;

- данные с управляющего сервера распределяются публично или передаются владельцу этих данных.

\section{5. Принципы и системы отображения электронных навигационных карт}

Развитие и широкое использование современных навигационных систем типа ГЛОНАСС / GPS и систем АИС определили необходимость применения информационных технологий в области морской картографии. Высокоэффективные навигационно-информационные компьютерные системы с электронными картами получают в судовождении все большее распространение. 
Навигационно-информационная компьютерная система (НИКС) является центральной системой, управляющей работой автоматизированного комплекса судовождения (АКС). Она обеспечивает выполнение функций навигации, предупреждения столкновений судов, сигнализации об опасных ситуациях, контроля технических средств, управления движением судна, снабжения судоводителя необходимой информацией для обеспечения безопасного судовождения. Многие производители электронной аппаратуры (прежде всего систем радиолокационной прокладки - САРП и систем управления движением судов - СУДС) приступили к созданию собственных электронно-картографических систем. Наибольшее распространение в настоящее время получили системы ECDIS и ЕCS.

Electronic Chart Display and Information System (ECDIS) - это навигационно-информационная компьютерная система, удовлетворяющая правилу V/20 Международной конвенции ИМО по безопасности жизни на море (СОЛАС-74). В соответствии с этим правилом все суда должны быть снабжены картами, наставлениями для плавания, пособиями по огням, знакам, радиотехническим средствам, «Извещениями мореплавателям», таблицами приливов и другими специальными публикациями, необходимыми на предстоящий рейс. Требуемые карты, а также другие необходимые на рейс навигационные пособия могут быть обеспечены путем их представления на экране ECD1S. Таким образом, ECDIS является юридически признанным эквивалентом бумажных навигационных карт и пособий для плавания. Требования к ECDIS, eе аппаратуре и программному обеспечению определяются международными организациями: ИМО, Международной гидрографической организацией (МГО, англ. IHO - International Hydrographic Organization), Международной электротехнической комиссией (МЭК, англ. IEC - International Electrotechnical Commission).

Использование ECDIS освобождает судоводителя на ходовой вахте от выполнения многих рутинных операций, повышает результативность деятельности, обеспечивает использование большего объема и номенклатуры данных, увеличивает скорость 
их обработки, улучшает точность и достоверность результатов, повышает безопасность мореплавания и приводит к росту финансовых показателей работы судна. Однако сложность подобных систем требует от судоводителя хорошей подготовки.

Electronic Chart System (ECS) - это навигационная или навигационно-информационная компьютерная система с электронными картами, которая не удовлетворяет в полной мере требованиям к ECD1S и не может использоваться без применения официальных бумажных карт.

Под электронной картой (ЭК, EC - electronic chart) в общем случае понимается цифровая топографо-геодезическая (картографическая) модель, сформированная на машинном носителе с использованием программных и технических средств, которая отображает определенный район Земли в условных знаках в принятой проекции, системе координат и высот и предназначена для анализа, моделирования и решения информационных и расчетных задач по данным о местности и обстановке. Электронная карта существует в виде компьютерного файла. Специальное программное обеспечение может отображать информацию из этого файла на экране дисплея, печатать на принтере, прокладывать маршруты движения и многое другое.

Цифровые электронные карты могут быть представлены в виде растровых электронных карт (планов) и векторных цифровых карт (планов).

Растровая электронная карта (Raster electronic navigational chart - RNC) - это картографическая информация, представленая в виде матрицы с элементами в виде кодов цветов картографического изображения. Растровые электронные карты создаются путем сканирования традиционных топографических материалов или растеризацией векторных цифровых моделей местности. Растровые материалы могут быть черно-белыми, полутоновыми и цветными. Основной характеристикой растрового изображения является его плотность, измеряемая обычно в точках на дюйм (dpi). Растровая карта является копией оригинала с точностью до элемента (пикселя) сканирования. Учитывая, что точность нанесения 
объектов на бумажную карту не выше $0,1-0,2$ мм, то сканирование с разрешением около 500 dpi (размер одного пикселя примерно 0,1 мм) обеспечивает сохранение в растровой карте всех деталей исходной бумажной карты.

Первые навигационно-информационные компьютерные системы использовали растровые электронные карты. Производство растровых карт обеспечило в начале 90-х годов быстрое создание мировой коллекции карт. Основными недостатками растровых карт являются ограничения по настройке отображения картографической информации на экране компьютера (кроме отображения, делать с растровой картой практически ничего нельзя) и невозможность их использования для автоматического контроля безопасности мореплавания. Получаемый после сканирования файл имеет большой объем, поэтому отображение растровых карт на маломощных компьютерах происходит медленно. Растровые карты используются там, где невозможно или нецелесообразно использовать векторную карту. Например, это касается спутниковых карт, т. к. они используют оригинальные спутниковые снимки. Скриншот растровой карты и некоторые возможности работы с ней в прикладном пакете OziExplorer (http://www.oziexplorer.com/) приведены на рисунке 4.5.1.

Векторная электронная карта (Vector electronic navigational chart - VENC) - это электронная карта, картографическая информация которой представлена в виде последовательности векторов (то есть в основе создания изображения лежат математические функции). Семантическая информация у векторной электронной карты может не определяться (отсутствовать). Векторные электронные карты создаются сканированием графического изображения традиционных планов с последующей векторизацией. При создании векторной карты также применяются автоматизированные методы, использующие информацию, передаваемую с электронных накопителей геодезических приборов. Исходной информацией для векторных карт при этом могут служить непосредственно данные геодезической съемки местности, результаты аэро- и космической фотометрической съемки районов Земли. Оператор имеет воз- 


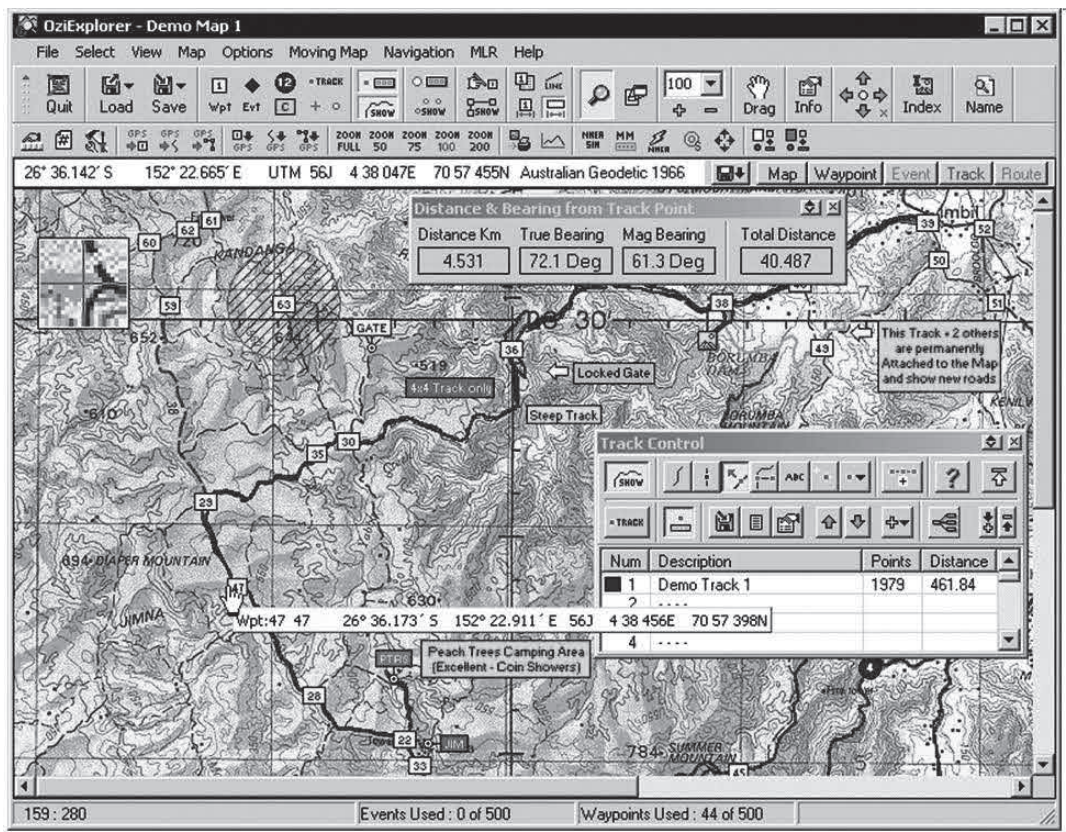

Рис. 4.5.1. Вид растровой карты в прикладном пакете OziExplorer

можность для самостоятельного нанесения и редактирования на электронной карте собственной пространственной информации, включающей районы, линии, символы, тексты. Обеспечивается ввод простейших текстовых атрибутов.

Векторная карта, по сути, представляет собой базу данных, в которой хранится информация об объектах карты в виде их геометрического и атрибутивного описания. Атрибутами являются, например, высота дерева, ширина дороги, скорость течения реки, название населенного пункта и т. п. Геометрическое описание определяет контуры объектов (в общем случае криволинейные), представляя их, как правило, ломаными прямыми, которые с допустимой погрешностью аппроксимируют исходные кривые контура.

Объект на карте характеризуется горизонтальными координатами (широта, долгота) и вертикальной координатой (высота или глубина). В основе отсчета горизонтальных координат лежит та 
или иная геодезическая система, называемая также горизонтальнылм геодезическим вотумом. Основой для отсчета вертикальных координат служит уровень моря, принимаемый за ноль глубин. Этот уровень называют вертикальным геодезическим датумом либо приливным уровнем. Скриншот векторной карты в системе dKart Explorer представлен на рисунке 4.5.2 [126].

Все объекты векторной электронной карты обычно распределяются по слоям карты - определенным тематическим уровням. Электронная картографическая система поддерживает работу одновременно с несколькими пользовательскими слоями. Слоями могут быть навигационные средства, глубины, качество данных, характеристики и другие. Разделение нагрузки карты на слои позволяет системе управлять видимостью этих слоев. Количество информационных слоев может быть различным, однако выделяется, по крайней мере, три слоя, определяющих соответственно три вида нагрузки карты: базовую, стандартную и полную.

Картографическая информация хранится в памяти в формализованном виде и определяется форматом представления информации,

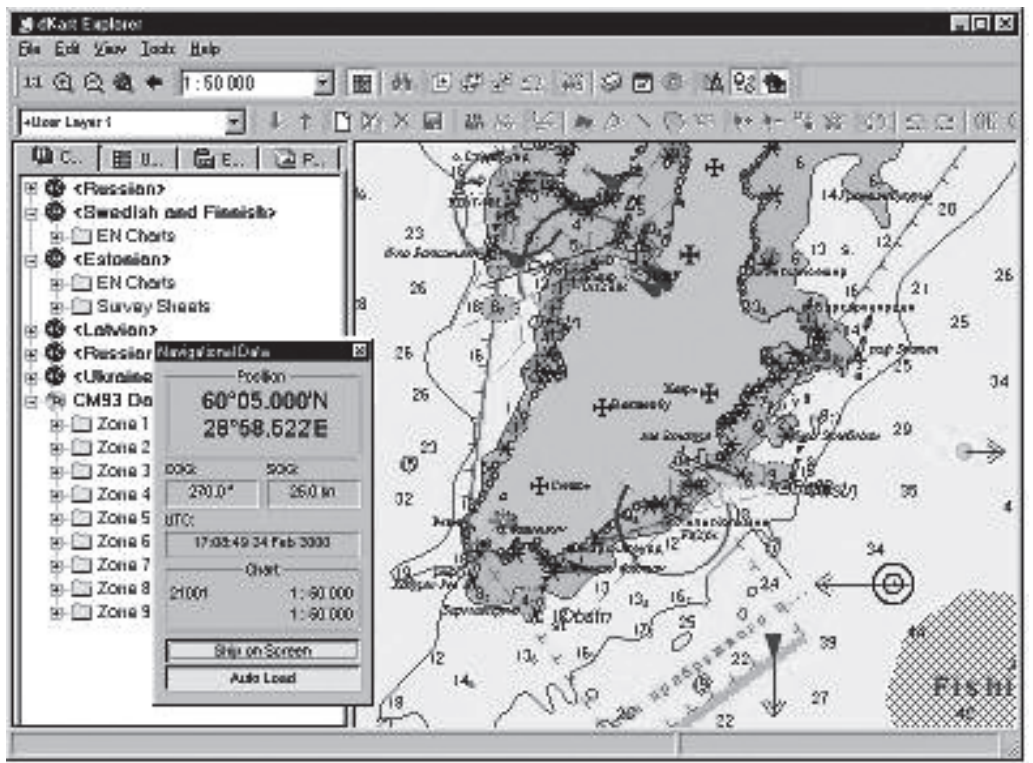

Рис. 4.5.2. Скриншот векторной карты в системе dKart Explorer 
классификатором информации и правилами цифрового описания объектов.

Формат определяет внутреннюю структуру векторной карты. От него зависят такие характеристики, как объем файла векторной карты и время доступа к требуемому объекту. Производители программного обеспечения создают форматы, которые позволяют оптимизировать те или иные функции. В настоящее время существует несколько десятков форматов векторных карт, единого стандарта нет.

Классификатор информащии представляет собой электронный структурированный список всех объектов карты и всех атрибутов, которые могут содержать объекты. Объекты, как правило, хранятся в базе данных в виде записи типа: 31410000 (объект «река»), 2 (объект линейный), 15 (глубина 15 м), 1,5 (скорость течения 1,5 м/с). «Расшифровки» записей хранятся в классификаторе, поэтому без него векторная карта - бессмысленный набор цифр. Классификаторы разрабатывают производители векторных карт и сопровождают их при использовании.

Правила цзифрового описания устанавливают единообразное описание однотипных объектов векторной карты в процессе создания геометрического образа объекта карты. Например, объект «мост» может быть описан координатами центра моста и вектора, определяющего направление моста. Может быть и другое описание, например, координатами двух концов моста. Правила, как и классификаторы, сопровождают векторную карту.

Производители векторных карт зачастую создают свои собственные форматы, классификаторы и правила цифрового описания, поэтому векторные карты различных источников несовместимы между собой.

Основной недостаток векторных карт - существенные затраты на производство, но они занимают меньший объем памяти, чем растровые карты, и обладают расширенными возможностями при компьютерной обработке.

Векторные карты позволяют системе распознавать картографический объект. Система макросов предоставляет дополнительную 
гибкость в работе с картографической информацией (например, с картами ледовой обстановки или с картами погоды) и базами данных. Используя макросы, пользователь может расширить возможности программы по поиску, отображению и обработке информации произвольной природы. Оператор имеет возможность ввести цель в ручную, назначив стартовую позицию, курс и скорость. В случае наличия заранее запланированного маршрута система может выполнять привязку введенной цели к маршруту, моделируя в реальном времени ее движение в соответствии с координатами поворотных точек. Несмотря на то, что процесс отображения векторной карты на экране компьютера сложнее, чем отображение растровой карты, программное обеспечение достаточно легко справляется с этой задачей. Учитывая, что объем векторной карты гораздо меньше, чем растровой, процесс отображения векторной карты идет существенно быстрее.

При отображении векторных карт достаточно просто реализуются такие возможности, как:

- масштабирование (увеличение и уменьшение в произвольное число раз);

- скроллинг (перемещение по карте);

- разворот изображения карты;

- включение (выключение) видимости отдельных объектов и группировок (слоев карты);

- выделение цветом или миганием каких-либо объектов или групп;

- изменение цвета, размера фона и стиля отрисовки требуемых объектов.

В зависимости от полноты информации различают полномерные и упрощенные (стилизованные) электронные карты. Полномерные навигационные ЭК равноценны официальным бумажным навигационным картам и содержат всю картографическую информацию, необходимую для безопасного и эффективного судовождения. Для использования полномерных карт требуются достаточно мощные средства хранения и отображения информации, которыми ряд автоматизированных навигационных систем не обладает. В таких 
системах могут использоваться упрощенные ЭК. В них изображение местности на экране дисплея не эквивалентно бумажной навигационной карте и не удовлетворяет требованиям к безопасности мореплавания.

В зависимости от требований, которым удовлетворяют электронные карты, они делятся на ECDIS-карты и ECS-карты. ECDIS$\kappa a p m b l$ - являются обязательно официальными, векторными картами. Данные для них подготавливаются государственными гидрографическими организациями. ECDIS-карты стандартизованы по содержанию, структуре, действующему формату обмена картографической информацией и полностью удовлетворяют по содержанию, цвету и формату представления специальным требованиям ИМО и МГО. ECS-карты не полностью отвечают специальным требованиям ИМО и МГО.

В соответствии с определением в системах ECDIS могут использоваться только ECDIS-карты. Применение систем ECS не освобождает судоводителя от ведения прокладки на бумажных картах. В них используются растровые ЭК, векторные ЭК, не полностью удовлетворяющие требованиям к ECDIS-картам, и упрощенные ЭК. В комбинированных НИКС возможны два режима работы: в режиме ECDIS используются карты, имеющие статус ECDIS; а при использовании растровых или векторных ECS-карт режим работы приравнивается к ECS, в этом случае наряду с выполняемой системой прокладкой на ЭК обязательно ведение прокладки на бумажных картах.

Базовая нагрузка - включает информацию карты, которая не может быть удалена с дисплея, требуется всегда, во всех географических районах и при любых обстоятельствах: береговую черту (для полной воды); выбранную капитаном для собственного судна безопасную изобату; в ограниченной безопасной изобатой области отдельные подводные опасности с глубинами, величины которых меньше, чем безопасная; в пределах этой же области отдельные опасности, такие как мосты, линии электропередачи, включая буи и знаки, которые используются или не используются как средства навигации; системы движения; масштаб; вид ориентации карты и режим дисплея; единицы глубин и высот. 
Стандартная нагрузка - это минимальный набор данных, обеспечивающих безопасность при прокладке и планировании пути. Стандартная нагрузка включает базовую, линии осыхания, стационарные и плавучие средства навигации, границы фарватеров, каналов, приметные визуальные и радиолокационные объекты, запретные и ограниченные районы и некоторые другие сведения.

Полная нагрузка, кроме стандартной, включает всю другую информацию: значения глубин, подводные кабели и трубопроводы, маршруты паромов, детали отдельных опасностей, детали навигационных средств, предупреждения мореплавателям, дату издания ЭК, ноль глубин, географические названия и другую информацию.

Кроме непосредственно картографической информации, на ЭК отображаются данные, характеризующие процесс судовождения: текущее место собственного судна и траектория его движения; планируемый маршрут, оперативная информация, вводимая с пульта оператором; безопасная изобата собственного судна; условные знаки сопровождаемых АРП судов и векторы их скорости либо данные об элементах движения судов, получаемые от транспондера АИС, и ряд других данных.

Навигационно-информаџионная компьютерная система (НИКС) строится на основе персонального компьютера с клавиатурой и манипулятором и включает в себя (рис. 4.5 .3 [126]): средства отображения информации о процессе судовождения, устройства документирования и регистрации информации, средства сигнализации.

Информационно-программное обеспечение систем отображения электронных карт включает операционную систему, систему управления информационными базами, информационные базы (базы данных, базы знаний и базу программ), а также программы, обеспечивающие получение информации от датчиков и обмен информацией между различными устройствами.

Операционная система (OC) представляет собой комплекс программ, которые организуют работу компьютера и управление его ресурсами. Картографическая база данных (КБД) содержит картографические и навигационно-гидрографические данные, в 


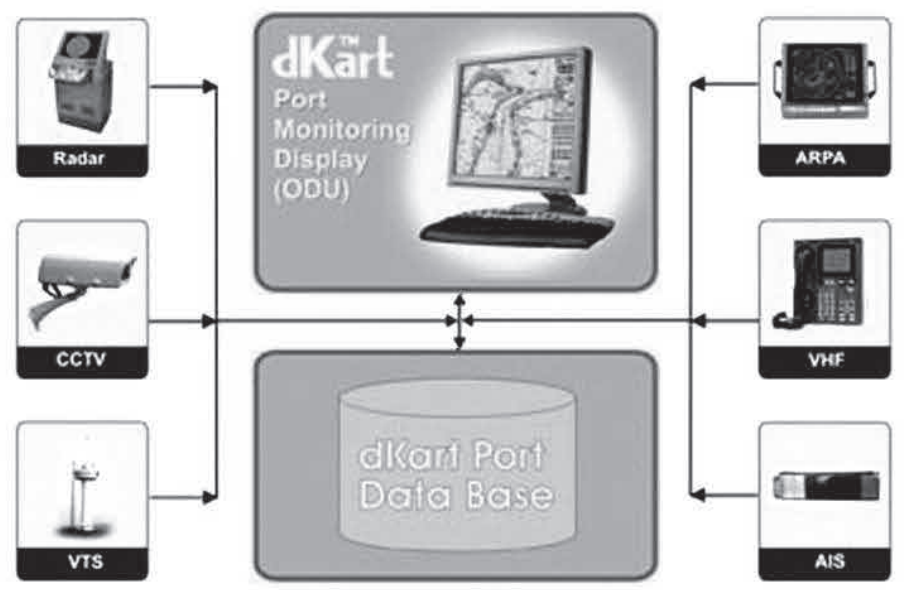

Рис. 4.5.3. Структурная схема навигационно-информационной системы dKart Port Monitoring System

том числе каталог-справочник ЭК, цифровые данные основных ЭК, таблицы классификации и кодирования картографических объектов, таблицы опорных точек аппроксимации меркаторской проекции, таблицы селекции объектов ЭК, библиотеку символов, сокращений и их описаний.

Система управления информационными базами (СУБД) - это совокупность программ, обеспечивающих управление работой баз программ и данных, обработку данных, взаимодействие оператора с системой при работе с информационными базами.

При решении задач судовождения необходимы сведения из многочисленных навигационных пособий, поэтому, кроме КБД, в памяти НИКС могут содержаться и другие базы данных: корректур, предварительной прокладки, рекомендованных маршрутов, данных для предвычисления приливо-отливных явлений, сведений о навигационных средствах (огнях, знаках, радиотехнических и радиолокационных средствах), данных о средствах связи и расписании их работы, правил плавания, сведений о портах, данных о судне, его маневренных и других характеристиках.

НИКС может быть снабжена электронным каталогом карт и книг. В этом случае она обеспечивает просмотр записей о картах 
и пособиях, поиск нужных карт и пособий, подбор карт и пособий на переход, загрузку в каталог и регистрацию новых карт и пособий, составление пользовательской коллекции карт и выполнение других функций.

B ECDIS возможно планирование и корректировка маршрутов с использованием базы данных готовых маршрутов, построение маршрутов по данным прошлых рейсов, предварительная прокладка и получение дополнительной информации о средствах навигации, правилах плавания, станциях обслуживания мореплавателей, районах маршрутизации движения, взаимодействующих с судовыми транспондерами береговых станций контроля движения, системах управления движением на подходах к портам.

ECDIS ведет непрерывный контроль проводки судна по маршруту, для чего представляет судоводителю данные о маршруте: расстояние (DTG), пеленг и расчетное время (TTG) движения до ближайшей путевой точки; ожидаемое время прибытия в эту точку (ETA), направление на эту точку (WTG), поправку к текущему курсу для выхода в эту точку (разница между HOG и WTG); текущее направление линии запланированного пути (CUR), следующее за ним направление (NXT), боковое смещение от линии пути (XTE). Также ECDIS позволяет показать на карте допустимые границы марирута (Clearing lines), предупреждает об отклонениях от маршрута, выходящих за заданный предел, а также о подходе к точке поворота и другие функции.

ECDIS контролирует работу подключенных к ней навигационных устройств и сообщает о неисправности любого из них судоводителю. Через сеть Интернет по электронной почте оператор может запрашивать и получать необходимую информацию: корректуры к картам и пособиям, новые карты и другие данные, осуществлять экспорт (импорт) данных маршрута. Корректура электронных карт может осуществляться автоматически через спутниковые каналы связи и через сеть Интернет или вручную. Операции ручной корректуры просты в исполнении и могут быть выполнены непосредственно в море.

Предусмотрена возможность подключения к ECDIS авторулевого для работы в режиме управления движением судна. Для этого 
авторулевой должен быть адаптивным и способным автоматически выполнять повороты при переходе на новый отрезок пути по предварительно заданным значениям радиуса или угловой скорости поворота. При нарушении в ECDIS функции удержания судна на маршруте система должна подать тревожный сигнал, отключить функцию автоматического управления движением судна по маршруту и перевести авторулевой в режим стабилизации курса.

Аппаратное и программное обеспечение ECDIS обязательно сертифицируется. На случай выхода из строя ECDIS резервируется. Резервная система может иметь ограниченные функции ECDIS либо полностью дублировать ее. В резервную систему от основной постоянно должны передаваться данные предварительной прокладки и данные всех корректур.

Помимо преимуществ, ECDIS имеют определенные ограничения и погрешности, обусловленные следующими основными причинами [21] .

- несовершенство устройств оцифровки карты и средств ее отображения;

- неточность картографической информации;

- погрешности, возникающие из-за ошибок датчиков информации;

- различие координатных систем датчиков и карты;

- ошибочная интерпретация данных.

Учитывая это, судоводитель в процессе эксплуатации системы ECDIS должен выполнять ее проверки, включая сверку информации ECDIS с информацией, получаемой с помощью других независимых технических средств контроля движения судна.

Дополнительные преимущества электронной картографии дают возможность использования в сервисе обновления векторных навигационных карт переносных элементов флэш-памяти, например, NavStick USB Норвежской компании Navtor, вместо компакт-дисков, а также обновление морских электронных карт через мобильную сотовую связь, обеспечивающую возможность передачи как простых ежедневных корректур, так и автоматическую загрузку целых морских электронных карт. 


\section{6. Принципы организации взаимодействия модулей программного комплекса системы управления движением судов}

Современная СУДС (РСБМ) включает в себя центр сбора, обработки, хранения и анализа информации. Отдельные сегменты системы взаимодействуют с помощью использования радиорелейных линий связи. Обработка информации в СУДС полностью автоматизирована и выполняется компьютерами специального назначения. В результате обработки информации формируется картина судоходной обстановки, которая отображается на ситуационных дисплеях операторских дисплейных модулей (ОДМ).

Ядром системы наблюдения за судоходством является программное средство визуализации сети базовых станций АИС для мониторинга, опционального воспроизведения и анализа данных. Поступающие на серверы системы данные АИС проверяются, сохраняются и отображаются на WEB-сервере и выделенных автоматизированных рабочих местах (AРМ) пользователей. Сети базовых станций АИС по радиоканалу от бортовых средств судов позволяют получать, обрабатывать, хранить и отображать данные по местоположению и идентификации судов, параметрам их движения, порту назначения, характеру груза и прочим. Пример редактора базы данных СУДС приведен на рисунке 4.6.1 [101].

База данных судов содержит следующую минимальную информацию:

- название, позывной, идентификатор морской подвижной радиослужбы (MMSI), IMO номер судна;

- флаг, судовладелец (оператор), агент судна;

- тип и основные размеры судна;

- порты (страны) отправления и назначения;

- даты и время входа в район действия СУДС и выхода из него;

- якорное место, грузовой терминал и номер причала;

- даты и время постановки на якорь или к причалу; 
- осадка, вид и количество груза, наличие (количество) пассажиров при входе в район действия СУДС и при выходе из него;

- сведения о предыдущих посещениях судном района действия СУДС.

Вся информация поступает в соответствующий локальный ЦУДС и в центр обработки данных РИСС.

Объединение АИС в сети позволяет оптимизировать размещение и использование средств навигационного обеспечения, принятие управленческих решений, транспортные потоки, изменения схем движения и разделения движения судов и другие.

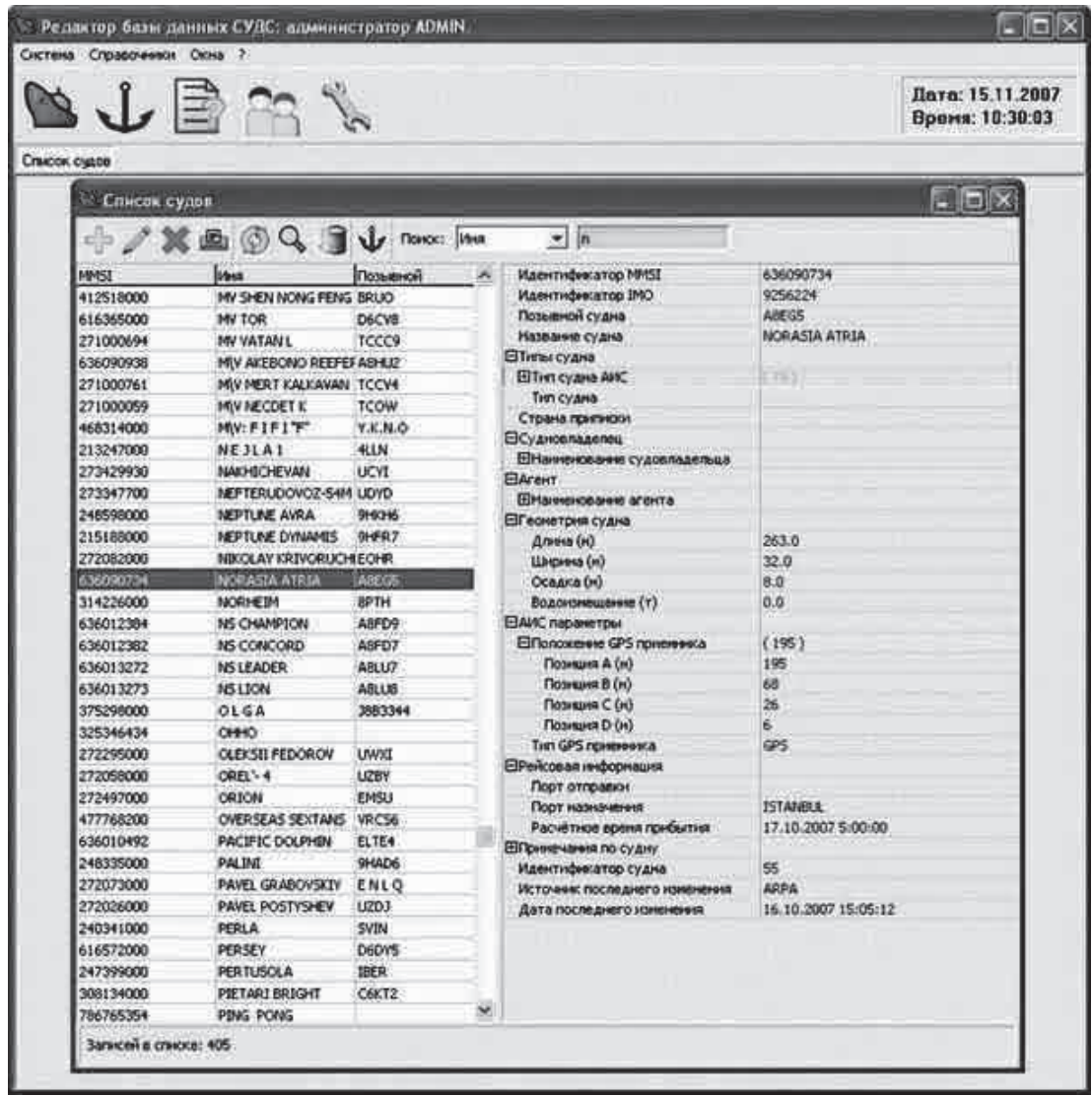

Рис. 4.6.1. Вид редактора базы данных судов СУДС 
Центральным звеном информационной поддержки СУДС является база данных (БД) системы. Типовые требования к БД СУДС включают необходимость обеспечивать ввод, обработку, хранение и вывод информации об обслуживаемых судах, месте их нахождения и перемещениях в районе действия СУДС. Информация в БД СУДС должна содержать следующие сведения:

- название, позывной, идентификатор морской подвижной радиослужбы (MMSI), IMO номер судна;

- флаг, судовладелец (оператор), агент судна;

- тип и основные размеры судна;

- порты (страны) отправления и назначения;

- даты и время входа в район действия СУДС и выхода из него;

- якорное место, грузовой терминал и номер причала;

- даты и время постановки на якорь или к причалу;

- осадка, вид и количество груза, наличие (количество) пассажиров при входе в район действия СУДС и при выходе из него;

- сведения о предыдущих посещениях судном района действия СУДС.

В СУДС высшей и первой категории базы данных должны быть связаны со средствами обработки радиолокационной информации и аппаратурой АИС. Информация из БД предоставляется морским спасательным координационным центрам, государственным надзорным и контрольным органам в области судоходства.

Архитектура современных баз данных (БД РСМБ) учитывает достижения в области систем управления БД и использует технологии создания сложных программных систем. В результате БД имеют следующие основные свойства:

- надежность и отказоустойчивость;

- оперативность и полнота информации для пользователей системы;

- оптимизация сетевого трафика;

- нечувствительность к временному разрыву соединений между отдельными узлами распределенной системы;

- возможность доступа к системе внешним пользователям через Интернет; 
- наличие модуля межсистемного информационного взаимодействия.

Рассмотрим для примера структуру БД, приведенную на рисунке 4.6.2 [104]. Подобная структура лежит в основе БД РСМБ в восточной части Финского залива. БД СУДС представляет собой распределенную систему и включает центральный сервер, серверы локальных служб управления движением судов (ЛСУДС), серверы региональных центров управления движением судов (РЦ УДС). Каждый из серверов имеет свой экземпляр БД РСБМ. Синхронизация экземпляров БД происходит посредством непрерывных двухсторонних репликаций информации путем слияния БД периферийных серверов с БД центрального сервера.

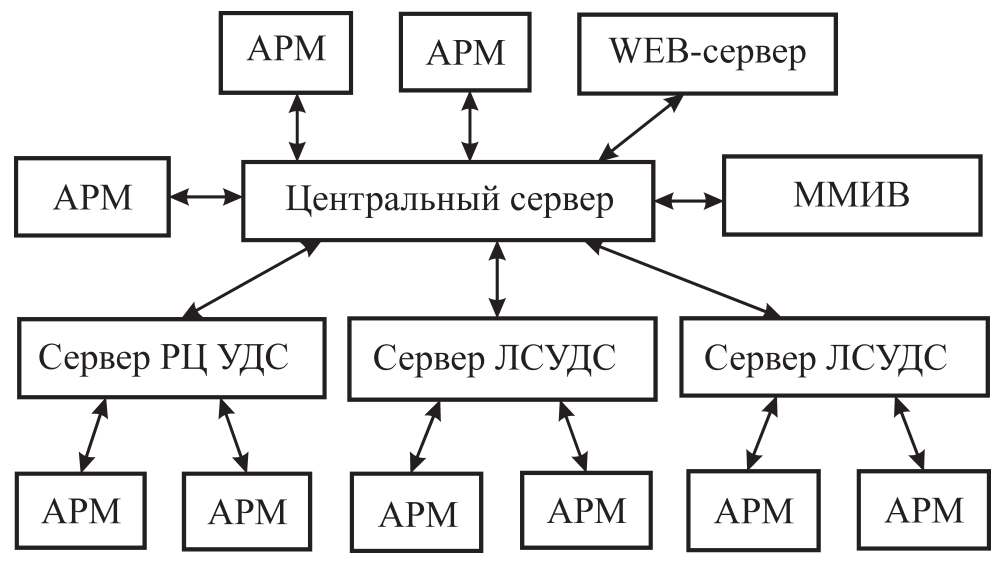

Рис. 4.6.2. Структура базы данных системы управления движением судов: АРМ - автоматизированные рабочие места;

ММИВ - модуль межсистемного информационного взаимодействия

Репликация (от лат. replicatio - повторение) - это одна из техник масштабирования баз данных, которая состоит в том, что данные с одного сервера БД постоянно копируются (реплицируются) на один или несколько других серверов БД. Такие копии называются репликами, а обмен репликами - синхронизацией. Другими словами, репликация - это процесс создания копий (реплик) файлов, между которыми может осуществляться обмен обновляемыми данными 
или объектами. Механизм репликации позволяет приложению использовать не один сервер для обработки запросов, а несколько. Таким образом, появляется возможность распределения нагрузки с одного сервера на несколько. Любое изменение в экземпляре БД РСБМ на каком-то из серверов сразу же распространяется на все остальные экземпляры БД РСБМ через механизм репликаций.

Повышение надежности и отказоустойчивости достигается путем дублирования центрального сервера в виде двухмашинного кластера. Данные хранятся на RAID-массиве, который является общим для каждого из узлов кластера. Один из узлов кластера является рабочим, а другой находится в горячем резерве. В случае отказа основного узла кластера резервная машина переводится в рабочее состояние.

Запросы пользователей автоматизированных рабочих мест (AРM) на получение информации из БД РСБМ выполняются на сервере, с которым соответствующий АРМ находится в одном сегменте локальной сети. Таким образом обеспечивается оптимизация сетевого трафика. В этом случае не требуется задействовать радиорелейные линии, осуществляющие взаимодействие отдельных сегментов сети.

Архитектура БД РСБМ позволяет системе работать даже в случае временного разрыва связи между отдельными сегментами локальной сети распределенной системы. В этом случае изменения, сделанные пользователем, происходят только в одном экземпляре БД РСБМ. Однако как только связь восстановится, то механизм репликаций обеспечит отложенную синхронизацию всех экземпляров баз данных.

В состав БД РСБМ входит WEB-сервер, который обеспечивает возможность взаимодействия системы с удаленными пользователями через Интернет. В качестве клиентского приложения в этом случае используются стандартные средства операционной системы для просмотра WEB-сайтов. Такой подход позволяет легко расширять круг пользователей системы, особенно тех, которые не участвуют в процессе наполнения базы данных информацией, а только используют сведения, подготовленные на других рабочих местах. 
Интернет-технологии дают возможность в целях экономии усилий использовать Web-ориентированные методы. Так, например, клиентское приложение, исполняемое на стороне Web-сервера и взаимодействующее с судоводителем посредством интернет-браузеров, позволяет снизить до минимума требования к персональным компьютерам, установленным на судах.

Организовывать взаимодействие БД РСБМ с базами данных других организаций или государств позволяет модуль межсистемного информационного взаимодействия (ММИВ). Процедура взаимодействия достаточно легко реализуется с использованием XML-протокола обмена основной информации по судам.

\section{7. Системы судовых сообщений}

Системы судовых сообщений (CCC, Ship Reporting System SRS) рассматриваются как системы, дополняющие СУДС (VTS) или расширяющие район действия СУДС. Организационно-технической основой систем судовых сообщений является сбор и обработка в установленном порядке информации от судов, поступающей по каналам морской радиосвязи в береговой центр.

Организация ССС включает следующие основные мероприятия;

- выделяется район действия системы, имеющий определенные географические границы;

- организуются береговые центры, которые на основе специальных полномочий и соответствующего технического оснащения обеспечивают функционирование системы судовых сообщений;

- в районе действия системы вводится такой режим плавания, когда суда в добровольном или обязательном порядке в соответствии с установленными процедурами передают в береговые центры специальные сообщения, информация которых регистрируется, систематизируется, обрабатывается и в случае необходимости используется в различных целях.

По мере развития в районах оживленного судоходства систем разделения движения и систем управления движением судов в судоходстве все более и более стала расширяться практика 
радиообмена информацией между судами и различными береговыми центрами. Стала очевидной необходимость разработки и внедрения на морском флоте стандартного формата судовых сообщений. В 1983 году на Ассамблее ИМО была принята Резолюция А.531(13) «Общие принципы для систем судовых сообщений», которая в последующие годы несколько раз изменялась и дополнялась.

Участие в ССС до середины 1990-х годов было добровольным. Однако в соответствии с дополнениями к СОЛАС-74, принятыми ИМО в 1994 году, стало возможным введение обязательных систем ССС. Решение о введении ССС принимается ИМО по представлению правительства соответствующего государства или договаривающихся правительств, если предполагается, что под район действия системы попадут воды, находящиеся под юрисдикцией нескольких государств.

Развертывание морскими странами районов А1 ГМССБ вдоль побережий способствовало созданию прибрежных ССС, использующих голосовую радиосвязь в УКВ-диапазоне и базовые станции районов А1 ГМССБ в качестве инфраструктуры. Начиная с 1996 года в различных районах мира введены в действие следующие CCC (SRS) этого типа: Торресов пролив и Большой барьерный риф (Австралия) - REEFREP; Большой Бельт (Дания); Гибралтарский пролив (Испания и Марокко); Малаккский и Сингапурский проливы - STRAITREP; Черноморские проливы (Турция); пролив Ла-Манш (Франция) - MANCHEREP. Указанные прибрежные SRS, действующие в международных водах или проливах, прошли процедуры официального рассмотрения и одобрения в ИМО и получили статус обязательных для использования судами под флагом стран - членов ИМО. Большинство прибрежных SRS в той или иной степени интегрированы с VTS, действующих в этих же районах, или взаимодействуют с VTS.

Правовой основой для введения и функционирования ССС в настоящее время являются следующие документы ИМО:

- Международная конвенция по охране человеческой жизни на море, СОЛАС-74 (Глава V, Правило 11); 
- Международная конвенция по поиску и спасанию на море SAR-79 (Глава 5);

- Резолюции MSC.43(64) Руководство и критерии для систем судовых сообщений и A.851(20) Общие принципы систем судовых сообщений и требования к судовым сообщениям, включая руководство по сообщениям об инцидентах с опасными грузами, вредными веществами и (или) поллютантами.

Правило 11 главы V СОЛАС-74 определяет назначение ССС в обеспечении безопасности человеческой жизни на море, повышении безопасности и эффективности судовождения и защите морской среды. Организационные структуры ССС информационно обеспечиваются получаемыми формализованными сообщениями и выполняют следующие задачи:

- контроль судоходства вблизи узлов морских коммуникаций, в проливных зонах и на подходах к портам;

- обеспечение работы служб СУДС;

- организация в кратчайшие сроки поиска и спасания судов в случаях аварий и других чрезвычайных обстоятельств, с привлечением к этим операциям в первую очередь судов, находящихся вблизи судна, терпящего бедствие;

- предупреждение загрязнения моря и инцидентов с опасными грузами, а также проведение работ по ликвидации последствий происшедших загрязнений или инцидентов;

- уточнение метеорологической обстановки и прогнозов погоды по метеосообщениям судов.

Указанные задачи выполняются посредством регулярных передач судами сообщений о своих намерениях и действиях; приема, сбора, обработки и анализа содержания сообщений береговыми структурами систем; путем выработки (в случае необходимости) перед силами, участвующими в поиске, спасании, оказании помощи и ликвидации последствий происшествий, связанных с потерей опасных грузов или загрязнением моря, соответствующих задач и управляющих решений по их исполнению.

При планировании систем судовых сообщений учитывается множество различных факторов: 
- факторы, связанные с окружающей средой и ее защитой;

- метеорологические и гидрографические факторы (преобладающие ветры и течения, наличие банок и подводных опасностей, СНО и их видимость);

- характеристики судопотока (плотность, интенсивность, средняя скорость, состав), наличие пересекающихся судопотоков и узких фарватеров, уровень аварийности, наличие и характер других видов деятельности в районе действия системы;

- состав и характеристики береговых средств обеспечения (техническое оборудование и программное обеспечение);

- способы связи «судно-берег» и методы обработки передаваемой информации;

- мероприятия по обеспечению надежности и эффективности функционирования оборудования и систем;

- наличие и квалификация специалистов, возможность их подГотовки;

- интерфейсы взаимодействия развертываемой ССС и действующих в этом районе систем обеспечения безопасности судоходства, управления движением судов, предотвращения загрязнения моря, а также других систем судовых сообщений.

В обязанность судна, участвующего в ССС, входит передача в береговые центры системы определенной информации заданного формата в установленные правилами моменты времени. В соответствии с требованиями Резолюции MSC.43(64) в CCC связь между береговой властью и участвующими судами должна быть ограничена передачей только такой информации, которая необходима для достижения целей системы, и эта информация не должна использоваться для иных целей. Способы связи должны быть ясными, простыми, скрытными, эффективными и не должны налагать чрезмерных обязанностей на капитанов, вахтенных помощников и лоцманов, что отвечает принципу свободы плавания и свободного прохода. Язык сообщений должен быть понятным береговым службам и участвующим в системе судам. В случае возникновения языковых трудностей следует использовать язык, предложенный капитаном судна, или 
английский язык с применением фраз из Стандартного морского словаря-разговорника.

Чаще всего информация передается по радиотелефону, однако можно использовать также и другие каналы связи, например, спутниковые каналы ИНМАРСАТ, факсимильные каналы связи, каналы передачи данных. В радиотелефонном режиме передачи сообщений отдельные слова для обеспечения надежности произносятся по буквам с помощью использования фонетической таблицы Международного свода сигналов (№ 9016) или Регламента связи.

В настоящее время в системах применяется несколько типов сообщений, формализованных в соответствии с действующим стандартом. Каждое сообщение начинается с наименования системы и идентификатора типа сообщения, состоящего из двух букв латинского алфавита. Каждый раздел сообщения начинается с новой строки и идентифицируется заглавной буквой латинского алфавита. Как правило, в любой ССС используются следующие типы сообщений:

- сообщение о плане перехода (идентификатор SP) - первоначальное, передается до входа (выхода) в район порта;

- сообщение о координатах судна (идентификатор PR) - передается, как правило, один раз в сутки в установленное время или по мере необходимости;

- сообщение об отклонении от курса (идентификатор DR) передается, если судно отклонилось от намеченного маршрута или по решению капитана;

- конечное сообщение (идентификатор FR) - передается по прибытии в порт или при выходе из района действия системы.

Кроме того, существуют специальные сообщения, которые передаются в случае, например, аварийного происшествия, инцидента, связанного с потерей опасного груза или сброса в море нефти либо нефтепродуктов.

В зависимости от района действия ССС можно разделить на категории:

- глобальныле, действующие практически в любой точке Мирового океана; в настоящее время фактически единственной глобальной системой судовых сообщений является система AMVER; 
- региональные, обслуживающие обширные районы, включающие, как правило, несколько морей или воды нескольких государств; большая часть действующих систем относится к этому типу;

- прибрежные, район действия которых ограничивается международными проливами с интенсивным судоходством или прибрежными водами с повышенной осторожностью плавания (районы с повышенной экологической чувствительностью);

- специального назначения - национальные системы CCC (SRS), например, для судов с большой осадкой или судов, перевозящих опасные грузы.

Зона действия автоматизированной системы взаимопомощи судов при спасании AMVER (Automated Mutual-Assistance Vessel Rescue System) охватывает практически весь Мировой океан. Система включает разветвленную сеть береговых и морских радиостанций (более 130 станций), развернутых по всему миру и обеспечивающих бесплатную передачу сообщений [48].

Система AMVER была создана в 1958 году, реконструирована в 1971 году и находится под управлением Береговой охраны США. Участие в системе AMVER является обязательным для всех судов, плавающих под флагом США, а также для иностранных кораблей, находящихся в американских водах и связанных с военным риском. На добровольных началах участвовать в системе AMVER могут любые суда вместимостью 1000 т и более, совершающие рейсы продолжительностью свыше 24 часов в любом районе Мирового океана. Участвующие в системе AMVER суда пересылают сообщения о своем движении и местонахождении в оперативный центр Береговой охраны США, находящийся в Мартинсбурге (Западная Вирджиния). С этой целью используются электронная почта (Интернет), система спутниковой связи ИНМАРСАТ-С, служба высокочастотной радиотелексной связи, высокочастотная радиосвязь, телекс, цифровой избирательный вызов (DSC), факс.

Оперативный центр ведет постоянное слежение за движением зарегистрированных судов, собирает и обрабатывает различную 
информацию о судах, необходимую при проведении поисково-спасательных операций. Эта информация является конфиденциальной и передается только по запросу специальных служб любых стран, занятых в спасании судов. Подробная информация для пользователей публикуется в руководстве AMVER User's Manual, которое издается на 16 языках, в том числе и на русском.

Принцип работы системы AMVER следующий [48]. Когда Спасательно-координационный центр (СКЦ) принимает сигнал бедствия, то в AMVER направляется запрос о судах, находящихся вблизи места бедствия. С помощью специальной компьютерной программы формируется поверхностная картина (SURface PICture - SURPIC), отображающая расположение близлежащих судов, которая сопровождается текстом с информацией об этих судах. Информация включает следующие сведения: названия, позывные, координаты, курсы, скорости, порты назначения и предполагаемое время прибытия.

В СКЦ определяется район поиска, в котором предполагается нахождение аварийного судна. Для поиска аварийного судна из близлежащих судов формируется «поисковая группа». Для поисковых судов рассчитываются локсодромические курсы таким образом, чтобы обеспечить оптимальное обследование района поиска. Каждому судну дается задание на поиск, сообщаются координаты точек входа в район поиска и выхода из него. Пример использования кругового района SURPIC для организации поиска аварийного судна с использованием четырех поисковых судов изображен на рисунке 4.7.1 [48].

Во время поиска суда регулярно сообщают в СКЦ свои координаты, данные о погоде и информацию, заслуживающую внимания. В случае необходимости СКЦ может заказать SURPIC к востоку от района поиска или в любом другом месте, на любое время и любых размеров. Исчерпывающую информацию о работе системы AMVER можно узнать на сайте по адресу: http//AMVER.com.

K системам регионального типа относится Японская система судовых сообщений JASREP (Japanese Ship Reporting System). Система JASREP была введена в эксплуатацию в 1985 году. Она 


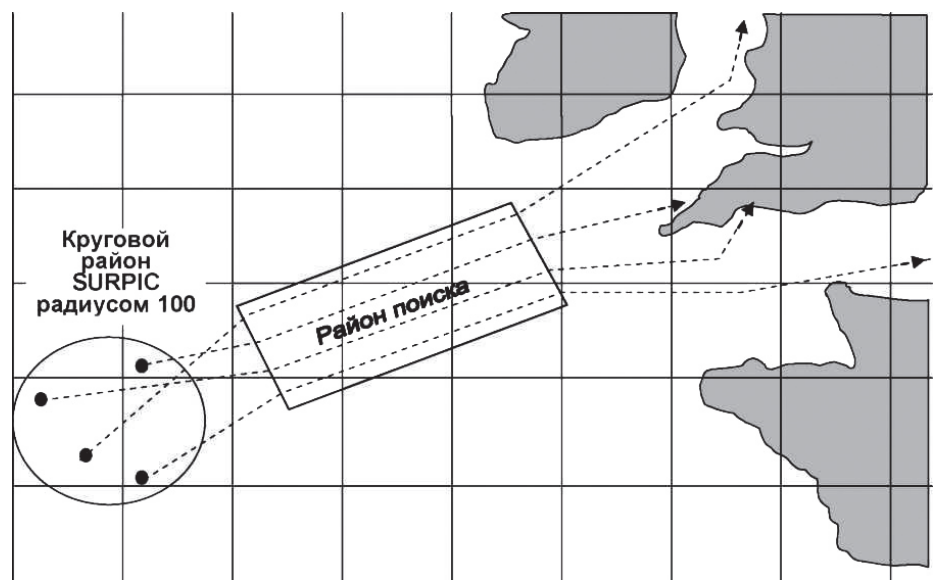

Рис. 4.7.1. Пример использования кругового района SURPIC для организации поиска аварийного судна

обслуживает обширный район от побережья Камчатки до Филиппин и находится в ведении Управления морской безопасности Японии (рис. 4.7 .2 [137]).

Передаваемая в сообщениях информация является конфиденциальной и используется только для поисковых и спасательных операций. Система позволяет сократить временной интервал между потерей контакта с судном и началом поисково-спасательных мероприятий; быстро определить суда, которые могут быть при-

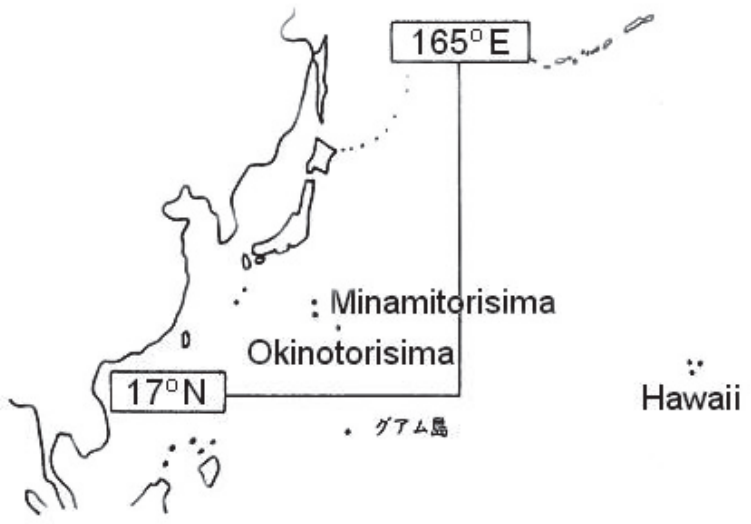

Рис. 4.7.2. Зона действия региональной системы судовых сообщений JUSREP 
влечены для оказания помощи; ограничить поисковый район, если координаты судна точно не известны; облегчить условия оказания срочной медицинской помощи или медицинских консультаций судам, не имеющим на борту врача.

Участие в системе JASREP начинается, когда судно посылает в штаб-квартиру Управления морской безопасности сообщение о плане перехода, а заканчивается, когда до или после прихода в порт или при выходе из зоны обслуживания системы передается заключительное сообщение. Судовые сообщения передаются телеграфом на коротких волнах на коротковолновую радиостанцию Управления морской безопасности в Токио или на одну из 22 радиостанций, работающих в диапазонах СВ, КВ или УКВ. Сообщения могут передаваться с помощью других средств связи, например, телексом, в виде письменного сообщения, телеграммой или по телефону (включая случаи, когда информация передается через судовладельца или агента).

Если после получения последнего сообщения от судна, участвующего в JASREP, в течение 24 часов не поступит сообщения о местоположении или заключительного сообщения, то Управление морской безопасности принимает меры, чтобы удостовериться в безопасности этого судна. Выполняется радиопоиск, во время которого судно запрашивается по радиотелеграфу, делаются попытки связаться с судовладельцем, агентом или специализированными береговыми службами. Радиостанция JNA на специально выделенных частотах передает всем судам общий вызов в период времени, начиная с 55 минут каждого нечетного часа японского стандартного времени JST, равного (UTC + 9) часов. Все суда должны прослушивать передачи радиостанции JNA, насколько это практически возможно. Затем в зависимости от обстоятельств могут быть начаты поисковые операции. Учитывая это, сообщения о местоположении или заключительное сообщение суда должны передавать в обязательном порядке и без нарушения сроков. Подробную информацию о системе JASREP можно найти в руководстве JASREP. Users Manual for Ocean-going Ships, издаваемом Управлением морской безопасности Японии. 
Суда могут одновременно участвовать в системах JASREP и AMVER. Для этого разработана специальная процедура передачи сообщения особого типа, а оперативные центры этих систем постоянно обмениваются информацией о судах.

Береговая инфраструктура прибрежных систем судовых сообщений, как правило, формируется на основе базовых станций морских районов А1 ГМССБ. В них используется голосовая УКВрадиосвязь. Прибрежные системы судовых сообщений охватывают, в основном, прибрежные международные воды и проливы. Большинство прибрежных систем появилось после 1996 года. Основное назначение прибрежных систем судовых сообщений заключается в содействии обеспечению безопасности и эффективности судоходства, а также защите морской окружающей среды.

Характерным примером прибрежной CCC (SRS / VTS) является STRAITREP (рис. 4.7.3 [13]), действующая в международных водах Малаккского и Сингапурского проливов. Она одобрена IMO и обязательна для использования судами, следующими по проливам в системе разделения движения. С организационно-технической точки зрения интегрированная система безопасности мореплавания

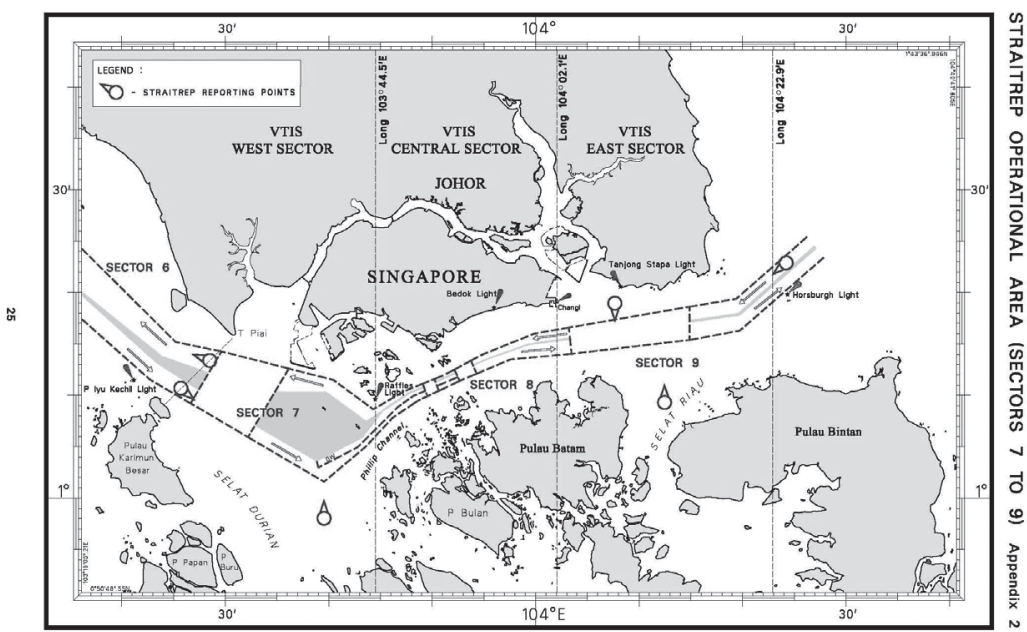

Рис. 4.7.3. Прибрежная система безопасности мореплавания SRS (VTS) STRAITREP 
STRAITREP действует в прибрежной зоне протяженностью более 200 миль, имеет три субцентра и обслуживает несколько портов. С правовой точки зрения в юго-восточной части Малаккского пролива и в Сингапурском проливе имеется несколько Служб (систем):

- SRS, действующая в международных водах совместно с системой разделения движения;

- VTS Келанг, обеспечивающая порты Келанг, Порт-Диксон и Малакка и подходы к ним в пределах территориальных вод Малайзии;

- VTS Джохор, обеспечивающая порты Джохор-Бару и БатуПахат и подходы к ним в пределах территориальных вод Малайзии;

- VTS Сингапур, обеспечивающая акваторию порта с ближайшими подходами в пределах территориальных вод Сингапура.

Участвующие суда должны в установленных точках передавать в береговые центры сообщения, содержащие информацию о судне, маршруте движения и опасных грузах на борту. На побережье Малайзии установлено 7 мощных РЛС, совмещенных с ОВЧ радиостанциями, которые обеспечивают контроль судоходства на акватории проливов. Управление работой системы осуществляется из трех Центров VTS - Келанг, Джохор (Малайзия) и Сингапур. Центры VTS имеют смежные секторы ответственности и обмениваются информацией между собой. Центры VTS Келанг и Джохор дополнительно обеспечивают контроль судоходства на подходах к нескольким портам Малайзии. Центр VTS Сингапур имеет свои береговые РЛС и радиостанции местного значения, обеспечивающие контроль судоходства на акватории порта и на подходах к нему.

По существу, STRAITREP является региональной VTS с функциями контроля судоходства и только с формальной точки зрения является SRS.

Судно, участвующее в системе STRAITREP, также может участвовать еще в двух добровольных системах судовых сообщений глобальной AMVER и региональной SINGREP.

Участие судна в любой из систем безопасности мореплавания, помимо предоставления определенных возможностей, накладывает на него и конкретные обязательства. Судоводители еще на этапе 
планирования рейса должны учесть наличие и возможности системы судовых сообщений в районе предстоящего плавания. При этом следует выбрать возможные варианты адресования и передачи сообщений через береговые радиостанции или иным способом в зависимости от маршрута перехода, перевозимого груза и указаний судовладельца.

\section{8. Перспективы развития систем безопасности судоходства}

Развитие систем безопасности мореплавания базируется на разработке и внедрении таких технологий, как электронная навигация (е-Navigation, е-Навигация), модернизированная Глобальная морская система связи при бедствии и для обеспечения безопасности (МГМССБ), интеллектуальные технологии в управлении. Рассмотрим основные особенности этих направлений развития.

Использование в мировой морской практике новейших цифровых технологий, таких как ГМССБ (GMDSS), АИС (AIS), LRIT (Longrange Identification and Tracking, Система дальней идентификации и контроля местоположения судов), VDR (Voyage Data Recorder, Автоматический регистратор данных рейса, «черный ящик»), выявило ряд проблем в области судоходной промышленности. Новые виды морской техники и эксплуатационные стандарты разрабатывались и внедрялись ИМО в значительной степени спонтанно, причем, как правило, по инициативе промышленности с целью повысить безопасность судоходства путем усиления контрольных функций. Каждая из новых систем после нескольких лет массовой эксплуатации внесла свой вклад в развитие конвенционного судоходства, основой которого являются Конвенции ИМО, Международный кодекс по управлению безопасностью и другие инструменты ИМО. Однако мировая статистика аварийности стабильно демонстрирует, что, независимо от внедрения обязательных навигационных инструментов, главной причиной аварий на море является человеческий фактор [7]. Парадокс состоит в том, что с ростом технической и информационной насыщенности судна средствами, предназначенными 
для обеспечения безопасности мореплавания, растет нагрузка на судоводителя. Кроме того, при жестких требованиях к механической прочности судна и устойчивости к воздействию среды практически не контролируется надежность программного обеспечения. В этом контексте гармонизация требований к оборудованию и его эффективному использованию требует дополнительных усилий.

С другой стороны, быстрое развитие и внедрение на морских судах новых технологий судовождения, основанных на использовании электронных технических средств (СНС, АИС, ЭКС, космическая связь и другие), коренным образом изменило практику работы судоводителей, что потребовало внесения изменений в идеологию современной навигации и судоходства. Для исправления проблемной ситуации ИМО разработала глобальную стратегическую программу е-Навигации, в основе которой лежит координация систем морской навигации и вспомогательных береговых служб в соответствии с потребностями пользователей [43]. На рисунке 4.8.1 представлена схема взаимодействия основных модулей в системе е-Навигации.

В соответствии с определением ИМО, «...е-Навигация - это гармонизированные сбор, интеграция, обмен, представление и анализ морской информации на борту судна и в береговых системах посредством электронных средств для совершенствования процесса перехода (судна) от пирса до пирса (в портах отхода и назначения) и соответствующих сервисов, обеспечивающих безопасность мореплавания, судов и береговой инфраструктуры и защиту окружающей среды» [34].

Это означает, что капитан, вахтенный помощник и береговые службы должны быть обеспечены современными устройствами, использование которых позволит сделать морское судоходство и системы связи более надежными, безопасными и удобными. Это приведет к сокращению числа ошибок. Целью внедрения е-Навигации является повышение безопасности и эффективности мореплавания за счет создания единой информационной среды для судовых и береговых штурманов, использования сервис ориентированной архитектуры всех систем и готовности всех систем к использованию новых сервисов е-Навигации по мере их появления. 


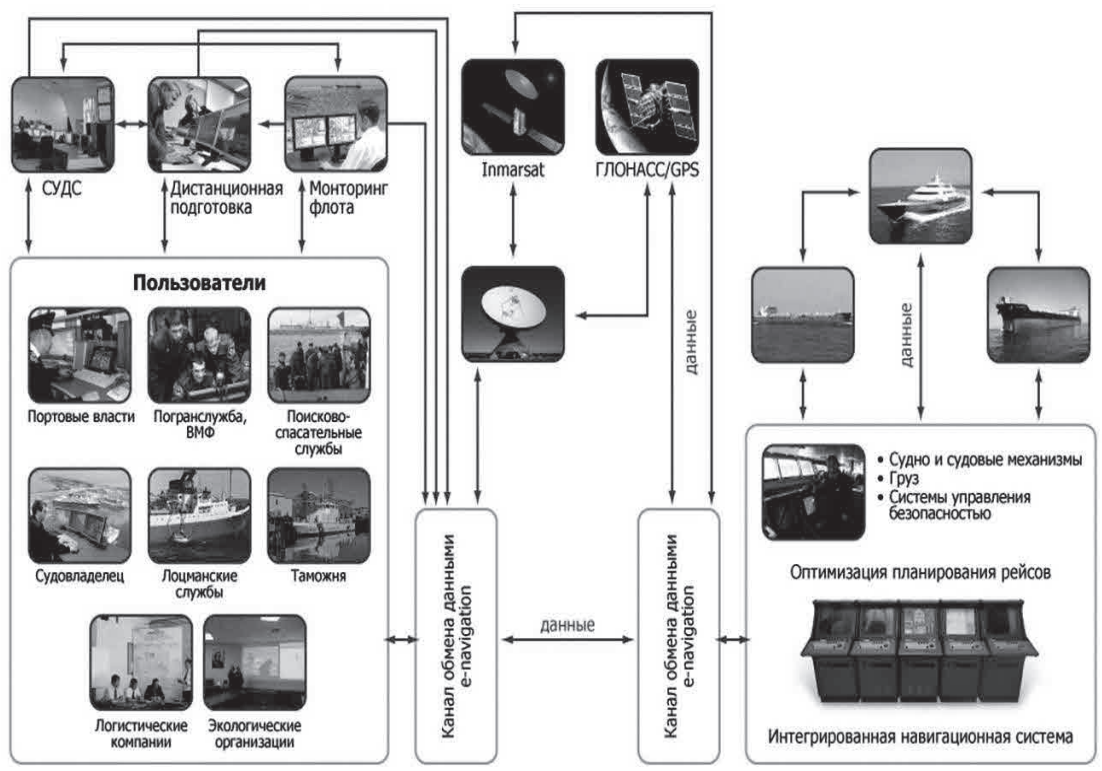

Рис. 4.8.1. Архитектура взаимодействия систем с использованием технологии е-Навигации

Внедрение е-Навигации в системы безопасности мореплавания подразумевает обмен информацией между судном и берегом посредством бинарных сообщений АИС с последующим графическим представлением обработанной информации судоводителям и операторам СУДС, включая передачу различной навигационной информации [20]:

- гидрометеорологических данных;

- информации по опасным грузам;

- сообщений о закрытии фарватеров;

- данных о количестве человек на судне;

- псевдоАИС цели (цели СУДС);

- назначения маршрутов;

- адресных сообщений и тревоги;

- данные о запретных (опасных) для захода судов областях.

Структурная схема системы безопасности мореплавания с еНавигацией представлена на рисунке 4.8.2 


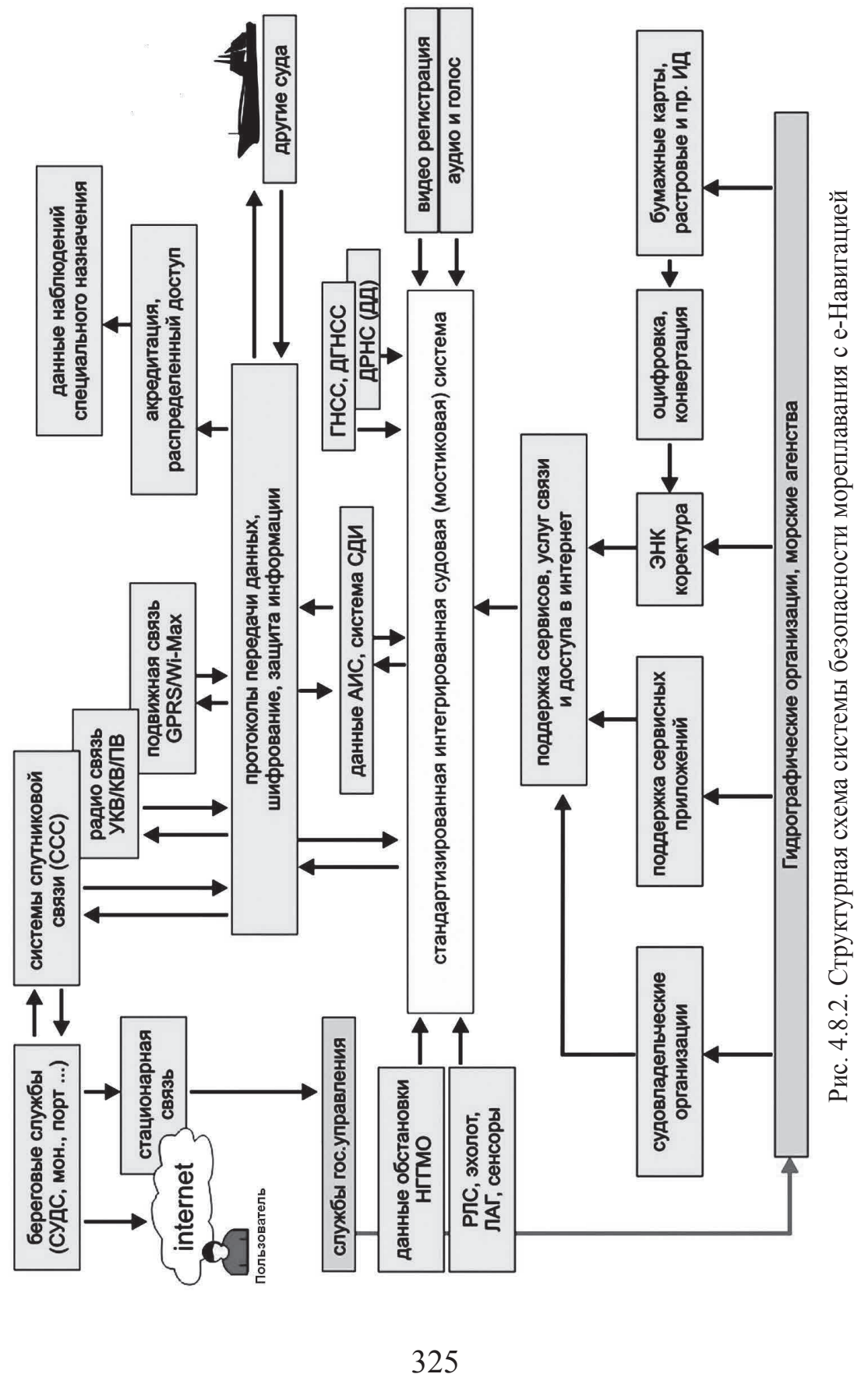


Можно выделить пять экономических мотивов и целей реализации программы е-Навигации [31]:

- снижение расходов на поддержание, печать и доставку потребителям коллекций навигационных карт и пособий при ограниченных бюджетах гидрографических служб;

- оптимизация физических средств навигационного оборудования (CHO);

- повышение достоверности и точности планирования рейсов судов, участвующих в мультимодальных перевозках, а также повышение эффективности использования флота;

- упрощение процедур обязательных докладов при одновременном повышении информированности береговых и портовых властей. В качестве возможного решения рассматривается вариант «единого окна», когда оператор судна предоставляет информацию береговым властям, используя наземную инфраструктуру связи, а мониторинг фактического движения судна ведется посредством АИС, в том числе космического базирования;

- обеспечение безопасности судоходства и повышение эффективности мер по защите окружающей среды, повышение информированности судоводителя при планировании и выполнении рейса от пирса до пирса без информационной перегрузки.

Основной тренд развития технологии навигации направлен на ее информационное обеспечение в цифровом виде, создание систем, спроектированных на основе принципов Human centric design - расширенных понятий эргономики, которые включают интуитивно понятный человеко-машинный интерфейс, профессионально ориентированную логику (в отличие от вызова отдельных функций системы), устойчивость к ошибкам ввода данных, автоматический отбор и представление информации о навигационной ситуации и т. п.

Таким образом, центральной задачей программы е-Навигации является снижение зависимости судоходства от физических средств навигационного оборудования, получение экономической выгоды и обеспечение конкурентных преимуществ для национальных экономик различных стран. 
Стратегическая программа ИМО в области навигации уже реализуется на уровне национальных программ в развитых странах. В Австралии, Швеции, Норвегии, Канаде, Японии, Южной Корее такие национальные программы учтены в существующей структуре государственных органов, отвечающих за обеспечение безопасности мореплавания. В Европейском союзе научно-исследовательские проекты в области е-Навигации ведутся на гранты ЕС (например, SafeSeaNet, Monalisa). В Англии инициирована работа по возрождению радионавигационной системы e-Loran для обеспечения надежности координатно-временного обеспечения навигации.

В США национальная программа e-Navigation Strategic Action Plan по созданию инфраструктуры е-Навигации принята в виде директивы по созданию специального координирующего органа - Комитета по морской транспортной системе (CMTS). Стратегический план предусматривает участие Береговой охраны США, Корпуса армейских инженеров, Национальной администрации атмосферы и океанов (NOAA), Национального управления безопасности перевозок, Морской администрации, Аппарата океанографа ВМФ, Администрации исследований и инновационных технологий и собственно секретариата CMTS. Программа e-Navigation Strategic Action Plan также включает развитие инфраструктуры информационных систем речного судоходства и ее интеграцию с инфраструктурой обеспечения морского судоходства.

Информационная безопасность объектов систем безопасности мореплавания в России обеспечивается в соответствии с требованиями Федерального закона № 16 «О транспортной безопасности» от 09.02.2007 г. и включает в себя защиту технических и программных средств информатизации от ошибочных действий персонала, техногенных воздействий и стихийных бедствий, а также защиту технических и программных средств информатизации от преднамеренных воздействий. В рамках федеральных целевых программ «Мировой океан», «Поддержание, развитие и использование системы ГЛОНАСС», «Развитие гражданской морской техники», «Развитие транспортной системы России» и ряда других программ финансируются различные НИОКР, которые могут иметь отношение 
к технологии навигации будущего. Современное развитие навигации требует и в России адекватных решений, направленных на создание необходимой национальной инфраструктуры устойчивого информационного обеспечения е-Навигации.

Разработка и использование виртуальных средств навигащионного оборудования совместно с возможностями базовых станций АИС будут направлены на сокращение затрат на установку и поддержание навигационных знаков в ледовых условиях и труднодоступных местах.

Модернизация ГМССБ происходит в направлении разработки новых стандартов для судового и берегового оборудования. Пересмотр элементов и процедур ГМССБ связан с необходимостью внесения поправок в главу IV МК СОЛАС, пересмотром и разработкой эксплуатационных требований к судовому радиооборудованию, береговым системам радиосвязи и навигационного обеспечения, применением современных технологий распространения информации и передачи данных [99].

Модернизация ГМССБ в соответствии с рабочим планом подкомитета ИМО по радиосвязи, поиску и спасанию (IMO subcommittee on radiocommunications and search and rescue - COMSAR) предусматривает два уровня - высокий и детализированный. Высокий уровень связан с развитием базовых функциональных требований и уточнением определений. Детализированный уровень рассматривает вопросы о включении в МГМССБ новых систем и электронных технологий (таких как АИС, систем судового охранного оповещения, опознавания судов на дальнем расстоянии, элементов е-Навигации), о принятии новых требований к оборудованию спасательных шлюпок и плотов в части обеспечения дальней радиосвязи, об эволюции спутниковых аварийных радиобуев с учетом внедрения среднеорбитальной спутниковой группировки с поисково-спасательной нагрузкой и другие вопросы.

В качестве элементов МГМССБ предполагается использовать новые технологии и системы в таких областях, как:

- АИС, включая применение спутникового АИС для мониторинга судов и использования новых типов сообщений; 
- цифровые технологии связи и передачи данных в УКВ- и КВ-диапазонах;

- модернизированные спутниковые системы и цифровые системы передачи информации по безопасности мореплавания и морской безопасности (охраны) в диапазоне 500 кГц в направлении берег - судно (NAVDAT).

Предполагается также разработка кодекса ГМССБ, который будет включать обязательную и рекомендательную части и определит требования к оборудованию для различных типов судов.

В период до 2020 г. потребителям станут доступны дополнительные сигналы Глобальной навигационной спутниковой системы (ГНСС), включая сигналы ГАЛИЛЕО, новые сигналы GPS: L5, GPS L1C, GPS L2C и сигналы ГЛОНАCC - M (L1, L2).

Новые технологии при создании береговых радиолокационных станций базируются на многодиапазонности, территориальной распределенности радиолокационных станций с возможностью совместной обработки информации, применении сложных зондирующих сигналов, доплеровской фильтрации, а также на использовании полностью твердотельных высоконадежных приемопередатчиков малой мощности. Значительное снижение уровня пиковой мощности в несколько раз увеличит надежность и ремонтопригодность БРЛС. Использование таких технологий позволит увеличить наработку на отказ приемопередатчика до 30-50 тыс. часов. Применение доплеровской фильтрации позволит мгновенно определять скорость движущихся объектов.

В модернизированных и новых системах безопасности мореплавания предполагается внедрение новых услуг:

- лоцманской проводки с берега;

- удаленного заказа и корректуры электронных карт из картографических баз данных через мобильную широкополосную связь;

- организации берегового ледового сервиса, обеспечивающего передачу на борт спутниковых снимков, цифровых ледовых карт и рекомендованных маршрутов.

Ожидается пересмотр требований к оснащению морских нефтегазовых платформ средствами связи и навигации. Предполагается, 
что на стационарных платформах будут устанавливаться элементы береговых СБМ, что позволит замкнуть информационные потоки с платформ на региональные системы наблюдения за судоходством.

Сбор и предоставление информации для государственного надзора в СБМ будут обеспечиваться путем развития систем сбора и обработки информации о движении судов, создания региональных информационных систем наблюдения за судоходством, внедрения комплексной интегрирующей информационной системы (КИИС) «МоРе». Эта система объединяет информационные системы государственного портового контроля, системы обеспечения и поддержки поисково-спасательных и аварийно-восстановительных работ на водном транспорте, информационные системы поддержки надзорной и контрольной деятельности на водном транспорте и предоставляет оперативную информацию о расстановке флота, параметрах движения судов, данные о перевозке опасных грузов и другую актуализированную информацию.

Для расширения международного сотрудничества в части развития СБМ Российская Федерация предполагает участвовать в двусторонних и многосторонних договорах и соглашениях с соседними государствами, продолжать работу в международных проектах Балтийского моря GOFREP и HELCOM AIS (проект Хельсинкской комиссии по охране морской среды Балтийского моря). Также планируется информационная интеграция систем для передачи согласованных данных о движении судов в Азово-Черноморском бассейне, создание совместной российско-норвежской информационной системы управления движением судов в Баренцевом море (Barents VTMIS), возможно сотрудничество в Беринговом море. Ключевые идеи СБМ, основанные на комплексном применении радиотехнических систем навигации и связи, средств высокоточного местоопределения судов при любых условиях видимости, установления морских районов А1, А2 ГМССБ, систем передачи информации, обеспечивающей соблюдение правил плавания судов, доказали свою эффективность и верность концептуальных подходов, заложенных при разработке и внедрении региональных систем безопасности мореплавания. Будет происходить дальней- 
шая информационная интеграция СУДС как на региональном и национальном, так и на транснациональном уровнях, с зарубежными СУДС и системами мониторинга за судоходством.

В Международной ассоциации морских средств навигации и маячных служб обсуждается возможность обращения в ИМО для учреждения СУДС с областью действия, выходящей за пределы территориального моря прибрежных государств.

В этом направлении перспективными являются разработки в области создания мобильных систем управления движением судов (МСУДС / MVTS - Mobile Vessel Traffic Services, по аналогии с CУДС / VTS), проводящиеся в Мурманском государственном техническом университете [10]. Эти системы не имеют «привязки» к конкретному району базирования и благодаря чему способны обеспечить безопасное мореплавание в любом районе с интенсивным судоходством, включая удаленные морские акватории.

В системах МСУДС используется глубокая автоматизация и информатизация процессов, позволяющая предоставлять судоводителю необходимую навигационную информацию и освобождающая оператора Центра управления МСУДС от утомительных рутинных действий по оперативному контролю и выработке управляющих решений.

В основе построения и функционирования МСУД лежат формализованные процедуры представления и отображения схем движения судов на подконтрольной акватории. Для этого программными методами создается виртуальная сеть полос движения судов, привязанная к карте акватории. Номера поворотных точек (узлов) сети специальным образом кодируются. Виртуальная сеть хранится в памяти ЭВМ и используется для выработки управляющей и навигационной информации, необходимой для безопасного движения судов на подконтрольной акватории. Для определения путей в МСУДС используется бестабличная кодовая маршрутизация, при которой кратчайший путь между двумя точками движения судна определяется по кодовым комбинациям номеров узлов в виртуальной сети.

К основным достоинствам МСУДС относятся: простота и экономичность процедур управления; ориентация на использование 
доступных стандартных технических средств наблюдения, навигации и телекоммуникации; быстрота развертывания и прекращения деятельности; мобильность и маневренность, позволяющие системе без проблем менять местоположение и перемещаться в пространстве; отсутствие привязки к конкретной местности, нетребовательность к необходимости наземного базирования. Указанные преимущества создают предпосылки для широкого распространения этих систем на практике. Системы МСУДС могут использоваться в удаленных морских районах, не доступных стационарным СУДС. Оборотной стороной глубокой автоматизации процессов является функциональная ограниченность МСУДС по сравнению с традиционными СУДС. Поэтому эти системы не являются полноценным эквивалентом СУДС, но могут рассматриваться как средство расширения функциональных возможностей стационарных СУДС при совместном использовании. Конвергенция традиционных стационарных и мобильных СУДС в зоне морского порта является перспективным средством получения дополнительных возможностей по обеспечению безопасности движения судов. В работе [11] доказана эффективность применения подобных систем в районах рыбного промысла.

Таким образом, дальнейшее развитие систем безопасности мореплавания происходит в направлении углубления информатизации, автоматизации и интеллектуализации, расширения эргономических решений, разработки новых стандартов, использования новейших достижений науки и техники. 


\section{Контрольные вопросы}

1. Каково предназначение лоцманской службы? Назовите причины установления прибрежным государством обязательной лоцманской приводки.

2. Когда появилась лоцманская служба в России? Какие основные этапы развития она прошла?

3. Что представляют собой системы управления движением судов? Каково их назначение? Чем обусловлен активный характер таких систем?

4. Назовите основные этапы развития систем управления движением судов. Какие основные технические средства характеризуют особенности СУДС различных поколений?

5. Какие основные международные и национальные нормативноправовые документы определяют функционирование систем управления движением судов?

6. Опишите типовую структуру современной СУДС. Каково назначение ее структурных компонентов?

7. Каково назначение, состав и принципы функционирования автоматических идентификационных систем?

8. Назовите наиболее распространенные типы электронных картографических систем. Какие типы электронных карт в них используются?

9. К Какую структуру имеет программный комплекс региональной СУДС? Назовите основные принципы взаимодействия модулей программного комплекса СУДС.

10. Какие типы сообщений используются в системах судовых сообщений? 


\section{5. ОБЕСПЕЧЕНИЕ БЕЗОПАСНОСТИ СУДОХОДСТВА В РАЙОНАХ РЫБНОГО ПРОМЫСЛА}

\section{1. Особенности плавания в районах рыбного промысла}

Рыбное хозяйство России представляет собой сложный производственно-хозяйственный комплекс с развитой многоотраслевой кооперацией и международными связями, глубоко интегрированный как в экономику России, так и в мировое рыболовство. Большое значение в размещении отечественного рыболовного флота в районах Мирового океана, координации научно-технических исследований, развитии экспортно-импортных операций и формировании международно-правовых норм и механизмов по их выполнению отводится развитию международного сотрудничества (двустороннего и многостороннего).

Более 87 \% общей добычи рыбы приходится на районы океанического рыболовства (рис. 5.1 [65]). Российская Федерация

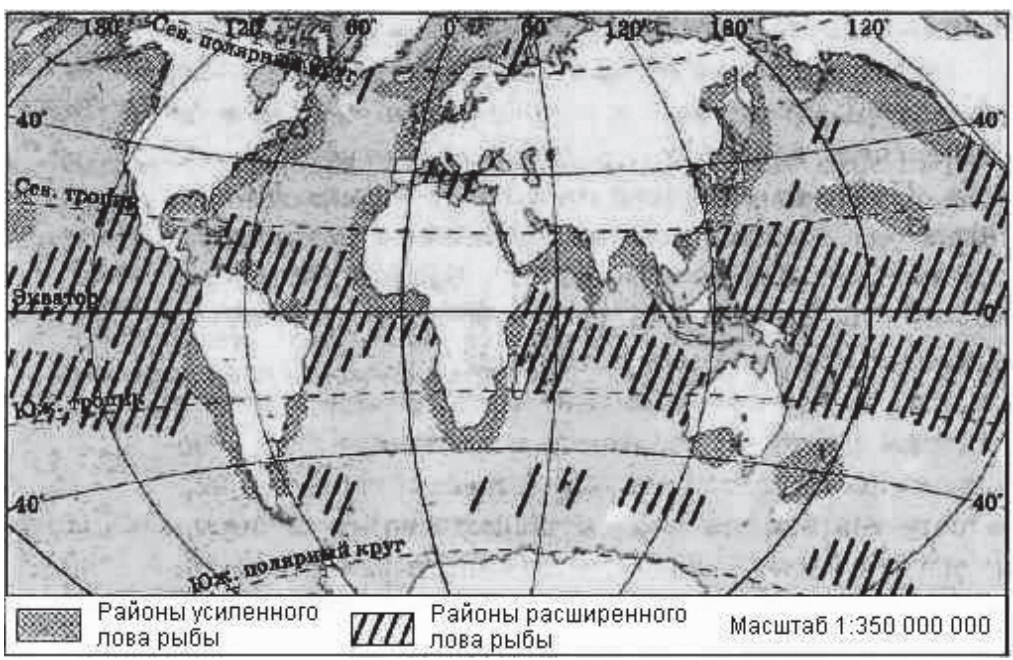

Рис. 5.1. Районы ловли рыбы в Мировом океане 
имеет самую большую в мире береговую линию (38,8 тыс. км). Ее берега омывают воды трех океанов и 14 морей. Российский промысловый флот находится в Атлантике, в Тихом и Индийском океанах, в Северном море.

Промысел судами ведется в подрайонах и экономических зонах. Например, в Тихом океане промысел ведется в основном в Центрально-Беринговском подрайоне, в Северо-Курильской зоне, в подрайоне НАМПО, в зонах Вьетнама, Орегон, Перу и Чили, Колумбии, Эквадора и Новой Зеландии. Ежегодно промысловые суда посещают до 230 портов 69 стран мира и, несмотря на их приписку, осуществляют промысел в различных районах Мирового океана [64].

Существующая система двусторонних и многосторонних связей России в различных областях рыбного хозяйства сформировалась в 70-80-х годах, когда рыболовный флот осуществлял промысел почти во всех районах Мирового океана. В последующие годы геополитическая обстановка в мире изменилась, и рыболовный флот России ушел из многих отдаленных районов промысла. Однако международное сотрудничество продолжало развиваться прежде всего с соседними странами.

Рыболовный промысел сильно отличается от других видов деятельности на море. Это нашло отражение в специифике его правового регулирования и организации мероприятий по обеспечению безопасности судоходства. При движении к месту лова и возвращении в порт из района рыбного промысла промысловое судно находится в правовом поле общих правил и норм мореплавания, обязательных для всех кораблей. А в районе промысла промысловое судно должно следовать нормам, регулирующим плавание с учетом специфики выполнения производственных задач.

Совместный промысел чаще всего осуществляется судами под разными флагами, поэтому для обеспечения безопасности промысла используются нормы международного права, которые подразделяются на общие и специальные.

К общим нормам, обеспечивающим безопасность морского промысла, относятся: Брюссельская конвенция для унификации 
некоторых правил относительно столкновения судов 1910 года; Международная конвенция об охране человеческой жизни на море 1974 года с поправками 2005 года (СОЛАС-74/2005); Международная конвенция о подготовке и дипломировании персонала рыболовных судов и несении вахты 1995 года (ПДНВ-Р-95); Международные правила предупреждения столкновений судов 1972 года (МППСС-72); Международный свод сигналов 1965 года (MCC-65); Международная конвенция о грузовой марке 1966 года; Международная конвенция о спасании 1989 года и другие.

К специальныл нормам международного права, регулирующим совместное плавание и промысел судов, а также их безопасность на промысле относятся: Конвенция о порядке ведения промысловых операций в Северной Атлантике 1967 гола; Правила безопасности при ведении промысла омаров и рыбы в Атлантическом океане с целью предотвращения повреждения ставных орудий лова; Правила рыболовства в Балтийском море; Правила рыболовства для российских судов, работающих в районе действия Соглашений между Правительством Российской Федерации, США и Канады о рыболовстве в северо-восточной части Тихого океана; Соглашение между Правительством Российской Федерации и Правительством Соединенных Штатов Америки о рассмотрении претензий, возникающих в связи с повреждением рыболовных судов или орудий лова и о мерах по предотвращению промысловых конфликтов; Положение о российской части Российско-Японской комиссии по урегулированию претензий, связанных с рыболовством; Положение о РоссийскоАмериканской комиссии по рыболовным претензиям; Соглашение между Правительством Российской Федерации и Правительством Канады о взаимных отношениях в области рыболовства; Соглашение между Правительством Российской Федерации и Правительством Королевства Норвегии о порядке урегулирования претензий, связанных с повреждением орудий лова 1993 года и другие.

Кроме международных правил, безопасность на промысле регулируют многочисленные национальные правила ведения промысла и обеспечения безопасности, в том числе местные правила и правила обычной морской практики [81, 113, 114]. 
Нарушение правил безопасности может привести к негативным последствиям, которые в зависимости от тяжести подразделяются на кораблекрушения, аварии, аварийные происшествия и эксплуатационные повреждения. Кроме того, непосредственно во время промысла могут происходить и так называемые промысловые аварии и инцицдеты , связанные с повреждением орудий промысла и судна в целом.

Промысловая авария или промысловый инцидент определяются рядом специфических признаков [81]:

- промысловая авария (инцидент) происходит в районе промысла;

- среди участников промысловой аварии должно быть хотя бы одно промысловое судно;

- промысловыми судами являются не только рыбодобывающие, но и рыбообрабатывающие, приемотранспортные и иные суда, работающие на промысле;

- участники промысловой аварии заняты промысловой деятельностью;

- следствием промысловой аварии являются промысловые убытки и ущербы;

- промысловая авария связана с особыми условиями совместного промысла;

- при расследовании промысловых аварий должны быть учтены особенности совместного промысла и гидрометеорологические факторы.

Промысловые аварии в той или иной степени влекут за собой возникновение угрозы для человеческих жизней, промысловых судов, их оборудования, груза рыбы, а также для окружающей среды.

Промысловые аварии обуславливаются рядом объектuвных факторов, к числу которых относятся следующие:

- отсутствие возможности маневрировать или ограниченность в маневрировании при лове рыбы;

- высокая концентрация судов на ограниченном пространстве моря (например, при ночном лове кильки на участке моря радиусом 5 миль концентрируется свыше 50 судов [81]); 
- вынужденные частые приближения судов друг к другу, в том числе и при плохой видимости;

- вынужденные отвлечения внимания судоводителей от наблюдения за окружающей обстановкой в связи с выполнением производственных задач;

- отсутствие впередсмотрящего по носу судна и специального наблюдателя на мостике;

- невозможность во многих случаях дать задний ход или уйти с пути другого судна;

- затрудненный контроль орудий лова, особенно при плохой видимости и волнении моря, обусловленный их большой длиной, которая достигает 1-2 миль от судна.

Для обеспечения безопасности судоходства в районе рыбного промысла необходимо выполнение следующих условий совместного плавания:

- неуклонное соблюдение правил МППСС-72, правил совместного плавания и промысла ПСПП-72 [79] и местных правил предупреждения столкновений судов;

- организация движения и маневрирования судов, например, когда суда с тралами идут по установленным общим направлениям (север - юг; северо-восток - юго-запад и т.д.) через рыбную банку, а суда, закончившие траление и обработку трала, обходят стороной суда, идущие с тралами, заходят в начало потока тралящих судов и совершают очередной проход с тралом через банку;

- выполнение всеми судами группы требований по пассивной (на судах и орудиях лова) и активной (подаваемой звуком, светом и по радио) сигнализации;

- постоянная связь всех судов друг с другом на каком-то одном радиоканале и координация своих маневров для избежания столкновения и опасного сближения.

Для успешной координации действий руководитель промысла должен постоянно контролировать порядок совместного плавания, давая обязательные указания капитанам судов и внося коррективы в правила плавания, если этого требуют гидрометеорологические и другие условия. 
Специфической особенностью промысловых аварийных случаев является то, что в качестве ущерба при столкновениях и навалах во время промысла квалифицируются повреждения судами орудий лова, сцепление орудий лова и прочие случаи, связанные с орудиями промысла. В связи с этим особое внимание при расследовании аварийных случаев уделяется нарушениям правил МППСС-72, ПСПП-72, местных правил плавания. При расследовании выявляется, в чем конкретно проявилась противоправность действий судов при совместном плавании, повлекшая за собой какой-либо ущерб. Так, в Правиле 26 МППСС-72 судно, занятое тралением, должно выставлять два круговых огня, расположенные по вертикальной линии, верхний - зеленый, нижний - белый, или знак, состоящий из двух конусов вершинами вместе, расположенных по вертикальной линии один над другим. Судно длиной менее 20 м вместо конусов выставляет корзину. Если выметанные снасти простираются в море по горизонтали более чем на 150 м от судна, то в направлении этих снастей - белый круговой огонь или знак в виде конуса вершиной вверх. Судно, занятое промыслом вблизи других судов, занятых ловом рыбы, может выставлять дополнительные сигналы, описанные в Приложении II к МППСС-72 [66].

В частности, в Приложении II указывается, что все огни промысловых судов должны иметь видимость не менее 1 мили. Суда, производящие лов кошельковыми неводами, ловушками, выставляют дополнительно два желтых огня, расположенных вертикально. Эти огни должны попеременно давать проблески каждую секунду. При этом продолжительность света и затемнения должна быть одинаковой.

Если судно занято тралением, то оно дополнительно выставляет:

1) при выметке снастей - два белых вертикальных огня;

2) при выборе снастей - белый огонь над красным, расположенные вертикально;

3) при зацеплении трала за препятствие - два красных огня, расположенные вертикально;

4) при парном (близнецовом) тралении каждое судно ночью показывает луч прожектора, направляемый вперед и в сторону другого судна этой пары. 


\section{2. Государственный надзор за безопасностью плавания судов рыбопромыслового флота в районах промысла}

Морское рыболовство - это вид экономической деятельности государства, направленный на разведку, добычу (вылов) и доставку потребителям водных биологических ресурсов (улова) и продуктов переработки, а также охрану, защиту и сохранение водных биологических ресурсов с помощью специальных технических средств - морских рыбопромысловых судов. При переходе в район промысла и при осуществлении промысла водных биоресурсов судоводительский состав морских рыбопромысловых судов должен обеспечивать навигационную и иную безопасность плавания судов.

В настоящее время безопасность мореплавания регламентируется как национальными нормативными правовыми актами, так и международными договорами, заключенными и ратифицированными Российской Федерацией.

Правовое регулирование системы государственного надзора за безопасностью плавания судов рыбопромыслового флота в районах промысла в настоящее время регламентируют следующие законы и постановления:

- Федеральный закон Ф3-81 1999 года «Кодекс торгового мореплавания Российской Федерации (КТМ РФ)» [78], согласно которому государственный надзор за торговым мореплаванием в части обеспечения безопасности плавания судов рыбопромыслового флота в районах промысла при осуществлении рыболовства вменен федеральному органу исполнительной власти в области рыболовства;

- постановление Правительства Российской Федерации № 450 2008 года «Об утверждении Положения о Министерстве сельского хозяйства Российской Федерации (Минсельхоз РФ)» [121], которым функция по выработке и реализации государственной политики и нормативно-правовому регулированию в сфере обеспечения безопасности плавания судов рыбопромыслового флота возложена на Минсельхоз РФ. Практическая реализация возложенной на 
Минсельхоз РФ функции вменена структурному подразделению центрального аппарата Минсельхоза РФ - Департаменту регулирования агропродовольственного рынка, рыболовства, пищевой и перерабатывающей промышленности (Департамент рыболовства). Департамент рыболовства осуществляет в установленном порядке свою деятельность во взаимодействии со структурными подразделениями Минсельхоза РФ, подведомственными Минсельхозу РФ, Федеральной службой по ветеринарному и фитосанитарному надзору и Федеральным агентством по рыболовству;

- постановление Правительства Российской Федерации № 444 2008 года «Об утверждении Положения о Федеральном агентстве по рыболовству (Росрыболовство)» [77] (ПП РФ № 444), в соответствии с которым Росрыболовство уполномочено осуществлять государственный надзор за торговым мореплаванием в части обеспечения безопасности плавания судов рыбопромысллового флота в районах промысла при осуществлении рыболовства. Пунктом 1 ПП РФ № 444 Росрыболовство осуществляет свои полномочия в установленных законодательством Российской Федерации случаях на территории, в исключительной экономической зоне и на континентальном шельфе России, а также в случаях, предусмотренных международными договорами Российской Федерации, на территории иностранных государств и в открытых районах Мирового океана. Пунктом 4 ПП РФ № 444 Росрыболовство осуществляет свою деятельность непосредственно через свои территориальные органы, представительства и представителей за рубежом и подведомственные организации во взаимодействии с другими федеральными органами исполнительной власти, органами исполнительной власти субъектов Российской Федерации, органами местного самоуправления, общественными объединениями и иными организациями;

- приказы Росрыболовства об утверждении 20 территориальных управлений Росрыболовства, включая Северо-Западное, Баренцево-Беломорское, Двинско-Печерское, Нижнеобское, Енисейское, Ленское, Северо-Восточное, Охотское, Амурское, Приморское, Азово-Черноморское, которые уполномочены осуществлять функ- 
цию по государственному надзору за торговым мореплаванием, в части обеспечения безопасности плавания судов рыбопромыслового флота в районах промысла, во внутренних морских водах, в территориальном море, исключительной экономической зоне и на континентальном шельфе Российской Федерации.

В соответствии с Административным регламентом по исполнению государственной функции - надзора за обеспечением безопасности плавания судами рыбопромыслового флота в районах промысла при осуществлении рыболовства [82], предметом проверки являются содержащиеся в документах юридического лица или индивидуального предпринимателя сведения и принимаемые ими меры по исполнению обязательных требований, установленных нормативными правовыми актами и международными договорами Российской Федерации в области обеспечения безопасности плавания судов рыбопромыслового флота в районе промысла.

Правительство Российской Федерации своим постановлением № 10232012 года «О реализации положений главы IX приложения к Международной конвенции по охране человеческой жизни на море 1974 года (СОЛАС-74) и Международного кодекса по управлению безопасной эксплуатацией судов и предотвращением загрязнения (МКУБ) (ПП РФ № 1023)» [76] уполномочило Минсельхоз РФ осуществлять в отношении рыболовных судов и их судовладельцев следующие функции:

- определять порядок освидетельствования рыболовных судов и их судовладельцев на соответствие требованиям Кодекса;

- определять порядок выдачи документа о соответствии судовладельца требованиям Кодекса и изъятия такого документа;

- определять порядок выдачи рыболовному судну свидетельства об управлении безопасностью и изъятия такого документа.

Этим же постановлением Правительство Российской Федерации возложило контроль и надзор за выполнением обязательств, в соответствии с Конвенцией СОЛАС-74 и Кодексом МКУБ, на Росрыболовство.

Кодексом МКУБ определено, что копию документа о соответствии требованиям безопасности компании (которая должна 
находиться на рыболовном судне) капитан по требованию предъявляет «Администрации» или «уполномоченной (признанной) ею организацией». Такой Администрацией с 2012 года является Минсельхоз Российской Федерации, а уполномоченной организацией - Росрыболовство [105].

\section{3. Безопасность групповых переходов судов к району рыбного лова}

Подготовка промысловых судов к групповому переходу в район промысла, а также возвращение группы судов в порт требуют специальной технической и правовой подготовки.

ИМО разработала и приняла на своих Ассамблеях целый ряд правил обеспечения безопасности группового плавания, в том числе в Резолюциях:

- А.484(XII) «Основные принципы, подлежащие соблюдению при несении навигационной вахты на рыболовных судах»;

- А.539 (13) «Дипломирование капитанов и вахтенных помощников на рыболовных судах длиной 24 м и более»;

- А.576(14) «Требования к капитанам и вахтенным помощникам рыболовных судов длиной менее 24 м неограниченного и ограниченного плавания»;

- А.646(16) «Безопасность рыбаков на море».

В подготовке промысловых судов к групповому плаванию можно выделить несколько этапов [65]:

1. Капитан и экипаж судна обеспечивают исправное техническое состояние судна и годность его к плаванию, удостоверяемые документами Регистра. Судовладелец укомплектовывает судно аварийным, противопожарным и спасательным снабжением, топливом, водой, провизией, квалифицированным экипажем, комплектом промысловых и навигационных пособий и карт по всему району плавания и промысла с нанесенными границами режимных зон иностранных государств, зон лицензионного рыболовства, буферных зон, крепостных зон и т. д.

2. Отработка действий экипажа по всем основным видам судовых тревог проводится перед оформлением выхода судна в рейс. 
В рейсовых заданиях должно быть предусмотрено время на указанную отработку после полного укомплектования судоэкипажей и завершения погрузочных и хозяйственных работ в порту. Для судов более 600 регистровых тонн на это должно быть предусмотрено не менее одних суток, а для судов менее 600 регистровых тонн время устанавливается исходя из типа судна и количества экипажа. Капитан записывает в судовой журнал замечания по этим испытаниям.

3. Все суда должны быть обеспечены всеми требуемыми нормативными актами по специальному перечню, а также комплектом текстов международных договоров и соглашений по режиму плавания и промысла, переведенных на русский язык. В числе таких международных актов должны быть тексты 10 международных конвенций, установленных в разделе 2 «Применимые инструменты» Парижского меморандума 1982 года, или тексты 8 конвенций, предусмотренных Токийским меморандумом 1993 года, или другим Меморандумом, в зависимости от региона промысла.

4. Суда, направляемые для работы в осенне-зимний период, должны подвергаться специальному освидетельствованию ведомственной комиссией, составляющей акт об их пригодности для работы в ледовых условиях. Если они направляются в районы возможного интенсивного обледенения, должны быть обеспечены оборудованием и инвентарем для борьбы с обледенением, атласами обледенения судов, атласами опасных и особо опасных гидрометеорологических явлений.

5. В организациях судовладельцев устанавливается круглосуточная связь с судами, находящимися в море, с определением времени обязательного выхода судов на радиосвязь. В случаях неявки судна на радиосвязь немедленно объявляется общий поиск по флоту.

6. Капитан судна, судовладелец и портнадзор проверяют загрузку судна в точном соответствии с Инструкцией об остойчивости судов для капитана. Любые случаи неправильной загрузки (перегруз, неправильная балластировка, нарушение порядка приема и расходования запасов топлива, воды и прочие) категорически запрещены и являются основанием для невыпуска судна из порта. При групповом плавании, как на промысле, так и на переходе, 
выделяются дежурные суда для круглосуточной радиосвязи на аварийных частотах. Переходы судов в отдаленные районы и обратно должны производиться, как правило, с использованием рекомендаций Гидрометслужбы соответствующего государства о выборе маршрутов плавания в зависимости от имеющихся и прогнозируемых гидрометеорологических условий.

Резолюции и рекомендации ИМО обобщают международную практику группового плавания промысловых судов. Они определяют правила обеспечения безопасности группового плавания судов в сложных или опасных гидрометеорологических условиях. Эти правила подразделяются на две группы - общие и региональные.

К общим правилам безопасности группового плавания промысловых судов, совершающих переход в район промысла или обратно в порт, можно отнести следующие [65]:

1) переходы судов вместимостью менее 600 брутто регистровых тонн из порта на промысел и обратно в осенне-зимний период осуществляются только группами не менее 2-3 единиц и не более 8 единиц или в сопровождении судов вместимостью более 600 брутто рег. т;

2) групповое плавание осуществляется при видимости друг друга на расстоянии не более одной мили. Крупнотоннажные суда следуют с подветренной стороны группы;

3) уход из группы считается грубейшим нарушением безопасности; виновные капитаны привлекаются к строгой персональной административной и дисциплинарной ответственности;

4) одиночные переходы судов менее 600 брутто регистровых тонн в осенне-зимний период могут быть разрешены только в исключительных случаях, но при условии разработки и осуществления в каждом отдельном случае специальных мер по обеспечению безопасности судов;

5) для судов вместимостью менее 600 брутто регистровых тонн запрещается плавание и ведение промысла в районах частого интенсивного обледенения, если они не оснащены средствами и инструментами для борьбы с обледенением; 
6) судам валовой вместимостью 100 брутто регистровых тонн и менее разрешается производить промысел группой не менее 3 судов. В составе каждой группы назначается флагманское судно, способное обеспечить радиосвязь с судами и берегом, снабженное буксирным тросом и укомплектованное опытными судоводителями и механиками. Капитану такого судна предоставляются все права флагманского капитана;

7) до начала группового плавания предприятие - собственник судов устанавливает состав группы, дистанцию удаления судов друг от друга, наименование флагманского судна, порядок постоянного наблюдения за группой судов, сроки и порядок радиосвязи с судами группы, порядок немедленной передачи гидрометеорологических прогнозов, штормовых предупреждений и других сообщений об опасности. Все указанные сведения и правила доводятся до сведения экипажа каждого судна группы в виде письменного документа - плана перехода и Инструкции о совместном плавании судов в условиях группы.

К региональным правилам безопасности группового плавания промысловых судов относятся «Дополнительные требования по обеспечению безопасности плавания и промысла флота по бассейнам» (1978 года), которые содержат особые правила для Дальневосточного, Западного, Северного районов и Северо-Западной Атлантики.

Так, в Охотском море южнее параллели 55 градусов северной широты, в Японском море и вдоль Курильских островов с 15 декабря по 15 марта суда менее 600 брутто регистровых тонн могут следовать только группами не более 8 судов в сопровождении крупнотоннажного судна и не более 5 единиц в сопровождении судна вместимостью более 600 брутто регистровых тонн или морского буксира мощностью более 800 кВт (1200 л.с.).

В северной части Тихого океана и в южной части Берингова моря переходы этих судов осуществляются группами не менее трех судов по специально разработанным рекомендованным маршрутам.

Группа рыболовных судов в Приморском крае (маломерный флот) представлена на рисунке 5.3.1. 


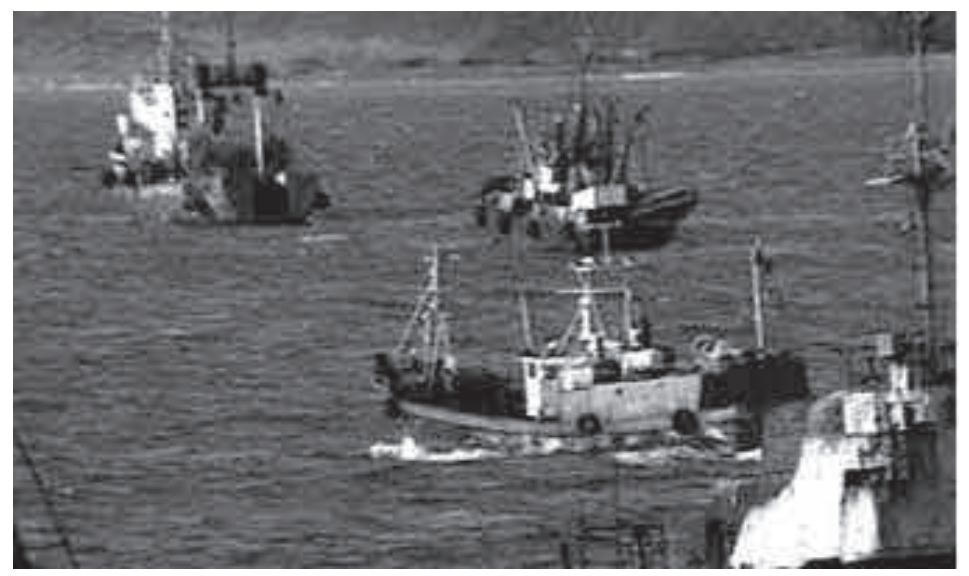

Рис. 5.3.1. Группа рыболовных судов в Приморском крае

Прибывающие для работы в экспедициях суда вместимостью менее 600 брутто регистровых тонн закрепляются поименно за плавбазами, плавзаводами, производственными рефрижераторами, другими крупнотоннажными обрабатывающими судами, которые обязаны вести постоянный контроль за их местонахождением и состоянием и оказывать им необходимую помощь.

В местном плавании вдоль побережья при условии благоприятного прогноза погоды допускаются одиночные переходы судов вместимостью менее 600 брутто регистровых тонн между портамиубежищами, расположенными на расстоянии не более 100 миль.

В Западном бассейне суда МРТР-300 осуществляют переходы из портов Балтийского моря в Северное и Норвежское моря группами не менее двух судов с 15 октября по 15 апреля, а обратно - в течение всего года.

В Северном бассейне переходы судов из портов Белого и Баренцева морей в районы Северо-Западной, Центрально-Восточной Атлантики и далее разрешаются группами не менее 2 судов в течение всего года. Допускается одиночное плавание судов типа РС в Баренцевом море до параллели 71 градус северной широты между меридианами 25 и 41 градусы восточной долготы. Суда СРТР-40, СРТ-300-400 могут следовать к острову Колгуев и производить промысел в 100-мильной зоне от берега после 1 декабря при отсутствии 
льда, при организации постоянного дежурства спасательных судов и наличии постоянной радиомикрофонной связи.

В Северо-Западной Атлантике в период с 15 ноября по 1 апреля суда могут производить промысел при следующих условиях:

1) следовать в этот район могут лишь суда, имеющие ледовые подкрепления корпуса;

2) вместе с промысловыми судами в группе должны находиться плавбазы, транспортные рефрижераторы, спасательные буксиры;

3) все крупнотоннажные суда должны иметь на борту прожекторы повышенной мощности и погружные электронасосы производительностью не менее 100 т/час;

4) должен быть организован регулярный прием факсимильных карт и другой ледовой информации от радиометеорологических центров;

5) на крупнотоннажных судах должно быть не менее 2 водолазных станций и материалы для подводной резки и сварки; на каждом судне должен быть полуторный запас аварийно-спасательного снабжения.

Помимо ограничений на плавание, установлены и прямые запреты на плавание в ряде районов:

1) судам менее 600 брутто регистровых тонн запрещено плавать в Охотском море севернее параллели 55 градусов с 15 ноября до 1 апреля;

2) в Беринговом море севернее параллели 55 градусов между меридианами 162 градуса восточной и 170 градусов западной долготы с 15 декабря по 1 апреля и севернее параллели 58 градусов к востоку от меридиана 170 градусов западной долготы - с 15 декабря по 15 апреля;

3) судам типа РС-300, СО-300, МРТ и другим меньшего тоннажа и мощности запрещается плавание в Баренцевом море севернее параллели 71 градус северной широты и восточнее меридиана 42 градуса восточной долготы с 1 декабря по 1 апреля;

4) судам типа ПТС мощностью 160 и 140 кВт (220 и 150 л.с.), кроме запретов в п. 3, запрещается плавание в Чешской губе и у острова Колгуев с 16 октября до открытия навигации. 
Подобные ограничения установлены и в ряде других стран.

Вместе с тем мировая статистика аварийности рыболовных судов свидетельствует о том, что относительно небольшие суда, находящиеся в море, не могут считаться в безопасности, даже если они совершают переход в составе группы судов или следуют в сопровождении крупнотоннажного судна, поскольку они подвержены действию непреодолимой силы в виде шторма, внезапного шквала, смерча, торнадо, тайфуна, аномально высоких волн, цунами, сильного обледенения, падения метеорита и прочих необычных явлений. Наиболее опасны для рыболовных судов относительно небольшого тоннажа (до 600 брутто рег. т) морские ураганы, сила которых такова, что даже плавание в составе группы не может гарантировать безопасность судов. Так, ураган «Дэн» в октябре 1989 г. потопил и уничтожил около 700 рыболовных судов у побережья Вьетнама [100].

\section{4. Безопасность совместного плавания и промысла судов}

Особенностью плавания в районе рыбного промысла является необходимость работы на ограниченном пространстве. Для обеспечения безопасности судоходства в таких условиях необходимы хорошие знания правил МППСС-72 [66], Правил совместного плавания и промысла (ПСПП-72) [79], местных правил, а также требуются хорошие практические навыки ведения промысловых операций, включая постановку и выборку трала в группе судов, своевременное выставление ночных огней и дневных сигналов в соответствии с промысловой операцией.

Согласно МППСС-72 (Правило 5. Наблюдение) «каждое судно должно вести постоянное надлежащее визуальное и слуховое наблюдение так же, как наблюдение с помощью всех имеющихся средств, применительно к преобладающим обстоятельствам и условиям, с тем чтобы полностью оценить ситуацию и опасность столкновения».

Несоблюдение этого основополагающего Правила часто приводит к развитию опасной ситуации. Последствия могут быть 
обусловлены не одним действием или бездействием, а несколькими деяниями, каждое из которых либо само по себе, либо во взаимодействии с другими способно вызвать тяжкие последствия.

Иллюстрацией является следующий аварийный случай, рассмотренный в рамках уголовного дела. В результате нарушения правил судоходства столкнулись плавбаза и средний рыболовный траулер. Суд установил, что гибель рыболовного траулера явилась следствием нарушения правил безопасности капитанами обоих судов, а также вахтенным штурманом плавбазы. Следуя по курсу в опасном районе плавания без уменьшения скорости, четвертый помощник М. (не имеющий права самостоятельного несения вахт) не докладывал о появляющихся судах капитану, палубное освещение, мешающее наблюдению, не выключил, впередсмотрящего на бак не выставил, за окружающей обстановкой визуального и радиолокационного наблюдения не вел. Из-за этого М. своевременно не обнаружил траулер, следующий пересекающимся курсом. Капитан плавбазы, зная о том, что М. согласно аттестации мог занимать на плавбазах только должность четвертого помощника, в связи с чем не имел права на самостоятельное несение вахты, поручил ему командование судном. Капитан траулера, визуально обнаружив плавбазу и определив до нее расстояние, проявил самонадеянность и допустил опасное сближение с плавбазой. Только за два кабельтовых он дал команду «Право на борт», но она оказалась явно запоздалой и потому недостаточной для предотвращения кораблекрушения.

Суд обоснованно пришел к выводу о том, что допущенные указанными лицами нарушения как каждое в отдельности, так и в совокупности закономерно привели к гибели судна.

Совместный морской промысел осуществляется в разных видах:

- совместный лов рыбы судами одного флага в конкретном районе, организуемый и возглавляемый начальником экспедиции;

- совместный лов рыбы двумя судами, использующими один (близнецовый) трал;

- лов рыбы в конкретном районе группой судов под разными флагами, промышляющими на ограниченном пространстве каким- 
то одним видом орудий промысла (тралом, кошельковым неводом, дрифтерными сетями, ловушками, ярусами и пр.);

- совместный дрейф ошвартованных друг к другу судов при приеме-сдаче улова, получении рыболовного снабжения (бочки, соль, тара, тралы, сети, тросы и пр.), бункеровке водой, топливом, осуществлении текущего ремонта силами и средствами плавбазы или специального судна и т.п.

Промысел ведется одиночными судами, отрядами судов (до 20 единиц), группами судов (3-5 единиц), промысловыми экспедициями (40-80 судов). Промысловые суда осуществляют групповые переходы к району промысла и совместное плавание во время промысла. Плавание судов в составе группы имеет как негативные, так и позитивные последствия [100]:

- примерно на 30 \% возрастает риск столкновений и навалов судов и связанных с ними пожаров, взрывов и загрязнений морской среды;

- на 20 \% возрастает риск повреждения орудий лова при совместном промысле группы рыболовных судов;

- на 30-40 \% снижается риск гибели людей на аварийных судах при групповом плавании, так как другие суда могут их спасти;

- на 50 \% возрастает вероятность оказания помощи аварийным судам и грузам.

Правила ПСПП-72 устанавливают порядок совместного плавания и промысла судов флота рыбной промышленности России, ведущих лов и обработку рыбы, морского зверя и других морепродуктов в одном районе. Они являются обязательными для выполнения экипажами судов, руководителями промысла и другими должностными лицами, занимающимися эксплуатацией флота. Выполнение этих Правил обязательно также при наличии на промысле судов иностранного флота.

ПСПП-72 (Правило 1.10) определяет основополагающий принцип обеспечения безопасности судоходства в районе промысла: «суда, работающие с орудиями лова, и суда, следующие через район промысла, должны производить маневры при расхождении согласно ППСС и настоящих Правил с таким расчетом, чтобы не 
мешать работе других судов или орудий лова и предпринимать все возможные действия к тому, чтобы обойти сети, яруса и другие небуксируемые орудия лова».

Правила ПСПП-72 (Правило 1.6) определяют обязанности руководителей промысла и флагманов подразделений по обеспечению безопасности судов в море при выполнении промысловых работ:

- следить за изменениями режима плавания и рыболовства в районе промысла и своевременно оповещать об этом флот;

- непрерывно осуществлять оперативное руководство и наблюдение за плаванием и промыслом судов в море и знать их местонахождение;

- запрещать промысел и принимать меры к рассредоточению флота, если в районе промысла создается такая обстановка, что в результате концентрации флота оказывается невозможным соблюдать минимальные расстояния между судами и орудиями лова, установленные настоящими Правилами;

- при ведении промысла в условиях ограниченной видимости устанавливать параллельные курсы траления и выводить из группы суда с неисправными радиолокаторами;

- своевременно оповещать суда экспедиции о всех изменениях режима территориальных вод и специальных прибрежных зон иностранных государств, вблизи которых ведется промысел;

- следить, чтобы каждое судно, находящееся на промысле, всегда имело отчетливо нанесенные в установленных местах присвоенные отличительные номера, знаки, надписи, а также окраску, предусмотренные Правилами окраски судов флота рыбной промышленности СССР;

- в случае необходимости выставлять специальные суда-радиомаяки и выделять патрульные суда из состава промысловых при лове рыбы в районах промысла, прилегающих к границам территориальных вод и специальных прибрежных зон иностранных государств;

- устанавливать время промысла для различных орудий лова в случае, когда в одном районе суда ведут промысел различными орудиями лова (Правило 1.11); 
- на основании анализа промысловой обстановки и данных разведки давать указания флагманам подразделений о расстановке судов по районам промысла с учетом возможности размещения количества судов, обеспечивающего безопасное ведение промысла и промысловое маневрирование (Правило 2.2).

Порядок взаимодействия вновь прибывающих судов с судами, занятыми промыслом в данном районе, определяет ПСПП-72 (Правило 1.12). Суда, прибывающие в промысловые районы, где уже ведется активный лов или выставлены орудия лова, должны быть осведомлены через руководителя промысла, капитанов судов или любыми другими способами об особенностях работы в данном районе, о местоположении и протяженности выставленных в море орудий лова. Эти суда должны действовать таким образом, чтобы не мешать и не препятствовать уже проводимым промысловым операциям.

Расстановку судов непосредственно на месте промысла, учитывая при этом промысловую обстановку, состояние погоды и моря, географическое расположение промыслового района, производят флагманы подразделений, а также дают указания о количестве сетей в дрифтерном порядке, рекомендации по их ассортименту и длине поводцов, глубине и курсу траления и исходные данные по другим видам орудий лова (ПСПП-72, Правило 2.3).

Ряд норм ПСПП-72 определяют безопасность совместного плавания и промысла судов.

Обязанности капитана по обеспечению безопасности судна при выметывании дрейфующих орудий лова определяет Правило 2.4. При выборе места для выметывания дрейфующих орудий лова капитан судна должен учитывать расположение находящихся поблизости других промысловых судов и их орудий лова, состояние погоды и моря, а также прогноз погоды, течение и границы запретных районов плавания и промысла с тем, чтобы исключить случаи сцепления орудий лова и заноса их в эти районы.

Правилом 2.8 запрещается выметка дрейфующих орудий лова вблизи каналов, фарватеров, проливов, через которые осуществляется интенсивное движение судов, а также в районах рекомендо- 
ванных курсов и систем разделения движения судов. Суда, занятые активным ловом, должны его осуществлять не ближе 3 миль от ставных орудий лова (Правило 2.9).

Флагманы подразделения устанавливают курсы траления, сообразуясь с гидрометеорологической и промысловой обстановкой, а капитаны судов обязаны строго их придерживаться. При совместном плавании крупнотоннажных и малых рыболовных судов в одном районе, когда последние из-за ухудшения погоды не могут работать, малые суда должны выходить из этого района, чтобы не мешать крупнотоннажным судам продолжать промысел (Правило 2.12). Внешний вид траулера с кормовым тралением показан на рисунке 5.4.1, а схема тралового лова - на рисунке 5.4.2.

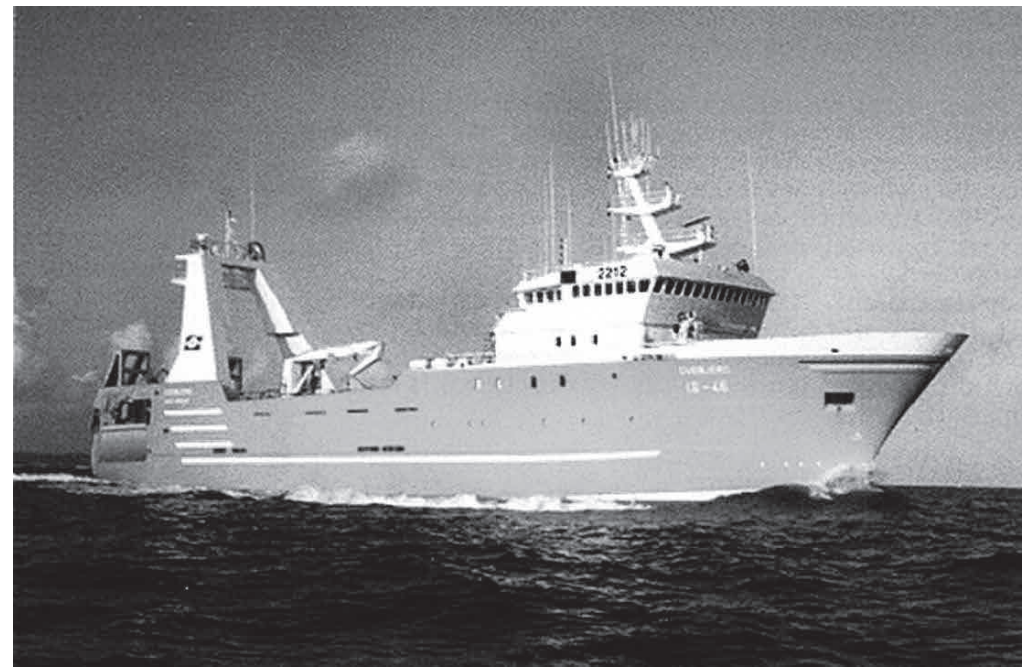

Рис. 5.4.1. Траулер с кормовым тралением

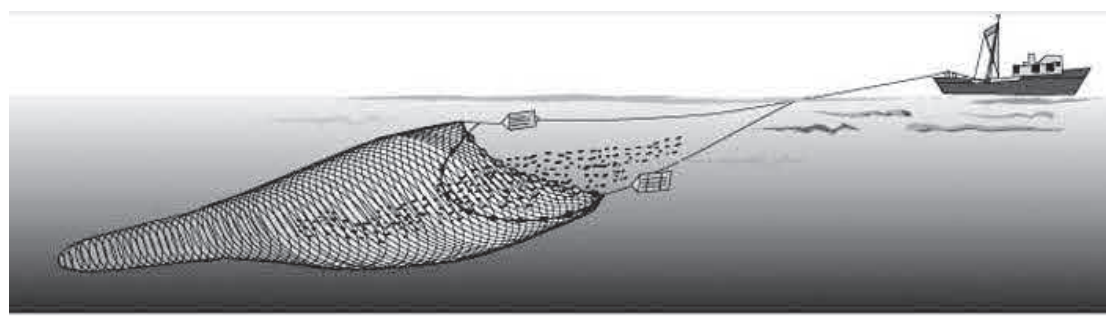

Рис. 5.4.2. Схема тралового лова 
При совместной работе крупнотоннажных и малых судов в одном районе, когда последние из-за ухудшения погоды не могут работать, малые суда должны выходить из этого района, чтобы не мешать крупнотоннажным судам продолжать промысел.

При одновременном подходе к косяку и отсутствии флагмана и авианаводки первым начинает прицельное траление или замет кошелькового невода судно, которое выходит к косяку с наветренной стороны. В штилевую погоду или если таких судов окажется более одного, то суда, видящие справа от себя другие суда, уступают им первое траление или замет (Правило 2.24).

ПСПП-72 (Правило 2.10) запрещает работу судов близнецовыми тралами и кошельковыми неводами в группе других промысловых судов при дальности видимости менее 5 кабельтовых.

Расхождение судов, занятых ловлей рыбы или других видов морепродуктов, должно производиться в соответствии с МППСС. При этом необходимо учитывать особенности плавания с орудиями лова в соответствии с ПСПП-72. При маневрировании необходимо учитывать, что суда с пассивными орудиями лова являются менее маневренными и имеют преимущество перед судами с активными орудиями лова. При следовании пересекающимися курсами судно, уступающее дорогу, не должно проходить по корме судна с тралящим орудием лова, которому оно уступает дорогу, на расстоянии менее 4 кабельтовых (ПСПП-72, Правило 2.14).

Суда, следующие прямо или почти прямо друг на друга с тралящими орудиями лова, должны уклоняться вправо так, чтобы траверзное расстояние между ними в момент расхождения было не менее 2 кабельтовых и следовать после расхождения таким образом, чтобы исключить возможность сцепления орудиями лова (ПСПП-72, Правило 2.15).

Суда, следующие с тралящими орудиями лова на параллельных курсах, могут производить маневр обгона при условии, что траверзное расстояние между ними будет не менее 2 кабельтовых (ПСПП-72, Правило 2.16). Поворот судна, следующего с тралящим орудием лова, может быть произведен только в сторону, где отсутствуют другие суда. Поворот судна запрещается, если это 
мешает движению других судов, занятых тралением (ПСПП-72, Правило 2.17).

В целях обеспечения безопасности судов, занятых производственной деятельностью, запрещается подходить к судну, спускающему или поднимающему орудия лова, ближе чем на 2 кабельтовых (ПСПП-72, Правило 2.18). При совместной работе судов с бортовыми и кормовыми типами тралящих орудий лова и судов, занятых ловом рыбы близнецовыми тралами, следует вести особо тщательное наблюдение за огнями и сигналами, чтобы избежать прохождения между судами, работающими в паре близнецовыми тралами (ПСПП-72, Правило 2.19). Внешний вид траулера для лова рыбы близнецовым и донным тралами показан на рисунке 5.4.3, а схема близнецового лова - на рисунке 5.4.4.

При выборе места и направления для спуска трала, замета кошелькового невода или снюрревода капитаны не должны мешать

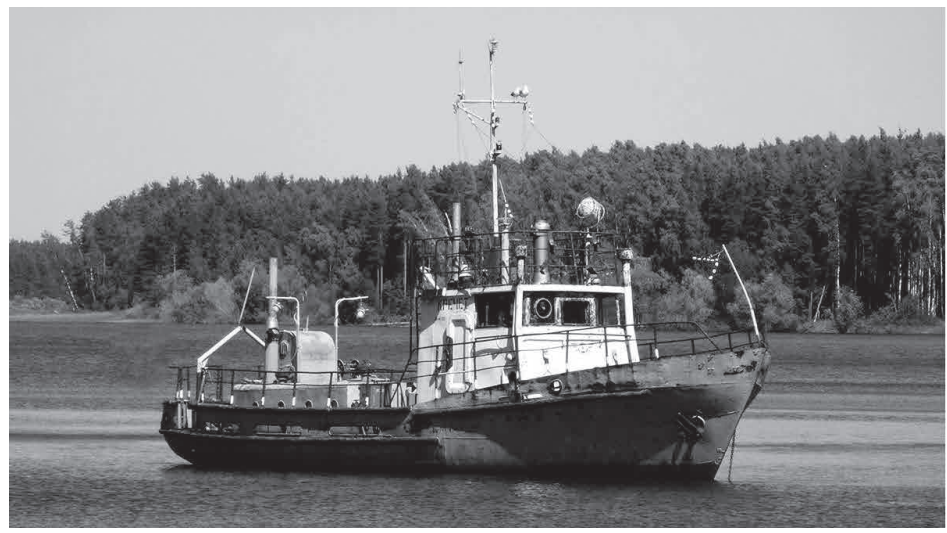

Рис. 5.4.3. Судно для лова рыбы близнецовым и донным тралами
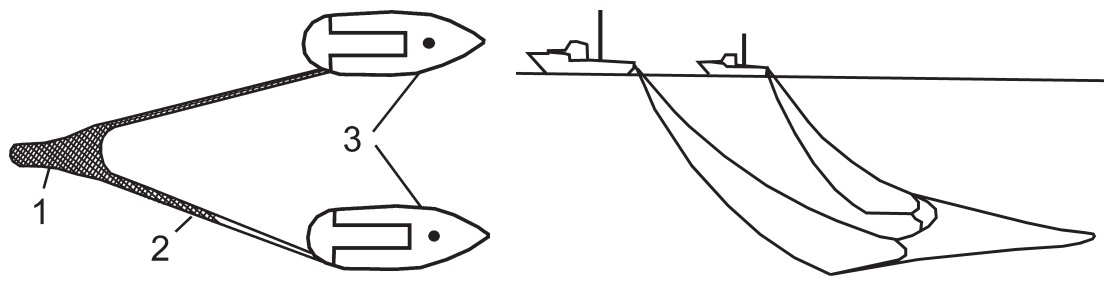

Рис. 5.4.4. Схема близнецового лова: 1 - трал, 2 - ваер, 3 - промысловые суда 
работе других судов, следующих с тралящими орудиями лова, а также лежащих в дрейфе и занимающихся их подъемом (ПСПП-72, Правило 2.20).

Запрещается производить вытравливание ваеров, начинать подъем трала, замет кошелькового невода или снюрревода по носу судна, следующего с тралящим орудием лова, если расстояние до него менее 1 мили (ПСПП-72, Правило 2.21). В случае срочной необходимости подъема трала (задев, выход из строя рулевого устройства, остановка главного двигателя) следует всеми имеющимися средствами предупредить об этом сзади идущее судно и находящиеся вблизи суда. Внешний вид промыслового комплекса для работы с кошельковым неводом показан на рисунке 5.4.5, а схема лова кошельковым неводом - на рисунке 5.4.6.

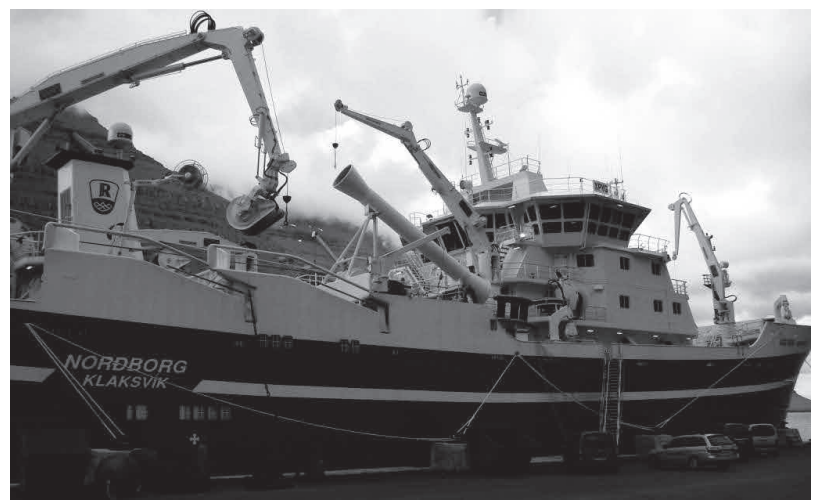

Рис. 5.4.5. Промысловый комплекс для работы с кошельковым неводом

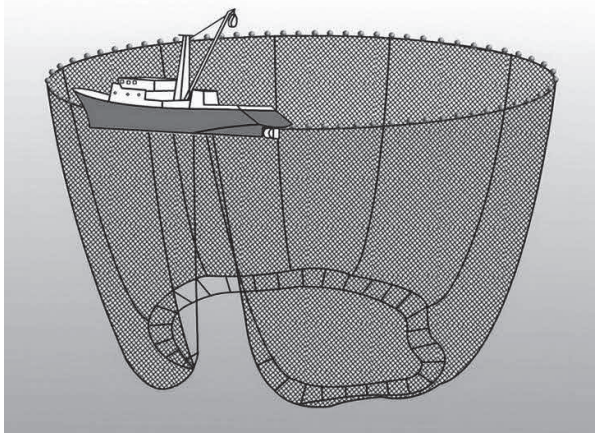

Рис. 5.4.6. Схема лова кошельковым неводом 
При работе кошельковым неводом, снюрреводом или закидным неводом суда должны рассчитывать свой маневр так, чтобы после замета расстояние между их орудиями лова и между судами было не менее 5 кабельтовых (ПСПП-72, Правило 2.22). Внешний вид промыслового судна для лова снюрреводом и донным ярусом показан на рисунке 5.4.7, а схема лова снюрреводом - на рисунке 5.4.8.

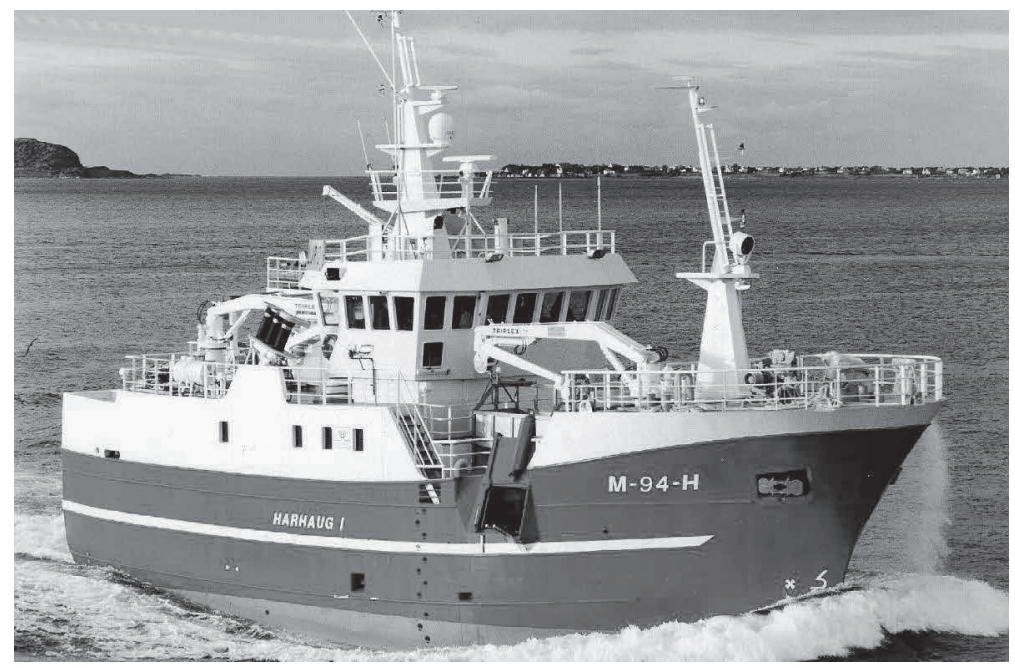

Рис. 5.4.7. Судно для промысла снюрреводом и донным ярусом

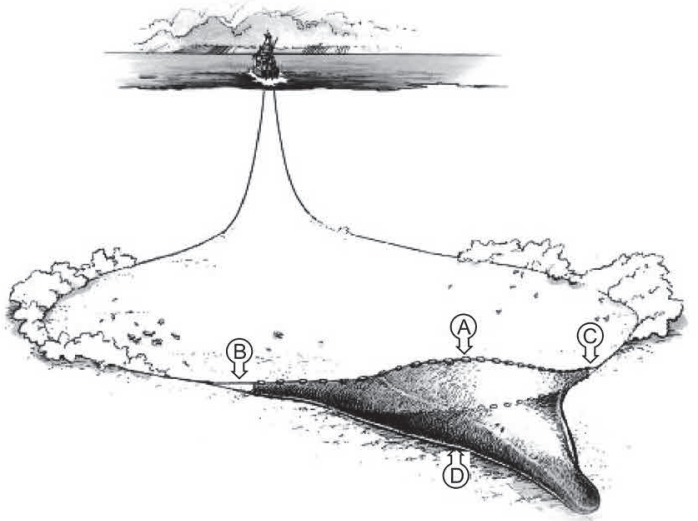

Рис. 5.4.8. Схема лова снюрреводом: (А) - верхняя подбора, (B) - левое крыло, (C) - правое крыло, (D) - нижняя подбора 
Безопасность судна при лове рыбы с помощзью электрического света обеспечивают следующие правила. При лове рыбы с постановкой судна на якорь и применением подводного источника света капитаны должны выбирать место для постановки судна на якорь с таким расчетом, чтобы расстояние между ближайшими судами, производящими лов рыбы, было не менее 2 кабельтовых (ПСПП-72, Правило 2.25). При лове рыбы с применением надводных источников света капитаны судов должны выбирать место для выметывания дрейфующих ловушек с таким расчетом, чтобы с учетом силы и направления ветра, дрейфа своего судна и других судов расстояние между судами было не менее 5 кабельтовых (ПСПП-72, Правило 2.26).

Во время поиска или перехода запрещается проходить вблизи судна, производящего лов рыбы с помощью электрического света, на расстоянии менее 1 кабельтового и включать при этом палубное освещение и прожекторы, а мимо судов, занятых ловом сайры, на расстоянии менее 5 кабельтовых, а также направлять луч прожектора в направлении этих судов (ПСПП-72, Правило 2.27).

Одним из опасных последствий аварий во время промысла является производственный ущерб, состоящий в повреждении орудий лова. Капитаны судов во время плавания и промысла в открытом море обязаны принимать все необходимые меры, исключающие сиепления и повреждения орудий лова. Капитаны судов, допустившие по своей вине сцепление орудий лова, должны принять все меры к их распутыванию, а в случае повреждений орудий лова по их вине несут материальную ответственность за причиненные убытки (ПСПП-72, Правило 2.29). Во всех случаях, когда произошло сцепление орудий лова, судно, в результате действий которого произошло это сцепление, должно предпринимать все необходимые меры для того, чтобы свести к минимуму повреждения, которые могут быть причинены орудиям лова другого судна. А рыболовное судно, орудия лова которого оказались зацепленными, не должно предпринимать действия, которые могут увеличить ущерб (ПСПП-72, Правило 2.32).

Когда рыболовное судно, занятое тралением или ведущее промысел другими орудиями лова, находящимися в движении, 
зацепляет судно, которое по необходимости стоит на якоре или дрейфует в районе промысла, оба эти судна должны рассматриваться как находящиеся в трудном положении. Оба судна должны немедленно предпринять меры для разъединения таким способом, при котором возможность повреждения будет сведена к минимуму. После разъединения капитан судна, занятого промыслом, должен убедиться в безопасном состоянии другого судна и его экипажа, и только после этого может покинуть район происшествия (ПСПП-72, Правило 2.33). Когда судно зацепляется с другим, то судно, находящееся в затруднительном положении, должно немедленно выпустить белую ракету и затем дать другому судну сигнал по Международному своду сигналов L (Л) - «Вы должны немедленно остановить ваше судно» и действовать в соответствии с Правилом 2.33 (ПСПП-72, Правило 2.34).

Указанные правила будут выполняться, если судоводители получают информацию от других судов в виде сигналов об их действиях и промысловых операциях. Для этого должны быть выставлены дополнительные огни в ночное время, знаки и флажные сигналь днем при постановке трала, выборке трала и если орудия лова легли на грунт (МППСС-72, Правила 2 и 26, Приложение II). Сигналы выставляют по Международному своду сигналов 1965 года (МСС-65) [60].

Международный свод сигналов (ICS - The International Code of Signals / INTERCO) - это международная система сигналов и кодовых сообщений, используемая судами для передачи важных сообщений, касающихся безопасности мореплавания и охраны человеческой жизни на море, особенно в случаях возникновения языковых трудностей общения. Комбинации буквенно-цифровых символов обозначают конкретные стандартизованные сообщения. При составлении Свода было принято во внимание, что широкое применение радиотелефона и радиотелеграфа позволяет всегда, когда отсутствуют языковые трудности, осуществлять простую и эффективную связь открытым текстом.

Сигналы, используемые в МСС-65, состоят из следующих видов сигналов: 
- однобуквенных сигналов, предназначенных для очень срочных, важных или часто употребляемых сообщений;

- двухбуквенных сигналов, составляющих Общий раздел и касающихся безопасности мореплавания, в том числе для рыбного промысла (часто после них идёт цифровой вымпел, уточняющий сообщение);

- трехбуквенных сигналов, составляющих Медицинский раздел и начинающихся с буквы М (Mike).

Каждый сигнал МСС-65 имеет завершенное смысловое значение. Этот принцип проходит через весь Свод. В отдельных случаях с целью расширения значения основного сигнала используются цифровые дополнения.

Международный свод сигналов принят на четвертой Ассамблее Межправительственной морской консультативной организации (ИМКО) в 1965 году. Решением XVII сессии Комитета по безопасности на море ИМКО МСС-65 введен в действие с 1 апреля 1969 года.

Свод издан на девяти языках: русском, английском, французском, немецком, итальянском, испанском, греческом, норвежском и японском. Первое издание Международного свода сигналов (МСС-65) на русском языке вышло в свет в 1969 году.

Второе издание подготовлено на основе издания 1969 года, в которое включены все дополнения и изменения, принятые Комитетом по безопасности на море ММКО за период с 1969-го по 1980 год. В настоящее время МСС-65 поддерживается ИМО, которая выпустила последнее печатное издание в 2005 году.

Дополнительные огни должны выставляться с захода и до восхода солнца, а также могут быть выставлены в светлое время суток в условиях ограниченной видимости и при всех других обстоятельствах, когда это представляется необходимым при ведении промысла группой. В это время никакие другие огни, которые могут быть ошибочно приняты за предписанные огни, или уменьшают видимость и отличительный характер таковых, или мешают поддерживать должный обзор, не должны выставляться (ПСПП-72, Правило 4.2). Дополнительные огни должны быть расположены на расстоянии не менее 0,9 м в сторону и ниже основных рыболовных 
огней. Дополнительные огни должны помещаться там, где они лучше всего видны, и находиться на расстоянии не менее 0,91 м друг от друга. Нижний из этих огней должен находиться не менее 1,5 м над бортовыми отличительными огнями, а на судах длиной менее 12,19 м не менее 1,5 м над планширем. Дополнительные огни должны быть видны на расстоянии не менее 1 мили вокруг по всему горизонту, насколько это возможно, но их видимость должна быть меныше видимости рыболовных огней, выставляемых в соответствии с МППСС (ПСПП-72, Правило 4.3).

Два белых огня один над другим означают «Я выметываю сети». В дневное светлое время суток судно поднимает знак, состоящий из двух конусов, расположенных вертикально один над другим вершинами вместе, и на рее фок-мачты поднимает флаг «Я выметываю сети» (Z) по Международному своду сигналов 1965 года (MCC-65 [60]).

Белый и красный огни один над другим означают «Я выбираю трал». Днем судно поднимает флаг «Я выбираю трал» (G). Сигнальные флаги Международного свода сигналов МСС-65 и их значения показаны на рисунке 5.4.9.

Суда, занятые ловом рыбы близнецовым тралом, когда они оба заняты в парном тралении, дополнительно к огням и знакам, предписанным МППСС для судов, занятых ловом рыбы, должны нести в свое время суток флаг «Держитесь в стороне от меня, я произвожу парное траление» (Т), поднимаемый на фок-мачте, а в темное время суток показывает луч прожектора, направленный вперед и в сторону судна, работающего в паре (ПСПП-72, Правило 4.4).

Суда, занятые ловом рыбы кошельковым неводом, должны показывать два огня янтарного цвета, расположенные вертикально один над другим. Эти огни должны попеременно мигать с частотой примерно один раз в секунду таким образом, чтобы верхний огонь загорался в то время, когда нижний гаснет, и наоборот. Эти огни должны показываться только в то время, когда свободное продвижение судна затруднено вследствие работы его орудий лова, предупреждая тем самым другие суда держаться в стороне от него (ПСПП-72, Правило 4.5). 


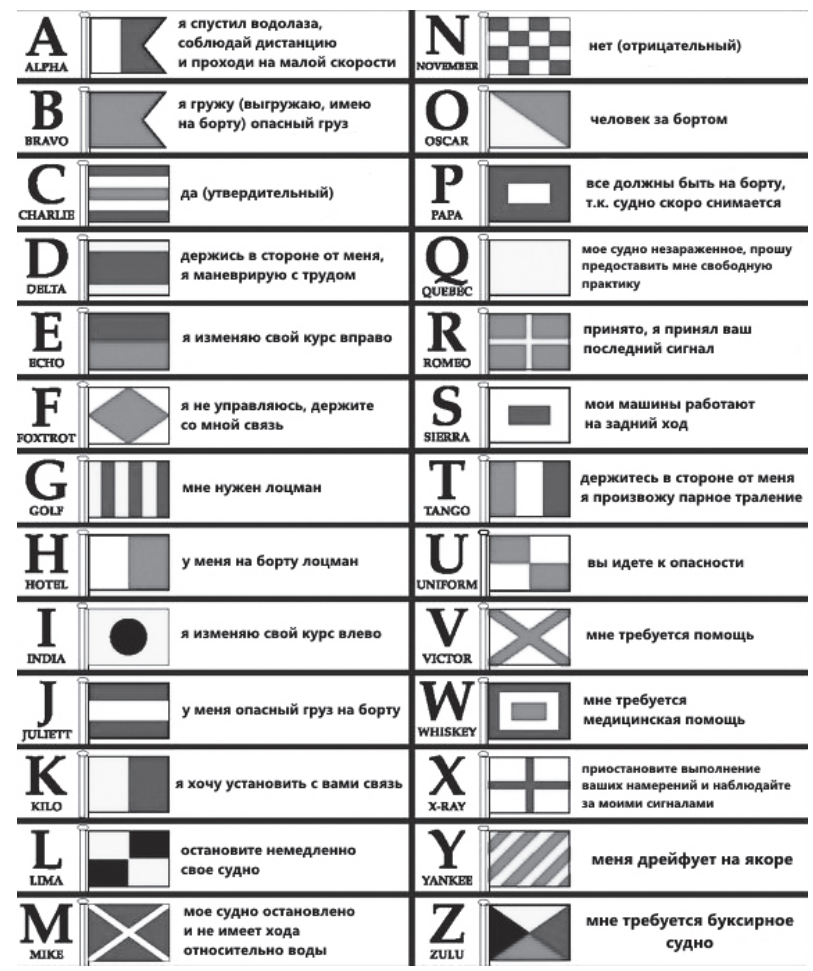

Рис. 5.4.9. Сигнальные флаги Международного свода сигналов МСС-65

Суда, занятые ловом рыбы тралящими орудиями, сетями или ярусными крючковыми снастями, когда они производят спуск или подъем орудий лова, помимо огней и знаков, предусмотренных ППСС для судов, занятых ловом рыбы, должны показывать (ПСПП-72, Правило 4.6):

a) с момента начала и до момента окончания спуска (постановки) орудий лова в светлое время суток флаг Z(3) - «Я выметываю сети», а в темное время суток - два белых огня, расположенные вертикально один над другим.

Моментом начала спуска (постановки) орудий лова следует называть тот момент, когда любое орудие лова, часть его или часть его вооружения вывалены за борт на воду с целью приведения его в рабочее состояние. 
Моментом окончания спуска (постановки) орудий лова является тот момент, когда орудие лова и его вооружение полностью спущены за борт и находятся в рабочем состоянии;

б) с момента начала и до момента окончания подъема (выборки) орудий лова в светлое время суток флаг $\mathrm{G}(\Gamma)$ - «Я выбираю сети», а в темное время суток - белый огонь над красным, расположенные вертикально.

Моментом начала подъема (выборки) орудий лова следует называть тот момент, когда орудия лова, их часть или часть их вооружения начинают поднимать на борт судна с целью подъема улова.

Моментом окончания подъема (выборки) орудий лова следует называть тот момент, когда орудия лова и их вооружение полностью подняты на борт судна.

Суда, занятые ловом рыбы и остановившиеся вследствие того, что их орудия лова зацепились за подводное препятствие или легли на грунт от чрезмерного улова, или же вследствие сцепления орудий лова, помимо опознавательных огней и знаков, предписанных ППСС для этих судов, должны в светлое время суток поднимать флаг Р (П) - «Мои сети зацепились за препятствие», а в темное время суток нести два красных огня, расположенных вертикально один над другим (ПСПП-72, Правило 4.7).

Звуковые сигналы при ограниченной видимости определяют правила МППСС-72 (Правило 35) и ПСПП-72 (Правило 4.8). В соответствии с ПСПП-72 суда, во время тумана, мглы, снегопада, сильного ливня или при других условиях, ограничивающих видимость днем или ночью, суда, занятые ловом рыбы, должны подавать через промежутки не более 1 мин три последовательных звуковых сигнала: один продолжительный и вслед за ним два коротких. Дополнительно рыболовные суда должны подавать через промежуток времени 4-6 секунд одним из трех сигналов МСС-65:

- два длинных и один короткий звук при выборке снастей (в соответствии с $\mathrm{MCC}-65(\mathrm{G})$ - голф), промежуток между сигналами не более 1 минуты;

- два длинных и два коротких звука при выметке снастей (в соответствии MCC-65 (Z) - зулу); 
- один короткий, два длинных и один короткий звук в случае, если снасти зацепились за препятствие (по МСС-65 (Р) - папа).

Продолжительность звуковых сигналов составляет: длинного от 4 до 6 секунд, а короткого около 1 секунды.

Любое судно, для того чтобы привлечь внимание другого судна, может подавать звуковые сигналы, но такие, которые не могли бы быть по ошибке приняты за сигналы, установленные МППСС-72.

Необходимо отметить, что огни и знаки не являются взаимозаменяемыми. Порядок смены огней знаками и знаков огнями должен строго соблюдаться и производиться в соответствии с истинным восходом и заходом солнца.

Сигнально отличительные огни будут обнаружены другим судном ранее силуэта самого судна при ухудшении визуальной видимости.

Огни следует выставлять независимо от ожидаемой продолжительности явления, вызвавшего ухудшение видимости, в том числе и при кратковременном (снежном заряде, полосы тумана и т.д.).

Огни следует выставлять при всех обстоятельствах, когда они могут дать дополнительную информацию о судне.

Включение огней днем в условиях ограниченной видимости должно производиться с одновременным выставлением знаков для светлого времени суток.

Суда, занятые ловом рыбы и лишившиеся возможности управляться в результате выхода из строя главного двигателя, рулевого устройства, промысловой лебедки, намотки орудий лова на винт или перо руля и т.д., а также при спуске или подъеме снастей промысловой лебедки или других механизмов, обеспечивающих эти действия, в темное время суток несут два красных огня по вертикали [36].

В дневное светлое время суток флаг заменяется двумя черными шарами, расположенными по вертикальной линии один над другим. Рыболовные огни и знаки в этом случае необходимо держать до того момента, пока орудия лова не будут подняты на борт и не перестанут представлять опасность для судов, следующих вблизи. При этом для предупреждения проходящих судов необходимо с 
помощью прожектора показать направление ваеров и сетной части трала, если трал оказался не выбран при аварии с механизмами выборки или при выходе из строя главного двигателя, а также по этому направлению необходимо выпустить белые ракеты или использовать другие способы и средства предупреждения, которые не могли бы быть приняты за другие сигналы, установленные МППСС-72.

Выполнение правил маневрирования при совместном промысле с учетом хорошей морской и промысловой практики позволяет избежать сцепления орудий лова. Однако если это случилось, то разъединение и распутывание их следует производить так, чтобы как можно меньше повредить орудия лова и исключить аварийные случаи с судами. Для предупреждения этого при сцеплении орудий лова одного судна с орудиями лова другого или с судном, стоящим на якоре или дрейфующим в районе промысла, необходимо судну, находящемуся в более затруднительном положении, немедленно выпустить белую ракету для обращения внимания сцепившегося судна и предупреждения других судов, находящихся поблизости, и поднять по МСС-65 флаг «Вы должны немедленно остановить ваше судно» (L) - лима, направить луч прожектора в сторону опасности по направлению сцепившихся орудий лова, выпустить белые ракеты в сторону орудий лова.

Кроме визуальной информации при работе в скоплениях судов ведется наблюдение и на УКВ - 16-м канале. Практикуется у судоводителей при аварийных ситуациях оповещать все суда на промысле об аварийных происшествиях: о выходе из строя главного двигателя и аварийном происшествии с тралом, а также давать координаты места, чтобы другие суда приняли должные действия и обошли данный район и аварийное судно [36].

В районах, где для разведки промысловых скоплений рыбы и морского зверя, а также для наводки промысловых судов на эти скопления применяют специальные самолеты и вертолеты, промысловые суда должны быть оборудованы средствами надежной прямой радиотелефонной связи с этими летательными аппаратами, а на каждом промысловом судне в носовой части верхней палубы 
или на люке трюма должен быть нанесен белой краской бортовой номер судна, отчетливо видимый с самолета или вертолета (ПСПП-72, Правила 5.1, 5.2).

На современном этапе при оборудовании промысловых судов радиолокационными приборами САРП и электронной картографией, совместимой с эхолотами, для успешной работы и принятия правильных решений штурманский состав перед постановкой трала наносит в САРП цели судов (следующих в одном направлении и контркурсами), которые будут важны при тралении, и постоянно поддерживает связь между судами. Расхождение судов на контркурсах должно происходить на траверсной дистанции более 2 кабельтовых, при обоюдном изменении курса вправо при положении руля не более 5 градусов, для увеличения дистанции отхода между судами, чтобы не было сцепления тралов согласно ПСПП-72 [36].

При тралении необходимо вести постоянное визуальное наблюдение и знать контуры и названия судов, работающих в районе промысла. Также следует вести слуховое наблюдение, чтобы знать, где, когда и кто собирается выбирать или ставить трал, определять, как по отношению к данному судну находится ваше судно, и какие меры придется вам принимать для расхождения с ним.

Важно постоянно следить за векторами нанесенных в САРП судов, по которым можно определить сближение, при неменяющемся пеленге и уменышении дистанции между судами - дистанция кратчайшего сближения меньше 2 кабельтовых.

При обгоне другого промыслового судна необходимо держаться в стороне и проходить на траверсе более 2 кабельтовых согласно ПСПП-72.

При постановке трала необходимо соблюдать дистанцию до судна, идущего с тралом, соотносить скорость и курс постановки трала, чтобы не создавать помех и аварийных ситуаций.

Знание особенностей тралового промысла, использование сигнализации, наблюдение визуальное и слуховое, своевременное включение необходимых огней при промысловых операциях, знание особенностей архитектуры промысловых судов 
для их опознания, а также временных интервалов выборки и постановки трала позволят обеспечить безопасность работы в группе судов.

\section{5. Обеспечение безопасности рыболовных судов}

В целях обеспечения безопасности жизнедеятельности рыбаков и сохранности судов и оборудования от морских рисков три организации ООН - Продовольственная сельскохозяйственная организация (ФАО), Международная организация труда (МОТ) и Международная организация по морскому праву (МОМП) заключили соглашение о сотрудничестве по выработке норм и правил охраны труда рыбаков и соблюдения техники безопасности рыболовными судами. При этом каждая организация взяла на себя обязательство действовать исключительно в сфере своей собственной компетентности, а именно:

- ФАО - общие принципы рыболовства;

- МОТ - проблемы найма и использования рабочей силы в рыбной промышленности;

- МОМП - страхование жизни, судов и оборудования от морских рисков.

Совместная группа консультантов от трех организаций составила Перечень норм и правил охраны труда рыбаков и соблюдения техники безопасности рыболовныли судами [135]. Цель нормативного документа - уменьшить риск нанесения телесных повреждений рыбакам и, по возможности, предотвратить несчастные случаи и аварии, а также уменьшить риск возникновения опасных ситуаций на рыболовных судах. МОМП координировала всю работу по выдвижению предложенных поправок, но каждая поправка должна была стать ещё и предметом окончательного одобрения со стороны всех трёх указанных организаций.

Документ включает два раздела:

- в разделе А перечислены функциональные и профессиональные требования по охране труда капитанов судов и матросов судовых команд; 
- в разделе Б указаны обязательные требования по охране труда и правила техники безопасности при строительстве и технической оснастке рыболовных судов.

В разделе А содержится исходная информация в отношении правил по охране труда и технике безопасности при выходе рыболовных судов в море на путину. Особое внимание уделяется таким характеристикам, как правила судовождения, мореходные качества судна и уровень соответствия технологического оборудования предъявляемым нормам.

Другие меры профилактического характера включают:

- сохранение судном должной остойчивости;

- предупреждение случаев выпадения людей за борт судна;

- поддержание общего порядка на палубе, в машинном отделении и других местах, где установлено механическое оборудование и работают машины;

- изучение противоаварийных устройств и приспособлений;

- работу по предотвращению пожаров и ознакомление с мерами предосторожности и медицинским оборудованием для оказания первой помощи.

Кроме того важно обеспечить бесперебойную работу всех предохранительных и спасательных механизмов, установленных на борту судна.

Основным фактором безопасности рыболовного судна являются его мореходные качества и эксплуатационные характеристики. Капитаны рыболовных судов, длина которых превышает 24 метра, должны быть хорошо осведомлены обо всех аспектах судовождения, манёвренности, эксплуатационных характеристик и остойчивости управляемых ими судов. Каждый капитан должен уметь устранять все возможные последствия для остойчивости своего судна от перегрузок, возникающих как при приёме на борт партии выловленной рыбы, так и при пополнении судном запасов воды и топлива. Он должен также предвидеть все отрицательные последствия затопления в палубных отсеках, заклинивания межпалубных перегородок и вытаскивания на борт тяжелых рыболовецких снастей. 
Часть А Кодекса была принята первой сессией объединенного совещания консультантов ФАО/МОТ/ИМО по безопасности на борту рыболовных судов, которое состоялось в штаб-квартире МОТ в Женеве в сентябре 1968 года. Позднее, весной 1973 года, Комитет по безопасности на море (КБМ) ИМО на своей тридцатой сессии одобрил поправки к части А. На этой же сессии Комитет одобрил окончательный текст части В, который был одобрен Советом ФАО на его 64-й сессии (осень 1974 года), а также Административным советом МОТ на его 195-й сессии (февраль 1975 года).

Безопасность рыболовных судов зависит от конструкиионных особенностей и прочности остова корабля, рассчитанного на определённую нагрузку. Следовательно, прочностные характеристики и конструкционные особенности корпуса судна и его палубных надстроек должны в полной мере выдерживать все мыслимые нагрузки в ходе его эксплуатации. Водонепроницаемость судна должна быть полной, и все отверстия и раскрытия, включая палубные и бортовые проёмы, которые во время лова рыбы должны оставаться открытыми, но через которые вода может проникать внутрь корабля, должны иметь надёжные заслонки и перегородки.

Для обеспечения безопасности рыболовных судов очень большое значение имеют штормовые портики. Они позволяют воде свободно стекать за борт даже из тех мест на рабочей палубе, в которых фальшборты образуют искусственные водосборники. На небольших рыбацких баркасах высота таких фальшбортов была увеличена для того, чтобы повысить безопасность членов судовой команды, работающих на открытой палубе. Тяжесть весовой нагрузки воды на палубу может быть очень большой и, если воду оттуда быстро не слить, чрезвычайно опасной для остойчивости корабля. Вот почему так важно оставлять хотя бы минимальную площадь под штормовые портики: они обеспечивают быстрый и эффективный водослив с палубы.

В последних моделях даже небольших или средних по размеру рыболовных судов на рабочих палубах предусматривается строительство шельтердеков, то есть навесных палуб. Вместе с тем вместо проектирования штормовых портиков для водослива 
с рабочей палубы целесообразно устанавливать мощные водоотливные насосы при условии, если межпалубное пространство на таких судах может оставаться полностью водонепроницаемым на период выполнения большей части операций по улову рыбы или если пропускающее воду отверстие ограничено небольшим водонепроницаемым отсеком. Предложив большую высоту надводного борта судна, этот проект значительно повысил конструкционную остойчивость рыболовных судов.

Кроме прочностных характеристик и водонепроницаемости, самыми важными факторами обеспечения безопасности рыболовного судна являются его остойчивость на воде и общие мореходные качества.

На основе информации о расчётных значениях остойчивости плавающих судов с учетом положительного опыта эксплуатации и информации об опрокидывании рыболовных судов под воздействием рыболовного груза или ненормальном наклонении в поперечной плоскости под влиянием внешних сил были разработаны критерии минимальной остойчивости судов на воде.

С одной стороны, можно рассчитать остойчивость корабля, находящегося в неподвижном состоянии. Но в плавании его передвижения на воде зависят от множества динамических сил, которые очень трудно, если вообще возможно, учесть, поскольку ветровые нагрузки и морские течения весьма далеки от простых линейных зависимостей.

С другой стороны, рыболовное судно, с которым за 15-20 лет эксплуатации на море при всевозможных метеоусловиях и режимах морской качки не случилось ни единой аварии или несчастного случая, можно рассматривать как достаточно безопасное.

Поэтому при определении остойчивости судна рекомендуется принимать в расчёт критерии погоды, то есть ветровые нагрузки, воздействие морской качки и последствия затопления палубы судна морской волной. Все эти расчётные данные и другая подобная информация должны передаваться капитану судна, который отвечает за оценку остойчивости судна в любых погодных условиях. 
Остойчивость корабля в значительной мере зависит от высоты надводного борта судна. Вопрос о допустимых уровнях загрузки рыболовных судов рассматривался в 1977 году на международной конференции по безопасности рыболовных судов (Торремолинос, Испания), так как Конвенция о международной грузовой ватерлинии может применяться только к грузовым судам. Было решено воздержаться от выдвижения требований в отношении соблюдения судном допустимых уровней загрузки рыбой во время путины, однако должен быть установлен максимально допустимый предел грузовой ватерлинии, удовлетворяющий критериям остойчивости каждого судна в отдельности [135].

Существенные различия в деятельности и конструкции транспортных и рыболовных судов не позволяли непосредственно применять к ним Конвенции СОЛАС и Конвенцию по грузовой марке 1966 года. Для решения этой проблемы ИМО были приняты Рекомендации по остойчивости рыболовных судов в неповрежденном состоянии, Рекомендации по конструкции рыболовных судов в отношении остойчивости и безопасности экипажа, Кодекс практики относительно точности информации об остойчивости для рыболовных судов, а совместно ФАО и МОТ подготовили Кодекс безопасности рыбаков и рыболовных судов.

Международная конвенция по безопасности морских судов (The Torremolinos International Conventional for Safety of Fishing Vessels, 1977, SFV-77) была разработана в ходе проведения международной конференции по безопасности рыболовных судов, состоявшейся в 1977 году в Торремолиносе, Испания. Этот международный договор основан на технической работе, проводившейся в течение нескольких лет силами МОМП, в основном в рамках подкомитета по безопасности рыболовных судов соответствующего комитета по безопасности МОМП. До этого этот комитет подготовил рекомендации по проблеме остойчивости неповреждённого судна, которые были опубликованы МОМП и впоследствии включены в Конвенцию 1977 года по безопасности рыболовных судов.

Конвенция SFV-77 содержит 10 глав: общие положения; конструкция, водонепроницаемость и оборудование; остойчивость 
и связанные с ней мореходные качества; механические, электрические установки и периодически необслуживаемые машинные отделения; противопожарная защита, обнаружение и тушение пожара; защита экипажа; спасательные средства; порядок действий при авариях, учебные сборы и учения; радиотелеграфия и радиотелефония; судовое навигационное оборудование.

В этой Конвенции утверждалось, что сфера её применения будет распространяться только на новые рыболовные суда, длина которых превышает 24 метра.

Торремолиносская конференция одобрила рекомендацию в отношении разработки стандартов по технике безопасности для рыболовных судов с навесной палубой, длина которых меньше 24 метров. Это решение было принято в связи с тем, что большинство рыболовных судов в мире имеют длину менее 24 метров.

На рыболовные суда меньшего размера эта Конвенция не распространялась, поскольку типология небольших судов национальных рыболовных флотилий весьма разнообразна, а имеющаяся при этом техническая информация весьма ограничена. Другими словами, правила техники безопасности для этих рыболовных судов не были разработаны только лишь потому, что не хватило исходной информации. Например, даже для каботажных рыболовных судов, длина которых превышает 24 метра, имеет большое значение соответствие между их конструктивными особенностями и способами рыболовства. Все эти особенности в большинстве случаев оказывают серьёзное воздействие на остойчивость и мореходные качества рыболовных судов.

Техническая информация, на основе которой были разработаны правила техники безопасности, включенные в международную Конвенцию, в большинстве случаев была предоставлена промышленно развитыми в сфере рыболовства странами Европы и Северной Америки. Однако вскоре после конференции 1977 года выяснилось, что некоторые другие страны в мире предвидят трудности в ратификации тех частей Конвенции, которые касаются самых небольших в их рыболовецких флотилиях судов, превышающих в длину 24 метра. 
Торремолиносская международная конвенция по безопасности рыболовных судов 1977 года по ряду причин не вступила в силу. Позднее, также в Торремолиносе, Испания, была созвана еще одна международная конференция, которая приняла Торремолиносский протокол 1993 года к Торремолиносской международной конвенции по безопасности рыболовных судов 1977 года.

Протокол Торремолиноса 1993 года ослабил ряд ограничений в некоторых разделах Конвенции, касающихся определённого класса рыболовных судов. Изложенные в нём требования в отношении двигательных установок и электрооборудования и временно необслуживаемых зон в машинных отделениях, согласно Протоколу 1993 года, должны учитываться и применяться только в отношении новых судов, длина которых составляет не менее 45 метров.

Раздел, посвященный мерам противопожарной безопасности, начиная от методов обнаружения источников пожара и заканчивая способами его тушения и борьбы с огнем, был разделён на две части:

- в части А изложен набор требований, применимый только в отношении новых судов, длина которых не менее 60 метров;

- часть В содержит менее строгие требования к судам, длина которых колеблется от 45 до 60 метров.

Раздел, посвященный радиосвязи, касается судов, длина которых превышает 45 метров. Сфера применения Протокола была расширена за счёт распространения его положений и на рыболовные суда, ведущие переработку рыбы.

Протокол не содержит конкретных требований к определенному оборудованию для обеспечения безопасности для рыболовных судов длиной менее 45 м, такому как спасательные средства.

Торремолиносская международная конвенция по безопасности рыболовных судов 1977 года, как и Торремолиносский протокол 1993 года, не вступила в силу из-за целого ряда технических и юридических препятствий.

Некоторые государства предприняли инициативы по разработке единообразных региональных стандартов для обеспечения безопасности рыболовных судов на приемлемом уровне путем установления того, какие правила, содержащиеся в приложении 
к Протоколу, должны применяться полностью или частично к таким судам.

Разработанные региональные стандарты были рассмотрены Подкомитетом по остойчивости и грузовой марке и безопасности рыболовных судов (SLF) КБМ ИМО с точки зрения целесообразности разработки образца для других стран и регионов (документы MSC 68/INF.10 и MSC 70/INF.24). Эти региональные стандарты предоставили ценную информацию в отношении пересмотра части В Кодекса.

В июне 2005 года Административный совет МОТ одобрил пересмотренные тексты Кодекса безопасности рыбаков и рыболовных судов и Факультативное руководство по проектированию, постройке и оборудованию малых рыболовных судов.

Прошедшая в октябре 2012 года в Кейптауне (Южно-Африканская Республика) под эгидой Международной морской организации (ИМО) Дипломатическая конференция по безопасности рыболовных судов приняла Соглашение об осуществлении положений Торремолиносского протокола 1993 года к Торремолиносской международной конвенции по безопасности рыболовных судов 1977 года (Кейптаунское соглашение 2012 года). Конфереция отменила и заменила Торремолиносский протокол 1993 года, вместе с тем статьи Кейптаунского соглашения 2012 года и правила приложения к Торремолиносскому протоколу 1993 года с учетом изменений, изложенных в приложении к этому Соглашению, рассматриваются и толкуются вместе как единый документ [38].

Кейптаунское соглашение 2012 года устанавливает международные требования к конструкции, водонепроницаемости, остойчивости и непотопляемости, механическим и электрическим установкам, противопожарной защите, спасательным средствам и устройствам, навигационному и радиооборудованию рыболовных судов. Также устанавливаются требования по освидетельствованию рыболовных судов и выдаче свидетельств, формы Международного свидетельства о безопасности рыболовного судна и Международного свидетельства об изъятии. 
Если специально не предусмотрено иное, положения приложения к Соглашению применяются к новым судам, которые построены, начиная с момента вступления Соглашения в силу.

Определено, что Кейптаунское соглашение 2012 года вступает в силу через двенадцать месяцев после даты, на которую не менее 22 государств, рыболовный флот которых в совокупности имеет не менее 3600 судов длиной 24 м и более, занятых рыболовством в открытом море, выразят свое согласие соблюдать положения настоящего Соглашения.

Российская Федерация подписала Заключительный акт Дипломатической конференции по безопасности рыболовных судов (Кейптаунское соглашение 2012 года) 11 октября 2012 года.

Для безопасности рыболовных судов и судовых команд важно, чтобы образование, профессиональная подготовка и аттестация всех служащих на борту судна соответствовали общепризнанным стандартам. С этой целью в 1995 году в штаб-квартире МОМП в Лондоне была подписана Международная конвенция по вопросам профессиональной подготовки, аттестации и контроля наёмного персонала рыболовных судов [52].

Конвенция подписана Российской Федерацией в 1996 году (постановление Правительства Российской Федерации от 30 сентября 1996 года № 1154).

Государства, от имени которых была заключена Конвенция, взяли на себя обязательство не мешать соответствующей законотворческой деятельности (то есть не препятствовать принятию соответствующих законов, постановлений, распоряжений, правил и инструкций). С точки зрения сохранения жизни и обеспечения гарантий прав собственности на море и защиты морской среды служащий плавсостава мореходных судов должен соответствовать предъявляемым требованиям и быть годным к выполнению возложенных на него служебных обязанностей.

В приложенных к Конвенции инструкциях и наставлениях отражены обязательные требования к аттестации капитанов судов, офицеров корабельной службы, судовых инженеров-механиков и радистов. В них подробно излагаются также основные правила 
техники безопасности, обязательные для исполнения служащими плавсостава на всех рыболовных судах, и инструкции по соблюдению требований к надзору за штурманами на борту рыболовных судов.

В список контрольных вопросов при аттестации кандидатов на должности капитанов судов и лиц штурманского состава для дальнего плавания включены следующие: судовождение; корабельная служба; определение местоположения судна электронными средствами связи; метеорологическая служба; связь; противопожарная безопасность; спасение утопающих; судовые маневровые свойства и средства; конструктивные особенности и остойчивость рыболовного судна (в том числе при плавании по чистой воде и в условиях обледенения); подъем улова рыбы на борт и уборка рыболовных снастей; английский язык; медицинская помощь; морское право; спасательные работы на море; перечень норм и правил охраны труда рыбаков и соблюдения техники безопасности рыболовными судами в объеме требований ФАО, МОТ и МОМП к разделу А и в части загрязнения морской среды.

Раздел В содержит перечень мест для ловли рыбы на море. С точки зрения безопасности места, перечисленные в разделе В, подразделяются на следующие три категории:

1. Моря дальнего плавания.

2. Акватории Мирового океана, отстоящие от мест укрытия корабля на расстоянии до 200 морских миль.

3. Акватории Мирового океана, отстоящие от мест укрытия корабля на расстоянии до 50 морских миль.

Однако чаще всего под местами для рыбного промысла, или рыбными отмелями, подразумевают отдельные районы рыбной ловли в прибрежных водах или в открытом море.

Районы для прибрежного рыболовства сосредоточены в прибрежных водах, хотя их удалённость от береговой линии может быть различной. Это зависит от местных условий. Во фьордах или других небольших узких заливах со скрытой естественной полосой укрытий от морской стихии на однодневную рыбалку выходят небольшие катера (с открытой палубой или полурубкой). 
На более длительную рыбалку снаряжаются всевозможные типы небольших местных судов, оборудованных небольшими рубками.

Ловля рыбы в открытом море представляет собой рыбный промысел вдали от морского побережья, при этом внешние границы береговой линии не определены. Рыболовные суда, предназначенные для ловли рыбы в открытом море, как правило, проектируются как суда дальнего плавания, поскольку во многих прибрежных странах открытое море (или океан) начинается сразу же за естественной полосой береговых укрытий фьордов или шхер.

Согласно международно-признанной классификации рыболовным судном может быть любой корабль, используемый в коммерческих целях для ловли рыбы, китов, тюленей, моржей или других представителей живых ресурсов моря. Перерабатывающее судно - это корабль, который используется исключительно для переработки пойманной рыбы.

Рыболовные суда, уходящие на промысел рыбы в открытое море, имеют различные модификации и размеры. В их числе траулеры с кормовым тралением рыбы (на их борту установлены технологические линии для переработки живой рыбы), кошельковые сейнеры, сейнеры для ловли рыбы крючковыми орудиями лова, плавучие базы и т.д. По своим характеристикам рыболовные суда настолько сильно отличаются от других мореходных кораблей, что заключение международных соглашений по вопросам охраны труда и сохранения жизни на море для каждый из них в отдельности весьма затруднительно или невозможно.

\section{6. Обеспечение безопасности при проведении промысловых операций}

Безопасность моряков при ведении промысла обеспечивается неукоснительным соблюдением правил и инструкций по технике безопасности (ТБ) и точным выполнением своих обязанностей согласно «Промысловому расписанию».

На всех опасных местах на судне необходимо вывешивать хорошо видимые плакаты, наносить предупредительные надписи и 
знаки безопасности. Как правило, вблизи механизмов, устройств и установок должны быть вывешены инструкции по безопасной их эксплуатации. Инструкции, предупредительные надписи и плакаты по ТБ должны быть составлены на русском и на национальном языках республики, к порту которой приписано судно, причем оба текста должны быть тождественны [114].

Каждый поступающий на судно член экипажа должен пройти вводный инструктаж по ТБ по ГОСТ 12.0.004-78 «Организация обучения работающих безопасности труда». Далее с поступающим проводится первичный инструктаж на рабочем месте в 2 этапа. Причем второй этап - на рабочем месте с индивидуальным показом безопасных методов труда. Далее в течение 2..5 смен проводятся работы на рабочем месте под наблюдением квалифицированного работника; после чего оформляется в судовом журнале по ТБ допуск к самостоятельной работе.

Не реже 1 раза в 3 месяца начальники судовых служб проводят повторный инструктаж по ТБ всех своих подчиненных.

Перед началом промысла начальник службы добычи и обработки проводит с членами экипажа, участвующими в добыче и переработке морепродуктов, инструктаж по ТБ.

Перед началом перегрузочных работ в море второй помощник капитана проводит текущий инструктаж по ТБ с работниками, принимающими участие в перегрузочных работах, независимо от сроков и должностей предыдущего инструктажа.

Внеплановый инструктаж по ТБ проводят начальники судовых служб в случаях [113]:

- изменения правил ТБ;

- изменения технологического процесса, замене или модернизации оборудования;

- нарушении работником требований ТБ;

- перерывах в работе более 60 дней (для работ, к которым предъявляются повышенные требования ТБ - более 30 дней);

- пересадке с судна на судно в море;

- выполнении погрузочно-разгрузочных работ на другом судне;

- привлечении к работам на подвахте по другому виду работ. 
Текущий инструктаж проводят с работниками перед производством работ, на которые оформляют наряд-допуск (работы с повышенной опасностью). Перечень работ с повышенной опасностью определяет судовладелец. Ответственным руководителем работ с повышенной опасностью на судне является начальник судовой службы.

Проведение всех видов инструктажа, кроме текущего, оформляется в судовом журнале профработы по ТБ с обязательной подписью получившего инструктаж и лица, его проводившего.

Командный состав судна обязан ежегодно проходить проверку знаний по ОТ, проводимую работниками служб ТБ - членов комиссии по проверке знаний по специальности.

Судовладелец организует ежегодную проверку знаний судовых специалистов, не относящихся к командному составу (обычно на судне).

Контроль и непосредственная ответственность за соблюдение правил ТБ во время всех видов судовых работ возлагается на лицо командного состава, непосредственно возглавляющего его работу.

При производстве ремонтных работ на судне ответственность за соблюдение правил ТБ возлагается на старшего помощника капитана или старшего механика, а также начальников судовых служб, в зависимости от характера ремонтных работ.

При производстве погрузочно-разгрузочных работ на борту другого судна ответственность за соблюдение правил ТБ возлагается на старшего помощника капитана этого судна.

Все рабочие места, расположенные на высоте 0,75 м и более, должны иметь ограждение. Во всех местах возможного пребывания и перемещения людей (палубы, служебные и санитарно-бытовые помещения) должны предусматриваться штормовые поручни. Bce рабочие места и проходы должны быть очищены от посторонних предметов, снега, льда, рыбных отходов и т.п., при необходимости палубы следует посыпать песком.

Перед началом швартовки все грузовые стрелы и другие выступающие за борт предметы и устройства должны быть завалены внутрь судна и закреплены, а места у швартовых устройств 
должны быть освобождены от посторонних предметов, лицам, не занятым на швартовых работах, запрещается находиться в районе швартовых операций.

Пересадка людей с судна на судно, если они ошвартованы друг к другу, является работой с повышенной опасностью и разрешается только с помощью допущенных средств и приспособлений, гарантирующих безопасность пересаживаемых, применение для этих целей штормтрапов запрещено.

Временная транспортировка производится только при крайней необходимости. Разрешение на транспортировку дают капитаны судов по согласованию друг с другом. Общее руководство временной транспортировкой осуществляет старший помощник капитана судна, рабочая клеть которого используется.

Пересадка людей с судна на судно, если они ошвартованы друг к другу, допускается с помощью спасательных шлюпок при силе ветра не более трех баллов, волнении моря не более двух баллов и хорошей видимости. Суда должны находиться в пределах видимости, между ними и шлюпкой должна обеспечиваться радиосвязь, а за шлюпкой - непрерывное наблюдение с обоих судов. Пересадка людей происходит под непосредственным наблюдением и ответственностью капитанов. Экипаж шлюпки и пассажиры должны быть обеспечены индивидуальными спасательными средствами. При внезапном ухудшении погоды или видимости шлюпка должна немедленно подойти к ближайшему судну и по радио доложить о своем местонахождении. Для посадки и высадки людей из шлюпки допускается использование штормтрапов при применении страховочных поясов и штерта.

Запрещается высадка людей на берег с помощью шлюпок.

При выполнении работ, где возможно падение человека в воду, обязательно ношение жилетов рабочих страховочных [113].

Все промысловые операции и расстановка для их выполнения членов экипажа должна производиться в соответствии с действующими для данного типа судна и вида лова «Промысловыми расписаниями», которые составляются с учетом проекта судна, обеспечения выполнения промысловых операций безопасными 
приемами и методами, согласованы и утверждены в установленном порядке. Судовое промысловое расписание утверждается капитаном судна.

К выполнению промысловых операций допускаются только специально обученные лица, имеющие квалификацию не ниже матроса 1-го класса. Члены экипажа, выполняющие промысловые операции и впервые работающие на судне данного типа и в данном виде лова, а также члены экипажа, вызываемые на подвахту, должны пройти обучение непосредственно на рабочем месте. Ответственность за обучение возлагается на помощника капитана по добыче [114].

Капитан или вахтенный помощник для обеспечения безопасности членов судового экипажа при выполнении промысловых операций обязан [114]:

- поставить в известность вахтенного мастера по добыче о маневрировании судна;

- путем соответствующего маневрирования судна обеспечить безопасные условия работы и исключить намотку орудий лова и их оснастки на винт;

- немедленно удалять людей в безопасное место в случае аварий с орудиями лова;

- не допускать присутствия посторонних людей в местах выполнения промысловых операций.

Помощник капитана по добыче и вахтенный мастер по добыче для обеспечения безопасности людей обязан [114]:

- обеспечить безопасные условия труда для членов судового экипажа, выполняющих промысловые операции;

- немедленно удалять людей в безопасное место в случае аварий с орудиями лова, промысловыми механизмами и возникновении других опасностей;

- обеспечить выполнение инструкций и правил по ТБ членами экипажа, выполняющими промысловые операции;

- не допускать присутствия посторонних людей в местах выполнения промысловых операций;

- постоянно следить за состоянием и своевременно устранять неисправности орудий лова; 
- постоянно следить за состоянием и исправностью промысловых механизмов и устройств, обращая особое внимание на детали, находящиеся под нагрузкой.

Каждый член судового экипажа, выполняющий промысловые операции, обязан [114]:

- знать и выполнять свои обязанности согласно «Промысловому расписанию», а также правил и инструкций по ТБ;

- не создавать своими действиями опасности для других членов экипажа;

- немедленно сообщить помощнику капитана по добыче или вахтенному мастеру о любых повреждениях или неисправностях промысловых механизмов, орудий лова и их оснастки;

- знать применяемые на судне типы канатов и сетематериалов, их разрывные характеристики, способы соединения канатов, обеспечивающие безопасность работы с ними.

Запрещается эксплуатировать растительные канаты при наличии разрыва каболок, прелости, значительного износа. Другие канаты запрещается эксплуатировать в случаях [113]:

- наличия деформации;

- при износе, если в любом месте на длине, равной 10 диаметрам, количество оборванных проволок составляет 5 \% и более общего количества проволок в канате;

- если пряди или проволоки выдвигаются из каната;

- если оборвана прядь;

- если проволоки имеют плоские поверхности из-за чрезмерного износа;

- если имеются признаки коррозии;

- если оборванные проволоки имеются только в одной пряди;

- если имеется более одной оборванной проволоки, непосредственно прилегающей к металлическому креплению.

Промысловые операции по спуску-подъему орудий лова, выполнение которых связано с изменением хода или направления движения судна, должны выполняться только по командам капитана или вахтенного помощника капитана [114]. 
Капитан или вахтенный помощник капитана все свои команды должен отдавать только через лицо, руководящее в данный момент работами на палубе (старшего мастера или мастера по добыче).

При подъеме больших уловов непосредственное руководство на мостике и промысловой палубе осуществляют капитан и старший мастер по добыче. Во время промысловых операций на судне между лицами, отдающими команды и их выполняющими, должна быть установлена надежная звуковая связь (голосом или специальным переговорным устройством), независимо от условий погоды, состояния моря и звуковых помех.

Запрещается производить смену промысловой вахты во время выполнения операций по выборке или постановке орудий лова. Смена вахты должна производиться в полном составе.

Каждый член судового экипажа при выполнении промысловых операций должен быть в специальной защитной каске, в страховочном жилете, одежде, обуви, рукавицах или перчатках установленного образца и иметь при себе на ремне в ножнах остро заточенный с двух сторон нож.

Одежда, жилет, обувь, каска должны быть хорошо пригнаны по размеру и не иметь развивающихся и выступающих частей. При выполнении промысловых операций носить кольца и браслеты на руках, а также галстуки и косынки на шее запрещается.

При работе в штормовую погоду члены промысловой команды обязаны иметь предохранительные пояса, которые страховочными концами должны надежно крепиться к судовым конструкциям [114].

Волнение оценивается по «Шкале состояния поверхности моря» (Инструкция Главного управления гидрометеорологической службы СССР от 1 января 1954 года) путем сравнения фактической высоты волны с данными таблицы (табл. 5.5.1) [113]. 
Таблица 5.5.1

Шкала состояния поверхности моря

(Инструкция Главного управления гидрометеорологической службы СССР от 1 января 1954 года)

\begin{tabular}{|c|c|c|c|c|c|c|c|c|c|c|}
\hline Баллы & 0 & 1 & 2 & 3 & 4 & 5 & 6 & 7 & 8 & 9 \\
\hline $\begin{array}{c}\text { Высота } \\
\text { волны (м) }\end{array}$ & 0 & $\begin{array}{l}0,1- \\
0,25\end{array}$ & $\begin{array}{c}0,25- \\
0,75\end{array}$ & $\begin{array}{c}0,75- \\
1,25\end{array}$ & $\begin{array}{c}1,25- \\
2,0\end{array}$ & $\begin{array}{c}2,0- \\
3,5\end{array}$ & $\begin{array}{c}3,5- \\
6,0\end{array}$ & $\begin{array}{l}6,0- \\
8,5\end{array}$ & $\begin{array}{l}8,5- \\
11,0\end{array}$ & $\begin{array}{c}11,0 \\
\text { и бо- } \\
\text { лее }\end{array}$ \\
\hline 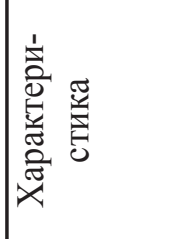 & 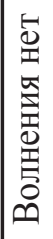 & 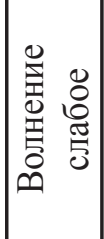 & 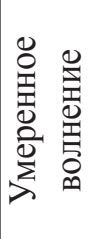 & 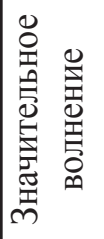 & & 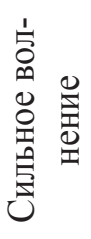 & & 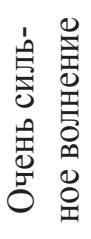 & & 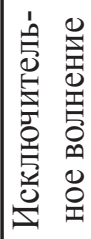 \\
\hline
\end{tabular}

Ограничения для ведения промысла в зависимости от состояния моря (для определенного водоизмещения судна и вида промысла) указаны в таблице 5.5.2. При волнении моря большем, чем указано в таблице, ведение промысла запрещается. При гидрометеорологических условиях, указанных в таблице, грузовые операции должны быть прекращены, а суда отойти друг от друга. К этому периоду орудия лова должны быть подняты на борт и закреплены [113].

Таблица 5.5 .2

Ограничения для ведения промысла

в зависимости от состояния моря

\begin{tabular}{|c|c|}
\hline Тип судна и водоизмещение, тонны & $\begin{array}{c}\text { Волнение } \\
\text { моря, баллы }\end{array}$ \\
\hline $\begin{array}{r}\text { Промысловые суда кормового (бортового) траления: } \\
20-60 \\
61-300 \\
301-700 \\
701-2000 \\
2001 \text { и более } \\
\end{array}$ & $\begin{array}{l}3(3) \\
4(4) \\
5(5) \\
6(6) \\
7(6)\end{array}$ \\
\hline Рыболовные базы водоизмещением 20000 и более & 4 \\
\hline Рыбообрабатывающие базы & $4(3)$ \\
\hline
\end{tabular}


Все рабочие места, где производятся промысловые операции, в темное время суток должны быть хорошо освещены.

Перед выходом судна в рейс и после длительного перехода в район промысла должны быть произведены проверки технического состояния и исправности промысловых механизмов и промысловых и грузовых устройств. Все замеченные в результате осмотра неисправности должны быть немедленно устранены. О замеченных неисправностях и их устранении должна быть сделана запись в журнале технического состояния [114].

Перед пуском промысловых механизмов и грузовых устройств необходимо предупредить людей, работающих с ними, а при необходимости удалить в безопасное место. Для остальных членов экипажа выход на промысловую палубу необходимо запретить, вывесив соответствующие предупредительные плакаты у выходов и проходов, и объявить о пуске по судовой трансляции. Пуск промысловых механизмов и грузовых лебедок для выполнения промысловых операций должен производиться плавно, без рывков.

При изготовлении, оснастке и починке орудий лова, а также сетных работах находиться под оснасткой и сетной частью, а также в мешке и мотне запрещается.

При перемещении крупных рыб по палубе необходимо быть внимательным и соблюдать осторожность. Находиться со стороны хвоста рыбы запрещается. Крупные рыбы, поднятые на палубу, должны быть обязательно оглушены или умерщвлены перед тем, как с ними будут производиться какие-либо работы.

При выполнении каких-либо работ с оглушенными крупными рыбами запрещается:

- просовывать в полость рта рыбы руки или нож;

- прикасаться к телу рыбы голыми руками;

- располагаться так, чтобы рыба находилась между ног;

- становиться и садиться на рыбу.

Кормовое траление [114]. При спуске и подъеме трала между стойками ворот слипа должно быть установлено надежное ограждение. После подъема мешка трала с уловом на палубу при тралении и на переходах судна ворота слипа должны быть закрыты. 
Находиться на наклонной плоскости слипа во время спуска и подъема трала, а также при тралении запрещается.

Работы на слипе в период промысла допускаются только при волнении моря не более 4 баллов и при выполнении следующих требований:

- судно должно идти самым малым ходом носом на волну;

- люди, работающие на слипе, должны быть одеты в рабочие страховочные жилеты и каски, иметь предохранительные пояса и подстраховываться с помощью страховочных концов;

- руководство работой должно осуществляться лично старшим мастером по добыче.

Лица, выполняющие промысловые операции у слипа у подвесных ваерных блоков, должны быть в предохранительных поясах со страховочными приспособлениями (рамы, обухи и др.).

При спуске и подъеме разноглубинного трала находиться в зоне движения грузов-углубителей и работать с ними в районе слиповой канавки запрещается. Выбранные на палубу грузы-углубители должны быть надежно закреплены.

При включении или отключении досок, заводе ваеров в ролики и выведении их из роликов необходимо выполнять следующие требования:

- траловые доски должны включаться и отключаться только поочередно;

- выборка ваеров после выхода траловых досок из воды, выборка и травление ваеров (кабелей) между отдельными операциями траловых досок, а также заводка ваеров в ролики и выведение их из роликов должны производиться на самой малой скорости, плавно и без рывков;

- при выполнении операции крепления досок на стопорные цепи и отдаче их, включении и отключении гаков шкентелей досок и гаков стопорных оттяжек, заводке и сбрасывании ваеров на слип выборка или травление ваеров должны быть прекращены, траловая лебедка остановлена, а её барабаны застопорены;

- для безопасного включения и отключения гаков шкентелей траловых досок, а также заведения и выведения из роликов ваеров 
и сбрасывания их на слип ваерам должна даваться достаточная слабина. Включение и отключение стопорных концов должно производиться только на промысловой палубе, а не на слипе;

- матросы, выполняющие операции по включению и отключению траловых досок, а также по заведению, выведению ваеров из роликов и сбрасыванию их на слип, должны находиться от роликов со стороны бортов судна и сбрасывать ваера на слип в положении «от себя».

В случае задева трала вахтенный мастер по добыче обязан:

- предупредить всех людей, находящихся в районе промысловой палубы и ближайших опасных местах;

- немедленно доложить вахтенному помощнику капитана и вызвать старшего мастера по добыче;

- вытравить необходимое количество ваеров до получения ими достаточной слабины.

Члены судового экипажа, находящиеся в районе промысловой палубы и ближайших опасных местах, получив предупреждение о задеве трала, должны немедленно укрыться в ближайших безопасных местах и находиться там до тех пор, пока не будет дано разрешение покинуть их.

При тралении запрещается:

- переходить через ваера, пролезать под ними, прикасаться к ним частями тела, использовать их в качестве опоры и находиться между ними;

- находиться между ваерами, а также между ваером и слипом;

- находиться под подвесными роликами, а также у роликов со стороны слипа;

- выполнять работы и перегибаться через фальшборт в районе схода ваеров в воду.

При подъеме трала на палубу заводку стропов и подсоединение вытяжных концов (джильсонов) необходимо производить только при остановленной лебедке.

При подъеме мешка с уловом заводка дележных стропов должна производиться плавно, без рывков, мешок при этом должен подниматься над палубой на высоте не более 10 см. 
При развязывании гайтана мешок с уловом должен быть обязательно опущен на палубу.

Подъем мешка для выливки рыбы должен производиться только после того, как мешок взят на стопор, а человек, развязывающий гайтан мешка, отойдет в безопасное место.

Перед открытием крышки рыбного бункера все работающие с мешком трала должны быть предупреждены лицом, открывающим бункер.

Выливка улова при работе по схеме «дубль» должна производиться только после окончания спуска второго трала.

При подъеме или спуске трала и выливки улова запрещается:

- становиться на сетные части и оснастку трала, ваера, кабели, переходные концы и т.П., а также переходить через них и проходить под ними;

- наматывать на руку оттяжку спускного конца и спусковой конец при выметке сетной части трала по слипу, а также крепить спусковой конец за конструкции судна;

- находиться между стопорными концами и кабелями, а также между стопорными концами и слипом во время включения и отключения стопорных концов и травлении кабелей;

- находиться между слипом и ваерами (переходными концами) при заведении их в подвесные ролики, а также выведении из них и сбрасывании на слип;

- становиться на планширь и перегибаться через него при приеме и креплении траловых досок на стопорные цепи и отдаче траловых досок со стопорных цепей;

- находиться на промысловой палубе во время выборки ваеров и кабелей, подъема сетной части трала и мешка с уловом на палубу;

- находиться со стороны слипа у подвесных и направляющих роликов при выполнении отдельных операций;

- разносить стопорные концы (оттяжки) и вытяжные концы (джильсоны) во время травления и выборки ваеров и кабелей;

- находиться в рыбных ящиках в момент выливки в них улова;

- выливать улов из мешка без дележки, если масса улова больше разрешенной грузоподъемности грузовых устройств; 
- находиться на мешке с рыбой в момент его подъема и разворачивания грузовыми устройствами;

- находиться на пути движения мешка при его перемещении грузовыми устройствами для выливки улова;

- находиться под мешком с уловом или рядом с ним при его подъеме и перемещении;

- использовать ломы и свайки при остропке мешка;

- находиться в момент развязывания гайтана между кутком и слипом.

При выборке трала сетным барабаном не следует допускать слабины сетного полотна.

Запрещается применять нештатные приспособления для укладки жгута на сетной барабан.

Запрещается выполнение ремонтных работ с промысловыми механизмами под нагрузкой.

Бортовое траление [114]. При выводе траловых досок за борт на штатные места необходимо:

1) остановить судно;

2) вывести траловые доски поочередно.

Руководство работой по выводу траловых досок осуществляется старшим мастером по добыче.

При включении или отключении траловых досок необходимо:

1) траловые доски включать или отключать только поочередно и по команде мастера по добыче, когда барабаны траловой лебедки будут застопорены;

2) выбирать и травить ваера между отдельными операциями по включению или отключению траловых досок на самой малой скорости плавно, без рывков;

3) при выполнении операции крепления досок на стопорные цепи и отдаче их, а также включении и отключении гаков шкентелей досок необходимо прекратить выборку или травление ваеров, траловую лебедку остановить, а ее барабаны застопорить;

4) для безопасного включения и выключения гака шкентеля доски ваерам дать достаточную слабину; 
5) забрасывание и выведение переходных концов производить только при помощи багра (а не вручную) с длинным древком;

6) траловые доски крепить на стопорные цепи только после того, как они правильно подойдут к борту судна;

7) при взятии траловых досок на стопорную цепь её нужно забрасывать (а не закладывать) за обе дуги доски.

При взятии ваеров на стопор или отдаче их со стопора надлежит:

1) гак мессенджера забрасывать на носовой ваер только после того, как травление или выборка ваеров будет приостановлена, барабаны траловой лебедки застопорены, а ход судна уменьшен до самого малого;

2) лицу, забрасывающему гак мессенджера на носовой ваер, выполнять эту операцию только в предохранительном поясе со страховочным концом;

3) после захвата гаком мессенджера кормового ваера скорость выборки мессенджера уменьшить до самой малой;

4) взятие ваеров на цепной стопор-блок производить только после того, как гак мессенджера подойдет с ваерами к фальшборту и выборка мессенджера будет прекращена;

5) операцию взятия ваеров на стопор выполнять вдвоем;

6) цепь стопор-блока заводить снизу ваеров, кольцо и чеку надежно закрепить;

7) гак мессенджера снимать с ваеров только после взятия на стопор, для безопасного снятия гака мессенджер осторожно и плавно стравить лебедкой, пока ваера не «сядут» на стопор-блок;

8) перед отдачей ваеров со стопора всех людей удалить в безопасное место, а ход судна сбавить до малого или остановить;

9) лицу, отдающему ваера с цепного стопор-блока, эту операцию выполнять только при помощи легкого ломика длиной 75 см и находиться при этом на расстоянии вытянутой руки от стопор-блока в сторону носа судна.

Во время траления вахтенный мастер обязан следить за натяжением ваеров и ленточными тормозами траловой лебедки.

В случае задева трала обязанности вахтенного мастера по добыче те же, что и при кормовом тралении. 
Работа близнецовым тралом [114]. Между судном-флагманом и судном-близнецом в период лова должна быть обеспечена надежная связь.

Взятие кабелей на стопор и отдача их со стопора должны производиться при остановленном ходе судна, остановленной лебедке и застопоренных барабанах.

Отдача кабелей со стопора должна производиться только при помощи легкого ломика длиной 75 см. Лицо, отдающее кабель со стопора, должно находиться от него на расстоянии вытянутой руки в сторону кормы у носовой траловой дуги на судне-флагмане, а не на судне-близнеце в сторону носа у кормовой траловой дуги.

При работе с близнецовым тралом запрещается:

- давать полный ход судну, если ваера не натянуты и имеют слабину;

- при передаче и приеме переходного конца давать ход судну, пока кабели не будут отданы со стопора;

- находиться между фальшбортом и переходным концом при его выборке;

- выливать за борт и принимать из-за борта груз вручную;

- при выборке ваеров, подъеме и спуске трала необходимо выполнять требования, изложенные выше.

Работа с тралами по двухбортной траловой схеме [114]. При работе с тралами по двухбортной траловой схеме необходимо выполнять следующие правила:

- выводить выстрелы за борт и заводить их на борт необходимо поочередно и только после полного прекращения хода судна;

- при выведении и заведении выстрелов нахождение людей в зоне их движения запрещается;

- выведенные за борт выстрелы должны быть надежно закреплены перед началом промысловых операций;

- при укладке выстрелов в гнезда поправлять их руками запрещается;

- при спуске, подъеме трала и тралении нахождение людей на рабочей палубе в зоне движения ваеров, а также на выстрелах запрещается; 
- люди, работающие на выстрелах, должны быть в рабочем страховочном жилете, предохранительном поясе, страховочный конец которого необходимо прочно закрепить за страховочное приспособление;

- операции по регулировке голых концов мутника, траловых досок, а также ремонт сетного полотна на выстрелах запрещается;

- при нахождении людей на выстрелах проведение маневров судна, приводящих к резкому крену, запрещается.

Кошельковый лов [114]. При кошельковом лове экипаж рабочей шлюпки должен комплектоваться не менее чем из двух наиболее опытных и физически сильных членов экипажа судна, один из которых назначается старшим.

Лица, работающие в шлюпке, должны быть в рабочих страховочных жилетах и защитных касках.

Рабочая шлюпка должна быть обеспечена:

- трехсуточным запасом продовольствия и питьевой воды на каждого члена экипажа;

- спасательным кругом;

- водоотливными средствами;

- сигнальным фонарем с продолжительностью действия не менее 24 часов;

- заведенной вокруг корпуса «брагой» из стального троса или капронового каната и буксирным концом.

При замете кошелькового невода в ночное время за рабочей шлюпкой должно быть установлено постоянное наблюдение.

При работе со шлюпкой запрещается:

- ставить шлюпку при замете невода под прямым углом к направлению замета;

- оставлять людей в рабочей шлюпке при буксировке ее во время переходов судна.

Люди, находящиеся в рабочей шлюпке, должны быть предупреждены заранее перед отдачей невода, чтобы они могли подготовиться к возможному рывку.

Член судового экипажа, отдающий буксир рабочей шлюпки или сбрасывающий плавучий якорь, должен находиться в безопасном 
месте, где исключено попадание петли стяжного троса или сетной части невода.

Замет и кошелькование осуществляются только под руководством капитана судна. Выборку и выливку улова капитан может поручить вахтенному помощнику капитана.

При выливке рыбы каплером лицо, работающее на замке каплера, должно находиться в безопасном месте или на безопасном расстоянии от линии движения каплера и открывать замок при нахождении каплера на весу при помощи специального конца.

Если каплер закрывается гайтаном, то для развязывания гайтана каплер с рыбой должен быть обязательно опущен на палубу.

Обобщая изложенное, можно сделать следующее заключение. Рыболовный промысел является специфичным видом деятельности на море. Это нашло отражение в нормативно-правовых документах и мероприятиях по обеспечению безопасности судоходства в районных рыбного промысла.

Безопасность судоходства рыбопромысловых судов регламентируется национальными нормативныли правовыми актами и международными договорами, заключенными и ратифицированньли Российской Федерациией, которые имеют общее и специальное назначение. При переходе к месту лова и возвращении в порт из района рыбного промысла промысловое судно подчиняется общим правилам и нормам регулирования мореплавания, обязательным для всех кораблей, а в районе промысла безопасность совместного плавания регулируется специиальными нормами, соглашениями и правилами ведения промысла и обеспечения безопасности.

Безопасность моряков при ведении промысла обеспечивается неукоснительным соблюдением правил и инструкций по технике безопасности, а также точным выполнением своих профессиональнblх обязанностей согласно «Промысловому расписанию».

Знание и неукоснительное выполнение на практике требований и рекомендаций по обеспечению безопасности судоходства являются необходимым условием безопасной и успешной производственной деятельности на море. 


\section{Контрольные вопросы}

1. Назовите особенности плавания рыбопромыслового судна. В чем состоит специфика правового регулирования и организации мероприятий по обеспечению безопасности судоходства рыбопромыслового судна?

2. Назовите специфические признаки промысловой аварии.

3. Какие административные органы осуществляют надзор за обеспечением безопасности плавания судами рыбопромыслового флота?

4. Назовите этапы подготовки промысловых судов к групповому плаванию к району рыбного лова.

5. Назовите общие правила безопасности группового плавания промысловых судов, совершающих переход из порта в район промысла или обратно в порт.

6. Какие правила определяют порядок взаимодействия вновь прибывающих судов с судами, занятыми промыслом в данном районе?

7. Какие правила определяют безопасность совместного плавания и промысла судов?

8. Как должны быть выставлены дополнительные огни в ночное время, знаки и флажные сигналы днем при постановке трала, выборке трала и если орудия лова легли на грунт?

9. Какие конструкционные особенности рыболовных судов определяют безопасность?

10. Какие существуют ограничения для ведения промысла в зависимости от состояния моря? 


\section{ЛИТЕРАТУРА}

1. Акимова, И. Лоцманской службе России почет! [Электронный peсурс] / И. Акимова. - Режим доступа : http://www.korabel.ru/ news/comments/locmanskoy_sluzhbe_rossii_pochet.html.

2. Аполлонов, Е. М., Бойцов, Г. В. и др. Проблемы повышения уровня безопасности судов и плавучих сооружений / Е. М. Аполлонов, Г. В. Бойцов, А. А. Захаров, О. Е. Литонов, А. Б. Нестеров // Научн. техн. сб. Российского морского регистра судоходства. Вып. 24. - СПб., 2001. - С. 30-47.

3. Астреин, В. В. Разработка технологий выработки решений по предупреждению столкновений судов в море: дис. ... канд. техн. наук: 05.22.19 / Астреин Вадим Викторович. - Новороссийск, 2010. - 152 c.

4. Баскин, А. С., Блинов, И. А. и др. Навигационно-гидрографическое обеспечение мореплавания / А. С. Баскин, И. А. Блинов, Б. В. Елисеев и др. - М.: Транспорт, 1980. - 229 с.

5. Береговые объекты глобальной морской системы связи при бедствии и для обеспечения безопасности (ГМССБ). Техникоэксплуатационные требования. Свод правил СП Х.XXXXX.2014 (проект). - М., 2014. - 35 с.

6. Бирюкович, М., Букшпрун, М. Судовая радиолокационная станция «Нептун» / М. Бирюкович, М. Букшпрун. - М.: Морской транспорт, 1957. - 204 с.

7. Борисова, Л. Ф. Анализ причин столкновения судов и проблемы безопасности мореплавания / Л. Ф. Борисова // Наука и образование : Материалы Междунар. научно-техн. конф. (Мурманск, 7-15 апреля 2004 г.) : в 6 ч. / Мурман. гос. техн. ун-т. - Мурманск, 2004. - Ч. 5. - С. 245-249.

8. Борисова, Л. Ф., Скороходов, Д. А. Задачи обеспечения безопасности в области судоходства. / Л. Ф. Борисова, Д. А. Скороходов // Научно-технический сборник Российского морского регистра судоходства. - 2012. - № 35. - С. 8-17.

9. Борисова, Л. Ф., Скороходов, Д. А. Информационное обеспечение судоводителя при принятии решения безопасного управления 
морским транспортным процессом / Л. Ф. Борисова, Д. А. Скороходов // Научно-технический сборник Российского морского регистра судоходства. - 2012. - № 35. - С. 18-29.

10. Борисова, Л. Ф., Соловьев, А. А. Мобильные системы управления движением судов / Л .Ф. Борисова, А. А. Соловьев. Мурманск: Изд-во МГТУ, 2008. - 134 с.

11. Борисова, Л. Ф. Мобильная система управления движением судов для обеспечения безопасности мореплавания на акватории с интенсивным судоходством : дис. ... канд. техн. наук : 05.22.19 / Борисова Людмила Федоровна. - Мурманск, 2005. $-175 \mathrm{c}$.

12. Борисова, Л. Ф. и др. Нормирование показателей безопасности мореплавания и рисков потерь / Л. Ф. Борисова, Д. А. Скороходов, 3. Д. Борисов // Вестник МГТУ : Труды Мурманского гос. техн. ун-та. - 2010. - Т. 13. - № 4/2. - С. 868-876.

13. Борисова, Л. Ф., Артамонов, В. С. и др. Обеспечение безопасности мореплавания с помощью стационарных и мобильных систем управления судоходством : монография / Л. Ф. Борисова, В. С. Артамонов, Д. А. Скороходов, В. С. Звонов, А. С. Поляков; под общей ред. Ю. Л. Воробьева. - СПб.: Санкт-Петербургский университет ГПС МЧС России, 2012. - 199 с.

14. Борисова Л. Ф. Оценка безопасности судоходства на основе учета вероятностных показателей / Л. Ф. Борисова // Наука и образование-2014 : материалы Междунар. науч.-техн. конф., Мурманск, 24-28 марта 2014. - Мурманск : ФГБОУ ВПО «МГТУ», 2014. - С. 132-136.

15. Борисова, Л. Ф. и др. Принципы и категории обеспечения безопасности мореплавания / Л. Ф. Борисова, Д. А. Скороходов, З. Д. Борисов // Вестник МГТУ: Труды Мурманского гос. техн. ун-та, спец. выпуск: МГТУ 60 лет. - 2010. - Т. 13. № 4/1. - С. 719-729.

16. Борисова, Л. Ф., Холодов, Г. Г. Проблемы безаварийного позиционирования судов при выполнении технологических операций и транспортировки грузов в Арктике и методы их решения / Л. Ф. Борисова, Г. Г. Холодов // Научные проблемы 
транспорта Сибири и Дальнего Востока. - 2013. - № 2. - С. 122-126.

17. Борисова, Л. Ф., Холодов, Г. Г. Проблемы безопасности мореплавания при добыче и транспортировке углеродосодержащего сырья в Евро-Арктическом регионе / Л. Ф. Борисова, Г. Г. Холодов // Научные проблемы транспорта Сибири и Дальнего Востока. - 2013. - № 1. - С. 162-165.

18. Бурханов, М. В. Справочник-экзаменатор по огням, знакам и сигналам МПСС-72 / М. В. Бурханов. - М.: МОРКНИГА, 2010. $-158 \mathrm{c}$.

19. Буянов, Н. Ф. Особо опасные и чрезвычайные гидрометеорологические явления / Н. Ф. Буянов. - Владивосток: Дальневост. кн. изд-во, 1967. - 24 с.

20. Васильев, В. Я. и др. Развитие береговых систем обеспечения безопасности мореплавания в Российской Федерации. / В. Я. Васильев, С. В. Родионов, А. Р. Шигабутдинов // Наука и транспорт : Морской и речной транспорт. - 2013. - № 1 (5). - С. 34-38.

21. Ватущенко, Л. Л. и др. Электронные системы отображения навигационных карт / Л. Л. Ватущенко, В. А. Лдипевич, А. А. Кошевой. - 2-е изд., перераб. и доп. - Одесса: ОГМА, 2000. - 120 с.

22. Вейхман, В. В. Безопасность мореплавания [Электронный pecypc] / В. В. Вейхман. - Режим доступа: http://sea-safety. ucoz.ru/.

23. Винарова, С. PPU лоцмана на личном iPad - российский продукт на острие технологий [Электронный ресурс] / С. Винарова - Режим доступа: http://portnews.ru/comments/1867/

24. Возле Папуа - Новой Гвинеи введена система установленных путей движения судов [Электронный ресурс] // Maritime Telegraph | Морской Телеграф. - 2014. November 26. - Режим доступа: http://mtelegraph.com/new-traffic-separate-system-ofpng.html.

25. ГМССБ [Электронный ресурс]. - Режим доступа: http://sealibrary.ru/gmdss/ 76-sistemi-ubpch-i-tor.html.

26. ГМССБ за три недели : учебное пособие по работе в глобальной морской системе связи при бедствии (ГМССБ/GMDSS) 
[Электронный ресурс] // Помощь морякам. - Режим доступа http:// crew-help.com.ua.

27. Головко, В. И. и др. О создании концепции Единой системы контроля и управления судоходством Российской Федерации с использованием спутниковых технологий связи и навигации / В. И. Головко, Г. И. Москвин, А. Д. Куропятников // Новости навигации. - 2004. - № 1. - С. 11-20.

28. Головко, В. И. Этапы и перспективы развития СУДС в РФ / В. И. Головко // Морской флот. - 2006. - № 6. - С. 30-34.

29. ГОСТ Р 59840-95. Передача речи по трактам связи. Методы оценки качества, разборчивости и узнаваемости [Электронный pecypc]. - М : Стандартинформ, 1995. - Режим доступа : http:// docs.cntd.ru/document/ 1200027288.

30. Гриняк, В. М. Как управляют движением на море [Электронный pecypc] / В. М. Гриняк. - Режим доступа : vvsu.ruıfiles/.

31. Губернаторов, С. С. Навигация будущего - стратегическая программа e-Navigation. Навигационные системы и связь / С. С. Губернаторов // Морской и речной транспорт. - 2014. № 1 (8), - С. 52-56.

32. Джунусова, Д. Н. Международное морское право : учебник. 2012 [Электронный ресурс] - Режим доступа : http://textbooks. global/mejdunarodnoe-pravo-soderj/mejdunarodnoe-morskoepravo.html.

33. Единая государственная система информации об обстановке в Мировом океане [Электронный ресурс]. - Режим доступа : http://www.morinfocenter.ru/marine_safety_systems.

34. Е-навигация и РИС: Анализ технологий и примеры возможных реализаций проектов береговых систем [Электронный pecypc]. - Режим доступа : ftp://ftp.marsat.ru/Forum2011/ modeev transas.doc.

35. Захаров, А. Формализованная оценка безопасности - универсальный инструмент для снижения риска на транспорте / А. Захаров // Транспорт Российской Федерации. - 2006. № 3. - С. 66-68. 36. Иванов, А. М. Обеспечение безопасности мореплавания в районе промысла при работе с тралом [Электронный ресурс] // 
Научные труды Дальрыбвтуза. - 2011. - Т. 23. Режим доступа : http://cyberleninka.ru/.

37. ИМО Резолюция А.801(19) «Обеспечение радиослужб для Глобальной морской системы связи при бедствии и для обеспечения безопасности (ГМСС'Б)» 23.11.1995 г. с поправками.

38. Кейптаунское соглашение : наша карта на грядущее десятилетие [Электронный ресурс]. - Режим доступа : www.lausanne. org/ctcommitment

39. Конвенция о борьбе с незаконными актами, направленными против безопасности морского судоходства [Электронный ресурс] - Режим доступа: http://sergvelkovelli.com/

40. Конвенция о континентальном шельфе. Женева, 1958. // Сборник международных договоров СССР по вопросам мореплавания. ГУНиО. - № 9050. - МО СССР. - 1988. - С. 26.

41. Конвенция Организации Объединенных Наций по морскому праву. Монтего-Бей, 1982. // Сборник международных договоров СССР по вопросам мореплавания. ГУНиО. - № 29050. - МО CCCP. - 1988. - C. 29-87.

42. Консолидированный текст Конвенции СОЛАС-74 с изменениями и дополнениями 2008 года и до 2012 года. Глава V Безопасность мореплавания [Электронный ресурс]. - Режим доступа : http://www.evpatoriya-mdm.ru/ seaman/solas_74/ solas74 21.html.

43. Концепция е-Навигации, разработанная ИМО [Электронный ресурс]. - Режим доступа: http://www.internavigation.ru/news.phtml. 44. Костиков, В. А. Надежность технических систем и техногенные риски : учебное пособие / В. А. Костиков. - М. : Московский государственный технический университет гражданской авиации, 2008. - 136 с.

45. Крупные проекты. Региональная информационная система наблюдения за судоходством в Черном и Каспийском морях [Электронный ресурc]. - Режим доступа : http://www.ea.transas. $\mathrm{ru} /$ company/projects/.

46. Куканова, И. Судоходство под наблюдением [Электронный ресурс] / И. Куканова // Информационно-публицистическая газета 
«Волго-Невский Проспект». - 2009. - № 9. - Полоса 3. - Режим доступа: http://vnpinfo.ru/arkhiv/itemlist/category/2067-2009_2067. html.

47. Лебедев H.Ю. E-Navigation как связующее звено транспортной отрасли [Электронный ресурс] // Международный транспортный форум «Транспорт России». - Москва. - 2009. - 18-20 ноября. - Режим доступа : http://slidepedia.net/documents/706710/ suds.ppt.

48. Лентарев, А. А. Морские районы систем обеспечения безопасности мореплавания: учебное пособие / А. А. Лентарев. - Владивосток: Мор. гос. ун-т, 2004. - 114 с.

49. Лентарев, А. А. Развитие концепции пространственного разделения судопотоков. / А. А. Лентарев // Вестник Морского государственного ун-та. - Вып. 56. - Серия : История морской науки, техники и образования. - Владивосток : Мор. гос. ун-т, 2012. - C. 10-30.

50. Лентарев, А. А. Развитие средств и методов управления движением судов / А. А. Лентарев. - Владивосток: МГУ им. адм. Г. И. Невельского, 2001. - 250 с.

51. Лоцманские проводки [Электронный ресурс]. - Режим доступа : http://www.delta-pilot.ua/uk/node/527.

52. Международная конвенция 1995 года о подготовке и дипломировании персонала рыболовных судов и несении вахты (ПДНВ-Р,95). (Заключительный акт, приложение 2). - СПб.: ЗАО ЦНИИМФ, 2000. - 192 c. International Convention on Standards of Training, Certification and Watchkeeping or Fishing Vessel Personnel, 1995 (STCW-F,95).

53. Международная конвенция о грузовой марке, 1966 г., измененная протоколом 1988 года к ней (КГМ-66/88), (пересмотренная в 2003 г.). - 3-е изд. - СПб.: ЦНИИМФ, 2014. - 320 с.

54. Международная конвенция о спасании (SALVAGE) (Лондон, 28 апреля 1989 года) [Электронный ресурс]. - Режим доступа : http://www.conventions.ru/.

55. Международная Конвенция ПДНВ-78 (International STCW Convention, 1978). - СПб.: ЗАО ЦНИИМФ, 1996. - 552 с. 
56. Международная конвенция по поиску и спасанию на море 1979 г. (САР-79) с поправками 2004 г. - Вып. 12 : International Convention on Marit. - Серия : Судовладельцам и капитанам. СПб.: ЗАО ЦНИИМФ, 2005. - 64 с.

57. Международный кодекс морской перевозки опасных грузов. MКМПОГ. IMDG Code. В 2-х томах. Включающий поправки 36-12. - СПб.: ЦНИИМФ, 2014. - 1254 с.

58. Международный кодекс по охране судов и портовых средств (Кодекс ОСПС). - Вып. 7. - Серия : Судовладельцам и капитанам. - СПб.: ЗАО ЦНИИМФ, 2003. - 82 с.

59. Международный кодекс по управлению безопасной эксплуатацией судов и предотвращением загрязнения (Редакция 2010) [Электронный ресурс]. - Режим доступа : http://ibicon.ru/assets/ files/0-2010-ISM-IBICON.pdf.

60. Международный свод сигналов МСС-65. - Изд. 2-е, исправл. и доп. - СПб.: ГУНиО МО, 1982. - 159 с.

61. Международный союз электросвязи. Руководство для использования в морской подвижной и морской подвижной спутниковой службах : в 2-х томах. - Изд-во ITU : 2013. - 670 с.

62. Миляков, Д. Ф. Системы мониторинга судов в концепции E-Navigation. КБ навигационных систем НАВИС. Технологии и оборудование ГЛОНАCC/GPS/GALILEO. [Электронный ресурс] / Д. Ф. Миляков. - Режим доступа : http://slidepedia.net/ documents/945786/suds.ppt.

63. Мишальченко, Ю. Возникновение и развитие «лоцманского дела» [Электронный ресурс] / Ю. Мишальченко // Морское право. - 2004. - № 2. - Режим доступа : http://www.delta-pilot. ua/en/node/249.

64. Морские обитатели мигрируют к полюсам [Электронный pecypc] - 19.06.2015. - Режим доступа : http://www.aqualover. ru/news/.

65. Морское судоходство и задачи по обеспечению его безопасности. [Электронный ресурс] - Режим доступа : http://bibliofond.ru/. 66. МППСС (2001). Конвенция «О международных правилах предупреждения столкновений судов в море», 1972 г. (редакция 
2001 года) [Электронный ресурс]. - Режим доступа: http://www. imodocs.com/txt/data_www/texts/MPSS01.php3.

67. Навигационные услуги с использованием СУДС Кольского залива: ФГУП «Росморпорт» [Электронный ресурс]. - Режим доступа : http://www.rosmorport.ru/mur_serv_nav.html.

68. Навигационные услуги с использованием СУДС : ФГУП «Росморпорт» [Электронный ресурс]. - Режим доступа : http://www. rosmorport.ru/nvr_serv_nav.html.

69. НД 2-020101-078 Правила по оборудованию морских судов. СПб : Российский морской регистр судоходства, 2014. - 340 с.

70. Общие положения об установлении путей движения судов. (Резолюция А.572(14) от 20 ноября 1985 г.). ГУНиО. МО СССР. $-1987 .-32 \mathrm{c}$.

71. О введении в действие «Положения о лоцманской службе и лоцманской проводке судов по внутренним судоходным путям Российской Федерации» [Электронный ресурс] // Предпринимательское право. - Режим доступа : www.businesspravo.ru.

72. Общие принципы ГМССБ. [Электронный ресурс]. - Режим доступа : http://moryak.biz/modules.php.

73. Основные характеристики морской подвижной службы [Электронный ресурс] // Моряк. - Режим доступа : http://seaspirit. ru/morskie-konvencii/gmdss/ osnovnye-xarakteristiki-morskojpodvizhnoj-sluzhby.html.

74. Основы ГМССБ [Электронный ресурс]. - Режим доступа : http://seacomm.ru/dokumentacija/5027/.

75. ПДНВ - руководство для моряков (с учетом новых Манильских поправок 2010 года). Международная федерация транспортников [Электронный ресурс]. - Режим доступа : www. itfglobal.org.

76. Подписание Заключительного акта Дипломатической конференции по безопасности рыболовных судов [Электронный pecypc]. - Режим доступа : mintrans.ru.

77. Постановление Правительства РФ от 11.06. 2008 г. № 444 «Об утверждении Положения о Федеральном агентстве по рыболовству» [Электронный ресурс]. - Режим доступа : fish.qov.ru. 
78. Постановление Правительства РФ от 12.06 .2008 г. № 450 «Об утверждении Положения о Министерстве сельского хозяйства Российской Федерации» // СЗ РФ. - 2008. - № 25 с изм. на 2013 год.

79. Правила совместного плавания и промысла судов флота рыбной промышленности, утвержденные Приказом Министерства рыбного хозяйства от 4 сентября 1972 г. № 285. ПСПП-72.

80. Правовое регулирование лоцманской и ледокольной проводки [Электронный ресурс]. - Режим доступа : http://region51murman. narod.ru/ index/0-90.

81. Правовое обеспечение безопасности совместного морского промысла [Электронный ресурс] // Актуальные проблемы российского права. - 2007. - № 01 (4). - Режим доступа: http:// www.studmed.ru/docs/.

82. Приказ Минсельхоза РФ от19.12.2013 г. № 489 «Об утверждении Административного регламента по исполнению государственной функции государственного надзора за торговым мореплаванием в части обеспечения безопасности плавания судов рыбопромыслового флота в районах промысла при осуществлении рыболовства» [Электронный ресурс]. - Режим доступа : mcx.ru.

83. Приказ руководителя Комитета РФ по рыболовству от 30.08.1995 г. № 140 «Об утверждении Устава службы на судах рыбопромыслового флота Российской Федерации» [Электронный ресурс]. - Режим доступа : http://www.bestpravo.ru/.

84. Приступа, А. С. Методология оценки эффективности обеспечения безопасности в экономических информационных системах: автореф. дис. ... канд. экон. наук: 08.00.13 / Приступа Артем Сергеевич. - М., 2005. - 23 с.

85. Программа «Поддержание, развитие и использование системы ГЛОНАСС на 2012-2020 годы». Федеральное космическое агентство (РОСКОСМОС) [Электронный ресурс]. - Режим доступа : http://www.federalspace.ru/115/.

86. Протокол о борьбе с незаконными актами, направленными против безопасности стационарных платформ, расположенных на континентальном шельфе [Электронный ресурс]. - Режим доступа : http://www.un.org/. 
87. Радиосвязь на морском флоте и Глобальная морская система связи при бедствии (ГМССБ). Принципы построения и применения систем радиосвязи на морском флоте России [Электронный pecypc]. - Режим доступа : Igor_Mak®Design.

88. Разработка базовых элементов систем слежения и мониторинга с использованием сигналов автоматической идентификационной системы (АИС) [Электронный ресурс] // Связь на море и реке2011: материалы конф. - 2011. - 23-24 ноября. - Режим доступа : http://slidepedia.net/documents/.

89. Разработка методологии управления безопасностью транспортных систем (на примере Северо-Западного региона) : отчет о НИР (промежуточный) / Д. А. Скороходов, А. Л. Стариченков, И. В. Степанов, С. Б. Хабарова. - СПб : ИПТ РАН, 2004. - 105 с. 90. Регламент радиосвязи. - Женева : Отпечатано в Швейцарии, 2012. $-2270 \mathrm{c}$.

91. Рекомендации для плавания в районах разделения движения. ГУНиО. - № 9037. МО СССС. - 1976. - 156 с.

92. Рекомендация МСЭ-R Резолюция М.330 Координация служб НАВТЕКС [Электронный ресурс]. - Режим доступа : http://www. rfcmd.ru/sphider/docs/ITU-R_Rec_List_ANO_R.htm.

93. Рекомендация МСЭ-R P. 368-9 (02/07). Кривые распространения земной волны в полосе частот между 10 кГц и 30 МГц.

94. Рекомендация МCЭ-R М.493-11 (05/04). Система цифрового избирательного вызова для использования в морской подвижной службе.

95. РД 31.64.54-2001. Правила радиосвязи морской подвижной службы и морской подвижной спутниковой службы Российской Федерации [Электронный ресурс]. - Режим доступа : http:// www.marcomm.ru/.

96. Р 78.36.026-2012 Рекомендации по использованию технических средств обнаружения, основанных на различных физических принципах, для охраны огражденных территорий и открытых площадок [Электронный ресурс]. - Режим доступа : http://www.ktso.ru.

97. Руководство МАМПС. Руководство по международному авиационному и морскому поиску и спасанию, Издание 2013 года. Лондон/Монреаль: ИМО/ИКАО, 2013. - 150 с. 
98. Семионичев, Д. С. Управление техническим состоянием судовой энергетической установки на основе метода формализованной оценки безопасности : дис. ... канд. техн. наук : 05.08.05/ Семионичев Дмитрий Сергеевич. - СПб., 2010. - 209 с.

99. Сессия подкомитета IMO. 16.03.2011 [Электронный ресурс] // Информационный центр «Рыбные ресурсы». - Режим доступа : www.fishres.ru.

100. Сидорченко, В. Ф. Безопасность группового мореплавания. Международно-правовые аспекты. - Серия : Теория и практика международного права [Электронный ресурс] / В. Ф. Сидорченко, В. И. Егоркин // Юридический центр Пресс. - 2004. - С. 20. Режим доступа : http://iknigi.net/.

101. Система наблюдения за надводной обстановкой. Bueno со advanced technology [Электронный ресурс]. - Режим доступа : http://bueno-tech.com/ traffic_rus.html.

102. Система ИНМАРСАТ [Электронный ресурс]. - Режим доступа : http://seaman-sea.ru/images/stories/main10/sistema inmarsat.jpg.

103. Системы обеспечения безопасности мореплавания. Единая государственная система информации об обстановке в мировом океане [Электронный ресурс]. - Режим доступа : http://flot. cniimf.ru/marine_safety_systems.asp.

104. Системы управления движением судов [Электронный ресурс]. - Режим доступа : http://www.mkis.su/.

105. Скрынник, А. М. Проблемы осуществления государственного надзора за безопасностью плавания судов рыбопромыслового флота в районах промысла (на примере Азово-Черноморского рыбохозяйственного бассейна) // Рыбное хозяйство. - 2014. № 2. - C. 33-40.

106. СОЛАC-74 (SOLAS) консолидированный текст с поправками 2008 [Электронный ресурс]. - Режим доступа : http://www. conventions.ru/.

107. Стариченков, А. Л. Методология обеспечения безопасности транспортных средств: дис. ... д-ра техн. наук : 05.22 .01 / Стариченков Алексей Леонидович. - СПб., 2012. - 473 с. 
108. Статистические методы анализа безопасности сложных технических систем : учебник / Л. Н. Александровская, И. З. Аронов, А. И. Елизаров и др.; под ред. В. П. Соколова. - М.: Логос, 2001. - 232 с. 109. СУДС в Новороссийске [Электронный ресурс]. - Режим доступа : http://www.ea.transas.ru/products/shorebased/vts/finskiy/. 110. СУДС Navi-Harbour [Электронный pecypc] // Transas. - Режим доступа : http://www.transas.ru/products/VTS.

111. СУДС [Электронный ресурс]. - Режим доступа : http:// slidepedia.net/ documents/20899/suds.ppt\#sthash.sHbmTij0.dpuf. 112. Таратынов, В.В.Целесообразность разделения морских путей

/ В. В. Таратынов // Морской флот. - 1969. - № 9. - С. 19-20.

113. Техника безопасности (всем морякам). [Электронный ресурс]

- Режим доступа : http://www.kazreferat.info/read/.

114. Техника безопасности при ведении промысла. [Электронный pecypc] - Режим доступа : http://www.kazreferat.info/read/.

115. Тренина, Д. Лоцманская мобильность от «Транзас» [Электронный ресурс] / Д. Тренина. - Режим доступа : http://spbit. ru/news/n43774/.

116. Береговые станции службы НАВТЕКС. Свидетельства Росморречфлота [Электронный ресурс] // ФГУП «Морсвязьспутник». - Режим доступа : http://www.marsat.ru/certificates/4.

117. «Транзас» поставит навигационные системы для морских лоцманов Аляски [Электронный ресурс] // Posted by: Admin on Feb 03, 2009 - 01:57 PM. - Режим доступа : http://www.crewing. biz.ua/Article24026.html.

118. Транзас представляет современный модуль 3D CУДС [Электронный ресурс]. - Режим доступа : http://dev.envos.org/ blogs $/ 4870 /$.

119. Транзас провел модернизацию на одном из объектов Региональной системы управления движением судов (СУДС) Керченского пролива [Электронный ресурс]. - Режим доступа : http:// www.transas.ru/.

120. Транзас Pilot PRO [Электронный ресурс]. - Режим доступа : http://portnews.ru/upload/basefiles/1151_pTchrpapnpzpachs $\% 20$ Pilot\%20PRO\%20Rus.pdf. 
121. Федеральный закон РФ от 30.04. 1999 г. № 81 «Кодекс торгового мореплавания Российской Федерации» [Электронный ресурс] // КонсультантПлюс. - Режим доступа : http://www.consultant.ru/. 122. Чемин, А. А. Разработка методов оценки эффективности систем защиты информации в распределенных информационных системах специального назначения: автореф. дис. ... канд. техн. наук : 05.13.19 / Чемин Александр Александрович. - М., 2009. - 22 с. 123. Черняев, Р. Н. Финский залив. Региональная система безопасности мореплавания [Электронный ресурс] / Р. Н. Черняев, В. И. Санников, Ли За Сон, Л. М. Малахов // ИНФОРМОСТ «Радиоэлектроника и телекоммуникации»-21. - С. 29-32. Режим доступа : www.informmost.ru.

124. Шарлай, Г. Н., Пузачев, А. Н. Справочная книжка оператора ГМССБ: учебное пособие [Электронный ресурс] / Г. Н. Шарлай, А. Н. Пузачев. - Владивосток, 2000. - Режим доступа : pismenny@fesma.ru.

125. ЭКС для лоцманов Navi-Sailor 4000 PILOT [Электронный pecypc]. - Режим доступа : http://www.transforce.ru/products/ Navi-SailorPilot.

126. Электронная картография [Электронный ресурс]. - Режим доступа : http://www.morintech.ru/explorer.htm\#ships_db.

127. Элементы ГМССБ [Электронный ресурс]. - Режим доступа : http://seacomm.ru/dokumentacija/5027/.

128. Яковлев, В. Г., Ничипоренко, Н. Т. Импульсные радиолокационные станции радиоволн мм-диапазона морского применения / В. Г. Яковлев, Н. Т. Ничипоренко // Наука и транспорт : Морской и речной транспорт. - 2013. - № 1 (5). - С. 48-50.

129. Яшин, С. Состояние лоцманского дела в России [Электронный pecypc] / С. Яшин // Морской флот. - 2002. - Режим доступа : http://www.morflot.su/index.php.

130. Beattie, J. H. Routing at Sea / J. H. Beattie // J. Navig. - 1978. V. 31. - № 2. - P. 167-202.

131. Borisova, L. F. Safety of the Arctic Marine Transport in Russia and Means of Its Support / L. F. Borisova // European Journal Of Natural History. - 2014. - № 2. - P. 45-46. 
132. Burnham, O. T. Prescribed Courses for the Navigation of the Great Lakes of North America / O. T. Burnham, C. M. Jansky // J. Navig. - 1964. - V. 17. - № 23. - P. 376-385.

133. Dimokk 0. Морская лоцманская служба [Электронный реcypc] / Dimokk 0. - Режим доступа : http://seaspirit.ru/morskiekonvencii/morskoe-pravo/morskaya-locmanskaya-sluzhba.html.

134. Hara, K. Statistical Model for Determining the Width of a Separation Zone at Encounter Routes with Crossing Traffic / K. Hara, H. Kirutani, K. A. Inoue // Int. Congr. «Man and Navigation». - 1979. - V. 2. - P. 85-91.

135. Hjalmar R. Bardarson. Основные способы промыслового рыболовства и технологические процессы [Электронный ресурс].

- Режим доступа : https://base.safework.ru/.

136. IALA-AISM [Электронный ресурс]. - Режим доступа : http:// www.iala-aism.org.

137. Illustrated on Marine Traffic Safety Law // NSF, Japan Coast Guard. April 2003. -46 p.

138. IMO Maritime Safety Committee 94th session Agenda item 13

: FORMAL SAFETY ASSESSMENT, INCLUDING GENERAL CARGO SHIP SAFETY, MSC 94/13/1 , 10 September , 2014. - 5 p. 139. Oudet L. Future Developments in Routing at Sea / L. Oudet // J. Navig. - 1979. - V. 32. - № 1. - P. 53-76.

140. SafeSeaNet [Электронный ресурс] // European Maritime Safety Agency - Режим доступа : www.emsa.europa.eu.

141. The American Practical Navigator. 2002 Bicentennial Edition. National Imagery and Mapping Agency, USA. Pub. - № 9. - 879 p. 142. White P. Directions in the Common European Transport AreaTowards a competitive and resource efficient transportation system. / Paper White // EN Brussels, 03.28.2011. 


\section{СВЕДЕНИЯ ОБ АВТОРЕ}

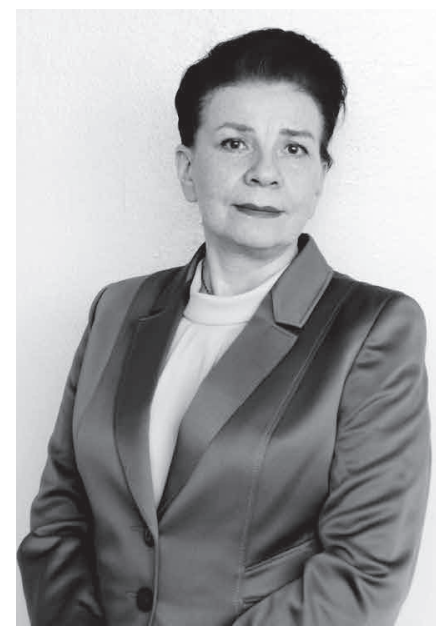

\section{Борисова \\ Людмила Федоровна -}

кандидат технических наук, доцент, доцент кафедры радиотехники и радиотелекоммуникационных систем и кафедры математики, информационных систем и программного обеспечения Мурманского государственного технического университета (МГТУ).

В 1979 г. окончила Куйбышевский электротехнический институт связи (КЭИС). После окончания в 1985 г. аспирантуры при Ленинградском электротехническом институте связи им. проф. М.А. Бонч-Бруевича (ЛЭИС) (Ленинград) по распределению работает в МГТУ. В разные годы преподавала на кафедрах автоматики и вычислительной техники, электрооборудования судов, радиотехники и радиотелекоммуникационных систем, высшей математики и программного обеспечения ЭВМ, вела курсы повышения квалификации работников образования МГТУ.

В 2005 году успешно защитила кандидатскую диссертацию по специальности 05.22.19 - эксплуатация водного транспорта, судовождение, на тему «Мобильная система управления движением судов для обеспечения безопасности мореплавания на акватории с интенсивным судоходством». Имеет ученое звание доцента, звание профессионального инженера России в номинации «Транспорт (водный)».

Область научных интересов: информационно-технологическое и телекоммуникационное обеспечение морских транспортных процессов и систем.

Автор более 150 печатных работ и патентов. Среди них Патент РФ на изобретение № 2395122 «Способ управления движением подвижных объектов». 


\section{КАФЕДРА РАДИОТЕХНИКИ \\ И РАДИОТЕЛЕКОММУНИКАЦИОННЫХ СИСТЕМ \\ В МОРСКОМ ИНСТИТУТЕ МУРМАНСКОГО \\ ГОСУДАРСТВЕННОГО \\ ТЕХНИЧЕСКОГО УНИВЕРСИТЕТА}

Федеральное государственное бюджетное образовательное учреждение высшего профессионального образования «Мурманский государственный технический университет» (МГТУ) было создано в 1950 году как высшее мореходное училище в системе рыбной промышленности страны. Пройдя долгий путь от высшего мореходного училища до университета, МГТУ приобрел статус ведущего технического вуза региона по подготовке высококвалифицированных специалистов для рыбной отрасли Мурманской области, Северо-Арктического региона и страны в целом.

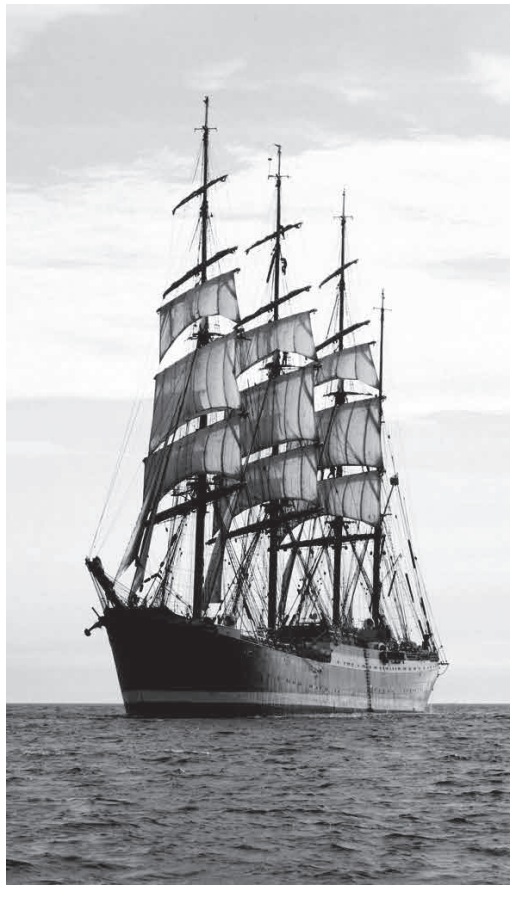

В составе университета 6 институтов: Морской, Естественнотехнологический, Экономики, управления и права, Дистанционного обучения, Дополнительного профессионального образования и Научных исследований, инноваций и технологий. В структуру университета также включены Апатитский и Полярнинский филиалы, Архангельский морской рыбопромышленный техникум, Мурманский морской рыбопромышленный колледж им. И.И. Месяцева. В настоящее время в вузе обучаются около 10 тысяч студентов.

МГТУ является судовладельцем четырехмачтового учебного парусного судна «Седов», занесенного в Книгу рекордов Гиннесса. На барке оборудованы учебные классы, имеются обширная 


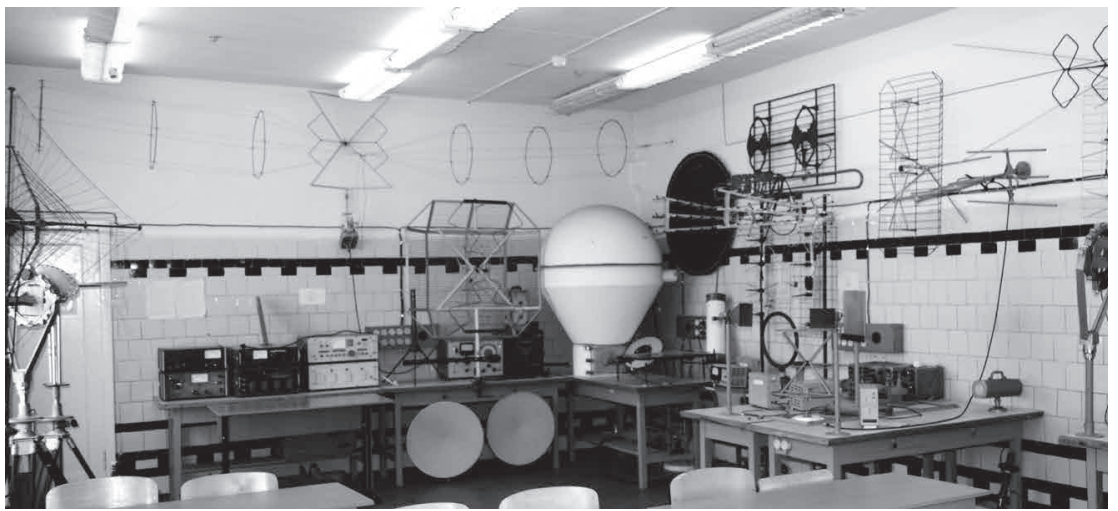

библиотека и кинозал. Судно участвует в международных парусных регатах. В 2012-2013 годах прошло первое кругосветное плавание барка.

Подготовка радиоинженеров началась в 1991 году в Мурманском высшем инженерном морском училище имени Ленинского комсомола (МВИМУ, прежнее название МГТУ). В 1993 году на судоводительском факультете была образована кафедра «Судовые радиотехнические устройства», которая в настоящее время носит название «Радиотехника и радиотелекоммуникационные системы» (заведующий кафедрой кандидат технических наук Н.В. Калитенков) и является подразделением Морского института МГТУ.

В 1997 году состоялся первый выпуск радиоинженеров. Всего за прошедшие годы было подготовлено 240 инженеров
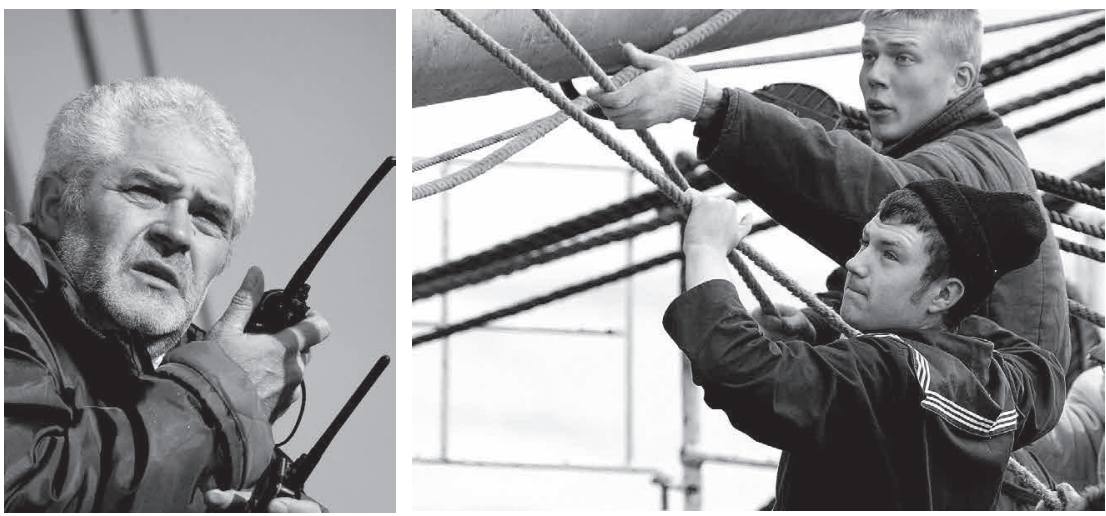

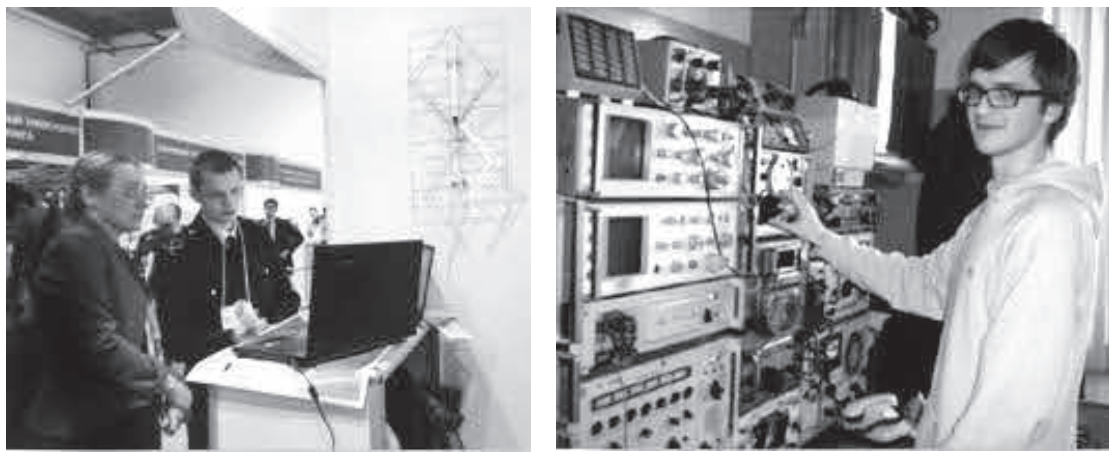

по специальностям «Техническая эксплуатация транспортного радиооборудования» и «Радиотехника», 27 бакалавров по направлению «Радиотехника», в 2013 году начата подготовка по специальности «Радиотехнические системы и комплексы».

Обучение будущих специалистов ведется в созданных на кафедре лабораториях радионавигационных систем, аналогово-дискретной схемотехники, радиопередающих устройств, электродинамики распространения радиоволн и АФС, радиообмена, электронных приборов, радиоизмерений, телевидения и видеотехники, тренажерном классе ГМССБ, а также в компьютерном классе при использовании виртуальных лабораторных комплексов и специализированных программных продуктов. На кафедре постоянно

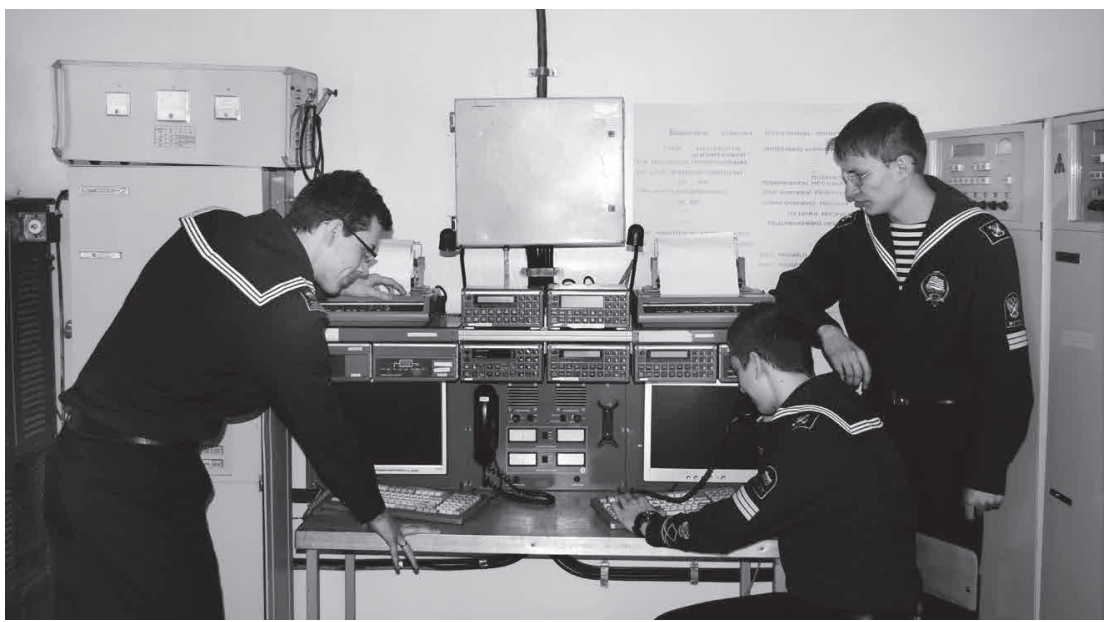


ведется работа по совершенствованию материально-технической базы и созданию новых лабораторий.

Кафедра сотрудничает с ФГУП «Атомфлот», Полярным геофизическим институтом, КНЦ РАН, ООО «Мир Антенн Стронг» (Ростов-на-Дону), ОАО «Мурманский траловый флот», ЗАО НПП «Оборудование систем телекоммуникаций (ОСТ)», Саратовским

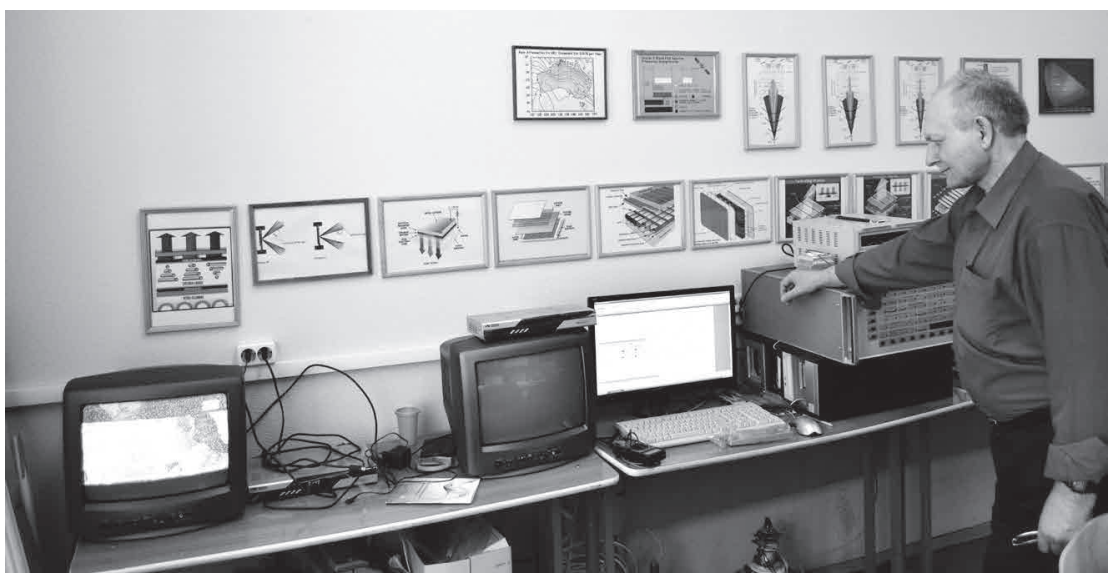

электромеханическим заводом «РЭМО», ОАО «Воентелеком», 826-м ремонтным заводом средств связи (Мурманский филиал), операторами сотовой связи Мурманска (МТС, Ростелеком, Мегафон, Теле2, Билайн), ОАО «Аэропорт Мурманск» в области проведения научных разработок и прохождения практик курсантов и студентов.

Должная подготовка курсантов и студентов во время обучения и прохождения практик является залогом успешной карьеры выпускников на промысловых флотах, в пароходствах и береговых флотских структурах, на промышленных предприятиях и в НИИ, в сферах государственной и военной служб. Наши выпускники работают в ОАО «Мурманский траловый флот», ООО «РОБИНЗОН», ЗАО «ВЕГА», ФГУП ПИНРО, ОАО «Воентелеком», ООО «Эра-Сервис», ОАО «Мегафон», ОАО «МТС», ОАО «Теле2», ООО «Билан», филиале «35 СРЗ», ОАО «ЦС «Звездочка» в Мурманске и других. 


\section{ОБЕСПЕЧЕНИЕ БЕЗОПАСНОСТИ СУДОХОДСТВА В РЫБОПРОМЫСЛОВЫХ РАЙОНАХ}

Учебное пособие

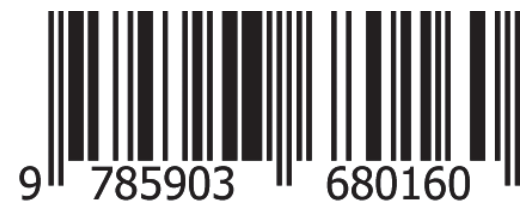

Главный редактор - Клигман О.М.

Компьютерная верстка, дизайн Макаренко Ю.И. Корректор - Князева Л.Ф.

Общероссийский классификатор продукции ОК-005-93, том 2; 953000 - книги, брошюры.

Санитарно-эпидемиологическое заключение не требуется.

Bсе права защищены. Книга не может быть воспроизведена полностью или частично

в бумажном или электронном формате без письменного разрешения правообладателя.

Знак информационной продукции

(16- (Федеральный закон № 436-Ф3 от 29.12.2010 г.)

Подписано в печать 20.07.2016 г. Формат 60 х 84 1/16.

Офсетная печать. Бумага офсетная. Усл.-печ. л. 22,50. Уч.-изд. л. 23,84.

Тираж 1000 экз. 